\author{
Universidade de São Paulo \\ Faculdade de Arquitetura e Urbanismo \\ Programa de Pós-graduação em Arquitetura e Urbanismo \\ Área de Concentração: Projeto de Arquitetura
}

\title{
PATRIMÔNIO PAISAGÍSTICO E TURISMO NA ILHA DE SANTA CATARINA: A PREMÊNCIA DA PAISAGEM NO DESENVOLVIMENTO SUSTENTÁVEL DA ATIVIDADE TURÍSTICA
}

Ayrton Portilho Bueno

\begin{abstract}
Tese apresentada à Faculdade de Arquitetura e Urbanismo da Universidade de São Paulo como requisito parcial para obtenção do grau de Doutor
\end{abstract}

Orientador: Professor Doutor Miguel Alves Pereira

São Paulo

Junho de 2006 
AUTORIZO A REPRODUÇÃO E DIVULGAÇÃO TOTAL OU PARCIAL DESTE TRABALHO, POR QUALQUER MEIO CONVENCIONAL OU ELETRÔNICO, PARA FINS DE ESTUDO E PESQUISA, DESDE QUE CITADA A FONTE.

\section{ASSINATURA:}

E-MAIL: ayrtonbueno@hotmail.com

Bueno, Ayrton Portilho

B928p Patrimônio paisagístico e turismo na llha de Santa Catarina: a premência da paisagem no desenvolvimento sustentável da atividade turística / Ayrton Portilho Bueno. - - São Paulo, 2006.

375 p. : il.

Tese (Doutorado - Área de Concentração: Projeto de Arquitetura) - Faculdade de Arquitetura e Urbanismo da Universidade de São Paulo.

Orientador: Miguel Alves Pereira.

1. Paisagem - Projeto 2. Turismo 3. Desenvolvimento sustentável I. Título 
Aos meus pais Clélia (in memorian) e Jorge, e à minha filha Cecília. 


\section{AGRADECIMENTOS}

É necessário manifestar minha gratidão aos que possibilitaram este percurso.

Ao Professor Miguel Alves Pereira, pelo direcionamento seguro

e que me permitiu descobrir limites e possibilidades. Além da

orientação, livre e libertária, agradeço a convivência.

Ao Professor Joaquim Sabaté Bel, da Universidade Politécnica de

Barcelona, pela forma como me recebeu, abriu portas e apontou caminhos contemporâneos da arquitetura, bem como à equipe de seu despacho, CCRS Arquitects, pela amigável recepção.

À Fundação Coordenação de Aperfeiçoamento de Pessoal de Nível Superior-CAPES do Ministério de Educação e Cultura pela oportunidade de realizar estudos junto ao Departamento de Urbanismo e Ordenação Territorial da Universidade Politécnica de Barcelona. Aos funcionários secretaria da Pós-graduação da Faculdade de Arquitetura e Urbanismo e a João Roberto da Próreitoria de Pós-graduação da Universidade de São Paulo.

Aos colegas e funcionários do Departamento de Arquitetura e Urbanismo da UFSC, em especial à Danúsia e à Pró-reitoria de Pós-graduação da UFSC, especialmente à Elci Junckes. Aos Laboratórios de Informática e de Microcomputadores do Curso de Arquitetura e Urbanismo da UFSC (Elcio e Jair) e ao grupo $\mathrm{PET} / \mathrm{MEC} / \mathrm{ARQ} / \mathrm{UFSC}$, à Vera Helena Moro Bins Ely.

Aos colegas Alina Gonçalves Santiago, Gilcéia Pesce do Amaral

e Silva, Almir Francisco Reis, Luís Eduardo Fontoura Teixeira e àqueles que contribuíram, de um modo ou de outro, para o aprimoramento das idéias.

Ao Dario de Almeida Prado pelas fotografias obtidas no sobrevôo de avião. Aos colegas Flávio Simões, pelo acesso e uso do

Laboratório de História e Teoria da Arquitetura do Centro Universitário Ritter dos Reis - UniRitter/Porto Alegre, Paulo Corrêa, pela força digital em Barcelona. 
Aos amigos e colegas pelo apoio imprescindível: Clarisse Rath, Fernanda Lonardoni, Roseane Coelho, Gabriel Fermiano do Desenho Alternativo, Luís Carlos Córdova. A Marco Calloni, Elisa Beatriz Onzi e Fernanda Mazzini pela força na tradução italiana. Ao acadêmico Everson Martins e ao colega Fabio Nunes pela digitalização de imagens e editoração. Ao escritório de arquitetura Desenho Alternativo, à Sra. Dulci Eleni Westphal da biblioteca da Fundação de Tecnologia e Meio Ambiente do Estado de Santa Catarina, à Srta. Nórien Favero do Mabu Ecoresort, ao eng. Erny da Pioneira da Costa Construções e Incorporações e à Sra. Cristiane do Sindicato de Hotéis, Bares, Restaurantes e Similares da Grande Florianópolis.

Ao Fabrício da Aeroconsult e ao comandante Pedrini do Aeroclube de Santa Catarina pela segurança do vôo. 


\section{RESUMO}

O entendimento do papel do território e da paisagem no desenvolvimento da atividade turística na llha de Santa Catarina, em Florianópolis, é o tema central desta tese. Para tanto, com especial atenção para os aspectos cênicos e ecológicos da paisagem, entendida enquanto sistema físico e perceptivo, foi analisada a base natural do território, principal fator da atratividade turística, e as transformações motivadas pela ação humana. A evolução da paisagem é apresentada por meio de momentos significativos do crescimento da cidade, tendo destaque as transformações provocadas pela atividade turística.

A atividade turística, aliada ao crescimento urbano, mereceu estudo em seus aspectos sociais, políticos, econômicos, culturais, e em seus padrões de assentamento no território, identificando-se as conseqüências do modelo que, associando urbanização e turismo, orienta seu desenvolvimento na llha de Santa Catarina.

A investigação levou a conclusão que tal modelo é sócio-espacialmente insustentável, e permitiu apontar para modelo de aproveitamento do território pela atividade turística considerando a premência da paisagem enquanto elemento central na atratividade dos fluxos turísticos e da qualidade de vida dos residentes.

Assunto: projeto da paisagem

Palavras-chave: paisagem, turismo, desenvolvimento sustentável. 


\section{ABSTRACT}

\section{LANDSCAPE HERITAGE AND TOURISM IN THE ISLAND OF SANTA CATARINA: THE URGENCY OF LANDSCAPE IN THE SUSTAINABLE DEVELOPMENT OF THE ACTIVITY}

Understanding the role of territory, and landscape in the development of tourism activity in the island of Santa Catarina, in Florianópolis, is the central theme of this thesis. The natural basis of the territory, main factor of tourist attraction, and the transformations caused by human action were analyzed with special attention to the scenic and ecological aspects of the landscape, here understood as a physical and perceptive system. The evolution of the landscape is presented through the meaningful moments of city growth, with emphasis on the transformations provoked by tourism activity.

Tourism activity, together with urban growth, was addressed in its social, political, economical, and cultural aspects, and in its pattern of settlement distribution in the territory, identifying the consequences of the model that associating urbanization and tourism, orients its development in the island of Santa Catarina.

The investigation led to the conclusion that such model is not socially or spatially sustainable, and allowed pointing to a model of appropriation of the territory by tourism activity that considers the pre-eminence of the landscape as the main element in the attraction of tourist flows, and in the quality of life of residents.

Theme: landscape design

Keywords: landscape, tourism, sustainable development 


\section{SUMÁRIO}

\section{INTRODUÇÃO}

\section{CAPÍTULO I}

\section{AMBIENTE, TERRITÓRIO E PAISAGEM: CONCEITOS E METODOLOGIAS}

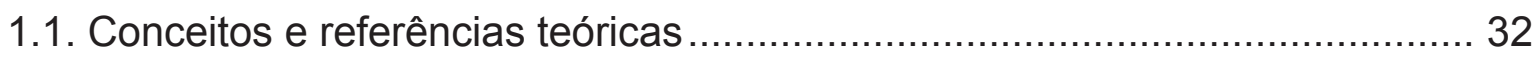

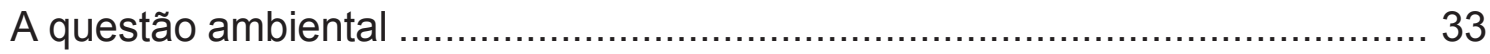

A concepção contemporânea de conservação ambiental .............................. 35

Considerações sobre desenvolvimento e sustentabilidade ............................40 40

O território como sistema sócio-ambiental ................................................ 45

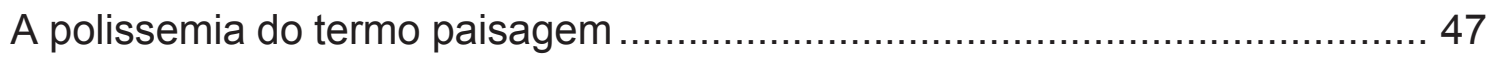

Atitudes da sociedade em relação ao território e à paisagem ........................ 53

Uma compreensão arquitetônica de território e paisagem ............................ 54

Ambiente urbano, território e paisagem urbana ...................................... 57

Planejamento do ambiente, do território e da paisagem ............................ 61

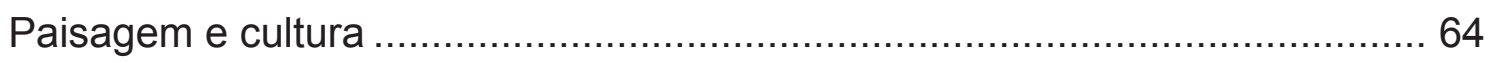

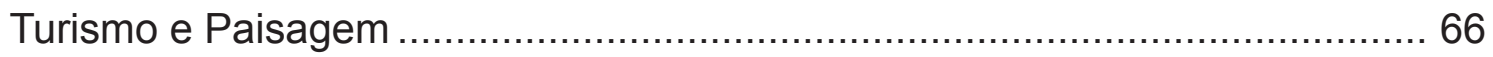

Considerações sobre a escala na abordagem do território e da paisagem ..... 67

A descrição da estrutura da paisagem ....................................................... 69

1.2. Metodologia e instrumentos de análise ....................................... 70

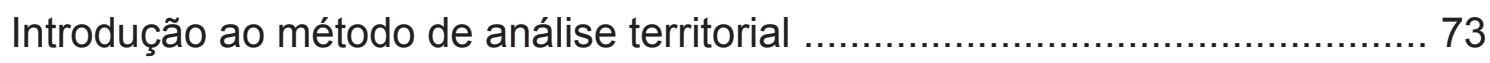

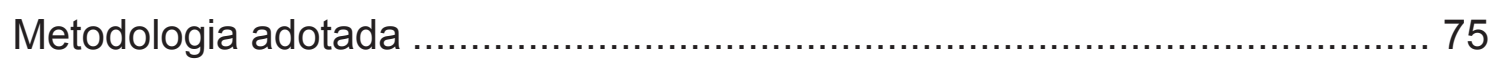




\section{CAPÍTULO II}

O TERRITÓRIO NATURAL 80

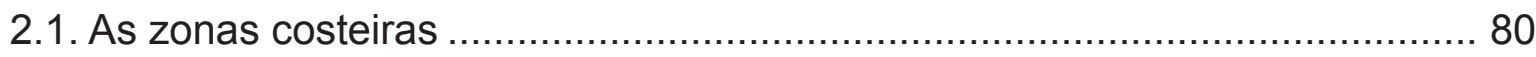

2.2. A zona costeira brasileira e a costa catarinense .......................................... 82

$2.3 \mathrm{O}$ território e a paisagem original da Ilha de Santa Catarina ......................... 85

2.4. Os principais elementos remanescentes da

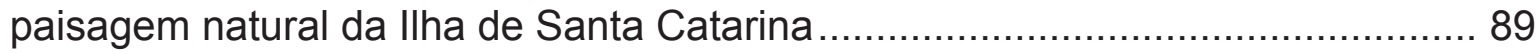

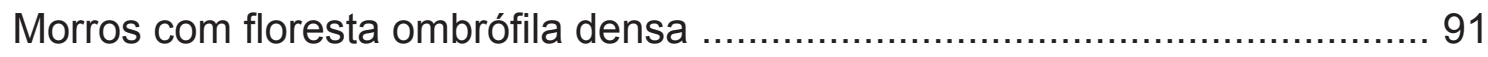

Planícies quaternárias com cobertura vegetal variada .................................. 92

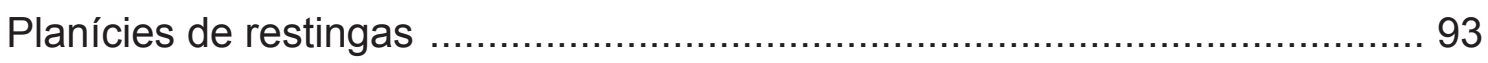

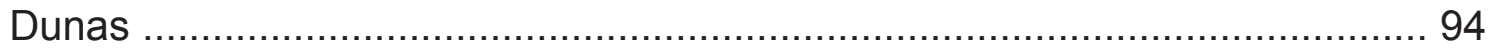

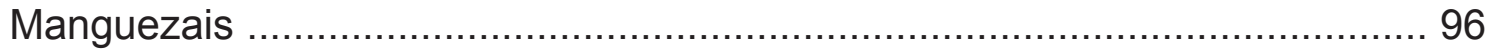

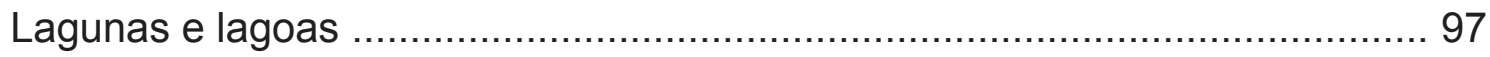

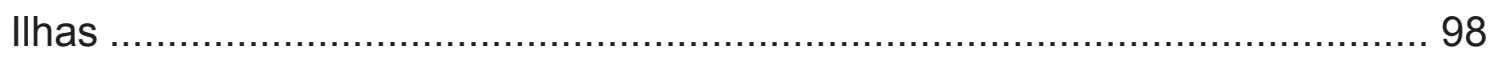

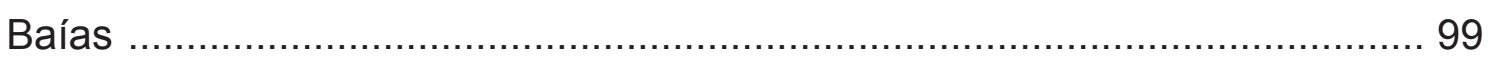

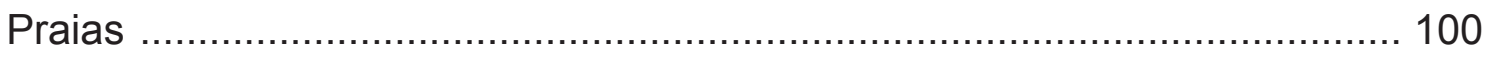

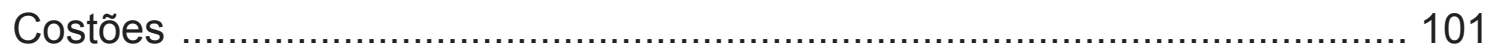

2.5. Considerações sobre o território natural ............................................... 102

\section{CAPÍTULO III}

O TERRITÓRIO HUMANIZADO .................................................... 104

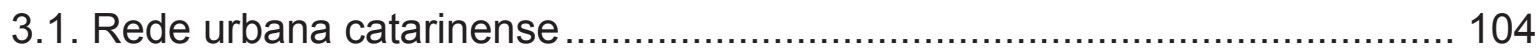

3.2. Evolução urbana de Florianópolis ........................................................... 110

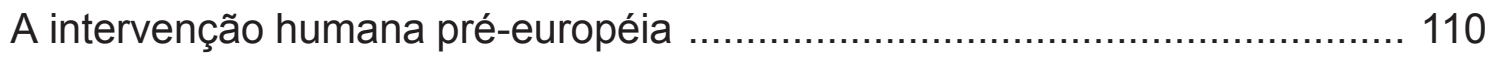

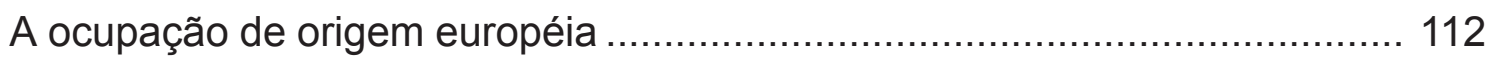

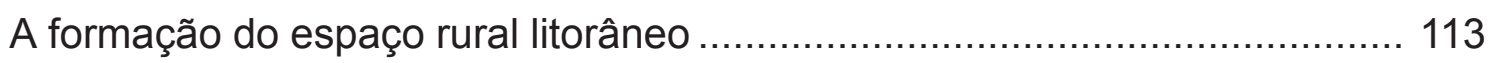

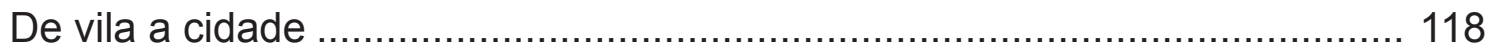

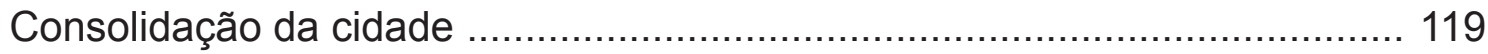

Explosão demográfica, urbanização e conurbação ......................................... 121

Movimento em direção à orla - os balneários e a urbanização turística ........ 124 


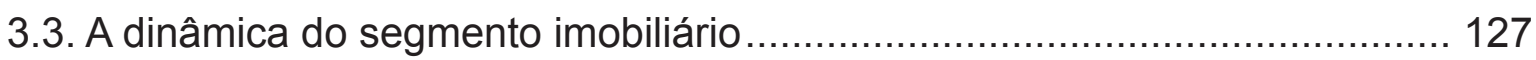

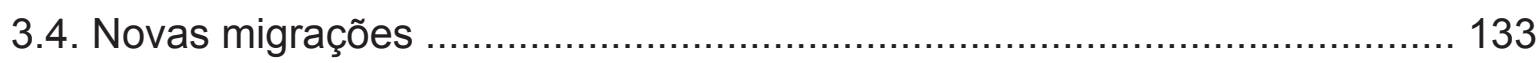

3.5. Considerações sobre o capítulo .................................................... 136

\section{CAPÍTULO IV}

A ILHA TURÍSTICA .................................................................... 137

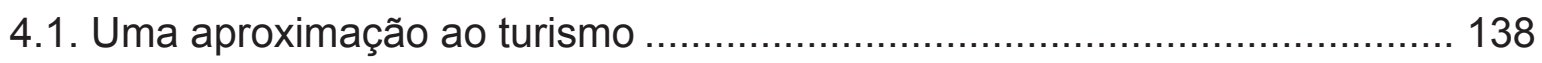

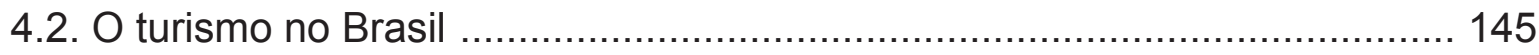

4.3. O turismo em Florianópolis e na Ilha de Santa Catarina ............................ 148

O território se adequando ao turismo - os planos diretores

e de desenvolvimento da atividade ................................................ 158

4.4. Repercussões da urbanização turística ............................................ 180

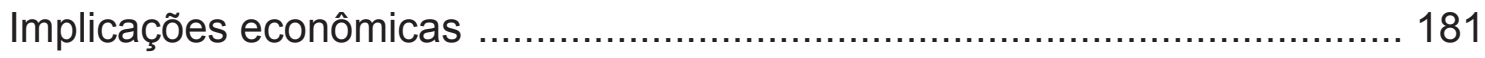

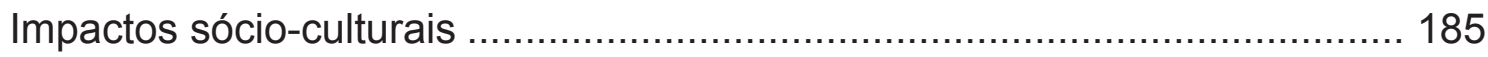

Impactos sobre o patrimônio histórico-cultural ......................................... 187

Impactos sobre as Infraestruturas .............................................. 189

4.5. Conflitos, disputas e movimentos de resistência à urbanização turística. ... 195

4.6. Exemplos de conflitos sócio-ambientais da urbanização turística ............... 202

A urbanização no Distrito da Lagoa da Conceição ................................... 202

O Plano Diretor do Campeche ................................................................ 204

O Distrito do Pântano do Sul ...................................................... 208

4.7. Considerações sobre o modelo de desenvolvimento

turístico da Ilha de Santa Catarina ...................................................... 210

PARTE III: A PAISAGEM EM EVIDÊNCIA ................................. 214

\section{CAPÍTULO V}

\section{A DINÂMICA DA PAISAGEM NA ILHA DE SANTA CATARINA ..... 215}

5.1. O mosaico paisagístico e as principais áreas homogêneas ...................... 215

Principais áreas homogêneas com predomínio de elementos naturais ......... 220

Principais áreas homogêneas artificializadas ...................................... 223

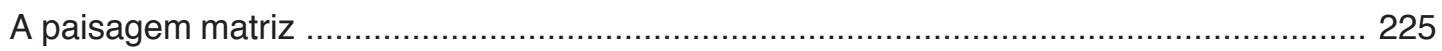

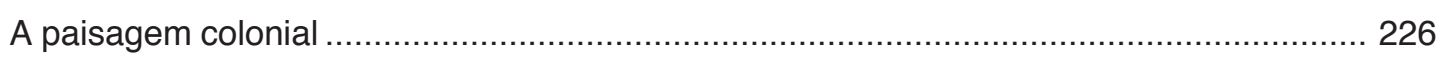

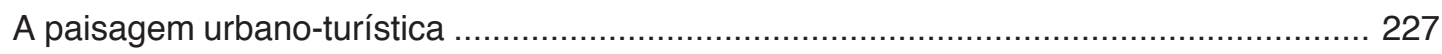


5.2. As Unidades de Paisagem da Ilha de Santa Catarina 229

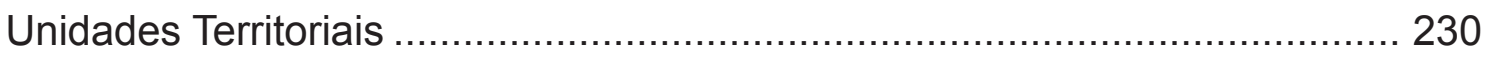

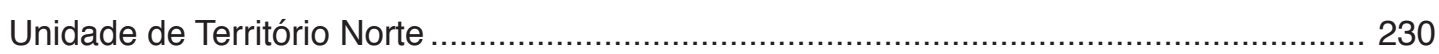

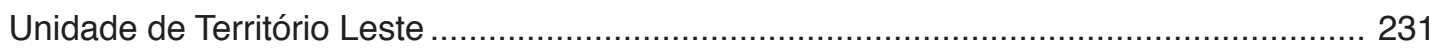

Unidade de Território Planície Central ........................................................................ 232

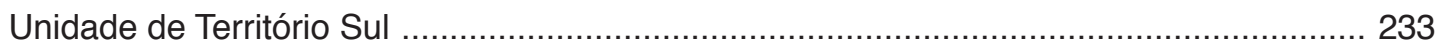

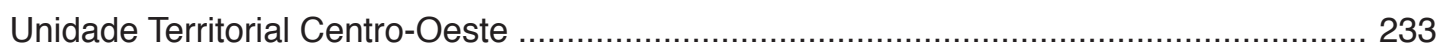

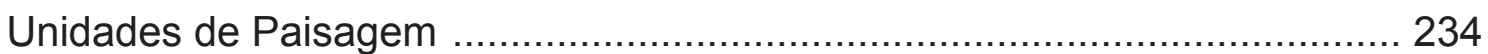

U.P. Centro-Trindade ..................................................................... 237

Elementos (naturais e humanos) constitutivos da Paisagem ......................................... 237

O caráter e a organização da paisagem ......................................................................... 239

A visão da paisagem. Belvederes, destaques, corredores e bacias visuais ...................... 240

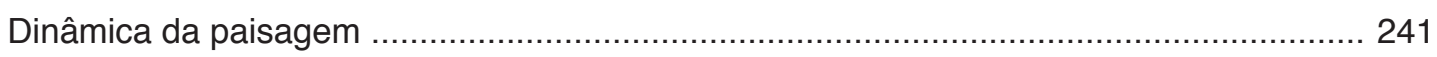

U.P. Saco dos Limões-Costeira .................................................... 242

Elementos (naturais e humanos) constitutivos da paisagem .......................................... 242

O caráter e a organização da paisagem ..................................................................... 243

A visão da paisagem. Belvederes, destaques, corredores e bacias visuais ...................... 243

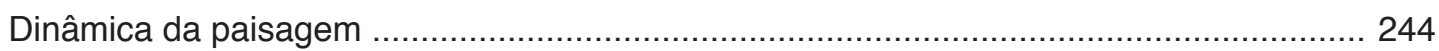

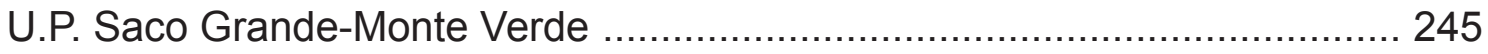

Elementos (naturais e humanos) constitutivos da paisagem ......................................... 245

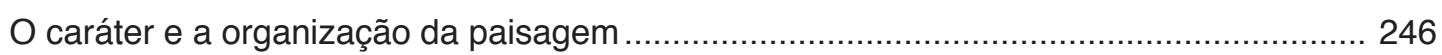

A visão da paisagem. Belvederes, destaques, corredores e bacias visuais ...................... 246

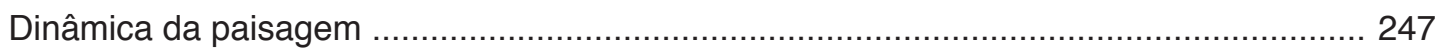

U.P. Santo Antônio-Sambaqui ............................................................. 248

Elementos (naturais e humanos) constitutivos da paisagem ......................................... 248

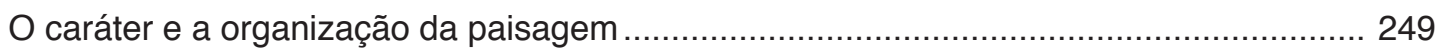

A visão da paisagem. Belvederes, destaques, corredores e bacias visuais ...................... 249

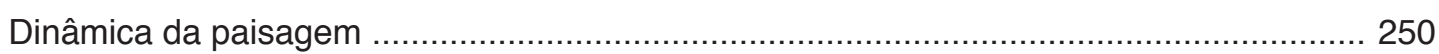

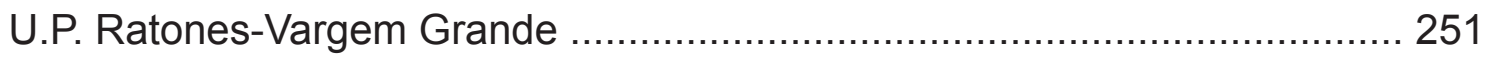

Elementos (naturais e humanos) constitutivos da paisagem ......................................... 251

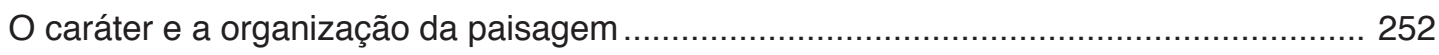

A visão da paisagem. Belvederes, destaques, corredores e bacias visuais ..................... 253

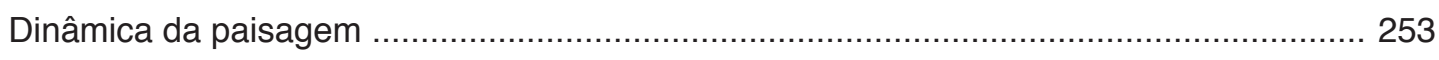

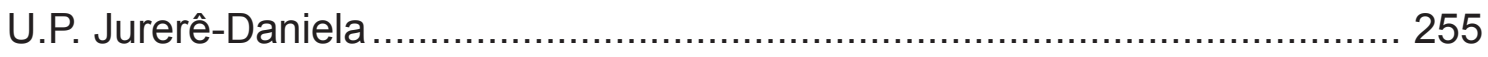

Elementos (naturais e humanos) constitutivos da paisagem ....................................... 255

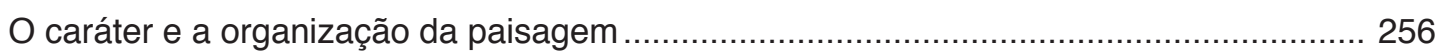

A visão da paisagem. Belvederes, destaques, corredores e bacias visuais ...................... 256

Dinâmica da paisagem ................................................................................... 257 


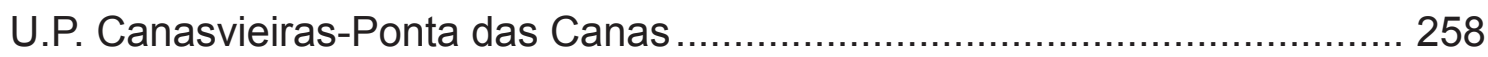

Elementos (naturais e humanos) constitutivos da paisagem ......................................... 258

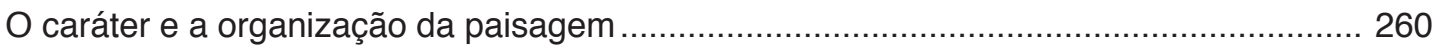

A visão da paisagem. Belvederes, destaques, corredores e bacias visuais ..................... 260

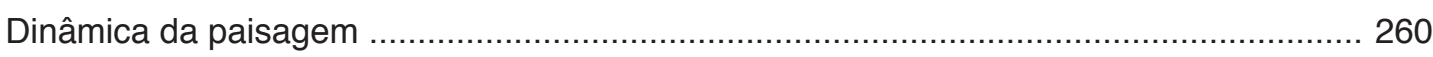

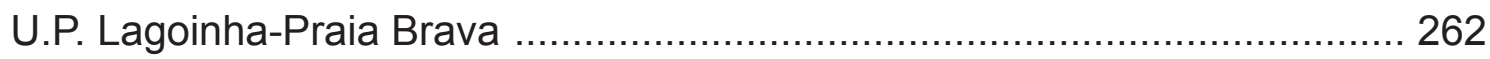

Elementos (naturais e humanos) constitutivos da paisagem ........................................... 262

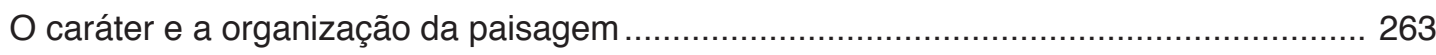

A visão da paisagem. Belvederes, destaques, corredores e bacias visuais ...................... 263

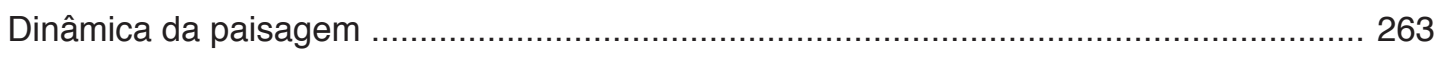

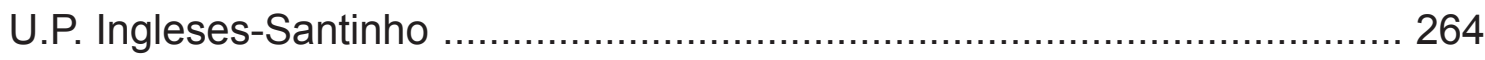

Elementos (naturais e humanos) constitutivos da paisagem .......................................... 265

O caráter e a organização da paisagem .......................................................................... 266

A visão da paisagem. Belvederes, destaques, corredores e bacias visuais ...................... 266

Dinâmica da paisagem ...................................................................................... 266

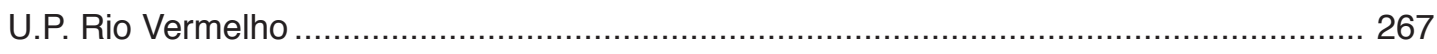

Elementos (naturais e humanos) constitutivos da paisagem ......................................... 268

O caráter e a organização da paisagem .................................................................... 269

A visão da paisagem. Belvederes, destaques, corredores e bacias visuais ..................... 269

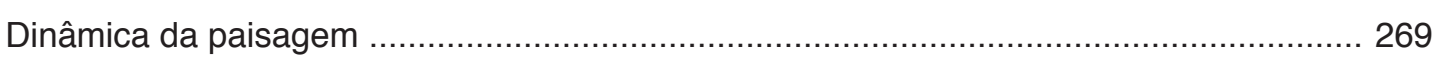

U.P. Lagoa da Conceição-Barra da Lagoa .................................................. 271

Elementos (naturais e humanos) constitutivos da paisagem .......................................... 271

O caráter e a organização da paisagem .................................................................... 273

A visão da paisagem. Belvederes, destaques, corredores e bacias visuais ...................... 273

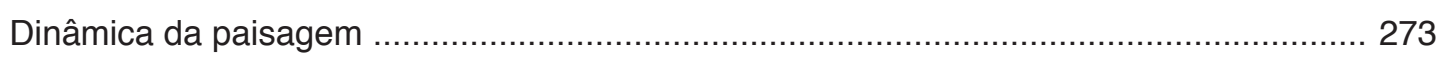

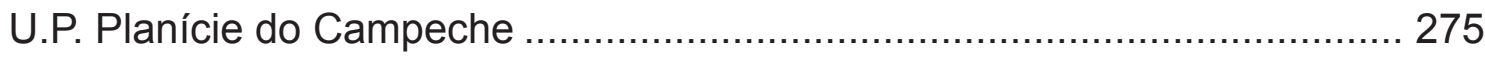

Elementos (naturais e humanos) constitutivos da paisagem ....................................... 275

O caráter e a organização da paisagem .................................................................... 277

A visão da paisagem. Belvederes, destaques, corredores e bacias visuais ..................... 277

Dinâmica da paisagem .................................................................................. 278

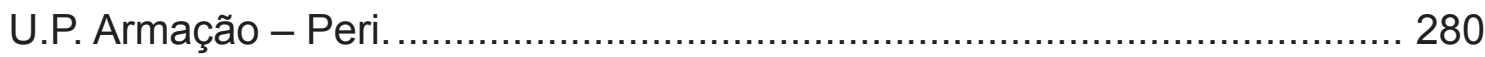

Elementos (naturais e humanos) constitutivos da paisagem ........................................ 280

O caráter e a organização da paisagem ........................................................................ 281

A visão da paisagem. Belvederes, destaques, corredores e bacias visuais ..................... 282

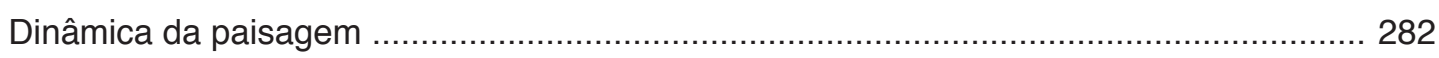

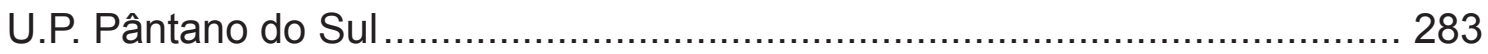

Elementos (naturais e humanos) constitutivos da paisagem ........................................ 284

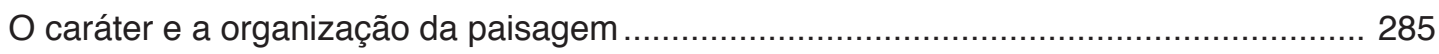

A visão da paisagem. Belvederes, destaques, corredores e bacias visuais ..................... 285

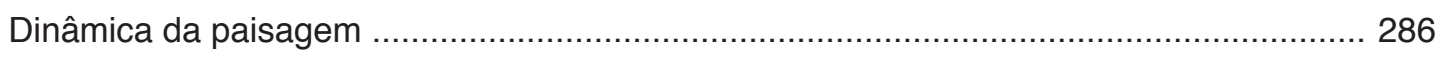




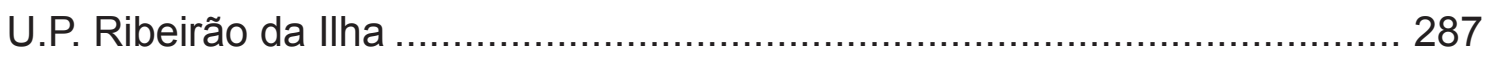

Elementos (naturais e humanos) constitutivos da paisagem .......................................... 287

O caráter e a organização da paisagem ........................................................................ 288

A visão da paisagem. Belvederes, destaques, corredores e bacias visuais ...................... 288

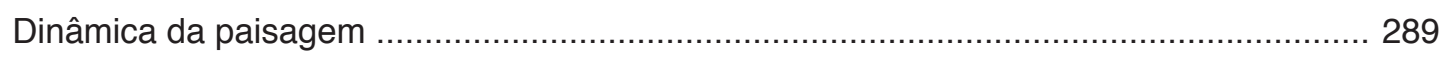

5.3. Os padrões urbanos e arquitetônicos

associados ao turismo na paisagem da llha de Santa Catarina ......................... 290

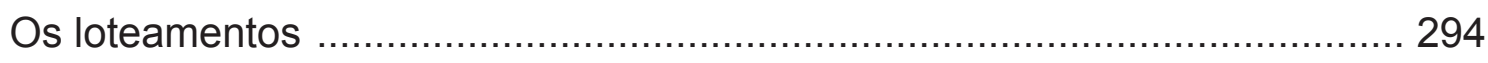

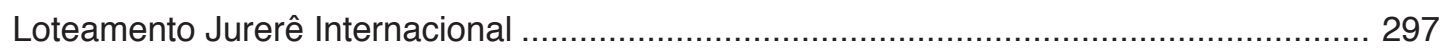

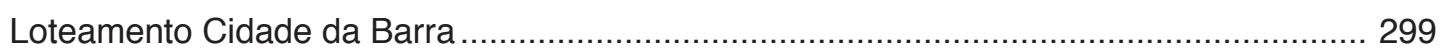

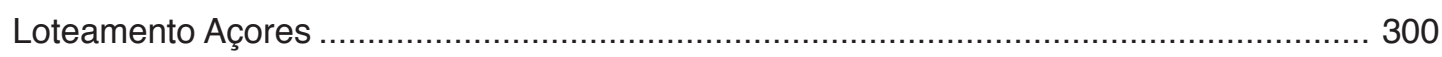

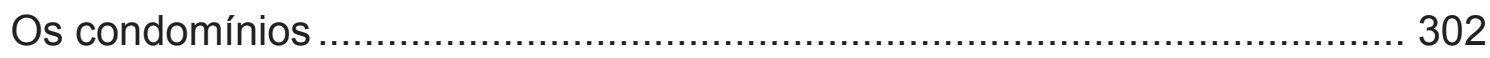

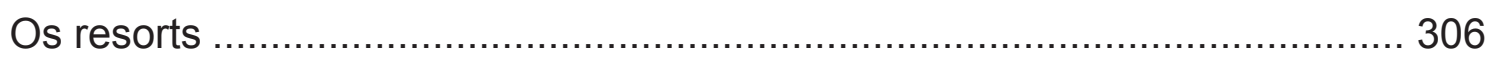

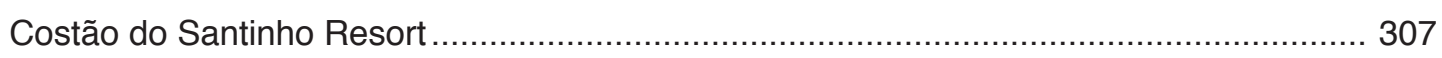

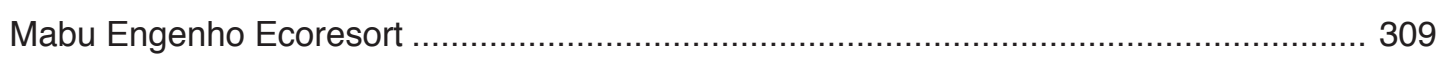

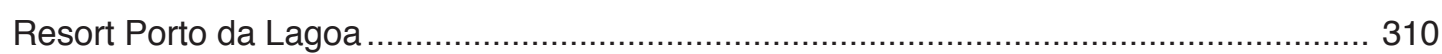

Hotéis de balneários na paisagem da llha .............................................. 311

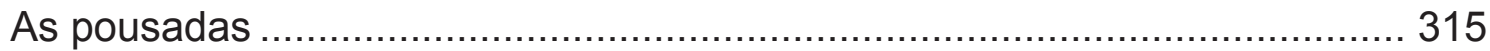

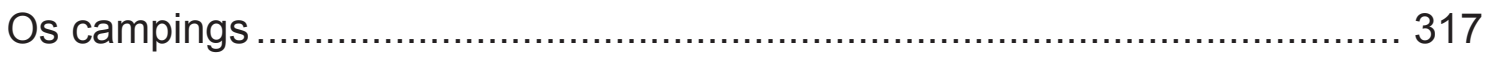

Camping da CIDASC (Companhia de Integração e

Desenvolvimento da Agricultura do Estado de Santa Catarina) ....................................... 318

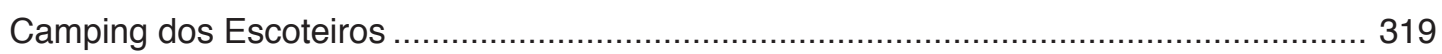

5.4. Considerações evidentes sobre a paisagem ………………………...... 319

\section{CAPÍTULO VI}

EM BUSCA DE UM MODELO

TERRITORIAL PARA O DESENVOLVIMENTO

TURÍSTICO NA ILHA DE SANTA CATARINA ................................ 322

PARTE IV: CONCLUSÃO E BIBLIOGRAFIA ...................................340

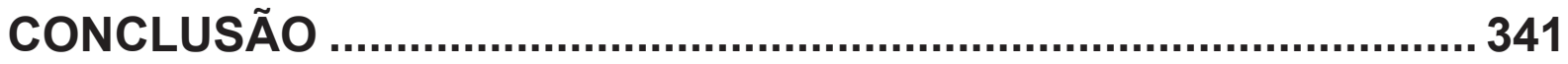

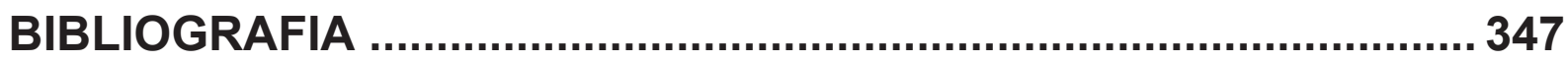

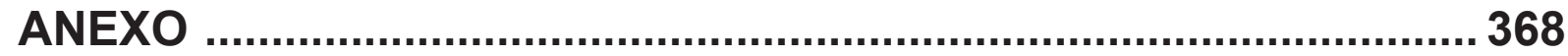




\section{LISTA DE FIGURAS}

Figura 2.1: Mapa da formação geológica da costa catarinense ............................. 85

Figura 2.10: Planície de restinga na Praia da Lagoinha do Leste .......................... 94

Figura 2.11: Campos de dunas fixos e semi-fixos da praia da Joaquina .................. 95

Figura 2.12: Mangues e Dunas na llha de Santa Catarina. ..................................... 95

Figura 2.13: Mangue do Itacorubi, já cercado pela urbanização e cortado pelo siste-

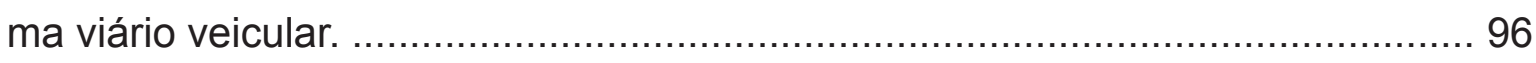

Figura 2.14: Mangue na Bacia do Rio Ratones. ……............................................ 96

Figura 2.15: Lagoa da Conceição. ................................................................. 97

Figura 2.16: Ilha do Francês em frente ao

promontório que divide Jurerê e Canavieiras .................................................. 98

Figura 2.17: Vista da Baía Norte em primeiro plano e da Baía Sul ao fundo, com a urbanização da parte continental da cidade .................................................... 99

Figura 2.18: Praia de Naufragados no extremo sul da Itha.................................. 100

Figura 2.19: Praia da Lagoinha, norte da ilha.

Em segundo plano a Praia de Canasvieiras................................................. 100

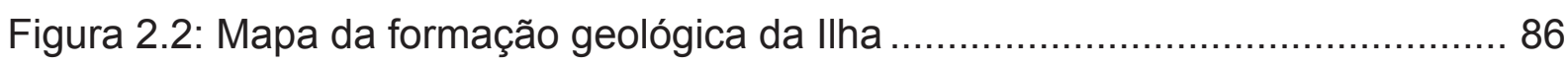

Figura 2.20: Costão no sul da llha de Santa Catarina ........................................ 101

Figura 2.22: Desenho de esquema de bacias de inundação e anfiteatro de morros .... 103

Figura 2.3: Bacias Hidrográficas da Ilha de Santa Catarina. .................................... 87

Figura 2.4: Imagem da região da cidade de Florianópolis,

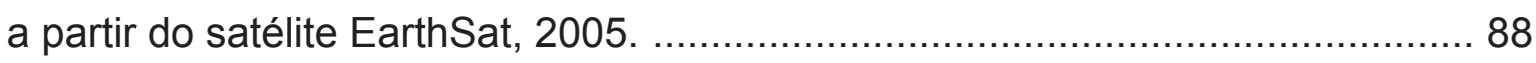

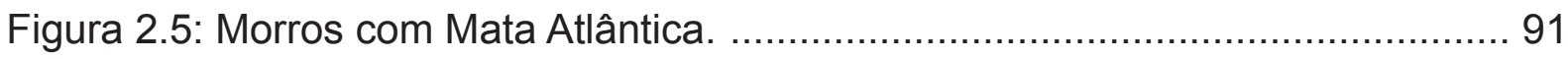

Figura 2.6: Morros no entorno da Lagoa da Conceição........................................ 92

Figura 2.7: Morros nas proximidades do Pântano do Sul, no sul da ilha................. 92

Figura 2.8: Planície quaternária com remanescentes de florestas e sob pressão

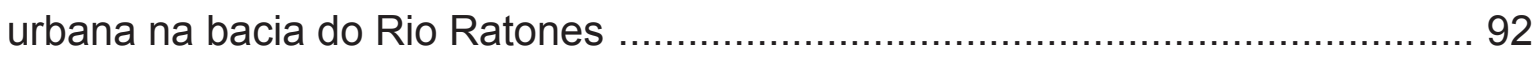

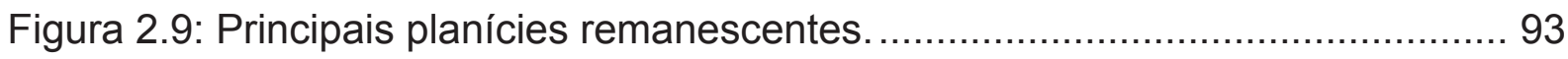

Figura 3.1: Mapa de distribuição de renda da micro-região de Florianópolis. S/escala.

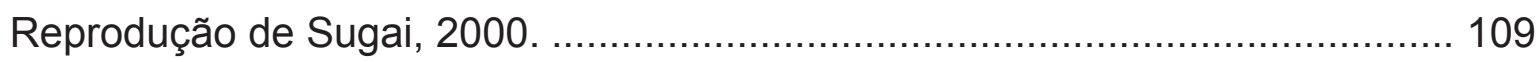

Figura 3.2: Casa na meia encosta no Ribeirão da llha. ....................................... 115

Figura 3.3: Dinâmica da dispersão colonial. ....................................................... 116 
Figura 3.4: Mapa Terras comunais na Ilha de Santa Catarina.

Fonte: reproduzido de Campos, 1991. 117

Figura 3.5: Imóvel rural em processo de valorização

imobiliária na costa lesta da Ilha 132

Figura 4.1: Turistas em Florianópolis entre 1986 e 2004. Fonte: PMF, 2005. 149

Figura 4.10: Mapas de Caracterização das Zonas

e Centros turísticos do PDT - IPUF, 1999. S/escala 173

Figura 4.11: Sistema viário principal. Fonte: IPUF. 193

Figura 4.12: Reprodução s/escala Plano Diretor do Campeche, IPUF, 1997 206

Figura 4.13: Reprodução s/escala do Plano Diretor da

Planície do Campeche. Substitutivo da Comunidade, 2000. 207

Figura 4.14: Reprodução do Plano Diretor de Urbanização

Específica do Pântano do Sul. Consórcio entre a comunidade e IPUF. 209

Figura 4.2: Turistas nacionais em Florianópolis

entre 1986 e 2004. Fonte: PMF, 2005. 149

Figura 4.3: Turistas estrangeiros em Florianópolis

entre 1986 e 2004. Fonte: PMF, 2005. 150

Figura 4.4: Receita estimada (em US\$) com turismo

em Florianópolis entre 1986 e 2004. Fonte: PMF, 2005. 153

Figura 4.5: Reprodução de mapa analítico do PDB, IPUF, 1985. S/escala. 163

Figura 4.6: $1^{\circ}$ e $2^{\circ}$ Modelos Teórico desenvolvidos pelo IPUF para o PDB-85, onde se destaca a ampliação da área de expansão urbana em direção à planície do Campeche. S/escala. Fonte: IPUF 164

Figura 4.7: Mapa sem escala da divisão das Unidades Espaciais de Planejamento. IPUF, 1985. Montagem a partir de mapa original na escala 1/25000. 166

Figura 4.8: Zonas turísticas segundo o Plano

Diretor dos Balneários. Fonte: IPUF, 1985. 169

Figura 4.9: Fragmento do Plano Diretor dos

Balneários de 1985. Fonte: IPUF, 1985. 171

Figura 5.1: Mapa sobre aerofoto de 1938. 216

Figura 5.10: Vista da Av. Beira Mar Norte, com edificações verticalizadas. 241

Figura 5.100: Vista do loteamento a partir do sudeste. 299

Figura 5.101: Vista do Loteamento a partir do norte. 299 
Figura 5.102: Situação do loteamento Açores. 300

Figura 5.103: Vista geral do loteamento, com floresta

quaternária em segundo plano e morros em terceiro plano. 301

Figura 5.104: Vista geral do loteamento evidenciando o adensamento na orla. .... 301

Figura 5.105: Situação de condomínio na praia Mole. 304

Figura 5.106: Vista da entrada de condomínio fechado na praia Mole. 304

Figura 5.107: Vista do Condomínio evidenciando o

excessivo adensamento e a distribuição espacial inadequada. 304

Figura 5.108: Vista de entrada de condomínio fechado. 305

Figura 5.109: Situação de condomínios na Ponta das Canas. 305

Figura 5.11: Vista do centro e bairros continentais,

com a conurbação com os municípios vizinhos.

Figura 5.110: Vista de condomínio na Ponta das Canas. 305

Figura 5.111: Condomínio vertical com muita evidência em promontório em Jurerê. 305

Figura 5.112: Vista do Resort Costão do Santinho e entorno. 309

Figura 5.113: Vista do Resort Costão do

Santinho evidenciando a superposição ao morro das Aranhas. 309

Figura 5.114: Vista lateral do resort. 309

Figura 5.115: Vista da região de implantação do Ecoresort Mabu. 310

Figura 5.116: Implantação do Ecoresort Mabu. 310

Figura 5.117: Vista Geral do empreendimento

que se destaca do entorno pela altura dos prédios. 311

Figura 5.118: Vista da frente do resort. 311

Figura 5.119: Vista de hotel com altura média na orla da Canasvieiras. 314

Figura 5.12: Unidade de Paisagem Sacos dos Limões-Costeira. 242

Figura 5.120: Vista de hotel em altura na orla da praia dos Ingleses. 314

Figura 5.121: Vista de hotel com altura média em rua interna de Canasvieiras. .... 314 Figura 5.122: Vista de pousada com edificações isoladas em encosta, com baixo impacto na paisagem.

Figura 5.123: Vista de pousada com edificações semi-isoladas e médio impacto na paisagem.

Figura 5.124: Vista de pousada em encosta com impacto similar ao entorno. 
Figura 5.125: Situação do Camping da

CIDASC em meio ao Parque Florestal do Rio Vermelho. 318

Figura 5.126: Vista do interior do Camping da CIDASC. 318

Figura 5.127: Vista do acesso ao Camping da CIDASC. 318

Figura 5.128: Principais sistemas naturais e pressões urbanasa. 319

Figura 5.13: Vista da Costeira do Pirajubaé,

mostrando aterro novo e encostas ocupadas. 244

Figura 5.14: Vista da ocupação do morro da Costeira. 244

Figura 5.15: Unidade de Paisagem Saco Grande-Monte Verde. 245

Figura 5.16: Vista da rodovia SC-401 que liga o centro às praias do norte da llha..... 247

Figura 5.17: Vista da rodovia SC-401 com

comércio e serviços de médio porte nas laterais. 247

Figura 5.18: Vista do Mangue do Saco Grande, com urbanização próxima e sem amortecimento. 247

Figura 5.19: Unidade de Paisagem Santo Antônio-Sambaqui. ............................. 248

Figura 5.2: Mapa sobre aerofoto de 1957 217

Figura 5.20: Vista do núcleo urbano de

Santo Antônio envolvido pela expansão urbana recente. 250

Figura 5.21: Vista da ponta do Sambaqui. 250

Figura 5.22: Vista de condomínio fechado na orla. 250

Figura 5.23: Vista da rodovia SC-401 na U.P. 251

Figura 5.24: UP Ratones-Vargem Grande. 251

Figura 5.25: Vista da foz do Rio Ratones. 253

Figura 5.26: Vista da planície com as bacias dos rios Papaquara e Ratones. 253

Figura 5.27: Vista de promontório na U.P. com significativa cobertura vegetal. ..... 254

Figura 5.28: Vista de área rural na planície da Vargem Grande. 254

Figura 5.29: Vista de via local na Vargem Grande. 254

Figura 5.3: Mapa sobre aerofoto de 1977 218

Figura 5.30: Unidade de Paisagem Jurerê-Daniela. 255

Figura 5.31: Vista de Jurerê com loteamentos em primeiro plano. 257

Figura 5.32: Vista da ponta da Daniela, ocupada por loteamento sobre restinga..... 257

Figura 5.33: Vista de Jurerê e promontório que separa da praia da praia do Forte. ... 257

Figura 5.34: Vista da orla praiana em Jurerê. 258 
Figura 5.35: Vista do Forte de São José da Ponta Grossa.................................. 258

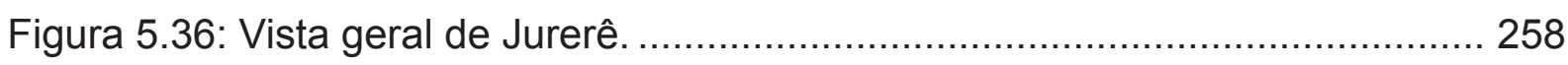

Figura 5.37: Unidade de Paisagem Canasvieiras-Ponta das Canas ..................... 259

Figura 5.38: Vista de Canasvieiras e promontório que separa de Jurerê. .............. 260

Figura 5.39: Vista do promontório entre Canasvieiras e Jurerê............................... 261

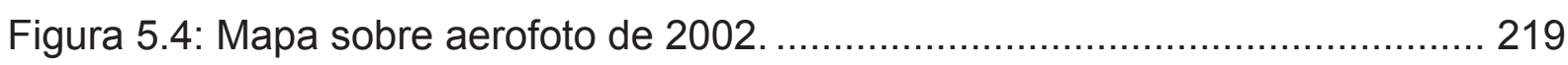

Figura 5.40: Vista da ocupação turística no promontório...................................... 261

Figura 5.41: Vista da Ponta das Canas e ocupação

turística sem zona de amortecimento em relação à restinga recente. ............... 261

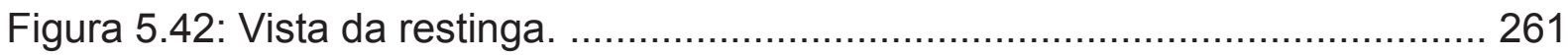

Figura 5.43: Unidade de Paisagem Lagoinha-Praia Brava................................... 262

Figura 5.44: Vista da Praia Brava. ................................................................ 263

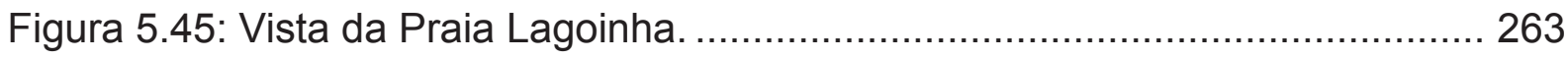

Figura 5.46: Vista da Praia Brava nos anos 1980 ........................................... 264

Figura 5.47: Vista praia da Lagoinha com urbanização sobre restinga. ................. 264

Figura 5.48: Unidade de Paisagem Ingleses-Santinho...................................... 264

Figura 5.49: Vista da praia dos Ingleses e região. A presença

das dunas restringiu em parte a maior expansão dos assentamentos............... 266

Figura 5.5: Evolução das áreas homogêneas.................................................. 225

Figura 5.50: Vista da região norte de Ingleses com condomínios em média altura. ... 266

Figura 5.51: Vista do mosaico de restinga,

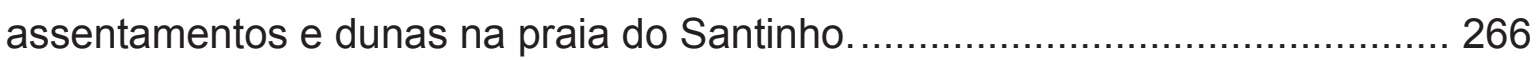

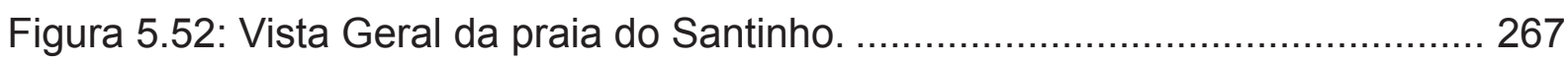

Figura 5.53: Vista da região sul da praia do

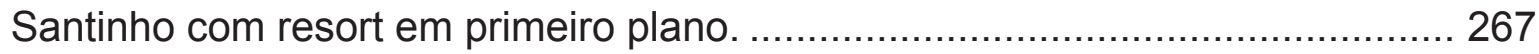

Figura 5.54: Unidade de Paisagem Rio Vermelho ............................................ 267

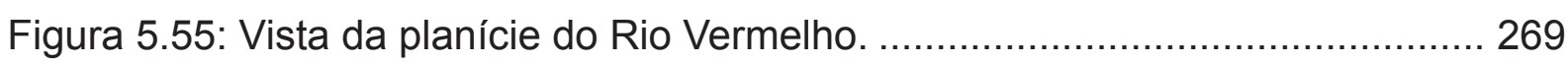

Figura 5.56: Vista da região norte do Rio Vermelho limítrofe às dunas. ................. 270

Figura 5.57: Vista das marcas da estrutura

fundiária colonial orientando o subparcelamento. ........................................... 270

Figura 5.58: Vista de via secundária na U.P. .................................................. 270

Figura 5.59: Vista da SC-406 em meio ao Parque florestal do

Rio Vermelho, com vegetação exótica fechando a perspectiva. 
Figura 5.6: Unidades Territoriais. 230

Figura 5.60: Unidade de Paisagem Lagoa da Conceição-Barra da Lagoa, ............ 271

Figura 5.61: Vista do núcleo urbano da Lagoa da Conceição.

Figura 5.62: Vista da Lagoa da Conceição evidenciando o mosaico da paisagem. ... 274

Figura 5.63: Silhueta de trecho urbanizado na Lagoa da Conceição. 274

Figura 5.64: Vista dos morros da Praia Mole e Barra da Lagoa. 274

Figura 5.65: Vista de condomínio fechado horizontal na praia Mole. 274

Figura 5.66: Vista de casa colonial tradicional. A placa no poste convida

a visitar evento de decoração apelando para praia da Polinésia Francesa. 274

Figura 5.67: Vista de casa tradicional em

lote subparcelado em direção à encosta. 275

Figura 5.68: Vista do canal da Barra da Lagoa já bastante ocupado na orla. ........ 275

Figura 5.69: Vista da Barra da Lagoa com expansão por loteamento residencial. ..... 275

Figura 5.7: Esboço da divisão em Unidades de Paisagem................................... 236

Figura 5.70: Vista do núcleo urbano da Barra da Lagoa. .................................... 275

Figura 5.71: Unidade de Paisagem Planície do Campeche. ................................ 276

Figura 5.72: Vista geral do pontal do Campeche. ……................................... 278

Figura 5.73: Vista do parcelamento na região da região leste do Campeche. ....... 278

Figura 5.74: Vista geral da praia do Campeche............................................ 279

Figura 5.75: Vista do padrão de ocupação suburbana na região do Campeche. ... 279

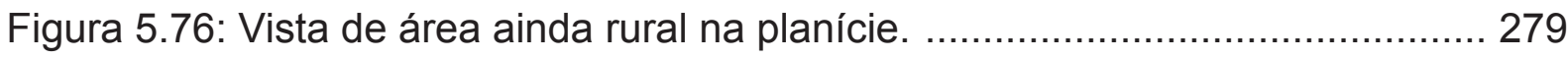

Figura 5.78: Unidade de Paisagem Armação-Peri.............................................. 280

Figura 5.79: Vista da praia da Armação com a

Lagoa do Peri e morros do Parque ao fundo. .................................................. 282

Figura 5.8: Unidade de Paisagem Centro-Trindade ......................................... 237

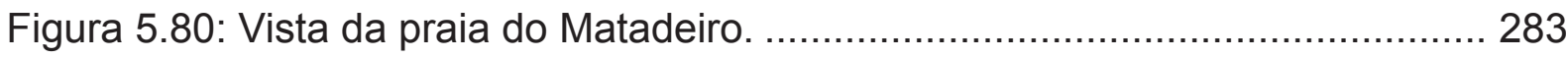

Figura 5.81: Unidade de Paisagem Pântano do Sul. ........................................... 283

Figura 5.83: Vista da planície do Pântano do Sul. ............................................... 286

Figura 5.84: Vista do núcleo urbano do Pântano do Sul...................................... 286

Figura 5.85: Vista de área rural na planície,

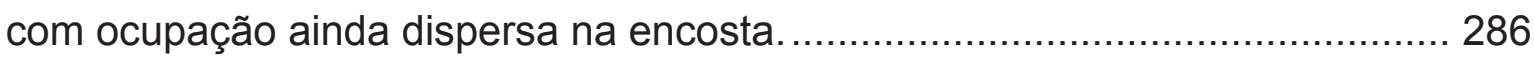

Figura 5.86: Unidade de Paisagem Ribeirão da Ilha. ......................................... 287

Figura 5.87: Vista da orla da U.P. na baía sul. ............................................... 289 


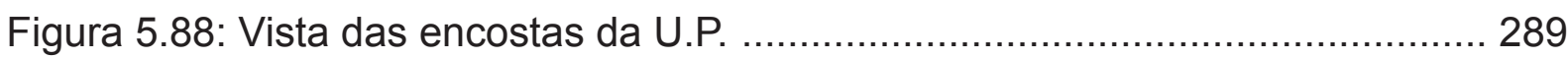

Figura 5.89: Vista da ponta do Caiacangaçú. ............................................... 289

Figura 5.9: Vista do centro insular e pontes. $O$ aterro afastou

o centro do mar e facilitou a circulação de veículos.

Figura 5.90: Vista da praia dos Naufragados que

faz parte do Parque Estadual da Serra do Tabuleiro.

Figura 5.91: Vista da região insular e continental do

Parque da Serra do tabuleiro. 289

Figura 5.92: Recorte do Plano Diretor com zonas turísticas ATR e ATH e ATE...... 292

Figura 5.93: Situação do Loteamento Juererê Internacional à esquerda da foto. .. 297

Figura 5.94: Vista geral a partir do oeste do loteamento Jurerê Internacional. ...... 298

Figura 5.95: Vista a partir do norte do loteamento

Jurerê Internacional, com planícies ao fundo. 298

Figura 5.96: Vista de zona residencial

adensada recentemente implantada no loteamento. 298

Figura 5.97: Vista de novas áreas de comércio no loteamento. 298

Figura 5.98: Vista do eixo comercial e de serviços -

Open Shopping - do loteamento. 298

Figura 5.99: Situação do loteamento Cidade da Barra à esquerda da foto. 299 


\section{LISTA DE QUADROS}

Quadro 4.1: Áreas funcionais e índices urbanísticos do Plano Diretor dos Balneários-85 para no município de Florianópolis 170

Quadro 4.2: Áreas destinadas ao uso turístico (em hectares). Fonte: IPUF/1998 . 175 Quadro 4.3: Áreas não destinadas especificamente ao uso turístico (em hectares). Fonte: IPUF/1998. 175

Quadro 4.4: Incentivos para a construção de hotéis em Florianópolis. Comparação dos limites para ocupação para hotéis e outros usos. Fonte: IPUF/1998.

Quadro 5.1: Quadro de Unidades de Território e Unidades de Paisagem 235 


\section{ABREVIATURAS}

ABIH - Associação Brasileira da Indústria Hoteleira;

ACIF - Associação Comercial e Industrial da Grande Florianópolis;

AGLURB - Aglomerado Urbano de Florianópolis;

AER - Área de Exploração Rural;

AlH - Área de Incentivo a Hotelaria;

AMC - Área Mista Comercial;

AMS - Área Mista de Serviços;

AMOLA - Associação de Moradores da Lagoa da Conceição;

AMR - Área Mista Residencial;

APC - Área de Preservação Cultural;

APL - Área de Preservação Limitada;

APP - Área de Preservação Permanente;

ARE - Área Residencial Exclusiva;

ARP - Área Residencial Predominante;

ATE - Área Turística Exclusiva;

ATR - Área Turística Residencial;

BADESC - Banco para o Desenvolvimento do Estádio de Santa Catarina;

BB - Banco do Brasil;

BESC - Banco do Estado de Santa Catarina;

BIRD - Banco Interamericano de Desenvolvimento;

CASAN - Companhia de Águas e Saneamento de Santa Catarina;

CDL - Câmera de Dirigentes Lojistas;

CEF - Caixa Econômica Federal;

CELESC Centrais Elétricas de Santa Catarina;

CEPAL - Comissão de Estudos para a América Latina;

CIRM - Comissão Interministerial de Recursos do Mar;

CITUR - Companhia de Turismo e Empreendimentos de Santa Catarina;

CMMDA - Comissão Mundial sobre o Meio Ambiente;

CMTur - Conselho Municipal de Turismo;

CNDU - Conselho Nacional de Desenvolvimento Urbano;

COMCAP - Companhia de Melhoramentos da Capital; 
CONAMA - Comissão Nacional de Meio Ambiente;

COTESPHAN - Comissão Técnica do Serviço do Patrimônio Histórico, Artístico e Natural do Município;

CVB - Convention Visitors Bureau de Florianópolis;

DEATUR - Departamento Autônomo de Turismo de Florianópolis;

DIRETUR - Diretoria Municipal de Turismo;

ELETROSUL - Centrais Elétricas do Sul do Brasil;

EMBRATUR - Empresa Brasileira de Turismo, atual Instituto Brasileiro de Turismo;

ESPLAN - Escritório Catarinense de Planejamento;

FATMA - Fundação de Amparo à Tecnologia e ao Meio Ambiente do Estado de Santa Catarina;

FISET - Fundo de Investimento Setorial do Turismo;

FLORAM - Fundação Municipal de Meio Ambiente;

FUNGETUR - Fundo Geral de Turismo;

GZT - Sociedade Alemã de Cooperação Técnica;

GZT - Sociedade Alemã de Cooperação Técnica;

IBAMA - Instituto Brasileiro de Meio Ambiente e Recursos Naturais Renováveis;

IBDF - Instituto Brasileiro de Desenvolvimento Florestal;

IBGE - Fundação Instituto Brasileiro de Geografia e Estatística;

IHGSC - Instituto Histórico e Geográfico de Santa Catarina;

IPHAN - Instituto do Patrimônio Histórico e Artístico Nacional;

IPTU - Imposto Predial e Territorial Urbano;

IPUF - Instituto de Planejamento Urbano de Florianópolis;

MDU - Ministério de Desenvolvimento Urbano e Meio Ambiente;

MEC - Ministério de Educação e Cultura;

MinC - Ministério da Cultura;

OMT - Organização Mundial do Turismo;

ONU - Organização das Nações Unidas;

PDB - Plano Diretor dos Balneários;

PDDS - Plano Diretor do Distrito Sede;

PDT - Plano de Desenvolvimento Turístico;

PDTAUF - Plano de Desenvolvimento Turístico do Aglomerado Urbano de Florianópolis;

PLANET - Plano Estratégico de Turismo para Florianópolis; 
PMF - Prefeitura Municipal de Florianópolis;

PNGC - Plano Nacional de Gerenciamento Costeiro;

PNUMA - Programa das Nações Unidas para o Meio Ambiente;

SANTUR - Santa Catarina Turismo;

SEFIN - Secretaria da Fazenda e Finanças de Florianópolis;

SEPHAN - Serviço do Patrimônio Histórico e Artístico e Natural do Município;

SETUR - Secretaria de Esporte Turismo e Cultura de Florianópolis;

SHBRS - Sindicato dos Hotéis, Bares, Restaurantes e Similares da Grande Florianópolis;

SINDUSCON - Sindicato da Indústria da Construção Civil da Grande Florianópolis;

SUDESUL - Superintendência de Desenvolvimento da Região Sul;

SUSP - Secretaria de Urbanismo e Serviços Públicos;

TURESC - Turismo E Empreendimentos de Santa Catarina;

UDESC - Universidade do Estado de Santa Catarina;

UEP - Unidade Espacial de Planejamento;

UIOOT - União Internacional dos Órgãos Oficiais de Turismo, atual OMT;

UFSC - Universidade Federal de Santa Catarina;

UNCLOS - Conferência das Nações Unidas sobre o Direito do Mar;

UNESCO - United Nation Educational, Scientific and Cultural Organization;

USP - Universidade Federal de Santa Catarina;

WOT - World Tourism Organization. 


\section{INTRODUÇÃO}

As cidades brasileiras vêm enfrentando dificuldades de financiamento em sua administração, fazendo com que a busca de alternativas econômicas para a sustentabilidade dos municípios seja uma metas das mais desejadas de alcançar. Em Florianópolis, capital do estado de Santa Catarina, cidade de porte médio, marcantemente terciária e localizada em grande parte em um território ecologicamente inadequado para a alocação de indústrias pesadas, possui qualidades ambientais atrativas de visitantes, o que tem possibilitado que o turismo seja visto como alternativa econômica consistente por diversos segmentos sociais preocupados com o desenvolvimento da cidade.

A apresentação do turismo na condição de indústria limpa, ainda que mascare aspectos nem sempre positivos que a sua presença implica, faz jus às características diferenciadas da atividade, que não estão diretamente associadas à poluição ambiental e à deterioração de ambientes como o são aquelas relacionadas com a indústria tradicional refletidas no caráter urbano-industrial da maior parte das metrópoles do mundo. Ainda assim, dependendo do tipo de turismo e das características do território onde ele se implanta, a atividade pode trazer problemas ambientais e entraves ao desenvolvimento.

O território do município de Florianópolis, que abrange uma pequena porção continental e a llha de Santa Catarina, é constituído por diversos ecossistemas naturais representativos do litoral brasileiro, conformando uma paisagem rica e agradável à vista de quem dela se aproxime. Além disso, a cidade tem sido transformada, de fato, desde sua ocupação pelas correntes migratórias de origem européia e que marcaram profundamente sua paisagem especialmente pela formação do espaço rural litorâneo que ainda hoje é percebido.

A paisagem resultante, caracterizada pela justaposição do modelo de assentamento colonial das correntes migratórias vindas das ilhas portuguesas do Atlântico Norte Açores e Madeira ainda no século XVIII, sobre uma configuração fisiográfica e ecológica, de difícil e escassa possibilidade de apropriação se consideradas sua fragilidade, apresenta peculiaridades que justificam o interesse turístico.

Mais recentemente, a partir de meados do século XX, as transformações sócioeconômicas estruturais no país e o incremento da acessibilidade à região, fizeram com que a cidade sofresse um processo de urbanização, tardio em relação às demais capitais de economia industrial do país, e que veio se desenvolvendo paralelamente à 
atividade turística. A urbanização e o turismo, surgindo simultaneamente no espaço e no tempo, formam um processo conhecido como urbano-turístico que, ao se expandir, se apresenta como o principal vetor das profundas alterações no território e na paisagem que a cidade vem conhecendo.

Paradoxalmente, o modelo de desenvolvimento da atividade turística e seu rebatimento no espaço, pensado e posto em prática pelas administrações públicas, tem sido estreitamente influenciado por estruturas de organização empresarial vinculadas à construção civil e à atividade imobiliária, resultando em um padrão de ocupação do território cujos custos ambientais, sociais e econômicos são tal monta que colocam em xeque o seu próprio desenvolvimento.

A rica paisagem da cidade e, especialmente, da llha de Santa Catarina, utilizada como o grande mote de atratividade de fluxos de visitantes, é elemento fundamental no desenvolvimento da atividade turística. Mas, ao mesmo tempo, tem sido relegada a mero suporte da expansão física dos assentamentos humanos, nem sempre turísticos, com perda de importantes atributos da diversidade ecológica, essenciais para o equilíbrio do ambiente, e de referências espaciais de dimensão cultural, herdados da colonização, que influem nas qualidades cênicas da paisagem.

A compreensão desta situação, a partir de uma leitura, com base em sua evolução, da paisagem em sua estrutura formal e dos processos socioeconômicos e culturais que concorrem para a sua formação, é o assunto de que trata esta tese. A partir dessa compreensão, busca diretrizes para um outro modelo de ordenação territorial em que a atividade turística possa se desenvolver tendo a consideração da paisagem como elemento principal do planejamento.

\section{Hipóteses de trabalho e objetivos}

As hipóteses deste trabalho sugiram da percepção, num primeiro momento sensitiva, e posteriormente de investigações mais sistematizadas, das transformações sócioespaciais que a região objeto de estudo tem experimentado ao longo das últimas três décadas. Parte-se de premissas que têm orientado, mais ao nível do discurso do que das ações concretas, estas transformações promovidas pela inserção do turismo no rol de atividades do município. 
A primeira premissa é de que a região de do município de Florianópolis tem alto potencial de atratividade turística em função de seu patrimônio paisagístico. A segunda é que seu patrimônio paisagístico (natural e construído) é um dos mais, senão o maior, importantes elementos de sustentação desta atratividade.

Uma terceira premissa é de que a paisagem da llha de Santa Catarina vem perdendo valores e diversidade que sustentam aquelas premissas anteriores, resultando num território em que as paisagens com alto potencial de valorização cultural (ainda que também econômica) se apresentam de forma fragmentada e outras se estruturam de modo desordenado (relacional e internamente). Isto vem ocorrendo não exclusivamente pela atividade turística em si, mas, e principalmente, pela falta de uma visão do planejamento do espaço insular que considere a preeminência da paisagem com uma perspectiva abrangente e integral do território, e que não utilize modelos e instrumentos de planejamento e de projeto tradicionais de assentamentos urbanos para o espaço turístico.

Em direção à formulação hipotética desta tese, parte-se do pressuposto de que a configuração paisagística do território, enquanto expressão da apropriação cultural de recursos naturais, é importante recurso patrimonial, com valores morfológicos passíveis de reconhecimento, de fundamental importância na atividade turística, mas também na qualidade de vida dos residentes e na afirmação de valores de identidade local.

Investigações anteriores remetem a constatações de que este recente processo de transformação urbana do município de Florianópolis, em especial de sua parte insular, tem sido impulsionado principalmente pela atividade turística. Apesar do potencial da região em atrair a atividade, especialmente pelas características que a diferenciam dos demais pólos turísticos do país e de países vizinhos na região do Rio da Prata, e em que pese existirem inúmeros planos de organização espacial e de desenvolvimento turístico em distintas esferas da gestão sócio-espacial, seu aproveitamento como base para um desenvolvimento urbano equilibrado e sustentável, discurso presente nas agendas oficiais e no ideário da sociedade local, não se concretizou até então. A hipótese central levanta, então, a seguinte questão:

O desenvolvimento urbano da cidade não tem levado em consideração, na justa medida, nem tirado partido de maneira adequada e racional do potencial turístico de seu patrimônio paisagístico (natural e cultural) para alcançar transformações sócio-espaciais que apontem para um futuro sustentável para a atividade e principalmente para a cidade. 
Uma outra hipótese, complementar a esta, é que o desenvolvimento da cidade passa pela devida compreensão do potencial de seu patrimônio paisagístico e que o seu aproveitamento de modo adequado pode alavancar transformações regionais.

Para confirmar essas hipóteses, esta tese tem como objetivo:

1. Reconhecer os principais remanescentes dos sistemas naturais que conformam o mosaico paisagístico e territorial da cidade, especialmente da llha de Santa Catarina.

2. Compreender o processo de transformação provocado pela humanização do território, vinculado à dinâmica sócio-econômica da cidade em diferentes momentos de sua formação.

3. Entender e explicar as transformações que a atividade turística vem promovendo, em diversas dimensões, na cidade e na Ilha, quais os atores envolvidos no processo, e o papel desempenhado pelos segmentos sociais diretamente ligados à questão.

4. Investigar o fenômeno turístico e as transformações que tem promovido na paisagem, em diferentes escalas de abordagem, buscando, em chave de projeto, apontar para modelo de ordenação territorial que considere a premência da paisagem no desenvolvimento sustentável da atividade.

A tese se divide em quatro partes com seis capítulos, em que são tratadas as questões relacionadas aos objetivos. A primeira parte dá coerência e consistência teórica à investigação e às reflexões levadas a cabo, e é composta pelo primeiro capítulo, que trata das bases conceituais e metodológicas adotadas no trabalho. Esse capítulo aborda, basicamente, os conceitos de ambiente, de território e de paisagem, com atenção ao potencial e às limitações do desenvolvimento sustentável, e apresenta a metodologia e instrumentos analíticos utilizados na investigação.

A segunda parte busca entender a região objeto de estudo, ou seja, a cidade de Florianópolis e a llha de Santa Catarina. É constituída por um segundo capítulo que estuda o território natural da cidade, inserido no contexto da zona costeira catarinense e brasileira e um terceiro capítulo que estuda a humanização do território, abordando os contextos socioeconômico e cultural e o rebatimento espacial provocado, em especial pela urbanização recente. Encerrando a segunda parte, o quarto capítulo trata da incorporação da atividade turística no contexto cidade, analisando o fomento, o planejamento e os impactos do processo. Aborda ainda o papel do estado, do empresariado relacionado ao turismo e dos setores organizados da sociedade reagentes ao turismo, assim como alguns conflitos decorrentes desse processo. 
A terceira parte da tese é constituída por dois capítulos. O quinto capítulo faz a leitura da paisagem em diferentes escalas, abordando a paisagem na escala do conjunto de sistemas naturais e humanos que configuram a integralidade do território da Illha de Santa Catarina, na escala das Unidades de Paisagem, porções de menor dimensão que compõem o mosaico paisagístico da cidade, e na escala dos padrões urbanos e arquitetônicos dos estabelecimentos turísticos que conforma a paisagem. sexto capítulo busca alternativa ao modelo vigente, apontando para um modelo de ordenação territorial que considere a premência da paisagem no desenvolvimento sustentável da cidade e da atividade turística.

Por fim, na última parte, a conclusão do trabalho. 


\section{PARTE I}

Bases Conceituais e Metodológicas 


\title{
CAPÍTULO I
}

\section{AMBIENTE, TERRITÓRIO E PAISAGEM: CONCEITOS E METODOLOGIAS}

\begin{abstract}
"Entendo o meio ambiente humano como o resultado das interações das sociedades humanas com o suporte: a base física e biológica que as envolve, contribuindo para este suporte, esta base, de diferentes maneiras para sua subsistência biológica e espiritual. Este suporte, base física e biológica, já tem uma história de interações: desde o aparecimento do homem é objeto da ação do homem, alterando essa base. Dai, poderá se sintetizar a concepção de ambiente como interação da sociedade com o suporte físico, quer tenha aparência comumente denominada 'natural' ou construída. A interação se dá no espaço geográfico pelas adaptações, transformações, readaptações e novas transformações das sucessivas formas encontradas, elaboradas e reelaboradas. A essas conFORMAções, conFIGURAções, carregadas da interação social com o suporte temos denominado PAISAGENS" (Magnoli, 1986, destaques da autora).
\end{abstract}

\subsection{Conceitos e referências teóricas}

Este capítulo busca o entendimento da paisagem, enquanto expressão morfológica do território e do ambiente, que permita sua inserção como aspecto fundamental nos processos de ordenamento do território, e em especial do espaço turístico com base em um desenvolvimento sustentável. Partindo da revisão da questão ambiental, discute as possibilidades e limites do desenvolvimento sustentável para em seguida abordar conceitos e noções associados aos termos território e paisagem. Finaliza buscando evidenciar o papel que assumem na feitura de planos e ações comprometidos com um desenvolvimento sustentável, dando especial atenção ao aproveitamento da paisagem enquanto recurso natural e cultural em processos de desenvolvimento turístico.

Independente das concepções que possamos ter dos termos, paisagem, território e ambiente são conceitos distintos, mas que mantêm uma determinada associação. Ambiente, segundo o Dicionário Aurélio, é o meio, conjunto de condições naturais e influências que atuam sobre os organismos vivos ou as coisas, e que os cerca ou envolve por todos os lados. Território, enquanto extensão de terra, é a expressão física do ambiente, mas pode também ser entendido como, o espaço conformado pelos hu- 
manos percebido em termos de paisagem. A paisagem, um espaço de terreno que se abrange num lance de vista (segundo o dicionário Aurélio), pode ser compreendida como um atributo do ambiente, na medida em que expressa determinado momento do meio físico e biótico.

Entretanto, numa escala mundial, a compreensão e o uso desses termos têm diferido em função do domínio de conhecimento em que são empregados, assumindo conotações afinadas com os objetivos e estudos que indivíduos, grupos e as sociedades atuais dedicam ao ambiente nos distintos níveis de informações e conhecimento em que se situam.

Atualmente, ambiente, meio, território, ecossistema e paisagem passam a ser palavras, ao fim e ao cabo, relacionadas com a discussão das prioridades utilitárias de exploração dos recursos naturais, da busca do equilíbrio ecológico, condicionadas por questões de percepção do significado que assumem. Assumindo o inter-relacionamento dos termos, iremos tratar primeiramente do entendimento e da importância atual dada ao ambiente, para depois enfocar território e paisagem.

\section{A questão ambiental}

A questão ambiental surge no cenário mundial decorrente do embate entre os processos de urbanização e a compreensão da necessidade de um melhor e mais racional aproveitamento dos recursos naturais diante da sua finitude. A compreensão da finitude dos meios e da necessidade de manejo dos recursos naturais para fins humanos, embora sempre tenha existido nem sempre exigiu ações práticas de caráter global e local como agora. Nos últimos quarentas anos as ciências do ambiente evoluíram teórica e conceitualmente, difundindo-se rapidamente pela quase totalidade das sociedades e regiões do planeta, com distintas condições de vida, consolidando uma consciência ambiental mundial.

A partir do entendimento do meio ambiente como "... a biosfera, isto é, as rochas, a água e o ar que envolvem a Terra, juntamente com os ecossistemas que eles mantém... ", incluindo também “... os recursos construídos pelo homem, tais como casas, cidades, monumentos históricos, sítios arqueológicos, os padrões comportamentais das populações - folclore, vestuário, comidas e o modo de vida em geral, que as 
diferenciam de outras comunidades" (Holder, 1991, p.19), a seguinte revisão da evolução da compreensão da temática e do movimento social em direção ao seu equacionamento busca dar consistência no esclarecimento da noção da questão ambiental que sustenta o discurso a ser adotado na tese.

A consciência da dependência da natureza se evidenciou no processo civilizatório provavelmente após a sedentarização dos grupos humanos, que passaram a perceber, de modo mais claro, a importância dos limites de exploração das regiões onde se estabeleciam. $\mathrm{Na}$ antiguidade, a cidade de Roma já experimentava os efeitos da superpopulação na estrutura urbana, com evidente degradação na qualidade de vida dos habitantes e na Idade Média surgiram evidentes sinais de uma crise urbana e ambiental.

Mas é com Renascença, especialmente no período barroco, quando ocorreram grandes transformações sócio-culturais, baseadas na nascente ciência, na mecânica de Newton e no resgate da geometria euclidiana, que se nota significativas modificações do espaço e da compreensão do tempo, ratificadas no lluminismo. E é com a revolução industrial, trazendo modernização tecnológica, sócio-econômica e sóciocultural refletindo-se na expansão dos limites territoriais das cidades, que a problemática evidencia-se.

Com o desenvolvimento da industrialização, os argumentos economicistas de conquista da natureza passam a fundamentar ${ }^{1}$ a maior parte das ações para atingir cada vez maiores níveis de progresso humano, a base de maior consumo e número de consumidores e da expansão dos limites de exploração territorial.

Nos últimos duzentos anos, a compreensão do ambiente e a noção proteção e de conservação da natureza começam a fazer parte do ideário da humanidade com ênfase e de modo explícito. Foram aguçadas correntes de pensamento de base transcendental e filosófica, surgidas inicialmente em obras literárias e artísticas, que inspiraram o nascimento de uma ética ecológica, vindo, mais tarde, a desembocar em diferentes formas de compreensão da questão ambiental e de distintas ações pragmáticas de conservação.

\footnotetext{
${ }^{1}$ Progresso e desenvolvimento econômico, conceitos instituído já na primeira revolução científica - o renascimento, significava crescimento numa direção, de modo linear e em busca de um estado de equilíbrio estático. A moderna ideologia do progresso tem seu fundamento na consolidação do imaginário da conquista da natureza pelo homem.
} 
Pensadores do início do séc. XIX como John Ruskins na Inglaterra, Violet-le-Duc na França, e Henry Thoureau, George Perkins Marsh e Frederic Law Olmsted nos EUA entre outros, passam a valorizar, ora de modo romântico, ora de modo objetivo, os fundamentos naturais, geralmente privilegiando a visão biocêntrica, em detrimento das implicações sócio-econômicas.

A valorização do retorno à natureza selvagem se contrapunha a utilização da natureza racionalizada dos jardins simétricos do barroco, e buscava o resgate de uma pureza e simplicidade de vida perdidas com os avanços tecnológicos da revolução industrial. Ao mesmo tempo em que na Inglaterra os arquitetos passam criar espaços urbanos com grande destaque para a presença da natureza, surgem nos EUA os primeiros grupos ambientalistas e naturalistas que vieram a pressionar o governo para a criação dos parques nacionais americanos ainda no século $\mathrm{XIX}^{2}$.

Entretanto, o apelo ao desenvolvimento, fundamentado em argumentos positivistas e progressistas permaneceu atraente e predominante, levando a industrialização em um ritmo acelerado, demonstrando pouca preocupação com os limites da interferência humana nos recursos naturais. Se até a segunda metade do século XX estes limites não haviam sido ultrapassados de forma perceptível pela população mundial, a partir de então este modelo de desenvolvimento passou a ser questionado por argumentos e fatos, dado que o crescimento da população mundial no pós-guerra e a expansão do capitalismo industrial acentuaram as evidências da problemática ambiental.

\section{A concepção contemporânea de conservação ambiental}

A concepção contemporânea de conservação ambiental se deve à evolução da percepção por parte das sociedades mundiais da escassez dos recursos naturais não renováveis, reiterada ao longo dos últimos séculos e intensificada há recentes quarenta anos. Estudiosos de diversas partes do mundo passam a trocar informações e experiências sobre o comportamento humano e suas relações com o ambiente e a finitude das

\footnotetext{
2 O Regent's Park (1881) de John Nash e Humphrey Repton e o Plano de Birkenhead Park (1843-1844) de Joseph Paxton, ambos em Londres, inspiraram Frederick Law Olmsted, criador do Central Park em Nova York, primeiro grande parque urbano da América. Teorias como a da evolução das espécies e outras surgidas neste século deram base à posturas e ações paradigmáticas do ambientalismo nascente como a criação dos parques de Yellowstone (1872) e Yosemite (1890) nos EUA.
} 
fontes de recursos consumidos pelo modelo de desenvolvimento das nações industrializadas, visando propostas que apontem na direção de possíveis soluções do problema.

Um importante passo no reconhecimento que os problemas ambientais são de interesse mundial foi a criação do Clube de Roma em 1968, que buscava soluções para os já graves problemas ambientais. O ano de 1970 é declarado pela ONU o Ano do Meio Ambiente, propondo reflexões e ações que equacionassem a questão ambiental e a perspectiva mundial de proteção de recursos naturais escassos.

O informe Limites do Crescimento ${ }^{3}$, apresentado ao Clube de Roma em 1971 propunha imediata paralisação do crescimento econômico e populacional - crescimento zero, como forma de proteger os recursos naturais não renováveis da terra e a estabilidade dos sistemas naturais. Esta postura deixava de considerar a perspectiva de países em vias de desenvolvimento, cuja pobreza trazia tanto ou mais problemas ambientais quanto os desenvolvidos.

Já em 1971, em Founeux na Suíça, o Painel Técnico de Preparação da Conferência de Estocolmo, equaciona o problema ambiental a partir de dois vetores: o da falta de desenvolvimento, onde a pobreza e a poluição e as altas taxas de crescimento populacional já comprometiam regiões e metrópoles de países não desenvolvidos; e o do desenvolvimento, decorrente da industrialização, com características de exagerado consumo de energia e matéria e altos índices de poluição.

Em Estocolmo, 1972, na Conferência das Nações Unidas para Desenvolvimento e o Meio Ambiente Humano, o estreito relacionamento entre desenvolvimento e ambiente leva a proposição de metas sócio-ambientais, considerando necessidades de crescimento econômico de países em vias de desenvolvimento como forma de reduzir problemas ambientais. Introduz a noção de responsabilidade ambiental com a correção de danos causados pelo desenvolvimento econômico de países ricos, e propondo a estabilização populacional em médio prazo ${ }^{4}$.

\footnotetext{
${ }^{3}$ Este informe, produzido sob a coordenação de D. Meadows do MIT (Massachusetts Institut of Tecnology), partia de uma metodologia que incluía complexos modelos matemáticos aplicados à dinâmica de sistemas. Basicamente, concluía que, mantido o ritmo de crescimento demográfico e econômico assumido pela maioria das nações desenvolvidas e pretendido pelas em desenvolvimento, as conseqüências seriam desastrosas para a população mundial devido à escassez de recursos energéticos e materiais, deteriorados pela poluição, contaminação e extinção das fontes, entre outras causas.

${ }^{4}$ No decorrer da década, com a revisão da máxima de crescimento zero, o Informe Brant (1980) chega a propor a transferência de recursos em larga escala de países do primeiro para países do terceiro mundo como modo de mitigar problemas ambientais decorrentes da pobreza.
} 
Um dos resultados mais expressivos da conferência foi a criação do Programa das Nações Unidas para o Meio Ambiente - PNUMA, com sede mundial em Nairobi e diversas sub-sedes (Brasília inclusive), que analisa e fomenta atividades de proteção ambiental nos países membros da ONU. A reunião de Montreal de 1976, além de corroborar as metas anteriores, destacou a interdependência entre campo e cidade, postulando uma maior consideração desta relação nos debates ambientais.

Os anos 1980 viram surgir diferentes organizações de caráter ambiental, umas com visão biocêntrica, outras mais sócio-cêntricas, e ao final da década algumas vertentes se apresentavam como as mais atuantes e influentes: a coordenada pelo Earth First, cuja ótica biológica prevalece, e propõe a redução drástica da população e desocupação de ecossistemas ameaçados; e uma segunda corrente, representada pelas idéias mais politizadas defendidas pelo Partido Verde alemão - nova ética ecológica e não crescimento populacional, com redistribuição de poder e realocação de recursos produtivos; e uma terceira que busca a sustentabilidade ambiental e social, passando pelo planejamento familiar, pelo repasse de recursos de sistemas produtivos predatórios para sistemas produtivos sustentáveis.

De certo modo, estas vertentes se fizeram notar também na América Latina e no Brasil (Viola, 1990) com repercussões na conscientização e irradiação da temática, influindo em processos de produção do espaço. Uma posição aparentemente conciliadora das anteriores surge de discussões promovidas de modo abrangente a diferentes setores sociais e regiões pela Comissão Mundial sobre o Meio Ambiente e Desenvolvimento. Criada pelo PNUMA em 1983, a CMMDA, coordenada pela primeira ministra da Noruega, Gro Harlem Brundtland, finalizou o relatório - Nosso Futuro Comum em 1987.

Entre estatísticas e relatos dos avanços e recuos no controle do desenvolvimento mundial, decorrentes dos problemas ambientais, destaca-se a incorporação de modo oficial pela ONU da expressão Desenvolvimento Sustentável ${ }^{5}$, onde o meio ambiente passa ser considerado, senão o principal, um limitador do crescimento em geral e do progresso econômico.

\footnotetext{
5 O conceito que deu sustentação ao termo se baseou em um outro - o de ecodesenvolvimento, surgido na reunião de Founeux, de 71, baseado na teoria sistêmica aplicada a biologia, onde se considera a potencialidade dos ecossistemas, inclui a participação dos diferentes grupos sociais nas decisões e a redução de desperdícios e reciclagem de resíduos. Sustentabilidade tem origem no conceito ecológico de comportamento prudente; produção ótima sustentável e em economia a renda é uma orientação para uma conduta prudente considerando-se o consumo máximo em determinado período de tempo sem eliminar o capital. A escassez de recursos naturais leva a extensão do critério de sustentabilidade do capital produzido para incluir o capital natural.
} 
A Assembléia Geral da ONU convoca em 1989 um encontro das nações membro para a elaboração de estratégias de reversão dos processos de degradação ambiental. O resultado acontece na Conferência das Nações Unidas sobre O Meio Ambiente e Desenvolvimento, em 1992 no Rio de Janeiro, conhecida como a Cúpula da Terra, onde é apresentada AGENDA 21 (Declaração do Rio).

Pactuada por cento e setenta países, a AGENDA 21 propõe 27 princípios, com direitos e deveres, no sentido de atingir de maneira global o Desenvolvimento Sustentável. Uma das principais conclusões dessa reunião é a compreensão que somente decisões globais e resultantes da associação de esforços, envolvendo solidariedade e cooperação entre os blocos Norte e Sul, seria possível aproximar-se do Desenvolvimento Sustentável. Aponta que a responsabilidade de conservação do ambiente e dos recursos naturais é comum a todos, mas distingue graus diferenciados de degradação dos diferentes blocos.

Alerta que a humanidade chegou a um momento de decisão quanto ao futuro desejado - mantendo o modelo político econômico vigente, com aprofundamento das diferenças entre os países, a fome e a pobreza e a conseqüente destruição dos ecossistemas dos quais depende a vida na terra; ou buscando paradigmas ético-ecológicos de inclusão social e econômica das populações dos países, especialmente os pobres, com a preocupação de preservar o meio ambiente.

Aponta os modelos de produção e consumo adotados principalmente por países ricos são tidos como causadores da degradação ambiental em larga escala além de aprofundar as diferenças e desequilíbrios entre ricos e pobres e, num esforço coletivo mundial, merecem ser transformados em modelos de desenvolvimento ecologicamente racionais, energicamente eficientes e socialmente inclusivos, buscando o desenvolvimento sustentável.

O documento dedica especial atenção às áreas urbanizadas por perceber que é nelas que a maior parte da população mundial se reproduz e onde se realiza cerca de $60 \%$ da riqueza bruta mundial, mas acarretando imensos problemas que podem levar a insustentabilidade sócio-ambiental. Incentiva a adoção do planejamento e da ordenação territorial sustentável, de sistemas sustentáveis de energia e transporte em assentamentos humanos, com novos paradigmas urbanísticos que tratem conjuntamente a questão ecológica e a social. 
Propõe planejamento de cidades médias em regiões com urbanização desconcentrada, a partir da troca de experiências, técnicas e de aporte financeiro, criando condições do surgimento de redes de cidades sustentáveis em escala global, evitando a migração para as grandes cidades e promovendo oportunidades em áreas não urbanas.

A Comissão de Desenvolvimento e Meio Ambiente da América Latina e do Caribe, criada nos anos 1980 pelo Banco Interamericano de Desenvolvimento e pelo Programa das Nações Unidas para o Desenvolvimento, reforçava os argumentos da AGENDA 21. Em um documento intitulado Nossa Própria Agenda (1992), especialmente na seção 3.1.2, trata da deterioração ambiental nos assentamentos humanos da região, notadamente nos centros urbanos, resultado da urbanização dos últimos 50 anos e aponta para a possibilidade de um colapso urbano.

Destaca que os principais problemas ambientais que assolam os assentamentos urbanos na A. L. se referem à falta de serviços sanitários, deficiência de moradia, serviços básicos e ambientes de trabalho; falta de segurança; e poluição doméstica e industrial, além da vulnerabilidade a acidentes e desastres naturais, e que estes devem ser estudados e equacionados nos diferentes níveis geográficos ou escalas de abordagem.

Critica os modelos de desenvolvimento adotados na região e relaciona a industrialização, as altas concentrações de população e a baixa qualidade sanitária e urbana destes assentamentos a fatores de pressão no ambiente, destacando estes aspectos como os maiores desafios, especialmente os dejetos humanos. Percebe ainda que o modelo industrial empobreceu o campo e inchou as cidades, mas mantém esperança na capacidade de absorção da cidade dos excessos populacionais para a solução da própria problemática. Por fim, acredita que um provável colapso poderá ser evitado a partir da gestão aprimorada do ambiente, por meio de suportes e assistência técnica e financeira dos países desenvolvidos ${ }^{6}$.

Também em 1992 a Convenção das Nações Unidas Sobre Mudanças no Clima recomendou ações enérgicas no sentido de inverter a tendência de mais de um século dos países industrializados no incremento das emissões de gases que provocam o

\footnotetext{
${ }^{6}$ Como por exemplo, a implementação de cadastro e coleta de impostos, a transferência e o desenvolvimento de tecnologia de controle e reciclagem doméstica e industrial, bem como a disponibilização de créditos.
} 
efeito estufa. A conseqüência desta recomendação foi a reunião de 55 países, concluindo pela necessária redução de emissão destes gases, sendo protocolada em 1997, na cidade japonesa de Kyoto ${ }^{7}$, o protocolo se compromete a reduzir, entre o período de 2008 até 2012, em 5\% os níveis em relação ao ano de referência de 1990.

Hoje a consciência da importância do ambiente na manutenção da vida no planeta já é tão difundida e aceita que a necessidade de proteção e conservação do ambiente, notadamente de seus patrimônios naturais e culturais, é parte integrante de programas de desenvolvimento de nações e dos requisitos exigidos pelas agências de fomento.

Pelo menos ao nível do discurso, a adoção de padrões éticos no que se refere à interferência antrópica nos biomas terrestres, já consegue ditar "preceitos de preservação e conservação nas agendas de desenvolvimento sustentável prognosticadas para o século XXl" (Franco, 2001, p.33).

\section{Considerações sobre desenvolvimento e sustentabilidade}

O conceito de Desenvolvimento Sustentável, termo intensamente utilizado e debatido nos meios acadêmicos, políticos e sociais e que se consolida na segunda metade do século $X X$, se baseia na noção de sustentabilidade assentada em três fundamentos: conservação de sistemas ecológicos sustentadores da vida e biodiversidade; garantia de sustentabilidade dos usos que utilizam recursos renováveis e manutenção das ações humanas dentro da capacidade de carga dos ecossistemas sustentadores (Franco, 2001, p.26).

Surge em um contexto em que crescimento populacional, diferenças de poder econômico e político e a deterioração ambiental estão relacionados de modo interdependente e circular, um influindo nos demais fenômenos, todos espacialmente impactantes e perceptíveis em ambientes urbanos, local de concentração das contradições do processo de produção do espaço e de suas externalidades negativas.

O desenvolvimento sempre esteve associado à idéia de progresso material das sociedades, grupos e indivíduos, de modo geral com o aproveitamento indiscriminado dos recursos disponibilizados pela natureza, e nem sempre com uma noção de justiça

\footnotetext{
7 O Protocolo de Kyoto foi aberto para assinaturas em 1998, e mesmo com a negativa do mais importante emissor de gases decorrentes da industrialização enquanto nação, alguns estados daquela federação já o assinaram e outros mais demonstraram interesse, tornando o compromisso abrangente e promissor.
} 
social e solidariedade com os demais indivíduos, grupos e sociedades, e menos ainda quanto às demais espécies.

O atual equacionamento da questão ambiental, com indicativo de mudança de paradigma, leva a considerar-se que a escassez de recursos naturais leva a extensão do critério de sustentabilidade do capital produzido para incluir o capital natural. Mas não só, pois o desenvolvimento sustentável busca a integração de preocupações e ações ambientais com políticas socioeconômicas, em concepções abertas e com alternativas flexíveis diante das transformações espaço-temporais:

"... não se caracteriza como um estado fixo de harmonia, mas sim como um
processo de mudança, no qual a exploração de recursos, o gerenciamento
dos investimentos, a orientação do desenvolvimento tecnológico e as mudan-
ças institucionais compatíveis com o futuro, bem como com as necessidades
do presente".(Franco, 2001, p.41).

A noção de Desenvolvimento Sustentável prevê evolução, não em busca de equilíbrio estático do sistema, mas de um equilíbrio dinâmico e em adaptação. Como reação à idéia, contemporânea a modernidade progressista, do retorno à natureza com fins de regeneração moral, espiritual e física, ou seja, em busca de um equilíbrio estático, se interpõe a idéia de processos evolutivos, naturais e/ou culturais, como alterações dentro de sistemas complexos através da seleção de traços transmissíveis pela genética ou socialmente, por meio da tradição cultural (Constanza, 1994, p.116).

O Desenvolvimento Sustentável, portanto, centra-se na qualidade de vida e tem dimensões ambientais (qualidade e possibilidade de vida dos diferentes seres), ecológicas, tecnológicas, econômicas, culturais e políticas (inclusão social nas decisões) interdependentes e sem relação de hierarquia.

A questão central é a qualidade de vida, que pode ser entendida como o grau de prazer, satisfação e realização alcançados por um indivíduo ou grupo em seu processo de vida, tanto como pré-requisito de existência numa escala de hierarquia de necessidades básicas (de sobrevivência física, geralmente medidas por padrões materiais e de consumo por unidade de tempo), mas também as de sustentação psicológicas e culturais (de difícil mensuração) entre as quais a fruição da paisagem se inclui.

O desenvolvimento sustentável tem sido abordado e se apoiado em matrizes discursivas que tendem a esvaziar, ou ao menos diluir seu significado e validade, especialmente quando ligado ao ambiente urbano, associação que muitos julgam contraditória. Isso se dá num 
contexto em que as análises urbanas e ambientais, partindo de vertentes do conhecimento distintas, entram em conflito na busca pela hegemonia do pensamento teórico cujas conseqüências, principalmente na prática do planejamento e da ordenação territorial, não tem contribuído para a melhora da qualidade de vida das sociedades.

Ao explicar o ambiente urbano, a teoria social crítica, de modo geral, relevou a questão ambiental a um segundo plano, mesmo quando incorporou (num viés ecológico político) a fragmentação sócio-cultural e priorizou questões de raça, gênero, etnias e, reduzindo sua compreensão a aspectos legais, sanitários e a práticas políticas e movimentos sociais, concentrou-se em temas como o lixo, águas e poluição e no reconhecimento da sociedade consciente e organizada.

Já na análise ambiental atual, mesmo que tenha avançado conceitual e metodologicamente, se percebe uma subestimação da dimensão urbana, sócio-política e cultural, muitas vezes tratada como não natural. As análises ambientais e urbanas, ao se oporem ou se excluírem, configuram um falso dilema na medida em que "a questão ambiental, por ser global, é comum a forma dominante de vida em sociedade, a cidade contemporânea" (Machado, 2000, apud H. S. M. Costa, 2000).

Atualmente, a discussão da problemática ambiental urbana tem repensado a noção de sustentabilidade, que apresenta imprecisão e, talvez por isso mesmo, certo desgaste. Uma das principais questões se refere às diferentes noções que o termo assume. Como todo discurso ${ }^{8}$, o da sustentabilidade é uma construção social que ampara objetivos e práticas, com obvias incoerências e contradições, tornando objetivas diferentes representações e idéias.

Conceitos e esquemas intelectuais, enquanto construções objetivas do mundo social e natural, não são neutras (Acselrad, 1999), e, portanto, a busca pela hegemonia, representada pela adoção de perspectivas determinísticas de viés técnico ou político, tende a negar a diversidade que o próprio termo sustentabilidade propõe. Diante da atual crise

\footnotetext{
${ }^{8}$ Acselrad (1999) destaca as principais matrizes discursivas da sustentabilidade urbana: aquela que representa o fenômeno urbano pelo viés tecno-material, com recorrente desconsideração da dimensão política seja por meio do modelo da racionalidade eco-energética ou pelo modelo do equilíbrio metabólico, ecossistêmico, de interação entre os elementos e sistemas. Uma outra matriz entende o espaço urbano como o lócus das externalidades negativas, mas também da busca da qualidade de vida, cujo equacionamento se dará na temporalidade do processo de construção dos direitos às condições de salubridade e da manutenção da possibilidade de usufruto dos valores simbólicos do espaço urbano. Articula eficiência energética e qualidade de vida com ênfase na morfologia urbana. Uma terceira matriz discursiva trata a cidade como o espaço da re-construção da legitimidade das políticas urbanas por meio da pactuação política durável.
} 
de ideologias, a presença do discurso ambiental tem sido uma alternativa aglutinadora de diversas forças sociais, pela nobreza da causa e por seu aparente desinteresse.

Entretanto, nas cidades do terceiro mundo, essa tendência à unificação em torno da perspectiva ecologista/ambientalista não tem garantido sua eficiência nem mesmo sua implementação, seja por motivos estruturais das sociedades, que assumem compromissos seguindo tendências internacionais não pactuadas por sua totalidade, seja por incapacidade de gestão técnica e financeira.

Uma superação da desses conflitos e contradições entre as distintas análises é mais do que necessária, pois, segundo Harvey (1996): “... se o pensamento biocêntrico está correto e as fronteiras entre atividades humanas e o ecossistema devem ser destruídas, isto significa não somente que processos ecológicos devam ser incorporados em nossa compreensão da vida social: significa também que fluxos de moeda e mercadoria e as ações transformadoras dos seres humanos (na construção dos sistemas urbanos, por exemplo) têm de ser entendidas como processos fundamentalmente ecológicos" (p.392, apud Costa, 2000), o que foi corroborado por Jane Jacobs (2002) em recente publicação.

O desenvolvimento urbano passa a ser uma especificidade do desenvolvimento sustentável, com dimensões de ambiência, com os intrínsecos conflitos derivados da convivência em sociedade, "... associadas a práticas de vida urbana à busca de meIhores condições de vida, por meio da criação e/ou manutenção de condições materiais/ambientais que venham promover e expressar justiça sócio-ambiental' (Costa, 2000).

No nível da análise teórica da questão ambiental urbana, a consideração da complexidade e da diversidade dos conflitos e atores envolvidos, da assimetria das relações de poder e da impossibilidade de solidariedade capitalista, industrial ou pós-industrial, especialmente no terceiro mundo, leva os estudiosos a uma postura de aceitação ou não da hegemonia do projeto de modernidade capitalista, o que geralmente resulta em posturas niilistas, quando não cínicas e em atitudes pouco pragmáticas, com resultados tão nefastos quanto as posturas ingênuas, pretensamente neutras relacionadas ao positivismo. Num esforço de superação desta questão, o enfoque teórico e metodológico pretendido nesta instância busca entender de maneira integrada os processos estruturais bem como as ações individualizadas e de grupos, ou seja, incorporando teorias pós-estruturalistas. 
Conforme a estratégia de desordem da diferença de Soja (2000), busca-se superar análises que tendem a reduzir os conflitos à oposição clássica entre classes (de cunho marxista-estruturalista), e mesmo de raça e gênero, busca-se "... mecanismos de articulação entre as distintas partes do conflito preocupando-se com as desigualdades e com a identificação de novos caminhos..." (Costa, 2000). E que a teoria e a metodologia daí surgidas, em que pese a atual perda de credibilidade do planejamento como instrumento de justiça sócio-ambiental ${ }^{9}$, se reflitam em ações reguladoras por meio do planejamento, rumo a melhores condições de vida.

Assim, ao se considerar a questão ambiental como catalisadora de uma possível transformação sócio-ambiental, apostando ${ }^{10} \mathrm{em}$ seu potencial emancipatório, o desenvolvimento é entendido como passível de ser sustentável sempre que o crescimento econômico não seja alheio à dimensão sócio-ambiental e aponte para propostas mais progressivas no que tange à busca da justiça social, maior qualidade de vida, ambientes mais saudáveis e compromissados com o futuro. Isso requer maior democratização do espaço e permanente negociação entre as partes conflitantes.

Neste movimento, o desenvolvimento sustentável apóia-se tanto em aspectos de territorialidade (localismos, regionalidades), na gestão consorciada do desenvolvimento e, por conseguinte, do território, abrangendo os diferentes níveis administrativos e de representação, na consideração da diversidade sócio-econômica e cultura (democratização do espaço), como o adequado trato dos aspectos de qualificação do espaço, tais quais os estudos morfológicos do território e da cidade, a consideração das questões demográficas e de capacidade de suporte, com a elaboração de parâmetros e indicadores de sustentabilidade, e a organização dos sistemas de transporte, de abastecimento, de tratamento de dejetos e de conservação e otimização da energia.

\footnotetext{
${ }^{9}$ A associação, geralmente expressa pela teoria crítica e incorporada por ambientalistas, entre processo de urbanização e a consolidação de determinado projeto de modernidade leva a considerar planejamento e modelos de organização territorial como mantenedores dessa modernidade, destacando-se especialmente suas características negativas de massificação, opressão e predação de recursos.

${ }^{10}$ Como Peet e Watts (1996, apud Costa, 2000) têm apontado com a ecologia da libertação.
} 
Além disso, um repensar da relação público-privado, chave para a implementação das ações de planejamento e ordenação do território, torna-se indispensável, a fim de superar a associação simplista do último termo a ações devastadoras e o primeiro como o único defensor da sustentabilidade, reconhecendo-se a capacidade do setor privado no desenvolvimento, assim como a necessidade do compromisso social com a sustentabilidade, resultado de pactos abrangentes entre os distintos setores envolvidos.

\section{O território como sistema sócio-ambiental}

A noção de território está explicitamente associada à matriz biofísica do ambiente e, por isso, é importante elemento na busca do equilíbrio entre desenvolvimento e sustentabilidade. Ainda que o território seja uma continuidade espacial com expressões heterogêneas, na maioria das acepções, a homogeneidade, em pelo menos um aspecto, é considerada um fator de definição relevante da especificidade territorial. Tanto pode ser, em uma visão física, zona homogênea natural, como pode ser zona homogênea por fatores sócio-culturais, numa visão humana-política.

Nas disciplinas que têm o espaço como objeto, como a geografia, vem-se alargando a visão mais restrita de território que alude a terras, relevos, vales e costas, às águas, e às condições atmosféricas e climáticas, passando a considerar os seres vivos, e em especial o ser humano. Siran afirma que: "... do território fazem parte a sua fisicalidade e os fatores e elementos físicos e humanos que o determinaram: disso fazem parte a sua história, o ambiente, a paisagem; em suma, do território fazem parte toda aquela especificidade própria que determina um espaço físico e humano, mas não só: deve-se considerar as relações que no momento alargam sempre mais as limitações" (Siran, 1978).

Vittorio Gregotti, com sua visão oriunda da arquitetura, diz que território é "uma junção espacial e social que, juntos, estão sujeitos à transformação e à modificação. As modificações, por meio da regulação geométrica, conhecem e transformam o lugar em objeto arquitetônico, que funda o ato original e também simbólico de estabelecer contato com o solo, com a idéia de natureza juntamente com as coisas presentes, através da construção do princípio original" (Gregotti, 1982). 
Mas mesmo tendo explícita sua base espacial, o termo território ainda é compreendido por algumas disciplinas como uma entidade sem matriz biofísica (ao fim e ao cabo, ecológica) ou dedicando a esta, menos peso. A citação de cunho sociológico exemplifica:

"Território é o espaço ambiental construído, é um fato social e político, não natural, é objeto de nossa representação geográfica, e é o lugar da transformação social e da socialização... O território, intenso como espaço ambiental e base material das várias civilidades, e por elas simbolicamente ordenado e investido... O território é o espaço que vem construído de uma civilidade com seus valores e seus usos. O território é o lugar onde se manifesta com mais evidência a crise de valorização econômica e da macroestrutura institucional" (Fiorani, 1985).

Atualmente, se consolida uma visão abrangente do termo território, que por sua natureza complexa e sistêmica desautoriza simplismos, nos levando a considerar o posicionamento holístico como aquele que nos permite uma meta-percepção, resultante da consideração de todos os pontos de vista disponíveis, buscando a compreensão da meta-realidade advinda de todas as realidades perceptivas parciais.

Correntes atualizadas de pensamento sugerem, e para elas nos inclinamos, um entendimento de território como construção sócio-ecológica, onde as artificialidades construídas pelos humanos se dão em uma matriz biofísica preexistente. Se do ponto de vista sociológico não há território sem a ação transformadora e apreensiva humana, para as disciplinas que tratam do espaço, menos território há sem que se leve em conta sua matriz biofísica (clima, substrato, solo, relevo, hidrografia, vegetação, fauna, etc.), ainda que cada uma dessas disciplinas dê pesos diferentes aos objetos de estudo da outra.

Ao se entender o território como sistema, admite-se que a realidade é formada por elementos e fenômenos inter-relacionados que configuram uma realidade territorial, como um conjunto de elementos, materiais ou imateriais, "... de tal modo relacionados elou interdependentes que constituem um todo orgânico, inexplicável pela mera aposição de suas partes" (Folch, 2003, p. 24).

Ao estabelecer que o território é configurado como um sistema, composto de subsistemas e elementos, ele sugere que o sistema ${ }^{11}$ humano pode atuar no sentido de maior aproveitamento na ordenação do próprio território:

\footnotetext{
${ }^{11}$ Alguns autores não consideram as unidades de paisagem conformadas pela ação antrópica, representadas nas unidades de cobertura e uso/ocupação e cobertura do território, como sistema por não apresentarem, como na ecologia clássica de visão sistêmica, as características de sistemas: interdependência dos componentes, existência de um ciclo de matéria e de mecanismos de auto-regulação (Metzger, 2001).
} 
"O território é muito mais que um cenário, porque é um sistema. Diferentemente dos atores em um cenário, que atuam conforme um roteiro escrito por alguém, em um sistema, os agentes da vida real improvisam a atuação, ainda que algumas sejam pactuadas para maior otimização das ações" (Folch, 2003, p 13).

A partir deste arcabouço teórico pode-se pensar o "território como espaço contínuo (envolvendo o urbano e o rural) com vitalidade e persistência de uns elementos vinculantes, mais além da dialética cheio/vazio, que permanecem com suas intensidades, suas lógicas e suas funções, em formas e graus diferentes" (CCRS, 1994, p. 13) (anotação minha).

\section{A polissemia do termo paisagem}

O conceito de paisagem, como o de território, tem sido utilizado com diferentes significados em função da distinta origem disciplinar do conhecimento. No entendimento corrente, paisagem é, segundo o dicionário Aurélio, "um espaço de terreno que se abrange num lance de vista", e em português trata-se de um termo traduzido. Duas vertentes explicam a origem do termo, conforme sua raiz latina ou anglo-saxã.

Nesta última corrente lingüística, a noção correspondente à paisagem deriva de landscape, palavra composta de origem indo-européia, com contribuição germânica e celta, que resultou em uma série de palavras em diferentes variações em distintas línguas européias. Assim como em alemão, landschaft e em holandês, landscap, e muitas outras, mantêm a mesma raiz, porém com diferentes significados: em alemão, pequena unidade administrativa; em inglês americano, paisagem natural. Land, na Inglaterra, era entendida como porção de terra com limite definido por lei. Scape, de origem anglo-saxão, essencialmente significa forma e servia para designar uma coleção de aspectos (formais) de um ambiente.

Segundo Jackson (1984, p.8), landscape teve seu significado consolidado a cerca de 300 anos e teve origem no âmbito de artistas: porção de terra que podia ser abarcada por um olhar. Ao ser introduzido na Inglaterra, passou a significar a representação de uma determinada realidade, e não a realidade concreta sendo assim a interpretação artística de um determinado pedaço do mundo delimitado pela visão do artista. As paisagens naturais passam a ser o objeto de representação artística, geralmente com pouca ou nenhuma intervenção humana. No inglês britânico atual assume conotação de porção de ambiente, enquanto continente de manifestações naturais e culturais. 
Pela vertente latina, a palavra evoluiu originalmente do Latim - pagu, passando no romano - pagensis, levando ao italiano - paesaggio e ao francês - paisage, pays. Em português ${ }^{12}$, a palavra paisagem deriva do francês, paysage, que segundo o Dicioniére Robert, significa "partie de un pays que la nature prèsent á un observateur". Até o século XVIII na Espanha, se utilizou o termo paisista em vez de paisajista para designar pintores.

Se até esta época, o termo esteve relacionado, por força da origem, a uma imagem estática, em visão frontal ou oblíqua, de um espaço aberto, como nas pinturas, pelo final do século XVIII, com as idéias do iluminismo, passa a ser associado a uma realidade mais concreta, representando-se uma natureza nem sempre tão bela quanto queriam os críticos de arte e os artistas.

A partir de meados do século XIX, o termo assume uma noção cientificizada com a consolidação e o avanço dos estudos naturais (biologia, geologia, hidrologia), passando gradativamente a ser relacionado com o ambiente como um todo, em visões que incorporam, ora de modo parcial, ora inter-relacionado, conceitos de disciplinas sociais (ecologia, geografia, sociologia, antropologia, semiótica, urbanismo e arquitetura).

A definição de origem geográfica de Bertrand (1972): "paisagem é uma determinada porção do espaço resultado de uma combinação dinâmica, portanto instável, de elementos físicos, biológicos que, reagindo dialeticamente uns sobre os outros fazem da paisagem um conjunto único e indissociável em perpétua evolução", e a definição ecológica de Forman (1986): "paisagem é uma porção de território com características heterogêneas composta por subsistemas ecológicos que interagem reciprocamente e se repetem de forma similar através desse espaço", sugerem que a vertente científica percebe que paisagem e ambiente são estruturas ligadas na sua essência. Se paisagem está mais associada à noção de representação, geralmente uma descrição formal de um determinado instante, de natureza estática, ambiente, por sua vez, tem conotação processual.

$\mathrm{Na}$ abordagem da ciência ambiental, em especial da ecologia da paisagem de influencia norte-americana, as interações entre os elementos organizam o meio e o estudo e análise da paisagem requerem, de modo imprescindível, a compreensão do funci-

\footnotetext{
${ }^{12}$ Diálogos de Roma (1955, Madrid p.199) de Frederico de Holanda, escrito em português em 18 de outubro de 1548 (primeiramente editado em Madrid in: História de las Ideas Estéticas en España, Madrid, 1901) utiliza em momento pioneiro da literatura, o termo paisagem. Apresenta um diálogo na boca de Michelangelo, criticando a pintura flamenga: "O seu pintar é trapos, maçonaria, verduras de campos, sombras de árvores, e rios e pontes, a que chamam paisagens, e muitas figuras para cá, e muitas acolá" (p.132), (grifo meu).
} 
onamento dos ecossistemas ${ }^{13}$ presentes no ambiente. A ecologia da paisagem de viés biológico estuda de que maneira a estrutura da paisagem condiciona o funcionamento do sistema (composto de sistemas), isto é, dos fluxos que se dão dentro e entre estes elementos de paisagem e entre paisagens vizinhas ou distantes.

Recentemente, reforçando sua linha de pensamento, Forman (1995), postulou que a ecologia da paisagem é o estudo das interações entre os aspectos temporais e espaciais da paisagem e seus componentes de flora, fauna, e culturais. Centra-se, assim, nas relações espaciais entre elementos da paisagem ou ecossistemas; os fluxos de energia, nutrientes minerais e espécies entre os elementos; a dinâmica ecológica do mosaico paisagístico ao largo do tempo, não necessariamente em escala ampla.

Na geografia, a noção associada ao termo nem sempre é consensual e vem se adaptando ao largo dos últimos dois séculos, e com mais rapidez na segunda metade do século $X X^{14}$, às novas maneiras de pensar. Se até o fim dos anos 1960, paisagem e complexo natural territorial eram dois valores dominantes para o estabelecimento de uma geografia física, onde a paisagem era abordada pelo exame de componentes visíveis, na passagem para os anos 1970, seu estudo passa a se valer de conceitos geo-sistêmicos de estrutura e funcionamento, considerando a ação antrópica como fator funcional.

Naquele momento, os modelos se baseavam em dois subsistemas: o biofísico e o sócio-econômico, muito utilizados também pela Ecologia da Paisagem ${ }^{15}$ de influência européia, que privilegiou a preocupação com o planejamento regional e ordenação do território, onde se vinculava às unidades de paisagens culturais, enquanto espaço de terreno com características comuns, com suas potencialidades de aproveitamento econômico.

Ao inserir o conceito de paisagem no estudo do ambiente, com especial atenção à ação antrópica, a geografia humana enfatiza que a paisagem é um construto social, logo, impregnada de história, evolução temporal. "A ciência da paisagem é uma disciplina antrópica" (Bertrand,1982, p.469).

\footnotetext{
${ }^{13}$ Ecossistema como entendido idealmente por Odum (1975): entidade natural que inclui todas as partes animadas e inanimadas para produzir um sistema estável, no qual as trocas entre as partes inscrevem-se em encaminhamentos circulares. Num primeiro momento estuda-se a relação entre suporte e a cobertura, e depois as unidades individualmente, com suas dinâmicas próprias, com suas trocas e transferências de matéria e de energia internas e externas. Este fluxo de energia deve contribuir para a estabilidade do sistema e para que a "entropia não o destrua".

${ }^{14}$ A introdução do pensar estruturalista, por exemplo, consolidada nos anos 1970, levou o conceito de sistemas aos estudos em geral, dos sociais à biologia, e na ecologia fortaleceu o termo.

${ }^{15}$ Estabelecida por, entre outros, Carl Troll em meados do século XX (1939) e bem desenvolvida nos anos 1970, por J. J. L. Tricart em sua corrente culturalista.
} 
Milton Santos (1986), com sua contribuição vinda da geografia crítica, chamada por alguns de radical ${ }^{16}$, sustentou que paisagens são formas mais ou menos duráveis, sendo seu traço comum a combinação de objetos naturais e fabricados, ou seja, o resultado da acumulação de muitas gerações, apontando para a simbologia social que a noção de paisagem carrega: "Pour interpréter l'espace correctement il nous faut repérer et écarter tous lês simboles destinés à faire écran à notre capacité d'appréhension de la realité" (Santos, 1978).

Nesta corrente da geografia humana, a paisagem enquanto realidade é o resultado da produção do trabalho do homem de diferentes épocas; não sendo um todo acabado e pronto, vai se formando através de acréscimos e substituições de objetos transformando-se numa herança de momentos, respondendo diferentemente às demandas sociais. Transcende, assim, à dimensão visual, "mostrando-se realidade concreta, um todo real estruturado e organizado por componentes que obedecem a uma lógica própria enquanto unidade e enquanto parte de um todo" (Palet,1988, p.20).

Paisagem, enquanto realidade objetiva e dialética, poderia ser compreendida ainda, conforme sugere Palet (1988), como um momento de um todo, este sendo um sistema aberto, composto de um conjunto de elementos (partes) que, tendo estrutura, funcionamento e histórias próprias se relacionam e interagem mutuamente.

Partindo da noção de paisagem recorrente na geografia atual que a descreve como uma determinada configuração ambiental, onde a ação antrópica sobre os meios físico e biótico se faz presente, cabe destacar a dimensão cultural da paisagem, sendo esta o resultado de um processo contínuo de recriação da natureza e da herança construída, portanto, do fazer histórico (Claval, 1999).

A geografia cultural fez reconhecer que as paisagens trazem as marcas das culturas e, ao mesmo tempo, as influenciam: "O estudo das paisagens é o estudo das mediações pelas quais os grupos humanos asseguram sua possessão sobre o espaço e submetem-se a sua influência..." (Berque, 1984).

Mesmo aceitando que "o impacto das culturas sobre o espaço humanizado não se limita à paisagem" e esta não reflita "... fielmente, todos os aspectos de uma cultura", Claval sustenta que "a paisagem é um modo de abordar problemas culturais, assim como antropológicos, sociais, simbólicos e estéticos" (1999, p.318).

\footnotetext{
${ }^{16}$ Conforme Rouegerie e Berouchatchvili (1991, p.122)
} 
A partir do momento em que uma paisagem torna-se um objeto de contemplação e valorização cultural as relações do grupo social com o espaço mudam de natureza (Donnadieu, 2002 e Berque et alii, 1999). Em contraposição à lógica vertical, dos que atribuem direitos de utilização do solo, surge à lógica horizontal dos que atribuem significados às paisagens que procuram proteger.

O conjunto ou grandes porções da paisagem, assim como o ambiente, valorizada mais pela cultura do que pela economia, passam a preocupar as sociedades pela necessidade de manutenção e preservação delas (o que já comprometeu a eficácia funcional de alguns espaços humanizados). "Soma-se às preocupações de funcionalidade econômica, social e de simbolismo localizado, a dimensão simbólica global' (Claval,1999, p.316).

Nos últimos anos, correntes da geografia passaram, de modo progressivo, a interpretar uma paisagem condicionada pela percepção do significado. Com o desenvolvimento da semiótica nos anos 1980, o estudo da paisagem derivou em considerações sobre o sujeito interpretante, não só em suas operações mentais de representação, mas também de escolha e de atribuição de significado ao objeto estudado (percepção, paisagem mental, escolha de ações, efeitos disso na paisagem). Estas linhas de estudos, mesmo que tenham evoluído nos últimos anos, ainda carecem de maior rigor conceitual e uma formatação metodológica que possam conduzir a uma semiótica da paisagem.

A partir do lluminismo, a arquitetura, a arquitetura da paisagem, o paisagismo e o urbanismo procuraram tratar a questão de modo científico, ainda que com esquemas conceituais e metodológicos derivados da biologia e da geografia. A diversidade de enfoque e entendimento dos termos paisagem, território e ambiente, também se faz notar nesse campo de conhecimento, indo da visão puramente morfológica até a noção de sistema em processo.

Conforme reconhece Hackett: "a palavra 'Paisagem' tem vários significados como a vista percebida por um observador ou o meio ambiente habitado pelo homem e outras formas de vida" (Hackett, 1971, p.1), e alguns autores estudados e comentados abaixo exemplificam tal diversidade.

Maria F. P. Leite, com entendimento próximo àquele dos geógrafos críticos, destaca que "paisagem é produto de negociações entre sociedade e a natureza, e está permanentemente sujeita à crítica e avaliações" (Leite, 1991, p.30). Por outro, lado, Jackson, define o conceito reafirmando o antropocentrismo do termo paisagem: “... é a compo- 
sição de espaços construídos pelo homem; um espaço sintético sobreposto a um espaço de características naturais" (Jackson, 1984, p.8).

Alguns arquitetos paisagistas entendem a "paisagem como um reflexo do dinamismo dos sistemas naturais e sociais" (Laurie, 1978, p. VII), implicando que sua aparência reflete estruturas e sistemas em permanente processo. Magnoli (1986) afirma que "paisagem é o suporte físico no qual se estrutura a sociedade e cuja morfologia é o resultado da interação entre a lógica própria dos processos do suporte e a lógica dos sistemas culturais e sociais".

Neste enunciado, ambiente e paisagem são conceitos distintos e entrelaçados. A paisagem remete às conformações e configurações do ambiente. $O$ ambiente é o resultado das interações entre sociedade humana e a base física e biológica que a envolve, para sua sobrevivência biológica e espiritual.

O conceito de paisagem associado ao conceito de ambiente é abordado também pelo arquiteto-paisagista Silvio Soares Macedo, a saber: "Paisagem - a expressão morfológica em um determinado tempo, do processo constante da ação dos seres vivos sobre os diversos pontos do planeta associados ao movimento contínuo das diferentes estruturas geológicas e águas" (Macedo, 1994, p. 54).

O paisagista Paulo Pellegrino, ao privilegiar os aspectos perceptivos da cognição, afirma: "A interação entre indivíduo e seu ambiente, através da experiência, estabelece um contacto de duplo sentido entre o sujeito interpretante e o signo objeto da interpretação, a paisagem com uma geração de significados, caracterizando um processo de percepção ambiental..." (Pellegrino, 1989, p. 72).

Neste sentido, cabe relembrar que uma paisagem pode estimular os dez receptores sensoriais (Bartley, 1978, p. 82, apud Rodrigues, 1997), sendo que cada um capta parcialidades. A percepção humana é a soma destas parcialidades. $\mathrm{O}$ olfato e a audição participam na memorização de paisagens. $O$ tato, ao permitir se sentir o ambiente de modo sinestésico, no caminhar pisando no solo, roçando objetos e gentes, amplia a experiência com a paisagem. Mas a visão é reconhecida como a mais importante, pela amplitude e capacidade de distinção, ultrapassando o aspecto puramente sensorial.

Ao se admitir que ela se realiza a partir da relação entre sujeito e objeto, se entende a paisagem, além de sua fisicidade, como objeto de percepção visual e de atribuição de significado. Trata-se, portanto, de uma representação abstrata do ambiente, com 
todas as limitações do sujeito da percepção, e com toda a bagagem ideológica do significado atribuído ao objeto percebido.

Assim, ela pode também ser definida como um produto e como um sistema, sempre com expressão morfológica: “... como produto porque é resultado de um processo social de ocupação e gestação de um território; e como um sistema, na medida em que a partir da ação sobre ela impressa, com certeza haverá uma reação equivalendo ao surgimento de uma alteração morfológica parcial ou total" (Macedo, 1993, p.11).

Esses conceitos e abordagens de paisagem, ainda que revelem diferenças de enfoque, se complementam. Para Magnoli, a paisagem é um atributo do ambiente: conformações e configurações do ambiente humano, num viés claramente cultural. Para Macedo, a paisagem é uma manifestação do ambiente: sua expressão morfológica, reafirmando aspectos estruturais da fisiografia. Para Pellegrino, a paisagem é uma relação entre indivíduo e ambiente: a percepção visual do ambiente e a atribuição de significado ao objeto percebido, em um enfoque que privilegia a cognição.

Em todos, além da herança da geografia sócio-culturalista que se revela inequivocamente, a paisagem é entendida como uma entidade visual que é percebida com certo distanciamento, ou seja, paisagem é o lugar onde não nos encontramos.

Ao ser definida ao nível do visível, a paisagem é uma realidade morfológica de expressão material, formada por volumes, objetos, formas, cores, etc. objetos culturais, de características naturais e artificiais, marcando o espaço criado pelo homem sobre a natureza, podendo ser interpretada de modo distinto em função do sujeito cognitivo.

\section{Atitudes da sociedade em relação ao território e à paisagem}

Tem-se, pelo visto acima, que a realidade é percepção, e a percepção é a imagem do observador a partir da qual ele constrói seu conceito de realidade. A percepção da realidade depende do olho do sujeito, que tende a vê-la em acordo com suas convicções e interesses. São, assim, configuradas diferentes paisagens, que por sua vez são percebidas de modo distinto, em função das diferentes abordagens. Na percepção do território, isto fica muito evidente quando são comparadas as percepções que diferentes grupos sociais e disciplinares têm de paisagens, reafirmando a convicção de que a realidade ambiental, territorial e paisagística não é patrimônio perceptivo de ninguém. 
As atitudes da sociedade em relação ao território variam entre produtivistas, utilitaristas, funcionalistas, formalistas, estéticas, patrimonialistas e naturalistas, de onde se pode perceber por trás de cada uma delas o estereótipo, entre outros, do economista, do arquiteto, do advogado ou do ecologista reduzidos aos seus papéis mais específicos.

Em processos de proteção ambiental, geralmente são os ecólogos, pelo inestimado e imprescindível conhecimento que sobre organismos e sistemas que participam do território e configuram sua paisagem, os convocados a decidirem as medidas de proteção de espécies e lugares. Mas é um erro pensar que somente eles podem definir e arbitrar tal proteção. Proteção e conservação, assim como a capacidade de carga, são conceitos tão sociológicos quanto ecológicos. Conhecer o funcionamento dos sistemas naturais não leva necessariamente à compreensão do território.

\section{Uma compreensão arquitetônica de território e paisagem}

Diante da breve revisão da compreensão do termo paisagem em diferentes disciplinas, nos parece claro que a parcialidade de algumas interpretações e o reducionismo de outras que, no mais benigno dos casos, obedecem a percepções parciais, especificidades disciplinarias, preferências ideológicas ou a interesses inconfessos, tende a ofuscar a capacidade de análise e de interpretação necessária para a abordagem que se pretende em relação à questão ambiental, territorial e em especial à paisagem.

$\mathrm{Na}$ arquitetura e urbanística, o desenvolvimento científico tem avançado no entendimento de processos urbanos, de suas estruturas de sustentação física, suas formas, e suas lógicas de formação e transformação, e de capacidade de sustentabilidade de novas situações construtivas, mas quanto ao território e sua paisagem, a disciplina ainda tende a associar-se a prescrições para a preservação genérica, calcada em pressupostos geo-ecológicos. (CCRS, 1993).

As acepções de ambiente, território e paisagem podem ter base na geografia e na ecologia, de modo a embasar os conceitos e terminologia adotados pela arquitetura e urbanismo, mas enquanto processo com dimensão formal, passa a ser objeto de estudo da urbanística, da arquitetura e de arquitetos da paisagem, que buscam harmonização entre processos e produtos por meio do desenho intencional e preventivo, inserido numa compreensão culturalmente crítica da realidade. 
Ainda que o território, enquanto espaço antropizado ou em estreita relação com este, apresenta elementos naturais e construídos ao longo de sua "colonização", que remetem a valores comuns à arquitetura e à geografia, a nossa disciplina nos impulsiona para além, na medida em que incorpora elementos de proposição. O território, por meio da estrutura de sua paisagem, sintetiza como, ao longo do tempo, condicionado pelas influências geográficas e biológicas por um lado e, por outro, pelas forças sociais e econômicas de cada período, o homem organiza a natureza (CCRS, 1993).

Pela perspectiva morfológica que assumimos, o estudo do território e das paisagens representa o estudo das interações do homem, agente mais transformador, com seu espaço de vida e das aplicações práticas na solução da questão ambiental. Tendemos a nos preocupar, também e fundamentalmente, com o estudo da paisagem modificada pelo homem, formando paisagens culturais, numa escala abrangente que considera a o planejamento da ocupação do espaço, a ordenação do território, e levando em conta a otimização dos limites e potencialidades ecológicas e econômicas do ambiente. $O$ estudo das partes heterogêneas e interativas que compõem o mosaico paisagístico é representado, na perspectiva urbano-arquitetônica, no estudo das unidades de cobertura ou de uso e ocupação do solo.

Território e paisagem representam figuras, imagens com formas e, ainda que muitas vezes naturalmente condicionadas, culturalmente reconhecíveis (às vezes passíveis de taxonomia), contendo elementos de comunicação social, com valores cênicos, estéticos, simbólicos, psico-sociais, funcionais, ecológicos e éticos. E, muito importante, sua existência é resultado de um processo operativo humano que pode ser consciente, isto é, resultado de uma vontade projetual, ainda que de difícil implementação e controle.

$\mathrm{Na}$ formação de uma disciplina arquitetônica e urbanística autônoma, enquanto área do conhecimento que também incorpora o viés técnico da construção territorial, a consolidação de suas bases epistemológicas e fundamentos técnicos deve se embasar nesta especificidade, com a preocupação da projetação, que exige que se eleja soluções para os problemas de ordem territorial, propondo configurações e discernindo dentre as alternativas a partir de suas conseqüências na sociedade e no ambiente.

Estes fundamentos teóricos específicos da arquitetura e da urbanística no trato da ordenação territorial, ainda que the confiram certa autonomia, não a liberam de aportes das demais disciplinas já relacionadas, especialmente da própria geografia, das demais 
ciências sociais, bem como da ecologia da paisagem, reforçando as bases epistemológicas cientificas. $\mathrm{O}$ trato do território e da paisagem exige inter, multi e transdisciplinariedade, e as especificidades se fazem necessárias para levar o conhecimento além da visão generalizante e generalista que tem caracterizado a aplicação destes métodos includentes.

Além disso, mesmo que não seja difícil identificar os elementos que compõem uma paisagem, outra tarefa é saber como eles funcionam, se relacionam e estruturam o ambiente que a produziu, sendo ainda difícil cartografar interações entre sistemas vivos e o suporte físico, com especial atenção para o homem, em escala significativa para a ordenação territorial, como já tem avançado a ecologia da paisagem. Dependendo da escala do fenômeno, estas transformações dos elementos e da estrutura não são facilmente percebidas e compreendidas, o que nos impõe o desafio de adequar a abordagem pretendida ao conhecimento dos processos sócio-ambientais presentes na área a ser estudada.

Ainda que a imagem percebida pareça ser sua característica mais marcante, esta estrutura imagética se altera. A sua funcionalidade, seu mais importante papel ao suportar os fluxos decorrentes de processos naturais ou antrópicos, também pode ser alterada. Esses fluxos podem ser de energia, materiais, de organismos vivos, incluindo as pessoas, e de informação, incluindo a genética.

Os processos subjacentes a estes fluxos podem ser físicos (o aquecimento da superfície terrestre que possibilita os ventos, p.ex.), geomorfológicos (o sistema de vertentes), biológico (a dispersão de organismos) ou antrópicos (expectativas e demandas sociais sobre habitação, trabalho, ócio, etc.). A estrutura condiciona o funcionamento, que por sua vez, altera a estrutura destas paisagens. $E$ as paisagens conformam novos sistemas com outras paisagens vizinhas, num algoritmo fractal... Mesmo que se parta da análise morfológica, da forma do território, a ênfase deve passar das pautas para a relação entre as pautas e os processos.

Ao se considerar também a concepção funcional (de viés ecológico) da paisagem, assume-se a existência, nesta estrutura espacial, de fluxos e de processos básicos de transferência de energia e matéria em escalas local, regional e global que dão suporte a vida. A paisagem entendida, então, como um sistema com uma série de processos que se dão dentro e entre as manchas (as pautas que formam o mosaico territorial e paisagístico) que o integram. 


\section{Ambiente urbano, território e paisagem urbana}

Se a anatomia paisagística e territorial, que embasa a compreensão urbanoarquitetônica de ambiente e instrumenta a ordenação territorial, pode se explicar também a partir de um ponto de vista da fisiologia sócio-ecológica, seria correto afirmar que o equacionamento da relação campo-cidade é fundamental. Hoje mais do que antes, ambiente e território se articulam a partir da cidade, em um mundo essencialmente urbano. Existe dificuldade dos ecologistas assumirem o fato urbano, assim como existe dificuldade dos urbanistas assumirem a cidade para além dos fatos urbanoarquitetônicos, seguidamente estendendo sua concepção urbanística até o território.

Mas o estudo das tensões entre os dois domínios, o território ocupado e território livre (ainda que trabalhado por agricultura ou simplesmente usufruído contemplativamente, relativamente mais livre do que o intensamente urbanizado) é fundamental para a compreensão do território.

Ainda que em determinados recortes analíticos se considere o território a partir de dualidades como urbano-rural, campo-cidade, cheio-vazio, ocupado-desocupado, compacto-difuso e centro-periferia, na realidade ele é um espaço contínuo, conformando um sistema em que a alteração de um dos elementos pode modificar o conjunto todo.

Reconhece-se, assim, que o trato do relacionamento da escala urbana expandida, como a conurbação de uma área metropolitana, e recursos naturais de significância, merece aprofundamento, envolvendo porções maiores do território para além dos tênues limites urbanos e de classificações que tendem a simplificar como: "O território destituído de população põe-se como recurso natural. O território habitado põe-se como recurso humano" (Franco, 2001, p.49), que não prevê gradações e temporalidades distintas na utilização e fruição do território.

Mas, ao se admitir a continuidade territorial, ela nos remete a questão da gradação da ocupação do território, pois a cidade se dilui no território e apresenta zonas de transição entre o espaço cheio e o vazio, com diferentes tipos de densificação construtiva, geralmente induzidas pela heterotrofia da cidade mesma ${ }^{17}$.

\footnotetext{
${ }^{17}$ Folch (2003, pp.31-32) distingue três tipologias paraurbanas, aqui resumidos: espaço periurbano, de pouca urbanização, justo na periferia da cidade; espaço rururbano, que se distingue pela presença de elementos de origem ou tipologia urbana em pleno ambiente rural; espaço vorurbano, que se trata de um âmbito marginal, misto de periurbano e rururbano.
} 
Artificialidade natural da espécie humana ${ }^{18}$, o ambiente urbano é um sistema ecológico e social que constitui o âmbito existencial de grande parte da espécie humana, incorporando um sistema de fluxos de matéria e energia regidos pela informação e submetido a uma escala ética de valores sócio-econômicos inseridos no espaço. A urbanística de ordenação territorial não é mais do que o arranjo anatômico deste(s) sistema(s), visando um relacionamento adequado e sustentável com o ambiente urbano.

Após analisar definições e conceitos de ambiente urbano, elaborados por biólogos, ecólogos, paisagistas e urbanistas, entre outros, Antonio Cláudio Moreira nota que a maioria das abordagens aponta para um relacionamento entre sociedades e natureza que prioriza a preservação dos recursos naturais. Tentando superar as limitações de cada noção analisada, percebe o "ambiente urbano como relações entre o espaço construído e a natureza nas aglomerações de população e de atividades humanas. $O$ espaço construído é o resultado de profunda transformação do ambiente para adequálo às necessidades da aglomeração, e para transformá-lo em habitat da população e das atividades humanas aglomeradas" (Moreira, 1993, p.2).

Moreira define como características do ambiente urbano, a aglomeração de população e de atividades humanas, o espaço construído e a natureza profundamente modificada pela aglomeração, sem desconsiderar a finalidade de reprodução do capital e da força de trabalho. Entendendo os problemas ambientais urbanos não apenas como desastres possíveis, mas pelo aspecto de conflitualidade entre os atores, afirma que: "o ambiente é o conjunto de relações dos homens com o espaço construído e com os remanescentes da natureza que convivem com os homens no espaço urbanizado e construído" (1993, p. 4).

\footnotetext{
${ }^{18}$ Cidade para Odum (1988), é um ecossistema com comunidades de organismos vivos, onde predomina o homem, e um meio físico em permanente transformação fruto da atividade interna, e um funcionamento à base de trocas de matéria, energia e informações. O volume de energia que caminha para fora dos organismos vivos, a energia que faz funcionar o sistema e a enorme mobilidade horizontal, que permite o relacionamento com outros ecossistemas nos arredores num alto grau de complexidade, são características do ecossistema urbano. É ainda um ecossistema incompleto ou heterotrófico, ou seja, que depende de grandes áreas e recursos externos, mas difere de um sistema heterotrófico natural por apresentar um metabolismo muito mais intenso por unidade de área, exigindo um influxo muito grande de entrada de energia, matéria, e um a saída também grande de resíduos, geralmente com alto potencial poluidor. Assim, os ambientes de entrada e saída são de extrema importância e mais do que para sistemas autotróficos como florestas.
} 
Ambiente urbano, conclui este autor, teria a seguinte definição: "relações dos homens com o espaço construído e com a natureza, em aglomerações de população e atividades humanas, constituídas por fluxos de energia e de informação para nutrição e biodiversidade; pela percepção visual e atribuição de significado às conformações e configurações da aglomeração; e pela apropriação e fruição (utilização e ocupação) do espaço construído e dos recursos naturais" (Moreira, 1993, p.5).

A urbanidade do ambiente citadino é necessária para que se realizem as vantagens da aglomeração, sua propriedade mais fundamental. Assume-se, assim, que o espaço urbano merece especial atenção no estudo da estrutura do território, e tem tanta, talvez até mais, significação ecológica quanto os sistemas "naturais". Mas, se para se realizar, deteriora seu entorno, ela passa a ser um agente contaminante e de degradação ambiental, desequilibrando o sistema territorial em que se insere.

A tensão entre as aspirações cívicas de seus habitantes e as condições ambientais do território onde se inscreve a cidade é premissa fundamental da discussão ambiental ampla, e se temos entendimento sistêmico do território deve-se incluir a cidade nos estudos, a princípio como um sistema autônomo, mas “... esta autonomia urbana (urbs) só tem sentido quando responde à atividade e necessidades da cidadania (civitas), e só quando se adecua aos condicionamentos ambientais maiores (oikos) chega a servir de base para uma verdadeira cidade (polis). Neste contexto, as palavras recobram seu valor semântico que etimologicamente sempre tiveram: a 'política' da 'urbe' se mostra como um exercício de 'ecologia' carregado de sentido' civil'". (Terradas, 2003, p.28)

Ainda que a cidade seja logisticamente fundamental, é pouco produtiva biologicamente, ou seja, é heterótrofa. Importa a maior parte de sua energia e materiais (ainda que processe a maior parte do conhecimento e da informação) e exporta resíduos para a periferia e entorno de influência, participando, ora vertebrando, ora desestruturando, no processo de formação do território global.

Entretanto, o fato de ela não se auto-sustentar não significa que não possa ser sustentável (nenhum animal é auto-suficiente). Não se atinge a sustentabilidade urbana assumindo como principal, a característica de outro sistema, como se fosse possível imaginar um bosque ou uma plantação habitados com alta densidade (a cidade em um parque já foi pensada pelos modernos e ainda hoje seduz pensadores urbanos). 
Atualmente, os estudos do ambiente já têm reconhecido a importância do fato urbano na discussão ambiental como um todo, inclusive da necessidade de "introduzir na discussão de política de preservação ambiental o conceito de paisagem urbana por considerá-lo mais apropriado para o caso do planejamento urbano e do urbanismo" (Zanchetti, 1993, p. 68). Discutir o processo histórico de formação dos ambientes urbanos permite inserir a noção de que paisagens urbanas devam ser um elemento fundamental na formulação de políticas de preservação e conservação do meio ambiente de áreas metropolitanas.

Gordon Cullen (1961) introduziu a questão da paisagem urbana, ao ver a cidade como um fenômeno social onde a aglomeração de fatos construídos relacionados aos elementos da natureza humana cria uma "ocorrência emocionante no meio ambiente", que por sua vez é relacionada com o sentimento de lugar e de envolvimento do indivíduo com a cidade em sua percepção diária.

Cullen percebeu também o papel da qualidade paisagística no ambiente urbano criando seqüências visuais, vistas, lugares "... envolvendo três aspectos importantes no planejamento urbano: a organização territorial das edificações e construções urbanas, a arquitetura e a natureza". Ainda que tenha evidenciado a necessidade e a especificidade do conhecimento morfológico sobre a paisagem urbana, a aplicabilidade dos conceitos e métodos de Cullen se revelou mais adequada à pequena escala espacial, como pequenos trechos urbanos, percursos, lugares, etc., não dando atenção a paisagens mais amplas.

Este viés morfológico, intra-urbano e localizado, proposto a partir dos anos 1960, vem sendo reorientado em diversos estudos com distintos recortes, ampliando a compreensão do território enquanto entidade continente da relação campo-cidade, com o correspondente gradiente de urbanização. Nessas análises morfológicas se associam estudos mais abrangentes dos processos sociais e ecológicos com vistas a estabelecer correlações significativas entre pautas e processos que possam sustentar a ordenação territorial.

"A concepção da trama urbana, a forma de inscrição de seu traçado no relevo, a disposição e proporção de ruas e das quadras edificadas, o desenho urbano de cada bairro e suas formas de costura com os bairros adjacentes, a situação e conformação das grandes infraestruturas, o tratamento das principais artérias e vias de comunicação, o peso, a localização e a natureza das zonas verdes (vestígios da vegetação pré-existente, parques novos, pequenos ou grandes jardins públicos ou privados, verde intersticial, etc.) são elementos carregados de informação histórica, política e ambiental, imprescindíveis para a compreensão da realidade sócio-ecológica global" (Rodà, 2003, pp. 27-28). 


\section{Planejamento do ambiente, do território e da paisagem}

Apesar da diversidade de tradições de planejamento, nos ambientes acadêmicos, sociais e políticos atuais existe certo consenso em considerar que o paradigma de planejamento espacial chamado de convencional vem passando por questionamentos teóricos e práticos, especialmente no trato das questões ambientais. Desde seu surgimento, enquanto prática técno-científica de ordenação territorial, o planejamento esteve atrelado a idéias positivistas e desenvolvimentistas em que os recursos da natureza podiam ser explorados de maneira ilimitada.

Os modos de planejamento urbano derivados do paradigma convencional, pretensamente estáveis, lineares e dedutivos, baseados em informações objetivas e exaustivas, com interpretações do geral para o particular, e persistentes até início dos anos 1980, perderam a confiança por uma série de inadequações em relação à situação atual, reflexo de uma crise que afetou as ciências sociais de maneira geral. Algumas características destes modelos de planejamento podem ser destacadas.

Em vez de definição de metas, processos e cenários alternativos se antecipavam formas e vetores definitivos; a distinção, quando não antagonismo, entre planejamento e gestão do território; intervenções abrangentes em ação única e de largo prazo, mesmo diante das rápidas e imprevisíveis transformações da realidade, globalizada e pósindustrial ao invés de intervenções seletivas e de potencial de difusão e transformação progressiva do entorno; aposta na tecnocracia para elaborar programas de necessidades e dos problemas a serem enfrentados, bem como as prioridades, não considerando valores de grupos sociais envolvidos e das circunstâncias do momento, evitando participação e debates, essenciais para resolução de conflitos.

Entretanto, a perda de confiança neste tipo de planejamento permitiu, por outro lado e como conseqüência das transformações sociais, o surgimento de acólitos da desregulamentação, da minimização de controles, quando não do desaparecimento da própria atividade, com conseqüências exemplares e desastrosas por todo o Brasil.

O planejamento, independente das diferentes interpretações e aplicações e apesar das críticas, busca manter sua funcionalidade enquanto instrumento político e técnico de redução das incertezas futuras, e a consolidação de parâmetros éticos alternativos aos convencionais se fez notar a partir dos anos 1960 nos EUA e Europa e, no Brasil, de forma mais significativa, nos anos 1980. 
Planejamento, no limite mais abstrato de suas qualidades semânticas, remete a sonho, intenção, levando a idéia de projeto, de empreendimento. Estas últimas palavras remetem ao ato de transformação para atingir determinadas intenções. Intenções, por sua vez, envolvem visões de mundo. Este conjunto de idéias que a palavra Planejamento implica, revela de certo modo, os valores e o caráter de quem planeja.

Dentre as alternativas de desenvolvimento que se apresentam na passagem do século $\mathrm{XX}$ para o $\mathrm{XXI}$, as estratégias de planejamento em que se considera o desenvolvimento sustentável com a justa atenção para o ambiente e o território, em especial para as ações de caráter regional, como forma de enfrentamento dos desequilíbrios sócio-econômicos globais, têm sido atraente para os estudiosos do tema.

Diante dos desafios da globalização e do paradoxo de desenvolver e conservar apontase para a região como base territorial de meios (millieu) inovadores, e com a valorização do lugar e região como base territorial essencial, "... como reações apropriadas da cultura, nos dias atuais, à força desmanteladora da globalização" (Franco, 2001, p.11) que, segundo estudiosos, acentua a segregação entre incluídos e uma maioria de excluídos.

Têm surgido, então, teorias e práticas de planejamento que buscam garantir a possibilidade de vida de gerações futuras considerando: a capacidade de suporte dos ambientes considerados como a inter-relação de ecossistemas (tanto para impactos como para absorção de resíduos); o conceito de economia de longo prazo (com justiça inter-geracional) e a definição do que deve ser preservado e ou sustentado (sem a consideração dos recursos naturais como capital social).

São assumidas, por esta via, intenções da Agenda 21 que afirma que o combate à pobreza urbana só será possível mediante o planejamento e a administração do uso sustentável do solo, o que para isso exige levantamento e classificação de recursos do solo, considerando sua adequação funcional, fragilidade e medidas de proteção. A busca da sustentabilidade do ambiente passa também por sua qualificação, o que nos dias de hoje assume conotação relacionada tanto à prevenção e recuperação como ao incremento artificial das condições territoriais.

Entretanto, temos sido induzidos, por algumas correntes da teoria social crítica, a pensar que "... a preocupação com aspectos formais (a paisagem também o é) dissimularia o aperfeiçoamento da essência das coisas, essa sim, a única válida" (Yázigi, 1997, p.73), que o não visível prevalece sobre o mundo visível, e que somente estu- 
dando dimensões mais abstratas da vida entenderíamos e atingiríamos a emancipação da realidade. Outros sugerem que a valorização dos aspectos formais do espaço só teria interesse estético, como se a morfologia também não estruturasse a práxis social, conforme se pode perceber nesta afirmativa de Claval:

"A paisagem é, na maioria dos casos, um produto não planejado da atividade humana, sem concepção estética global: a preocupação com a beleza só pode ser alcançada em alguns casos, a maioria na pequena escala da edificação, do setor urbano sob forte controle" (Claval, 1999).

Dada sua dimensão cultural, o estudo e busca da qualificação da paisagem, entidade visual que apresenta uma morfologia, não implica descuidar dos demais âmbitos de conhecimento e problemas sociais e ambientais, justamente porque "cultura é justamente o conjunto de respostas que o grupo dá aos desafios do meio" (Yázigi, 1997, p.74).

O desenho e o planejamento da paisagem, do território e de ambientes, enquanto escolhas intencionais e conscientes, passam a exigir ser mais uma medida de controle do que de dominação da natureza. Ao se evitar os impactos antrópicos casuísticos sobre a natureza e seus ecossistemas, que são auto-organizáveis, poderemos planejar sobre princípios com os quais eles trabalham (quando conhecidos) para transformar os ecossistemas humanos em ecossistemas sustentáveis (Lyle, 1985).

O ambiente, assim como a territorialidade e a paisagem, enquanto aspectos fundamentais para a ordenação territorial com desenvolvimento sustentável, locais ou regionais, passam a exigir adequada conceituação e instrumentação para a definição correta de seu papel na implementação e gestão do planejamento.

Na discussão sobre a ordenação do território e do planejamento da paisagem não devemos nos ater tão somente na reprodução de paisagens, nem descrevê-las em detalhes, nem a catalogação simples, nem submetê-las a uma cosmética ao gosto de grupos sociais específicos ou de elites, senão que devemos considerar a capacidade de gestionar o território adequadamente.

Um planejamento do ambiente conseqüente deve ser entendido como um entrelaçamento inter, multi e trans-escalar com uma visão ecossistêmica em três instâncias: ecossistemas urbanos, agro-ecossistemas e ecossistemas naturais. Desse modo, seus limites de intervenção transcendem à delimitação territorial política, pois assume a noção dos inter-relacionamentos de fluxos de energia, matéria e informações que se estabelecem entre aquelas instâncias. 
Gestionar adequadamente um território e sua paisagem, portanto, passa por reconhecer sua condição de sistema, ou inclusive, sistema de sistemas (já que cada elemento ou unidade de território é também um sistema), em que interagem múltiplas variáveis de todo os tipos: físicas, biológicas e culturais, em que a matriz espacial, entendida em sua estrutura morfológica, é fundamental.

Estruturar o território respeitando o patrimônio paisagístico significa, entre outras coisas, a manutenção do tamanho mínimo de funcionalidade das unidades de território constituintes do todo espacial. A boa gestão inclina-se para a mescla de unidades territoriais compactas e densas, entremeadas por espaços livres, complexos e consolidados, sistemas naturais intercalados e interconectados, compondo um mosaico paisagístico diversificado, compondo, quando, possível uma polivalência paisagística em contraposição ao rururbano banalizado e anódino.

Mesmo que se considere que a realidade é o que se percebe, não são as percepções que se deve gestionar de um modo ou de outro, mas sim os fatos em que se sustentam (Folch, 2003), porque "gestionar uma paisagem não é desenhar um cenário, senão, reorganizar, em função de umas constrições naturais e uns objetivos, um sistema de tal modo que siga funcionando" (Terradas, 2003, p.66).

Se tivermos em conta que a configuração de paisagens é um produto social e representa pactos, mediações conscientes ou não entre os agentes presentes na produção do território, a ampliação dos presentes na concertação de interesses que configuram a paisagem resulta ser mais significativo e consistente do que a participação de poucos e recorrentes atores, especialmente se são assinaladas as representações de sua evolução material e cultural.

\section{Paisagem e cultura}

As possibilidades de utilização do recurso patrimonial paisagístico podem alavancar uma série de alternativas de ordenação territorial especialmente se considerada sua dimensão cultural para além da fruição estética e dos preceitos ecológicos. A paisagem passa a ser entendida como um elemento de construção de identidade e mesmo como um modo de promoção de cidadania, “... já que a afirmação dos mais diferentes grupos, num contexto de participação no planejamento, passaria por sua inclusão no sistema, como meio de eliminar a miséria da paisagem" (Yázigi, 1997, p.74). 
A paisagem como expressão de cultura que pode e merece ser conservada é importante pelo reconhecimento do passado, mas também como resultado de práticas culturais do presente. As relações que o ser humano estabelece com os demais e com a natureza se plasmam na paisagem e irão refletir as concepções e decisões da sociedade: sua consideração ao meio-ambiente e de como se negociam as ações nele inscritas.

Insiste-se na compreensão de paisagem em seu sentido mais amplo: a paisagem enquanto recursos naturais, mas também a paisagem agrícola construída durante séculos, a paisagem urbana e mesmo as mais recentes expansões urbanas por sobre o território. E a compreensão de conservação e preservação, enquanto conceitos sócioecológicos, deve superar a simples intangibilidade de espaços naturais, incorporando a idéia de conservação e preservação ativas, numa visão contemporânea do uso social da natureza, conforme a abrangente definição de Pellegrini Fillho:

"A conservação de bens naturais e culturais, dando-lhes ao mesmo tempo uma função conveniente, com soluções adequadas ao desejado progresso; portanto implicando o uso adequado de atrativos da natureza e da cultura, porém evitando ou se minimizando prejuízo a eles ou sua perda" (Pellegrini Filho, 2001)

A significação e a consistência da paisagem como representação material de uma sociedade são elementos de importante afirmação cultural. As paisagens, carregadas de cultura e testemunhas das transformações no processo de construção do território, podem contar a memória da região, narrando uma história que dê significância ao passado no presente, reforçando a identidade do grupo social local.

Essa aposta na preponderância da paisagem no projeto territorial, gerando diretrizes e políticas públicas (respaldadas pelo devido aparato jurídico-institucional) crê em sua capacidade de ser "... fonte de reinterpretação de culturas" (ibidem, p. 97). Apostar na paisagem pode gerar princípios urbanos e arquitetônicos e inclusive de paisagismo privado que contribuam na construção de identidades neste momento histórico globalizante de sociedades e culturas, em que a modernização e flexibilização das relações econômicas, com maior eficiência na exploração de recursos, o incremento de acessibilidades e comunicações se somam para facilitar os lucros industriais (inclusive da indústria do turismo), têm levado a homogeneização e perda de qualidades distintivas das regiões. 


\section{Turismo e Paisagem}

O turismo é uma das atividades sócio-econômicas atuais que representam com mais fidelidade o que entendemos por globalização, em seus aspectos positivos e negativos. Surgido, dois séculos atrás, como antecipadora dos atuais movimentos de integração mundial, vem se desenvolvendo com intensa capacidade de mobilização de fluxos de pessoas e capital, e na maioria das vezes, tendo o meio-ambiente como matéria prima. O contato com a natureza, ou "... a vivência de espaços urbanos diferenciados das aglomerações metropolitanas, com condições de vida qualificadas pela proximidade a regiões com belezas naturais" (Ruschmann, 2002), vem sendo uma das maiores motivações das viagens de lazer.

A paisagem é um de seus principias motores, senão o principal, além de que “... é um bem livre e público, porque foi produzida pela natureza e pela coletividade, incorporando nesta acepção a paisagem construída" (Joan Cals, apud: Sabaté,1996, p. 146), e, portanto, seu tratamento enquanto elemento de ordenação das relações sociais, econômicas e culturais que se estabelecem, merece especial atenção e "se regiões e localidades decidem investir no turismo, elas devem considerar também a qualidade do meio ambiente e cabe-Ihes a decisão de estipular um custo de manutenção da natureza" (Ruschmann, 2002, p. 25).

$\mathrm{Na}$ busca de estabelecer este custo, a consideração de valores subjetivos e simbólicos dos recursos ambientais, tais como as paisagens e cenários panorâmicos socialmente reconhecidos, ainda que sabidamente de difícil mensuração rigorosa, deve se basear em inventários que levem em conta as distintas percepções e representações materiais das distintas práticas sociais em distintas épocas, inclusive as associadas ao desenvolvimento turístico.

Os principais interessados na manutenção das qualidades ambientais atrativas do turismo, tais como a administração pública, o capital financeiro, imobiliário e de serviços, assim como os próprios turistas deverão compartilhar os custos desta ação ${ }^{19}$. Se levarmos em conta experiências internacionais e nacionais (principalmente) e as conseqüências da falta de controle da exploração da indústria turística, pensa-se que a

\footnotetext{
${ }^{19}$ Os custos serão resultado do cruzamento, semelhante ao que se aplica a qualquer indústria, do "orçamento das receitas e despesas provenientes dos fluxos turísticos, assim como dos investimentos e de seu funcionamento" (Ruschmann, 2002, p. 25).
} 
qualificação das localidades por meio da ordenação territorial e paisagística deve receber a atenção do Estado, como mediador dos interesses mercadológicos e do interesse público.

Joan Cals, economista catalão que teoriza sobre economia do turismo, entende a atividade como consumidora da paisagem, considerada como produto escasso ou em vias de extinção em grande parte dos centros de atração turística, especialmente na costa mediterrânea, onde concentrou seus estudos. A paisagem associada ao turismo é entendida como bem econômico de aproveitamento coletivo, com caráter não exclusivo, isto é, tem uso público, e não exclusível, ou seja, deve ser fruída por todos e de modo gratuito, nem seu gozo diminui a sua disponibilização por outros indivíduos (exceto em casos de congestão turística).

Ainda segundo Cals, enquanto indústria, o turismo, ao aproveitar a paisagem, especialmente por dimensão cultural, poderia ser visto como mais próxima da indústria dos meios de comunicação do que da indústria imobiliária, que é como comumente é reconhecido nos meios empresariais e mesmo na administração pública brasileira, baseando-se em princípios urbanísticos convencionais. Esta concepção do turismo tende a recriar imagens e paisagens das cidades e lugares habitualmente não turísticos, negando a possibilidade de transferir ao território princípios e regras de comunicação social, tais como a mitificação, a ritualização e a inversão. A paisagem turística é vista então como expressão de cultura.

Assume-se, assim, a possibilidade de formação do território por meio do aproveitamento da paisagem pelo turismo, entendido aqui como não necessariamente agressor do meio ambiente, mas sim como fator de desenvolvimento que pode trazer, em determinadas condições de controle, sustentabilidade a determinadas regiões.

\section{Considerações sobre a escala na abordagem do território e da paisagem}

A matriz da paisagem tende a ser o elemento mais visível nos estudos do território. É o que se chama de estrutura da paisagem e descreve e representa um determinado momento da superfície terrestre, ainda que, como já foi dito, as paisagens não sejam estáticas e sua estrutura muda ao longo do tempo, constituindo sua dinâmica. 
A leitura estrutural ou morfológica do território e de suas paisagens, nesta concepção, pressupõe e busca identificar e descrever estruturas espaciais, os conjuntos de manchas, sua distribuição, sua forma, seu tamanho e a sua associação ao relevo. Em um primeiro momento de classificação de um território, a descrição das paisagens (pautas) é fundamental. Para um aprofundamento da compreensão da anatomia territorial paisagística é necessária a consideração do âmbito escalar, ou seja, das relações entra as medidas das coisas e o caráter dos fenômenos.

O parâmetro territorial básico é a escala espacial. Quando se muda a escala de um mapa significa trocar a legenda, não só sua dimensão. As coisas existentes no mapa mudam seu significado, não só seu tamanho. Se nos estudos de paisagem a heterogeneidade é importante para a distinção entre diferentes territorialidades, devese levar em conta que numa escala abrangente qualquer recorte espacial é homogêneo e que pode vir a ser heterogêneo se visto mais de perto.

A cada âmbito escalar se tem associado um tipo de fenômeno que se torna incompreensível se estudado de muito perto ou de muito longe. Folch (2003, p.39) estabelece uma relação de âmbitos escalares aproximados com possibilidades de estudos específicos: a escala biológica (<1:100); a escala arquitetônica (1:100-1.000); a escala urbanística/ecossistêmica (1:1.000-10.000); a escala micro-territorial/ecológica (1:10. 00-25. 000); a escala meso-territorial/paisagística (1:25. 000-100.000) e a escala macro-territorial (>1:100. 000).

A importância dada à escala para cada estudo disciplinar do território busca evitar os erros perceptivos, ao se escolher a escala adequada ao fenômeno analisado. Um exemplar arbóreo individual e isolado só tem destaque em escala biológica (1:50) e pouco considerado ao nível territorial (1:25. 000). De acordo com alguns modelos descritivos de paisagens e territórios, seus limites já não podem ser dados pela vista, já que se faz necessária utilização de mapas e fotografias.

Já a escala temporal nos faz considerar que os fenômenos territoriais não são instantâneos. Mapas congelam como sincrônicos fenômenos na realidade diacrônicos e com diversos ritmos. E relativiza o conceito de irreversibilidade e de adequação temporal das ações de ordenação territorial (prazos de recuperação de áreas degradadas e de consolidação de áreas verdes criadas, por exemplo). 
A escala espaço-temporal nos remete a uma leitura de caráter misto. Aos ritmos temporais diferentes há que se incorporar os espaços medidos em tempo, como os espaços de deslocamento feitos em distintos meio de transporte, e as transformações territoriais atreladas a momentos históricos.

Esta escala é tida por ecologistas da paisagem como escala de percepção, ou seja, aquela em que “... cada espécie percebe a paisagem em função de suas características ecológicas (tamanho de território, especificidade do habitat, capacidade de locomoção, etc.)" (Metzger, 2001, p.7).

\section{A descrição da estrutura da paisagem}

A matriz da paisagem ocupa a maior parte dos modelos descritivos do território que sustentam as análises morfológicas e tem um papel fundamental para o funcionamento ecológico do território e na conservação da biodiversidade.

A paisagem é percebida em função da escala, numa perspectiva de tempo e espaço. Para efeitos de análise e planejamento, pode-se utilizar delimitações estáticas e com tendência a homogeneização abrangente, mas sempre tendo em consideração que a realidade é um processo, com transformação contínua de formas, de funções e da estrutura (em ritmos diversos). E somente esta compreensão permite um discurso que contribua para a interferência na realidade.

Daí surge a necessidade de discutir a dimensão de uma paisagem, ou a unidade de paisagem que definiria o recorte de estudo ou análise. Uma unidade de paisagem é uma porção de superfície terrestre com limites reais que podem ser definidos técnica e politicamente e com homogeneidade relativa, podendo apresentar diversidade de elementos em sua composição. Esta variação é função da abrangência do estudo e depende do nível de precisão que se pretende atingir.

A natureza não estabelece limites rígidos, e segundo Forman, (1986) é o impacto das intervenções humanas que tende a estabelecer mudanças rígidas entre paisagens, embora seja possível destacar exemplos de paisagens naturais contrastantes por todo o planeta. Se da perspectiva ecológica, estes elementos poderiam ser considerados ecossistemas, devendo apresentar como característica a auto-regulação funcional (segundo Moroni, 1974), outros, como Lyle (1985) e Delpoux (1974) preferem uma divisão pela lógica fisiográfica. 
O geógrafo francês sustenta que todos os casos concretos de caracterização de uma paisagem podem ser divididos em duas unidades elementares: pelo seu suporte e suas características climáticas e geológicas (cor, forma, textura, micro-relevo); e pela cobertura, que materializaria a influência dos parâmetros climáticos, pedológicos, biológicos, florísticos, faunísticos e entre eles, o parâmetro antrópico (pressão humana atual ou passada, reflexo da atividade sócio-econômica).

Bertrand (1972) define delimitações em unidades superiores (zona, domínio, região) e unidades inferiores (geossistemas, geofaces e geotopo), citando como exemplo a divisão em região (continente de uma bacia hidrográfica), zona (continente de uma sub-bacia) e área (onde o elemento principal seria um córrego)

A urbanística e a arquitetura, ao buscar descrever o território e paisagens com fins de ordenação territorial, tendem a utilizar delimitações decorrentes de outras disciplinas como a da ecologia da paisagem que considera "... a paisagem como um sistema funcional de escala quilométrica, integrado por partes que interagem, e que por sua vez podem ser definidas mediante seu tipo, extensão, forma e configuração ou disposição no espaço" (Rodà, 2003, p.43), mas incluindo definitivamente os elementos humanos, sejam construídos ou relativamente naturais, formando o mosaico de áreas homogêneas naturais e antropizadas que descreve a totalidade do território e das paisagens.

Ao se trabalhar com a preocupação da ordenação, do planejamento e do projeto territorial, o mosaico paisagístico a ser considerado, ou seja, o conjunto interativo de elementos da paisagem deve mostrar as unidades de cobertura e de ocupação do território, numa escala espacial (e conseqüentemente temporal) ampla, muito mais do que o estudo de estruturas bio-ecológicas (relações de animais e plantas com o meio abiótico).

Ainda que o uso de limites entre unidades seja um recurso intelectual, pois se converte uma estrutura dinâmica em estática, para propósitos de representação cartográfica, com escala e tudo, sua importância não pode ser negligenciada para o estabelecimento dos conjuntos interativos da paisagem.

\subsection{Metodologia e instrumentos de análise}

Ao se buscar a instrumentação dos conceitos que resulte em uma metodologia de análise do território, se partirá da análise da morfologia e da configuração de paisagem, 
relacionada com sua construção histórica, entendendo o território como resultante de um processo sócio-ambiental, e, portanto, continuamente mutante. A investigação foi desenvolvida a partir de estudos exploratórios, pesquisa bibliográfica e iconográfica, estudos etnográficos, observação direta, análise de conteúdo e descritivos.

Os estudos exploratórios permitiram uma aproximação ao objeto estudado, identificando fatos e fenômenos e questões potenciais, ora de modo empírico e, por vezes, de natureza científica, com vistas à delimitação, à caracterização e a uma compreensão inicial da realidade. A partir da experiência acadêmica durante os últimos anos, nos campos do ensino, da pesquisa e da extensão, foram sendo realizadas interlocuções com agentes envolvidos no processo de construção do espaço da cidade, observações diretas do ambiente em que se insere o objeto de investigação e leituras de documentos relacionados à temática, que permitiram definir o objeto de estudo.

A pesquisa bibliográfica de acervos concretos e virtuais em bibliotecas nacionais e estrangeiras levou a uma atualização de conteúdos e revisão de conceitos com interface com o tema. Receberam especial atenção aquelas noções acerca do ambiente, do território e da paisagem, na medida em que estes termos seriam centrais na construção da tese e dariam a base conceitual da instrumentação analítica da paisagem. A abordagem da temática relativa ao turismo e ao planejamento de espaços turísticos foi também alvo de revisão e discussão crítica, o que permitiu sistematização e novos entendimentos do fenômeno estudado. A análise documental e o estudo da iconografia no contexto da paisagem se revestiram de importância ao possibilitar a criação de imagens mentais de épocas não vivenciadas e recentes, permitindo compreensão dos ambientes.

Os estudos etnográficos, relacionados aos grupos sociais atuantes no contexto sócio-espacial, foram empreendidos por meio de vivência e leituras de bibliografia relacionada ao tema, buscando interpretar as idiossincrasias de cada agrupamento, do inter-relacionamento entre eles e de seu relacionamento com o ambiente, permitindo a compreensão dos interesses, poderes e estratégias envolvidos na construção do espaço.

A observação direta se deu pela possibilidade de vivência do investigador junto ao objeto estudado, técnica aceita se levada com flexibilidade no distanciamento e preci- 
são formal nas interpretações e análises. A vivência no ambiente de estudo permitiu o acompanhamento sistêmico das transformações espaciais, perceptíveis para o observador qualificado, e a convivência com diferentes atores sociais, considerando os interesses e as representações de cada segmento.

A análise de conteúdo possibilitou a interpretação dos fenômenos analisados nos aspectos e categorias eleitas para as análises empreendidas, especialmente da cartografia existente e elaborada, das transformações acontecidas, da natureza e desenvolvimento da atividade turística no contexto da região estudada, e da atuação dos atores sociais envolvidos. Estudos de natureza qualitativa e quantitativa, parciais e complementares, a partir da descrição de fatos complexos e coleta dados de diferentes fontes, com posterior interpretação e avaliação, permearam todos os procedimentos anteriores de modo a instrumentalizar as análises empreendidas.

O estudo de caso permitiu, ao se olhar a realidade de maneira sistêmica, delimitada, aprofundada e unitária, por meio da descrição analítica, a interpretação pragmática da questão, sustentada pelas bases teóricas e metodológicas eleitas, fazendo surgir, a partir da análise das categorias e variáveis escolhidas, elementos comprobatórios das hipóteses. De modo sistemático e objetivo, foram interpretados e avaliados dados da realidade e foram feitas inferências, embasadas no referencial teórico de sustentação da pesquisa, sobre cenários futuros, repercutindo nas conclusões da tese.

Tendo em vista a complexidade e diversidade de elementos que configuram a paisagem, se considerou necessário adotar três escalas de abordagem: uma abarcando as grandes áreas homogêneas, naturais e construídas pelo homem, que formam o mosaico paisagístico inteiro da região escolhida, estudada a partir de mapas e cartografia adequada; uma outra escala, na qual se utilizou instrumental cartográfico e visual/perceptivo, possibilitando a delimitação e análise de unidades de paisagem; e uma terceira, na qual, a partir da visualização de porções determinadas do território, foi possível perceber elementos de menores dimensões, os estabelecimentos turísticos, mas partícipes da transformação da paisagem.

As categorias de análise foram definidas em função do objeto de estudo e das escalas de abordagem adotadas, e também a partir das premissas e hipóteses levantadas. Na dimensão físico-territorial, foram utilizadas categorias analíticas da 
geomorfologia, como relevo, hidrologia e cobertura vegetal, incorporando a identificação dos principais sistemas naturais e suas funções ecológicas. Ainda na dimensão espacial, também foram utilizadas categorias analíticas do urbanismo para o entendimento dos sistemas culturais representados por assentamentos urbanos (em suas diversas gradações), áreas rurais e estabelecimentos turístico-balneários, entendidos como aqueles mais percebidos na paisagem.

Nas dimensões socioeconômica e cultural, as análises tiveram base nas categorias utilizadas pelas disciplinas específicas de estudo, se estudando as relações sociais de produção e consumo, sua evolução e atualidade na produção do espaço da cidade, destacando os atores sociais e suas idéias norteadoras, seus interesses, suas práticas e suas estratégias de atendimento de necessidades e demandas.

O cruzamento das informações analisadas nessas dimensões, co-relacionando dados quantitativos e qualitativos, levou a conclusões que permitiram inferências quanto as possibilidades de aproveitamento da base natural e da estrutura espacial colonial no impulso da atividade turística na cidade de Florianópolis, avançando, de modo prudente e responsável, para uma alternativa de aproveitamento do patrimônio paisagístico no desenvolvimento sustentável da cidade.

\section{Introdução ao método de análise territorial}

Com o intuito de confirmar as hipóteses levantadas, a aplicação de conceitos e metodologias de análise do território para identificar a estrutura morfológica da área objeto de estudo tem papel fundamental. A llha de Santa Catarina será analisado a partir da morfologia e de a configuração de sua paisagem relacionada com sua construção histórica, entendendo o território como resultante de um processo sócioambiental, e, portanto, continuamente mutante.

A partir da identificação minuciosa de sua estrutura paisagística, se buscará indicativos morfológicos que avancem na consideração deste patrimônio, essencial no desenvolvimento sustentável, como elemento chave na ordenação territorial, que por sua vez é âmbito importante para alavancar transformações sócio-econômicas.

"Os que estudam ciências ambientais dizem que são coisas de grande interesse e que é importante conectar entre elas estas reservas de naturalidade (gran- 
des bosques, grandes áreas agrícolas), (...). Nos dizem depois que também é importante interconectar-los com corredores, porque assim, as diferentes espécies, botânicas e animais, podem emigrar de um lugar a outro, e que com estas migrações aumentam a biodiversidade. (...) E um aumento da capacidade de resistência do sistema ecológico para se enfrentar a toda a artificialidade que nós introduzimos. (...) Mas sobre o que quero chamar a atenção é sobre isto; eu tenho dito pontos, tenho dito linhas, tenho dito superfícies: ponto, linha e superfície. Começam a se converter em uma linguagem minha, de arquiteto, de pessoa que desenha um território" (Bernardo Secchi, 1998).

A postura adotada neste trabalho busca alternativas aos instrumentos utilizados, em passado recente, pela disciplina. Promove a dimensão física a um nível além das técnicas e dados abstratos da economia e da sociologia, e da hiper-valorização dos aspectos funcionais e demográficos, e de descoberta da vocação territorial. Busca integrar, em chave de projeto, as demais informações e reflexões originadas em disciplinas correlatas que tratam dos problemas e questões de leitura e descrição do espaço, do projeto urbanístico e do planejamento territorial, porém se afastando das características de modelos originado nessas disciplinas que não se adequam ao trato do território com vistas a sua ordenação física.

A análise de âmbito territorial paisagístico far-se-á com base em distintas escalas e com a contribuição de diferentes abordagens disciplinares que tratam do meio físico-espacial, considerando a dimensão espacial do turismo, relacionada às demais que conformam o processo de formação do território. Mas mesmo se apoiando em outras disciplinas, convém reforçar, esta análise será feita a partir da visão arquitetônica, com conceitos e instrumentos próprios dessa disciplina, como o estudo das estruturas formais de configuração da paisagem e utilizando modelos descritivos da estrutura territorial.

A questão formal do espaço objeto de estudo reveste-se de interesse na medida em que a forma limita exteriormente um corpo, com feitio, aspecto e configuração, o que confere materialidade ao termo, assim como esta configuração é passível de reconhecimento pelo consciente social, mediada por artifícios disciplinares específicos (Holanda et alli, 2000). Ao se colocar o território e a paisagem como centro da análise, fica claro que ela será, por conseqüência, o objeto principal das estratégias de ordenação territorial, objetivo final desta tese. 


\section{Metodologia adotada}

Conforme vem sendo sugerido pelos trabalhos desenvolvidos há mais três décadas, no Departamento de Urbanismo e Ordenação Territorial da UPC, Barcelona ${ }^{20}$, e, em específico, pelos estudos realizados sob a direção do professor Joaquim Sabaté Bel, a análise do território e da paisagem se centra nas relações históricas de seus elementos e da compreensão das permanências e transformações ocorridas no processo de estruturação espacial.

A partir da leitura histórica de sua ocupação se percebe que, mais além da dicotomia campo-cidade, os ambientes urbanos, rústicos e naturais são elementos de uma complexa relação de continuidade, formando uma paisagem que reflete o processo de formação sócio-espacial. A paisagem é, então, entendida enquanto recursos naturais, “... porém assim mesmo a paisagem agrícola construída durante séculos, a paisagem urbana (...) e concretamente a própria dos desenvolvimentos turísticos..." (CCRS Arquitectes,1993, p. 79).

A metodologia adotada trata de ler, descrever e interpretar realidades sócio-espaciais complexas, por meio da realidade territorial e paisagística, do ponto de vista da arquitetura e da urbanística, bem como alicerça futuras intervenções no território.

Busca descobrir modelos estruturais do território que expliquem a realidade. "O modelo será, por um lado, o reflexo da realidade analisada, e por outro, o resultado sintético da intervenção voluntarista de quem projeta, do que atua sobre ele. É, portanto, um instrumento metodológico capaz de assumir o lado ativo do conhecimento, de compreender a dialética entre o conhecimento como reflexo e o conhecimento como projeto" (Juan Galindo, 2004, p. 128).

O modelo se estrutura na relação dialética de seus elementos em suposta harmonia e equilíbrio, sempre instável. "O modelo extrai da realidade estruturas de validez generalizáveis - abstratas, simbólicas, manipuláveis - nas quais os elementos parciais são interpretados precisamente em respeito ao resto de relações do conjunto. É, portanto, uma análise totalizadora, sintética, que permite descobrir a singularidade de um conjunto (sua estrutura) e, ao mesmo tempo, o modo de transcendê-lo" (Manuel de Solá-Morales, 1969).

\footnotetext{
${ }^{20}$ Pesquisas iniciadas pelo professor Manuel de Solá-Morales no final dos anos 1960
} 
A identificação do modelo processual do desenvolvimento da ocupação territorial possibilitará, num momento propositivo, a determinação e ações de caráter indicativo de possíveis modelos e critérios de ordenação, de normativas e de medidas indicativas nas unidades de tratamento homogêneo, de controle e gestão, com base nos parâmetros analisados, de transformação e/ou atualização daquele modelo, em função dos requerimentos futuros do lugar estudado.

Para descrever um território, em constante transformação, sua lógica processual e física, parte-se da leitura de seu processo de formação, de seus elementos constitutivos e de seus valores, enfim, de sua estrutura morfológica, por meio de cartografia evolutiva da ocupação e transformação do espaço.

Primeiramente, identifica os principais ambientes territoriais, partes homogêneas em escala regional, desde uma compreensão da fisiografia, da edafologia, e das grandes manifestações e transformações histórico-sociais, as urbanizações e ocupações humanas. Posteriormente, são distinguidas as peças territoriais com destacada homogeneidade, em uma escala menor, onde os contornos naturais e transformados são descritos pela forma dos solos e de sua cobertura, e da forma dos assentamentos que configuram a paisagem, assim como o papel que assumem na dinâmica territorial. Num outro momento, investiga, mais detalhadamente, os elementos da instalação urbano-turística que compõem e articulam o mosaico paisagístico, como funcionam e como têm se comportado tais elementos em relação aos demais.

A cartografia se baseia no somatório dos mapas topográficos e dos mapas de identificação do parcelamento da terra; sistematização das formas construídas (sistemas de acesso, divisão do solo, alterações no relevo, edificações) em relação aos fatores naturais; categorização de um mosaico de territórios mediante a identificação daquelas lógicas e sistemas de funcionamento.

Esta leitura pode identificar variáveis físicas de ocupação que apresentem certa permanência. Podem, deste modo, ser traduzidas em pautas e lógicas organizacionais do território, em meio ao cenário muitas vezes aparentemente disperso, fragmentado e desordenado da realidade, resultando num modelo de estruturação territorial que explica de modo sintético seu funcionamento.

As análises e o diagnóstico surgem de estudos próprios e de alguns trabalhos já realizados sobre a área, que contribuem para os objetivos. Lançar-se-á mão de inven- 
tários cadastrais, de mapas de localização e forma dos distintos modos de ocupação humana e dos principais recursos naturais e culturais existentes, superpostos ao mapa topográfico, interpretando a forma do território buscando descobrir estruturas morfológicas dos tecidos e sistemas territoriais. O instrumental metodológico deste trabalho se baseia na análise dos seguintes aspectos:

Aspectos geomorfológicos, edafológicos e ecológicos da região; topografia e hipsometria do território da llha; hidrografia do território e redes de drenagem e espaços hidrológicos; descrição física e funcional das áreas homogêneas: natural - lagoas, restingas, mangues, dunas, morros; agricultura - pastagem e cultivos; urbanizado formal e informal; leitura-inventário da artificialização e naturalidade do território; evolução da organização formal das áreas homogêneas; limites, conexões, permeabilidades e transições entre as áreas homogêneas; sistema viário - caminhos na terra, na água e itinerários; localização e distribuição das demais infraestruturas de porte; padrões urbanos e arquitetônicos dos estabelecimentos urbano-turísticos.

A cartografia temática já existente e utilizada é, conforme a origem de obtenção, descrita a seguir: mapas obtidos no IPUF - Instituto de Planejamento Urbano de Florianópolis: mapa Geológico, 1: 50.000; mapa Geomorfológico, 1: 50.000; mapa de Vegetação, 1: 50.000; mapa de Uso do Solo, 1: 50.000; mapa de Classificação de Solos do Plano Diretor dos Balneários, PMF - IPUF - 1985, com as Unidades Espaciais de Planejamento - UEP, e Topografía, 1: 10.000 (cotas de 50m), que necessitou ser compatibilizado com os demais mapas; aerofotos que compõem o mosaico da llha de Florianópolis na escala 1: 8.000, ano 2002; mapa do Modelo de Ocupação para a Ilha de Santa Catarina, sem escala; mapas dos Distritos, Zonas e Centros Turísticos, segundo o Plano de Desenvolvimento Turístico do Aglomerado Urbano de Florianópolis, PMF - IPUF - CNDU - BIRD - 1981, sem escala.

Cartografia obtida de outras fontes: mapa de Compartimentos Geomorfológicos da Ilha de Santa Catarina e do Continente Próximo, proposto por Olga Cruz, geógrafa e geomorfóloga do Departamento de Geociências - CFH - UFSC, 1998, 1: 100.000; mapa de Uso e Ocupação do Solo, proposto por Bastos, 2002, sem escala; mapa mosaico de aerofotos da llha de Santa Catarina, INFOARQ, Departamento de Arquitetura e urbanismo, CTC/UFSC, Florianópolis, 1994 e mosaicos de fotos da llha de Santa Catarina, na escala 1: 50.000, dos anos de 1938, 1957, 1977 e 2002, da AEROCONSULT LTDA. 
Os mapas analíticos do território e dos mosaicos da paisagem em diferentes épocas (1: 50.000), de elaboração própria, e utilizados nesta etapa, com vistas a entender a estrutura do território e da paisagem para propor uma divisão em Unidades de Território e de Unidades de Paisagem são: mapa de Morros e Bacias hidrográficas; mapa de Áreas Protegidas (Leis Federais, Estaduais e Municipais), mapa com as Áreas Protegidas, Áreas de Proteção Cultural - APC, Áreas de Exploração Rural - AER (não urbanizáveis, segundo o PDB/85) e Áreas e bacias visuais de Interesse Paisagístico (segundo critério do autor); mapa de Assentamentos Urbanos e Peri-urbanos; mapa dos Principais Ambientes Territoriais; mapas das Áreas com Uso Turístico do PDB/85; mapa de Áreas de Interesse Paisagístico e Bacias Visuais; mapa de Unidades de Território propostas pelo autor e mapas de áreas homogêneas, que permitem a definição das Unidades de Paisagem. 


\section{CAPÍTULO II}

\section{O TERRITÓRIO NATURAL}

Este capítulo trata da caracterização do território e do ambiente natural da llha de Santa Catarina, município de Florianópolis, como requisito para a compreensão da paisagem e dos atributos que mais lhe conferem atratividade turística. Dada à situação geográfica da cidade de Florianópolis e à condição insular de maior parte de seu território, se faz necessário o estudo da região litorânea onde se encontra o objeto de estudo. Para alcançar este objetivo, busca, inicialmente, uma definição de zona costeira, tratando em seguida de aspectos relativos à zona costeira brasileira e ao litoral catarinense, para depois, numa aproximação mais detalhada e atenta às origens geológica e aos sistemas naturais que conformaram a sua paisagem original, tratar do território da llha de Santa Catarina.

\subsection{As zonas costeiras}

As zonas costeiras são a base física do intercâmbio direto entre o mar e o continente, tanto nos aspectos físicos, químicos, biológicos e geológicos como nos aspectos sociais, políticos, econômicos e culturais. De acordo com a Conferência das Nações Unidas sobre o Direito do Mar (UNCLOS), "área costeira é aquela onde ocorre a interação entre a terra o e mar, na qual a ecologia terrestre e o uso afetam diretamente o espaço oceânico e vice-versa" (ONU, Nova York, 1981), ressaltando-se o fato de conter os ecossistemas, unidades naturais básicas que podem estar contidas em áreas de extensão variável ou formar apenas parte do grande ecossistema global (Coastal Area Management and Development, ONU, Nova York 1982).

Como não se trata de uma porção espacial com clara definição e percepção única, para a qual seja possível generalizar definições e interpretações, a delimitação deste ambiente tem variado conforme diferentes autores e instituições afinadas às disciplinas científicas. Tem, a jusante, as costas rasas do declive submarino praial (submarine beach slope, conforme Zenkovich, 1967, apud Cruz, 1998), e podem descer até dezenas de metros de profundidade, mas ainda entendidas como águas costeiras, e a montante, áreas de terra, direta ou indiretamente, ligadas ao mar. 
A zona costeira pode apresentar-se, portanto, com variadas larguras, incluindo, então, o litoral, mas adentrando-se também até regiões mais interiorizadas sob influência do mar. Do um ponto de vista mais abrangente, nos interessa que compreende, genericamente, a região de transição entre o mar e a terra, envolvendo as praias e entorno litorâneo. Geralmente forma campos, dunas, pântanos, brejos, lagoas, lagunas e falésias, podendo, em função do relevo (dependendo das oscilações do nível marinho e dos movimentos tectônicos nos diferentes tempos geológicos), incluir maciços montanhosos, mas sempre com a interação de processos marinhos, subaéreos e biológicos (Gellert, 1988, apud Cruz, 1998).

Ao se constituir por regiões com interface com o mar, condição base de sua qualidade, a sua localização é, também, sócio-ambientalmente, diferenciada da "hinterlândia", com características naturais e de ocupação próprias, o que the confere monopolização espacial de algumas atividades humanas. Possui, assim, uma série de vantagens locacionais, na medida em que o mar se constitui na maior reserva de recursos do planeta. Nos primórdios da civilização, seu valor estratégico se revelou pela possibilidade de exploração dos recursos marítimos, ocupação humana. Com o incremento da demanda por consumo daqueles recursos, notadamente nos últimos cinco séculos, aumentaram também os fluxos intercontinentais, com o transporte marítimo de produtos e mercadorias.

Essas vantagens atraem, entretanto, intensa ocupação, o que vem alterando a fisionomia de extensos trechos de litoral e regiões de entorno. Hoje, dois terços da população mundial se encontram nestas regiões, sendo responsáveis pelas grandes transformações que elas que sofreram ao longo da história recente. Ao contingente populacional corresponde uma concentração de atividades, em especial a atividade industrial, o que confere um caráter urbano a estas ocupações, podendo-se dizer que se trata da zona mais alterada do planeta, com perdas irreversíveis de ecossistemas e biotas importantes.

Mais recentemente, a apropriação cultural, que o identifica como um espaço de lazer Ihe confere a condição de localização de destinos turísticos e de lugar de descompressão social urbana por excelência, atraindo uma das indústrias com base espacial no litoral que mais tem crescido: a atividade turística e, notadamente, de veraneio.

A atenção internacional se voltou para as zonas costeiras, já com consciência da necessidade de sua conservação, nos anos 1970, em meio à consolidação e repercussão em diferentes segmentos da população da questão ambiental e de preocupações 
ecológicas, em nível mundial. Evidentemente que a percepção da finitude de recursos naturais, a superpopulação mundial, e o amplo conhecimento de casos de destruição de condições ambientais em nível planetário, favoreceram essa conscientização.

Leis, recomendações e cartas de caráter internacional surgiram, então, enfatizando a necessidade de trato diferenciado, pela fragilidade dos ecossistemas presentes, da região litorânea. Entretanto, a diversidade fisiográfica e ecológica nestas zonas, tornam esta tarefa complexa. Além disso, o enfrentamento da necessária ordenação de sua ocupação e aproveitamento tem sido dificultado, tento pelos diferentes pontos de vistas (técnicos e políticos) como pela disputa de competências e atribuições no planejamento e na gestão, inibindo ações harmoniosas e coerentes.

\subsection{A zona costeira brasileira e a costa catarinense}

A definição de zona costeira no Brasil segue orientações dos organismos internacionais. A Comissão Interministerial de Recursos do Mar - CIRM (1987) entende a zona costeira brasileira como a área de interação do ar, da terra e do mar, incluindo seus recursos marinhos e terrestres, renováveis ou não, podendo conter a faixa marítima, o solo e o subsolo marinhos de jurisdição nacional, setores de abrasão e sedimentação, planícies de restinga e sistemas lagunares, planícies e terras baixas sub-litorâneas, sob influência das marés, e as bacias hidrográficas dom interior dos continentes. Mais sucintamente, a zona costeira é definida pelo IBGE como "zona de interação dos meios terrestres, marinhos e atmosféricos".

Já o Plano Nacional de Gerenciamento Costeiro (instituído pela Lei Federal n. 7661 de 16/05/1988) em seu Artigo $3^{\circ}$, registra zona costeira como o "espaço geográfico de interação do ar, do mar e da terra, incluindo seus recursos renováveis ou não, abrangendo uma faixa marítima e outra terrestre", com os seguintes limites:

"I - faixa marítima: espaço que se estende por doze milhas náuticas medido a partir das linhas de base, compreendendo, dessa forma, a totalidade do mar territorial";

"II - faixa terrestre: espaço compreendido pelos limites dos Municípios que sofrem influência direta dos fenômenos ocorrentes na zona costeira" (Decreto Federal $n^{\circ} 5.300$ de 7 de dezembro de 2004, que regulamenta a Lei que instituiu o Plano Nacional de Gerenciamento Costeiro) 
O Brasil possui o mais extenso litoral inter e subtropical do mundo com cerca de 8.000 quilômetros de extensão. A longa e estreita faixa atlântica se caracteriza, na maior parte, pela tropicalidade, com a ocorrência de praias arenosas e ambientes quentes e úmidos na maior extensão de costa, com exceção do litoral sul.

A formação do litoral brasileiro, em seus aspectos fisiográficos e ecológicos mostra uma herança complexa e multifatorial, tendo como fato geológico mais radical a separação da massa continental hipotética original - Gondwan, nas massas continentais do Brasil e da África, no Cretáceo Inferior, há 210 milhões de anos. Desde o fim desse período, também chamado de Gondwanico, o escudo de terrenos cristalinos da América do Sul se tornou estável, mas a evolução do perfil de equilíbrio litorâneo acarretou "importantes deslocamentos da linha da costa, cujas causas múltiplas não são facilmente identificadas" (Salles, 2005, p.14).

No Cretáceo Superior, depois da formação das plataformas continental submarina, se soergueram os planaltos do platô (tabuleiro) brasileiro, e a zona costeira ficou sobre influência dos movimentos dos oceanos, com a linha da costa ficando diretamente dependente do nível do mar. Nos períodos interglaciares que se caracterizam pelo aquecimento, como no Holoceno, a fachada atlântica do Brasil envolveu um importante processo geológico e de (re)tropicalização, resultando nas atuais condições do ambiente costeiro brasileiro, que se destaca pela originalidade e diversidade.

O litoral do Brasil apresenta longos trechos de recente sedimentação e raros e pequenos setores de abrasão. Áreas de sedimentação marinha quaternária sobre estreitos setores de abrasão. O mar atinge falésias em pontas de esporões de serra ou à frente de maciços costeiros que foram ilhas há milhares de anos (no Quaternário Superior). O ambiente costeiro, dependente dos componentes fisiográficos, ecológicos, climáticos e hidrológicos, apresenta ecossistemas dinâmicos e diversificados: "Entre o efetivamente terrestre e o tipicamente marinho ocorrem múltiplos ecossistemas em lagunas, canais, estuários, 'largos' e gamboas” (Ab'Sáber, 2005, p.25).

No litoral brasileiro, de norte ao sul, até Santa Catarina, ocorrem dois principais agrupamentos de ecossistemas de flora: o primeiro, de vegetação psamófila (psamabiomas), com maior adaptação aos solos arenosos; e o segundo, dos helobiomas, formado por manguezais, sobre planícies rasas e lodosas, sujeitas à salinidade trazida pelas marés. Além destes, se pode notar a ocorrência de biomas de 
transição entre os dois citados, e "florestas tropicais biodiversas que chegam até as faixas de praias por intermédio de esporões rochosos de serras e serranias costeiras" (Ab'Sáaber, 2005, p.25).

A região costeira do sul do Brasil, definida pelo final das escarpas florestadas da Serra do mar, na fronteiras do Paraná com Santa Catarina, apresenta diferentes aspectos morfológicos, mesmo quando observada na escala menor, que a diferencia da região sudeste e da região do extremo sul do país. A paisagem geomórfica da zona costeira permite uma caracterização, grosso modo, a partir do isolamento das planícies costeiras das demais terras da hinterlândia situadas no planalto serrano.

Os contrafortes da Serra do Mar, que na região central do estado de Santa Catarina são reconhecidos como parte do domínio das serras do leste catarinense (Cruz, 1998) que se estendem na costa leste dos estados do Paraná e de Santa Catarina, apesar de, à distância, como vistos do mar, se mostrarem com aparência compacta, não são uniformes, se desdobrando e ramificando em inúmeros contrafortes que chegam até o litoral.

Da barra do rio Araripe, no estado do Paraná até o cabo de Santa Marta, ao sul do estado de Santa Catarina, “... a costa apresenta geomorfologia diferente, quer em menores reentrâncias da costa, suficientemente protegida das tormentas do largo ou, por elevados e bem orientados acidentes geográficos" (Salles, 2005, p.13). A partir daí, as encostas do planalto regional se afastam, paulatina e sincopadamente, da linha costa que passa a formar, praticamente, uma praia, linear e contínua até a foz do Rio da Prata, no Uruguai. Nesta região atua um clima subtropical de transição para ambientes temperados quentes, pela posição geográfica, recebendo, nos meses de inverno, ventos da massa polar do Atlântico Sul.

O território catarinense apresenta um relevo onde se destacam as duas situações bem distintas: o planalto regional e as planícies costeiras, intermediados pela encosta serrana e seus vales fluviais, com desníveis entre um e outro de até 1000 metros.

A hidrografia resultante apresenta rios que correm em direção a oeste, que irão abastecer a grande bacia do Rio da Prata, e rios que correm em direção ao mar. Os principais rios que marcam a costa catarinense são: aqueles que assinalam as divisas estaduais: o Mampituba, com o estado do Rio Grande do Sul, e o Saí-Guaçú, com o Paraná, e os rios Itapocú, Itajaío-Açú, Itajaí-Mirim, Tubarão e Tijucas, que desembocam em baías e estuários de grandeza regional. 
$\mathrm{Na}$ costa de Santa Catarina, o segundo litoral mais recortado do país, se alternam restingas e elevações costeiras, designados maciços costeiros, que foram ilhas em diversos momentos: os esporões cristalinos que formam as atuais ilhas de desvinculação (paleoilhas) (Ab'Saber, 2005). Esta costa, anteriormente ao atual período geológico, apresentava diversas ilhas, em sua maioria granítica de origem quaternária, de diferentes tamanhos e dispersas que com as sucessivas alterações no nível do mar, permitiu a consolidação de restingas em redor dos afloramentos mais a leste, pela sedimentação, ora de partículas erodidas das serras a oeste, tanto no continente como nas próprias ilhas (caso da llha de Santa Catarina) ora de depósitos sólidos marítimos, sendo que tais restingas são permeadas por lagunas e lagoas.

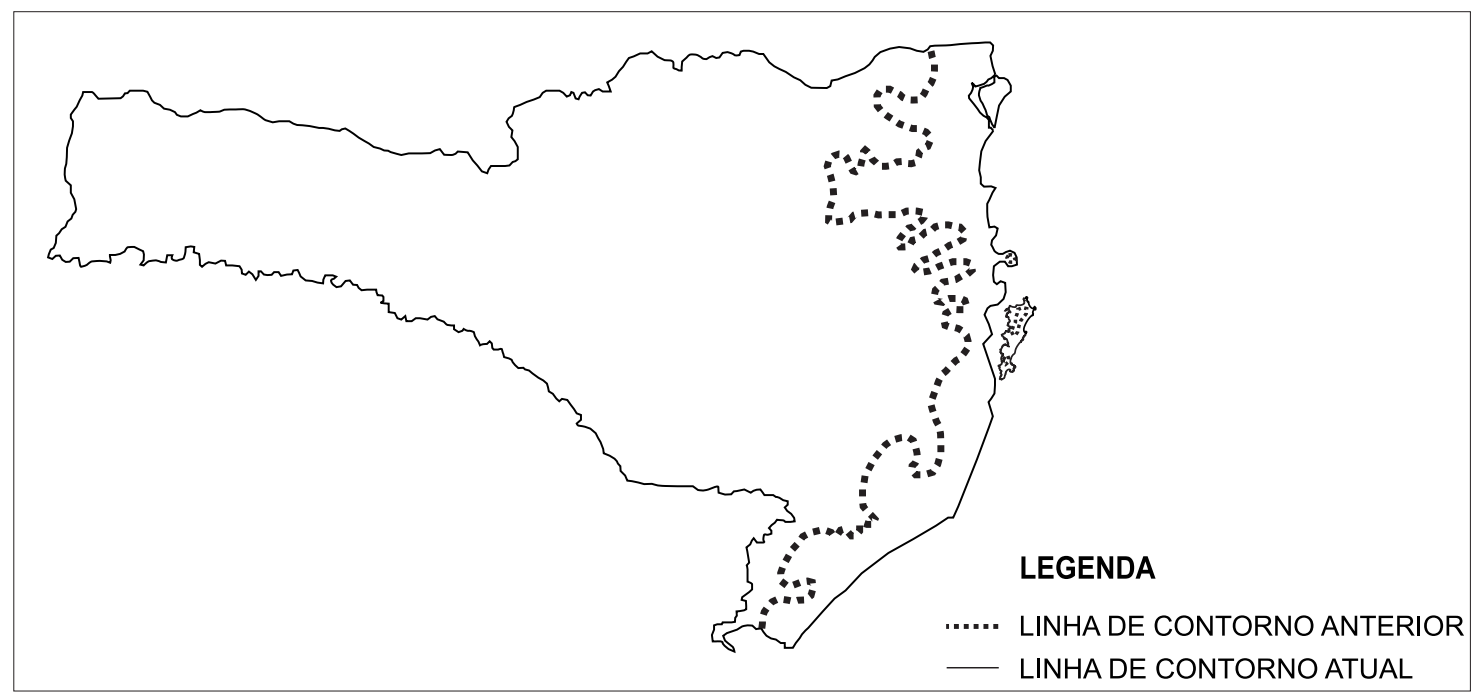

Figura 2.1: Mapa da formação geológica da costa catarinense

\subsection{O território e a paisagem original da Ilha de Santa Catarina}

A llha de Santa Catarina, com $54 \mathrm{~km}$ no sentido norte-sul e $18 \mathrm{~km}$ no sentido lesteoeste está localizada nas coordenadas médias de $27^{\circ} 35^{\prime} \mathrm{S}$ e $48^{\circ} 32^{\prime} \mathrm{W}$, "acidente costeiro do tipo das ilhas continentais desvinculadas dos esporões de serra e maciços costeiros (...)" (Ab'Saber, 2005, p.2). O bordo atlântico do planalto catarinense, na parte central da costa, perde a forma escarpada da S. do Mar, desfazendo-se em blocos falhados na linha da costa, resultando em paleoilhas e ilhas engastadas e 
florestadas. As características fisiográficas do continente próximo e da Ilha mantêm grande similitude pela presença de maciços cristalinos que conformam os morros e as planícies costeiras ${ }^{1}$.

O canal que separa a llha do continente tem origem geológica complexa, provavelmente com a ascensão do nível do mar no Holoceno, formando, nas áreas contíguas, planícies de marés onde ocorrem manguezais, relacionados com a discreta (re) tropicalização que se estabeleceu na costa catarinense, forma um estreito marítimo com aproximadamente 500 metros de largura e profundidade média de 28 metros.

Caruso (1990, p. 21) confirma a continuidade geomorfológica e fisiográfica entre o atual continente e a Ilha como se conhece hoje, ao perceber que os canais marítimos atuais foram leitos de rios no passado, ou seja, o mesmo embasamento, cortado pela força das águas:

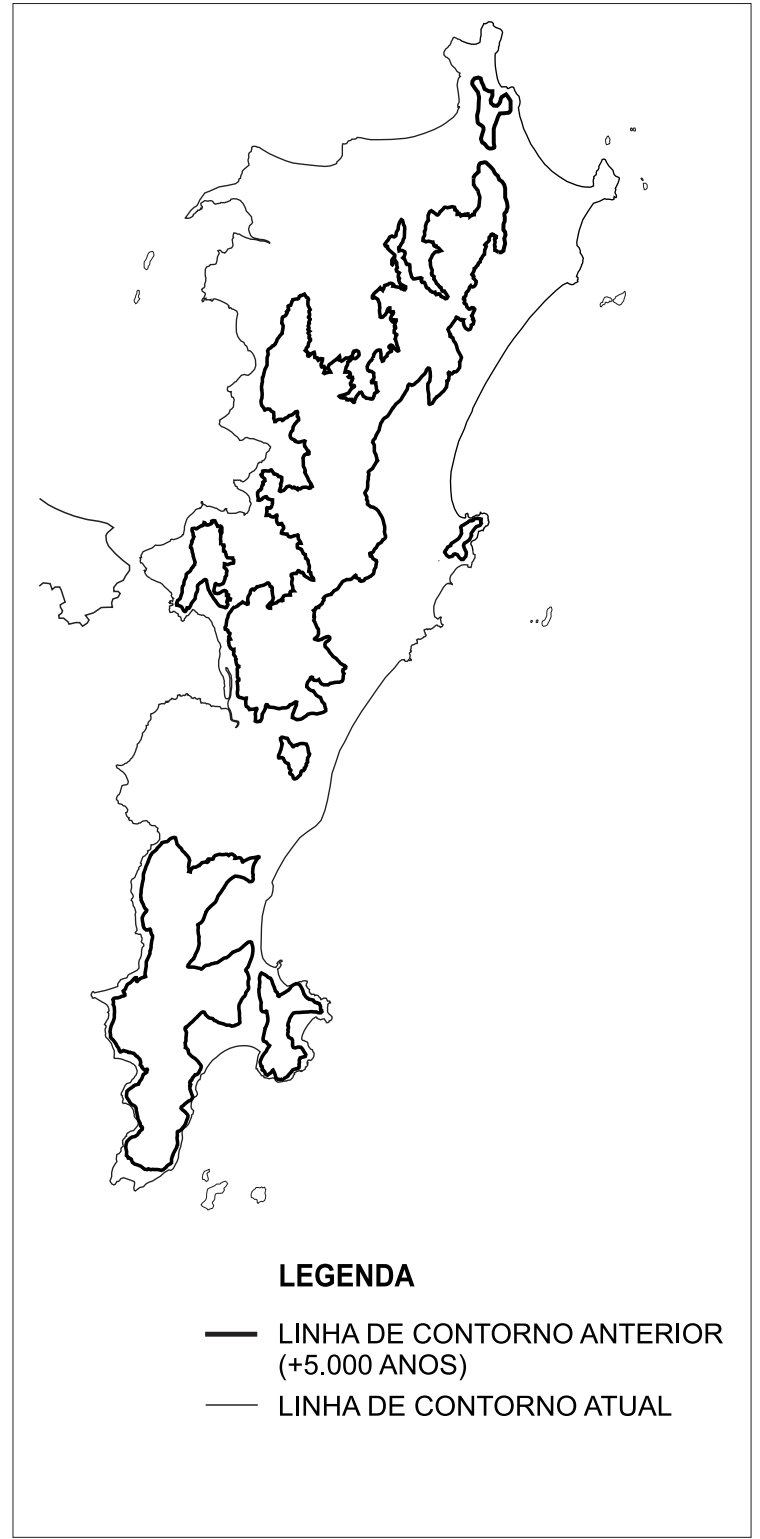

Figura 2.2: Mapa da formação geológica da llha

"A llha de Santa Catarina teve sua formação na depressão oriental do Brasil, bastante pronunciada do Rio de Janeiro para o sul. Nesse afundamento, que os geólogos correlacionam com derrames basálticos pós-triássicos, as águas invadiram os vales, os contrafortes que mais se projetavam para o oriente, transformam-se em cabos e partes mais altas das montanhas foram rodeadas pelas águas, transformandose em ilhas. Esse processo é revelado pelos canais existentes entre a llha de Santa Catarina e o continente, que são antigos leitos de rios e pela direção do relevo da Ilha, paralela a Serra do Mar".

${ }^{1}$ Diversos autores, inclusive a Fundação Instituto Brasileiro de Geografia e Estatística - IBGE colocam a microregião homogênea da Região Sul do país como dentro do domínio morfo-estrutural dos embasamentos de estilos complexos, em que se apresentam as Serras do Leste Catarinense, e dentro do domínio morfo-estrutural dos depósitos sedimentares quaternários, de planícies descontinuas. (Cruz, 98). 
Ainda que se possa considerar cada ambiente insular como ecossistemas específicos, dada à barreira oceânica, no caso da Illha de Santa Catarina, por sua estreita proximidade com o continente, as influências e relações são muitas, devendo-se, portanto, considera-la costeira. Internamente, apresenta grande diversidade paisagística e marítima: "De tal maneira que a alongada ilha de terrenos cristalinos predominantes decompostos e florestados possui um mostruário de feições que em miniatura relativa representa todo o rol de fatos fisiográficos e paisagens ecológicas do Brasil tropical atlântico, (...)" (Ab'Saber, 2005, p. 258).

Os fatos geomorfológicos, ou seja, as formações geológicas e da orografia, a morfologia do relevo e bacias hidrológicas, indispensáveis para o reconhecimento do território e da sua paisagem, apontam para uma primeira compartimentação em três grandes domínios: o litoral, as planícies costeiras e os maciços e morros, ou morrarias.

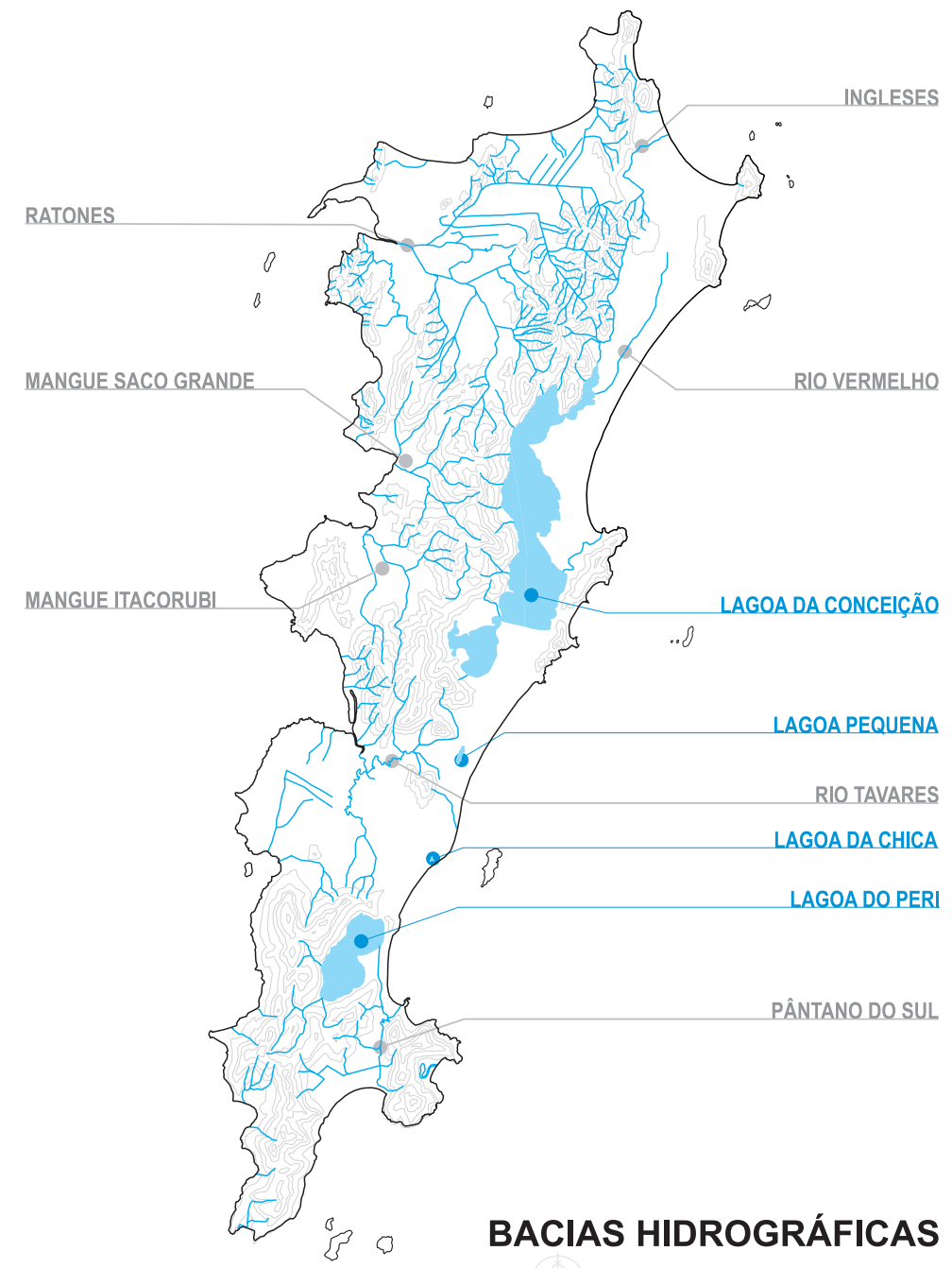

ESCALA GRAFICA $0-1$

Figura 2.3: Bacias Hidrográficas da llha de Santa Catarina.

\footnotetext{
${ }^{2}$ Esta setorização é adaptada da proposta pelo estudo de geomorfologia de Olga Cruz (98).
} 
As análises das inter-relações entre esses domínios geomorfológicos configuram, também, três grandes compartimentos insulares, caracterizados de modo muito claro a partir da identificação da dorsal central descontínua de maciços graníticos com diques basálticos, orientados na direção SSW-NNE e que dividem as bacias hidrográficas, e as planícies a LLeste e a OLeste $^{2}$ : um setor ao Sul, conformado por morros, planícies e litoral, um ao Norte, também com morros, planícies e litoral, e um setor no Centro integrado, basicamente por planícies e litoral.

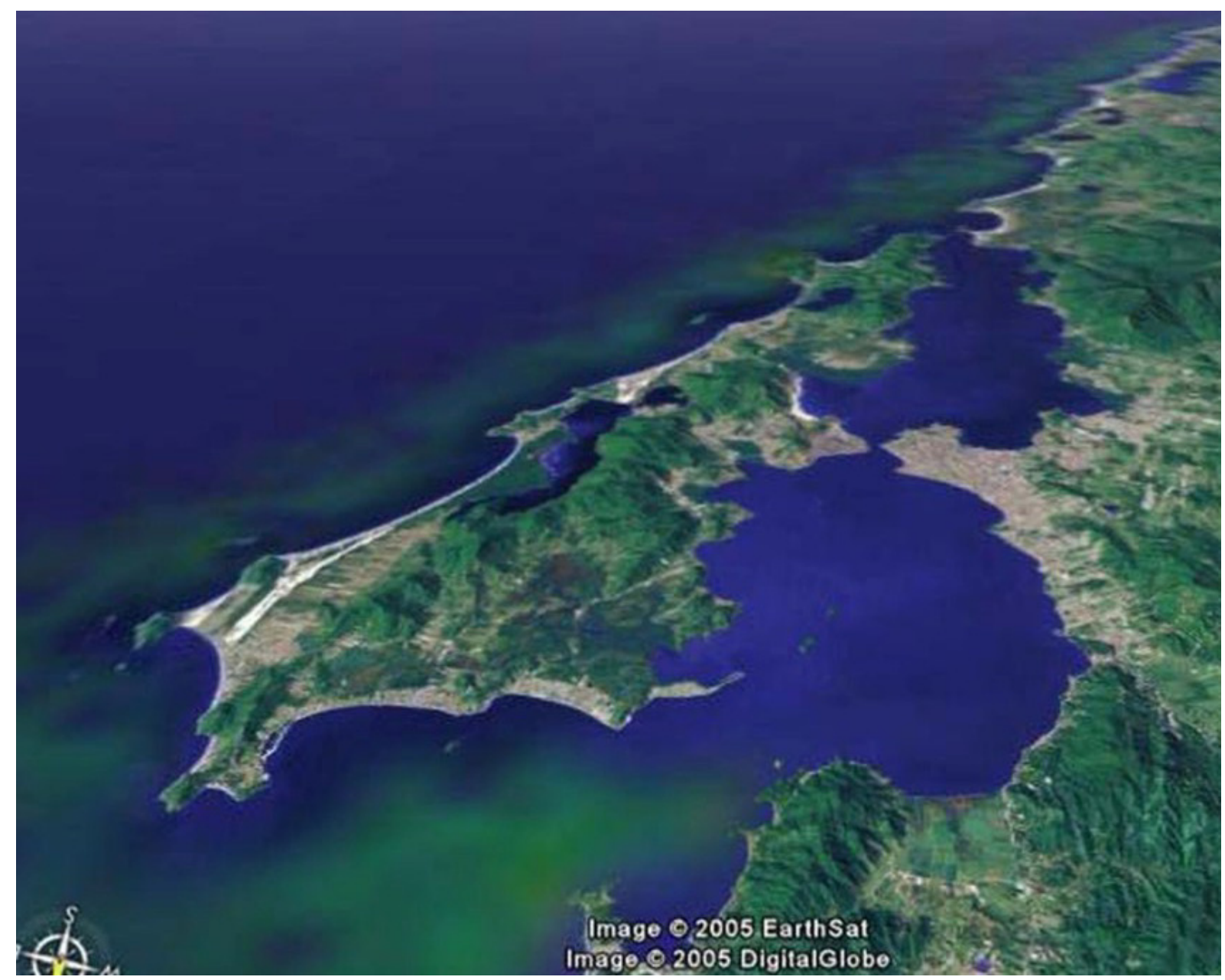

Figura 2.4: Imagem da região da cidade de Florianópolis, a partir do satélite EarthSat, 2005.

A análise pormenorizada desses compartimentos territoriais nos aponta algumas distinções dos setores definidos pelos morros e maciços. O setor Sul tem topos de 250 a 500 metros de altitude (o mais alto é o morro do Ribeirão, com 532 metros), de vertentes escarpadas, com algumas encostas chegando ao mar. No setor Norte, os maciços, com altitudes entre 150 a 400 metros, apresentam vertentes escarpadas 
mais interiorizadas e que em sua aproximação ao mar são mamelonadas, dividem as águas das maiores bacias da llha que se expandem em grandes planícies: a do Rio Ratones, a oeste, e a da Lagoa da Conceição, a leste. A parte central, localizada entre essas duas partes conformadas pelos morros, constituem uma grande planície, que quebra a continuidade da dorsal de cristalinos.

As planícies são maiores a leste que a oeste, e as diferenças são notadas não só pelas dimensões. A ação do mar aberta e dos ventos dominante e predominante na região (nordeste e sudeste) faz com que as planícies do leste se caracterizem por terraços recentes, geralmente ligadas à ocorrência de depósitos marinhos. "O litoral leste da ilha possuía irregularidades sucessivas, as quais sofreram retilinização costeira sincopada por restinga e a presença eventual de campos de dunas" (Ab'Saber,2005, p.258). Os cordões arenosos, alguns em formação dunar, e restingas encarceram algumas lagoas e lagunas, com morros e promontórios desbastados de vegetação pela exposição aos ventos e a salinidade.

Aquelas planícies que fazem frente para as baías internas, entre a Ilha e o continente, de mar calmo, apresentam também depósitos marinhos na formação dos terraços, mas justapostos e superpostos por depósitos eventuais de erosão dos maciços e promontórios existentes entre elas e o mar.

\subsection{Os principais elementos remanescentes da paisagem natural da Ilha de Santa Catarina}

A grande diversidade geomorfológica da llha de Santa Catarina favoreceu o estabelecimento de distintos ambientes e ecossistemas costeiros, apresentando praias de águas calmas, baías, praias de mar aberto, costões, morros, promontórios, mangues, lagunas, restingas e dunas. A ocupação urbana alterou quase que completamente sua pequena parte continental e tem causado impactos ao ambiente natural insular.

Apesar das alterações artificializantes ocorridas ao longo dos séculos, ainda é possível perceber essa diversidade e riqueza da maioria dos sistemas naturais. Os morros, presença marcante em relatos de viajantes passados, ainda mantêm aspecto próximo do original, pois a regeneração das áreas desmatadas para agricultura e pastoreio teve grande impulso no século XX, e ainda são cobertos em boa medida pela Floresta Ombrófila Densa (Mata Atlântica), abrigando uma fauna rica. As lagoas e os rios sofreram aterros, 
assoreamentos e contaminação, mas ainda mantêm seus espelhos d'água vivos e atraentes à vista. Os mangues também foram aterrados, e as dunas tiveram subtração de areia para material de construção e diminuição de sua área em diversas bordas mais pressionadas pela urbanização, mas ambos têm forte presença na percepção da paisagem insular.

As baías internas têm sofrido muito com o assoreamento e a contaminação, além de terem recebido aterros em diversas áreas próximas a conexão pelas pontes com o continente. As praias em áreas fora da zona central, agora tratadas como zonas balneárias, ainda mantêm suas principais características, apesar de que alguns rios e a Lagoa da Conceição tiveram suas barras adaptadas com molhes, permanecendo pouco alteradas em suas linhas de contorno. Os promontórios e costões ainda permanecem protegidos, quando localizados distantes da pressão urbana. As pequenas ilhas vizinhas pertencentes ao município ainda são mantidas praticamente sem ocupação, em condições de grande expressão ecológica.

As planícies quaternárias, por sua vez, vêm tendo sua integridade dilapidada pela urbanização recente, embora amplas áreas sem ocupação mantenham a paisagem com características naturais. Algumas planícies, por diversas razões, ainda se mantém com baixo grau de artificialização, depois de abandonadas pelo uso rural. Entre essas razões, a inadequação para ocupação urbana devido a baixa declividade de boa parte delas $(<2 \%)$, que exige investimentos mais pesados em drenagem e infraestruturas de saneamento, é certamente uma das mais importantes, juntamente com a problemática fundiária e a regularização imobiliária.

O estudo de Caruso (1990), numa aproximação ao ambiente original da llha de Santa Catarina nos mostra que dos $423 \mathrm{Km}^{2}$ do território insular, $380 \mathrm{~km}^{2}$, ou $90 \%$ do total tinham cobertura vegetal e florestal, sendo que as florestas pluviais de encosta atlântica e florestas de planície quaternária (a Mata Atlântica ou ombrófila) constituíam $313 \mathrm{~km}^{2}$, ou $74 \%$ da área da llha; os mangues $38,1 \mathrm{~km}^{2}$, ou (9\%); a vegetação de praia, dunas e restingas cobria $29,6 \mathrm{~km}^{2}$, ou $7 \%$; as dunas desnudas se espalhavam somente $4 \%$, e as lagoas $6 \%$ da território da llha.

A seguir, utilizando como base principal o Perfil de Florianópolis - Características Ambientais Biológicas (PMF, 2003), acrescido de informações de outras fontes, caracterizaremos as principais associações entre os geossistemas e os ecossistemas que formam as paisagens originais do município de Florianópolis, onde se encontra a llha de Santa Catarina, e região. 


\section{Morros com floresta ombrófila densa}

Os morros do município de Floria-nópolis eram originalmente cobertos, quase integralmente, pela Floresta Ombrófila Densa ou, como é mais conhecida, Mata Atlântica. Esta floresta caracteriza-se por sua elevada densidade e heterogeneidade em espécies, formando diferentes estratos de tipos vegetais: árvores, arvoretas, arbustos, ervas e elevado número de epífitas - que além de constituir um rico patrimônio genético, abrigam e produzem alimentos a um grande número de espécies da fauna.

A partir de 1750, com a chegada de colonos açorianos à Ilha de Santa Catarina, deu-se início a um processo de desmatamento em gran-

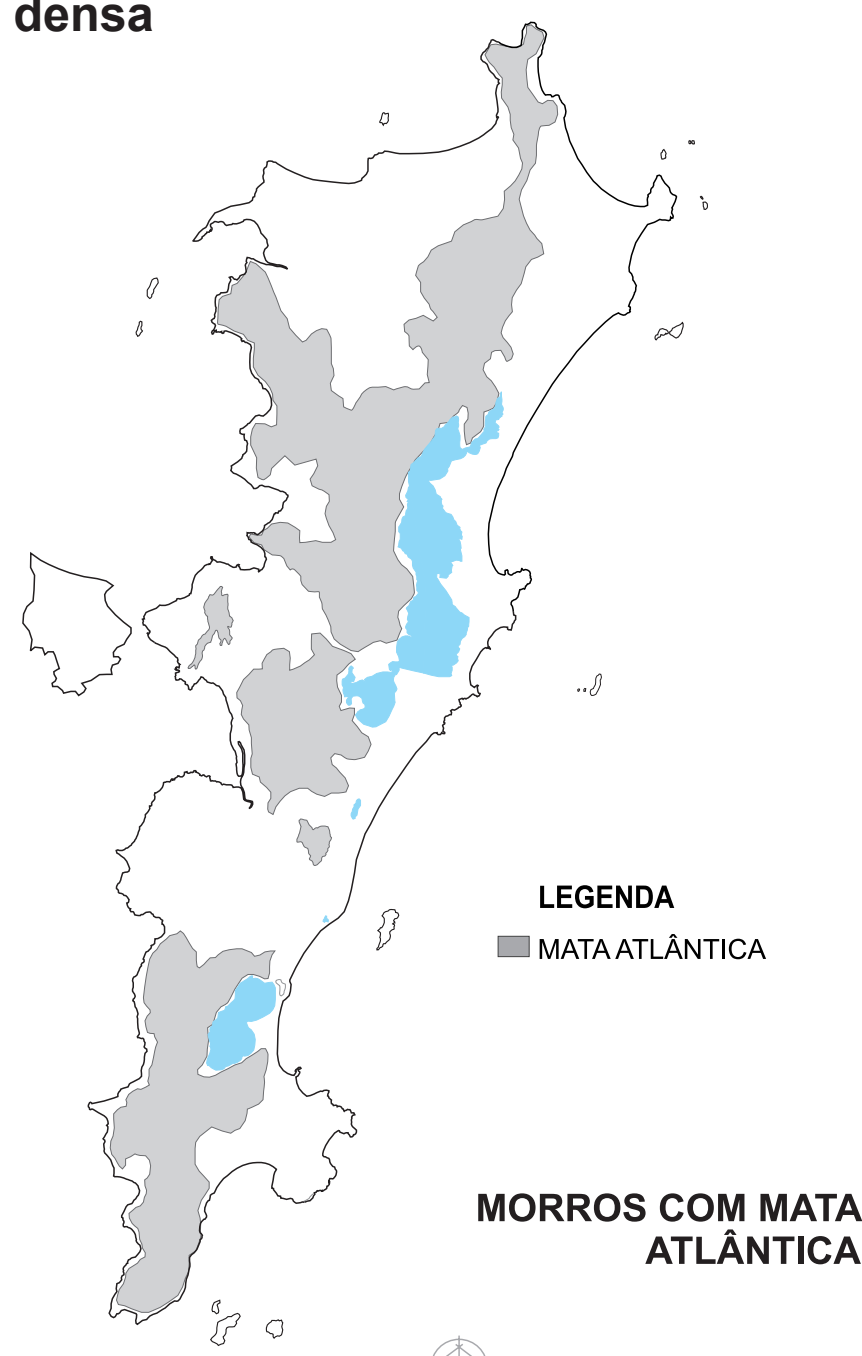

ESCALA GRÁFICA 0

Figura 2.5: Morros com Mata Atlântica. de escala visando produção agrícola. Com o declínio da agricultura, houve o abandono de muitas áreas, resultando no desenvolvimento, na maior parte das encostas da Ilha de Santa Catarina, de uma mata secundária em diferentes estágios de regeneração - capoeirinha, capoeira, capoeirão vegetação secundária - ou apenas por vegetação pioneira. Outro fator de alteração foi o reflorestamento, mais recente, com espécies exóticas de crescimento rápido, essencialmente o pinus e o eucalipto, realizado em alguns locais.

Somente em pequenas áreas, como nos morros do Ribeirão da llha e da Costa da Lagoa e nas encostas às margens da Lagoa do Peri, ainda encontra-se uma mata de aspecto fisionômico muito semelhante ao da floresta primária. Também nas encostas rochosas de solos rasos da Lagoinha do Leste ocorre ainda uma floresta primária pouco desenvolvida, formada por espécies rupestres. 
Os principais remanescentes desse ecossistema se encontram hoje em regeneração e se distribuem por boa parte dos morros da llha de Santa Catarina formando área de proteção por legislação federal e municipal (Código Florestal e áreas de Preservação Permanente, segundo o Plano Diretor dos Balneários e do Interior da llha - PMF/IPUF, 1985), e tendo suas encostas nas cotas mais baixas protegidas parcialmente por legislação municipal (Áreas de Preservação Limitada, segundo o PDB - PMF/IPUF, 1985).

Os morros cobertos pela mata atlântica formam poderoso elemento na paisagem da llha de Santa Catarina, pelas dimensões e cobertura vegetal, estando presente em todas as escalas de observação.

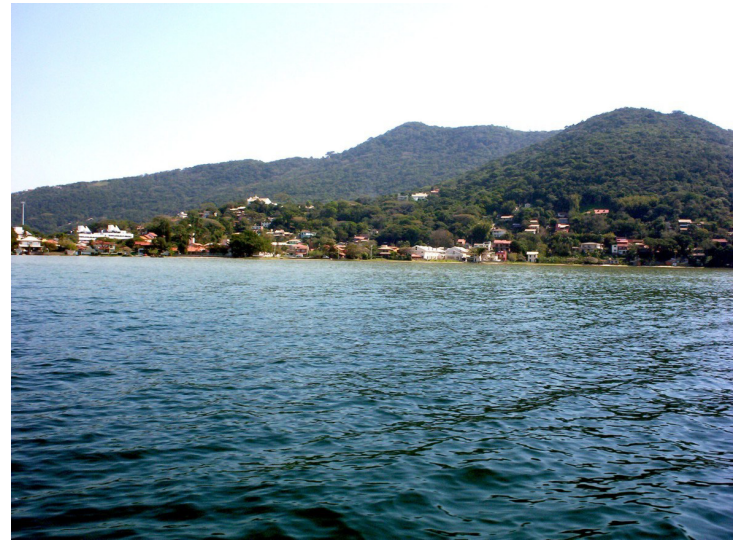

Figura 2.6: Morros no entorno da Lagoa da Conceição

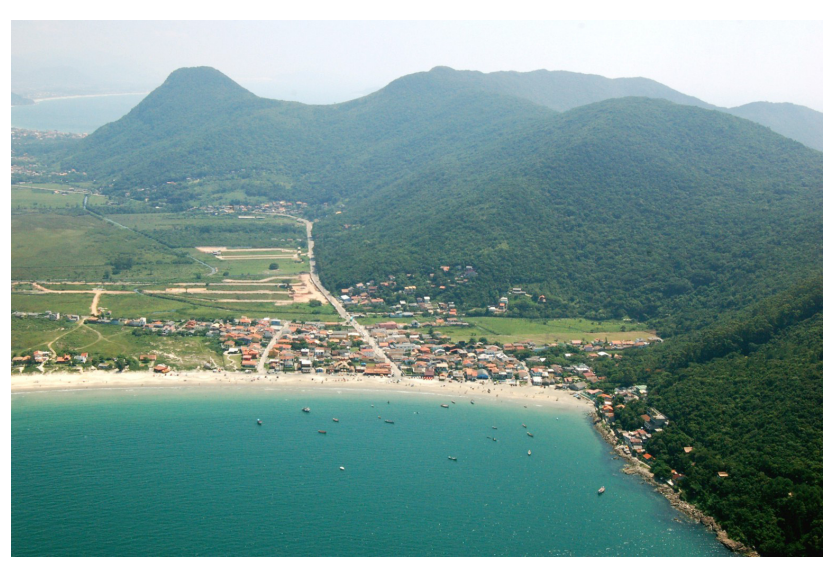

Figura 2.7: Morros nas proximidades do Pântano do Sul, no sul da ilha.

\section{Planícies quaternárias com cobertura vegetal variada}

As planícies quaternárias são formadas por sedimentos provenientes de antigas restingas e do desgaste provocado pelas águas nas terras altas. Na Ilha de Santa Catarina, mantém o regime hidrológico das bacias de inundação dos rios que descem das encostas dos morros. Sendo seus solos geralmente úmidos, até semibrejosos, se desenvolve uma vegetação edáfica muito típica - estrutural e fisionomicamente homogênea.

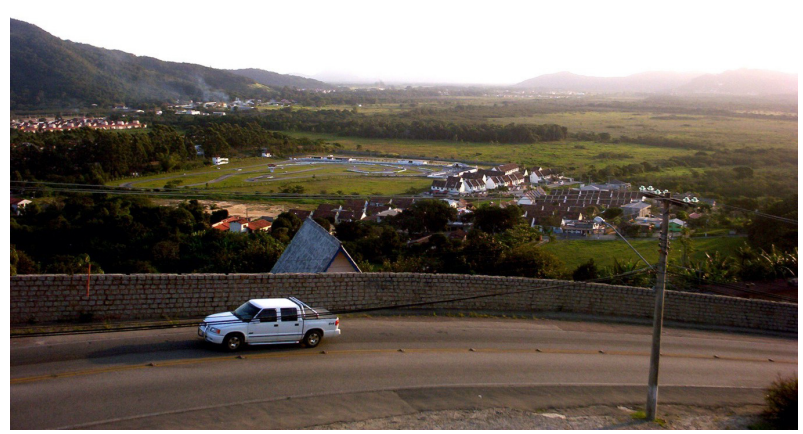

Figura 2.8: Planície quaternária com remanescentes de florestas e sob pressão urbana na bacia do Rio Ratones 
A vegetação arbórea e arbustiva que ali se estabelece se constitui em transição entre a vegetação de restinga e a floresta pluvial da mata atlântica (ombrófila densa), estando seus componentes mais ligados a esta. Nestes ecossistemas vivem diversos animais de diferentes espécimes, como pequenos mamíferos e ovíparos, voadores ou terrestres.

Os agrupamentos arbóreos de diferentes espécies, ora em grandes manchas homogêneas, ora acompanhando riachos e córregos, conformando proteção ciliar sinuosa, constituem um elemento paisagístico de forte interesse. Na ilha de Santa Catarina, os remanescentes formam grandes manchas distribuídas pelas planícies, com pouca interconexão, na maioria

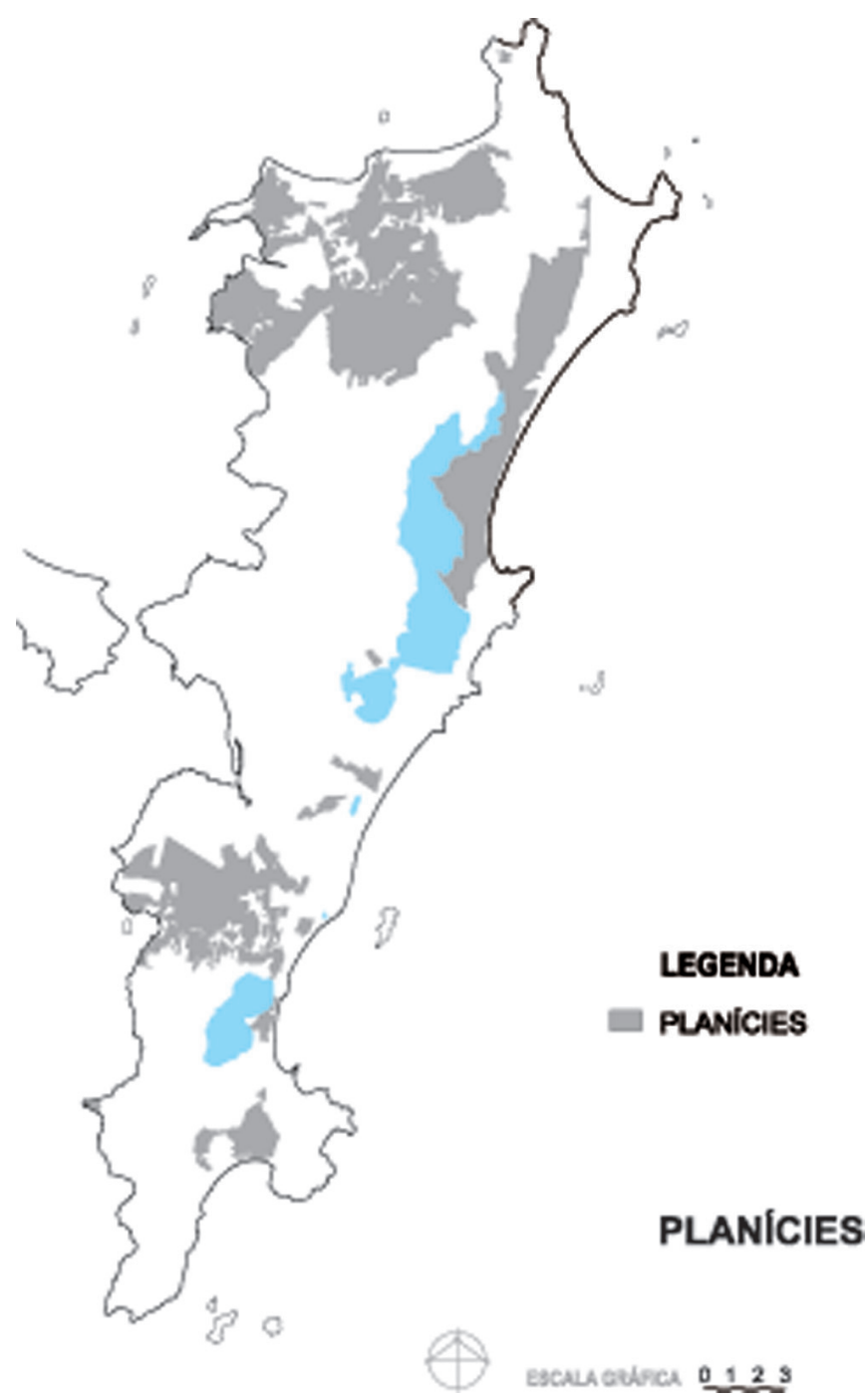

Figura 2.9: Principais planícies remanescentes. das vezes, formando agrupamentos isolados e cada vez menores em função da pressão imobiliária.

As planícies quaternárias exercem papel importante no regime hidrológico da llha, ao se constituírem em áreas de inundação de rios e riachos nascidos nos morros.

\section{Planícies de restingas}

As restingas são formações litorâneas, geralmente de forma alongada e plana, resultantes da deposição de sedimentos marinhos em ambientes protegidos por ilhas ou pontais rochosos, formando cordões em curvas paralelas à linha de costa. Freqüentemente o seu processo de formação origina lagoas e lagunas, constituindo condições físicas bastante diversas em um mesmo meio. Situadas entre os ambientes 
marinho e continental, as restingas possuem estrutura muito complexa e grande diversidade biológica, e a sua fauna e sua flora são compostas por espécies encontradas em diferentes ecossistemas.

A principal característica configurativa das restingas é o gradiente ambiental estabelecido em faixas paralelas à linha da costa, o dificulta a delimitação continental, pois se integra nos ambientes adjacentes em transições de continuidade com as florestas interiores. Dependendo da região do litoral brasileiro, assume diferentes con-

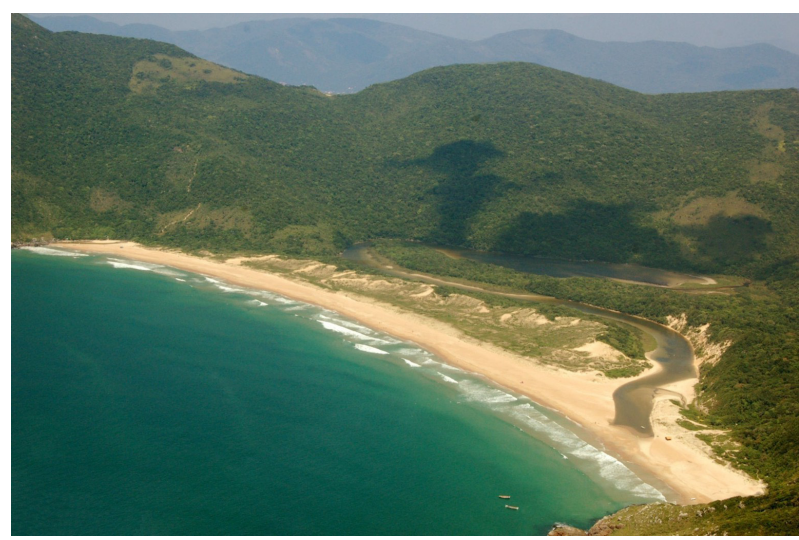

Figura 2.10: Planície de restinga na Praia da Lagoinha do Leste figurações, desde largas planícies com quilômetros de extensão e diversificada cobertura vegetal, até estreitas faixas arenosas com poucos espécimes da flora.

Na região de Florianópolis e da llha de Santa Catarina, decorrem do rebaixamento do nível do mar ocorrido há mais de cinco mil anos, formando as planícies sedimentares que uniram o antigo grupo de ilhas que hoje são seus morros. A cobertura vegetal desse sistema natural apresenta-se em tipologia arbórea, arbustiva e rasteira, formando belas a amplas paisagens a partir da distribuição pela planície.

Os principais remanescentes de restingas da llha de Santa Catarina se localizam nas bacias do Rio Ratones, a norte e noroeste da Ilha, do Rio Tavares, na planície centro-sul (do Campeche), na costa leste, paralela a praia de Moçambique, e na região do Pântano do Sul. Esses remanescentes vem se regenerando da intensa ocupação agrícola que sofreram até meados do século XX e, embora ainda hoje recebam ocupação pontual, estão mantidas amplas visuais e são percebidos como espaços naturais.

\section{Dunas}

As dunas são depósitos eólicos de areia que ocorrem isoladas ou em associação, sendo comum nas restingas situadas na costa leste da llha de Santa Catarina. Podem apresentar diversos cordões dunares em seqüência, entre os quais é comum a formação de depósitos de água. As dunas móveis formam montes de diversas alturas e formações 
dinâmicas, em função da forte instabilidade provocada pela ação dos ventos e chuvas. As dunas fixas são cobertas por formas vegetais arbustivas e gramíneas que se adaptam ao solo pobre em água e matéria orgânica e à ação do vento, constituindo-se em ambientes complexos e com grau de estabilidade maior do que as dunas móveis.

As dunas são elementos importantes na estabilização da linha de costa, protegendo estas áreas da abrasão marinha e diminuindo a ação dos ventos nas regiões mais interiores. Nelas ocorrem comunidades animais diversificadas compostas principalmente por insetos, crustáceos, répteis, aves e pequenos mamíferos. Seus terrenos arenosos e sem estrutura fixa são altamente permeáveis e impróprios à ocupação humana.

Os maiores ambientes dunares da região da llha de Santa Catarina são protegidos por legislação federal e estadual e foram tombados como Patrimônio Natural e Paisagístico do município, e são eles: Dunas dos Ingleses e Santinho, Dunas da Lagoa da Conceição, Dunas do Campe-che, Dunas da Armação e Dunas do Pântano do Sul. Na região conurbada de Florianópolis, destaca-se as Dunas da Pinheira. Os campos dunares da llha de Santa Catarina constituem-se principalmente por dunas fixas e semifixas, estas com cobertura vegetal especializada, e móveis, em

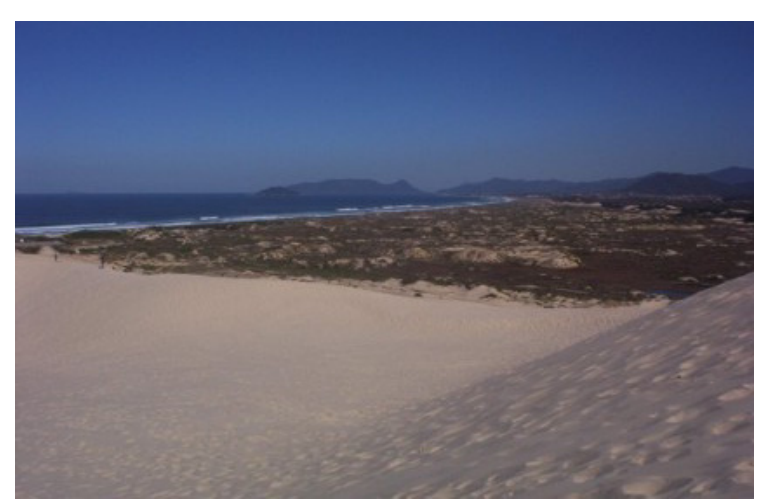

Figura 2.11: Campos de dunas fixos e semi-fixos da praia da Joaquina

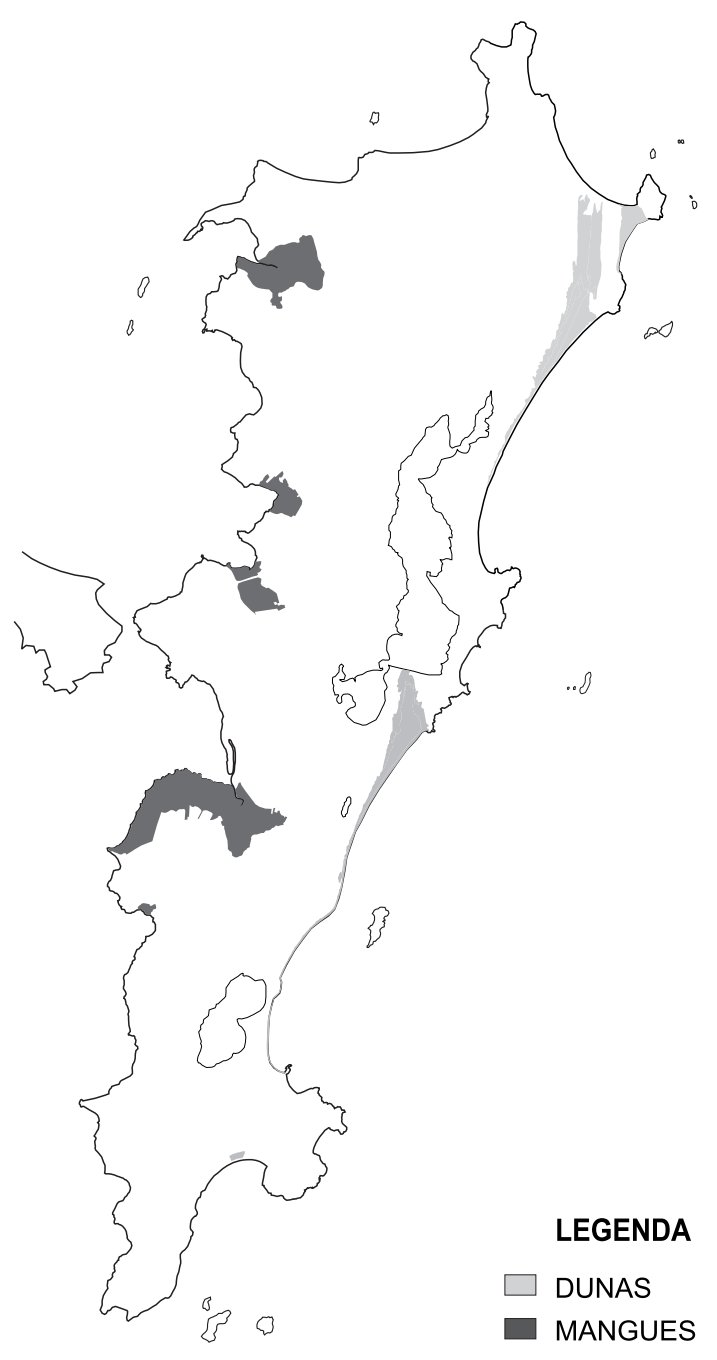

MANGUES E DUNAS

ESCALA GRÁFICA $\quad \underbrace{0} 1 \quad 2 \quad 3$

Figura 2.12: Mangues e Dunas na Ilha de Santa Catarina. 
geral sem cobertura, todas entremeadas por pequenas retenções de água da chuva nas zonas intradunares. O contraste visual das areias com o mar e as restingas tem forte valor paisagístico, formando mosaico rico com potencial de atração de visitantes.

\section{Manguezais}

Os manguezais são ecossistemas dinâmicos que ocorrem em terrenos litorâneos baixos, relativamente abrigados, formados por vazas lodosas e banhados por águas de salinidade variável. Esta condição deve-se à influência das marés, das correntes de águas doces e dos sedimentos carreados pelos cursos d'água. São sistemas de alta produtividade que fertilizam as águas costeiras através da alta produção de matéria orgânica, pela exportação da mesma e pela sua transformação em detritos, os quais serão utilizados por uma variedade de organismos (Odum \& Heald, 1975).

Dos oito manguezais de importância regional, situados nas baías Norte e Sul, cinco localizam-se na Ilha de Santa Catarina: Mangue do Rio Ratones, Mangue do Saco Grande, Mangue do Itacorubi, Mangue do Rio Tavares e Mangue da Tapera. Além desses, na região conurbada de Florianópolis destacam-se os seguintes manguezais, todos situados no município de Palhoça: Mangue da Palhoça, Mangue do Aririú-Cubatão e o Mangue do Massiambú. Nos manguezais da Ilha de Santa Catarina, não são encontradas muitas espécimes compondo a vegetação de mangue, mas os tipos arbóreos, arbustivos e gramíneos existentes apresentam-se exuberantes.

Os manguezais têm extrema importância na paisagem, tanto pelo papel ecológico, por se tratarem de nichos de vida e reprodução, como pela fruição da mancha verde da sua cobertura vegetal, ainda que de difícil apropriação humana.

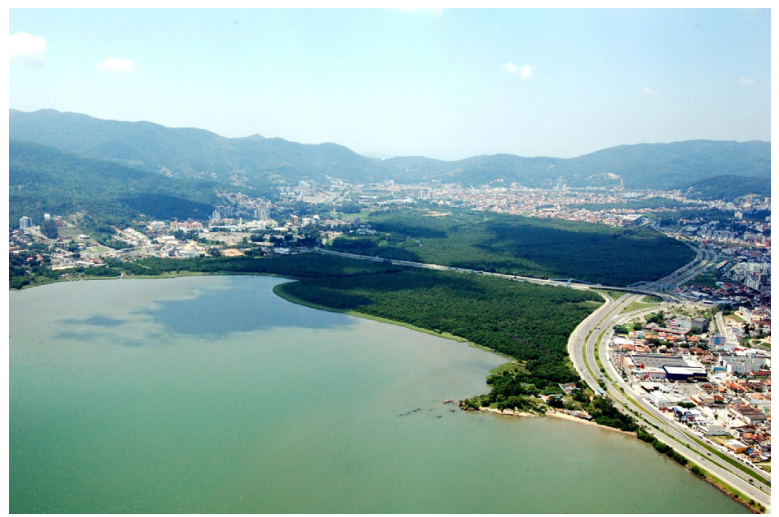

Figura 2.13: Mangue do Itacorubi, já cercado pela urbanização e cortado pelo sistema viário

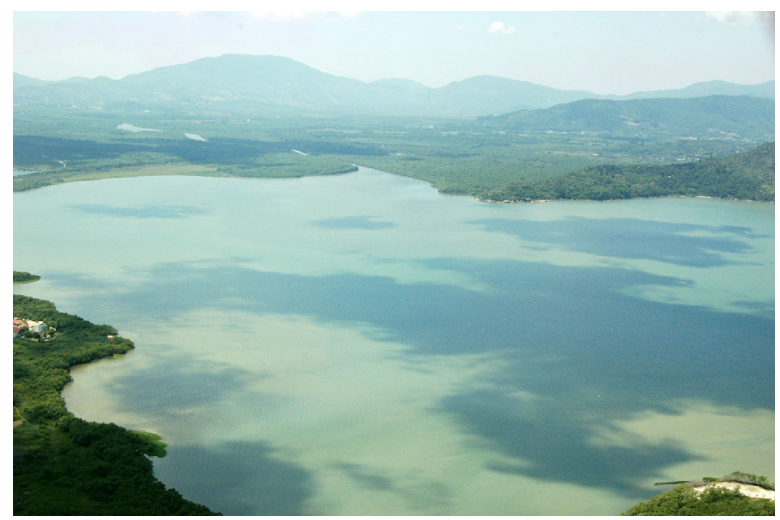

Figura 2.14: Mangue na Bacia do Rio Ratones. 


\section{Lagunas e lagoas}

As lagoas, depósitos de água doce ou salobra diferenciam-se das lagunas por não serem afetadas diretamente pelas águas do mar. Já as lagunas, com águas salobras e salgadas, sofrem interferência, através de canais de ligação com as águas do mar, da ação das marés associadas com ventos do litoral. Na região da llha de Santa Catarina, o rebaixamento do nível do mar ocorrido há mais de cinco mil anos, formando as planícies sedimentares que uniram o antigo grupo de ilhas que hoje são seus morros, isolaram depósitos de água de diferentes tamanhos e regimes hídricos.

Neste processo, se formaram várias lagunas, entre as quais destacamos a Lagoa da Conceição, a Lagoa do Peri e a Lagoinha do Leste. A Lagoa da Conceição, na realidade uma laguna costeira, de águas salobras e de forma alongada no sentido Norte-Sul, é o maior corpo d'água na llha de Santa Catarina (mais de $20 \mathrm{~km}^{2}$ ). $O$ canal situado na localidade da Barra da Lagoa faz sua ligação com o mar e permite o fluxo de água e organismos aquáticos entre este e a lagoa, tornando esta uma fonte de recursos pesqueiros para a população local. Delimita-se, a oeste, com uma linha de morros de relevo acidentado, onde se localizam dois dos quatro nú-

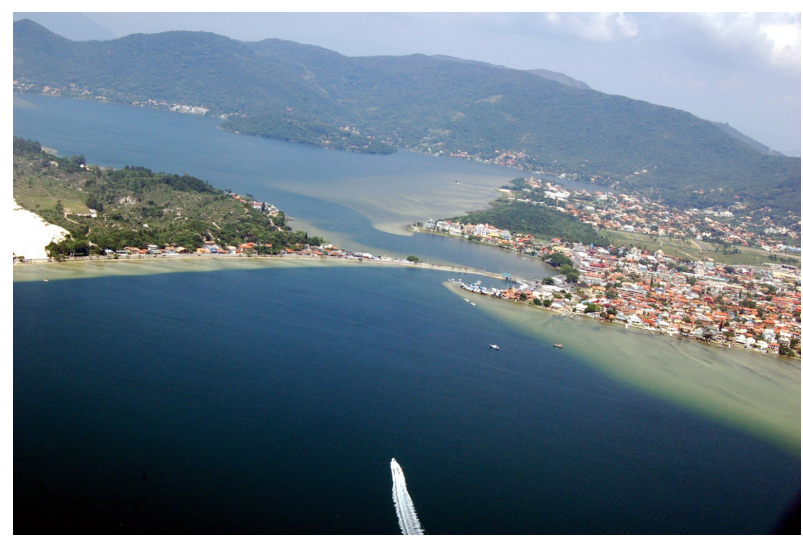

Figura 2.15: Lagoa da Conceição. cleos de vegetação secundária em estágio mais desenvolvido da llha de Santa Catarina. Ao leste é delimitada por maciços rochosos e, em sua maior parte, com feixes de restinga que a separam do mar. Ao sul estendem-se as dunas de mesmo nome.

A Lagoa do Peri, originária de uma antiga enseada que foi bloqueada em seu contato com o mar por um processo natural de sedimentação, hoje se situa acima do nível oceânico, ligando-se a ele por um canal de escoamento com fluxo d'água unidirecional. Com uma superfície aproximada de $5 \mathrm{~km}^{2}$, é a maior lagoa de água doce do litoral catarinense. As encostas que a cercam são cobertas pela floresta ombrófila densa que, em algumas áreas, ainda mantém suas características originais. Ao leste, a lagoa delimita-se com depósitos sedimentares recentes de origem marinha, eólica e fluvial, cobertos por vegetação litorânea. 
A Lagoinha do Leste, situada na costa sudeste da llha de Santa Catarina, e de pequenas dimensões, está ligada ao mar por passagem esporádica de suas águas. A cobertura vegetal de seu entorno é composta, principalmente, por espécies nativas e dá abrigo a uma rica fauna. Ainda podemos destacar a presença da Lagoa Pequena, no Rio Tavares, da Lagoinha do Norte, localizada no norte da ilha, da Lagoa da Chica, no Campeche e a Lagoa do Jacaré em Ingleses.

\section{Ilhas}

Nesta região do litoral brasileiro, as ilhas são resultantes daquelas formações graníticas que não chegaram a se conectar entre si por meio de depósitos arenosos. As que circundam a ilha de Santa Catarina fazem parte da plataforma continental e apresentam diferentes configurações: aquelas localizadas em mar aberto e expostas à ação do vento e do mar exibem costões rochosos com pouca ou nenhuma vegetação arbustiva, não dando condições para agrupamentos arbóreos significativos; aquelas do interior das baías e mais protegidas da ação eólico-marinha

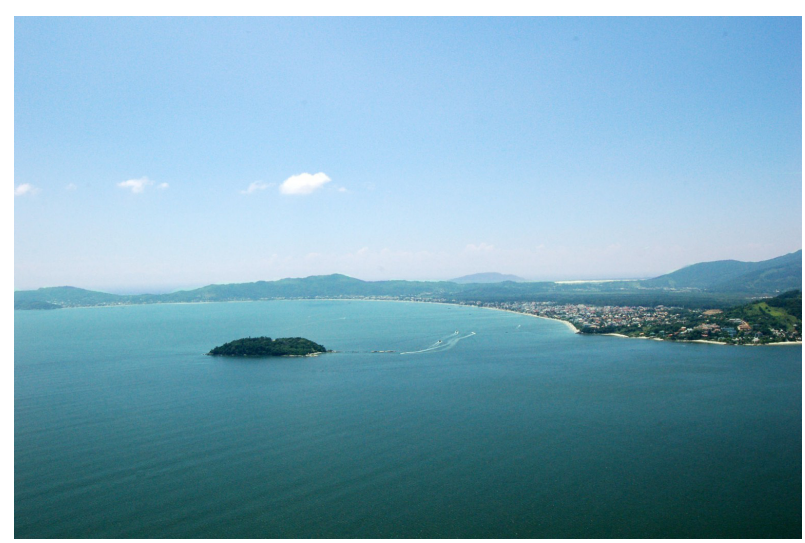

Figura 2.16: Ilha do Francês em frente ao promontório que divide Jurerê e Canavieiras são recobertas por vegetação mais frondosa, pertencente ao domínio da mata atlântica.

As ilhas que administrativamente integram o território do município de Florianópolis são: Ilha de Santa Catarina, Ilha das Campanhas, Ilha Badejo, Ilha Moleques do Norte, Ilha Mata Fome, Ilha das Aranhas Grande, Ilha das Aranhas Pequena, Ilha do Xavier, Ilha do Campeche, Ilha da Pedra, Ilha das Laranjeiras, Ilha das Três Irmãs Irmã do Meio, Irmã Pequena, Irmã de Fora; Ilha Moleques do Sul, Ilha Papagaios Grande, Ilha Papagaios Pequena, Ilha dos Cardos, Ilha Maria Francisca ou Flechas, Ilha do Largo ou Garoupa, Ilha Garcia, Ilha das Tipitingas, Ilha do Facão, Ilha dos Noivos ou Lamim, Ilha Três Henriques (laje), Ilha Diamante, Ilha da Guarita, Ilha Perdida, Ilha Guarás Pequena, Ilha Guarás Grande, Ilha Ratones Pequeno, Ilha Ratones Grande, Ilha do Francês, Ilha Fortaleza ou Araçatuba, Ilha das Pombas, Ilha 
das Vinhas, Ilha do Abraão, Ilha das Conchas. Dessas, as Ilhas da Fortaleza, dos Cardos, Moleques do Sul e as Três Irmãs fazem parte do Parque Estadual da Serra do Tabuleiro a partir do Decreto Estadual $n^{\circ} 1.260 / 75$ e as Ilhas dos Papagaios foram incluídas pelo Decreto $n^{\circ} 2.336 / 77$.

O interesse paisagístico daquelas menores, mais próximas da costa, é explicitado pelos belos enquadramentos visuais que possibilitam quando em meio a enseadas ou próximas aos promontórios laterais, com a vegetação dominando a cobertura. As mais distantes e de maiores dimensões, localizadas em mar aberto, formam amplas e marcantes paisagens ao contrastar seu formato cônico de diversas alturas com a linha do horizonte.

\section{Baías}

A Ilha de Santa Catarina é separada do continente por um corpo d'água denominado baía de Florianópolis. Esta baía possui uma área superficial de 430 km2, 50 km de comprimento e uma profundidade média de $3,2 \mathrm{~m}$; é dividida em duas partes, norte e sul, que se comunicam através de um canal com aproximadamente $550 \mathrm{~m}$ de largura e $21 \mathrm{~m}$ de profundidade. Ambas as partes, baía Norte e baía Sul, são ligadas ao Oceano Atlântico por um canal de $31 \mathrm{~m}$ e $10 \mathrm{~m}$ de profundidade respectivamente.

As baías Norte e Sul recebem contribuição de águas doces provenientes

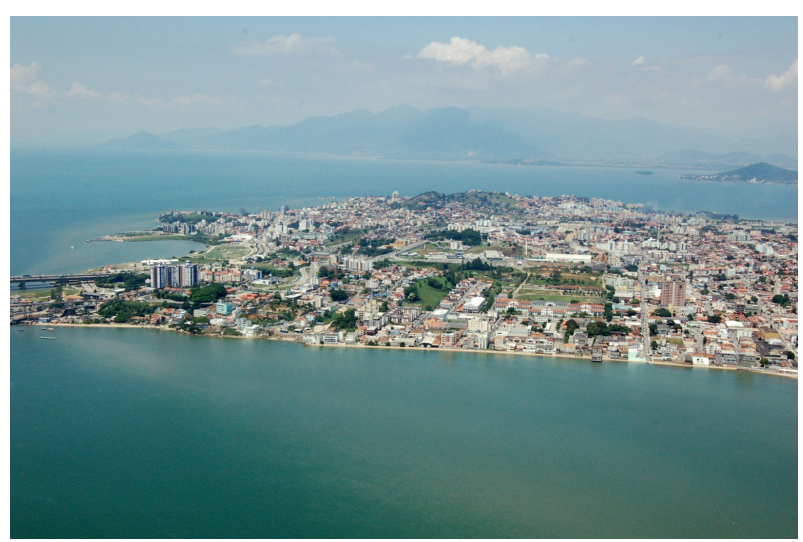

Figura 2.17: Vista da Baía Norte em primeiro plano e da Baía Sul ao fundo, com a urbanização da parte continental da cidade de bacias hidrográficas tanto insulares quanto continentais. As principais contribuições de águas fluviais que desembocam na baía Norte são os rios Ratones e Itacorubi, de origem insular, e o Rio Biguaçú, de origem continental, enquanto na baía Sul, são os rios Tavares e Ribeirão, de origem insular, e o rio Cubatão, de origem continental.

O comportamento das marés segue um andamento de tipo semidiurno e é influenciado tanto astronômica quanto eolicamente. As correntes de maré seguem as direções Norte-Sul e Sul-Norte simultaneamente e se encontram em frente da área central 
da cidade de Florianópolis. Sua velocidade média raramente supera $0,26 \mathrm{~m} / \mathrm{s}$, mas durante a sizígea pode atingir $0,75 \mathrm{~m} / \mathrm{s}$.

Seu aproveitamento enquanto local de atraque naval, meio de ligação entre localidades e de fonte de alimento vem desde o século XVI, e mais recentemente tem sido explorada para atividades esportivas e passeios marítimos, tendo em vista a qualidade paisagística que oferece.

\section{Praias}

As praias são formações arenosas depositadas no encontro do mar com a terra pela ação flúvio-marinha, decorrente do rebaixamento do nível do mar e das marés, e eólica, apresentam diversidade e complementaridade de espécies de fauna e flora. A cobertura vegetal, normalmente localizada na transição da areia com as restingas do interior, é rarefeita e especializada pela necessidade de adaptação à salinidade, aos poucos nutrientes, aos ventos e à inconstância do substrato arenoso. A praia é, ainda, local de vivência para diversos microorganismos, moluscos, crustáceos e aves variadas (gaivotas, fragatas, albatrozes e de rapina).

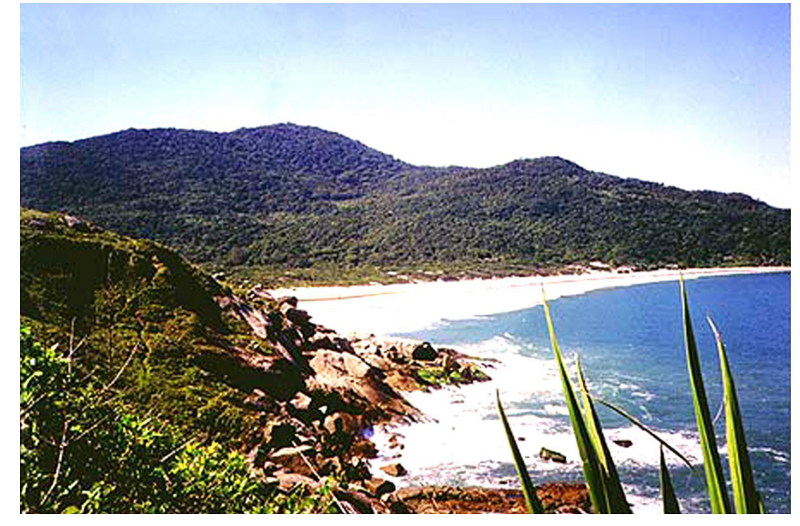

Figura 2.18: Praia de Naufragados no extremo sul da llha

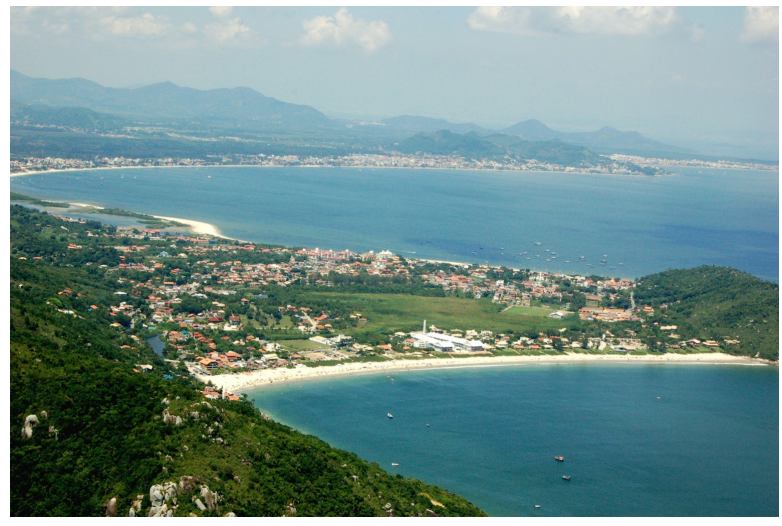

Figura 2.19: Praia da Lagoinha, norte da ilha. Em segundo plano a Praia de Canasvieiras.

As praias estão presentes todos os cantos da região de Florianópolis e llha de Santa Catarina e se apresentam em diversas configurações: aquelas do quadrante leste se estendem longilíneas, algumas por diversos quilômetros com extensos arcos praiais, areia fina e mar agitado, enquanto que as voltadas para a baía interior se enclausuram entre promontórios, formando pequenas enseadas de areia mais grossa com águas 
calmas; umas têm larga faixa de areia e pouca declividade, e outras, são estreitas e têm mais declividade; umas apresentam intensa apropriação (eventual e fixa) social e outras, ainda, apresentam aspecto rústico com maior presença de elementos naturais.

A acessibilidade às praias de Florianópolis também apresenta distinções, sendo que as mais atraentes, localizadas na porção norte da llha estão bem conectadas por rodovias pavimentadas e largas, enquanto que em outras áreas, vias estreitas e sem pavimentação restringem o fluxo a locais de banho de mar. Têm sido os lugares mais procurados pelos visitantes e turistas que afluem às zonas litorâneas, pelas amenidades e possibilidades de recreação em épocas de verão assim como pela fruição da paisagem que se configura nessa junção de terra e água.

\section{Costões}

Presentes em inúmeras partes da llha, os costões rochosos, decorrentes do encontro dinâmico da água e dos ventos com os promontórios e morros que avançam sobre o mar, formam cenários de grande qualidade paisagística. A estratificação horizontal de zonas de vivência biológica, distintas e interagentes, acima e abaixo do nível do mar, em função da adaptação às marés, luz solar e ventos, é evidencia a riqueza ecológica destes compartimentos naturais.

Assumem diferentes formas em função da configuração do relevo e da ação do mar e eólica. As ocorrências nos fechamentos de baías, geralmente com rochas fracionadas e mamelonadas, têm proeminência visual, além de permitem excelentes visuais a partir deles.

Outros, de formação verticalizada e abrupta, mais expostos ao mar de maior profundidade, são mais inacessíveis. Geralmente, estão associados a áreas de preservação, e embora seu uso, recreativo ou econômico por visitantes ou pescadores seja freqüente, e em certos locais tenham sido ocupados por edificações, ainda mantém características naturais em grande parte das ocorrências.

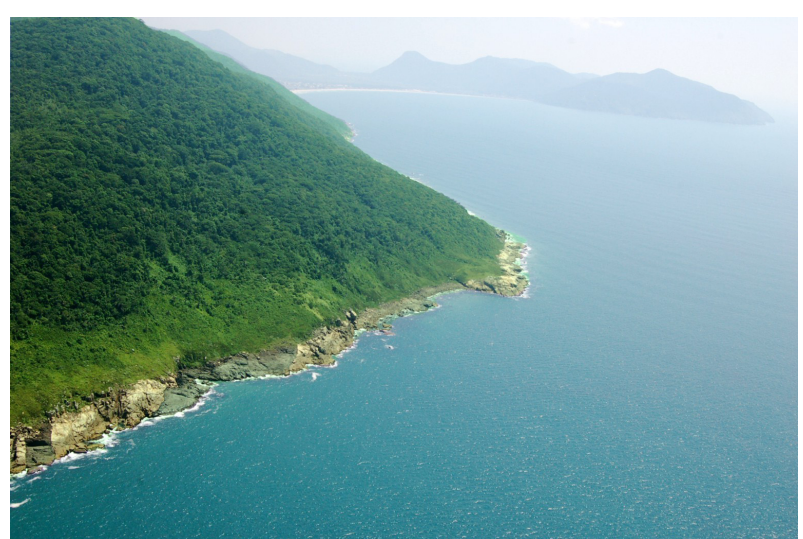

Figura 2.20: Costão no sul da Ilha de Santa Catarina 


\subsection{Considerações sobre o território natural}

Mesmo com a transformação pós-ocupação européia, que se inciou no século XVII, se intensificou no século XVIII e assumindo dimensão urbana no fim do século XX, o território da cidade de Florianópolis e llha de Santa Catarina, em suas interações entre as estruturas fisiográfica e ecológica, conseguiu se manter num equilíbrio dinâmico que ainda capaz de apresentar remanescentes de todos os seus sistemas naturais, alguns em boas condições.

O conjunto e o entrelaçamento desses sistemas, a maioria de formação recente, produziram uma paisagem de extremado valor cênico, além de apresentarem um funcionamento que se sustenta sob frágeis condições.

O funcionamento dos sistemas ecológicos e da estrutura geomorfológica, presentes no território da região onde hoje se implanta a cidade e, especialmente, a llha de Santa Catarina, mantêm estreita dependência entre uns e outros, na medida em que a formação e a existência de uns decorre da existência de outros, constituindo um ecossistema que, para se manter equilibrado, não prescinde de nenhum subsistema nem das relações e trocas por eles estabelecidas.

A relação funcional entre os diferentes domínios se explicita pela interação entre sistemas biológicos da fauna e da flora característicos das regiões costeiras, que trocam fluxos de matéria e energia através das zonas de transição formadas pelas encostas e sotomorros cobertos por vegetação associadas às duas situações. Os morros graníticos, recobertos com fina camada de sedimentos de natureza argilosa e pouca porosidade, mas com densa e diversificada mata, têm estreita relação funcional com as planícies, formadas pelos depósitos erodidos dos próprios morros, mas principalmente pela contribuição eólica e marinha.

E a relação se explicita, também, na relação geológica e hídrica que se estabelece entre morros e planícies, assim como as lagoas mangues e dunas, funcionando como bacias de drenagem naturais das águas vertidas, bem como local de deposição dos depósitos sólidos erodidos dos anfiteatros conformados pelos morros e encostas da llha de Santa Catarina. A alta taxa declividade, acima de $30 \%$, que configura os abruptos desníveis da maioria dos morros e a baixa taxa da declividade de boa parte das planícies, em torno de $2 \%$, tem feito com que até recentemente 
as planícies apresentassem aspecto pantanoso característica de áreas úmidas, reforçadas pela superficialidade dos lençóis freáticos dos aqüíferos resultantes da formação geológica da região.

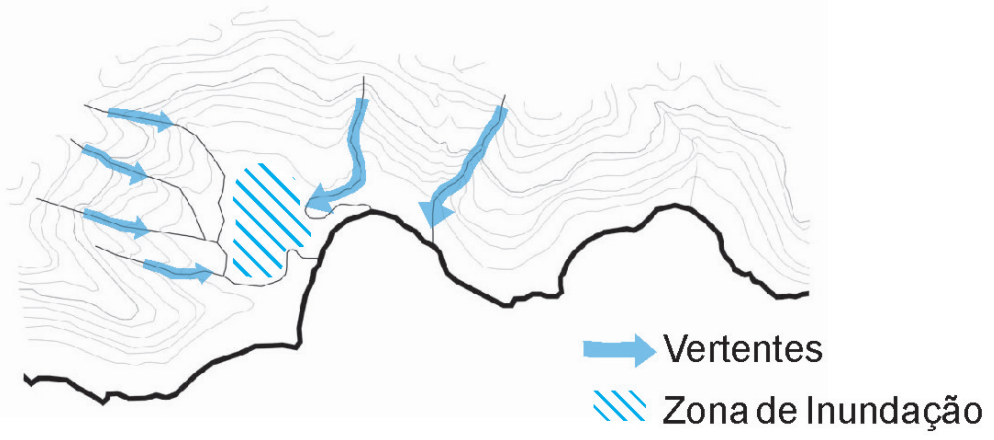

Figura 2.22: Desenho de esquema de bacias de inundação e anfiteatro de morros

A interrupção da interação entre estes dois domínios naturais na llha, com a impermeabilização de áreas porosas nas planícies e a alteração do perfil das áreas argilosas das encostas, já vem mostrando as conseqüências nos períodos chuvosos que caracterizam o verão na cidade. Estas importantes funções geo-ecológicas assumidas por estes dois importantes domínios podem dar pistas para um entendimento diferenciado das possibilidades de utilização de morros e planícies para atividades humanas, o turismo incluído.

Estas condições de funcionamento dos sistemas naturais, caracterizada pela fragilidade e interdependência dos sistemas e subsistemas, porém, diante da intensificação dos processos sócio-econômicos mais recentes com entrada em cena de vetores modernos e pós-modernos de desenvolvimento vêm sendo ameaçadas. As agressões ao ambiente natural e a conseqüente desqualificação da paisagem, pela humanização do território e pela introdução de novos elementos construídos, são perceptíveis em diferentes escalas de abordagem e serão estudadas nos próximos capítulos. 


\section{CAPÍTULO III}

\section{O TERRITÓRIO HUMANIZADO}

Após estudar o território e as paisagens naturais da llha de Santa Catarina é necessário analisar a presença humana na costa na região do município de Florianópolis e, mais detalhadamente na Ilha de Santa Catarina. O objetivo deste capítulo é entender e explicar o processo de humanização do território acima desvelado, iniciando com breve descrição da rede urbana catarinense, seguida da descrição da evolução urbana da cidade, com destaque para o crescimento urbano. Posteriormente, aborda aspectos relativos ao fenômeno do crescimento urbano, como a migração recente e a dinâmica imobiliária, com os decorrentes conflitos, disputas e os movimentos de resistência à intensidade da urbanização.

São estudadas as alterações no meio produzidas pelas principais intervenções antrópicas ao longo do tempo, correlacionado a relação homem-natureza com aquelas que se dão entre os homens. $\mathrm{O}$ estudo da interferência humana no ambiente, neste trabalho, se restringirá àquelas intervenções presumidamente significativas e transformadoras do território, em especial do relevo, da drenagem e da cobertura vegetal que configuram a paisagem em escala espaço-temporal visualmente perceptível, sem perder de vista, entretanto, o entendimento das relações sócio-econômicas e culturais que as explicam.

Utilizando um registro cronológico, mas não linear, busca-se o entendimento diacrônico e sincrônico dos vetores transformações provocadas pelas intervenções humanas, analisando as inter-relações, mediações, descontinuidades e permanências das motivações e das ações dos agentes sociais que atuam na região estudada. $A$ fim de inserir a região de Florianópolis no contexto estadual, inicia com uma breve explanação sobre a rede urbana catarinense para depois buscar, na evolução histórica, elementos explicativos da atual dinâmica sócio-espacial de Florianópolis.

\subsection{Rede urbana catarinense}

O Estado de Santa Catarina é o menor da região sul do território brasileiro, e sua rede urbana apresenta especificidades sócio-espaciais. Com 95.442 km², tem, atualmente, um Produto Interno Bruto em torno dos 32 bilhões de reais, e a maior parte dos 
mais de cinco milhões de habitantes (sendo $54 \%$, população economicamente ativa) concentra-se na zona costeira, distribuída em trinta municípios, sendo cinco (dos oito do estado) com mais de 100 mil habitantes: Joinville, Itajaí, Florianópolis, São José e Palhoça, e outros pólos econômicos com importante concentração populacional e de atividades, como Balneário Camboriú, com forte turismo, e São Francisco do Sul, porto marítimo internacional.

$\mathrm{Na}$ divisão fisiográfica geral do estado, se destacam um planalto inclinado para oeste, separado do litoral por desmoronamentos serrosos, e a costa, conformada por planícies e baixadas litorâneas, com esporões de serra avançando mar adentro. Estas características do relevo, formando as bacias hidrográficas e associadas à cobertura vegetal de cada um dos compartimentos e suas transições, condicionaram a implantação da rede urbana estadual. Os desníveis e os vales fluviais, com matas subtropicais fechadas, barraram, por muito tempo, a conexão entre o planalto e o litoral, isolamento até recentemente notado. Além dos condicionantes territoriais, a rede urbana catarinense teve grande influência da vias de circulação que foram se implantando ao longo dos séculos, mas que também, por longo tempo, tiveram que se adaptar as dificuldades na ultrapassagem do litoral para o planalto.

Neste marco geográfico, se formaram diversas cidades de porte médio com a diversidade econômica que caracteriza atualmente a rede urbana do estado. O estado não conta com nenhuma cidade de grande porte e, ainda hoje, nenhuma catarinense passa dos 600 mil habitantes, embora a conurbação atual do entorno de Florianópolis supere tal cifra.

A ocupação da região sul do país se deu após as capitanias mais ao norte, sendo que o rosário formado pelos núcleos litorâneos que caracterizou a costa brasileira a partir da ocupação portuguesa pioneira no século XVI se tornava cada vez mais disperso conforme seguia para o Sul, sendo este trecho um dos últimos a ser efetivamente ocupado. As cidades do litoral catarinense, em sua maioria fundadas em decorrência da política expansionista de Portugal, no século XVII, como as pioneiras São Francisco do Sul, em 1658, Nossa Senhora do Desterro, em 1662 e Laguna, 1682, foram povoadas por habitantes da capitania de São Vicente. Já as cidades mais antigas do planalto tiveram sua origem nas trocas comerciais, especialmente gado vivo, que desde início do século XVIII ligaram os campos do sul do país às capitanias do sudeste brasileiro. 
A migração açoriana e madeirense a partir de 1748, que se estabeleceu predominantemente no litoral, além de adensar essas regiões ocupadas e consolidar os povoamentos existentes, criou novos núcleos populacionais ao longo da costa, embora com padrão disperso e com características predominantemente ruro-pesqueiros, avançando, mais tarde, pelos vales das bacias hidrográficas acima, se interiorizando por diversos caminhos até o planalto e aproveitando, muitas vezes, as trilhas indígenas.

Os vales em direção a oeste, que permitiram o avanço para o planalto, tiveram sua ocupação efetivada, principalmente, a partir da migração germânica (na primeira metade dos anos 1800, se estabelecendo no centro norte do estado) e italiana (na segunda metade dos anos 1800, se estabelecendo mais ao sul do estado). O meio e o extremo oeste do estado tiveram ocupação mais recente, a partir de diferentes expansões coloniais, inclusive do Rio Grande do Sul, especialmente após a pacificação da região com o fim da Guerra do Contestado, em 1918.

$\mathrm{Na}$ final do século XIX e início deste, a construção de ferrovias no país ativou a vida de algumas regiões litorâneas mais afastadas das cidades maiores do centro e nordeste do país. No estado, as principais linhas se implantaram cruzando o estado de norte a sul (Contestado, no vale do rio de Peixe no meio oeste, e São Paulo-Rio Grande do Sul, na parte oriental do planalto) estruturando a rede urbana. As conexões entre planalto e litoral foram reforçadas, com pequenas linhas ferroviárias de conexão a portos antigos, como Laguna e São Francisco, mas também a novos complexos portuários como Imbituba e Itajaí, em resposta à produção econômica (carvão e têxtil, respectivamente) dos pólos produtivos de regiões mais interiorizadas.

A capital, Florianópolis, ficou fora deste impulso inicial de desenvolvimento do estado, passando a fazer parte, assim, durante boa parte do século XX, no rol das "cidades mortas" (Moraes, 1995), que por força de diferentes circunstâncias, ficaram, até a segunda metade do século passado, esquecidas na costa brasileira. No planalto serrano, Lages, fundada na rota dos tropeiros ainda no século XVIII, conseguiu se manter como pólo madeireiro até o segundo pós-guerra, quando as matas de araucária se exauriram e a cidade entrou em lenta decadência. As cidades do vale do Itajaí, formadas na metade do século XIX, como Blumenau e Joinville, começam a se industrializar pela metade do século XX e atualmente, se constituem importantes pólos industriais. 
A navegação, no litoral, e as ferrovias, no planalto e em conexões até os portos, desempenharam, até a primeira metade do século XX, importante papel no desenvolvimento e integração do estado, mas decaíram após os anos 1960, quando o país passou a privilegiar a matriz rodoviária. Alguns portos ainda mantêm importância nacional e internacional, mas os de Florianópolis e Laguna, por diversos motivos, entraram em decadência já no início do século passado.

O processo de industrialização nacional, consolidado nos anos cinqüenta, mudando o padrão de acumulação do capital vigente no país, que estabeleceu uma urbanização com característica urbano-industrial em diversas capitais, não se efetivou em Florianópolis. Os canais de ligação terrestres entre o estado e o resto do país (especialmente a BR-116, bem como a linha férrea que a antecedeu), privilegiaram, inicialmente, o planalto serrano, não alterando a precariedade de acesso terrestre à capital, nem do circuito intercosteiro, o que explica, em parte, o pouco engajamento da capital catarinense no ciclo inicial de desenvolvimento industrial do país, no pós-guerra.

Hoje, três importantes rodovias federais cruzam o estado, sendo duas no eixo norte-sul - a BR-116, no planalto, e BR-101, no litoral, e uma no eixo leste-oeste, a BR470. Este sistema principal, reforçado por outras rodovias federais e estaduais, articula as maiores cidades entre si. As conexões da capital Florianópolis e do litoral em geral com as demais regiões metropolitanas do sul do país se incrementaram, de fato, a partir da pavimentação da BR-101, no início da década de 1970, o que proporcionou o desenvolvimento de muitas cidades costeiras a partir da atividade industrial (Joinville se destacou na produção metal-mecânica e estreitou laços com cidades industriais do centro do país) e turística (desde cidades médias, como Laguna e Florianópolis até municípios menores, até Balneário Camboriú, Porto Belo e Garopaba, que tiveram forte incremento populacional e construtivo nas últimas três décadas).

Com tal estrutura, a rede urbana costeira apresentava, até meados dos anos 1970, uma baixa densidade ocupacional fora de áreas de expansão dos principais núcleos, quando ainda era possível encontrar nestas regiões, inclusive dentro dos limites do município-capital, praias semidesertas e comunidades com modo de vida tradicional (ruro-pesqueiro e artesanal).

Florianópolis, desfavorecida pela alocação interiorizada e equilibrada do capital industrial no território catarinense e pelo privilégio dado às estradas de rodagem no transporte 
de produtos e populações, manteve-se resguardada do dinamismo urbano até final dos anos 1950. A partir desta época, entretanto, começaram a se concretizar, lentamente, as condições para a efetivação de um processo de urbanização da região da capital, que atualmente se consolida, também com base na atividade turístico-imobiliária.

O litoral do estado, com 561, $4 \mathrm{~km}$, perfazendo, aproximadamente, $7 \%$ da linha da costa brasileira, é uma das regiões mais transformadas pela ocupação humana e se encontra inserido no processo de desenvolvimento regional, originado da descentralização industrial, ocorrida a nível nacional nos anos 60 . Nesta região concentram-se mais de $50 \%$ da população do Estado em trinta municípios, e conta com quatro portos (São Francisco do Sul, Itajaí, Imbituba e Laguna), dois aeroportos internacionais (Florianópolis e Navegantes) além de rodovias federais e estaduais.

É na zona costeira que se concentram os municípios com as maiores densidades demográficas do estado com Florianópolis apresentando 818 hab/ $\mathrm{km}^{2}$ e Balneário Camboriú com 869 hab/ $/ \mathrm{km}^{2}$. Municípios como Garuva, com densidade demográfica de $18 \mathrm{hab} / \mathrm{km}^{2}$ e Itapoá, com 16 hab/km² (IBGE, 2000), contrabalançam a tendência à concentração, explicáveis pela sazonalidade da incipiente atividade turística de veraneio em alguns lugares do litoral.

A micro-região de Florianópolis tem base econômica na pequena produção industrial, com destaque para incubadoras e indústrias de informática, pequenas fabricas de vestuário e calçados e indústrias de transformação leve, como pequenas metalúrgicas, fábricas de derivados de plástico e de alimentos. A produção primária é consumida, principalmente, pela demanda local e se estabelece nas regiões agrícolas localizadas nos municípios vizinhos a Florianópolis. O setor terciário se apresenta como principal impulsionador da economia no entorno capital, que polariza os serviços de administração pública, nos três níveis, além de empresas estatais e autarquias.

Capital do estado de Santa Catarina, o município de Florianópolis tem, hoje, uma área de $451 \mathrm{~km}^{2}$, sendo $12,1 \mathrm{~km}^{2}$ na porção continental e $438,9 \mathrm{~km}^{2}$ na llha de Santa Catarina, e uma população em torno de 369.000 habitantes, o que lhe confere a densidade demográfica de 818 habitantes $/ \mathrm{km}^{2}$, conforme último censo demográfico do IBGE (2000). Como a grande maioria das cidades brasileiras, vem crescendo de forma rápida e desordenada, e sua estrutura espacial se caracteriza pela concentração urbana, com centralidade funcional e geográfica do núcleo fundador, e uma periurbanização, dispersa em diversos núcleos, originários da ocupação colonial. 
No entorno imediato da capital de Santa Catarina, sede da Regoão Metropolitana de Florianópolis desde 1998, há conurbação urbana com mais de 600 mil pessoas e atividades terciárias características de centros metropolitanos, ainda que de médio porte. No continente próximo, as atividades industriais e agrícolas (que abastecem a região, mas também o centro do país) se mesclam com um tecido residencial de baixa densidade e uma discreta atividade turística rural, nas encostas das serras próximas. O adensamento urbano mais intenso (demográfico e de atividades) acontece com mais intensidade nas proximidades das pontes de conexão viária, polarizado pelo centro insular.

A partir dos anos 1970, o turismo e as atividades a ele associadas passam, progressivamente, a representar importante fonte de receita, mesmo que seu potencial ainda não tenha sido devidamente explorado e seus benefícios não se distribuam equilibradamente no conjunto da população. Diversas empresas comerciais, de capital local e externo, estimulados e atraídos pela recente e crescente demanda de centros comerciais de padrão elevado e de grande porte, têm se somado ao comércio varejista e atacadista tradicional, dinamizando o setor. A intensa migração de estratos sociais de alta renda para as determinadas regiões balneárias e locais do centro da cidade tem proporcionado o surgimento de inúmeros estabelecimentos de padrão até então pouco demandados pela população. Este fenômeno, ainda pouco estudado, aponta para processos recentes de sucessão populacional em alguns bairros.

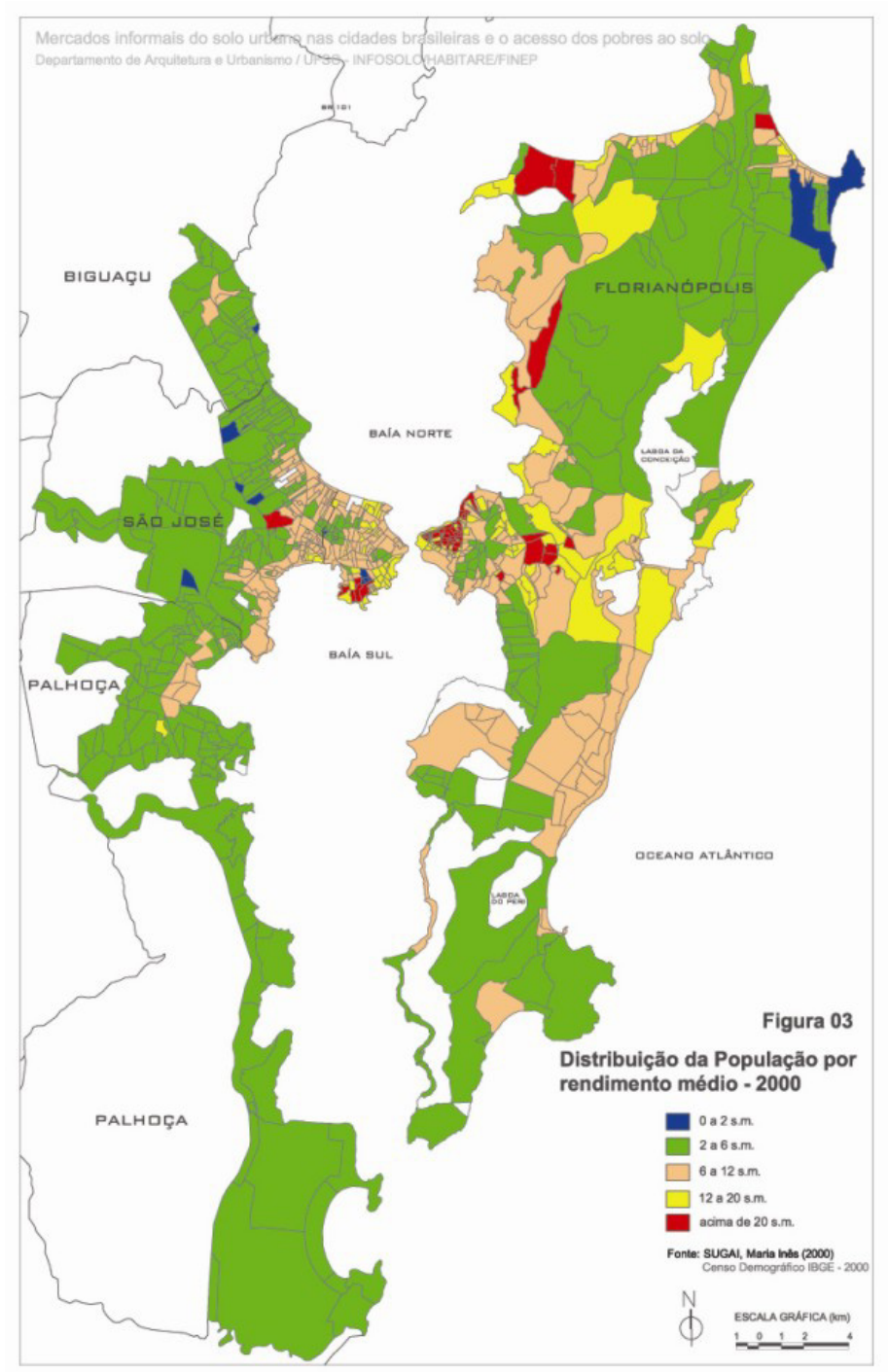

Figura 3.1: Mapa de distribuição de renda da micro-região de Florianópolis. S/escala. Reprodução de Sugai, 2000. 


\subsection{Evolução urbana de Florianópolis}

Analisar o processo de humanização do território em Florianópolis, com vistas a determinar o impacto do crescimento físico da cidade no território, requer estudar aspectos de sua evolução, num contexto econômico, social e cultural, considerando-se, de modo relacionado, os perfis econômicos assumidos pela cidade ao longo do tempo, a evolução de seu crescimento demográfico e o desempenho do setor da construção civil no município e região de influência, com a perspectiva dos impactos na paisagem.

A paisagem original começou a sofrer transformações humanas significativas a partir da ocupação bandeirante no século XVII, e apresentou, ao longo de sua história, diversos momentos marcantes em seu desenvolvimento. Os tempos coloniais, a época imperial e o período da primeira República imprimiram marcas no território da capital, pelas construções, obras públicas e, principalmente, pela formação da paisagem agrícola litorânea. Devido ao ritmo, lento, e ao poder de resiliência do território, as transformações destes períodos foram absorvidas e incorporadas à imagem de cidade pacata e provinciana cercada pela paisagem rural que caracterizou a cidade até recentemente.

Mas, se até a metade dos anos 1950, as alterações se apresentavam ambientalmente regeneráveis e/ou absorvíveis, a partir daí as transformações sócio-espaciais ocorridas no município passaram a alterar profundamente a sua estrutura territorial composta de espaços e sistemas naturais representativos do litoral brasileiro. A paisagem atual é resultante do processo de acumulação sucessiva das transformações decorrentes dos usos que foram dados ao território, sendo o seu estudo evolutivo, portanto, matéria essencial para sua compreensão.

No próximo tópico, serão destacadas as principais etapas e algumas fases de crescimento demográfico e de expansão da ocupação física em função do papel que a cidade representou na dinâmica do processo de formação sócio-econômica da nação, com um relato interpretativo que relaciona o perfil econômico com o crescimento demográfico, a dinâmica construtiva e a paisagem.

\section{A intervenção humana pré-européia}

Embora as intervenções anteriores à chegada de europeus tenham deixado elementos que comprovam intensa utilização da costa, a cifra demográfica não foi capaz 
de impingir transformações radicais na paisagem original, o que thes reservará somente comentário inicial. Ainda que existam especulações sobre a continuidade destas ocupações, não existem evidencias de sucessão ininterrupta, e ainda que seja provável que tenha havido simultaneidade, não é possível dizer o mesmo sobre substituição belicosa entre eles.

As primeiras evidências apontam para os chamados "povos do sambaqui", que aqui viveram há cerca de 5.000 anos passados, e deixaram diversas formações singulares pela deposição de restos de conchas durante centenas e milhares de anos, que até hoje ainda não foram todos descobertos, com muitos destruídos pela expansão ocupacional. Ainda restam, por toda a costa catarinense, diversos sítios arqueológicos e oficinas líticas que identificam locais por eles utilizados.

As populações seguintes foram de dois grupos indígenas distintos que, supostamente, se sucederam no tempo e no espaço. Os Itararés, cuja evidência de ocupação na Ilha de Santa Catarina registra data próxima do século $X$ desta era, chegaram a se estabelecer em pontos da costa oeste da llha de Santa Catarina, supostamente plantando e produzindo artefatos manufaturados.

O grupo subseqüente, os Carijós, é decorrente de migração de indígenas do grupo lingüístico tupi-guarani, que habitavam o litoral sul do Brasil, e se estabeleceram na Ilha por volta do século XIV ${ }^{1}$, em diversas aldeias que abrigavam de trinta a oitenta habitantes. Estas aldeias se implantaram por todos os quadrantes da Ilha, nas restingas e terrenos de planície, onde o cultivo, principalmente, de mandioca se adaptou, sustentando o sedentarismo que produziu cerâmicas de uso cotidiano e religioso.

Mantinham encontros eventuais com outras tribos interiorizadas do continente, relação que resultou na formação de uma rede de caminhos de ligação entre a costa e o planalto, chegando a alcançar a região andina (como o caminho de Peraibú, formado por diversas ramificações a partir do litoral sul brasileiro e afunilando no planalto). Foram estes habitantes que os primeiros europeus encontraram quando aqui aportaram e, segundo relatos existentes, com contatos amistosos.

1 Os índios carijós a chamavam de Meiembipe, que tem significado aproximado de "coisa estendida" (no mar), numa referência a forma alongada sobre a água da llha. 
Entretanto, sua presença na llha de Santa Catarina foi rareando com a intensificação e a interiorização dos assentamentos estrangeiros. Mesmo que não tenha havido registro de violência entre eles e os viajantes e moradores, a migração para longe dos novos vizinhos foi um fato interessante, numa atitude, aparentemente, de resguardo sócio-cultural, e já no século XVII não havia mais número significativo deste grupo indígena vivendo na llha de Santa Catarina.

A localização preferencial destas populações, junto aos ecossistemas mais dinâmicos da costa catarinense e da llha da Santa Catarina, como restingas, dunas e planícies quaternárias, aliada à baixa demografia, fez com que sua intervenção tenha sido totalmente absorvida pelo meio.

\section{A ocupação de origem européia}

Diversos relatos dão conta de que europeus, principalmente espanhóis, já haviam passado e mesmo vivido, de modo esporádico, na região da costa catarinense e da llha de Santa Catarina antes da chegada dos primeiros moradores portugueses e brasileiros deles descendentes. A região da llha era integrante das terras donatárias, cedidas pelo rei de Portugal a Pero Lopes de Souza em 1534, permanecendo assim até o início do século XVIII, quando o conjunto de terras voltou ser propriedade da fazenda real. O período de 1629 a 1651 é reconhecido como marco pioneiro, em que se estabelecem os primeiros bandeirantes. A pequena população inicial, composta de bandeirantes e índios escravizados, se concentrava na porção sul da península central da llha de Santa Catarina, junto ao estreito que a separa do continente, e as construções não passavam de duas dezenas.

Durante boa parte desse período não houve ocupação consolidada, o que só veio a acontecer com a requisição da sesmaria da llha, em 1678, por Francisco Dias Velho, bandeirante oriundo da capitania de São Vicente, quando a povoação se coloca como entreposto de abastecimento no processo de fundação e batalhas pela colônia de Sacramento na margem setentrional do Rio da Prata. Este período se encerra com o ataque pirata em 1687 e a morte de Dias Velho, pioneiro fundador da póvoa, com posterior decadência, estagnação e redução populacional.

Esta primeira etapa, de caráter colonial, teve seus primeiros momentos de desenvolvimento e pequeno crescimento populacional em função de motivações político- 
militares das nações que disputavam as terras meridionais do continente americano, após o Tratado de Tordesilhas. As baías da llha de Santa Catarina, pelas excelentes condições de atracadouro para a navegação, representavam ponto geográfico estratégico para a coroa portuguesa à época, com sua economia se restringindo ao abastecimento de madeiras, frutas, água e peixes para os navios.

As principais transformações na natureza, perceptíveis nas descrições relativas a esta época, se referem à dilapidação parcial da floresta ombrófila densa, que reinava nos morros, das florestas quaternárias e da vegetação de restinga das baixadas litorâneas, nas cercanias dos poucos núcleos espalhados pela costa oeste da llha. As transformações na paisagem decorreram do extrativismo seletivo de árvores e das queimadas, necessárias para a existência dos poucos campos agrícolas e pequenas roças, onde se cultivava mandioca, milho, feijão, arroz, banana e cítricos.

\section{A formação do espaço rural litorâneo}

Uma segunda etapa, de extrema importância, está associada à migração populacional das ilhas portuguesas do Atlântico Norte, e se caracteriza pela ocupação e transformação radical do território. Inicia-se com a chegada de novos povoadores vindos da Província de São Vicente, em 1700, confirmando o porto no papel de entreposto de comércio de produtos agrícolas e a região como lugar estratégico para a navegação.

Esta fase de relativa prosperidade teve reflexos na transformação da póvoa em Distrito (Freguesia) em 1714, quando 22 famílias viviam na llha; no recebimento do título de Vila da Nossa Senhora do Desterro em 1726, e na elevação à condição de sede da Capitania de Santa Catarina, sob o comando do Brigadeiro José da Silva Paes, em 1738 (Pereira, 1974). Sob seu comando se iniciou a construção das seis fortificações, que compunham o sistema de defesa das entradas das baías sul e norte, erguidas em locais estratégicos como promontórios e ilhas, e que hoje estão tombadas pelo Instituto do Patrimônio Histórico e Artístico Nacional.

Quando, por razões complexas, o Marques de Pombal decide enviar migrantes das ilhas portuguesas, que se encontravam com superpopulação, o que se efetiva com a paulatina chegada de 6.000 açorianos e madeirenses na llha e costa catarinense entre 1748 e1758, tem início um surto de crescimento populacional e de ocupação do território formando o espaço rural litorâneo característico desta migração. 
A Provisão Régia que estabeleceu a vinda dos colonos determinava também uma maneira de espacialização dos agrupamentos humanos que é marca até hoje do modelo disperso de ocupação territorial, conforme relata Cabral: "Os sítios mais próprios para fundar em cada um dos quais se estabeleçam pouco mais ou menos de sessenta casais dos que forem chegando" (1950, p.93). Alguns dos lugares escolhidos, como Santo Antônio de Lisboa, geralmente em baías voltadas para o continente, com facilidades de ancoragem para as embarcações, já eram ocupados, e receberam grande impulso a partir da imigração.

Este período marca a formação da estrutura poli-nucleada da llha, com a implantação de fortificações defensivas e do sistema de assentamentos pioneiros. Os diversos fortes erguidos em diferentes pontos estratégicos da llha, formando sistema de defesa das entradas das baías interiores e do núcleo pioneiro, utilizaram localizações estratégicas em promontórios a beira-mar e pequenas ilhas. Os assentamentos se espalharam pela costa e interior da llha, polarizando regiões com certo isolamento das demais.

A construção de capelas e armazéns em locais privilegiados, junto aos portos ou em promontórios, definiu o centro local de vida comunitária, origem da sede das freguesias (atuais distritos). As edificações rurais, moradias dos posseiros dos lotes coloniais $^{2}$, se localizaram no sopé dos morros, na meia-encosta, evitando as planícies encharcadas, as grandes declividades e as cotas mais altas, e aproveitando a transição entre os dois domínios naturais para dali realizarem a sua exploração.

Santo Antônio de Lisboa, a noroeste, e Ribeirão da llha, no sudoeste, foram importantes pontos de trocas comerciais, de chegada e dispersão de novos colonos pelo interior da Ilha. Do primeiro local saíram os ocupantes das localidades de Ratones, Jurerê, Canasvieiras e Rio Vermelho. Do segundo local, partiram os ocupantes de localidades como o Pântano do Sul e Armação. Da vila do Desterro saíram os povoadores da região da Lagoa da Conceição e arredores.

O contato entre os núcleos através do mar e por terra formou uma rede de portos e caminhos que perdurou pouco alterada até meados do século XX. Os caminhos do mar fortaleceram os assentamentos litorâneos com pequenos portos de comércio e transporte da produção agrícola, e os caminhos terrestres, com configuração linear ao longo das pequenas possessões coloniais, conectaram localidades interioranas com as demais, forman-

\footnotetext{
2 Conforme Cabral (1950, p.53), o edital de posse dos lotes coloniais previa a distribuição de terras com "um quarto de légua em quadro a cada uma das cabeças do casal do mesmo lugar", o que diante dos padrões de possessão de sesmarias que predominava no restante do Brasil, pode ser considerado de pequenas dimensões.
} 
do as estradas gerais, que estruturam, quase que integralmente, $o$ atual sistema viário da llha. A localização dessa estrutura linear com edificações residenciais na meia-encosta dos morros é uma forte característica da ocupação colonial e aponta para um modo de apropriação do território atento às variações do relevo.

A chegada dos novos colonos trouxe

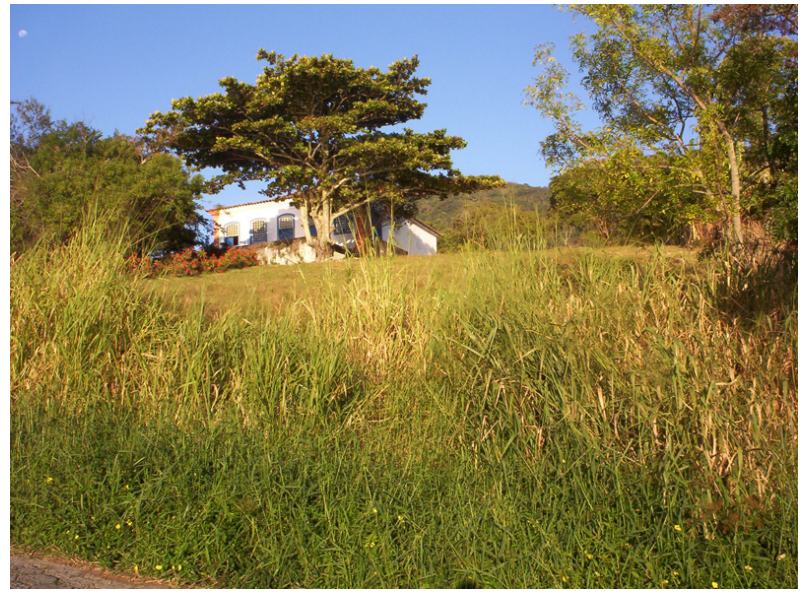

Figura 3.2: Casa na meia encosta no Ribeirão da llha. características singulares que diferenciaram esta de outras empresas coloniais do território brasileiro: o comunitarismo e o modo associativo ${ }^{3}$, refletidos no modo de produção e relações sócio-econômicas. As atividades produtivas de cultivo e transformação de produtos primários, como a farinha de mandioca e a tecelagem de algodão e linho, passaram a formar a base econômica da região, a partir do uso dos lotes privados e de terras de uso comunitário, herança do rocio ibérico.

$\mathrm{Na}$ pesca artesanal, essas características permanecem ainda hoje, refletidos nos grupos de pescadores que formam as parelhas que controlam as pequenas embarcações. No âmbito cultural, e as crenças e festejos religiosos formaram a base cultural dos colonos e levaram a construção de diversas capelas e igrejas nos núcleos coloniais, muitas vezes dando nome às localidades.

A experiência agrícola vicentista foi expandida pelos novos colonos, com novas técnicas de processamento de grãos, cana-de-açúcar e café sombreado, o que proporcionou o surgimento de diversos pequenos engenhos de farinha e açúcar por todo o interior da llha, dos quais restam, ainda hoje, alguns remanescentes em mau estado de conservação. A transformação do território em um espaço rural litorâneo se fez pela estruturação polinucleada dos assentamentos humanos e é hoje percebida por alguns como a herança mais marcante e diferenciada da colonização açoriana. A dispersão dos colonos açorianos ${ }^{4}$, pelos quatro cantos da llha, em pequenas e estreitas parcelas de território com dimensões semelhantes,

\footnotetext{
${ }^{3}$ A configuração social dos arquipélagos portugueses no século XVIII, apesar de o modo de produção mercantil impulsionar com bastante vigor as metrópoles mundiais e algumas colônias, estava calcada em relações sócioeconômicas de servilismo e pequenas empresas independentes (Silva et ali, 1996) e com resquícios sócioculturais do século XV (Santos, 1971), época em que foram colonizadas.

${ }^{4}$ Embora houvesse significativo número de madeirenses entre as famílias imigrantes, a predominância açoriana foi se estabelecendo como referência para a colonização dos vindos das ilhas portuguesas do Atlântico Norte.
} 
a formação de pequenas comunidades de agricultores-pescadores, e a instituição das terras comunais $^{5}$, conservaram extensas áreas sem ocupação intensa ou construções, permitindo a percepção de amplas paisagens horizontalizadas e pouco artificializadas.

Ao mesmo tempo em que o interior da llha e as terras do continente próximo iam

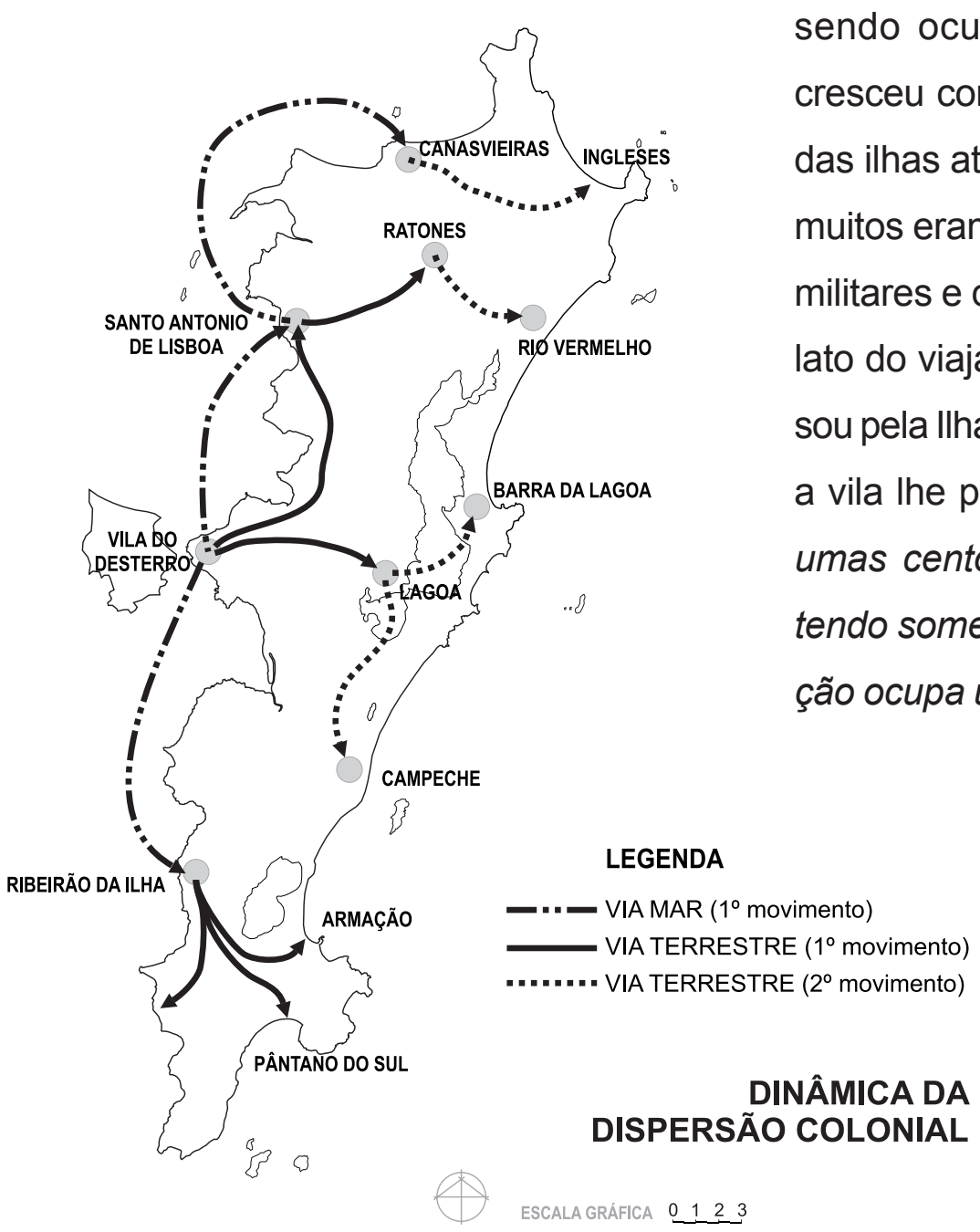
sendo ocupados, o núcleo fundador com a chegada dos migrantes das ilhas atlânticas portuguesas, já que recrutados para atividades lato do viajante Dom Pernetty que passou pela llha de Santa Catarina em 1763, vila the pareceu ser “... composta de tendo somente o rés-do-chão, a guarnição ocupa uma parte e a outra é ocupada pelos brancos de um lado e pelos negros ou mulatos do outro" (in: Haro, 1990, p. 82), com interessante apontamento sobre a segregação racial por meio do espaço.

Figura 3.3: Dinâmica da dispersão colonial.

\footnotetext{
${ }^{5}$ Segundo Campos (1991), a existência de terras comunais na região, cuja finalidade era o suplemento da propriedade individual, teve origem germânica e foi passada à Península Ibérica, chegando ao litoral catarinense via colonização. Este autor identifica quatro tipos comuns na região de influência açoriana: áreas comunais de uso local, campos de descanso e engorda de gado, campos estivais e campos de uso cooperativo. As restingas, pela grande extensão e menor qualidade para culturas agrícolas, foram as áreas preferidas quando do estabelecimento das terras comunais, embora morros, dunas e pântanos também tenham sido utilizados com esse fim. $O$ processo de apropriação privada dessas áreas teve vários momentos, incentivos e agentes. Incentivos legais foram oferecidos quando da municipalização do direito de regulação das terras devolutas da União, a partir da promulgação da Lei de terras em 1850; da passagem para o controle da Província no período republicano, a partir da Constituição de 1891; e mesmo depois do estabelecimento Estado Novo, quando o Decreto Estadual n. 46 de 11/07/1934, tratou as terras comunais como de uso devoluto, permitindo apropriação estatal, o que possibilitou a criação de um parque estadual na llha de Santa Catarina nos anos 1960, mas também a distribuição de títulos individuais.
} 
Já no fim do século XVIII, conforme relato de outro viajante, a cidade contava com quatrocentas casas e perto de 3.000 almas (La Perouse em 1797, in: Haro, 1990). No período de 1738 a 1780 , foram construídas, em média, 14 residências por ano (Veiga, 1993), o que dá medida relativa do ritmo de crescimento da vila de Nossa Senhora do Desterro.

Durante a maior parte do período coIonial açoriano, o principal produto de exportação da província para as regiões mais estabelecidas do norte era a farinha, que durante o ano de 1859 foi responsável por $50 \%$ do abastecimento nacional. Porém, durante um curto, mas significativo, período, o centro da economia passou a ser a pesca da baleia, cujo óleo, era encampado pela coroa portuguesa, via Rio de Janeiro. Esta atividade mercantil, com produção manufatureiroescravista e que entre 1771 e 1790 pescou perto 1000 baleias por ano, permitiu a constituição de uma classe senhoril local e fomentou o desenvolvimento da região (CECCA, 1997, p.198).

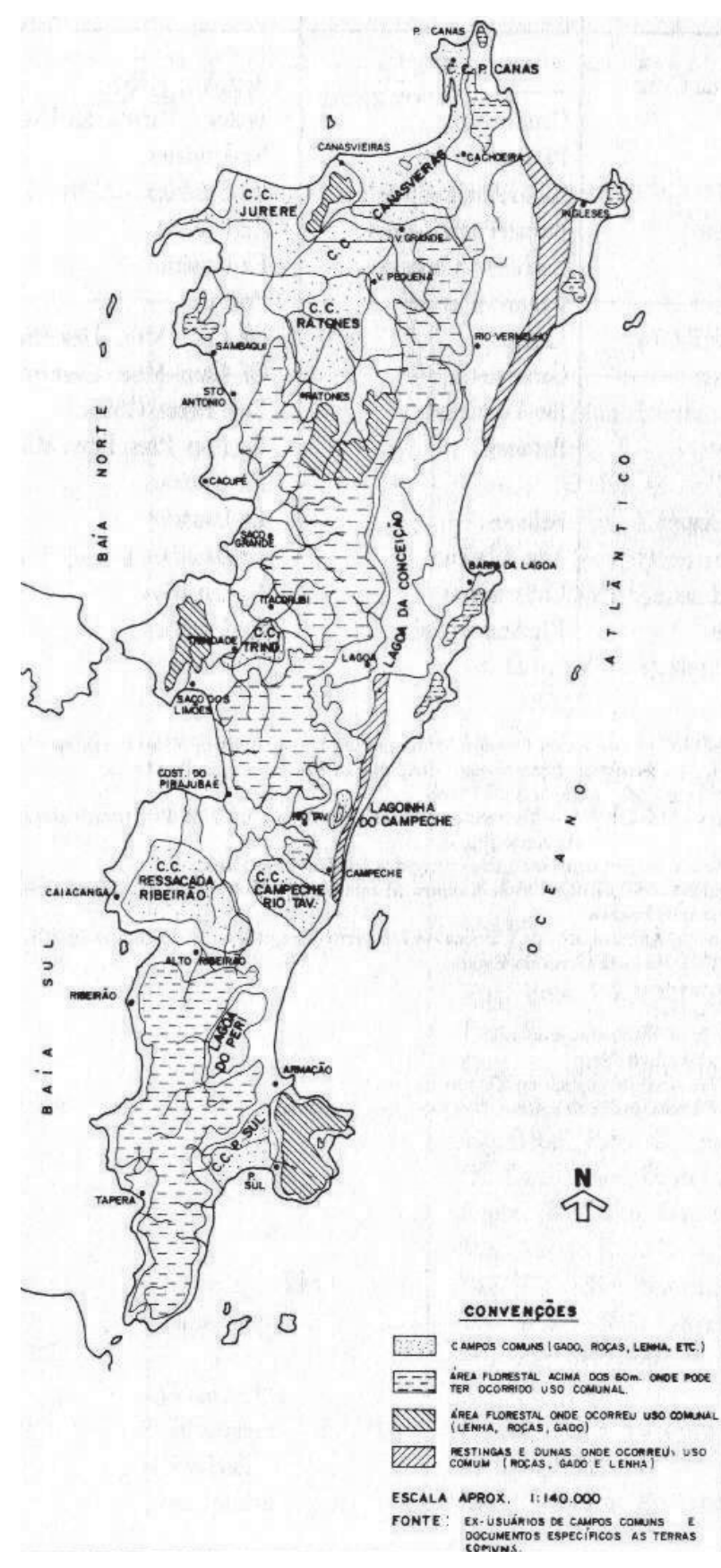

Figura 3.4: Mapa Terras comunais na llha de Santa Catarina. Fonte: reproduzido de Campos, 1991.

O impacto, ao longo dos anos, da atividade agrícola da empresa colonial açoriana indica, de maneira ainda hoje perceptível, traços de uma interferência humana não ajustada ao meio. O uso continuado dos solos de baixadas, com fina camada orgânica sobre sedimentos arenosos e pobres em nutrientes, para campos agrícolas, exauriu grandes áreas e não permitiu maior desenvolvimento, levando ao abandono dessas áreas, muitas delas virando campos comunais sem produtividade comercial. 
A utilização das encostas de solos argilosos com cobertura florestal da mata atlântica, ainda que mais exigente de esforços pela declividade e densidade de árvores, foi a seguinte alternativa. A exploração dos limites dos lotes nos cimos dos morros desmatou grandes áreas de montanha e levou a erosão de muitas vertentes, contribuindo para a falência ${ }^{6}$ do modelo agrícola (Lago, 1999). A paisagem atual, com matas secundárias, florestas de regeneração, restingas, capoeiras, capoeirinhas e capoeirões nos morros e baixadas litorâneas que recompõem a cobertura vegetal, foi se formando pelo paulatino abandono da intensa atividade agrícola.

\section{De vila a cidade}

As primeiras décadas do século XIX marcam o início de uma terceira etapa, coincidindo com o período Imperial do Brasil. Inicia-se com a abertura dos portos em 1808, a criação da Intendência da Marinha de Florianópolis em 1817, que tinha o objetivo de controlar os suprimentos das embarcações e fiscalizar as matas, e a Independência do Brasil. Desterro se consolida cada vez mais como pólo comercial e marítimo. Mas, mesmo que o porto da capital fosse considerado livre, o comércio da vila ainda era atrelado e dependente do Rio de Janeiro ou de Lisboa, impossibilitando desenvolvimento mais intenso.

Em 1803, o comandante de um navio russo, Almirante Lisiansky, comentava, em relação à cidade, que, "Por uma estimativa do governo, a população soma, no presente, a 10.142 almas, das quais, umas 4.000 são negras" (Haro, 1990, p. 152).

Entre 1830 e 1880, inicia-se uma segunda fase de prosperidade, com incremento da exportação, surgimento de uma burguesia comercial e início de uma vida urbana por excelência. A vila recebeu melhorias no porto, obras públicas (de saneamento básico) e construções (em especial para receber a família Imperial em 1845, quando se eleva Desterro à categoria de cidade), registrando-se um surto construtivo no ano de 1857, quando se construíram em torno de 40 residências

\footnotetext{
${ }^{6}$ A impossibilidade de gerenciamento direto de seus produtos, pela ação de intermediários, a postura monopolista do Rio de janeiro, principal importador, manipulando preços e a falta de estímulo do governo central, não estimulando a diversificação e profissionalização, fez com que as atividades rurais se debilitassem paulatinamente. Além disso, a própria estrutura fundiária também é alçada, por alguns estudiosos, à condição de entrave ao desenvolvimento da agricultura. O parcelamento dos lotes compridos e estreitos, derivado do sistema de sucessão de terras adotado no atendimento da hereditariedade, diminuindo ainda mais as áreas e restringindo os cultivos, não permitiu maior produtividade (Silva et ali, 1996).
} 
(Veiga, 1993). Até o final do século XIX o porto foi o principal elemento urbano de polarização de atividades comerciais (importação e exportação de produtos) e das interações sociais. Durante este período, ainda que a cidade pouco contribuísse na riqueza nacional em relação às demais províncias, manteve o status de capital da província. (Hübener, 1981, p. 43).

Após a proclamação da República, Desterro passa a se chamar Florianópolis (1894) em auto-homenagem imposta pelo Marechal Floriano Peixoto, que reprimiu e aniquilou foco monarquista na província, dando início a uma etapa de valorização da cidade, que retoma importância na paisagem insular. Os núcleos ruro-pesqueiros do interior $\mathrm{e}$ da orla da llha de Santa Catarina, assim como os do continente próximo, durante o período seguinte, experimentaram crescimento vegetativo menor, sendo boa parte dele sendo absorvida pelo sub-parcelamento dos lotes pioneiros, fragmentando ainda mais a estrutura fundiária, e pelo crescimento do núcleo central.

\section{Consolidação da cidade}

No século XX, conforme a Agenda 21 local,

“(...) a cidade firmou-se como capital do estado de Santa Catarina, urbanizandose, recebendo a implantação da rede de energia elétrica, o sistema de abastecimento de água e captação de esgotos, além da ligação Ilha-continente, e passou a sustentar-se economicamente pelo comércio, pela administração pública e pela indústria da construção civil. Somente nas últimas três décadas do século XX é que a atividade turística começou a se fortalecer como um dos pilares da economia da Ilha". (2000, pp. 24-25).

Até a virada do século XIX para o XX, cerca de metade da população da llha de Santa Catarina, que em 1890 era de 30 mil pessoas, era urbana, mas a dispersa ocupação ocupacional conferia à paisagem um caráter predominantemente agro-pastoril, mesmo que seu núcleo fundador já assumisse ares de cidade, com o embelezamento de ruas e praças e melhorias nas construções. Com o Início do século $\mathrm{XX}$, se percebe novo período de prosperidade, ainda que efêmero, acompanhando períodos áureos da economia mundial. $\mathrm{O}$ apogeu deste período é o início da construção da Ponte Hercílio Luz em 1926, infraestrutura que, substituindo sistemas de transporte na circulação entre continente e llha, veio alterar a dinâmica urbana, permitindo conexões produtivas importantes. 
No início daquele século, a cidade e a província começaram a receber programas e projetos desenvolvimentistas de governantes tecnocratas e planejadores pioneiros, como Felipe Schmidt (que implantou estradas para o interior do estado) e Hercílio Luz (que construiu o primeiro sistema de esgoto da capital, em 1916, o aeroporto e o saneamento da avenida com seu nome na capital), que buscavam colocar Santa Catarina no processo de desenvolvimento nacional (CEAG/SC, 1981), e deram base às futuras transformações.

A crise mundial de 1929 e a Revolução de 1930 no Brasil marcam o início de um período de estagnação urbana e econômica que se estendeu até o pós-guerra. A escassez de capitais em nível mundial e a pouca atenção dada pela ditadura de Getúlio Vargas aos estados não alinhados no período revolucionário levaram a um período de estagnação econômica, retro alimentada pela decadência da atividade portuária e pelo isolamento parcial da capital, prejudicando o desenvolvimento da cidade.

Neste período, porém, cresceu o setor público, com a afirmação do estado federal nas capitais, o que praticamente impediu a retração econômica. A pequena produção agro-pesqueira se manteve em diversas partes da llha, mas sendo, paulatinamente, prejudicada pela pesca industrial nascente e pelo abandono gradativo das atividades agrícolas.

O comércio interno tem destaque, atendendo demanda da crescente classe média, formada basicamente por servidores estatais, consolidando-a como importante segmento sócio-econômico na capital. As alterações na paisagem do município, notadas a partir dos anos 1930, são algumas obras de infraestrutura como a drenagem de diversas planícies úmidas e campos comunais (realizadas pelo DNOCS), prática antiga na llha ${ }^{7}$, e a construção da Avenida Hercílio Luz, canalizando um córrego, no centro da cidade.

Começa, então, a se consolidar a tendência à terceirização econômica da capital, que ainda se ressente de infraestruturas urbanas em pontos centrais e em diversas áreas fora da cidade. Na década de 1940 a capital ainda não havia, como a maioria das capitais do sul do Brasil, atingido desenvolvimento econômico de caráter urbano-industrial: a atividade portuária se encontrava em franca decadência, e as indústrias de maior porte (têxtil e de pregos) eram aquelas vinculadas à família Hoepcke (Pereira, 1974).

\footnotetext{
${ }^{7}$ Este trecho de relato de um viajante do século XIX, comprova: "O forte São José ocupa, sobre a Ponta Grossa, uma posição excelente, (...); escavaram neste lugar um canal que se dirige para o interior, sem dúvida para dar escoamento às grandes massas d'água estagnadas nas savanas". (Lesson, 1822, in: Haro, 1990, p.269).
} 
Nesta década também se verifica um aumento do território municipal com a incorporação das terras continentais adjacentes à ponte Hercílio Luz, até então pertencentes ao município de São José e que permaneciam ainda com características ruropesqueiras, e que seriam, na década seguinte, utilizadas para urbanização balneária, pela facilidade de acesso e disponibilidade de terras desocupadas.

O crescimento populacional do século XX, até fins dos anos 1950, manteve taxas em torno dos $2 \%$ ao ano exceto alguns poucos momentos das primeiras décadas, como aquele que ocorreu logo após a construção da ponte Hercílio Luz em 1928, dinamizando a porção insular e facilitando a ocupação mais intensa das terras no continente próximo.

Após a Segunda Grande Guerra, a capital experimentou taxas de urbanização significativas, fruto de desenvolvimento econômico no restante do estado. Com a decadência das atividades primárias na llha, cresce a atividade comercial de artigos transformados e industrializados, como tecido e mobiliário doméstico. Nos anos 1950, o comércio varejista já se destacava do restante das cidades do estado e o atacadista representava $25 \%$ do setor, tornando-se o principal pólo do litoral catarinense (Pereira, 1974).

\section{Explosão demográfica, urbanização e conurbação}

A partir da segunda metade do século passado, se inicia uma transformação sócio-espacial que vem alterando a paisagem da llha, de modo vertiginoso e negativo, e se caracteriza pelo constante incremento da taxa demográfica, extensa ocupação do território e intensa modificação da paisagem. O processo de urbanização da população, induzido por fatores como a rápida decadência da atividade rural e pesqueira $^{8}$ e a valorização fundiária das áreas do interior e litoral da llha, começa a tomar impulso a partir dos anos 50 , quando $75 \%$ da população já se encontravam em áreas urbanas.

\footnotetext{
${ }^{8}$ A decadência da pesca teve, além das locais, motivações estruturais e supra-regionais. Apesar de a estrutura comunitária presente na atividade e a profissionalização decorrente do período da baleia haverem possibilitado o nascimento de grupos sociais e econômicos especializados, as alterações estruturais na atividade, como a industrialização e os avanços tecnológicos na navegação, a crescente escassez do produto pescado, a intermediação dos atravessadores e a atratividade de serviços de outra natureza foram determinantes para que o setor se encontre debilitado.
} 
A transformação da paisagem da cidade, quase imperceptível entre 1930 e 1960, começa a se incrementar a partir do primeiro plano de urbanização para a área central de Florianópolis em 1955, e na silhueta da cidade passaram a se destacar algumas construções com maior altura. Fora do centro, a llha recebeu algumas experiências de urbanização e equipamentos turísticos ${ }^{9}$, na orla litorânea (Canasvieiras e Jurerê) e interior (Lagoa da Conceição), e na parte continental, Coqueiros, Bom Abrigo e Itaguaçú, inaugurando e antecipando a associação entre turismo e incorporação imobiliária.

A partir deste período, a população da capital passa a crescer em função de uma série de fatores, como as facilidades de acesso rodoviário (anos 60-70), a implantação de instituições de ensino federais e estaduais, empresas autárquicas e de administração pública, atraindo significativo número de pessoal técnico profissional de outras unidades da federação. Firma-se, então, como cidade de serviços, o que se consolida na década de setenta, quando as poucas indústrias aqui estabelecidas se deslocaram para o distrito industrial de São José às margens da BR-101. A construção civil passa a despontar neste setor da economia, gerando significativo número de empregos e considerável arrecadação de impostos.

Na década de 1970, enquanto o estado de Santa Catarina experimentou uma urbanização intensa, apresentando uma taxa de crescimento nas zonas urbanas de pólos industriais de 6,1\% (Campos, 2004), o município de Florianópolis apresentou crescimento demográfico de $3,8 \%$ ao ano, passando a concentrar quase $80 \%$ de sua população no perímetro urbano (Pimenta, 2005). O aumento demográfico, além do crescimento vegetativo da população local, em boa parte constituída por assalariados de classe média do serviço público, contou com a vinda de pessoas do interior do estado, atraídas pela polarização educacional, cultural, comercial e administrativa.

\footnotetext{
${ }^{9} \mathrm{O}$ uso balneário da praia em Florianópolis remonta às primeiras décadas do século $\mathrm{XX}$, em situações pontuais no espaço e no tempo. As praias do centro da cidade sempre foram associadas às atividades portuárias, e as praias do interior das baías, à pesca, sendo, portanto, locais de muita sujeira e pouco valorizados pela população. A praia de Fora, região da atual Beira-Mar Norte, foi um dos primeiros locais onde o banho de mar era realizado. O governador Hercílio Luz, percebendo o potencial da região litorânea da llha, chegou a anunciar em 1918, num jornal da época, a ligação por meio de bondes elétricos (nunca realizada) entre o centro e as demais regiões da Ilha, antevendo o desenvolvimento futuro. No norte da llha, em Canasvieiras, algumas casas de veraneio já se haviam estabelecido por lá quando em 1929 foi implantado um pequeno hotel. Os proprietários e usuários desses locais eram das classes dominantes da região, sendo a família Hoepke, de importantes industriais da cidade, a pioneira. O primeiro loteamento balneário foi implementado pela própria prefeitura da cidade, em meados dos anos 1950, na restinga de Canasvieiras, sobre antigas terras comunais, demonstrando interesse da administração pública na expansão da cidade.
} 
Alguns municípios da grande Florianópolis tiveram, recentemente, taxas de crescimento elevadas e superiores a capital, como São José, com 6,3\% 5, 47\%, e Palhoça com 7,52\% e 4,28\%, nas décadas de 1970 e 1980 respectivamente (IBGE, 2003). Paralelamente a essa intensa urbanização dos municípios vizinhos, a taxa de crescimento do município de Florianópolis manteve um ritmo acima de $2,5 \%$. Nestas últimas décadas do século, a rápida alteração no ritmo de crescimento populacional do aglomerado urbano de Florianópolis gerando grande demanda territorial, resultou na imensa conurbação com os diversos municípios da região, não permitindo que se entenda a capital sem que sejam levados em conta os demais municípios.

A instituição da Região Metropolitana de Florianópolis ${ }^{10}$ em 1998, necessária para o enfrentamento das questões decorrentes da intensa urbanização e da conurbação, ainda não repercutiu em atitudes administrativas solidárias nem num planejamento integrado, com soluções coletivas para problemas que afetam o conjunto das cidades. A clivagem política e a falta de tradição de planejamento e de recursos (técnicos e financeiros), em diversos municípios, têm impedido a consolidação de consórcios administrativos para a gestão do território compartiIhado. Por ser a capital, com maior peso político na região, as soluções adotadas em Florianópolis passam a ser exemplo e condicionar as demais administrações. Porém, com a maior parte de seu território na llha de Santa Catarina, a problemática da expansão urbana e da degradação da paisagem adquiriu contornos dramáticos, assim como nos municípios continentais que não possuem o mesmo potencial de atratividade turística.

\footnotetext{
${ }^{10}$ A RMF foi instituída pela Lei Complementar Estadual n.162 de 06/01/1998 e compreende, além da capital, os municípios de São José, Palhoça, Biguaçú, Antonio Carlos, Águas Mornas e Santo Amaro da Imperatriz. Em sua região de expansão envolve mais 13 municípios: Alfredo Wagner, Angelina, Anitápolis, Canelinha, Garopaba, Leoberto Leal, Major Gercino, Nova Trento, Paulo Lopes, Rancho Queimado, São Bonifácio, São João Batista e Tijucas. Possui área de 7074,90 km² $^{2} 7,4 \%$ do estado) e densidade de 115 hab/km² (enquanto no estado é de 56 hab/ $/ \mathrm{km}^{2}$ ), e apresentou taxa de crescimento entre os anos de 1996 e 2000 de 4,6\%, a segunda mais alta do Brasil, abaixo da Região Metropolitana de Belém do Pará, enquanto que o restante do estado cresceu no mesmo período a taxa de 2,38\%. É gerenciada pela Companhia de Desenvolvimento do Estado de Santa Catarina CODESC. A mesma lei estadual instituiu outras duas regiões metropolitanas no estado: a Região metropolitana do Norte/Nordeste Catarinense polarizada por Joinville e a Região Metropolitana do Vale do Itajaí, sendo Blumenau a cidade pólo. Apesar de ter a capital como pólo, considerando-se população e atividade econômica, a RMF não se constitui na mais importante região metropolitana do estado. Fonte: IBGE, censo demográfico de 2000 e site www.emplasa.sp.gov.br.
} 


\section{Movimento em direção à orla - os balneários e a urbanização turística}

Na llha, de 1960 em diante, os distritos do interior e costeiros, revertendo a tendência de estabilização populacional que se insinuou até meados do século, passam a receber grande contingente de novos moradores. Essa população, na maioria não nascidos no município, migra para a região por motivos relacionados à qualidade de vida e oportunidades de trabalho. Enquanto, depois dos anos 1970, o distrito sede passa a apresentar declínio nas taxas de crescimento, os distritos da orla passam crescer com a chegada de novos moradores, e a região norte da llha começa a experimentar um explosivo desenvolvimento urbano-turístico. Com a implantação da SC-401, rodovia estadual que liga o centro ao norte da llha, esta região passa a receber a maioria dos investimentos e equipamentos destinados a atender demandas de visitantes e turistas.

Nos anos 1980, a Lagoa da Conceição ${ }^{11}$, o Ribeirão da Ilha e Santo Antônio de Lisboa passam a se constituir em distritos residenciais, com vantagens e problemas decorrentes das condições de bairros afastados do centro. A partir desta década, também a região sul, com os distritos Campeche e Pântano do Sul e Tapera, também passa a fazer parte desse movimento de expansão da ocupação territorial com fins habitacionais para trabalhadores assalariados e de renda baixa, sem que os demais distritos tenham perdido seu dinamismo demográfico (Pimenta, 2005).

Além das crescentes facilidades de acesso a diferentes pontos da llha, outras causas e motivações concorreram para este incremento demográfico e construtivo. Os incentivos imobiliários, e dentre estes, a continuada titulação de terras comunais, a impunidade na ocupação de áreas sobre ecossistemas naturais e a possibilidade de verticalização das construções, caracterizaram tanto o processo de criação de um setor turístico no norte da Ilha, como das novas áreas habitacionais.

Este crescimento construtivo suburbano não foi sempre resultado de planejamento adequado e eficientemente fiscalizado, nem acompanhado da implantação de serviços de saneamento e melhorias no sistema viário e de transporte. Ocupações inadequadas do ponto de vista ambiental, falta de saneamento, sistema viário, comprometi-

\footnotetext{
${ }^{11}$ Entre 1970 e 2000, a população do distrito da Lagoa da Conceição passou de 4.985 para 32.335 habitantes (IBGE, 2000). De outra forma, a Lagoa da Conceição teve, entre 1980 e 1991, sua população ampliada em $87,21 \%$. Imagine-se, além da grande interferência na paisagem, o impacto no ambiente lacustre, especialmente aquele decorrente da falta de infra-estrutura adequada de saneamento.
} 
do pela falta de dimensionamento compatível e de pavimentação, e traçado inadequado de vias urbanas são problemas que transcendem o padrão de renda e a legalidade da maioria dos assentamentos balneários.

Evidentemente que, por se tratarem de áreas mais interessantes para os setores ligados ao turismo e à expansão imobiliária, com forte ascendência na administração pública, passaram a receber, da administração e da sociedade, atenção diferenciada das áreas carentes da periferia conurbada. Essa visão da cidade por parte da administração pública, diferenciando a cidade balneária do centro urbano, levou a um planejamento segmentado, com um plano específico para o setor central da cidade, o Plano Diretor do Distrito Sede (1977) e um outro para o restante da llha, o Plano Diretor dos Balneários (1985), que será descrito de modo mais preciso em outro capítulo.

Essa suposta divisão, por parte de alguns setores do planejamento municipal, entre uma cidade permanente e de uma cidade balneária, a partir do processo de desenvolvimento urbano-turístico, não tem trazido qualidade na ordenação espacial, sendo, inclusive apontado como entrave para o trato do território insular, por fracionar a continuidade do espaço público e desconsiderar a complementaridade existente entre os setores da cidade, especialmente entre balneários e zona central, contida no processo de urbanização urbano-turístico (Oliveira, 1999).

Desse modo, após a implementação do PDB, a implantação de inúmeros loteamentos extensivo de baixa densidade (em média 75 hab/ha.), muitos com morfologias tendendo ao auto-isolamento, de condomínios fechados ${ }^{12}$ e o incentivo construtivo para equipamentos de hospedagem, algumas vezes com alturas inadequadas para a orla marítima e com excessiva ocupação do lote, deram grande impulso à indústria da construção civil e à economia da cidade, mas ao mesmo tempo proporcionaram uma ocupação prejudicial ao ambiente e criaram uma paisagem urbana e arquitetônica vulgar, repetindo um modelo de turismo massivo já visto em diversas localidades turísticas decadentes ou em vias de obsolescência pelo mundo afora.

\footnotetext{
${ }^{12}$ Embora regulamentado em nível federal desde 1964 (Lei Federal n. 4.591/64), com regime jurídico atrelado ao direito privado (e não urbano), a legislação municipal que previu a figura do condomínio em Florianópolis surge em 1978 (Lei Municipal n. 1.566/78). Essa modalidade de urbanização logo passou a ser objeto de desejo das classes médias e altas, pela possibilidade do isolamento e de controle da segurança privada, contribuindo para a segregação sócio-espacial e destruição do espaço público. Pela natureza introvertida da tipologia, é também conhecido como condomínio ou loteamento fechado (Oliveira, 1999).
} 
A orla da llha, com mais investimentos e construções, vem sendo intensamente ocupada, e pela observação da distribuição e da ocupação dos domicílios nessas regiões, revela-se que as áreas da primeira franja costeira são as ocupadas, prioritariamente, por edificações de segunda residência destinadas para uso pessoal ou aluguel para turistas nas temporadas ${ }^{13}$. Nos balneários do norte da llha, somente áreas mais distantes da orla e de difícil acesso aos veranistas, como Cachoeira do Bom Jesus e o distrito dos Ingleses, nas ruas mais interiorizadas da planície, tiveram incremento populacional considerável, caracterizado por estratos sociais de renda menor. Nos distritos do leste, esse padrão ocupacional vem se repetindo especialmente na Barra da Lagoa e Campeche.

A conurbação urbana das últimas três décadas que se direcionou, num primeiro momento, para o continente e áreas imediatamente contíguas ao centro histórico da Ilha, agora se direciona para a orla e partes do interior, ocupando inadequadamente um território diferenciado pela condição insular, envolvendo questões ambientais (paisagísticas, ecológicas e culturais) e sociais (políticas, econômicas e jurídicas).

Com base num modelo de urbanização não adaptado ao contexto ambiental e paisagístico, o movimento em direção à orla tem apresentado problemas semelhantes aos da conurbação urbana em terras continentais. Depois de alterações de classificação do solo no Plano Diretor dos Balneários no ano de 2000, Florianópolis passou a ter $97 \%$ de sua população considerada urbana, com a expansão ocupacional ocorrendo de maneira difusa ${ }^{14}$ num território exíguo agravada pela fragilidade dos sistemas naturais remanescentes.

\footnotetext{
${ }^{13}$ Conforme dados do IBGE de 2000 , em torno de $15 \%$, ou seja, mais de 20 mil domicílios da capital tem uso ocasional, com a maioria localizada nos balneários da cidade.

${ }^{14}$ As casas unifamiliares de primeira ou segunda residência vêm tendo um êxito social enorme junto a diferentes camadas sociais da população de Florianópolis. Isto acontece, no caso das camadas mais abastadas, seguramente porque, de uma parte, são o moderno reflexo de um modo de vida isolado, confinado e individualista e, de outra, o símbolo de uma prosperidade que, para ser reconhecida, necessita distanciar-se cada vez mais dos núcleos metropolitanos em busca de solo mais barato ou regiões atraentes, trazendo prejuízos à paisagem similares as ocupações clandestinas. Para as camadas de menor renda, a opção de casa solta no lote atende ao sonho da casa própria, associado ao de ascensão social pela adoção de tipologia semelhante e localização em regiões de paisagens atraentes e próximas das classes mais abastadas, além de que o processo de produção da residência nesse segmento social é, geralmente, feito por meio da autoconstrução progressiva, individualizada e sem orientação técnica, sobre parcelamentos resultantes de pequenos empreendimentos de poucos recursos, inclusive projetual, condições que se fossem outras, poderiam resultar em outras tipologias urbanas.
} 


\subsection{A dinâmica do segmento imobiliário}

Ao se analisar a evolução da cidade de Florianópolis, considerando o contexto de cidade essencialmente terciária, e seu relacionamento com o ambiente, se pode perceber que a construção civil sempre foi um expressivo indicador do vigor do seu desenvolvimento, e atualmente é, também, o vetor econômico de crescimento que mais depende de espaço territorial.

A análise de dados disponíveis sobre o desenvolvimento da cidade e dos números relativos à construção civil, sugere que é possível estabelecer correlações positivas entre a sua economia e o crescimento do setor. Ao envolver direta e indiretamente um expressivo número de pessoas, a construção teve, especialmente, a partir de meados de século passado, e continua tendo ${ }^{15}$, grande importância na cidade.

Em consonância com ciclos econômicos, mais ou menos favoráveis, o segmento imobiliário, envolvendo a construção, a incorporação e a comercialização de bens imóveis, veio crescendo e é hoje forte vetor de poder na economia e na administração da cidade, especialmente ao se associar com o setor turístico. A seguir, é traçado um panorama da dinâmica deste setor que é responsável pelas maiores transformações na paisagem da região de Florianópolis.

Até a metade do século XX, a construção do Hotel La Porta em 1932 em pleno centro de Florianópolis, junto à Praça XV de Novembro, pela primeira vez uma edificação com quatro pavimentos e elevador, foi o fato mais marcante da construção civil, e já associava o setor da construção civil e da hotelaria, dando início ao estreito relacionamento hoje existente. Fora isso, ó período de entre 1930 e fins dos anos 1950 é marcado pela estagnação econômica se refletindo na timidez com que o setor da construção civil, que vinha transformando a paisagem de outras capitais, se portou na configuração da paisagem citadina, quando, então, nem o centro e o interior da llha, haviam despertado interesses imobiliários.

No rastro do surto de urbanização do pós-guerra, a cidade conheceu um de lento adensamento na malha central da cidade, processo que se arrastou até o fim dos anos

\footnotetext{
${ }^{15}$ Mesmo em nível nacional a construção civil, atualmente, alavanca uma cadeia produtiva que representa aproximadamente $13 \%$ do PIB brasileiro, sendo responsável por milhares de empregos e indiretos, conforme o site www.sinduscon-fpolis.org.br visitado em 2003.
} 
1960. Até os anos 1970, pouco mais de quinze edifícios, no centro da capital, superavam os 10 pavimentos, evidenciando o pouco dinamismo em relação às demais capitais do sul e sudeste do país.

A expansão da população para as planícies e encostas de trás-o-morro, na forma de loteamentos traçados sobre chácaras e sítios dos bairros da Agronômica, Trindade e Pantanal iniciada no começo do século passado, ganha impulso a partir dos anos cinqüenta, e mais fortemente, com a implantação de instituições estatais, como a Universidade Federal de Santa Catarina - UFSC em 1962, a Universidade Estadual de Santa Catarina - UDESC também nos 1960, a mudança da sede central da Eletrosul do Rio de Janeiro para Florianópolis em 1976, e diversas outras empresas estatais e privadas.

O boom imobiliário em nível nacional na década de 1970, decorrente da pujante economia e de facilidades de crédito repercutiu também em Florianópolis, impulsionando a construção civil na cidade (Campos, 2004). O aterro na Baía Sul, em frente ao casco urbano antigo e concluído em 1974, desfigurando a frente marítima e cortando relações entre o centro e o mar, e a construção da segunda ligação entre llha e continente, a ponte Colombo Sales, incrementando fluxos e a construção, deram novo caráter à Florianópolis, com a substituição das residências unifamiliares por prédios em altura, dando um almejado ar de metrópole à capital catarinense.

A urbanização turística, ainda iniciante, se concentrou no norte da Ilha, em loteamentos extensivos e com infra-estrutura incipiente, com a ocupação de grandes faixas de restinga em Canasvieiras e Jurerê ${ }^{16}$, principalmente.

Para atender as classes médias, com acesso mais fácil ao Sistema Financeiro da Habitação, surgiram projetos de arquitetura moderna, boa localização e padrão de acabamento, num frenesi imobiliário ${ }^{17}$ que provocou a indagação feita por Fernando Marcondes de Matos ainda no início da década: “(...) se realmente houve um crescimento econômico expressivo em Florianópolis ou, então, se a aplicação da quase totalidade da poupança local em investimentos imobiliários, provocando uma mudança na fisionomia urbana" (Matos, 1973, p. 169). As classes menos favorecidas foram

\footnotetext{
${ }^{16}$ Os parcelamentos de terras em Canasvieiras, promovido pelo município, e na Praia da Ponta Grossa, renomeada para Jurerê quase que por imposição da imobiliária empreendedora, foram pioneiros do modelo turístico imobiliário.

${ }^{17}$ As principais empresas da época: CEISA, A. Gonzaga e Emedaux chegaram a concluir, no ano de 1975, doze obras cada uma, construindo de 80 a 90 mil metros quadrados por empresa (Campos, 2002, p. 118).
} 
atendidas em parte por conjuntos habitacionais construídos com recursos do INOCOOP e COHAB/SC, á época, localizados nas franjas da cidade, mas a maioria veio a se estabelecer em clandestinas nas encostas dos morros centrais.

Em meio aos anos 1970, ocorreu o despertar de setores da sociedade com mentalidade desenvolvimentista, empresarial e administrativa para a ocupação urbana da orla da Ilha, favorecido pelas facilidades de acesso e pouco controle urbanístico. Durante esse período, a atividade construtiva se consolidou como indústria de transformação e foi a única do setor terciário que apresentou rentabilidade significativa, cujos lucros se deviam grande volume de financiamentos, taxas de juros compensadoras e um mercado ávido de modernidade (Campos, 2004, p. 118). A visão empreendedora imobiliária, inicialmente de modo lento e depois, mais agressivo, passou a se direcionar para as planícies do interior da llha.

A crise econômica dos anos oitenta fez com que o setor imobiliário local, mesmo passando por certo estado de letargia, diversificasse a aplicação do capital, investindo no mercado financeiro, extremamente rentável nesse período, o que permitiu a manutenção, e mesmo incremento significativo, da poupança. A desativação das grandes construtoras foi seguida da criação de médias e pequenas empresas, que se dedicaram a atender a demanda de alta renda por meio de artifícios de financiamento e administração da obra. Isto resultou na construção de muitos edifícios em altura na Avenida Beira Mar Norte e em outras regiões nobres da cidade, além de incorporações nos municípios vizinhos.

Além disso, desde o início dos anos 1980 se apresentaram condições, favorecidas pelas diferenças cambiais entre os países da região do Rio da Prata, para a expansão da atividade turística, com a vinda de visitantes, especialmente da Argentina. Isto fez com que o mercado se mantivesse aquecido, seja pela demanda real ou pela expectativa de incremento, agora se expandindo com vigor para a orla marítima, levando a expansão urbana a esses locais, facilitados por mais facilidades de acesso e de planos turísticos e de ordenação do solo instituídos nessa década.

A aquisição e a apropriação de áreas na zona litorânea proporcionaram a ocupação por loteamentos e condomínios em todos os quadrantes da llha. Grupos detentores de poupança e investidores de maior capital, da região e uns poucos de fora, empolgados com a atratividade turística "viram, a partir dos anos 70 a oportunidade que se abria na compra de 
terrenos fora do centro e, principalmente nas praias, onde as populações tradicionais, longe do espírito mercantil e da informação econômica não tinham condição de identificar o valor potencial das terras, que eram usadas numa agricultura de subsistência ou como mera herança de um longínquo processo de colonização". (CECCA, 1996, p. 117).

O processo de titulação de terras comunais ${ }^{18}$, iniciado já na primeira metade dos anos 1900, facilitou ainda mais esta apropriação privada de grandes áreas planas, onde aquelas se encontravam. Mas não só a elite tira proveito financeiro neste processo especulativo na zona balneária, pois residentes da classe média têm se aliado entre si e com grupos mais abastados para obter ganhos com a construção e aluguel de segundas residências em diversos loteamentos e em lotes já ocupados e compartilhados:

"Investir em imóveis, tornou-se uma forma mais atraente de rentabilidade do capital, mesmo para os pequenos investidores com pouca formação e conhecimento dos complicados mecanismos que regem a economia moderna. Incluem-se parcelas das comunidades tradicionais, particularmente os comerciantes..." (CECCA, 1997, p.118).

Desde pequenos proprietários de terra, originados da partição dos lotes coloniais rurais e posterior subdivisão hereditária, a grupos monopolistas de grandes glebas obtidas pelo remembramento daqueles, a especulação tem sido alternativa econômica de diversos setores, com o aproveitamento do potencial paisagístico, seja em empreendimentos de fins turísticos e habitacionais. Um Relatório sobre os problemas sócioambientais da Ilha de Santa Catarina de meados da década de 1990, identificou os principais agentes no processo de especulação imobiliária:

"Alia-se à elite local, um setor importante de classe média que tem peso destacado em Florianópolis (...) já que muitos integrantes deste grupo social extraem renda uma suplementar da valorização de imóveis e aluguéis turísticos na temporada de verão, (...) parcela das comunidades tradicionais, os comerciantes,...". (CECCA, 1996, p.118).

\footnotetext{
${ }^{18}$ Um exemplo desse processo pode ser entrevisto na descrição do caso das terras comunais onde hoje se encontram a praia de Jurerê e parte da ponta da Daniela. Inicialmente, foram oferecidas pelo governo municipal, que já se apoderara delas, como indenização, a Antonio Amaro, construtor naval e proprietário do estaleiro que se encontrava na área onde hoje se apóia a cabeceira insular da ponte Hercílio Luz, ainda nos anos 1920. Relatos dão conta que o empresário teve dificuldades na demarcação das terras e os títulos de escritura definitivos nunca foram emitidos em seu nome. Um influente advogado, político liberal que mais tarde viria ser governador do estado, Aderbal Ramos da Silva, comprou as terras da viúva do empresário em 1935. A partir de 1945, com a redemocratização do país e o pluripartidarismo, os campos comunais serviram de moeda de troca nas práticas de patronagem e clientelismo das correntes partidárias, com a progressiva apropriação privada de todas as áreas de uso comuns ainda existentes (Martins, 2004).
} 
Da metade da década de oitenta até 1990, devido às alterações na economia nacional (Plano Cruzado do governo Sarney em 1986) o setor se manteve com aquecimento parcial, e logo entrou em refluxo com o Plano Collor, que retirou liquidez do mercado. Isto, porém, não significou a paralisação das incorporações imobiliárias em Florianópolis, quando grande quantidade de obras, como centros comerciais, condomínios fechados e loteamentos, marcaram a paisagem. A ocupação, em meados dos anos 1980, da Praia Brava é um exemplo da ação imobiliária neste período' ${ }^{19}$.

A reativação da economia, com conseqüências no setor imobiliário, volta com a estabilização da moeda e o controle inflacionário do Plano Real (1994). A expansão urbano-turística, associada à atividade imobiliária, passa a transformar rapidamente toda a paisagem da orla de Florianópolis, restando poucas regiões na llha em que não se perceba seus impactos. Entre 1997 e 1998 foram licenciados mais de 500 mil metros quadrados (Pavei, apud Campos, 2004) no município, com destaque para os balneários, e durante essa década, aquelas pequenas e médias construtoras, que sobreviveram aos anos oitenta, cresceram, com algumas chegando a um patrimônio maior do que àquelas que vieram substituir.

Além do dinamismo imobiliário da região, contribuíram para isso, a reformulação do Sistema Financeiro da Habitação, já sob controle da Caixa Econômica Federal, que lançou mão de cartas de crédito, instrumento que "(...) passado o período inicial de adaptação, logrou excepcional aceitação (...)". (Aragão, apud, Campos, 2004, p.136), e a possibilidade de autofinanciamento pelas empresas construtoras, já capitalizadas, que fugiram, assim, das taxas bancárias.

No início do século XXI, a indústria da construção civil na região da Grande Florianópolis era responsável pelo emprego direto de mais de 37 mil pessoas, sendo que 4.200 somente no município de Florianópolis. Atualmente, numa perversa associação, o segmento turístico-imobiliário utiliza a promoção agressiva da cidade em âmbito nacional e internacional, atraindo mais moradores e os interesses do setor construtivo representam forte ameaça ao patrimônio ambiental da região. Essa opção defi-

\footnotetext{
19 Já orientado para extratos de renda mais elevados, em acordo com o perfil do turista e morador que os setores imobiliário e turístico planejaram atrair, foi criado uma urbanização de alto padrão na pequena baía cercada de morros, de difícil acesso, até então. Sobre a área agrícola abandonada, implantou-se morfologia litorânea urbana, reunindo casas isoladas no lote junto à encosta e condomínios em altura perto da orla, que hoje é freqüentado por visitantes e moradores de extrato sócio-econômico elevado.
} 
nitiva pelo modelo de desenvolvimento do turismo associado ao capital imobiliário teve pouco ou nenhum entrave na realização de sua acumulação e, conforme o CECCA:

"Não é difícil entender o peso do setor empresarial numa cidade marcada pela inexistência de um setor industrial moderno. Foi no comércio que se geraram os excedentes de capital que acabaram dirigindo-se preferencialmente para a especulação imobiliária". (CECCA, 1996, p. 117) ${ }^{20}$.

Os moradores tradicionais, que neste processo, são mais passivos do que os vetores da especulação, pressionados pela perda de rentabilidade do modo de produção a que estavam acostumados, passaram a vender suas terras, circunstancialmente desvalorizadas pela legislação, a preço baixo. Isso favoreceu a acumulação e formação de estoque de grandes porções de terra por parte de poucos proprietários.

A partir daí, legal ou ilegalmente, mas quase sempre de maneira ilegítima, a transformação dos antigos e debilitados solos rurais em solos urbanos ou urbanizáveis tornou-se uma constante ${ }^{21}$. Os monopólios formados pela compra dessas terras têm diversas composições e origens, mas tem sido comum a associação de empresas de incorporação imobiliária com capitais comerciais e industriais já nem tão locais e mesmo regionais, havendo até interesses internacionais.

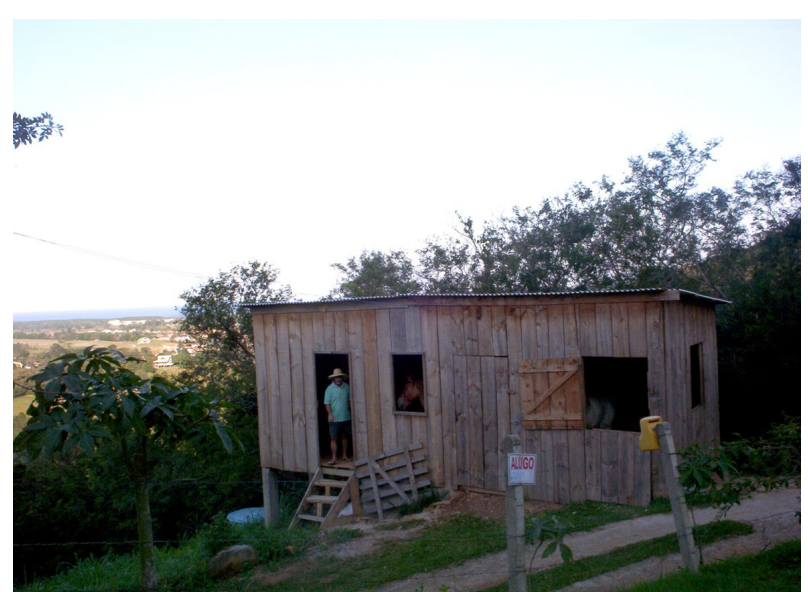

Figura 3.5: Imóvel rural em processo de valorização imobiliária na costa lesta da llha

A expansão urbano-turística calçada na incorporação imobiliária é a característica mais marcante no processo de formação e transformação do território do município de Florianópolis. Com a valorização da terra e de imóveis, decorrente da divulgação e atratividade da cidade, a especulação imobiliária passa a ser aspecto inerente a esse

\footnotetext{
${ }^{20}$ Diversas empresas do setor terciário, tradicionais na cidade, expandiram seus negócios, nos últimos anos, em direção à construção e incorporação imobiliária, como, entre outras, o grupo varejista Koerich, a pesqueira Pioneira da Costa e a revenda de automóveis do grupo Amauri.

${ }^{21}$ Segundo a arquiteta Sílvia Lenzi (apud, CECCA, 1996, p.120), com a aprovação do PDB em 1985 até 1992 , haviam sido aprovadas mais leis urbanas do que no período anterior, de 1955, época do primeiro plano urbano de Florianópolis, até a data de entrada em vigor do PDB, e que dessas, mais de $70 \%$ eram alterações de classificação de usos do solo no Plano Diretor dos Balneários.
} 
processo. Neste sentido, a lógica de interesses imobiliários e de elites hegemônicas locais tem tornado legal o que nem sempre é legítimo, seja pela omissão do poder público, por adequação da legislação ou pela consolidação de realidades já existentes.

\subsection{Novas migrações}

Fenômeno importante no processo de crescimento populacional recente, pela demanda de espaço construído para moradia, atividades e funções urbanas, além de transformações no perfil sócio-econômico e cultural, a migração merece consideração no estudo da produção do espaço e transformação do território da região de Florianópolis. Evidenciada a partir dos anos setenta da década passada, com a migração rural e de regiões próximas, ela impulsionou fortemente o crescimento urbano, com o adensamento da região central e ocupação de áreas contíguas.

A partir dos anos 1980, a ocupação de áreas da orla e expansões balneárias junto aos núcleos pioneiros teve impulso com a atração de novas levas de migrantes, agora de outras regiões do país, e que tem levado às imensas transformações no território. Levas de gaúchos, paulistas, paranaenses e cariocas, além de pessoas de cidades catarinenses do interior e, em menor proporção, porém perceptível, de platinos, se estabelecem preferencialmente nesses distritos, atraídos pela crescente facilidade de acesso e de serviços e pela qualidade da paisagem.

A migração de outros estados, mormente das metrópoles do sul e sudeste do país, mas também de outros países do cone sul, aumentou consideravelmente na última década do século XX, chegando a $10 \%$ da população residente na cidade no ano de 2000 (Campos, 2004), e não aparenta declínio em sua taxa de crescimento. Tem causa em uma diversidade de fatores econômicos e sociais e, para boa parcela dos migrantes, também por fatores culturais, como a idealizada busca de qualidade de vida em regiões menos conturbadas que as metrópoles industriais do país, o que parece possível em uma capital relativamente pequena, servida de comércio e serviços regulares, mas com insinuante presença da natureza.

Esta migração apresenta perfil variado, com bastante evidência de grupos sociais de classe média e média alta, mas não sendo desconsideráveis os estratos de menor renda que também se sentem atraídos pela propaganda oficial e pelas qualida- 
des relacionadas à região. Os extratos populacionais de menor renda, do interior e de outras cidades do país, vêm em busca de postos de trabalho ${ }^{22}$, em conseqüência do incremento da oferta de empregos no comércio e serviços relacionados ao turismo e construção civil. As classes mais abastadas vêm ocupar postos técnicos e profissionais de grau médio e superior na esfera pública e privada, embora haja alguns poucos que ainda mantém atividades nas cidades de origens, com a família aqui estabelecida, com vindas periódicas.

Apesar da indústria da construção civil ter considerável importância na economia municipa ${ }^{23}$ e na absorção do crescimento da população local, que ainda atinge taxas acima da média nacional, o padrão de desenvolvimento urbano-turístico, até agora não tem conseguido dar conta do déficit habitacional de mais de 12 mil unidades, registrado no início do século XXI (Política Habitacional de Florianópolis, 2002, p. 38).

A expansão urbano-turística não tem atendido grande parte deste déficit habitacional, pois a oferta tem se dirigido basicamente à classe média migrante e local, na forma de loteamentos horizontalizados e de baixa densidade, de primeira e segunda residência, ou de edifícios em altura com padrão mais elevado que a demanda social. Sem políticas públicas eficientes que dêem alternativas ao mercado, os setores de baixa renda, locais ou recém chegados na busca de ofertas de trabalho, em boa parte delas, direta ou indiretamente, relacionadas com o turismo, passam a resolver seu problema habitacional, por conta própria.

Com a ocupação de terras ainda não totalmente valorizadas e espalhadas por diferentes regiões, em situação irregular, em locais ambientalmente inadequados e de risco, utilizando a autoconstrução de baixo padrão, esta solução tem sido uma marca que os promotores do turismo e planejadores parecem não querer enxergar, problematizando ainda mais a questão urbana e sua relação com a paisagem da região.

\footnotetext{
${ }^{22} \mathrm{~A}$ avaliação e mensuração da migração de operários para trabalhar na construção civil são tarefas difíceis, pois nem todos vêm com esta intenção consciente e a maioria não tem qualificação profissional, além do amplo leque de opções de trabalho, geralmente informal, em outras atividades. A própria instabilidade do setor e a sazonalidade das atividades voltadas para o turismo prejudicam a investigação. De qualquer modo, bolsões de urbanização desordenada e sub-habitações, alguns no patamar da miséria, surgiram e surgem em áreas da cidade menos favorecidas de infraestrutura e serviços públicos, muitas vezes em áreas de proteção ambiental.

${ }^{23} \mathrm{O}$ Imposto Territorial Urbano - IPTU é responsável por 36,9\% da receita tributária do município (Fonte: site na WEB da Secretaria de Finanças do Município de Florianópolis, SEFIN-PMF, 2005).
} 
Embora a paisagem insular já apresente essa problemática, o estabelecimento dos novos moradores apresenta interessante distinção quanto à localização, reproduzindo, de modo mais contundente, a segregação urbana de outros centros urbanos. Enquanto os migrantes de renda e instrução mais altos conseguem se estabelecer na llha, preferencialmente em bairros junto à orla marítima e os extratos de renda média e baixa em ocupações legais e clandestinas se assentam em regiões menos valorizadas da Ilha, a maioria de trabalhadores sub-assalariados passa a ocupar a região conurbada.

Em bolsões de habitação subnormais e loteamentos clandestinos, se repete a situação comum ao processo de desenvolvimento urbano do país, e essa segregação estabelecida entre ilha e continente pode ter como uma das causas a localização das áreas industriais mais importantes no continente, mas se explica melhor pelo processo de valorização da terra insular.

O mercado imobiliário, a partir de um planejamento, elitista e excludente, tanto pelo paradigma tecnocrata e desenvolvimentista adotado, com pelas opções urbanomorfológicas induzidas pelos instrumentos urbanísticos, portanto, além avançar sobre o território insular, empurra os dele excluídos para áreas ainda não totalmente valorizadas, distribuindo os custos dessa produção do espaço para o município, e quando não, para a própria população.

$\mathrm{Na}$ llha de Santa Catarina, a migração de baixa renda também utiliza estas mesmas estratégias de assentamento, como se pode perceber na intensa ocupação das encostas do morro da Costeira do Pirajubaé, de parte das encostas na praia da Armação, nas invasões de dunas na praia dos Ingleses e mangues no bairro Carianos, e loteamentos irregulares no bairro da Tapera.

Mas a migração de extratos sociais de maior renda afeta também a paisagem de maneira semelhante. Ao ocupar encostas, beiras de praias e planícies sob a forma de casas isoladas, edifícios em altura ou de loteamentos legalizados, esses segmentos sociais têm se aproveitado da permissividade dos planos em relação ao patrimônio paisagístico e ecológico da região, especialmente onde se concentram, ou seja, na Ilha de Santa Catarina. 


\subsection{Considerações sobre o capítulo}

As transformações no território da região estudada pela antropização do ambiente vêm aumentando desde meados do século XVIII, especialmente com a migração das ilhas de Açores e Madeira, e sofreram considerável incremento a partir de meados do século XX, com novas levas de migrantes, regionais e nacionais, e com a expansão da atividade turística.

$\mathrm{Na}$ evolução da cidade, a formação do espaço rural litorâneo é um dos momentos transformadores mais marcantes na estrutura física da cidade, pois estabeleceu uma distribuição de assentamentos humanos, um parcelamento fundiário e um sistema de circulação que até hoje influem na morfologia do território, sendo sua característica que, aliada a condição insular, diferencia a cidade de outras conformações espaciais urbanas. O século $X X$ consolida a cidade terciária e passa a atrair contingentes populacionais, que se incrementam com as facilidades de acessibilidade proporcionadas a partir da segunda metade do século.

A partir dos anos 1950, as transformações na estrutura socioeconômica nacional, com reflexos na região, e a expansão da atividade turística levaram à rápida urbanização do território de modo a alterar as características anteriores. A urbanização passa a receber incremento com a chegada de novos migrantes, do meio rural e do meio urbano nacional, atraídos pelas qualidades da vida na cidade e pelas oportunidades de trabalho que a própria expansão dos segmentos imobiliário e turístico promove, demandando mais espaço físico.

A dinâmica imobiliária, com intenso crescimento e importância na economia da cidade terciária, vem se fazendo em paralelo com a expansão da urbanização da cidade, com todas as conseqüências desta opção. $O$ segmento da economia que envolve a construção civil e a atividade imobiliária teve intenso dinamismo, especialmente a partir dos anos 1970, justamente quando se percebe o incremento de uma nova onda de migração populacional, com as camadas de baixa renda se localizando em áreas pouco valorizadas ou, até então, não classificadas como urbanas, e as de maior renda em direção à orla da llha, em parcelamentos legalizados.

Essas alterações na demografia, na estrutura sócio-econômica e cultural afetaram o território e a paisagem pela necessidade de assentamento da população e de equipamentos turísticos, revelando a face especulativa do mercado da terra em uma região ambiental e turisticamente qualificada, mas com limites definidos pela sua condição insular. 


\section{CAPÍTULO IV}

\section{A ILHA TURÍSTICA}

O incremento significativo da atividade turística nas últimas décadas, como demonstrado por diversos indicadores, insere Florianópolis e, de modo mais evidente, a llha de Santa Catarina no rol dos destinos mais procurados do Brasil e do cone sul da América Latina. Paralelamente ao desenvolvimento da atividade, a cidade vem se deparando com problemas em conseqüência do modelo de ordenação territorial adotado com vistas à adequação ao turismo, que privilegia o segmento imobiliário e aposta na urbanização em detrimento de outras maneiras de desenvolvimento territorial da atividade turística.

Procurando explicar tal situação, este capítulo estuda a atividade turística na llha de Santa Catarina, município de Florianópolis, especialmente no que se refere ao impacto e as características da ocupação urbano-turística do território e à transformação da paisagem local. Inicialmente, são revistas noções e conceitos associados ao turismo e à atividade turística de modo a estabelecer as principais definições adotadas no trabalho. A seguir, busca situar a atividade na esfera mundial e nacional, estudando de modo mais profundo o âmbito local, com a análise do contexto de surgimento da atividade e da atuação dos principais agentes envolvidos na legitimação, no fomento, no planejamento da atividade e na produção do espaço turístico da região de Florianópolis.

As intenções, as diretrizes e as ações do trade turístico, bem como sua influência no processo de desenvolvimento da cidade, são estudadas em relação a adequação do território ao processo de desenvolvimento turístico, por meio das políticas públicas de planejamento da atividade e de ordenação do território, importantes elementos na conformação da paisagem da cidade, com atenção às repercussões na economia, no patrimônio histórico e cultural e nas relações sócio-culturais estabelecidas a partir do surgimento da atividade.

Finalizando, é analisada, a atuação dos setores organizados da sociedade envolvidos e/ou atingidos pelos impactos da atividade, destacadamente, entidades ambientalistas, associações de moradores e agências públicas e privadas de defesa do ambiente, apresentando casos exemplares de conflitos sócio-ambientais. 


\subsection{Uma aproximação ao turismo}

A Organização Mundial do Turismo (OMT), organização responsável pelo desenvolvimento do turismo no mundo, coloca essa atividade como a soma de relações e serviços resultantes do deslocamento temporário e voluntário dos visitantes por diferentes motivações. Para conhecer lugares e culturas distintas ou outros motivos, miIhões de pessoas têm se deslocado pelo mundo inteiro e, neste processo, relacionamse com lugares e outros indivíduos, o que lhes possibilita maior vivência cultural e emocional. Independente dos fatores motivacionais, o turismo vem experimentando grande expansão, se disseminando em quase todas as nações, bem como ganhando importância no mundo. Recentemente, essa atividade que envolve agentes públicos e privados e gera quantidade expressiva de empregos e renda para as sociedades vem sendo reconhecida como a terceira força econômica do mundo.

Seu desenvolvimento enquanto segmento produtivo surgiu a partir da revolução industrial que, alterando e modernizando transportes, tecnologias de produção e distribuição de bens e serviços, proporcionou o deslocamento e estadas mais freqüentes e sistemáticas de determinados setores, inicialmente os mais abastados, da sociedade norte-européia. A Segunda Guerra marcou o início de profundas transformações na atividade, com a popularização das viagens proporcionadas pelas novas relações de produção e consumo no mundo ocidentalizado, exigindo a especialização da oferta de produtos e serviços.

As facilidades na obtenção de crédito para organizações turísticas e viajantes, as férias remuneradas para amplos segmentos sociais, ampliação da informação sobre destinos e a formação de cadeias especializadas em transportes, recepção, alimentação e entretenimento de visitantes, proporcionaram surpreendente desenvolvimento da atividade durante a última metade do século XX. Em 2000, quase 700 milhões visitaram outros países e movimentaram quase U\$ 500 bilhões em despesas de transporte, hospedagem, alimentação, lazer, compras e serviços. Destes, 57\%, ou mais de 400 milhões de pessoas, viajaram no continente europeu, e 18,5\%, ou cerca de 130 milhões, viajaram nas Américas (OMT, apud EMBRATUR, 2001).

O turismo, que tem sido apresentado como uma indústria limpa e promissora enquanto atividade econômica sustentável, passou a fazer parte de agendas de governos, e mesmo de agenda supra-governamental, como no caso Organização Mundial 
do Turismo (OMT) ${ }^{1}$. Os benefícios quantitativos da atividade, como a melhoria do saldo da balança comercial dos países destinos, e qualitativos, como a melhoria no padrão de vida das sociedades locais, têm sido alardeados como alternativa de desenvolvimento para diferentes países.

O turismo moderno é fenômeno social nem tanto pela quantidade de pessoas envolvidas, mas por ser atividade coletiva que produz o desenvolvimento de instituições, relações sociais, políticas, econômicas e culturais complexas e porque ".... apresenta constantes e transcendentes transformações" (Arrilaga, 1976, p.18), adaptando-se às mudanças contextuais dessas dimensões da vida associada.

Mais recentemente, transformações de tecnologias e processos empregados nas relações de produção e consumo, decorrentes da incorporação da informação e do conhecimento, vêm possibilitando o crescimento e o desenvolvimento paulatino de um estágio civilizatório onde dimensões e valores se voltam a outras oportunidades de ocupação e interesse.

A flexibilização das barreiras fiscais, alfandegárias e geopolíticas associadas à produção e ao consumo, atualmente afetados pela tecnologia da informação são características da globalização econômica que vem exigindo adequação do planejamento, da estrutura de produção, dos processos gerenciais, das tecnologias e da qualificação dos recursos humanos envolvidos com o turismo.

"O turismo forma parte de um processo de crescente transnacionalização da economia capitalista crescentemente organizada como um sistema homogêneo e global, e tal processo tem importantes implicações nos países receptores de turismo de massa" (Villamil, 1983, p.11).

Ao procurar estabelecer uma compreensão do fenômeno do turismo, alguns autores têm privilegiado diferentes dimensões de abordagem, seja por critérios de tempo, de distância, de motivação ou outras variáveis. Sem a pretensão de revisar a bibliografia sobre o assunto, que Acarenza (1988) estuda de modo sistemático e com rigor, procura-se estabelecer um entendimento que nos permita o desenvolvimento de trabalho. Considerando que, em essência, o turismo é constituído de setores sociais, esquemas mentais e técnicas comuns a outros ramos da atividade humana, não the sendo reservada nenhuma autonomia absoluta, o seu estudo envolve, também, elementos e conceitos interdisciplinares.

\footnotetext{
${ }^{1}$ No mundo anglo-saxão é World Tourism Organization (WTO).
} 
A compreensão do termo turismo é associada ao lazer e à recreação, sendo comum, mesmo entre estudiosos, certa confusão no entendimento do significado de cada uma destas palavras. Buscando superar os efeitos negativos da imprecisão terminológica, Mathieson \& Wall (1982, p.7) associam o lazer ao modo de ordenação (mensuração) do tempo, após a conclusão das atividades de subsistência básica, como trabalhar, dormir, necessidades pessoais, manutenção doméstica, etc., e a recreação, por sua vez, abrange toda a gama de atividades desenvolvidas durante o tempo de lazer. Mesmo que algumas das atividades tidas como necessidades possam ser entendidas como formas de recreação, como, por exemplo, comer ou dormir, esta associação básica entre tempo e atividade nos parece útil.

Na definição, elaborada em 1963 na Conferência das Nações Unidas em Roma, e aprovada em 1968, como forma de uniformizar dados estatísticos internacionais, pela então União Internacional dos Órgãos Oficiais de Turismo (UIOOT, atualmente, Organização Mundial de Turismo), o turista é aquele visitante temporário que passa um mínimo de 24 horas no país visitado, tendo como motivação, tanto o lazer como negócios. Pessoas que ficam por menos de um dia no local visitado são considerados excursionistas (Mathielson \& Wall, 1982, p.11).

O visitante, conforme Castello (1974) englobaria ambas as categorias, e relacionase a qualquer pessoa que vá a um outro país que não o seu, sem que aí desenvolva atividade remunerada. Convém ressaltar que estas definições não prevêem deslocamentos internos aos países, tornando necessária a ampliação do conceito, adequando a sua abrangência a este estudo, já que grande parte dos fluxos turísticos na região estudada é doméstico.

Podemos, então, entender o turismo em função destas colocações relacionadas a espaço, tempo e sociedade, como os movimentos espaciais para desenvolvimento de atividades em tempo de lazer, bem como as facilidades criadas para atender os requerimentos daí decorrentes.

"Turismo é o conjunto de princípios que regulam as viagens de prazer ou de utilidade, tanto no que diz respeito à ação pessoal dos visitantes ou turistas como no que se refere à ação daqueles que se ocupam em recebê-los e facilitam seus deslocamentos" (Mathiot, 1977).

A relação estabelecida entre turistas e locais de visitação tem se baseado principalmente nos atrativos ambientais das regiões, às quais se atribuem quali- 
dades paisagísticas (naturais e/ou culturais) identificadas como turísticas. Mas, como a base espacial está relacionada com as estruturas culturais e sócio-econômicas das regiões turísticas, o lugar visitado, então pode ser considerado, como um ponto de partida para entender a relação que se estabelece entre ele e os seus consumidores.

Por se tratar de uma atividade onde os consumidores se deslocam até o produto, tendo estreita relação com os aspectos físico-locacionais e humanos do território visitado, os diferentes suportes espaciais desta relação - os ambientes naturais ou adaptados pelo homem, criam condições diferenciadas no desenvolvimento desta atividade. É necessária, assim, a ordenação do espaço onde a atividade desenvolverá e a organização dos elementos e serviços que possibilitam a estadia e estadia dos visitantes, pois somente a existência de atrativo turístico não é fato suficiente para que o turismo se desenvolva.

Para o que a atividade se realize com plenitude são requeridos serviços diretamente relacionados com o turismo (agências de viagens, guias, transporte e estabelecimentos de hospedagem turística, como hotéis, chalés, etc.), e serviços e equipamentos de caráter coletivo com uso não exclusivo pela atividade, como a acessibilidade (estradas, aeroportos) e serviços urbanos (ruas, água, esgoto, luz e limpeza pública), e serviços e equipamentos de apoio (assistência médica, bombeiros, telefone, posto de abastecimento, rede gastronômica, farmácias).

Numa dimensão mercadológica, o turismo possibilita oferecer novas mercadorias, sejam bens materiais, comerciais e de serviços, e imateriais, formando um conjunto de produtos compostos (variedade de natureza de seus recursos), e ainda que alguns não possam ser consumidos de maneira clássica, compõem o valor comercializado de mercadorias de consumo clássico, reservados para o tempo livre. Desse modo, o turismo, integrando o setor terciário, influencia, mas também é influenciado, direta e indiretamente, por outros segmentos da economia.

Entendendo-se o turismo como fenômeno social que origina atividade produtiva, envolvendo o turista, os visitados e os agentes (públicos ou privados) que mediam a relação com os locais visitados, e inserido que está na sociedade de consumo, ele obedece "... aos mesmos critérios de produção das demais atividades" (Sartor, 1980, p.13). 
Mas, por outro lado, apesar do enorme desenvolvimento experimentado, seus processos de produção e consumo ainda reproduzem, de forma hegemônica, o pensamento fordista. Esta lógica, amplamente aceita no setor turístico, tende a racionalizar e padronizar os produtos oferecidos e os comportamentos requeridos, proporcionando a economia de escala necessária para a acumulação do capital e as condições necessárias para o estabelecimento do turismo conhecido como de massa ou velho (Poon, A. 1989, p. 91, apud Ruschmann, 2002).

Num ambiente turístico voltado para as massas, de natureza funcional e que organiza os fluxos dos trabalhadores assalariados de diferentes países num processo global, os espaços e estruturas de lazer têm se organizado com base em modelo quantitativo (para atingir economia de escala) e com a visão de curto prazo. Este modelo de turismo e seu processo exigem adequações do ambiente para receber grandes quantidades de pessoas, sendo reduzido a negócio, transformado em mercadoria para visitantes e provocando impactos sócio-espaciais.

Além dos atributos de atração dos destinos turísticos, o grau de adequação a esse processo influi na eleição das regiões que irão receber os investimentos necessários para o pleno desenvolvimento da atividade, dificilmente presentes na esfera econômica local. Os resultados desse processo e desse modelo de turismo, além da homogeneização dos produtos turísticos oferecidos e a padronização dos tempos e modos de consumo, é a extremada competição entre os lugares para a atração dos fluxos como forma de manter a dinâmica necessária à plena realização da atividade.

O turismo de massa é caracterizado pelos vôos charter, pelos pacotes turísticos, por paisagens que propõem a standartização de experiências e de comportamentos e pela demanda de comodidades similares aos locais de origem. Este tipo de turismo, entretanto, é absorvido de modo diferenciado conforme a estrutura de classes, especialmente nos países em desenvolvimento. Na América Latina "se pode afirmar que boa parte da população (...) não tem ascendido à atividade turística devido aos mesmos motivos pelos quais não se tem alcançado a satisfação de outras necessidades" (Sejenovich,1983, p. 44).

O escasso comprometimento do capital mundial, que impulsiona o turismo de massa, com a problemática sócio-ambiental nos destinos turísticos tem sido constante ao longo da expansão da atividade, fazendo com que muitas localidades te- 
nham incremento explosivo da construção de equipamentos de hospedagem e da atividade imobiliária nos lugares turísticos e áreas próximas, geralmente com grande consumo de espaço.

Nos países periféricos, a transformação do território e a degradação dos ambientes, impactos comuns ao processo, tendem a se agravar pelas condições estruturais das sociedades. A ausência de comportamento sustentável, só exigido por populações residentes e planejadores com ampla consciência ambiental, faz que países periféricos à economia mundial encontrem inúmeras dificuldades para alavancar a atividade de modo sócio-ambientalmente equilibrado.

Além disso, a concentração do capital necessário para o processo de expansão da atividade turística nos centros econômicos mundiais e a busca de destinos ou localidades adequados do ponto de vista mercadológico faz com que freqüentes ciclos de expansão e crise se alternem, abalando estruturas locais e gerando descontinuidade de resultados: "Como a produção industrial, a colocação da atividade turística se decide em função de onde se dão as composições que maximizem os lucros da empresa" (Villamil, 1983, p. 17). Logo, numa economia globalizada, os destinos turísticos têm enfrentado fortes e permanentes disputas no mercado dos fluxos mundiais e regionais.

\footnotetext{
"O crescimento da demanda internacional de viagens tem sido acompanhada pela expansão na oferta de destinos e equipamentos turísticos, acirrando a competitividade entre os entes produtivos e lugares destinos, exigindo o estabelecimento e adoção de estratégias que permitam a longevidade e rentabilidade dos investimentos efetuados, originando o conceito e de viagem total' (Naisbitt, 1994)
}

No marco mercantil em que a atividade turística se orienta, em função da demanda manifesta no mercado, condicionando toda sua organização, o turismo não é somente orientado pela lei da oferta e da demanda, mas também por outros mecanismos conjunturais (Januário, 1997).

É um fenômeno dinâmico e sua demanda é motivada por diferentes graus de sensibilidade às mudanças e instabilidades do mercado, e como outras indústrias de economia global, exige constantes adequação, adaptação e flexibilização, além de esforço continuado na promoção e comercialização do produto.

Embora seja visto como alternativa econômica de regiões com alta atratividade, a inconstância da atividade e o desejo de se adequar às exigências do mercado têm como conseqüência a busca do atendimento imediato às demandas, o que, associada 
à falta de uma política integral de desenvolvimento da atividade, exerce enorme pressão nas sociedades e ecossistemas.

Ao consumir paisagens e não trazer os benefícios sugeridos pela propaganda e esperados pelas comunidades residentes, chegando a ameaçar a qualidade de vida e a sobrevivência dos lugares, esse modelo de turismo vem tendo dificuldades de ser entendido por determinados segmentos enquanto opção sustentável de desenvolvimento sócio-econômico para países periféricos à economia mundial.

Novos paradigmas, entretanto, apontam para a inclusão da variável ambiental, numa visão abrangente, onde a sustentabilidade sócio-espacial é chave na estratégia de consolidação, manutenção e sobrevivência (competição) no mercado globalizado. A afirmação do direito ao lazer e da diversidade sócio-cultural tem levado ao surgimento de diferentes modos de fazer turismo, o que alguns estudiosos chamam de novo turismo, cujas características são a flexibilização das atividades, a segmentação de mercados e a busca por autenticidade das experiências. A tomada de consciência nos países emissores e receptores de fluxo têm feito crescer a demanda por destinos turísticos ambientalmente sustentáveis, com diversidade ecológica e social, com oferta de alternativas culturais e recreativas, com autenticidade e possibilidade de interatividade entre visitantes e residentes.

Têm sido valorizados, também, compromissos coletivos entre governantes, empresários e sociedades locais no sentido de implementar políticas e ações de qualificação sócioespacial, como a preservação do patrimônio natural e cultural, adequação da ocupação do solo e manutenção de paisagens, oferta de equipamentos de consumo coletivo e fomento da investibilidade econômica sustentada (Anais do Congresso Europeu de Turismo, 2000, Beja, Portugal; Conferência Mundial de Turismo Sustentado, Ilhas Canárias, Lanzarote, Espanha, 1995, e Livro Verde da Comunidade Européia, Bruxelas, 1995).

$O$ interesse de certos segmentos de demanda tem impulsionado as grandes organizações e corporações, que controlam rumos do processo de expansão turística e promovem os novos destinos, geralmente centralizados nos países desenvolvidos, a atuar em locais diferentes dos destinos tradicionais, originando os denominados enclaves turísticos (Moretto, 2005). Vêm encontrando demanda, então, o turismo cultural, o de aventuras, o ecológico e o de negócios, entre outras modalidades, demonstrando a capacidade de renovação da atividade em busca de novos consumidores. 
Mesmo em pequena escala e sem ameaçar a hegemonia dos destinos turísticos tradicionais, os novos espaços de atratividade tem tido crescimento progressivo e proporcionalmente significativo, podendo estar localizados em regiões periféricas com determinadas especificidades.

A incorporação das dimensões sócio-política, cultural e ambiental, que vêm sendo integradas à pauta econômica na busca de um modelo novo de turismo, com a consideração da qualidade de vida nos locais visitados, requer, entretanto, a avaliação dos impactos não só com a valoração econômica das demais dimensões tendo em vista a sustentabilidade dos investimentos. Para uma verdadeira mudança de paradigma de desenvolvimento turístico na direção da sustentabilidade, é necessário considerar a relação custo-benefício da atividade para além da perspectiva de eficiência de investimentos e de arrecadação.

Desde quando o turismo assumiu dimensões excepcionais, a avaliação dos problemas e benefícios que esta atividade pode trazer tem sido de interesse de diversas áreas do conhecimento. As suas conseqüências complexas e contraditórias, a difícil medição de seus impactos, geralmente cruzados e com diferentes graus de importância, e a descontinuidade espacial e temporal entre causas e efeitos concorrem para a fraca sistematização das análises e avaliações, tornando a atividade de difícil planejamento.

\subsection{O turismo no Brasil}

O turismo no Brasil ocupa posição periférica na economia mundial (mercado externo e interno), participando com somente $0.6 \%$ do mercado global e ocupando a $26^{\text {a }}$ posição no ranking de destinos no mundo² (EMBRATUR, 2001). Apresentou lenta ascensão na última década, devido à adoção da Política Nacional de Turismo (EMBRATUR, 1996-1999) e entrou no século XXI com expectativas otimistas, levando à criação do Ministério do Turismo em 2003.

A partir do ano 2000, com o pico de 5,3 milhões de visitantes estrangeiros, a atividade no Brasil tem tido taxa de crescimento em torno de $15 \%$ enquanto no restante do mundo a atividade cresce cerca de $10 \%$. Naquele ano, a atividade representou $4 \%$ do

\footnotetext{
2 Para estabelecer comparação, a França, maior destino turístico mundial, recebeu em torno de 75 milhões de pessoas, a Espanha 52,5 milhões e o México 18,7 milhões no ano de 2003 (Folha de São Paulo, janeiro de 2005).
} 
PIB ou U\$ 25,8 bilhões, com U\$ 4 bilhões de divisas trazidas pelas visitas estrangeiras, (EMBRATUR, 2001). Para a temporada 2005/06, com base no planejamento estratégico que orienta o Plano Nacional de Turismo, a expectativa era de receber 5,5 milhões de visitantes.

A planta hoteleira nacional tem em torno de 10 mil estabelecimentos ${ }^{3}$ (Associação Brasileira da Indústria Hoteleira - ABIH, apud EMBRATUR, 2001). Ainda que incipiente, quando é comparada aos destinos turísticos internacionais, a geração de receitas derivadas da atividade turística sustentada tem enorme potencial pela extensão e diversidade territorial.

O processo de planejamento e fomento ${ }^{4}$ da atividade turística nacional tem mobilizado entidades privadas e governamentais especialmente a partir dos anos 1950, e se institucionalizou em 1966, com a criação da EMBRATUR - Empresa Brasileira de Turismo, autarquia com objetivos de difundir a imagem do país em mercados externos e incentivar a qualificação e a expansão da oferta de produtos e serviços de natureza turística em território nacional. Com ênfase inicial nas cidades tradicionalmente atrativas de fluxos do sudeste e nordeste brasileiro, transformou-se em Instituto Brasileiro do Turismo (mantendo a sigla EMBRATUR) nos anos 1990 e tem tido importante papel no desenvolvimento da atividade ao longo dos 40 anos de existência, buscando inserir o país no mercado mundial.

Em função do crescimento da atividade turística nas Américas e de indicativos de alterações no perfil dos consumidores, a Organização dos Estados Americanos desenvolveu, nos anos 1980, estudos da potencialidade de diversos países em promover a operação de circuitos turísticos integrados temáticos, culturais e ecológicos. $\mathrm{A}$ EMBRATUR, com apoio financeiro do Banco Interamericano de Desenvolvimento -

\footnotetext{
${ }^{3}$ Desses empreendimentos de hospedagem, somente 90 hotéis e 12.760 u.h. correspondem a cadeias nacionais, e as cadeias internacionais são responsáveis por 115 estabelecimentos e 16.450 u.h. (ABIH, apud EMBRATUR, 2001), o que evidencia a grande atomização do setor, num mercado onde a tendência à associação em cadeias é alternativa de sobrevivência num cenário de globalização de fluxos e operadoras de viagens.

${ }^{4} \mathrm{Em}$ todas as partes do mundo, o fomento da atividade turística exige a participação de organismos governamentais em sinergia com a iniciativa privada e a sociedade, e requer ações múltiplas: adequação/flexibilização da legislação para permitir instalação e oferta de serviços necessários para a sua realização; implementação de equipamentos de consumo coletivos facilitadores à mobilidade espacial e que melhorem a vida em sociedade; o estabelecimento de incentivos fiscais e/ou linhas de crédito subsidiadas e de longo prazo; a promoção institucional de destinos turísticos junto aos mercados consumidores reais e/ou potenciais; o apoio tecnológico e/oi legal à formação, qualificação e aperfeiçoamento de recursos humanos, operacional e gerencial necessários à atividade.
} 
BID, do Banco Nacional de Desenvolvimento Econômico e Social - BNDES e do Banco do Nordeste do Brasil, aproveitou aqueles estudos e deu início a implantação de diversos programas de alocação de infraestrutura e linhas de crédito para investimentos em diversas regiões, com a finalidade de dar apoio à atividade turística.

Ainda nos anos 1980, o Programa de Desenvolvimento de Infraestrutura Turística na região nordeste (PRODETUR/NORDESTE) foi o pioneiro e, apesar de ainda se encontrar em implantação, já realizou investimentos em saneamento básico, expansão e melhoria da malha viária, recuperação de patrimônio histórico, proteção e preservação do meio ambiente, expansão e melhoria de aeroportos, estruturação e atualização de órgãos públicos relacionados ao turismo, e atraiu novos investimentos nacionais e estrangeiros.

A partir da instituição da Política Nacional de Turismo (decreto n' 448 de 14/02/ 1992), visando o desenvolvimento da atividade e de seu equacionamento como fonte de renda para o país, a ser coordenada pelo Instituto Brasileiro do Turismo, nova denominação da EMBRATUR, algumas mudanças na postura da sociedade em relação ao turismo se fizeram notar.

Os desafios atuais diante da globalização exigiram mudanças estruturais e de paradigmas em termos de sustentabilidade e eficiência da atividade: estabelecimento de políticas públicas que facilitem a atração de capitais externos, ampliação da oferta de equipamentos de consumo coletivo junto aos principais centros de interesse turístico, buscando alcançar conceitos estratégicos de habitabilidade, visitabilidade e investibilidade de modo sustentado no território e a competitividade das empresas e destinos ${ }^{5}$.

Dentro desse novo marco, foram estabelecidas diretrizes no sentido de integrar o Brasil no mercado mundial: maior fomento da atividade, desenvolvimento pelas agências governamentais de planejamento estratégico, descentralização e articulação dos órgãos tomadores de decisão, qualificação dos serviços oferecidos, conscientização

\footnotetext{
${ }^{5}$ A OMT (2000) tem estabelecido e incentivado a aplicação de políticas públicas de fomento sustentado à atividade, aos quais diversos planos de desenvolvimento turístico de muitos países buscam se adaptar. A sustentabilidade sócio-ambiental é importante para a atividade, que ao se manter ou melhorar a condição de vida dos residentes (explicando o conceito de habitabilidade), qualifica também o destino turístico (explicando o conceito de visitabilidade) e permite desenvolvimento sustentável (explicando o conceito de investibilidade). Para atingir a sustentabilidade da atividade, alguns países, como a Espanha (PICTE - Plan Integral de Calidad del Turismo Español, 2000), com base no pensamento estratégico e na premissa do acirramento da disputa de fluxos no mercado mundial de viagens, prevêem ações no sentido de incrementar e qualificar a oferta no mercado turístico de produtos e serviços, com maior competitividade e longevidade, a fim de buscar o estabelecimento ou o reforço da condição de destino turístico.
} 
da necessidade de sustentabilidade ampla por parte dos agentes envolvidos, instituição de organismos de defesa do consumidor, desenvolvimento do turismo interno, além da promoção e inserção do país no plano internacional.

Depois do início do PRODETUR/NORDESTE, outras regiões passaram a se integrar ao programa, e a EMBRATUR em colaboração com o Banco Regional de Desenvolvimento do Extremo Sul - BRDE e órgãos oficiais de turismo dos estados do Mato Grosso do Sul, Paraná, Santa Catarina e Rio Grande do Sul estão finalizando Carta Consulta junto ao agente financeiro internacional, o BIRD, como forma de implementar o PRODETUR/SUL. Este documento proposta prevê a implantação de diversas ações e obras em todo o estado de Santa Catarina, com Florianópolis recebendo destaque proporcional a sua importância turística na região (PRODETUR, 2000), com ações articuladas ao Plano de Desenvolvimento Turístico que atualmente orienta a atividade na cidade.

\subsection{O turismo em Florianópolis e na Ilha de Santa Catarina}

A diversidade ambiental e a forte herança territorial decorrente da ocupação colonial fazem de Florianópolis uma localidade cuja relação entre natureza e ocupação urbana resulta num mosaico paisagístico natural e cultural de forte atrativo para diversas modalidades de turismo. Na temporada de 2003/2004, mais de 580 mil turistas vistaram a cidade, sendo quase 500 mil brasileiros e mais de 89 mil estrangeiros, gerando uma receita aproximada de 113 milhões de dólares. Deste total, os turistas nacionais contribuíram com cerca de US\$ 89 milhões e os estrangeiros perto de US\$24 milhões na economia da capital catarinense ${ }^{6}$, correspondendo a aproximadamente $0,6 \%$ dos ingressos de dólares do exterior no país no mesmo período (EMBRATUR, 2004).

Atualmente, Florianópolis vem sendo oferecida para turismo balneário, cultural-histórico, ecológico e de eventos ${ }^{7}$, contando com mais de 100 hotéis de categoria superior ou

\footnotetext{
${ }^{6}$ Estas cifras implicam gastos de US\$ 180/turista nacional e US\$ 268/turista estrangeiro. As médias de permanência, conforme pesquisa Mercadológica da SANTUR de 1997, era de 10,41 dias para os nacionais e 12,96 para os estrangeiros. Em 1981, outra pesquisa realizada pelo IPUF, constatou que a média de permanência dos turistas em geral era de 25,97 dias em residência própria, 19,14 dias em casas alugadas, 11,25 dias em campings, 9,07 dias em casas de amigos ou parentes e somente 6,89 dias em hotéis, confirmando a força da hospedagem extra-hoteleira em Florianópolis.

7. Na pesquisa da PROTUR/INQUIRY realizada em 1997, constante do Plano de Desenvolvimento Turístico de Florianópolis (1999) com dados de 1981 e 1997, o turismo é o maior motivo das vistas à cidade atraindo cerca de $90 \%$ do fluxo e os negócios atraem cerca de $7 \%$. As praias e as belezas naturais foram os atributos mais atrativos no ano de 1997, atraindo cerca de $24 \%$ e $25 \%$ dos visitantes respectivamente, quadro que não sofreu alteração significativa de lá para cá.
} 
turística e mais de 20.000 leitos na rede hoteleira (incluindo pousadas, campings e albergues), segmento que é diretamente responsável por cerca de 10 mil postos de trabalho e, se associado ao segmento de alimentação e lazer, eleva este número para mais de 20 mil.

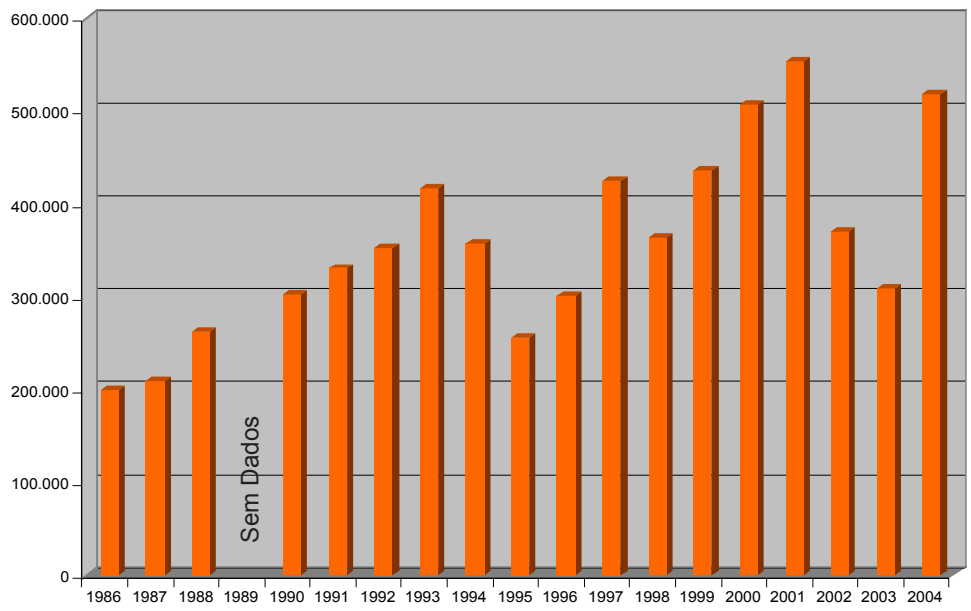

Figura 4.1: Turistas em Florianópolis entre 1986 e 2004. Fonte: PMF, 2005.

Apesar de certo prestígio junto aos países do cone sul da América $^{8}$, o turismo em Florianópolis se caracteriza, por enquanto, por uma demanda nacional, e essencialmente regional. Conforme dados da Santa Catarina Turismo - SANTUR (2001), 84\% dos visitantes são oriundos dos estados da região sul, de São Paulo e do Rio de Janeiro, chegando a quase um milhão de moradores durante as temporadas de veraneio (Convention Visitors Bureau de Florianópolis, 2005) e na virada do milênio esteve entre os três destinos mais procurados no Brasil.

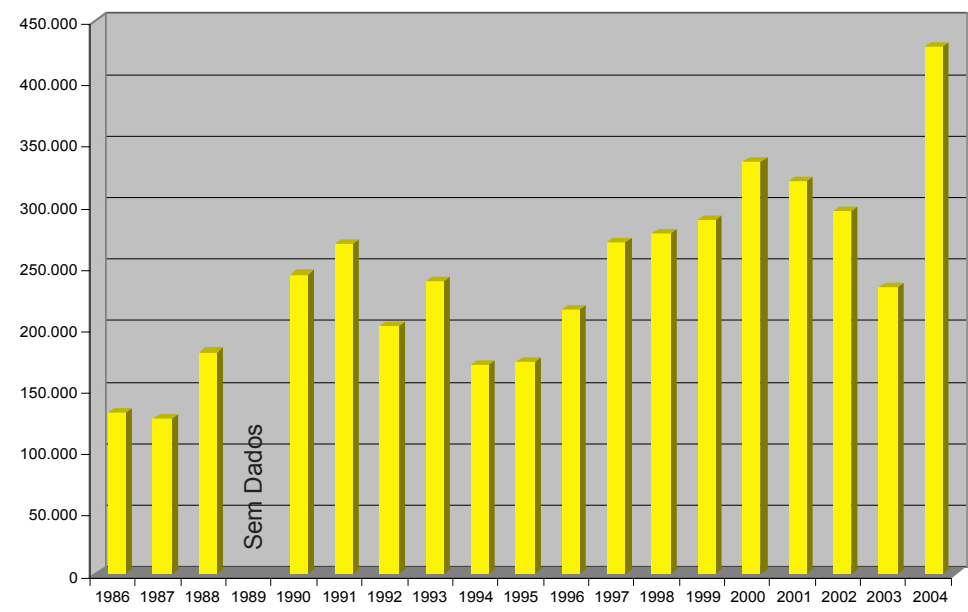

Figura 4.2: Turistas nacionais em Florianópolis entre 1986 e 2004. Fonte: PMF, 2005.

\footnotetext{
${ }^{8}$ Argentina, Uruguai, Paraguai e Chile, nesta ordem, são os emissores de fluxos internacionais mais expressivos.
} 
O planejamento e o fomento do turismo em Santa Catarina e Florianópolis surgiram após os primeiros sinais do aproveitamento da região para a exploração da atividade ainda nos anos 1970. O desenvolvimento da atividade turística em Santa Catarina e em Florianópolis desde o início daquela década fez com que fosse criado nesse período o Departamento Autônomo de Turismo - DEATUR. Órgão autárquico estadual de pouca flexibilidade administrativa, atrelado que estava à legislação federal, teve pouca oportunidade de captação de recursos financeiros a fim de viabilizar empreendimentos e infraestruturas de apoio ao crescente turismo da região.

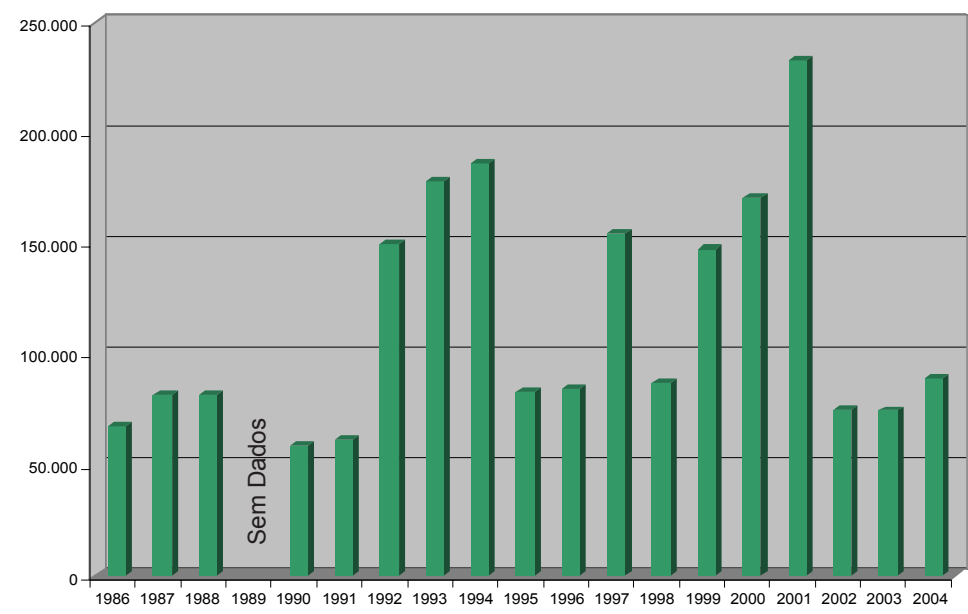

Figura 4.3: Turistas estrangeiros em Florianópolis entre 1986 e 2004. Fonte: PMF, 2005.

A busca de agilidade administrativa e de planejamento fez com que se transformasse em empresa de economia mista que, com recursos disponibilizados pela União através do Fundo Geral de Turismo - FUNGETUR, desde 1971 e do Fundo de Investimentos Setorial do Turismo - FISET, financiou a construção de hotéis e a implantação de infraestruturas viárias.

Na esfera municipal, o órgão gestor da atividade turística também foi criado no início dos anos 1970, a Diretoria Municipal de Turismo - DIRETUR, que na década seguinte, veio a se transformar em SETUR - Secretaria Municipal de Cultura, Turismo e Esporte. As dificuldades enfrentadas pela agência estadual se ampliaram na esfera municipal, pela menor estrutura e receita, com ações sempre a reboque do incremento turístico. 
Já nesta época, o ideário da agência estatal e do empresariado regional apostava na base natural, sem perspectiva de esgotamento dos recursos naturais e, mesmo não tratando diretamente de qual modelo de desenvolvimento turístico seria adotado, especialmente no que se refere à ocupação do território, mas alertando para a necessidade de infraestruturas urbanas, de acessibilidade e de equipamentos de hospedagem, já revelava o predomínio da racionalidade econômica funcional sobre outras dimensões e possibilidades do fenômeno turístico:

"Pode-se dizer que o potencial turístico o Estado de Santa Catarina é enorme, praticamente inesgotável necessitando apenas de uma ação coordenadora estadual e municipal, no sentido de proporcionar condições mínimas de infraestrutura urbana, de aceso e alojamentos para que o turista possa usufruir dos recursos naturais que possui o Estado possibilitando assim uma permanência mais prolongada nos núcleos turísticos. Isto, em termos econômicos, representa, sem dúvida alguma, forte impacto na economia estadual, aumentando e redistribuindo a renda interna, aumentando a oferta de empregos não somente diretamente no setor, mas também indiretamente em outros setores econômicos ligados ao turismo e, finalmente, fazendo do turismo uma alavanca do progresso e do bem-estar social" (DEATUR, 1973, p. 4-5).

Em meados dos anos 1970, é criada a empresa Turismo e Empreendimentos de Santa Catarina S/A - TURESC, que foi das primeiras ações de fomento ao turismo no estado, no rastro do crescimento econômico nacional e regional, sendo contemporânea de inúmeras ações estruturais e infraestruturais em Florianópolis, como o aterro da Baía sul e a construção da segunda ponte de ligação com o continente, a primeira ampliação do aeroporto Hercílio Luz e a eletrificação de diferentes localidades balneárias da llha. Essa melhoria em equipamentos de consumo coletivo qualificou as condições de vida no município e impulsionou o nascente turismo.

Em 1977, a TURESC se fundiu com a CITUR - Rodofeiras de Balneário Camboriú, agência de turismo do município balneário vizinho ${ }^{9}$, dando corpo a Companhia de Turismo e Empreendimentos de Santa Catarina S/A - CITUR, que em 1987 alterou sua denominação para Santa Catarina Turismo - SANTUR. Conforme Moretto (1993 e 2005), estas alterações pouco influenciaram a eficácia administrativa e operacional

\footnotetext{
${ }^{9}$ Balneário Camboriú, ícone do turismo de sol e praia massificado, é o balneário mais visitado do estado e apresenta alta densidade demográfica sazonal e altíssima densidade construtiva, especialmente na primeira franja litorânea. Chega a receber mais de um milhão de visitantes nas temporadas de verão e cumpre expectativas sociais de caráter urbano padronizadas.
} 
com relação ao espaço da llha de Santa Catarina, pois foram mínimos a promoção e o incremento de ações estruturais significativas na região.

A SANTUR orientou sua atuação para a expansão do parque hoteleiro e outras facilidades para a atividade, desempenhando funções na certificação de projetos em adequação às normas e critérios de desempenho físico-espacial na escala do empreendimento da EMBRATUR e na adequação da localização às áreas de interesse turístico, ficando as análises de viabilidade econômica e financeira dos projetos de negócios turísticos a cargo dos agentes financeiros gestores das linhas de crédito ${ }^{10}$.

A década de 1980, com a atividade turística atingindo a classe média brasileira e de países vizinhos, paralelamente ao reconhecimento do potencial turístico de outras regiões do estado ${ }^{11}$, levou agentes públicos e determinados setores da sociedade organizada a assumirem a atividade turística como forte alternativa econômica para Santa Catarina. Na capital, a evolução da atividade e do conhecimento do turismo fez com que as agências governamentais e agentes privados procurassem se adequar a novos contextos, para de cada vez mais transformar a atividade em um dos pilares econômicos do estado e da capital. No âmbito institucional, foi elaborado o Plano de Desenvolvimento Turístico do Aglomerado Urbano de Florianópolis, pelo Instituto de Planejamento Urbano de Florianópolis, demonstrando a pouca atuação da agência municipal, sendo que foi atualizado pelo Plano de Desenvolvimento Turístico de FlorianópolisPDT em 1999, que será analisado mais adiante.

Entre 83 e 86, após o primeiro surto turístico ${ }^{12}$ em Florianópolis, o planejamento turismo da agência estadual investiu com prioridade em ações de formação e aperfeiçoamento do mercado, facilitando a atualização e qualificação da oferta. A deficiência de diagnóstico e a carência de estudos mais aprofundados e de fontes de recursos foram constantes dos planos e ações, pois na capital, foram previstas obras pontuais para locar demandas específicas e aumentar a atratividade, como o Terminal Turístico Social na Barra da Lagoa e um Aquário na Lagoa da Conceição, que nunca foram realizadas.

\footnotetext{
${ }^{10}$ Os agentes mais participativos têm sido: o Banco Regional de Desenvolvimento do Extremo Sul - BRDE, o Banco para o Desenvolvimento do estado de Santa Catarina - BADESC, o Banco do Estado de Santa Catarina - BESC o Banco do Brasil - BB, e a Caixa Econômica Federal - CEF.

${ }^{11}$ Blumenau inicia a Oktoberfest após a enchente de 1983 e, em seguida, surgem outras festas ligadas à migração européia em diversas cidades.

${ }^{12} \mathrm{~A}$ vinda de significativo número de turistas argentinos nos primeiros anos da década teve como fator decisivo a diferença cambial, naquela época favorável à moeda Argentina.
} 
Entre 87 a 91, após a instituição do Plano Diretor dos Balneários em 1985, que, entre outras intenções, buscou ordenar o território para a alocação das atividades turísticas, a promoção do produto Santa Catarina foi o foco das ações (com a expressão Santa e Bela Catarina), além de incentivar a atração de eventos buscando mitigar a sazonalidade (Moretto, 2005).

Os resultados que permitiram manter a cidade com número crescente de visitantes, com pequenas variações para cima ou para baixo em função de alterações da economia nacional e das taxas de câmbio em relação ao dólar, que influi na vinda de turistas dos países vizinhos. O final dos anos 1980 apresentou oscilação no número de visitantes, e foi registrada pequena queda na taxa ocupação, devido à instabilidade que caracteriza o mercado do turismo ${ }^{13}$, com baixo índice de sobrevivência de inúmeros empreendimentos que haviam surgido na forma de pequenos estabelecimentos pouco qualificados.

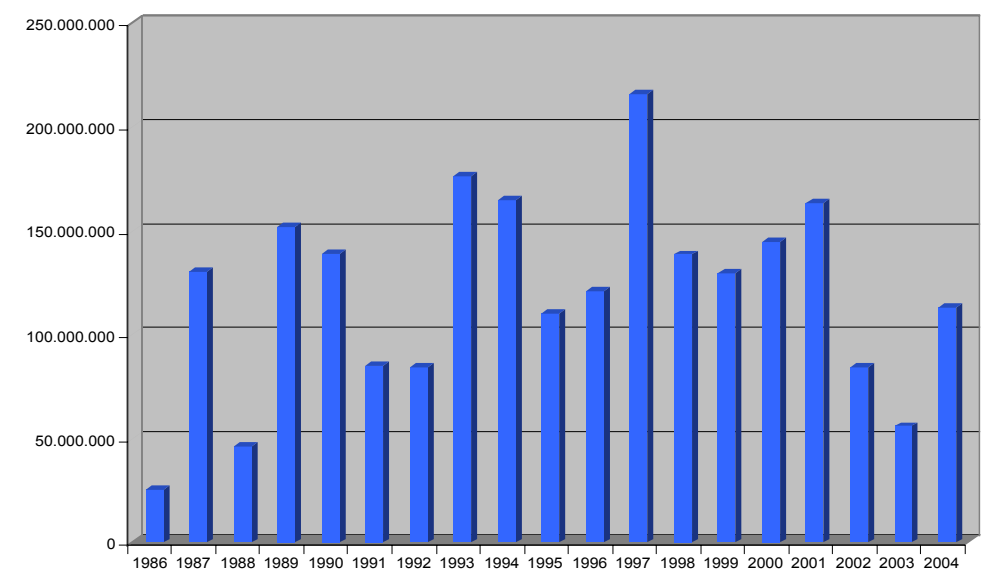

Figura 4.4: Receita estimada (em US\$) com turismo em Florianópolis entre 1986 e 2004. Fonte: PMF, 2005.

A expansão quantitativa da oferta de estabelecimentos turísticos e de loteamentos residenciais nos balneários prenunciou rápida perda de espaços paisagisticamente qualificados no território insular além de anunciar a insustentabilidade sócio-ambiental resultante do modelo de ordenação territorial, o que, a partir da divulgação das qualidades da vida na cidade, resultou na atração cada vez mais intensa de novos moradores, migrantes oriundos das grandes cidades do sul e sudeste do país.

\footnotetext{
${ }^{13}$ As mudanças e conseqüentes diferenças cambiais entre Argentina e Brasil fizeram com que o fluxo de visitantes do país vizinho não se mantivesse constante, frustrando expectativas de muitos empresários do ramo.
} 
Ao final da década e início dos anos 1990, agentes públicos e privados ligados ao turismo iniciam diversas campanhas para lançar a cidade num contexto de demanda turística mais ampla que a nacional. A partir de diversos fóruns e simpósios ${ }^{14}$, diversos setores da sociedade, como instituições públicas e empresas privadas, autônomos, ONG's e sindicatos, passaram a aglutinar conhecimento e esforços para estabelecer políticas e metas do setor do turismo.

Políticas e ações resultaram destes encontros, todas no sentido de adequar a cidade e a região à atividade turística, que juntamente com o segmento da produção de conhecimento e produtos de informática ${ }^{15}$, outra indústria considerada limpa, foram definidas como vetores da nova economia e do desenvolvimento local, na tentativa de oferecer alternativas ao predomínio de setor terciário tradicional.

É nesse período que é promovido, em 1994, pelo Departamento de Arquitetura e Urbanismo da Universidade Federal de Santa Catarina e pelo Instituto de Planejamento Urbano de Florianópolis a $1^{\text {a }}$ Oficina de Desenho Urbano de Florianópolis, evento que reuniu diversos profissionais do planejamento urbano local e nacional com a intenção explícita de pensar o território da cidade. Mesmo apontando diversas proposições de interesse turístico e para a valorização do território e da paisagem produzindo interessante material sobre as possibilidades de seu aproveitamento, a iniciativa não mereceu maior atenção do segmento produtivo, sugerindo o uso da paisagem somente como mote empresarial.

Em 1981 havia sido elaborado, com a coordenação de órgãos públicos, o Plano de Desenvolvimento Turístico do Aglomerado Urbano de Florianópolis, que em 1999 foi atualizado no Plano Turístico de Florianópolis, e no final da década de 1990 foi

\footnotetext{
${ }^{14}$ O Fórum Internacional de Planejamento Turístico da Grande Florianópolis, iniciado em 1994 e, cinco edições mais tarde, transformado em permanente, é o mais importante deles, mas houve outros, como os Seminários de Planejamento e a Imagem das Cidades Turísticas (que teve três edições a partir de1997). Ainda que haja diversidade de participantes e membros, as principais diretrizes tendem, quase sempre, a legitimar as aspirações do setor empresarial.

${ }^{15}$ Essa opção por este segmento do setor industrial teve repercussões a partir da intenção da administração municipal, no início dos anos 1990, de transformação da região metropolitana numa Tecnópolis, com a criação de três pólos, com incubadoras e indústrias ligadas à informação: o parque Alfa, no bairro Saco Grande, próximo do centro, o parque Beta, na planície do Campeche, e o Gama, no município de São José, no continente próximo. A análise desta tentativa, inconclusa, mas já sem o retorno esperado, é levada a cabo no trabalho de Rizzo (2005), onde ele discute e descrê da possibilidade de Florianópolis se integrar plenamente aos fluxos globalizados do capital industrial que financia a alta tecnologia da informação. Atualmente está em processo de aprovação o megaprojeto Sapiens Parque, que incorpora o turismo, a cultura, a saúde e o esporte a um parque tecnológico, localizado na da Bacia do Rio Ratones, mais precisamente, na planície do Rio Papaquara, no norte da Ilha.
} 
apresentado pela Associação Comercial e Industrial de Florianópolis - ACIF um Plano Municipal de Turismo em que a primeira diretriz era "Fazer dos patrimônios naturais, culturais e históricos as principais riquezas do Município de Florianópolis, viabilizando sua utilização para as atividades de forma a se gerar recursos que garantam sua prevenção e continuidade de seu desenvolvimento da qualidade de vida local (sic)" (ACIF, 2000).

Embora a preocupação do segmento turístico e imobiliário com a paisagem da cidade vinculando a atividade à qualidade de vida local e à sustentabilidade, o número crescente de visitantes após o Plano Real (1994), a expansão da receita e o incremento da atividade de construção civil, a intenção de valorizar o patrimônio paisagístico acabou por se submeter ao desenvolvimento da atividade.

O Plano Estratégico de Planejamento Turístico para Florianópolis - PLANET 2000 surge em 1995, com base no pensamento estratégico, do esforço de diversos agentes e segmentos sociais públicos e privados. Ao compreender que o mercado globalizado, com a expansão da cultura do lazer e da atividade turística e com a redistribuição dos papéis das cidades, exige estratégias e espaços turísticos competitivos, o Plano apontava para ações de melhoria de organização institucional, serviços e recursos humanos, proteção ao meio-ambiente, implantação de infra-estrutura e busca de imagem marcante para cidade.

$\mathrm{Na}$ consideração da paisagem e seu aproveitamento pelo turismo destacava a necessidade de “... compatibilizar a atividade econômica turística com a proteção e valorização do patrimônio natural" (PLANET, 1995, p. 7), de “... criar atrativos e facilidades visando ampliar a oferta turística da região...” (idem, p. 15), “... resgatar a cultura açoriana qualificando a atividade turística..." (idem, p. 17) e "... dotar a cidade de uma imagem moderna que realce e caracterize suas potencialidades..." (idem, p. 12) (grifos meu).

A promoção da cidade como destino turístico confluiu na afirmação de uma imagem turística, "associada a uma reestruturação de pautas e valores dos agentes que configuram a oferta" (Veiga apud Januário, 1997, p. 156), nem sempre entendida pela própria população. Na tentativa de criar um ambiente cultural mais orientado para os turistas do que para a população local, e inspirados pelo sucesso da Oktoberfest, a invenção de festas sem tradição e apoio das comunidades foi tentada. 
Sem a expectativa de proporcionar a manutenção e o desenvolvimento de elementos da cultura local, passou-se a utilizar as ligações com o mar e produtos das atividades locais como mote atrativo, confirmando que a "comercialização da imagem de uma cidade ou região como lugar turístico é, em grande parte, a comercialização de sua população, não como realmente é, mas como desejada pela indústria turística" (Veiga apud Januário, 1997, p. 51). O descolamento social e, às vezes espacial, levou a maioria delas, ao fracasso, mesmo quando bem produzidas e montadas ${ }^{16}$.

A valorização do patrimônio natural e paisagístico da cidade, a ordenação equilibrada do território e a valorização da cultura local, sem falar de melhorias na infraestrutura de saneamento, na segurança pública, no sistema viário e na imagem da cidade, foram metas nem sempre alcançadas pelos administradores da época e pelos que se sucederam nos anos seguintes.

Nessa época já eram perceptíveis algumas das conseqüências indesejadas da promoção da qualidade vida na capital e do crescimento do setor imobiliário e, pois além dos migrantes de classe média e alta que se localizavam em assentamentos urbanos legais, grupos sociais de baixa renda também se sentiram atraídos pelas oportunidades de trabalho na indústria da construção civil, bastante ativa na cidade, e na informalidade dos trabalhos na temporada de turismo.

Com o despreparo do Município para enfrentar tal situação e a valorização do preço da terra, essa leva constante de migrantes vem ocupando, de forma urbanoarquitetônica desqualificada, diversos lugares do município, muitos deles em regiões de valor paisagístico de interesse turístico e ecológico, mas outros em áreas de risco para as populações, formando uma nova paisagem indiretamente relacionada com o turismo.

A evidente hegemonia dos interesses empresariais passou a ditar estratégias para reduzir progressivamente o turismo de massa e apostar num turismo de alto

\footnotetext{
${ }^{16}$ As principais festas que entraram e saíram do calendário de eventos da cidade foram: a Florifesta, uma feira de exposição de produtos de pequenas empresas; a Festa Junina, tentando fugir da sazonalidade, a Festa do Mar, também na baixa temporada e promovendo a identidade insular. Outras, tradicionais, ou mais vinculadas às comunidades, permanecem, mas algumas, como a Festa da Tainha, que em determinado momento foi patrocinada por empresários interessados na aprovação comunitária a projeto no local, perderam muito o atrativo, sendo suspensas, também por motivo de corrupção na sua produção. A bem sucedida Festa Nacional da Ostra, talvez pela qualidade e demanda do produto oferecido, é a mais destacada atualmente, e vem projetando a cidade no cenário cultural-gastronômico nacional.
} 
padrão, com grandes projetos de cunho internacional que pudessem oferecer marinas e campos de golfe. Paralelamente a mobilização empresarial, as comunidades atingidas pelos projetos e setores sociais ligados à causa ambientalista também passaram a se organizar, com apoio de instituições acadêmicas e técnicas, resistindo a projetos e empreendimentos, reivindicando participação, atendimento de demandas sociais e atenção ao ambiente.

O Fórum Permanente de Planejamento Turístico, em 1999, num contexto social de percepção de deseconomias do modelo e de busca de consenso de estratégias, enfatizou a necessidade de superar a sazonalidade, de implantar circuitos temáticos integrados (ação de cunho regional), de incorporar o patrimônio cultural e natural na oferta e diversificação, de qualificar e modernizar os equipamentos de consumo coletivo, e de criar atrativos e empreendimentos adequados à modernização da economia municipal.

Em que pese os esforços de várias organizações, entidades e agentes sociais, relacionados, de modo direto e indireto, com a atividade turística em estabelecer metas e ações coordenadas com vistas a um incremento e desenvolvimento ordenado do setor, suas expectativas e atuações têm sido distintas, e por vezes contraditórias. Mesmo com diversos agentes empresariais relacionados com o turismo atuando em mais de uma entidade de representação corporativa e de interesses comuns (Januário, 1997), muitas vezes os resultados e ações são paradoxais e apresentam ambigüidades decorrentes de interesses diversos, e muitas vezes competitivos, internos ao segmento.

Conforme Januário (1997) e Moretto (2005), a análise das propostas e ações do trade turístico denota o caráter conflituoso dos diferentes interesses o que dificulta a convergência em um processo de consolidação da capital catarinense como destino turístico preferencial no mercado nacional, na região do Mercosul e, ainda mais, no mercado internacional.

Pulverização de esforços, interesses de minorias, ausência ou inconstância na busca de metas pactuadas com os demais setores da sociedade envolvidos, além da falta de compromisso com a qualidade de vida e visão de curto prazo de determinados entes empresariais, são alguns dos fatores que dificultam atingir a sustentabilidade da atividade no campo econômico e ambiental. 


\section{O território se adequando ao turismo - os planos diretores e de desenvolvimento da atividade}

Na medida em que a atividade se desenvolveu, agentes públicos e privados interessados em descobrir alternativas econômicas para a cidade passaram a exigir também a adequação do território para a implementação das estratégias de desenvolvimento. Além de ações no sentido de superar os problemas advindos da própria estrutura fundiária e do regime de titulação imobiliária local ${ }^{17}$, passaram a influenciar fortemente as políticas públicas de uso e controle do solo, que desde meados dos anos 1950 já se encontrava em progressivo processo de mercantilização.

Em 1970, a Superintendência de Desenvolvimento da Região Sul (SUDESUL), atendendo ao Plano Catarinense de Desenvolvimento, conjunto de metas e ações gerado durante o período de centralismo tecnocrático do fim dos anos 1960 por políticos e técnicos ligados ao governo do estado, encomenda um estudo a empresa privada para fundamentar o Plano de Regional de Turismo.

O Plano, percebendo o potencial da diversificada base natural da região da llha de Santa Catarina e a estratégica localização no contexto regional e de potenciais pólos emissores de fluxos, ressaltou a necessidade de implantação de infraestruturas de acessibilidade, de abastecimento de serviços urbanos e de equipamentos de hospedagem turística, já colocando o turismo como alternativa econômica (SUDESUL, 1971). Articulado com o Plano Integrado de Desenvolvimento da Área Metropolitana de Florianópolis ${ }^{18}$, este mais voltado para as questões espaciais numa visão territorial ampla, tinha o objetivo de inserir a região no mapa econômico e viário da nação.

Este projeto visava o mercado internacional, sendo elemento estruturante do espaço e potencialmente sustentador da atividade turística imaginada pelos planejadores.

\footnotetext{
${ }^{17} \mathrm{O}$ processo de adaptação fundiária aos novos interesses, como transferência de posse, parcelamento, remembramento e titulação de campos comunais das planícies litorâneas e outras terras devolutas, iniciado já na primeira metade do século XX, acabou por concentrar grandes glebas de terra em mãos de poucos proprietários das elites estaduais. Assim, boa parte dessas planícies ficou em posse de famílias tradicionais da elite catarinense, como Ramos, Bornhausen e Berenhausen. Outra parte, por negócios imobiliários mais recentes, passou para mãos de grupos empresariais, associados aos locais ou não, de outros estados, como Habitasul (do Rio Grande do Sul), que implantou o loteamento Jurerê Internacional, nos anos 1980, e o grupo CR Almeida, do Paraná, que detém, já há alguns anos, boa parte da planície úmida do Pântano do Sul.

${ }^{18}$ Este Plano foi desenvolvido pelo Escritório Catarinense de Planejamento - ESPLAN, coordenado pelo arquiteto catarinense Luís Felipe da Gama Lobo D’Eça, personalidade marcante e autor de muitos projetos para a cidade.
} 
A proposta envolvia a ampliação das linhas de créditos e, principalmente, a tentativa de orientar o planejamento da atividade turística do município de Florianópolis na direção da planície frontal à praia do Campeche, ao sul da Ilha, onde localizou o Setor Oceânico-Turístico. Nesta área, previa percursos turísticos fluviais conectando lagoas e rios da região, além de edificações de grande altura e densidade.

Antecipava, assim, algumas estratégias de desenvolvimento do turismo com base em ações integradas e complementares, mas sua visão futurista e desconectada do contexto ambiental não recebeu apoio da sociedade. A falta de recursos locais e a incapacidade de atração de investimentos externos, conflitos fundiários no local, além do privilégio a outros vetores de desenvolvimento da cidade ${ }^{19}$, inviabilizaram a proposta: "Com caráter essencialmente imobiliário, edificado a partir de referências exógenas, particularmente da Flórida (EUA) ${ }^{20}$, a proposta não foi viabilizada“" (Moretto, 2005, p.157).

Em meados dos anos 70, antes da criação do IPUF, a Prefeitura do Município adotava um macro-zoneamento espacial, ampliando e revisando o Plano Diretor de $1955^{21}$, já incorporando as áreas da orla e do interior do município e reconhecia os valores da paisagem, dividindo o território municipal em: 1) Zonas Não-Urbanizáveis - Áreas de Preservação Permanente (APP), constituída por praias de mar aberto com menos de 2000 m, encostas acima da cota 100 m, terrenos de marinha, ilhas marítimas e sítios arqueológicos; 2) Zonas Urbanizáveis - Zona Urbana (ZU); Zona de Urbanização Prioritária (ZUP); Zona de Expansão Urbana (ZEU) e Zona de Urbanização Diferida (ZUD).

As ZUP compreendiam os vazios urbanos, as áreas adjacentes às zonas urbanizadas, os balneários e outras áreas de interesse turístico e/ou de lazer. As ZUD compreendiam as áreas não incluídas nas ZUP e ZEU, mas que podiam ser urbanizadas mediante alteração do macro-zoneamento ou através de projetos de urbanização vin-

\footnotetext{
${ }^{19} \mathrm{~A}$ expansão prioritária para a região norte da cidade, contrárias às intenções do Plano do escritório de Gama D’Eça, foi muito bem investigada em tese de doutorado de Maria Inês Sugai (2002), em que evidencia a disputa de forças entre as elites locais e regionais, na definição dos vetores de desenvolvimento urbano, atrativo para a reprodução do capital por meio de ações imobiliárias.

${ }^{20} \mathrm{Na}$ esfera nacional, fazia referência ao Plano de Lúcio Costa para a Barra da Tijuca, no Rio de Janeiro.

${ }^{21}$ O primeiro Plano Diretor de Florianópolis é datado de 1955 (Lei Municipal $n^{\circ}$. 246), de autoria do escritório de arquitetura gaúcho liderado por Edvaldo Paiva mais os arquitetos Demétrio Ribeiro e Edgar Graeff. Decorria de políticas de desenvolvimento industrial do pós-guerra na América Latina impulsionadas pela Comissão de Estudos da América Latina - CEPAL. Não foi atento ao potencial turístico da cidade e apostou no vetor industrial, com revigoramento do porto, da parte central e continental da cidade, não dando a devida atenção ao interior da Ilha nem percebendo a tendência de valorização de pólos turísticos em nível nacional exemplificada pela rápida transformação da baixada santista no litoral de São Paulo e de Balneário Camboriú no norte do estado.
} 
culados a um plano econômico de implantação prioritária. Esse zoneamento se revelou insuficiente para controlar a expansão da atividade imobiliária e turística que exigia , por sua vez, adequação mais consistente.

Com a formação do Instituto de Planejamento Urbano de Florianópolis - IPUF, em 1977, órgão de planejamento municipal, com corpo técnico próprio, criado com a meta prioritária de rever o Plano Diretor anterior, renovam-se as discussões sobre o território da Ilha e sobre a necessidade de ordenar o processo de expansão urbano-turístico que já se acontecia no interior e orla da Ilha de Santa Catarina.

Nessa época, o IPUF passou a adotar um novo macro-zoneamento, tentando evitar a urbanização descontínua de áreas rurais e de áreas ecologicamente frágeis que as ZUD propiciavam. Esse macro-zoneamento ampliou as zonas não urbanizáveis, de modo a incorporar a elas a maior parte das ZUD e ZEU, embora buscasse manter um estoque de áreas urbanizáveis suficiente para a expansão urbana dos próximos 10 anos.

Com o apoio de órgãos federais de fomento ao turismo e a partir convênio entre Brasil e Alemanha, por meio do Conselho Nacional de Desenvolvimento Urbana CNDU, do IPUF mais a Secretaria Municipal de Turismo, com apoio da Sociedade Alemã de Cooperação Técnica $(G Z T)^{22}$, é produzido, em 1981, o Plano de Desenvolvimento Turístico do Aglomerado Urbano de Florianópolis, o PDTAUF. Este plano, introduzindo uma série de conceitos que atrelavam definitivamente a atividade sócio-econômica à dimensão físico-ambiental dos municípios envolvidos, visava conciliar o turismo com a expansão urbana que já não podia mais ser desconsiderada.

Reconhecendo o potencial turístico da cidade, o plano propunha “... a preservação do patrimônio natural e histórico da região" e tinha, entre outros objetivos, o de “... ampliar o acesso popular aos bens e serviços básicos e definir estruturas espaciais descentralizadas, que propiciassem um desenvolvimento urbano equilibrado", com classificação do atrativo turístico das regiões insular e continental, caracterização de zonas e centros turísticos e a identificação de "áreas de preservação da paisagem de interesse turístico".

\footnotetext{
${ }^{22} \mathrm{O}$ convênio compreendia intercâmbio em questões de urbanística, de patrimônio e turísticas.
} 
Uma das principais diretrizes do Plano de 1981 estava relacionada com a instituição em nível nacional da figura das zonas de interesse turístico ${ }^{23}$, em que se "... ampliam as áreas de onde tal uso seria permitido com aumento dos volumes máximos construídos em relação aos usos não turísticos" (grifos meus).

Para a programação da oferta turística, o PDTAUF define conceitos de turismo adequados às diferentes zonas turísticas em que a região foi dividida, a partir de critérios de aproveitamento do potencial natural, paisagístico e cultural, medidas de infra-estrutura relativas o setor, recomendações para atividades e eventos bem como para o incremento e aprimoramento da oferta de alojamento, gastronomia e lazer. Destacam-se dois tipos de medidas: a implementação de infra-estrutura pública de interesse turístico e o incentivo para empreendimentos privados. Para tanto prevê a demarcação de zonas turísticas a fim de proporcionar maior eficiência às medidas e ações propostas.

"Uma zona turística para fins de programação pode ser composta por vários distritos turísticos, desde que os mesmos apresentem vocação semelhante para mesmo tipo de turismo e formem uma mesma unidade espacial contínua, ou formada por um único distrito (por exemplo, o Centro de Florianópolis), quando não houver mais de um distrito com vocação semelhante ao mesmo tipo de turismo" (PDTAUF, IPUF, 1981, incluído no PDT, 1999, p. 134).

Foram definidas cinco zonas na llha de Santa Catarina: 1. Florianópolis Centro (turismo de negócios, eventos e congressos); 2. Norte da llha (turismo familiar e de veraneio); 3. Lagoa/Costa Leste (turismo multifuncional); 4. Sul da Ilha (turismo de passeios/veraneios); 5. Centro Oeste (turismo histórico/cultural).

Num segundo momento caracteriza os centros com as funções e respectivas abrangências. Os centros foram criados para fortalecer o desenvolvimento de cada zona, permitir e direcionar o desenvolvimento progressivo do espaço turístico, constituir um complemento do centro principal permitindo economias de espaço e tempo e evitar a extensão desordenada das áreas urbanizadas.

Os centros turísticos foram estabelecidos com abrangência regional (o centro da capital), com abrangência zonal (a Lagoa da Conceição e Canasvieiras), como centros turísticos de apoio (Jurerê, Ingleses), centros turísticos de distrito (Santo Antônio de

\footnotetext{
${ }^{23}$ A promulgação da Lei Federal n. 6.153/77, dispondo sobre a criação de Áreas Especiais e de Locais de Interesse Turístico e sobre o Inventário com Finalidades Turísticas dos Bens de Valor Cultural e Natural, entre outras disposições, assumiu a noção de sustentabilidade espacial como variável do desenvolvimento turístico.
} 
Lisboa, Barra da Lagoa, campeche, Armação) e centro turístico potencial (Ribeirão da Ilha), não enfatizando o potencial de regiões fora da orla.

O desenvolvimento da atividade e as novas orientações da atividade em nível mundial levaram sua revisão no sentido de implementar um planejamento estratégico, sendo o PDTAUF revisado no fim da década de 1990, surgindo o Plano de Desenvolvimento Turístico, que será analisado adiante.

Com base na metodologia de diagnóstico aplicada no PDTAUF, o IPUF, iniciou, na primeira metade dos 1980, um diagnóstico para um futuro plano diretor, cujo principal objetivo seria ordenar as funções urbanas nos balneários e no interior da llha de Santa Catarina, com vistas a adequação à atividade turística, definida pelo PDTAUF.

O Diagnóstico do Plano Diretor dos Balneários e do Interior da Ilha (IPUF, 1984), base para o futuro Plano Diretor fez uma correta leitura da situação territorial e ambiental, reconhecendo a llha como o grande espaço turístico da região, cujas bases são a qualidade da paisagem e da aglomeração urbana de pequeno porte.

Este diagnóstico percebeu que a paisagem da Ilha, na franja costeira e interior, é conformada por especificidades locais e pelas comunidades tradicionais, mas assinalando que "uma tendência progressiva e já bastante consolidada de abandono do modo de vida nativo e de enfraquecimento dos costumes e tradições seculares introduzidas na Ilha nos tempos coloniais" (IPUF, Diagnóstico PDB, 1984). Reconhecia, porém, a existência de condições objetivas para a preservação de alguns núcleos tradicionais em que ainda se mantinham a pesca artesanal, a cultura agrícola de subsistência e práticas culturais, laicas e religiosas, de origem colonial.

Enquadrou a expansão territorial em um "Modelo Teórico de Ocupação do Aglomerado Urbano de Florianópolis", onde a posição polarizadora do centro cívico e funcional é reforçada nas partes insular e continental (onde se localizam as principais estradas de acesso nacional e estadual), destinando as zonas costeiras da llha, para absorver o desenvolvimento turístico.

Este modelo territorial mantinha a estruturação urbana polinucleada da Ilha com os diversos assentamentos da orla assumindo funções complementares ao centro, reservando tratamento diferenciado para as áreas fora da região central e dando base para o plano que, complementando Plano Diretor do Distrito Sede do Município de Florianópolis (Lei Municipal $n^{\circ} .1851$ de 1982), iria orientar a ocupação de toda a llha de Santa Catarina. 
Alguns dos mapas do Diagnóstico apresentavam identificação de áreas homogêneas com certa continuidade, sugerindo visão mais integrada do território insular, mas com a adoção de unidades de planejamento, com a fragmentação das áreas homogêneas e o zoneamento proposto, perdeu toda a capacidade de influir positivamente numa concepção mais globalizante e respeitosa à paisagem, compreendida como um mosaico articulado e interdependente de áreas homogêneas que se diferenciam pelas suas especificidades ecossistêmicas e de ocupação antrópica.

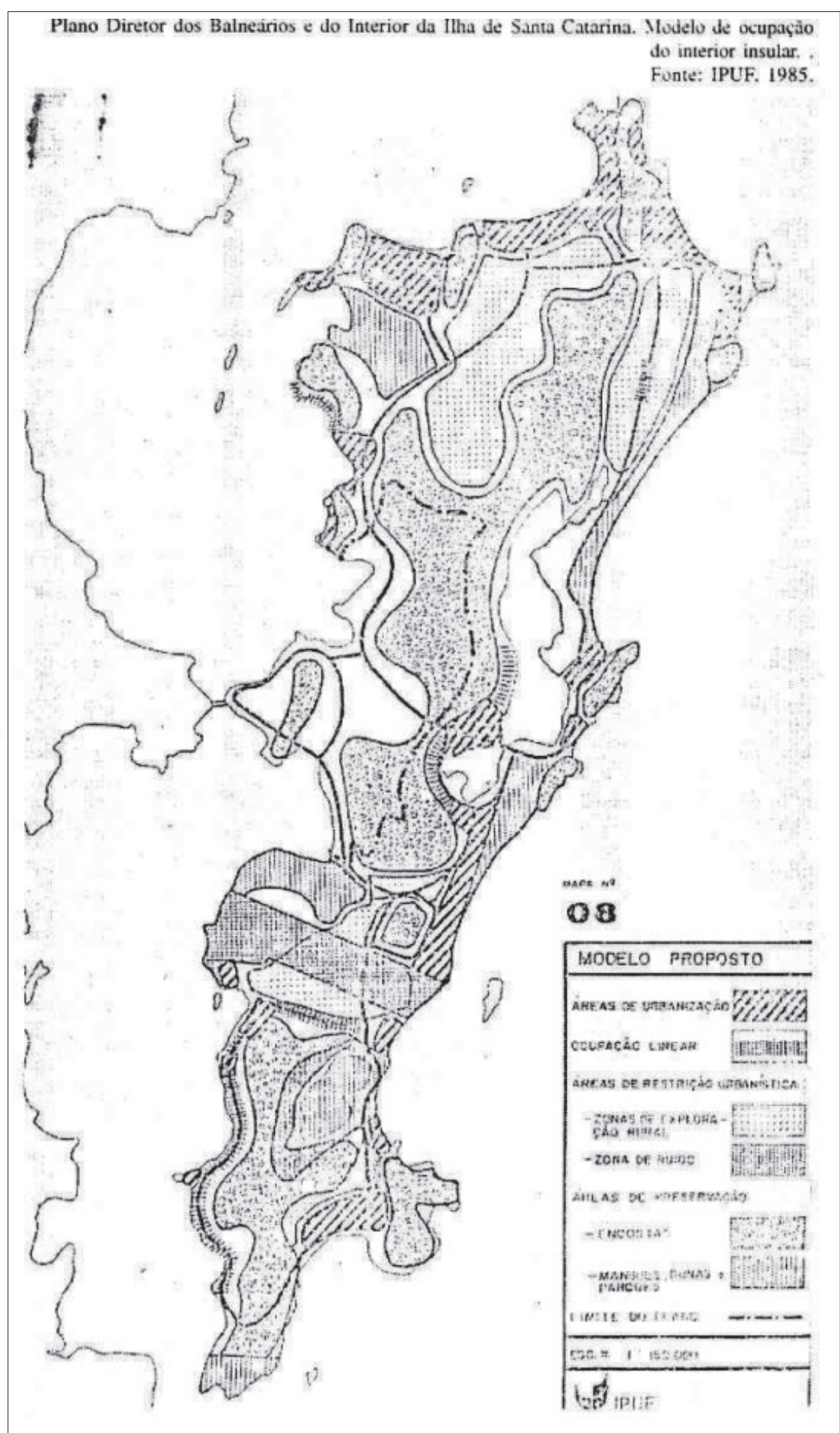

Figura 4.5: Reprodução de mapa analítico do PDB, IPUF, 1985. S/escala. 


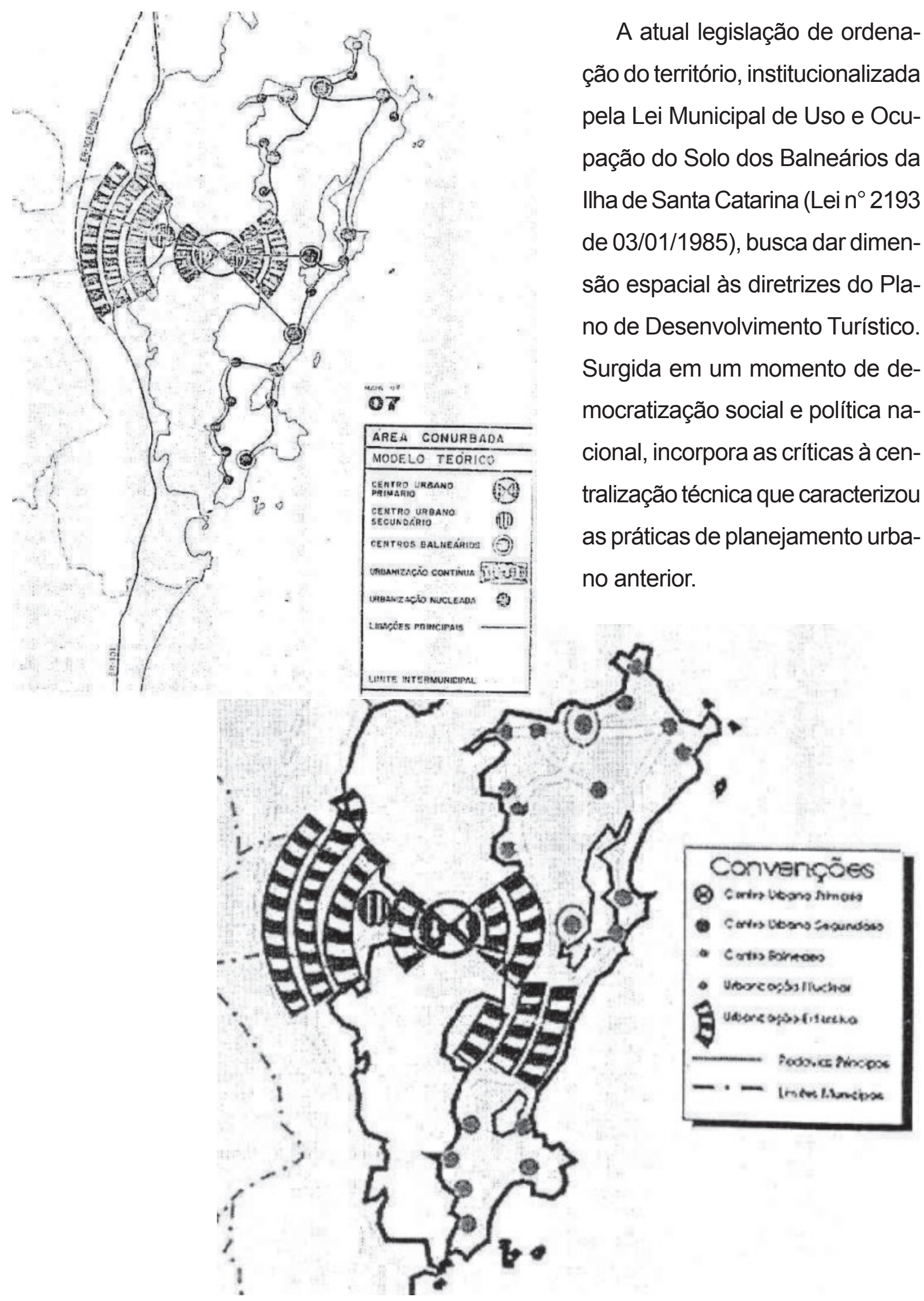

Figura 4.6: $1^{\circ}$ e $2^{\circ}$ Modelos Teórico desenvolvidos pelo IPUF para o PDB-85, onde se destaca a ampliação da área de expansão urbana em direção à planície do Campeche. S/escala. Fonte: IPUF 
Nesse aspecto, instituiu a participação popular, por meio do instrumento das audiências públicas, nas decisões técnicas ${ }^{24}$, prática que, mesmo se antecipando ao atual Estatuto da Cidade (Lei Federal $n^{\circ}$. 10257 de 2001), nem sempre foi ajustada às reais necessidades de certos setores da sociedade e nem impediu que uma postura tecnocrata e centralizadora de determinados setores daquela repartição se fizesse presente em diversas situações.

O Plano Diretor dos Balneários, como é conhecido, abarca o território costeiro e interiorano da llha e busca ordenar áreas que, nesse momento, já se encontravam sob intensa pressão de ocupação, baseado no instrumento do zoneamento, classificando os balneários como áreas especiais de interesse turístico. Concretamente, o Plano utiliza um segundo Modelo Teórico que sucedeu o primeiro apresentado no Diagnóstico e prevê, novamente, a expansão para a região da planície do Campeche (já sugerida no plano dos anos 1970), recolocada em questão pela forte pressão imobiliária na região acentuada pela rápida ocupação clandestina que vinha acontecendo e pela disponibilidade de amplas áreas ainda livres.

A visão integradora, refletida no primeiro modelo de expansão ocupação que ainda previa a manutenção mais contínua das grandes áreas naturais homogêneas e de interesse paisagístico, foi se perdendo no tempo, pressionada por interesses imobiliários e debilitada por questões técnicas que descuidaram do compromisso original.

O PDB, partindo de um macro-zoneamento, define as áreas urbanizáveis e nãourbanizáveis, visando assegurar os limites preliminares de urbanização e preservar os elementos naturais essenciais, prerrogativas para a elaboração do micro-zoneamento e divide a Ilha em UEP's - Unidades Espaciais de Planejamento. Estas Unidades de Planejamento são definidas em função de localização espacial e não acompanham a divisão administrativa que separa os distritos (antigas freguesias dos tempos da colônia) nem seguem nenhuma leitura do território que considere suas áreas homogêneas ou unidades de paisagem, não enfatizando a paisagem nem os bairros..

\footnotetext{
${ }^{24}$ Esta postura não surge somente de uma adaptação de novos paradigmas por parte dos técnicos, mas principalmente da forte pressão dos movimentos populares, decorrentes da ampliação das novas relações entre sociedade e ambiente, expressas nas organizações não governamentais e associações de bairros, conscientizadas dos limites do desenvolvimento. Em termos de Brasil, Florianópolis tem destaque neste tipo de movimento social, com estudos acadêmicos sobre suas origens, formas e possibilidades (Viola, 1990).
} 
No nível do micro-zoneamento, declara áreas de interesse turístico ${ }^{25}$ os distritos da orla da Ilha, seguindo Lei Federal, com exceção do distrito sede e contíguos a este, classificando os solos dos balneários com o zoneamento de uso condicionado aos limites das áreas naturais e à preservação do ambiente cultural e hierarquiza a rede viária que conecta os assentamentos urbanos.

As Áreas Não Urbanizáveis constituem a Zona Rural, com diferentes categorias, em função das características territoriais, definidas no microzoneamento: Áreas de Exploração Rural - AER, Áreas Protegidas - APP e Parques. Com a intenção de conter a expansão da urbanização, as Áreas de Exploração Rural - AER ficaram reservadas para o uso agro-pastoril, mesmo que o diagnóstico afirmasse a pou-

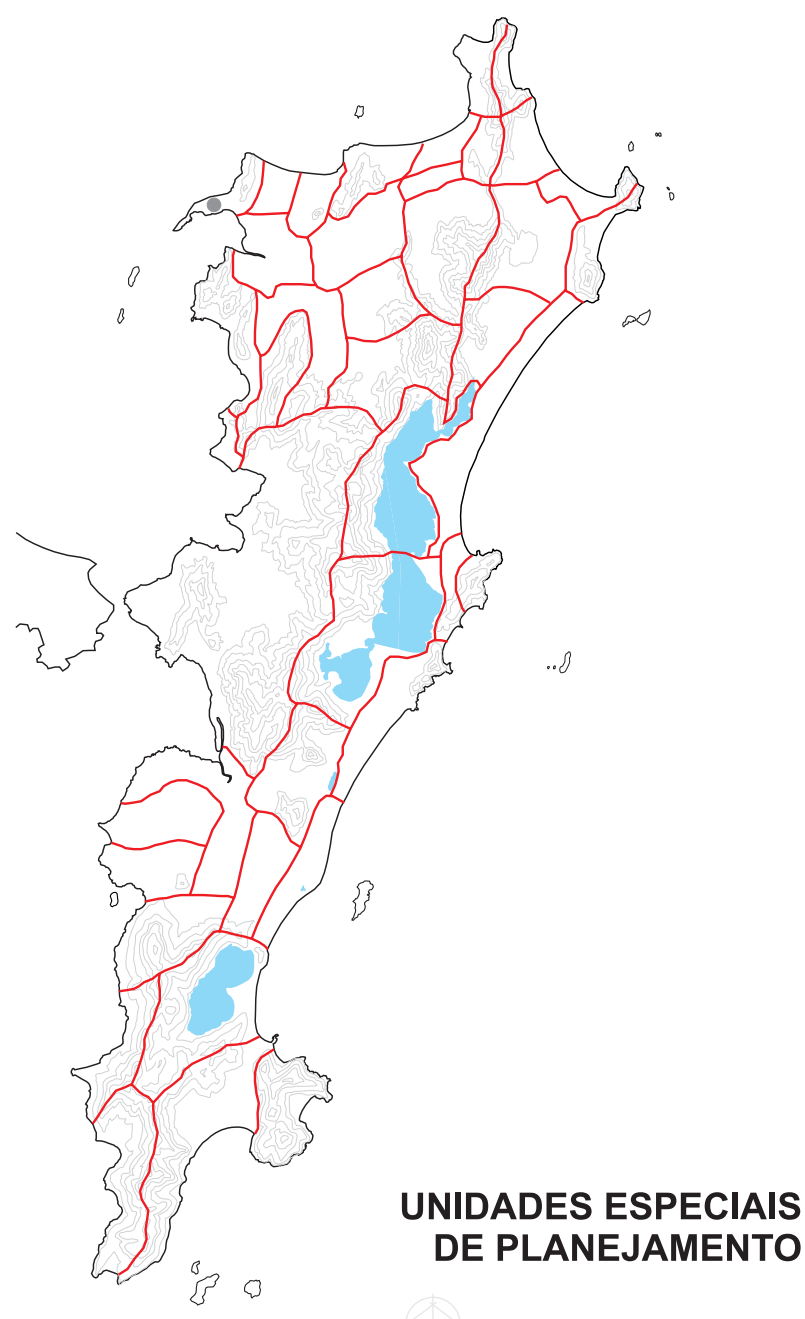

ESCALA GRÁFICA $0 \underbrace{0} \underbrace{2}_{-} 3$

Figura 4.7: Mapa sem escala da divisão das Unidades Espaciais de Planejamento. IPUF, 1985. Montagem a partir de mapa original na escala 1/25000. ca expressividade e possibilidade de desenvolvimento para a atividade, e à época da aprovação do Plano abarcavam grandes extensões de terras (as planícies do Campeche, do Rio Vermelho e do Pântano do Sul, e a região de Ratones, por exemplo) e abrangiam até o ano de 2000, $17 \%$ do território do município.

A classificação do Plano, buscando resguardar as áreas agrícolas ainda não urbanizadas junto aos balneários da urbanização e da ocupação desordenada, que vinham e vem ocorrendo, não foi capaz de obstaculizar a pressão imobiliária sobre tais

\footnotetext{
${ }^{25}$ A Lei Municipal n. 2.193/85, que institui o Plano Diretor dos Balneários e do Interior da Ilha de Santa Catarina, declara lugares na orla como Áreas Especial de Interesse Turístico, tendo como base a mesma concepção de sustentabilidade sócio-ambiental da Lei Federal n 6513/77.
} 
lugares. Ao classificar, de modo afinado com o parcelamento fundiário, como de expansão urbana parcelas de áreas adjacentes àquelas declaradas rurais pela nova legislação, subestimou a capacidade de pressão dos vetores ativos da sociedade sobre a terra e sobre a administração pública.

Essa disponibilidade de áreas para investimento interferiu na dinâmica imobiliária, não só não impedindo que boa parte das terras rurais fosse utilizada pela ocupação clandestina, como possibilitou sua transformação, através do artifício de alterações de zoneamento pontuais, em áreas de expansão urbana pela pressão do segmento imobiliário cada vez mais ávido de território. Na esteira dessa classificação de intenção protecionista, muitas dessas áreas foram compradas por grupos imobiliários a preços de terras rurais, como eram nominadas legalmente, permitindo a monopolização de estoques de solo potencialmente urbanizáveis.

Ao instituir as Áreas de Preservação Permanente ${ }^{26}$, a legislação se revestiu, neste aspecto, de significativa importância paisagística, pois as áreas protegidas passaram a abarcar $42 \%$ do território do município, e na Ilha de Santa Catarina, onde se concentram, e tiveram o mérito de conservar as áreas homogêneas dos morros e maciços, além dos mangues e dunas.

As Áreas de Preservação Permanente (APP) passaram, então, a incluir todas as áreas de preservação definidas pela legislação ambiental vigente na época, incorporando as encostas e praias: áreas de interesse natural e de ecossistemas significativo, aplicadas aos topos de morros e encostas com declividade igual ou superior a $46,6 \%$,

\footnotetext{
${ }^{26}$ Ao estabelecer, de modo ecológico, social e tecnicamente necessário $42 \%$ de áreas do município como de preservação, diminuiu em muito as possibilidades do segmento imobiliário, cuja rentabilidade depende do consumo de espaço, sendo importante vetor de poder na sociedade local, com organização e força política e econômica suficientes para pressionar o poder público. Ainda que a inflexibilidade na normatização da ocupação e o distanciamento de contextos territoriais e paisagísticos específicos permitam discrepâncias, a medida preservou ecossistemas e paisagens de extremado valor, não cabendo discordância. A gestão destas áreas, com demarcação de limites, manejo e fiscalização não tem sido tarefa fácil nem sem conflitos. Há, porém, mesmo entre defensores do controle da urbanização e da conservação do território, quem considere a legislação demasiadamente restritiva e advogam por melhor aproveitamento de determinadas áreas para determinados usos que qualificassem o turismo na Ilha de Santa Catarina, sem inutilizar a paisagem ou serem percebidos com tal. De fato, dois exemplos de ocupação por construções de hospedagem vinculadas a entidades religiosas, no promontório do Morro das Pedras (Alojamento Marista) e no alto do Morro da Lagoa (Convento Champagnat), parecem não serem percebidos pela maioria da população como agressores da paisagem. O primeiro é percebido, por muitos, como elemento que agrega valor à paisagem, em que pese estar em posição privilegiada e destacada. O segundo exemplo, embora tenha atraído manifestação contrária a sua concretização, garantida judicialmente por aprovação anterior aos controles mais rígidos do PDB para áreas acima dos morros, é muito pouco visualizado por residentes e turistas e, hoje, mal é notado na paisagem.
} 
acrescidos dos ecossistemas de dunas, de mangues, terras de marinha, praias, promontórios, tômbolos, restingas, ilhas, faixas paralelas aos mananciais (das nascentes até a captação para abastecimento) as áreas de parques florestais e reservas biológicas, que se tornaram non aedificandi.

A partir de um inventário elaborado com base na legislação ambiental (federal e estadual, em especial as relativas às florestas e águas), cria e/ou consolida parques com grandes dimensões para a Ilha, como o da Lagoa do Peri, municipal, e Rio VermeIho, estadual, e a Reserva Ecológica Extrativista do Pirajubaé, federal, e preserva do uso urbano, pequenas áreas verdes de recreio (áreas junto ao mar ou outros nichos destacáveis) e sítios arqueológicos.

Essas classificações tiveram grande impacto positivo na manutenção de elementos fundamentais da paisagem da llha, colocando a cidade como uma de maior índice de áreas preservadas do Brasil, e são reconhecidas por todos os que estudam a temática.

A Zona Urbana, que identifica as áreas com possibilidade de usos urbanos caracterizando as áreas urbanizáveis, está subdividida em Zona Urbanizada, relativa ao assentamento central e de bairros adjacentes e Zona de Expansão Urbana, coincidente com as zonas de interesse turístico nos balneários e no interior da llha. Na Zona Urbana, o PDB previu, inicialmente, $20 \%$ de Zona Urbanizada e o restante de Zona de Expansão Urbana. A partir do ano 2000, após a atualização do Plano de Desenvolvimento Turístico (detalhado mais adiante) e sob pressão ocupacional em diversas localidades da ilha, o macro-zoneamento incorporou no perímetro urbano as Áreas de Exploração Rural (ERA), que haviam sido criadas para contenção da expansão urbana.

Essa alteração, buscando adequação às diretrizes do Plano de Desenvolvimento Turístico (1999), que por sua vez havia sido influenciado pelas sugestões do PLANET -2000 (1995), visava disponibilizar áreas que não estavam sendo mais utilizadas para agricultura e pecuária, economicamente insignificantes, para a expansão urbana para os próximos 20 anos, satisfazendo necessidades empresariais do ramo imobiliário.

Fazem parte da Zona de Expansão Urbana as Áreas residenciais em diversos níveis, com a intenção de absorver o crescimento da população residente em Florianópolis decorrente de crescimento vegetativo dos moradores nativos e, principalmente, da 
migração. Os padrões urbanísticos exigidos para a legalização dos loteamentos e condomínios associados à valorização da terra têm feito com que, progressivamente, a oferta esteja sendo atendida pela elevação do padrão sócio-econômico dos novos moradores, criando extensas zonas contrastantes, em termos espaciais.

No micro zoneamento da Zona de Expansão Urbana, localizadas nos balneários, as zonas com fins turísticos, onde a atividade é incentivada pelos instrumentos urbanísticos correntes em urbanizações não costeiras, são definidas como Áreas Turísticas Residenciais - ATR, em cinco níveis de índices urbanos; Áreas Turísticas Exclusivas (ATE) (ver tabela), onde o uso turístico ganha de exclusividade e incentivos por meio de maiores taxa de ocupação e limite de altura.

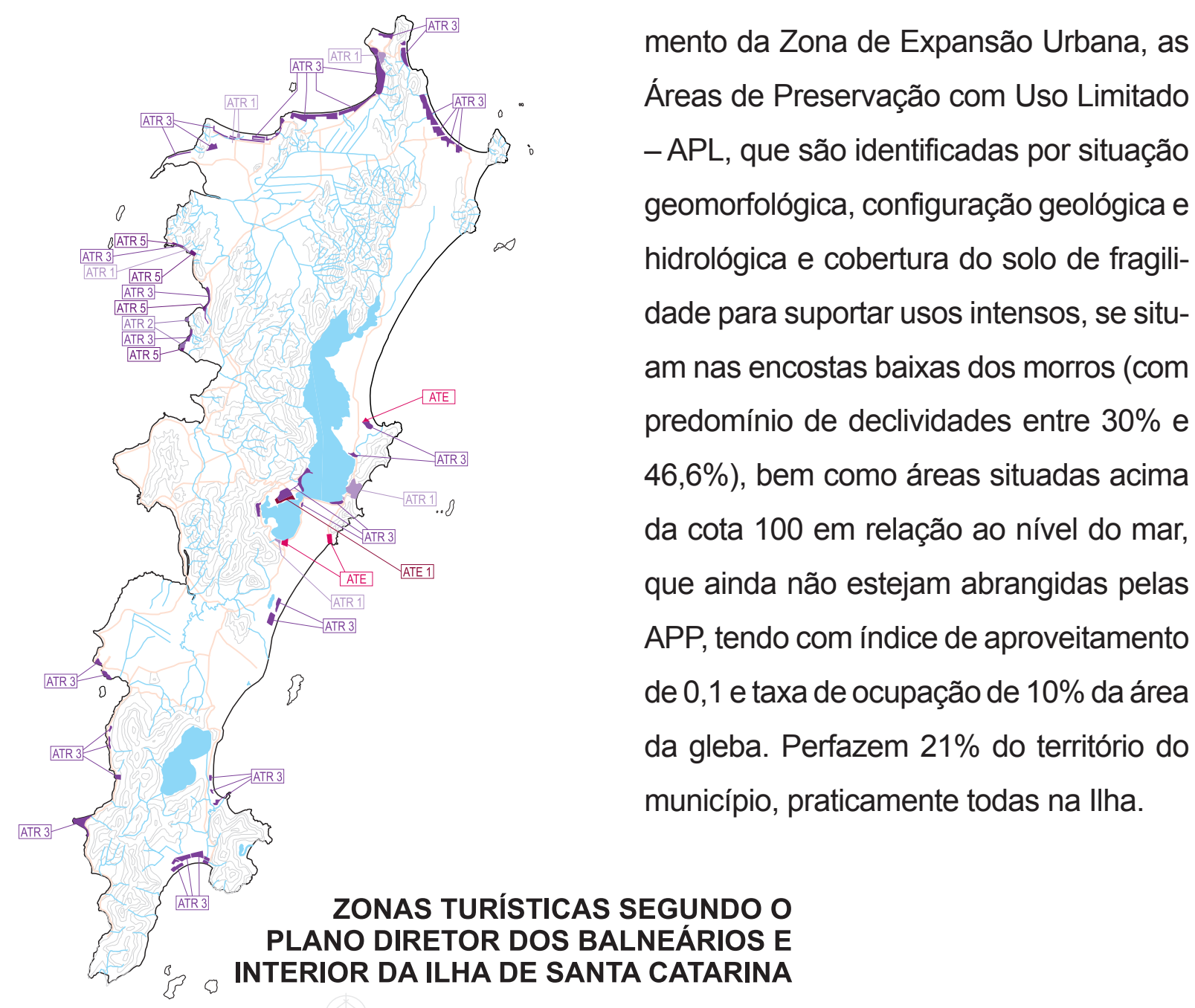

Também constantes do micro-zoneamento da Zona de Expansão Urbana, as Areas de Preservação com Uso Limitado - APL, que são identificadas por situação hrógica e cobertura do solo de fragilise situam nas encostas baixas dos morros (com predomínio de declividades entre $30 \%$ e $46,6 \%$ ), bem como áreas situadas acima da cota 100 em relação ao nível do mar, que ainda não estejam abrangidas pelas APP, tendo com índice de aproveitamento 0,1 e taxa de ocupação de $10 \%$ da área município, praticamente todas na llha.

ESCALA GRÁFICA 01123

Figura 4.8: Zonas turísticas segundo o Plano Diretor dos Balneários. Fonte: IPUF, 1985. 
Recebem, ainda, na Zona de Expansão Urbana, a classificação de Áreas de Preservação Cultural - APC, os pequenos assentamentos do interior e da costa com características tradicionais. Identificados como patrimônios ambientais humanos, são assim classificados para a defesa da ocupação e transformação turística. Estas áreas tem significado paisagístico pela manutenção de conjuntos urbanos e configurações sociais característicos da colonização açoriana, embora a preservação da imagem de algumas delas encontre sérias dificuldades pelo abandono das práticas tradicionais e desfiguração promovida pela adaptação e construção de alojamentos turísticos, pouco controlados.

Quadro 4.1: Áreas funcionais e índices urbanísticos do Plano Diretor dos Balneários-85 para no município de Florianópolis

\begin{tabular}{|c|c|c|c|c|c|c|}
\hline $\begin{array}{c}\text { Área } \\
\text { funcional }\end{array}$ & $\begin{array}{l}\text { Lote } \\
\text { mínimo } \\
\left(\mathrm{m}^{2}\right)\end{array}$ & $\begin{array}{l}\text { Testada } \\
\text { mínima } \\
\text { (m) }\end{array}$ & $\begin{array}{c}\mathrm{N}^{\circ} \text { máximo } \\
\text { pavimentos }\end{array}$ & $\begin{array}{l}\text { Índice de } \\
\text { aproveitamento } \\
\text { máximo }\end{array}$ & $\begin{array}{c}\text { Taxa } \\
\text { ocupação } \\
(\%)\end{array}$ & $\begin{array}{c}\text { Densidade } \\
\text { bruta } \\
\text { máxima * }\end{array}$ \\
\hline $\begin{array}{c}\text { ARP-1/ATR-1 } \\
\text { ARP-2/ATR-2 } \\
\text { ARP-3/ATR-3 }\end{array}$ & $\begin{array}{c}1500 \\
720 \\
450\end{array}$ & $\begin{array}{l}25 \\
20 \\
15\end{array}$ & $\begin{array}{l}2 \\
2 \\
2\end{array}$ & $\begin{array}{l}0,3 \\
0,6 \\
1,0\end{array}$ & $\begin{array}{l}30 \\
40 \\
50\end{array}$ & $\begin{array}{l}20 \\
45 \\
75\end{array}$ \\
\hline ARP $-0^{* *}$ & 250 & 10 & 2 & 1,0 & 50 & 130 \\
\hline $\begin{array}{l}\text { ARE-1 } \\
\text { ARE-2 } \\
\text { ARE-3 } \\
\text { ARE-4 } \\
\text { ARE-5 }\end{array}$ & $\begin{array}{c}5000 \\
3000 \\
1500 \\
720 \\
450\end{array}$ & $\begin{array}{l}40 \\
30 \\
25 \\
20 \\
15\end{array}$ & $\begin{array}{l}2 \\
2 \\
2 \\
2 \\
2\end{array}$ & $\begin{array}{l}0,1 \\
0,2 \\
0,3 \\
0,6 \\
1,0\end{array}$ & $\begin{array}{l}10 \\
20 \\
30 \\
40 \\
50\end{array}$ & $\begin{array}{l}7 \\
10 \\
20 \\
45 \\
75\end{array}$ \\
\hline AMC-1 & 450 & 15 & 2 & 1,2 & 60 & 150 \\
\hline AMR & 450 & 15 & 2 & 1,0 & 50 & 75 \\
\hline $\begin{array}{l}\text { AMS } \\
\text { AS }\end{array}$ & $\begin{array}{c}1500 \\
\text { s/parcel. }\end{array}$ & 25 & $\begin{array}{l}2 \\
2 \\
\end{array}$ & $\begin{array}{l}1,2 \\
1,0 \\
\end{array}$ & $\begin{array}{l}60 \\
60 \\
\end{array}$ & $\begin{array}{l}20 \\
20 \\
\end{array}$ \\
\hline ATE-1 & 450 & 15 & 2 & 1,0 & 50 & 325 \\
\hline AER & $\begin{array}{c}\text { Instrução } \\
\text { especial } \\
\text { INCRA } \\
n^{\circ} 14 / 76 \\
\end{array}$ & 2 & 0,2 & 20 & 15 & \\
\hline APL & s/parcel. & 2 & 0,1 & 10 & 7 & \\
\hline APC & \multicolumn{6}{|c|}{ Prevalecem os limites da área básica até existência de plano setorial } \\
\hline
\end{tabular}

ARP - Área residencial predominante; ATR - área turística residencial; ARE - área residencial exclusiva; AMC Área mista central; AMR - área mista residencial; AMS - área mista de serviços AS - área de serviços; ATE - área turística exclusiva; APL - área de preservação limitada; APP área de preservação permanente; AER - área de exploração rural. Fonte: IPUF, 1985. 
Com evidentes reflexos na conservação da paisagem cultural, essas áreas tradicionais não têm recebido o devido acompanhamento na manutenção de seus valores, pois foram consideradas pouco atraentes para as camadas sociais que o planejamento turístico já vinha tentando atrair, segundo se pode inferir de afirmações em documentos do IPUF no início dos anos $1990^{27}$.

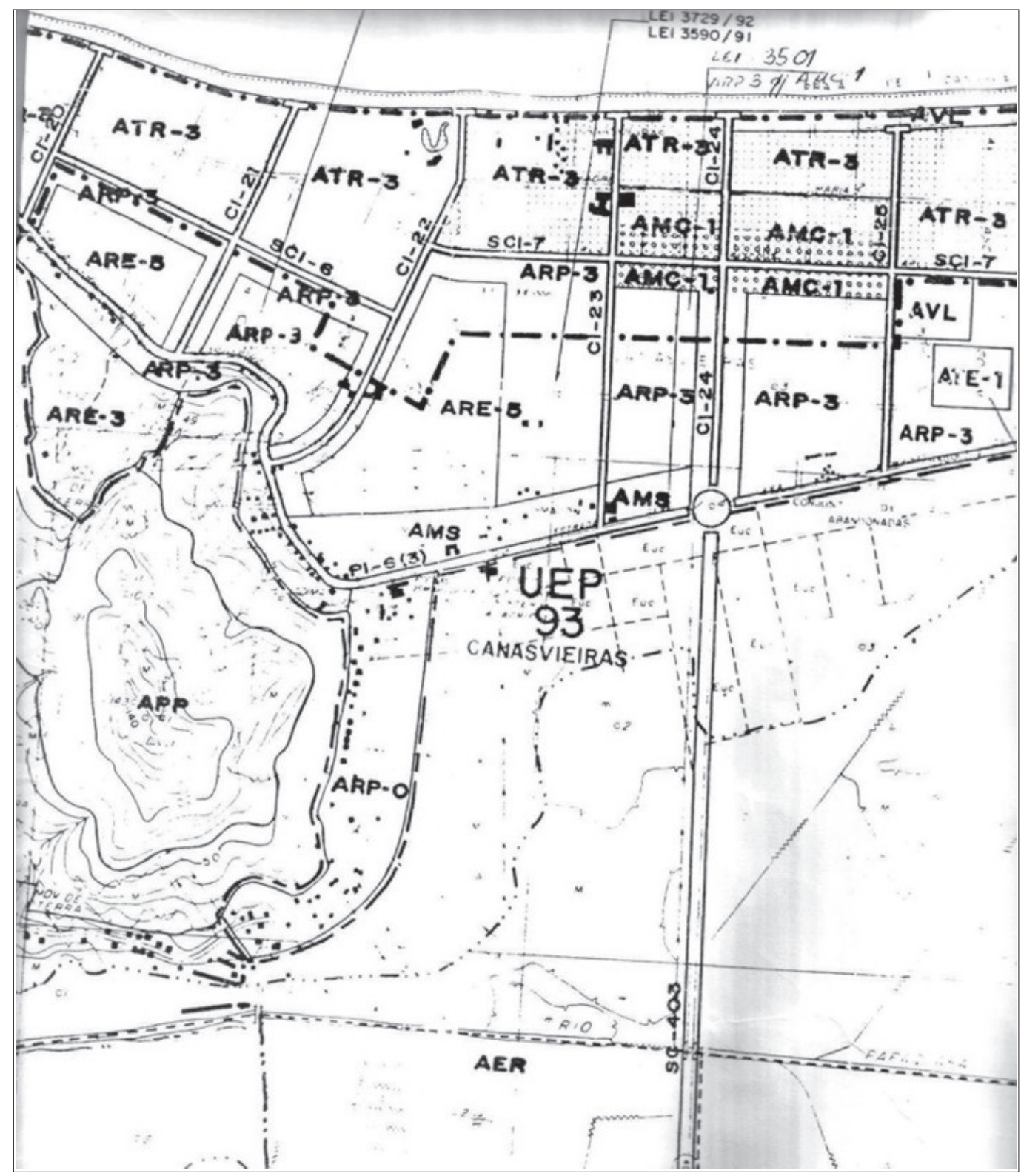

Figura 4.9: Fragmento do Plano Diretor dos Balneários de 1985. Fonte: IPUF, 1985.

\footnotetext{
${ }^{27}$ O Anexo II, que trata dos aspectos sócio-econômicos, do Plano de Reestruturação Urbana da Barra da Lagoa, já considerada APC, assinala que "a ocupação nativa (...) conseguiu manter-se nas áreas onde originalmente se processou, criando uma ambiência urbana pouca atrativa aos padrões de classe média e alta, com uma rede viária inadequada, grande mistura de usos e um padrão arquitetônico não valorizado" (IPUF,1991)
} 
O Plano de Desenvolvimento Turístico de Florianópolis - PDT, elaborado pelo IPUF - Instituto de Planejamento Urbano e Prefeitura Municipal de Florianópolis em 1999 atualizou o Plano de 1981, tratando do planejamento e do controle da atividade turística no município e buscando estreita relação com os dois planos de ordenação territorial da cidade: o Plano Diretor do Distrito Sede e o Plano Diretor dos Balneários. Este Plano de Desenvolvimento Turístico que hoje vigora, procura, a partir da interação entre ações do poder público e da iniciativa privada, implantar ações sugeridas pelo Plano Estratégico de Turismo para Florianópolis - PLANET 2000, resultado do I Fórum Internacional de Turismo da Grande Florianópolis.

Visando a transformação da região em um pólo turístico internacional, o PDT se propõe a avaliar a demanda e oferta turísticas e propor estratégias e medidas que sejam de competência do poder público e que afetem o turismo na região.

Valoriza os recursos ambientais e reconhece a importância da "... atratividade natural...", destacando a necessidade de preservação destes recursos para as gerações futuras. E se propunha a servir como "um instrumento para nortear as diversas ações e assegurar a preservação ecológica e a própria sustentabilidade econômica do local" (PDT, IPUF, 2000, pp.11-12).

$\mathrm{Na}$ base de sua conceituação e da estratégia de marketing destaca a característica insular da cidade associada ao fato de ser um centro urbano de médio porte como diferencial em relação às demais regiões turísticas do cone sul da América, ressaltando a qualidade da oferta quanto a aspectos geográficos, ao porte e a diversidade de atividades econômicas e serviços.

Elabora novo e extenso diagnóstico da atividade, com levantamento atualizado de dados sobre a demanda e a oferta, incorpora o inventário de atrativos turísticos agora com sua valoração por parte dos turistas, se apóia em estratégias de marketing. A análise da demanda turística se centra nos aspectos quantitativos do fluxo turístico e aspectos quantitativos e qualitativos do perfil dos turistas. A análise da oferta turística fez uma análise da capacidade e lotação dos meios de hospedagem, da gastronomia e da infra-estrutura urbana e buscou parâmetros para a viabilização de empreendimentos. Isto permitiu definir distritos, zonas e centros turísticos em função da diversidade de recursos ambientais e paisagísticos da cidade, apontando para uma diversificação de oferta de estabelecimentos turísticos. 
Enfatizou as zonas turísticas na contribuição para o desenvolvimento da atividade com a consolidação dos centros turísticos já detectados no PDTAUF de 1981, "nos quais deverão ser implantados os serviços necessários ao bom atendimento dos turistas.". (idem, p. 138). Os principais objetivos deste Plano no desenvolvimento prioritário de centros turísticos, confirmando o anterior, seriam permitir e direcionar um desenvolvimento do espaço turístico e evitar a extensão desordenada das áreas urbanizadas, como se a ordenação implicasse consumo de espaço.
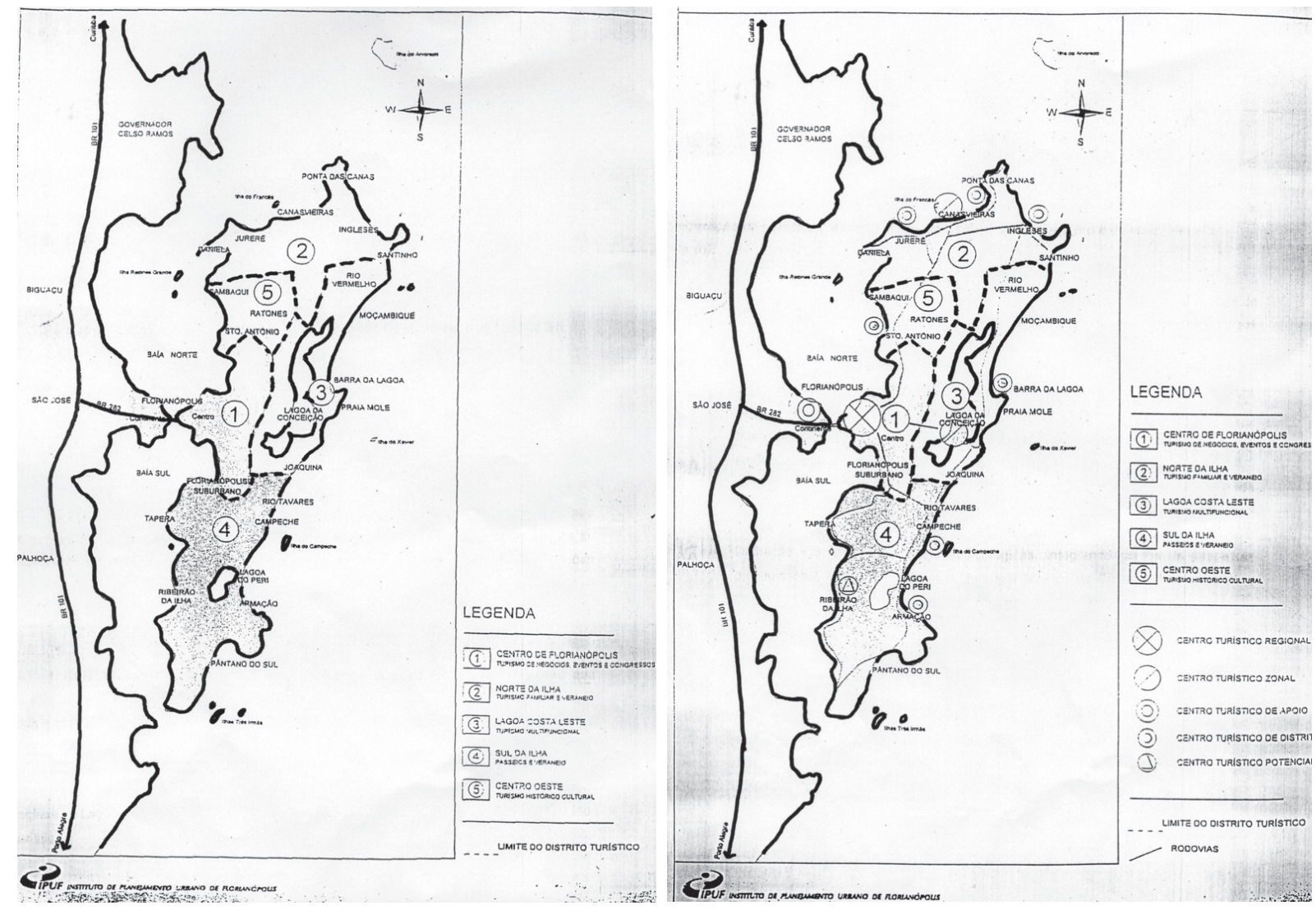

Figura 4.10: Mapas de Caracterização das Zonas e Centros turísticos do PDT - IPUF, 1999. S/escala

Os aspectos de ordenação do território, vinculados ao Plano Diretor do Distrito Sede (Lei Municipal n. ${ }^{\circ}$ 2193/85) e ao Plano Diretor dos Balneários (Lei Municipal n. ${ }^{\circ}$ 001/97), contemplam a infra-estrutura urbana, a paisagem, configurada pela bela região costeira da ilha e adjacências e por construções históricas, e manifestações culturais ainda existentes em alguns locais da llha (idem, pp.97-98). 
De modo geral, para todas as zonas classificadas, a recomendação para o aproveitamento das belezas naturais é no sentido de preservar as características da paisagem por meio da: a) fiscalização e cumprimento rigoroso da legislação no que tange às Unidades de Conservação e faixas consideradas Reservas Ecológicas ao longo dos cursos d'água; b) elaboração de Planos de Urbanização Específica (determinados pelo Plano Diretor dos Balneários e pelo Plano Diretor do Distrito Sede) e também de planos de águas para determinadas regiões lacustres; c) recuperação das coberturas vegetais e tratamento paisagístico dos locais de interesse turístico; d) implementação de estruturas urbanas complementares, como mobiliário e informação visual; e) implantação de trilhas ecológicas.

Neste caso, as ações têm tido pouco resultado no sentido de proteção e valorização do patrimônio paisagístico do município e mais ainda da llha de Santa Catarina, e é sensível a progressiva e rápida perda de qualidade do ambiente, pois o modelo de ordenação do território não considera o mosaico paisagístico de modo integral nem a complementaridade dos sistemas integrantes.

Para a preservação do patrimônio histórico e cultural propõe: a) recuperação de casarios históricos tombados; b) conservação e revitalização de espaços públicos e monumentos arquitetônicos e comemorativos; c) manutenção do caráter ambiental, cultural, tradicional e pitoresco da região; d) identificação dos principais eixos visuais para a preservação dos signos culturais, históricos e naturais da comunidade; e) demarcação dos sítios arqueológicos.

Neste aspecto, a situação é mais favorável no centro da cidade, onde têm se concentrado os estudos e ações de conservação e recuperação do patrimônio. Para a valorização dos conjuntos no centro existe o projeto RENOVAR, mas nos balneários não há nada específico, e quanto aos eixos visuais existe estudo para a área central, mas não para o conjunto da llha, o que seria de interesse para valorizar a paisagem.

Quanto à infra-estrutura de circulação viária de veículos e de pedestres recomenda: a) implantação de ciclovias, passeios de pedestres que possibilitem a integração entre "... pontos de maior importância histórica, turística e de lazer..."; especialmente no centro e beiras de mar; b) ampliação e integração das áreas de circulação de pedestres (no centro, por meio de incentivos a galerias, por exemplo), aumentando a acessibilidade a pontos de interesse; c) implementação de espaços para estocagem de veículos; d) demarcação de áreas de transbordo de passageiros. 
Dentre outras recomendações prevê ainda: a) incremento de instalações de alojamento para diferentes níveis de renda (de hotéis de luxo a campings); b) definição de tipologia arquitetônica apropriada para os meios de hospedagem, bares e restaurantes, de acordo com a região onde estão inseridos; c) incentivo à criação de parques temáticos voltados ao lazer e cultura; d) incentivo ao uso do mar com a construção de trapiches e marinas; e) incentivo a implementação de hospedagem direcionada ao turismo ecológico em regiões com potencial para isto. Neste sentido, a classificação não foi traduzida de modo evidente em sua intenção de diferenciar as zonas, nem nas tipologias nem nos padrões urbanos associados ao turismo, ficando aquém do necessário, pois a homogeneização construtiva é a regra..

Quanto aos incentivos aos investimentos turísticos são especialmente importantes os relativos à legislação urbana já vigente, e estes são basicamente: a) ampliação das áreas com permissão para o uso, o que é definido nos planos de uso do solo. Existem, ainda, outras zonas não destinadas especificamente ao uso turístico em que podem ser construídos hotéis e outras instalações turísticas, além da previsão de aumento destas existentes; b) aumento do volume máximo da construção em relação aos demais usos não turísticos, oferecido de três diferentes maneiras: a) aumento da taxa de ocupação mínima; b) aumento do índice de aproveitamento máximo; c) aumento do número de pavimentos.

Quadro 4.2: Áreas destinadas ao uso turístico (em hectares). Fonte: IPUF/1998

\begin{tabular}{|cc|c} 
Zonas & Distrito sede & Balneários \\
Área Turística Exclusiva & 96 & 1241 \\
\hline Área Turística Residencial & 5 & 59 \\
\hline \multicolumn{2}{c}{ Total de áreas 1401 hectares destinados à atividade }
\end{tabular}

Quadro 4.3: Áreas não destinadas especificamente ao uso turístico (em hectares). Fonte: IPUF/1998.

\begin{tabular}{|c|c|c|}
\hline Zonas & Distrito Sede & Balneários \\
\hline $\begin{array}{l}\text { Área Residencial } \\
\text { Predominante ARP }\end{array}$ & 550 & 1355 \\
\hline $\begin{array}{c}\text { Área Mista Central } \\
\text { AMC } \\
\end{array}$ & 282 & 101 \\
\hline $\begin{array}{c}\text { Área de Preservação com } \\
\text { Uso Limitado } \\
\text { APL }\end{array}$ & 1154 & 9470 \\
\hline
\end{tabular}


Quadro 4.4: Incentivos para a construção de hotéis em Florianópolis. Comparação dos limites para ocupação para hotéis e outros usos. Fonte: IPUF/1998.

\begin{tabular}{|c|c|c|c|c|c|c|c|c|c|}
\hline \multirow[t]{2}{*}{$\begin{array}{l}\text { Função } \\
\text { da Área }\end{array}$} & \multirow[t]{2}{*}{$\begin{array}{l}\text { Lote } \\
\text { mínimo }\end{array}$} & \multicolumn{2}{|c|}{$\begin{array}{l}\text { No. Máximo de } \\
\text { pavimentos }\end{array}$} & \multicolumn{2}{|c|}{$\begin{array}{l}\text { Taxa de } \\
\text { Ocupação } \\
\text { máxima }\end{array}$} & \multicolumn{2}{|c|}{$\begin{array}{c}\text { Índice de } \\
\text { Aproveitamento } \\
\text { máximo }\end{array}$} & \multicolumn{2}{|c|}{$\begin{array}{c}\text { Grau de Incentivo } \\
\text { (volume de } \\
\text { construção) } \\
\text { em termos: }\end{array}$} \\
\hline & & hotel & $\begin{array}{l}\text { outros } \\
\text { usos }\end{array}$ & hotel & $\begin{array}{c}\text { outros } \\
\text { usos }\end{array}$ & hotel & $\begin{array}{l}\text { outros } \\
\text { usos }\end{array}$ & absolutos & relativos \\
\hline $\begin{array}{l}\text { AlH } \\
\text { Balne- } \\
\text { ários }\end{array}$ & 450 & $\begin{array}{l}4+ \\
\text { ático }\end{array}$ & 2 & $50 \%$ & $10-60 \%$ & $\begin{array}{l}2,0+ \\
\text { ático }\end{array}$ & 1,2 & 1,02 & $85 \%$ \\
\hline $\begin{array}{l}\text { AlH } \\
\text { Distrito } \\
\text { Sede }\end{array}$ & 360 & $\begin{array}{l}18+ \\
\text { ático }\end{array}$ & 12 & 37-NP & 37-NP & $\begin{array}{l}5,0+\text { átic } \\
\text { o+base }\end{array}$ & 4,1 & 1,52 & $37 \%$ \\
\hline
\end{tabular}

Onde: AlH - Área de Incentivo à Hotelaria e NP+ número de pavimentos

Das definições básicas da estratégia de desenvolvimento do PDT que levaram às propostas de intervenção para reduzir deficiências e aproveitar o potencial da oferta turística, a mais importante diz respeito ao aproveitamento do potencial natural, paisagístico e cultural. Analisando as recomendações para as zonas turísticas, elas apontam para a preservação das características naturais e paisagísticas de morros e promontórios, além de parques, áreas de dunas, mangues (que já estavam protegidos pelo PDB de 1985) e orla de lagoas.

Apesar do discurso consciente e voluntarioso de qualificação da oferta e ampliação do mercado, as ações dos agentes públicos e privados de fomento, o planejamento e desenvolvimento da atividade apontam para a fraca cooperação, pouca coordenação e quase nenhuma sinergia entre eles, resultando em um processo pouco produtivo, comprometendo a atividade e perdendo competitividade.

O que se tem observado, a partir da adoção modelo de desenvolvimento territorial cristalizado nos planos diretores de ordenação do solo, sugere, entretanto, que as diretrizes turísticas destacadas pelos PDTAUF de 1981 e do PDT de 1999, de valorização das qualidades paisagísticas e ambientais da llha, bem como de seus valores culturais, não têm sido atingidas. Especialmente, se considerarmos a necessidade de tratar a região de modo global e a diversidade de unidades de paisagem, mais precisamente, com a manutenção das planícies que suportaram o uso rural e agora sofrem a ocupação urbana extensiva. 
Se a manutenção das qualidades ambientais e paisagísticas e a diversificação de trato ambiental e de tipos de turismo identificadas nos distritos, zonas e centros turísticos estabelecidos pelo PDT não tiveram reflexos na ordenação do território, as possibilidades de incremento de áreas para construção de estabelecimentos hoteleiros e de áreas para as atividades turísticas têm sido aproveitadas com bastante eficiência pelos segmentos do empresariado imobiliário e hoteleiro, inclusive com pressão pela ampliação das zonas inicialmente destinadas para a atividade.

A partir do final dos anos 80 iniciou-se, como já estava previsto no PDB/85, a definição dos planos setoriais espaciais. À parte a intenção de reconhecer as especificidades das diferentes partes da llha (dentre as quais deveriam ser destacadas variáveis como o território, a paisagem e os processos de crescimento da ocupação humana), proporcionou a adequação das diretrizes gerais do PDB às exigências do processo urbano turístico imobiliário que seguiu e segue desenvolvendo-se, adaptando-as à escala de intervenção menor, chegando a definições detalhadas de tipologias e de sistema de vias.

Foram, ou estão em processo de aprovação pela legislatura do município, diversos planos setoriais em distintas partes da llha, com diferentes dimensões territoriais, mas com padrões e nomenclatura urbanística pouco diferenciada ${ }^{28}$. O acompanhamento desses processos de legitimação do modelo expansionista do turismo e imobiliário permite destacar a dificuldade que a administração pública tem encontrado para sua implementação.

Se o PDB original tinha uma estratégia global de ordenação do espaço, agora, o que se destaca é sua desconsideração ao entendimento integral do território da ilha, o que permite a fragmentação de um território que à parte suas especificidades locais, situado em uma unidade fisiográfica insular com limites bem definidos. Essa fragmentação pode ser explicada pelas intenções de adaptação às realidades distintas, que o PDB homogeneizou, e, também, pelo reconhecimento das pressões comunitárias contra a centralização do PDB.

\footnotetext{
${ }^{28}$ Desde distritos inteiros a trechos deles, independente dos diferentes fatores que poderiam condicionar suas feituras, as áreas classificadas têm resultado em monótonas paisagens suburbanas. Os planos, sem ordem cronológica ou de dimensão, são: Plano de Reurbanização da Barra da Lagoa, Plano de Urbanização Específico do Retiro da Lagoa, Plano de Reurbanização da Praia Mole, Plano Diretor de Desenvolvimento de Entremares para a Planície do Campeche (por envolver vários distritos e Unidades Espaciais de Planejamento, é tratado como um Plano Diretor), Planos de Urbanização da Praia dos Ingleses ao Norte, Plano de Urbanização da Praia do Santinho, Plano de Urbanização do Distrito do Pântano do Sul, Plano de Urbanização do Distrito de Santo Antônio.
} 
Os Planos Específicos, ao revisarem as proposições originais, acabam por invalidar as melhores idéias do Plano Diretor dos Balneários original, como a reclassificação de imensas áreas rurais, criadas para a manutenção de áreas de contenção da urbanização, para áreas urbanizáveis. Contribui para isso a fragmentação em nível de proposição de espaços, que permite a estratégia de fragmentar também o processo de legitimação das propostas pela consulta popular.

Além disso, O PDB, que não contemplava grande unidade de proposição em relação ao ambiente nem especificava contingentes populacionais claros em função da capacidade de suporte, que já dava sinais, técnicos e sociais, de estar atingindo o esgotamento de diversos indicadores, também desconhecida, com a atualização de propostas por meio dos planos específicos, tem ampliado o seu horizonte de ocupação espacial e de densidade demográfica para limites desconhecidos pela administração e pela sociedade, mas certamente muito além do sugerido em 1985.

O mais grave dos planos específicos parece derivar de uma recente postura adotada pela administração. Devido a pouca capacidade funcional (não necessariamente da equipe técnica), a administração passou a aceitar a proposição de planos específicos desenvolvidos por terceiros, geralmente os grupos empresariais que detêm grandes porções de território. Ainda que sejam balizados por diretrizes gerais da administração pública, ao serem analisados e adequados por ela, e colocados em apreciação pública para posterior aprovação, a intensificação do aproveitamento do solo e as inadequações ambientais e paisagísticas são evidentes.

O que seria uma postura louvável, a de pactuar planos com as comunidades, hoje passa a ser um desserviço ao planejamento global de um território que, por ser insular, tem implicações paisagísticas gerais e deve ser compreendido e pensado integralmente. Se as comunidades têm dificuldades de pensar além do local, o órgão de planejamento teria que fazer o esforço de unificar as demandas parciais e incorpora-las em um plano unitário com diretrizes territoriais que considerassem de modo global a paisagem natural e cultural como recurso turístico.

Ainda que todos os Planos, diretor e específicos, reconheçam o destacado patrimônio ambiental e paisagístico da llha de Santa Catarina, nenhuma legislação urbana, plano diretor ou de desenvolvimento, ao nível global, parcial ou setorial, realizados para 
Florianópolis e região do entorno, têm privilegiado, de modo evidente, efetivo e integrado, esta particularidade de seu território. E, mesmo quando o PDB assume uma postura protecionista que se reflete em uma conservação inflexível de determinadas porções do território, fortemente apoiada em uma visão ambiental que privilegia os ecossistemas "em si", desconsiderando sua função social, ainda que induzindo à preservação, ao mesmo tempo que deixa outras, com tanto valor paisagístico e ecológico, para uso extensivo e intenso, não aponta para a sustentação ambiental, econômica e social a nem tão longo prazo.

Mesmo mais recentemente, quando diferentes setores da sociedade perceberam a importância do patrimônio paisagístico para a atividade turística, motor de suas mais importantes transformações sócio-espaciais, o que poderia legitimar pactos duráveis com essa orientação, não se tem conseguido traduzir a preeminência da paisagem enquanto elemento chave na ordenação do território.

Os distintos níveis de avanços na ordenação do território resultam das dificuldades de aceitação por parte da sociedade civil organizada ${ }^{29}$, e estas se devem, principalmente, à inadequação em relação aos assentamentos já existentes e de reclassificação de solos com vistas a aceitar mais ocupações. Além disso, o próprio processo para legitimá-los não vem sendo aceito por muitas comunidades, que perceberam a intencional fragmentação das discussões, exigindo a atual mudança na postura do órgão de planejamento quanto à participação das comunidades, que já se faz notar nas últimas propostas e audiências públicas de discussão de Planos Específicos.

Esses movimentos de resistência, integrantes do processo construção social do espaço em Florianópolis, serão adiante considerados para esclarecer o papel de setores que por razões diversas, por não se sentirem beneficiados ou se posicionarem contra as injustiças sociais e a degradação ambiental evidenciadas pela urbanização, se contrapõem ao processo de desenvolvimento da atividade turística do modo como vem acontecendo.

\footnotetext{
${ }^{29} \mathrm{O}$ autor tem presenciado diversas reuniões e audiências públicas para discussões desses Planos, ora enquanto coordenador de atividade de extensão universitária (via UFSC-Dept ${ }^{\circ}$ Arquitetura e Urbanismo) e prestando assistência técnica às comunidades envolvidas, ora como convidado pelas associações de moradores locais e, em outras vezes, pelo interesse em acompanhar o processo. Além disso, o simples acompanhamento da situação pelos periódicos locais e, às vezes, revistas semanais nacionais, e até numa recente telenovela que utiliza a temática, confirmam o enunciado.
} 


\subsection{Repercussões da urbanização turística}

Como na maioria dos lugares onde o turismo tem atraído fluxos e investimentos econômicos, as relações sócio-econômicas, políticas, culturais e as formas de relacionamento com o território têm sido modificadas no contexto da cidade de Florianópolis e da llha de Santa Catarina.

As políticas públicas têm sido extremamente influenciadas pelas diretrizes de desenvolvimento turístico, afetando todo o território, e os financiamentos e as obras públicas tendem a atender demandas dos setores organizados e relacionados ao turismo. A adequação da cidade às demandas do trade turístico, repercutindo no sistema econômico, especialmente no comércio e nos serviços, no sistema administrativo do estado e do município e de serviços públicos, tem feito com que determinados setores da estrutura social venham a se inserir na esteira do desenvolvimento do turismo e outros nem tanto, embora os custos sejam distribuídos.

Os recursos do patrimônio cultural, material e imaterial, também têm sido aproveitados na atração do turismo, e os custos sociais desse contato são revelados pelas transformações nos hábitos e costumes dos residentes, além da perda de edificações de valor histórico e afetivo nos núcleos humanos mais tradicionais da llha.

A falta de diretrizes territoriais gerais com vista à manutenção do patrimônio paisagístico, pactuadas e fiscalizadas adequadamente, tem resultado em poucos casos de atuação emergencial, pontual e de caráter retificador daquelas ações imobiliárias em desacordo com a legislação urbanística.

A perda e a desqualificação do espaço físico-territorial e de ecossistemas para a nova atividade vêm sendo estudadas pelas áreas da geografia, geologia, biologia, urbanismo e arquitetura ${ }^{30}$. Os limites ambientais, além dos naturais e ecossistêmicos, incluem os sociais que são identificáveis através de estudos, de ordem analítica e perceptiva, envolvendo distintos segmentos sociais. Estes estudos apontam para o fato de que os impactos mais fortes vêm se impondo pela urbanização e expansão física da cidade, que vem se adequando ao modelo de desenvolvimento turístico, e pela apropriação restrita dos benefícios dessa atividade. A utilização exploratória da

\footnotetext{
${ }^{30}$ No âmbito urbano-arquitetônico, destaco os trabalhos de Ferreira, 1992, Santiago, 1992, Oliveira, 1992 e 1999 e Reis, 1993 e 2002, que referenciaram muitas das análises deste trabalho.
} 
base natural vem sendo resultado evidente do desenvolvimento que a atividade atingiu nas últimas décadas.

Neste sentido, investigações acadêmicas de caráter econômico, antropológico, sociológico e de outras áreas afins ${ }^{31}$ têm revelado as contradições e dificuldades da atividade em contribuir de fato na qualificação da vida da cidade e as fortes reações contra a progressiva perda do espaço social, econômico, profissional, cultural e simbólico por parte das comunidades tradicionais da cidade. As reações à migração, que é associada à urbanização, e aos turistas, que parecem se aproveitar das qualidades da paisagem e das praias sem deixar o devido retorno material ao conjunto dos moradores, têm levado a estudos onde se busca demonstrar que a opção pela urbanizaçãoturística não tem contribuído, em aspectos econômicos e sócio-culturais, positiva e equilibradamente para cidade.

A descontrolada apropriação privada, por parte do capital turístico-imobiliário, do potencial paisagístico da cidade e de benesses socialmente produzidas vem transformando a terra, e a possibilidade de nela construir, em lucrativo negócio, acentuando a segregação, a favelização e a desigual distribuição de serviços urbanos pelo território da Ilha de Santa Catarina. A maior participação do Estado, no caso o poder municipal, na justa luta contra a desigualdade sócio-espacial se faz extremamente necessária e urgente, pois "Enquanto a produção do espaço é social, o processo de apropriação da valorização do solo, regido somente pelas leis de mercado, é privado" (Pimenta, 2005, p. 48), e sabe-se que nessa lógica, só alguns se beneficiam.

O ambiente urbano, as características sócio-culturais, especialmente as tradicionais vêm sendo transformados pela atividade urbano-turística e merecem análise em aspectos relacionados com a economia, a sociologia e com o patrimônio cultural.

\section{Implicações econômicas}

Os efeitos econômicos positivos sobre a balança comercial da cidade de Florianópolis, ainda não inserida definitivamente no mercado internacional, têm favorecido a abertura de oportunidades de emprego na economia formal e trabalho na

\footnotetext{
${ }^{31}$ Lins, Ouriques, Fantin, Scmail Lago, Rial, Januário e Schmeil entre outros, tem aprofundado questões relacionando o turismo com as dimensões sócio-econômicas e culturais.
} 
economia informal, além de estimular setores da construção civil ${ }^{32}$, da atividade imobiliária, dos serviços de manutenção e da indústria alimentícia, envolvendo outras regiões do estado.

Embora outras atividades econômicas tenham relevância, a atividade turística vem assumindo predominância na economia da cidade já há algumas décadas, fazendo com que as demais passem a ter no turismo o referencial de ajuste e condicionamentos relativos à sua área de atuação (Januário, p. 53)

A inserção abrupta da região, até então ainda com setores pré-industriais, numa economia mercantilista e dinâmica, proposta pelo modelo de desenvolvimento adotado, atinge diferentemente os setores sociais da cidade, estando eles associados aos grupos hegemônicos da economia local ou aos grupos tradicionais.

Os benefícios econômicos, como geração de empregos e retorno de investimentos privados, têm sido apropriados de maneira desigual, concentrando-se em grupos sociais já detentores, pela atividade comercial, da hegemonia socioeconômica da cidade: "Os benefícios econômicos, como geração de empregos e retorno de investimentos privados, têm sido apropriados de maneira desigual e combinada” (Moretto, 1993, p. 6).

Segmentos nem tão diretamente ligados ao turismo têm exercido forte influência nas decisões e diretrizes de desenvolvimento da atividade e da adequação do território, viabilizando a expansão da indústria da construção civil da atividade imobiliária ${ }^{34}$.

\footnotetext{
${ }^{32}$ Um dos segmentos que mais se beneficia dessa situação, os serviços de execução de obras de construção civil representaram no fim da década de 1990, o terceiro segmento na arrecadação de ISS no município de Florianópolis, com cerca de 9\% da arrecadação (Secretaria Estadual da Fazenda do Estado de Santa Catarina, 1999), mantendo-se nesse patamar no início do século XXI.

${ }^{33}$ Arrecadação de ICMS e ISS por atividade no município de Florianópolis
}

\begin{tabular}{|c|c|c|c|c|}
\hline Atividades & $\begin{array}{c}\text { No. } \\
\text { Contribuintes }\end{array}$ & $\%$ & $\%$ arrecadação ICMS & \% arrecadação ISS \\
\hline Indústria & 179 & 6,58 & 6,43 & 0,39 \\
\hline Comércio & 1.681 & 61,81 & 27,86 & 14,72 \\
\hline Serviços & 600 & 22,06 & 65,66 & 84,74 \\
\hline Outros & 259 & 9,52 & 0,05 & 0,35 \\
\hline Total & 2.719 & 100 & & 100 \\
\hline
\end{tabular}

Fonte: Secretaria Estadual da Fazenda de Santa Catarina, 1999.

${ }^{34} \mathrm{O}$ setor de serviços, especialmente os relacionados direta e indiretamente com o turismo, como compra, venda, loteamento, incorporação, administração, arrendamento, e locação de bens móveis e imóveis, experimentaram um crescimento expressivo na segunda metade do século XX, envolvendo $20 \%$ da população economicamente ativa do estado (FIBGE, 2000), e em Florianópolis envolve porcentagem semelhante. 
Este segmento, com lógica da máxima obtenção de lucros dos investimentos, por meio da "... expansão preferencial de parâmetros exponenciais - Produto Interno Bruto; Saldo na Balança de Pagamentos; Incremento do Fluxo Turístico e da taxa de ocupação da capacidade empresarial instalada" sob o argumento da necessidade de crescimento da economia, desconsiderou “.... totalmente a dimensão de limite quantitativo e a perspectiva da liquidação insustentável do capital natural em função da inexistência absoluta de equipamentos de saneamento e da não observância de limites no processo de uso do adensamento do solo" (idem, 1993, p. 2 ) $^{35}$.

Já os efeitos do turismo como fator de elevação do nível de vida da população local tradicional e do interior da llha, atualmente manifestos na possibilidade de venda e locação de lotes e do pequeno comércio e de serviços de apoio ao turismo, têm sido questionados, na medida em que a maior parte dos benefícios diretamente relacionados com a atividade é apropriada por uma maioria pessoas e entidades empresariais não localizadas da região ${ }^{36}$, restando aos moradores tradicionais atividades marginais ao processo.

A reduzida e temporária mobilização de mão-de-obra, além de atividades mal remuneradas ou a venda e a locações de imóveis pelos residentes locais, é contrastada com a concentração de lucros em poucas empresas, sendo que os custos pela da implantação dos deficientes serviços urbanos, infraestrutura, e equipamentos de uso coletivo, que além de facilitarem a vida dos residentes favorece a ocupação urbano-turística, têm sido socializados: "Os 'empreendedores imobiliários' foram comercializando terras sem a implantação de infraestruturas básica compatível. Na lógica desenvolvimentista, o lucro é internalizado e o prejuízo é externalizado" (idem, 1993, p. 14).

Mesmo que alguns membros das comunidades tradicionais se beneficiem do processo, a difícil aceitação do turismo, que é associado com perdas de espaço físico e social, é manifestada corriqueiramente. Com a venda de áreas nas encostas, nas pla-

\footnotetext{
${ }^{35} \mathrm{Um}$ dos resultados mais exemplares desta concepção desenvolvimentista em que se associa turismo e construção civil é Balneário Camboriú, ícone do turismo de massa urbano do estado, onde a cidade, embora convivendo com problemas comuns das cidades não turísticas tem a gestão totalmente voltada para a atividade (Bueno, 2004).

${ }^{36}$ Esta característica sócio-econômica do turismo em Florianópolis tem base na origem dos capitais investidos na região, e da mão de obra utilizada nesta atividade, grande parte de origem não local. Os estudos de Lins (1991) e Ouriques (1998) tratam esta questão de modo consistente.
} 
nícies e na orla, e a conseqüente perda dos espaços de produção (pesca e agricultura), os moradores tradicionais perderam seu espaço social. Os mais jovens, culturalmente afetados e profissionalmente despreparados, buscam alternativas no trabalho assalariado ou autônomo em residências de novos moradores, numa condição de "marginalização" (Lago, 1983).

A venda de imóveis promove ainda o deslocamento espacial de muitos moradores tradicionais que passam a ocupar áreas de menor valor, muitas vezes em regiões de loteamentos clandestinos e em áreas de risco ou protegidas por lei, incrementando a demanda de solo para uso habitacional. Com toda essa problemática, fica claro que a atividade turística não tem irradiado suas benesses pelos diferentes segmentos da sociedade local de modo equilibrado, dificultando a sua aceitação como uma alternativa consistente para alavancar o desenvolvimento da cidade.

As proposições e ações decorrentes do ideário empresarial têm se apoiado não só na possibilidade de usufruto das paisagens, enquanto principal produto consumido na atividade turística, mas também a subseqüente mercantilização do território, resultando numa intensa exploração imobiliária nem sempre diretamente voltada para o turismo. A expansão do turismo tem feito que tudo passe a girar em função do lucro, com o solo e a paisagem sendo comercializados, confirmando a observação de que "em alguns casos, os preços de aluguel, terrenos, impostos, mercadorias e outros serviços se tornam tão elevados que a população nativa se vê forçada a sair de seu próprio local" sendo este o caso do turismo litorâneo" (Rodrigues, 1997).

Segundo Pimenta (2005), o recente processo de ocupação do território da llha de Santa Catarina tem se caracterizado pela coexistência dicotômica de uma cidade legal, aquela aprovada pelos planos de ocupação dos órgãos públicos, e uma real, resultante de uma lógica excludente. Isto tem levado as populações de baixa renda a ocuparem locais impróprios (ambientes frágeis ou protegidos, como cumes de morros, encostas com grande declividade, orlas marítimas, mangues e dunas, mas também áreas desejadas pelo segmento imobiliário) em assentamentos de baixa habitabilidade e qualidade urbana, motivos que as deixam à margem da legalidade, com deseconomias para a sociedade e para a administração pública. 


\title{
Impactos sócio-culturais
}

A recente urbanização turístico-imobiliária tem levado a intensa disputa pelo espaço, não só o escasso território físico, mas também o simbólico e cultural. Os impactos sócio-culturais decorrentes do acelerado processo de urbanização turístico-imobiliário têm sido estudados por diversas áreas do conhecimento, e todos destacam a velocidade da troca, por imposição ou cooptação, de referenciais, espaciais e temporais das comunidades mais tradicionais.

\begin{abstract}
"Quando o turismo ocorre em áreas povoadas, como em zonas costeiras habitadas tradicionalmente por comunidades pesqueiras, observa-se geralmente impacto negativo, ocasionando, assim, séria transformação nos valores, nas tradições, nas crenças, desestabilizando essas comunidades. Trata-se de um processo irreversível. O problema é delicado, pois as populações autóctones desejam as mudanças e sonham com sua integração à vida moderna, com o acesso aos bens que o 'progresso' proporciona" (Rodrigues, 1997, p. 92).
\end{abstract}

Se na dimensão econômica, os benefícios da atividade turística não têm trazido qualidade de vida às populações locais, na dimensão social, que teria o fator econômico como aliado primordial para uma interação mais fácil, os efeitos do turismo parecem ser percebidos de modo negativo por boa parcela da população. Entretanto, embora o turismo carregue implícita a obliteração de culturas e hábitos ${ }^{37}$, isto não é exclusividade desta atividade, nem é possível dimensionar a sua cota de participação neste processo, tornando ainda mais difícil o entendimento e as origens dessa percepção negativa e a possibilidade de mitigá-la.

Os interesses de visitantes e visitados não são coincidentes, mas se imagina possível o aproveitamento deste momento espaço-temporal para melhoria da qualidade de vida de ambos os grupos sociais envolvidos. As possíveis vantagens da aproximação intercultural surgiriam da revalorização de tradições e costumes locais, numa perspectiva evolutiva e dinâmica, assim como da informação e conscientização dos grupos visitantes, no sentido de seu aprimoramento, e de formas de relacionamento para além do desconhecimento e da desconsideração reveladas em comportamento predatório e arrogante. Alguns estudiosos do turismo têm proclamado que o turismo em guetos,

\footnotetext{
${ }^{37}$ Conforme diversos autores, com Hernandez (1974) e Elias (2000) entre eles, as assimetrias culturais, como no caso dos contatos entre configurações sociais mais dinâmicas e cosmopolitas com outra mais tradicional, com alto grau de isolamento, paroquialismo das relações sócio-culturais e relativo arcaísmo das relações econômicas, tendem a transformar as características da segunda, nem sempre com benefícios.
} 
tido como "honesto" e com "menos efeitos negativos na estrutura social dos locais visitados" (Krippendorf, 1989, p.73), pela proteção de ambas as comunidades envolvidas, seria o mais adequado para determinadas regiões e tipos de turistas.

Em Florianópolis, onde os enclaves sócio-espaciais criados pelas estruturas urbanas, por meio de loteamentos autocontidos e condomínios fechados, não têm contribuído para uma maior integração, seja econômica ou social, e a segregação de ambientes turísticos não tem impedido a visibilidade dos diferentes modos de vida, já que as possibilidades de movimentação dos visitantes e de convivência com residentes são muitas, além de que as praias, espaço coletivo por excelência, são o palco para as novidades comportamentais.

Desse modo, as populações tradicionais locais vêm sofrendo com a modernização das relações socioeconômicas trazidas pela urbanização. A configuração social tradicional, com modo de produção pré-industrial, tradições culturais trazidas pelos colonos açorianos e originadas no século XV (Santos, 1971), e relações comunitárias de base familiar e paroquial, devido ao relativo isolamento em que permaneceram até recentemente ${ }^{38}$, foram radicalmente transformadas.

Além da freqüência e conteúdo diferenciado das informações, que dificultam a assimilação, a percepção da invasão e a perda de auto-estima, tem resultado em comportamentos avessos a "invasão turística" 39 e atraído reações contrárias à decisão de outros segmentos de assumir o turismo como alternativa de desenvolvimento.

Até mesmo nas festas e outras manifestações culturais tradicionais, a nova situação tem repercussões. Mesmo que se mantendo, apesar das contaminações provocadas pela inserção da região no cenário nacional e pelo acesso aos modernos meios de informação, as festas ainda permanecem, mas algumas se transformaram ${ }^{40}$, em função do papel da imagem da cidade na atração do turismo.

\footnotetext{
${ }^{38}$ Exemplo desse isolamento, entre os núcleos dispersos pela llha e o centro da cidade, é refletido pela maneira com que moradores das antigas freguesias e hoje distritos, se referiam, quando em viagem até o centro da capital. A expressão "ir à Florianópolis", como era comum até recentemente e ainda hoje utilizada por alguns, revela, além da distância física, também, uma sensação de não pertencimento à cidade, talvez pela percepção de abandono por parte das administrações municipais.

${ }^{39}$ É comum a passagem de um sentimento inicial de euforia com o turismo para um reações de xenofobia com o passar do tempo

${ }^{40} \mathrm{O}$ caso da "domesticação" da tradicional farra-do-boi, que de espetáculo bárbaro e motivo de apaixonadas discussões em nível nacional, com a ilegalidade decretada pelo Tribunal Superior de Justiça nos anos 90, passou a festa-espetáculo encarcerada em mangueirões, já sendo capaz de atrair turistas, é exemplar. De outro modo, e contribuindo para a continuidade da tradição, a encenação do boi-de-mamão vem recebendo novos elementos, nem todos originados da tradição açoriana, mas digeridos por ela, mantendo-a atualizada e atraindo interesse.
} 
A população urbana, mais cosmopolita, reage à inserção profissional dos novos moradores, e mesmo visitantes, em diversos setores produtivos da sociedade. Essa "invasão" é percebida desde as artes, em que às vezes são apropriados por "estrangeiros" os elementos da cultura tradicional, passando por cargos técnicos em empresas e pelos meios de comunicação, pela, pelo comércio e pela construção civil, chegando à política e à administração da cidade, até pouco tempo, redutos restritos aos locais.

Além disso, a insinuante presença de migrantes e "estrangeiros" causa indisfarçável reação dos residentes, como se aqueles fossem turistas permanentes, manifesta em artigos e cartas aos periódicos, conversas e discussões na cidade, nem sempre pacíficas. A migração rural e, principalmente, a de outros centros urbanos para a capital catarinense, decorrente da promoção das qualidades da cidade, acentuou os impactos sócio-culturais negativos do adensamento populacional e da expansão construtiva e os problemas decorrentes do modelo de ocupação territorial.

\section{Impactos sobre o patrimônio histórico-cultural}

Os impactos sobre o patrimônio histórico cultural foram intensos e implacáveis durante o recente processo de urbanização da cidade, especialmente no centro urbano, mas também em regiões balneárias, o que exigiu a urgente tomada de consciência cultural e de atitudes práticas por parte de diversos setores da sociedade. Conjuntos urbanos e arquitetônicos, de caráter civil, militar e religioso, os espaços públicos urbanos e rurais significativos, pelo uso prático ou simbólico, e muitas manifestações da cultura (pré-histórica e da colonização) sofreram e continuam sofrendo com a transformação da cidade.

Embora ações esporádicas de valorização e preservação do patrimônio cultural possam ser notadas desde a segunda metade do século XIX e também tenham acontecido ao longo das primeiras décadas do século $X X$, é somente a partir da conscientização sócio-cultural provocada pela urbanização desenfreada dos anos 1970, que ações amplas e concretas começam a serem tomadas pelo poder público. Aconteceu em diferentes esferas da administração, mas com crescente municipalização do processo de preservação, em que as decisões locais contam com apoio das diretrizes estaduais e nacionais. 
A criação do IPUF na década de 1970, incorporando a Comissão Técnica do Serviço do Patrimônio Histórico e Artístico Nacional - COTESPHAN, existente, até então, foi resultado da política nacional de descentralização. A seguir, foi implantada uma estrutura administrativa executiva municipal (SEPHAN), que permitiu, pela primeira vez, a inserção da área de preservação na esfera do planejamento e da legislação urbanística (Adams, 2002), com re-direcionamento e atualização na política do setor, se expandindo também à área de preservação natural.

Apesar do movimento de valorização e preservação do patrimônio cultural construído ser reconhecido por diversos setores da sociedade e com base legal institucionalizada, tendo obtido avanços, vem enfrentando problemas relativos às distintas percepções do que é um bem patrimonial, cultural ou natural. Com a atribuição não unânime de valores aos bens patrimoniais históricos e culturais, por falta de informação, diversos edifícios, conjuntos e paisagens, não são reconhecidos nem protegidos adequadamente pela sociedade.

A ação de proteção sobre patrimônio privado, não comunitário, devido à dimensão do acervo protegido e à incompreensão social, "(...) provocou uma reação forte e agressiva dos agentes proprietários e incorporadores imobiliários (...)" (Adams, 2002, p. 113), que exigiu contrapartidas municipais. E continuam acontecendo alterações de atos legislativos de proteção do patrimônio, revisões de tombamentos, descaracterização e mesmo a eliminação dos bens patrimoniais, no centro e demais distritos da cidade.

As fortificações, tombadas ${ }^{41}$ desde a primeira metade do século passado e esquecidas em sua degradação natural durante longo período, só voltaram a ter atenção recentemente, e as igrejas do período colonial, exigentes de constante manutenção, sobrevivem, mas com dificuldade de conservação.

Nas áreas culturais preservadas dos núcleos urbanos pioneiros (Áreas de Preservação Cultural, segundo, o PDB/85), o esforço institucional encontra barreiras sócioeconômicas. Espaços públicos tradicionais vêm sendo apropriados ou desfigurados pelas novas atividades e formas de relações sociais estabelecidas no espaço. A falta

\footnotetext{
${ }^{41}$ Primeira atuação no estado do, então, recém fundado Serviço de Patrimônio Histórico e Artístico Nacional, o tombamento, em 1938, das fortificações do sistema de defesa colonial implantado pelo Brigadeiro Silva Paes, foi, com o distanciamento do epicentro da urbanização do núcleo central, resguardado de ações destrutivas de sua integridade, mas também esquecido durante décadas.
} 
de retorno econômico e atratividade profissional das atividades ruro-pesqueiras, aliada à valorização da terra, faz com que a venda de lotes e mesmo das próprias casas seja opção recorrente para os moradores locais mais tradicionais.

As atividades produtivas tradicionais perdem seu espaço: o agricultor perde as planícies e encostas; o pescador, a proximidade com o mar. Ainda que o conjunto urbano se mantenha, é perceptível o processo de gentrificação e de mudança na imagem das edificações, esvaziando a intenção de manutenção do ambiente sócio-espacial tradicional. Os espaços urbanos vêm perdendo significado tradicional e os rurais, por sua vez, adquirindo status de mercadoria imobiliária.

As áreas agrícolas e de pastoreio e as terras comunais, heranças característica do processo de ocupação colonial açoriana, que juntamente com os outros acidentes geográficos que conformaram a estrutura territorial polinucleada da Ilha de Santa Catarina (e de outras regiões colonizadas pela mesma corrente migratória), vêm sendo relegadas enquanto patrimônio cultural pela intensa transformação de usos e ocupação suburbana.

A valorização da estrutura espacial da migração açoriana, atributo cultural percebido nas amplas áreas abertas com visuais horizontalizadas, além de contribuir para o equilíbrio ambiental, poderia ser um recurso paisagístico passível de aproveitamento turístico, poderia ser vetor de re-significação cultural do patrimônio paisagístico.

\section{Impactos sobre as Infraestruturas}

Os impactos do crescimento urbano e do turismo nos sistemas de infra-estrutura da cidade são percebidos notadamente durante as temporadas de veraneio, mas que já vem se fazendo notar no cotidiano. Manifestam-se, principalmente, na deficiência de serviços urbanos e infra-estruturas, resultando em contaminação e poluição de recursos naturais e congestão de espaços de uso coletivo, comprometendo a qualidade do ambiente.

Na região de Florianópolis, e de modo mais evidente, na Ilha de Santa Catarina, eles passam a afetar todos, se refletindo democraticamente na vida da população residente e dos visitantes, de pobres ou ricos. Tanto áreas de extratos sociais mais abastados como assentamentos de baixa renda sofrem com a falta de esgotamento sanitário, de água, de vias pavimentadas, da falta de espaços livres e áreas verdes, 
mas maneira geral, os menos favorecidos têm sofrido com mais intensidade as conseqüências e os impactos decorrentes desse modelo de desenvolvimento.

Ao dar preferência ao desenvolvimento urbano-turístico com a principal alternativa econômica para a cidade, os planos de implantação de equipamentos de consumo coletivo, infraestruturas e serviços urbanos têm sido orientados para áreas de interesse turístico-imobiliário em detrimento de áreas residenciais mais carentes.

O abastecimento de água na região central, sob a responsabilidade da concessionária CASAN - Companhia de Águas e Saneamento de Santa Catarina, que durante séculos vinha da própria Ilha, com o aumento populacional e o esgotamento de fontes naturais, teve de contar com a canalização de águas dos rios da região continental. Hoje, além das estações de tratamento de água dos rios Pilões e Cubatão que abastecem o centro, continental e insular, e bairros próximos, o sistema conta com ponteiras e poços artesianos públicos para atender a população do norte da llha e a estação de tratamento da Lagoa do Peri que atende as regiões sul e leste da llha.

O abastecimento irregular e a qualidade da água são constantemente questionados por moradores e visitantes, especialmente nos meses de maior demanda e nas regiões mais turísticas, que sofrem o impacto da sazonalidade, e têm provocado disputas sobre a prioridade do uso entre os diferentes agentes sociais do processo de urbanização ${ }^{42}$. Além disso, o próprio aproveitamento de lagoas também é questionado por ambientalistas embora as suas previsões de esgotamento dos mananciais ainda não tenham se concretizado.

De fato, a falta de conhecimento do potencial das reservas de água na llha por parte da concessionária, e a perspectiva para a questão, no caso da continuidade da expansão urbano-turística, não é muito favorável para residentes, empresários do turismo nem para visitantes, e um provável esgotamento das fontes certamente será um dos primeiros indicadores da obsolescência do modelo.

Se existem deficiências não abastecimento de água, o esgoto cloacal, também responsabilidade da CASAN, se encontra em pior situação. O sistema de esgotamento de águas servidas implantado na região central da cidade em 1916, pioneiro no estado,

\footnotetext{
${ }^{42} \mathrm{~A}$ quase totalidade dos domicílios tem abastecimento de água ( $90 \%$ água encanada) e o restante é abastecido com soluções alternativas ou tradicionais (poços ou nascentes), e mesmo o abastecimento encanado não é unificado, sendo feito por recolhimento de águas de mananciais no continente, abastecendo o centro e bairros próximos, por poços artesianos individualizados - ponteiras residenciais no norte da llha, e por aproveitamento de lagoa no sul e leste da llha.
} 
manteve-se assim até os anos 1980. A partir da intensificação da urbanização, novas estações de tratamento foram implantadas no norte, em Canasvieiras, leste, na Lagoa da Conceição, e no centro da cidade, no aterro da baía sul em frente ao casco histórico.

Cerca de $50 \%$, dos pouco mais de 100 mil domicílios presentes no município, são atendidos por esgoto encanado com tratamento em estações distribuídas pelos quadrantes do município, muitas em condições de exaustão física, inclusive com questionamentos técnicos sobre sua eficácia por parte das comunidades e ambientalistas. Os demais domicílios têm tratamento individual, a grande maioria por fossa séptica e uns poucos por fossa negra, e estudos ${ }^{43}$ têm comprovado o comprometimento da potabilidade de poços artesianos e da balneabilidade de águas do mar.

Existem casos agravantes da situação, comuns em todos os balneários, em que o esgoto cloacal é conectado em canalizações pluviais, contaminando diretamente rios, lagoas, lagunas e banhados, além de situações onde as águas pluviais, assim contaminadas, são lançadas diretamente no mar.

Cabe ressaltar que os sistemas individuais de esgotamento sanitário adotados na maioria dos balneários (exceção à Canasvieira, Jurerê e Lagoa, onde sistemas coletivos já existem, e os previstos na Barra da Lagoa, Ingleses e Canto da Lagoa) são inadequados para a condição territorial-ecológica da região. Os morros, graníticos e com recobrimento argiloso, ocupados parcialmente nas baixas encostas, geomorfologicamente relacionados com as planícies sedimentares, de terrenos arenosos ou argilosos e baixos, com ocupação urbana extensiva, fazem com que os resíduos tratados nas encostas escorram subterraneamente para as bacias de contribuição, contaminando o sistema hidrológico de aqüíferos e pântanos.

O sistema pluvial é descentralizado pelas diversas bacias de drenagem hidrográfica e as poucas redes de coleta estão concentradas, basicamente, na região do distrito sede e regiões centrais de alguns balneários. Além de sofrer a agressão acima descrita, o sistema não está dimensionado para o regime pluviométrico da região de Florianópolis, o que associado ao padrão ocupacional, tem resultado em enchentes periódicas, principalmente em áreas baixas. Com a ocupação de encostas, desmatadas e impermeabilizadas em extensos trechos de solos em declive, provo-

\footnotetext{
${ }^{43}$ Entre eles, o realizado pela empresa MPB Saneamento Ltda. no balneário dos Ingleses em 1992, além dos laudos elaborados anualmente pela Fundação Estadual do Meio Ambiente - FATMA.
} 
cando erosões, e a ocupação e impermeabilização das planícies, o resultado tem sido o alagamento de grandes áreas, trazendo seguidos transtornos à população e problemas aos administradores.

Alguns loteamentos de alto padrão, hoje em dia em função da legislação realtiva a grandes empreendimentos, têm soluções próprias para abastecimento e saneamento, mas passam a comprometer, pela proximidade e pela inadequação dos sistemas de tratamento de águas servidas adotados, as poucas e frágeis áreas protegidas das planícies e restingas (dunas, mangues, restingas, florestas quaternárias e áreas pantanosas), implicando perdas na qualidade de vida de todos.

O recolhimento e o tratamento de resíduos sólidos, a cargo da concessionária COMCAP - Companhia Municipal de Melhoramentos, sempre foram problemas na llha de Santa Catarina, e mais ainda com a aceleração da urbanização. Com escassas áreas adequadas para a estocagem e o tratamento, as soluções sempre foram paliativas e pouco comprometidas com o ambiente, como o aterro a céu aberto ao lado do Mangue do Itacorubi, que durante mais de cinco décadas ali permaneceu, com todos os problemas sanitários decorrentes disso, e ainda hoje é estação de classificação de lixo. Com uma taxa de crescimento de cerca de $7 \%$ ao ano e $99 \%$ dos domicílios atendidos pela coleta, os resíduos sólidos chegavam, em 1996, perto de 220 toneladas/dia (IPUF, 1996), quando foi criada uma estação de tratamento em município vizinho que, além de ter acirrado resistências por parte da comunidade receptora, não solucionou a questão por completo.

O sistema de abastecimento de energia elétrica, sob responsabilidade da concessionária CELESC - Centrais Elétricas de Santa Catarina, é talvez o que melhor responde ao desenvolvimento urbano da cidade, quase atingindo a totalidade do território e raramente, a não ser em situações de acidentes ou por motivo derivado das forças da natureza, tem deficiências no atendimento. Para alcançar essa desenvoltura e economia na instalação das redes tem se utilizado sistema de transmissão aéreo, com a implantação de torres e fiação por sobre morros, aumentando a percepção da urbanização se impondo à paisagem.

O sistema viário, principal, constituído por eixos rodoviários decorrentes dos caminhos coloniais, devido a condições topográficas e a presença de diversas áreas impróprias para a implantação de vias alternativas, absorvem com dificuldade o crescente fluxo viário cotidiano e se congestiona em nós viários nas temporadas de verão, apre- 
sentando sinais de obsolescência e problemas daí decorrentes, desproporcionais a dimensão de uma cidade de porte médio. Durante a baixa estação de turismo, tem movimentação de 165 mil veículos de residentes resultando numa taxa de motorização de 1 veículo para cada 2 habitantes (IBGE, 2000), chegando a dobrar quando considerados os visitantes da temporada de verão.

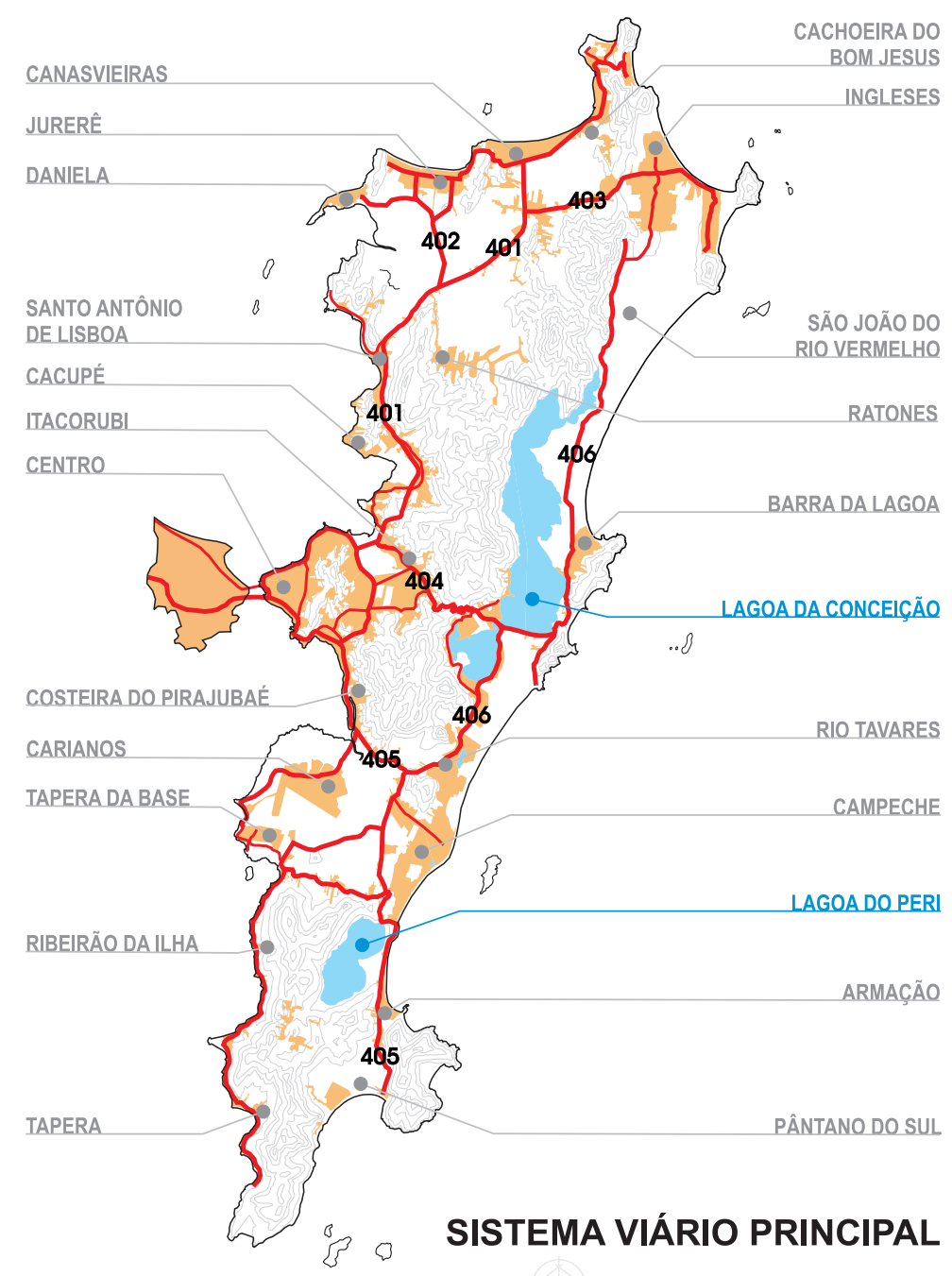

ESGALA GRÁFICA 0

Figura 4.11: Sistema viário principal. Fonte: IPUF.

$\mathrm{Na}$ área central, a estrutura urbana colonial já não atende os fluxos decorrentes das atividades ali estabelecidas, bem como a estocagem de veículos passa a ser outro problema ${ }^{44}$. Além disso, os assentamentos balneários da orla, de caráter permanente

\footnotetext{
${ }^{44}$ Segundo o IPUF, o déficit de estacionamentos na área central em 1996 era de cerca de 20 mil vagas, e nenhuma medida mitigadora deste problema, como o incentivo a edifícios garagens, tomou impulso.
} 
com características de zonas-dormitórios e desprovidos de atividades de comércio e serviços de abrangência urbana, produzem um intenso fluxo pendular para o centro.

Nos tecidos urbanos derivados do parcelamento da estrutura fundiária colonial nos balneários e no interior da llha, a maior disfunção é a falta de conectividade transversal ao desenho das vias de acesso aos loteamentos por sobreparcelamento, compridas e estreitas. Com a subdivisão da terra no sentido longitudinal, em estreitas vias (com 3 metros e até menos) com parcelas laterais, não é costume (para maior aproveitamento imobiliário) a conexão com as vias paralelas, o que acarreta o sobre-carregamento do sistema principal. Os assentamentos balneários legalizados com dimensionamento urbanístico moderno também se ressentem de congestão de vias e falta de vagas para estacionamento em determinados pontos mais procurados da orla, fazendo com que o acesso e circulação se transformem em uma das reclamações mais pertinentes de moradores com relação aos fluxos turístico.

A ineficiência e/ou inexistência de sistemas infraestruturais que possam garantir a mínima qualidade de vida para moradores e turistas, traz à tona diferentes percepções da questão, expressadas nos diários e periódicos comunitários municipais, fórum de muitas questões que envolvem o ambiente e o território. Enquanto as comunidades percebem as melhorias nos sistemas de infraestrutura, exemplificado por estações de tratamento, sistemas de abastecimento de água e pavimentação de rodovias, como soluções tardias para problemas presentes, empresários as vêem como investimentos para futura expansão imobiliária, cuja efetivação tornará a ação obsoleta.

O poder público tem arcado com os principais investimentos e custos das insuficientes e ocasionais melhoria e instalação de sistemas infraestruturais. As prioridades desses investimentos, quando acontecem, nem sempre discutidas com os diversos segmentos sociais e costumam beneficiar determinadas regiões, sendo socializados os custos, que raramente são cobertos por empresários.

Esse panorama da questão infraestrutural da cidade é bastante condicionado pela conformação de seu território, com compartimentos espaciais bem delimitados por barreiras naturais, mas é agravado pela expansão ocupacional difusa e de baixa densidade, modelo territorial reconhecidamente antieconômico, pelos custos da extensão dos sistemas e redes centralizados ou da implantação de sistemas setorizados, e antiecológico, pelo enorme consumo de território. 
Um fato, de importância desprezada pelo poder público e menosprezada pelo setor imobiliário, contribui com a problemática da infraestrutura urbana: o município de Florianópolis, capital do estado de Santa Catarina, é a única sede de federação da região sul do Brasil, que até o momento, ainda não conta com uma política urbana que contemple instrumentos efetivos de gestão social da valorização da terra ${ }^{45}$.

A utilização efetiva destes instrumentos ${ }^{46}$ poderia mitigar os gastos com a entrada de recursos privados para o erário público, via cobrança pelo direito de construir ou mesmo via a construção das melhorias necessárias para a implantação do empreendimento. Esses recursos administrativos e financeiros de gestão do espaço possibilitam maior controle do mercado por meio da orientação do crescimento e do adensamento populacional e edilício, a partir de zoneamento de potencial construtivo com planta de valores adaptada aos interesses de preservação de determinados atributos da paisagem previamente definidos.

\subsection{Conflitos, disputas e movimentos de resistência à urbanização turística.}

O modelo de desenvolvimento urbano-turístico adotado expresso em estratégias e projetos de interesse do empresariado tem encontrado crescentes entraves sócio-comunitários e legais para sua implantação. Como discurso e ação pública e privada não convergem e os resultados se distanciam cada vez mais de uma situação de equilíbrio e respeito ao território, diversos atores sociais, também públicos e privados vêm, ao largo dos últimos vinte anos, fiscalizando, exigindo adequações e mesmo opondo resistência ao desenvolvimento da atividade turística.

Duas visões opostas, politicamente sustentadas por diferentes agrupamentos sociais, sobre a atividade se defrontam na construção do espaço da cidade, cujo planejamento está voltado, desde os anos 1980, para a facilitação da atividade turística como um dos vetores do desenvolvimento sócio-econômico.

\footnotetext{
${ }^{45}$ Exigência federal, estabelecida e institucionalizada pelo Estatuto da Cidade em 2001, a ser adotada pelos municípios com população acima dos duzentos mil habitantes ou com potencial de aproveitamento turístico. Informação obtida no texto para debate de autoria de Nadia Somekh, Paula Santoro e Renato Cymbalista apresentado no Seminário - Solo Criado: Balanço e Perspectivas, promovido pela FAU Mackenzie, Instituto Polis e Lincon Institute of Land Policy em São Paulo, outubro de 2005.

${ }^{46}$ Estes instrumentos são conhecidos como Solo Criado ou Outorga Onerosa do Direito de Construir e seus derivados, como Operações Interligadas, Operações Urbanas e Transferência de Potencial Construtivo.
} 
A propagação da alternativa de desenvolvimento econômico a partir do turismo para o Município de Florianópolis tem apresentado uma visão extremamente positiva do futuro, com benefícios generalizáveis por todos os segmentos sociais, ressaltando seu papel de vetor de desenvolvimento social "limpo" na medida em que é tratado como a indústria sem chaminés, especialmente pelos benefícios econômicos que traz para as regiões visitadas.

Por outro lado, se contrapõe uma postura de reação e de caráter, aparentemente, mais realista, baseada na observação dos problemas advindos com sua presença. Nas cidades periféricas ao mercado global do turismo internacional, o vínculo entre pobreza e degradação comum às cidades brasileiras, Florianópolis incluída, passa a ter companhia do vínculo entre riqueza e degradação ambiental com a perda dos atributos da paisagem.

A intensa dilapidação do patrimônio ambiental e paisagístico da região e o privilégio ao atendimento de demandas originadas pela atividade turística, que não tem sido acompanhado pela mesma atenção a determinados setores da sociedade e a determinadas regiões da cidade, faz com que políticos, grupos ambientalistas e associações de bairro passem a se posicionar com bastante contrariedade, chegando a não aceitação da atividade como alternativa efetiva de desenvolvimento.

A maior parte das situações de conflitos e de contradições entre os diversos interesses e agentes envolvidos com o turismo, manifestos ou não, se expressam na dimensão espacial e podem ser identificados através da leitura da paisagem. A resistência, de florianopolitanos e recém chegados na cidade, à atividade turística tem inúmeras razões e causas, porém é muito evidente em situações em que o ambiente e a paisagem são afetados, com conseqüências negativas nas condições de vida dos residentes. Já é bastante comum em diversos setores da sociedade a exigência de políticas e ações que apontem na direção do desenvolvimento sustentado considerando, especialmente, a base natural como a mais importante fonte de atração de fluxos turísticos para a capital e, além disso, elemento chave na qualidade de vida dos residentes locais.

As ações de resistência à expansão urbano-turística e imobiliária da região de Florianópolis se enquadram dentro do contexto maior dos movimentos sociais urbanos, amplificados nos anos setenta do século passado. Tais movimentos, originados das contradições e injustiças do modelo de urbanização brasileiro, com rápido crescimento da 
densidade demográfica e das demandas públicas urbanas, e da necessidade política de participação dos cidadãos no reconhecimento e gestão de seu ambiente, buscam, ao fim e ao cabo, dar conta da qualidade de vida, da inclusão social e da convivência diversificada.

Como todos os movimentos sociais que atuam no contexto das relações entre os homens e a natureza no Brasil, os da região de Florianópolis encontram dificuldades ao sucesso de sua atuação, como questões relativas à assimetria de poder nas relações entre diferentes indivíduos e grupos e às diferentes experiências e expectativas urbanas de cada indivíduo-grupo social, o que é agravado pela pressão ocupacional da expansão urbano-turística e um crescimento demográfico maior que a média das cidades brasileiras.

Numa cidade socioeconômica e culturalmente multifacetada como Florianópolis, com setores da economia modernos e outros patrimonialistas e pré-industriais, com praticas políticas tradicionais, calcadas no clientelismo e patronagem (Werner, 1985), e sistemas modernos de divulgação e marketing de idéias, os conflitos e disputas têm marcado o recente processo de urbanização.

Desde o discurso anti-cidade, atrelado a um passado irrecuperável e calcado no mito da natureza intocável, até a almejada posição de metrópole turística nacional, a reboque de um futuro incerto, e a qualquer custo, são utopias urbanas (Fantin, 2002) que orientam os atores sociais neste contexto de disputa simbólica e material pelo espaço territorial de Florianópolis.

Dentro deste contexto, se percebe claramente duas correntes de pensamento a respeito da cidade, e embora não homogêneos internamente, apontam para os principais ethos que se apresentam nas discussões sobre o futuro da cidade. Mesmo que generalizando, especialmente neste recorte analítico, corra-se o risco de simplificação, pela homogeneização das partes, dos inter-relacionamentos e mediações presentes no fenômeno estudado, o estabelecimento dessa dualidade socioeconômica e cultural, também manifesta em agremiações partidárias, permite o exame da questão ambiental sem perder a perspectiva da ordenação territorial e da organização da paisagem.

Empresários do setor turístico-imobiliário, administradores públicos e agentes políticos locais formam a corrente de pensamento associada ao desenvolvimentismo, alicerçado na urbanização da cidade turística, e ao conservadorismo, relacionado às práticas e administrações autoritárias e tecnocratas. 
Como contraponto, começou a ter visibilidade, a partir do início dos anos 1980, uma corrente formada por grupos sociais conscientizados dos limites territoriais da cidade e das bruscas transformações sócio-culturais trazidas pela urbanização impulsionada pelo turismo, ligados às universidades, à administração pública, ao terceiro setor (ONG's) e a movimentos comunitários. Afeitos a idéias progressistas, pela reivindicação participativa em decisões sobre a cidade, e ambientais, pela luta pela preservação do ambiente natural e cultural insular (Fantin, 2002), mas existem também setores ideologizados pelo anti-desenvolvimentismo, que vão além das demandas ambientais, muitas vezes utilizadas só como pretexto.

A causa ambiental, ligado à emergência de valores pós-materialistas, é reconhecidamente complexa (pelas relações simultâneas e recorrentes de complementaridade, antagonismo e concorrência entre as partes de um todo) e envolve diferentes setores da sociedade (multissetorial) (Viola e Boeira, 1990). Dada à diversidade de atores nesses grupos, com percepções diferenciadas de ambiente, preservação e qualidade de vida, tem havido avanços e recuos, acertos e equívocos na disputa pelo espaço na Ilha de Santa Catarina.

Um estudo na região de Florianópolis do fim da década de 1980 identificou diversos grupos ambientalistas relacionados a setores que naquele período, como muitos ainda hoje, não se reconheciam como parte de um movimento potencialmente capaz de superar impasses próprios da modernidade. Desde os amadores, aos semiprofissionais e aos poucos profissionais, vinculados a instituições públicas de ensino ou a movimentos sociais, as entidades ambientalistas evoluíram, ainda que com atraso, em sintonia com o movimento ambientalista em nível mundial (Viola e Boeira, 1990).

Devido ao caráter da urbanização que se processava na cidade e região, excludente das camadas sociais de baixa renda, a existência de organizações comunitárias vem de antes dos anos 1980, quando vários grupos se faziam presentes, de modo incipiente e isolado, na discussão dos conflitos derivados da urbanização. Geralmente em áreas infraurbanizadas e sem redes de relações comunitárias tradicionais, a migração recente utilizou as lutas reivindicatórias para alcançar respostas do poder público às suas demandas.

As lutas, organizadas em torno de comunidades eclesiais de base, movimentos universitários e grupos de solidariedade, trouxeram à cena a noção de cidadania, demandando implantação de infra-estrutura e reconhecimento da posse. Restritas às 
áreas centrais de maior tensão demográfica e imobiliária, muitas em áreas de risco, não chegavam até as novas zonas de interesse imobiliário, impulsionado pela potencial turístico, nos núcleos pioneiros balneários.

Porém, nessas áreas do interior e dos balneários da llha, onde se concentravam as comunidades tradicionais, até então isoladas do centro da cidade, a facilitação do acesso e a chegada, lenta, mas progressiva, de novos moradores e das transformações decorrentes, passam a mudar comportamentos. Apesar da resistência inicial à participação nas novas redes de relação social, aonde moradores recém chegados e preocupados com a questão ambiental se faziam notar, lentamente, parcelas significativas da população tradicional passaram a se afastar das relações verticalizadas de clientelismo e apadrinhamento que sempre marcaram as reivindicações à administração pública, com conseqüências político-eleitorais.

A partir dos anos 1980, além do incremento da população vinda de centros urbanos maiores e com situação sócio-cultural mais cosmopolita, os grupos de defesa ambiental passam a fazer parte do cotidiano dessas regiões, com mais ou menos força reivindicatória e participativa junto à administração pública.

Em todos os bairros da cidade, mas especialmente nos balneários, a resistência ao modelo de urbano-turístico, com forte influência do segmento imobiliário, que se impõe tem tido importante papel na obstrução ou retardamento da degradação da qualidade de vida e da ocupação de áreas significativas do ponto de vista ambiental e da paisagem. Tanto empreendimentos privados como públicos têm encontrado entraves sociais às suas expectativas, ora pela exigência administrativa de respeito às legislações nas três esferas, ora pela ação dos movimentos de resistência.

Os empresários entendem os movimentos de resistência à urbanização desenfreada como atitude de grupos contrários ao desenvolvimento da cidade, que só teria como alternativa a adoção do modelo por eles preconizado ${ }^{47}$, embora posturas de sensibilização com o ambiente, devido à percepção da problemática que já afeta ne-

\footnotetext{
${ }^{47}$ Uma campanha promovida pelo setor empresarial, em meados dos anos 1990, envolvendo publicitários, jornalistas, políticos e grande parte da população, dividiu a cidade entre os que apoiavam ações desenvolvimentistas para a cidade - Os Amigos de Florianópolis, e os que reagiam a tais projetos - os contra. Permeada de interesse políticos e empresariais, a campanha colocava a possibilidade de a cidade fazer parte do rol de lugares turísticos famosos, como Miami, Acapulco, Ibiza e Cancun. Embora muitos moradores nascidos na cidade fizessem parte dos movimentos de resistência, a campanha trazia implícita uma contrariedade com a ação dos novos moradores que evidenciaram a questão ambiental.
} 
gócios, venham encontrando eco nesse meio ${ }^{48}$. Acham a legislação (para licenciamento em todos as esferas) rigorosa, irreal e desestimulante para o investidor ${ }^{49}$, na medida em que coloca entraves de ordem ambiental à expansão imobiliária.

Os empresários ligados direta ou indiretamente ao turismo argumentam que são poucos os que respeitam a legislação e reclamam da invasão de capitais externos ${ }^{50}$, numa afirmação implícita de necessidade de reserva de mercado (e terras) para empresas locais. Sem a necessidade de demonizar a atuação desse setor da sociedade, até mesmo pela importância que a atividade turística tem e pode continuar a ter no desenvolvimento da cidade, fica clara que a expansão urbana a partir da atividade turística tem apontado para a insustentabilidade.

A administração pública reconhece a problemática e deixa em evidência, como exemplificado no trecho abaixo, que diferentes visões convivem no setor institucional, não existindo equilíbrio de opiniões nas tomadas de decisões.

"Uma urbanização caótica em locais ambientalmente frágeis constituem
deseconomias para o cidadão a ao aparato gestor das cidades, porém garan-
te ganhos consideráveis ao sistema de especulação imobiliária, por exemplo.
A contaminação de corpos d'água e a degradação do meio natural e paisa-
gem, oriundas de processos - insustentáveis - de formação urbana em cida-
des turísticas, como é o caso de Florianópolis, tendem a matar a galinha dos
ovos de ouro do lugar" (www.pmf.sc.gov.br, 2003). O diagnóstico correto da administração municipal, sobre a fragilidade do ambiente e das deseconomias das quais todos se ressentem, não tem sido suficiente, porém,

\footnotetext{
${ }^{48}$ Em função desses entraves, o próprio setor imobiliário passou, mais recentemente, a realizar seminários em que são discutidas as possibilidades de desenvolvimento urbano em consideração ao meio ambiente e à paisagem, em se percebe o enfoque parcial e claro objetivo de legitimar suas aspirações. Desde 2000, o SINDUSCON Sindicato da Indústria da Construção Civil da Grande Florianópolis realiza debates com representantes da prefeitura, do empresariado e consultores ambientais e jurídicos, em que a conscientização e a necessidade de preservação ambiental são temas. Mesmo que existam exceções entre os participantes, fica clara a intenção de menos conciliar a atividade construtiva com o meio e mais de estabelecer estratégias de crescimento do setor, seja por meio de exemplos internacionais não adequados ao quadro infraestrutural local, ou por questionamentos à inflexibilidade da legislação.

${ }^{49}$ Palavras retiradas de recente declaração de Alaor Tissot, diretor da Federação das Indústrias de Santa Catarina e presidente da Florianópolis Amanhâ, ONG empresarial de caráter desenvolvimentista, no Seminário Desenvolvimento Urbano e Meio Ambiente, em Florianópolis, setembro de 2005.

${ }^{50}$ Segundo recentes dados do SINDUSCON (Sindicato das Indústrias de Construção Civil de Florianópolis), a construção irregular ou ilegal representa $50 \%$ do total edificado (em unidades) no município. Das construções legalizadas pelos órgãos de licenciamento, $25 \%$ são obras particulares (com mão de obra própria ou contratada temporariamente) e as demais $25 \%$ são executadas por empresas da construção civil. Dessas, somente $15 \%$ são sindicalizadas, $5 \%$ são empresas de fora do município (distinção que indica tendência à reserva de mercado por parte das empresas locais) e 5\% não se sindicalizaram (segundo Amauri Beck, presidente do Sinduscon, em discurso inaugural do Seminário Desenvolvimento Urbano e Meio Ambiente, Florianópolis, setembro de 2005).
} 
para que o Estado assuma papel decisivo na ordenação do território com vistas ao controle da expansão imobiliário-turística e à própria sustentabilidade da atividade no município. Pelo contrário, determinadas correntes do planejamento público tendem a aceitar a expansão imobiliária como inevitável, como bem representa a esclarecedora frase pinçada de parecer técnico do IPUF relativo às discussões sobre o Plano de Desenvolvimento da Planície de Entremares (Campeche): "Tentar impedir a ação das forças de mercado é fútil (...)" (IPUF, 1998, p. 17), numa clara declaração de abandono da função de zelar pelo interesse público e mediar as assimétricas forças sócio-econômicas que produzem o espaço da cidade.

As comunidades atingidas por projetos de empreendimentos imobiliários reagem às transformações, ainda que por motivações diferentes. Muitas delas formadas por migrantes recentes, e não é possível falar só daqueles de baixa renda, a partir do estabelecimento na capital desejada por muitos, às vezes em situações nem sempre legítimas, tratam de conservar seu espaço. Algumas, de maior renda e mais bem informadas, partem da concepção conhecida pelos urbanistas como NIMBY51, para assumir uma atitude territorial defensiva. Outras comunidades, sem poder político e econômico, buscam sobrevivência e reprodução por meio de ações reivindicatórias de ações que atendam aos seus interesses, prioritários aos turísticos e imobiliários.

Os grupos de resistência de orientação ambientalista, geralmente bem intencionadas e amparadas pelo teor nobre da causa, têm desempenhado papel de catalisadores sociais, buscando o empoderamento de grupos comunitários sem tradição reivindicatória, embora apresentem esporadicamente contradições conceituais e práticas. Na maior parte das vezes em que empreendimentos imobiliários turísticos tentam se implantar, a alteração da paisagem (percebida de distintos modos) é alegada, mas tais empreendimentos pouco se diferenciam das ocupações não turísticas em termos de ocupação de território.

Muitas vezes, o impacto no ambiente e na paisagem de empreendimentos que percorrem a via legal seria menor do que as ocupações clandestinas que ocorrem amiúde, sem tanta resistência por parte da população. Fica a impressão de que, em

\footnotetext{
${ }^{51}$ NIMBY é abreviação da expressão Not In My BackYard (traduzida livremente por não no meu quintal), utilizada por Mark Davis, no livro Cidade de Quartzo que caracterizou, nos anos setenta e oitenta, as disputas territoriais na região de Los Angeles, Califórnia.
} 
muitas situações, a resistência popular, bastante heterogênea e errática, não é tanto em relação à ocupação, mas a quem pertence a iniciativa, a quem irá diretamente usufruir dela e a que tipo de atividade.

Em muitos casos, não se nota, com clareza, a diferença que determinadas lutas ambientalistas estabelecem entre conservação de ambientes e a rejeição, de fundo mais ideológico do que ambiental, a empreendimentos privados, entre possibilidades alternativas de financiamento da cidade e especulação imobiliária e entre aproveitamento de potencial turístico e deterioração da paisagem.

\subsection{Exemplos de conflitos sócio-ambientais da urbanização turística}

Algumas áreas da cidade vem sendo palco de tensões decorrentes do modelo de desenvolvimento do turismo em conflito com os grupos sociais resistentes. Abaixo são destacados três casos emblemáticos acompanhados, em diferentes níveis de envolvimento pelo autor, e que permitem, de certo modo, perceber o que foi acima descrito. Os três casos são espacial e temporalmente diversos, mas refletem a mesma problemática da urbanização turística e nenhum deles foi, ainda, resolvido de maneira satisfatória, permitindo inferir que as soluções não serão alcançadas enquanto uma visão global do território e do potencial seu patrimônio paisagístico bem como de seu papel nas alternativas de viabilização econômica da cidade não forem discutidas amplamente pela sociedade local.

\section{A urbanização no Distrito da Lagoa da Conceição}

Ponto nevrálgico de estruturação da cidade, localizada no centro do setor leste da ilha, a antiga freguesia da Nossa Senhora da Conceição, atual distrito da Lagoa da Conceição, uma das paisagens mais turística da cidade, senão a principal, reflete e resume os principais conflitos do desenvolvimento na cidade. Desde meados dos anos setenta vem recebendo uma ocupação urbano-turística em paralelo ao crescimento vegetativo de sua população nativa, decorrente de migrações de estados vizinhos, especialmente Rio Grande do Sul e São Paulo.

A partir do Plano Diretor dos Balneários e do Interior da llha, de 1985, recebeu zoneamento de usos com índices urbanísticos que permitiram a construção de edifíci- 
os multifamiliares de até quatro alturas (pilotis, dois pavimentos, mais ático com 1/3 da área dos pavimentos), e 60\% de ocupação dos terrenos, e densidade demográfica de 175hab/ha., o que alterou a paisagem anterior que se caracterizava pela baixas altura das construções e densidade. Além disso, a difusão das áreas ocupadas ao redor do espelho d'água da lagoa, por cima de restingas, capoeiras e encostas, por meio de loteamentos, condomínios e parcelamentos (muitos irregulares), tem ultrapassado a capacidade de absorção dos efluentes sanitários pelo solo argiloso do entorno, sobrecarregando a capacidade de resiliência da Lagoa, já que a Estação de Tratamento de Esgoto $^{52}$ local atende menos da metade dos mais de 35 mil atuais moradores.

Concentra problemas de ocupação, de acessibilidade e congestionamento de fluxos. Dentre os grupos de resistência à urbanização proposta pelo PDB-85, as mais persistentes e atuantes são a Associação de Moradores da Lagoa da Conceição - AMOLA, que encampa as maiores reivindicações das demais organizações e associações de moradores da bacia, sempre na demanda da manutenção das qualidades ambientais locais, e a Fundação Lagoa, com demandas semelhantes. Desde melhorias da condição sanitária a implantação ciclovias, as demandas têm sido atendidas, quando o são, com defasagem em relação à dinâmica ocupacional. A falta de recursos da administração pública tem sido alegada com a principal causa do não atendimento das reivindicações dos moradores.

O movimento comunitário de defesa da qualidade de vida na região data do início dos anos oitenta, com o surgimento de diversos grupos. É, inclusive, dentre as comunidades da cidade, envolvidas com a questão ambiental, aquela que apresenta perspectiva territorial menos localizada. Além da forte influência e atuação de novos moradores oriundos de centros urbanos maiores e com mais experiência na atividade, podese atribuir este fato à localização central e estratégica no sistema viário da Ilha.

Em conjunto com as demais organizações e associações da bacia da Lagoa da Conceição, incluindo uma, denominada Arquitetos pela Lagoa, conseguiu, nos últimos anos, que diversas reivindicações junto ao poder público fossem atendidas total ou parcialmente, sendo a mais importante a criação do Comitê de Gerenciamento do Desenvolvimento da Bacia da Lagoa da Conceição.

\footnotetext{
${ }^{52}$ Foi inaugurada em 1989 pela concessionária estadual de águas e esgotos, CASAN e localiza-se junto às dunas da Joaquina, local já por si questionado pela comunidade, além de que se discute também o sistema adotado, que esparge as águas tratadas pela área de dunas, espalhando forte odor na redondeza e contaminando as lagoas intradunares.
} 
Composto por representantes das instituições públicas (CASAN, CELESC, Polícia Militar), dos órgãos de meio-ambiente e urbanismo municipais e estaduais (FLORAM e FATMA, SUSP e o IPUF) e da sociedade civil organizada (associações de moradores, comerciantes, prestadores de serviços, especialmente os de turismo, da indústria da construção civil e setores da universidade federal), sua mais importante conquista foi a moratória na construção de empreendimentos imobiliários de porte e com mais de dois pavimentos de altura enquanto não se incrementar o sistema de tratamento de esgoto da região.

Esta moratória, ainda que com claro impacto na paisagem, tem seu mais forte argumento na questão da salubridade das águas. Embora a paisagem seja colocada em questão no aspecto da verticalização e densidade construtiva, a extensividade da ocupação, economicamente insustentável, parece não preocupar ou não ser o centro das reivindicações dos ambientalistas, nem existe consenso entre os moradores de qual o cenário futuro seria mais adequado à diversificada estratificação sócio-cultural local.

\section{O Plano Diretor do Campeche}

Extensa área plana com núcleos urbanos dispersos por todas as partes, mas com muitas zonas ainda não ocupadas, esta região é caso exemplar das diferenças entre o planejamento urbano do poder público e a realidade local e reivindicações de moradores. Desde as primeiras intenções por parte do poder público, demonstrado em fins dos anos 1980, de proposta para o desenvolvimento e ordenação territorial da planície de entremares, região que inclui a praia do Campeche na costa leste, e o distrito da Tapera na costa oeste da llha, as comunidades envolvidas foram fortalecendo as bases de consciência ambiental e da resistência civil na defesa do ambiente.

Prevista desde o Plano de autoria do arquiteto Luís Felipe Gama Lobo D'Eça, onde era conhecida como Setor Turístico Oceânico, e reassumida num segundo momento pelo PDB-1985, a expansão urbana insular da cidade nesta extensa planície proposta pelo escritório técnico do IPUF se destaca das demais ações de planificação específica do PDB-1985 pela sua dimensão e características de projeto integral de desenvolvimento, na medida em que propunha praticamente uma cidade nova, com zoneamento indutor de atividades urbanas. 
Adotando paradigma urbanístico baseado na experiência das cidades novas inglesas, com clara influência da cidade de Milton Keynes ${ }^{53}$ em sua proposta de estruturação urbana, com um plano geral integrador de diversas peças diferentes, ainda que unidas pela matriz territorial sedimentar plana da região, surgiu da intenção de ser um enclave na paisagem, com ordenação urbana exemplar, regulada e disciplinada, buscando permitir uma vida em meio à natureza e tranqüila.

Logo de início, parte da comunidade do bairro Pontal do Campeche, junto à praia, formada pelo recente incremento populacional de migrantes ambientalmente esclarecidos e ambientalistas locais, reagiu contra o plano, especialmente pela desconsideração das pré-existências naturais e urbanas. A reação da comunidade, com boa parcela de moradores em loteamentos clandestinos, se deu a partir da constatação de que mesmo se encontrando em situação de irregularidade segundo a legislação urbana (loteamentos sobre áreas de exploração rural, conforme o PDB$85)$, todos eram contribuintes municipais e moradores de fato, favorecidos pelo abastecimento de água e energia das concessionárias estaduais. A forte consciência e organização comunitária local, que destacava a ameaça de tornarem-se definitivamente ilegais, em vez de uma solução inclusiva, fez com que o movimento de resistência ao Plano se irradiasse para setores sociais até antão não envolvidos, ampliando a resistência ao Plano.

O Plano, mesmo sendo alterado ao longo do tempo prevê a ocupação extensiva da planície. Inicialmente, foi prevista uma população de $\mathbf{4 5 0}$ mil habitantes num horizonte de 20 anos (a partir de meados dos anos 1990), e depois de discussões com a comunidade, a proposta do IPUF foi diminuindo esta estimativa para 330 mil e posteriormente para 280 mil habitantes. Os privilégios a implantação de áreas turísticas residenciais junto à orla, a implantação de vias expressas sobre sistemas naturais e humanos, a criação de diversos bairros e novas centralidades com edificações em altura, são algumas das características desse plano.

\footnotetext{
${ }^{53}$ Projeto de cidade nova na Inglaterra, a noroeste de Londres com paisagem predominantemente campestre, numa planície levemente ondulada e verdejante. Iniciado no fim dos anos 1960 foi apresentado em 1969 e tem processo permanente de adequação e implementação. Tem como principals autores, Richard Llewelllyn Davies, Walter Bor, John Monchaux, Weeks, Forestier, e Derek Walker. Nasceu da política do governo britânico de descentralização em resposta ao crescimento de Londres, com a criação de novas cidades, tradição do pósguerra retomada nos anos 1960, auge do planejamento urbano no mundo.
} 
A malha viária estrutural da proposta integra todas suas partes, mas as vias veiculares gerais, hipertrofiadas, sugerem a formação ilhas urbanas, com a perspectiva de convivência social introspectiva. Os caminhos de pedestres separados das vias de veículos remetem à segregação extremamente funcional do espaço A criação de centros de atividades diversificados com razoável verticalização com a intenção de pontuar a paisagem predominantemente horizontal desconsidera referenciais do território já presentes na área, como o Morro do Lampião e os morros do sul da llha. A classificação de usos, a proposta de sistema viário e as tipologias das edificações remetem a um padrão de urbanização inalcançável pelas ocupações já existentes, reforçando a idéia de gentrificação forçada.

Estas características do plano com interferência paisagística também serviram de argumentos defensivos do ambiente, embora não fossem o centro das atenções nem fossem muitos claros os cenários desejados, indo desde ações de reurbanização inclusiva passando por cenários de ocupação extensiva de loteamentos tipo subúrbio americano, por cidade jardins até idéias de retorno a uma natureza intocada já inexistente e irrecuperável.

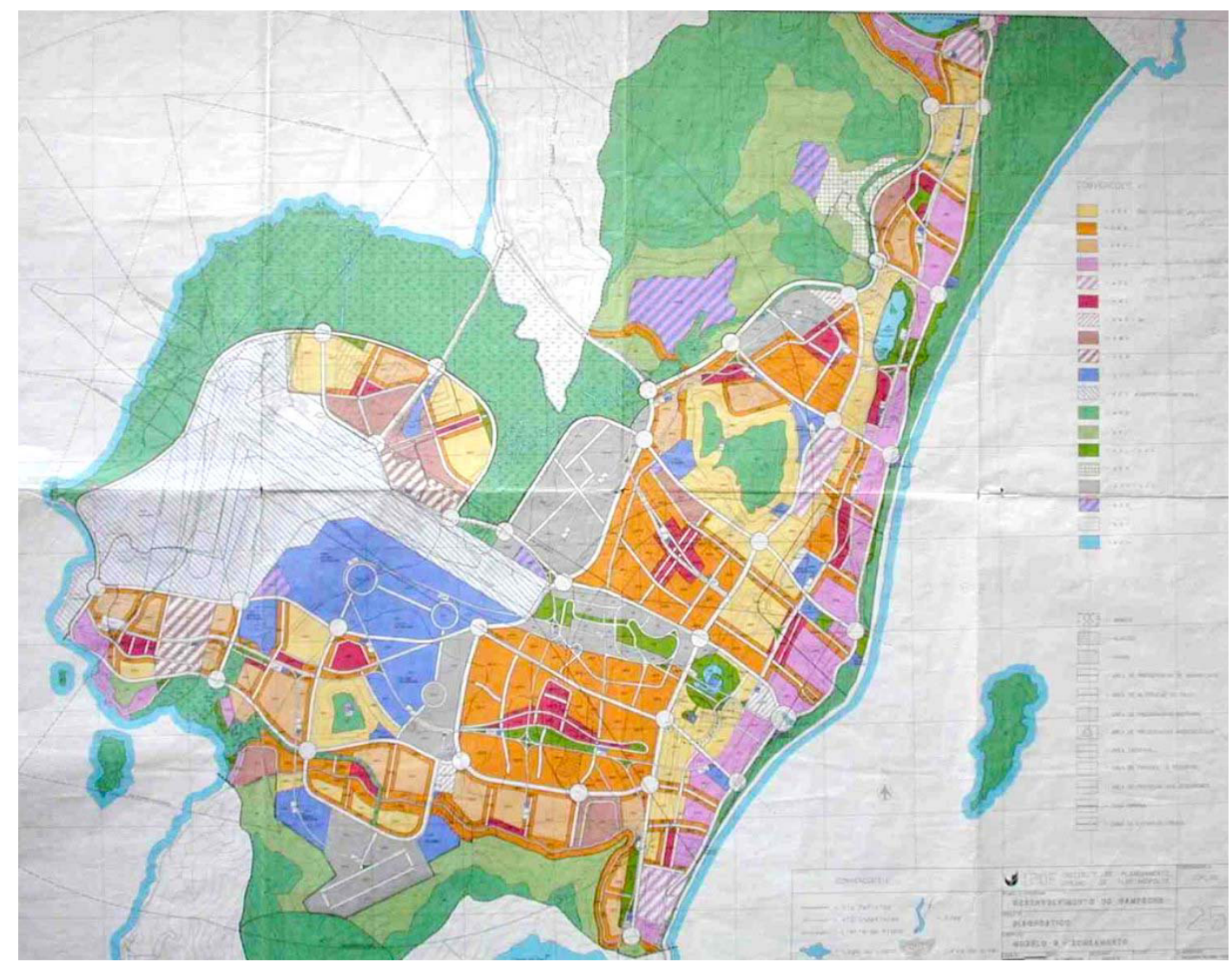

Figura 4.12: Reprodução s/escala Plano Diretor do Campeche, IPUF, 1997 
Depois de anos de discussões, reformulações e exposições públicas do plano com vistas à aprovação pelas comunidades envolvidas, seguidas de ações legais para inviabilizar o Plano do órgão público que se mantinha irredutível às reivindicações, em 1997, as comunidades, congregadas pelo Movimento Pró-qualidade de Vida do Campeche, lançaram o I Seminário de Desenvolvimento do Campeche. Reunindo trabalhos de consultoria técnica de diferentes departamentos da universidade federal, e a participação de boa parte da comunidade, o Seminário discutiu novas diretrizes e parâmetros para a planificação da região, o que mais tarde, em 2000, veio subsidiar um plano alternativo das comunidades, elaborado por representantes locais e por professores da UFSC.

Atualmente encontra-se em um impasse ainda não resolvido, embora postura menos pretensiosa e mais flexível do IPUF quanto à participação comunitária no destino de seus lugares venha sendo adotada mais recentemente em outros bairros integrantes do Plano Diretor dos Balneários e do Interior da llha, como no Pântano do Sul, Santo Antônio e Santinho, com mais ou menos aceitação das propostas populares conforme a situação e a complexidade dos conflitos.

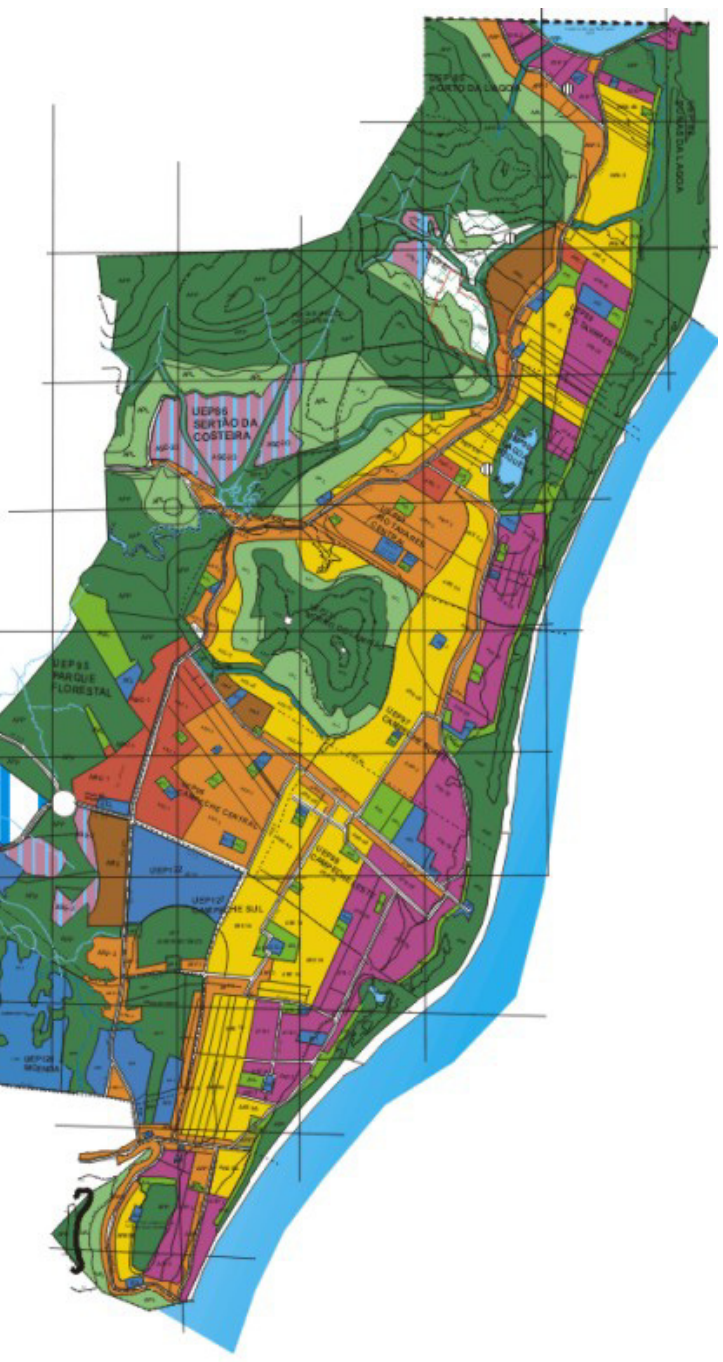

Plano Diretor da Planície do Campeche Substitutivo da Comunidade Mapa Geral - s/escala

Figura 4.13: Reprodução s/escala do Plano Diretor da Planície do Campeche. Substitutivo da Comunidade, 2000. 


\section{O Distrito do Pântano do Sul}

A região do extremo sul e sudeste da llha, com alta qualidade paisagística devido às extensas áreas não ocupadas e em regeneração da exploração agrícola do passado colonial, já sofreu importantes transformações devidas à expansão urbano-turística, embora mantenham em grande parte seus atrativos pela qualidade das panorâmicas amplas fechadas por morros e encostas. Também sofre com a falta de infraestrutura sanitária, agravada pela ocupação próxima às áreas úmidas, com lençol freático e aqüífero de superfície, o que acontece na principal bacia panorâmica (no Pântano do Sul) e junto ao Parque Municipal da Lagoa do Peri e rio Sangradouro (na praia da Armação).

Também conta com grupos de defesa do ambiente consistente e persistente, formado por associações de moradores e organizações não governamentais que tomaram impulso e coesão quando de recente ameaça de ocupação das áreas úmidas da bacia do Pântano do Sul. Os conflitos entre promotores imobiliários e comunidade surgiram no final dos anos 1990, época em que grupos de recentes proprietários de terras, um local e outro de fora do estado, estando parte delas ainda sob o estatuto de rurais (AER), apresentaram proposta de alteração do PDB-1985. Buscaram, por meio de proposta de projeto urbano para a área inteira, adequar zoneamento e índices urbanísticos da área plana da Unidade, boa parte já monopolizada pelos mesmos grupos, com urbanização residencial de média densidade e edificações para equipamentos hoteleiros em altura de dez pavimentos. Com anuência do poder público, num movimento que perece terceirizar o processo de planejamento para empresas imobiliárias, foi levado à consulta dos moradores locais.

As alterações paisagísticas e ambientais previstas na proposta dos empresários provocaram intensas discussões e reações nas comunidades envolvidas, levando a um impasse ainda não resolvido, mas que permitiu a recente incorporação da comunidade, representada por organizações de moradores e de assessores técnicos, na formulação de proposta alternativa.

Atualmente se encontra em discussão um plano, consorciado entre grupos comunitários, concessionárias de energia e água e IPUF, em que a densidade é mais baixa, são incorporadas mais áreas de proteção e corredores ecológicos, mas a ocupação da planície é confirmada, e de certo modo já se encontra em andamento com o início de 
dois loteamentos junto via principal de acesso, ainda que temporariamente embargados. A partir da quebra da unidade do movimento de resistência, já existe movimento de reação por parte de alguns grupos mais resistentes, com a intenção de transformar a planície pantanosa em Unidade de Conservação com base em lei federal.

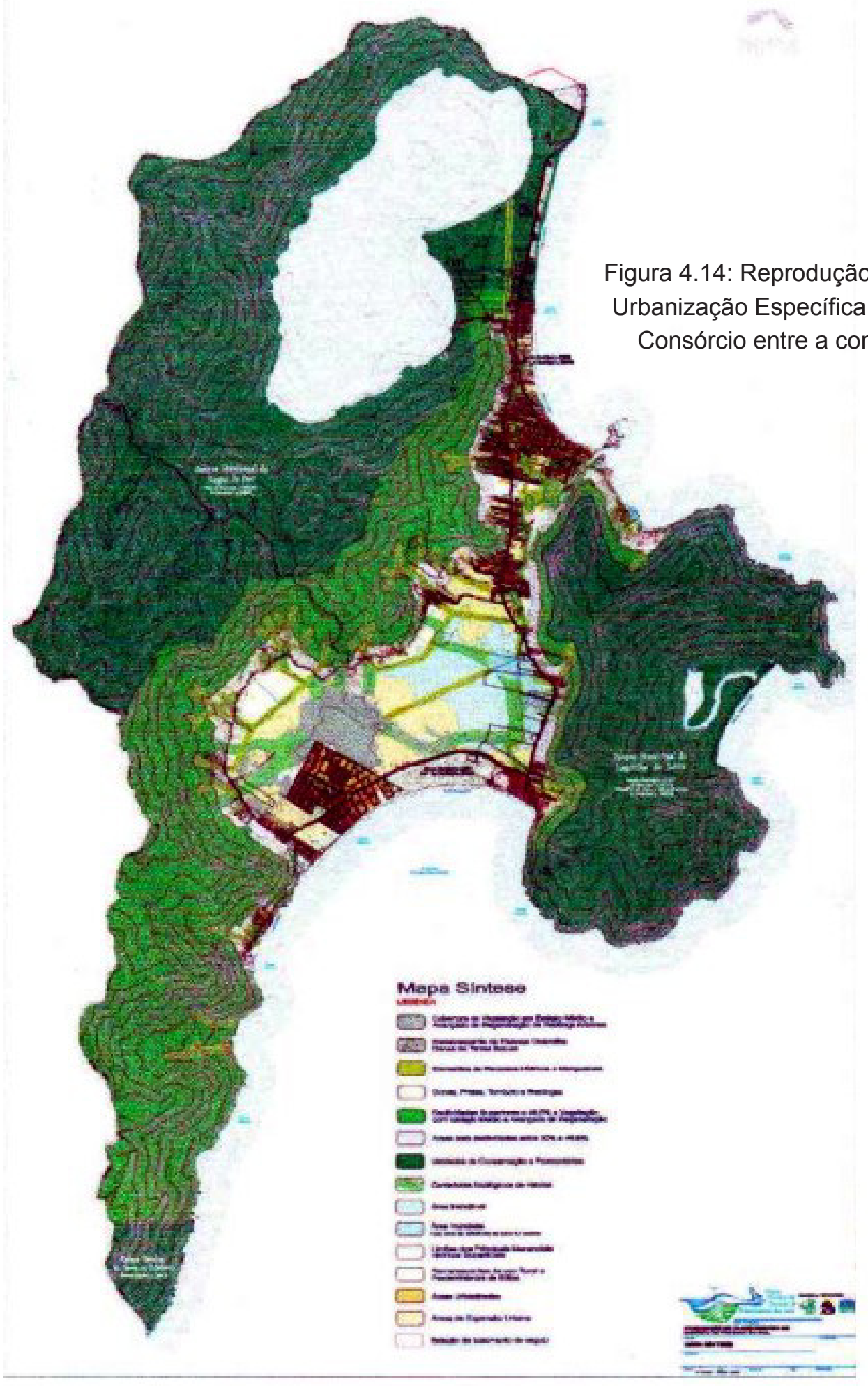




\subsection{Considerações sobre o modelo de desenvolvimento turístico da Ilha de Santa Catarina}

Ao se analisar os agentes e setores sociais envolvidos na produção do espaço territorial, as diretrizes, políticas públicas e ações para o desenvolvimento da atividade turística na cidade de Florianópolis e na Ilha de Santa Catarina, percebeu-se também as implicações sócio-econômicas, políticas e culturais, assim como a repercussão da apropriação ambiental promovida pela atividade.

Dessa análise, foi possível concluir que a avaliação da sustentabilidade da atividade deve considerar as outras dimensões do fenômeno, além da perspectiva da sustentabilidade econômica que tem sido alardeada pelos empresários ligados direta ou indiretamente à atividade.

A qualidade de vida, a riqueza da paisagem e da cultura, sempre citados pelo poder público, por empresários e por grupos comunitários e ambientalistas como elementos importantes para a cidade, parecem não sensibilizar determinados setores para além do discurso.

Apesar das premissas de planos e políticas públicas reconhecerem as excepcionais condições paisagísticas que potencializam o turismo, e que a ocupação desordenada e extensiva do solo tem levando à degeneração do ambiente, com conseqüências negativas à própria atividade turística, não é possível dizer que todas as intenções de valorização do patrimônio paisagístico, amplamente divulgadas pelos principais interessados no turismo, tenham se concretizado plenamente.

A falta de compromisso de certos atores sociais e a voracidade do empresariado imobiliário têm feito com que as diretrizes propostas sigam atendendo interesses localizados e comprometidos com a exploração massiva do turismo por meio da expansão suburbana, dos inúmeros loteamentos e condomínios, de baixa densidade com tendência à seletividade social, que possibilitam as segundas residências e os empreendimentos extra-hoteleiros que em nada contribuem para o verdadeiro ramo turístico.

Mesmo com as estratégias de inserção da cidade no mercado internacional do turismo, incorporadas a partir do início dos anos 1990 e que, baseadas no marketing e na competitividade, visam à qualificação e da oferta e da demanda, os esquemas de 
uso do território permaneceram, ou pior, vêm tendo seu vetor ocupacional e seu viés gentrificador ampliados. Ao apostar na qualificação do visitante e na atração e transformação de visitantes e proprietários de segundas residências em futuros moradores, com nível sócio-econômico acima da média nacional, homogeneizando a paisagem natural e a cultural, o segmento empresarial que aposta na urbanização turística tem feito com que o que era para ser turismo, passe a ser atividade imobiliária.

O amparo legal a estas transformações, obtido conseguido por meio de representações do segmento empresarial junto aos legisladores e administradores públicos, têm contribuído em muito para a atual degradação da paisagem da cidade. De acordo com Campos, boa parte dos problemas de ordenação territorial da cidade é decorrente da complacência do poder público, pois “(...), a forma como se comportaram inicialmente os gestores municipais, no tocante à questão territorial do município, principalmente no que se refere à expansão imobiliária, contribuiu para que tais problemas se agravassem, tendo em vista que, durante muito tempo, as construções foram erguidas sem que houvesse uma interferência adequada do poder público" (Campos, 2004, p. 141).

O estudo acima demonstrou que o desenvolvimento da atividade turística na llha de Santa Catarina tem obedecido a políticas e diretrizes traçadas por entes e organizações sociais ligadas ao empresariado que aposta num modelo ${ }^{54}$ de utilização extensiva e intensa do território como suporte da expansão urbana com graves conseqüências na base natural, atributo de maior atratividade do turismo.

Com o apoio da promoção turística da Ilha, por agências públicas e privadas, como alternativa de desenvolvimento econômico para a cidade, a organização expandida, já reconhecida em estudos de política social (Januário, 1997) e que associa empresários do turismo, da incorporação imobiliária e da construção civil, tem tido poderosa influência nos rumos do planejamento territorial do turismo.

\footnotetext{
${ }^{54}$ Esse modelo de desenvolvimento turístico que inicialmente serviu de exemplo aos planejadores do turismo em Florianópolis, ainda que não explícito, teve base na experiência espanhola do pós-guerra, onde a economia de escala prevaleceu e fez com que aquele país sentisse a necessidade de mudanças profundas no rumo do desenvolvimento da atividade, o que vem ocorrendo há mais de vinte anos em determinadas destinos turísticos espanhóis. Somente nos final dos anos 1980, quando já era possível perceber deseconomias para alguns setores privados e públicos, decorrentes da expansão imobiliária, foram necessárias ações no sentido de reverter a curva expansionista da atividade e modelos alternativos ao turismo de massa passaram a iluminar as idéias dos planejadores espanhóis.
} 
Essa forte influência, direta ou indireta, que o setor empresarial tem tido na concepção, e implementação de diretrizes e políticas públicas de impulso ao turismo, se contrapõe à participação de grupos comunitários e ambientais que têm sido obrigados a recorrer de ações públicas contra planos e projetos e protestos coletivos para verem atendidas suas demandas.

A respeito desse modo de planejar o espaço da llha, setores da sociedade, de diversas correntes de pensamento, têm se contraposto com idéias e ações, na medida em que essa forma de ocupação "... é um dos reflexos da forma como a Legislação municipal vigente de uso e ocupação do solo tem sido conduzida. Mesmo sendo fundamental para a vida urbana, a Lei tem-se mostrado como uma "caixa preta" haja visto que, poucos a conhecem profundamente e na maioria dos casos é utilizada para atender interesses particulares. Em torno disso, ela vem sofrendo modificações constantes acentuando assim as desigualdades existentes na cidade" (Bastos et alli., 2003).

Os conflitos decorrentes do modelo de expansão urbano-turística evidenciam que outros atores estão envolvidos no processo, ainda que forçadamente, e que estes poderiam vir a ter mais simpatia pelo desenvolvimento da atividade, desde que acompanhada pela melhoria das condições objetivas de vida dos moradores, até mesmo porque "... na realidade, muitos dos impactos negativos atribuídos ao turismo são resultado da falta de uma política estatal (políticas públicas) de desenvolvimento, não de problemas inerentes à atividade turística" (Villamil, 1983, p. 23).

Além da competição com destinos tradicionais e qualificados ${ }^{55}$, da sazonalidade, da falta de infraestruturas urbanas, e da flutuação cambial, um dos maiores desafios para que o turismo possa se desenvolver de maneira mais sustentável é a assimetria de poder entre os diferentes agentes produtores e consumidores do espaço da cidade. Desta maneira, a atividade somente se desenvolverá de modo sustentado se atentar para as demandas dos demais setores da sociedade, especialmente, os desprivilegiados, em termos da oferta de equipamentos de consumo coletivo, de infraestruturas, de empregos e da possibilidade de exercício da cidadania, e, no que concerne a esta tese, pela qualificação do ambiente pela valorização da paisagem.

\footnotetext{
${ }^{55}$ Somente na sub-região do Mercosul existem com estas características: Punta del Este, no Uruguai, Mar del Plata, na Argentina, além dos próprios destinos nacionais e estaduais, como Balneário Camboriú, 100 quilômetros ao norte da llha
} 
A paisagem natural e transformada ao longo dos anos pode ser considerada, ainda, como um patrimônio de valor inestimável. Este patrimônio pode ser compartilhado pela população residente e por visitantes atraídos pelo turismo na medida em que os impactos ambientais negativos provocados pela atividade, entendidos como limitadores da qualidade de vida da população usuária do espaço insular, e os impactos benéficos se reflitam também na manutenção da paisagem. O estudo mais aprofundado da paisagem merece um capítulo a parte. 


\section{PARTE III}

A Paisagem em Evidência 


\section{CAPÍTULO V}

\section{A DINÂMICA DA PAISAGEM NA ILHA DE SANTA CATARINA}

A análise da estrutura natural do território, da humanização deste território e do processo de desenvolvimento turístico da llha de Santa Catarina permite avançar no sentido de uma leitura de sua paisagem, sintetizando a inter-relação destes fatores na formação do ambiente.

Conforme dito anteriormente, para a compreensão da paisagem do objeto de estudo foram utilizadas três escalas de abordagem da paisagem, cada uma inter-relacionada com a outra, cuja ruptura da continuidade espacial só assume sentido se considerado o recorte analítico desejado.

\subsection{O mosaico paisagístico e as principais áreas homogêneas}

A primeira escala abordada abarca as grandes áreas homogêneas, naturais e construídas pelo homem, que formam o mosaico paisagístico global da llha de Santa Catarina, estudada a partir de mapas e cartografia adequada (1:50000). Na escala da cidade e da llha, buscou-se superar o caráter estático dos mapas com o acompanhamento de distintos momentos da evolução urbana de Florianópolis, utilizando-se ortofotocartas dos anos de 1938, 1957, 1977 e $2002^{1}$.

O estudo do território a partir da evolução cartográfica permitiu identificar as principais áreas homogêneas que compõem o mosaico paisagístico, peças do território com relativa unidade interna quanto a suas características geomorfológicas e de cobertura vegetal, e áreas artificializadas dominadas por assentamentos humanos, as características de homogeneidade morfológica dos tecidos urbanos ou áreas agrícolas, que articuladas definem a estrutura territorial.

As principais áreas homogêneas incorporam mais de um sistema natural, na medida em que sistemas geomorfológicos interagem com sistemas bióticos de cobertura vegetal e assentamentos humanos, formando unidades de áreas, abaixo identificadas. 1 Obtidas de mosaico montados pela empresa AEROCONSULT com fotos aéreas de sobrevôos realizados naque-
les anos e cedidas pelo IPUF. 


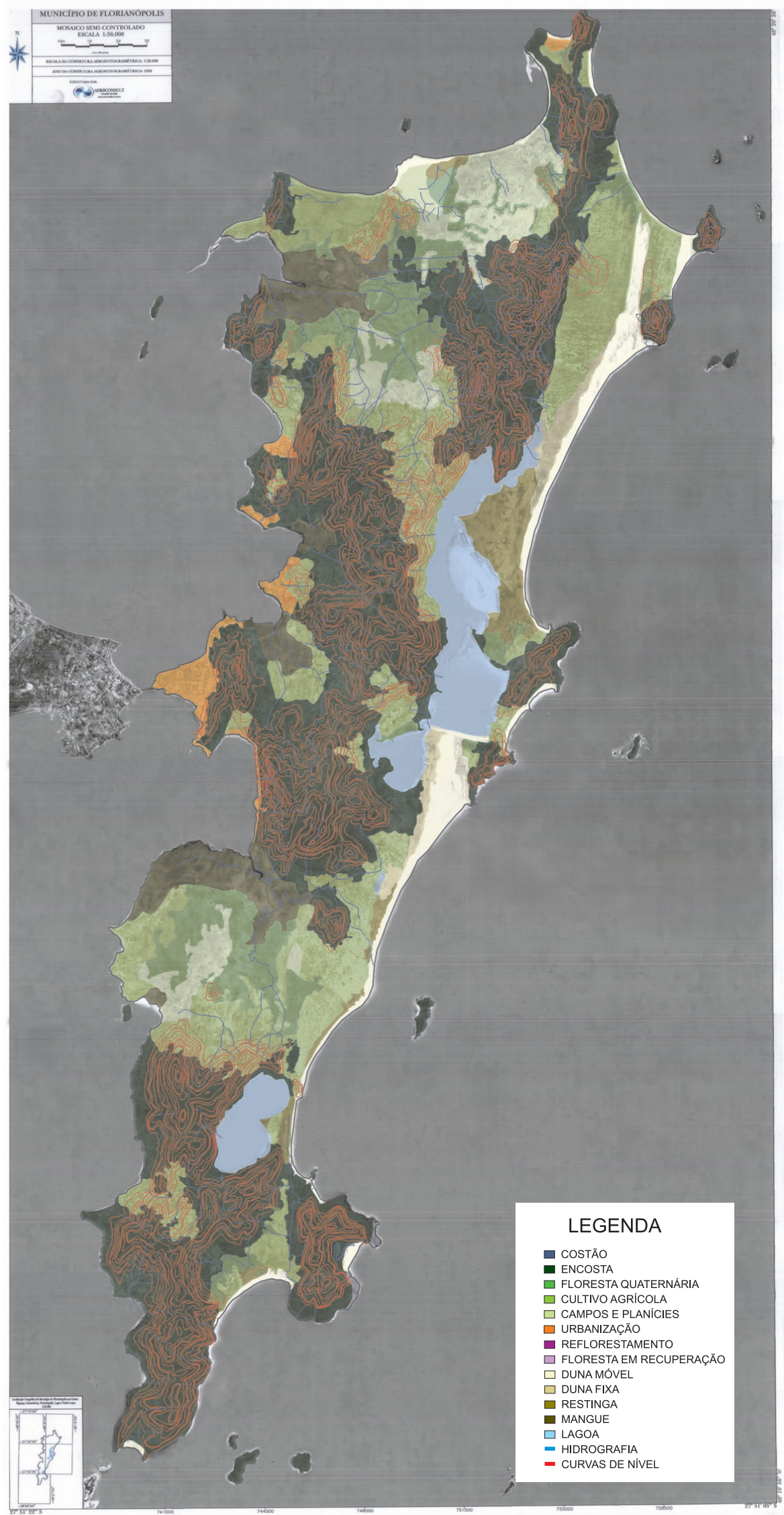

Figura 5.1: Mapa sobre aerofoto de 1938. 


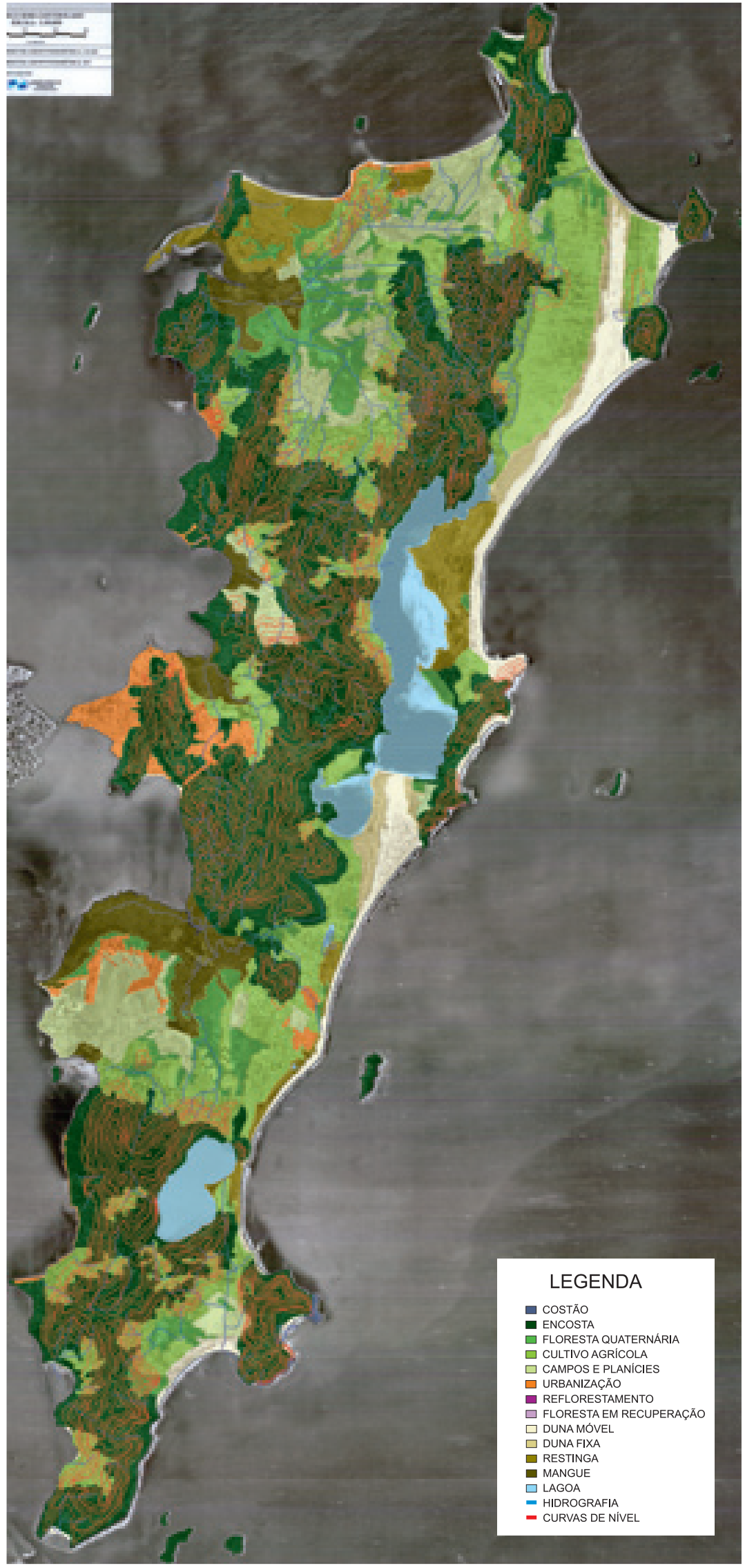

Figura 5.2: Mapa sobre aerofoto de 1957. 


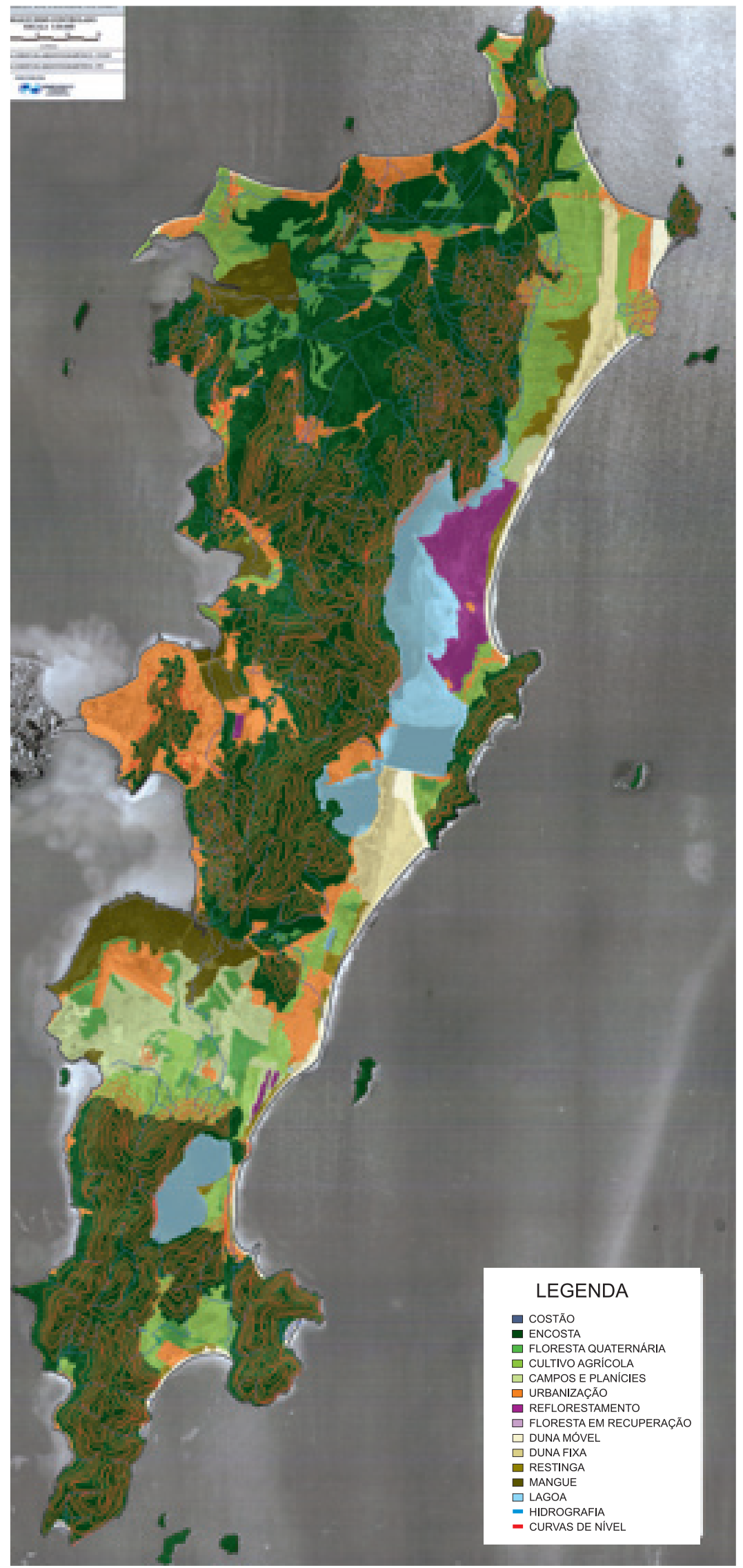

Figura 5.3: Mapa sobre aerofoto de 1977 


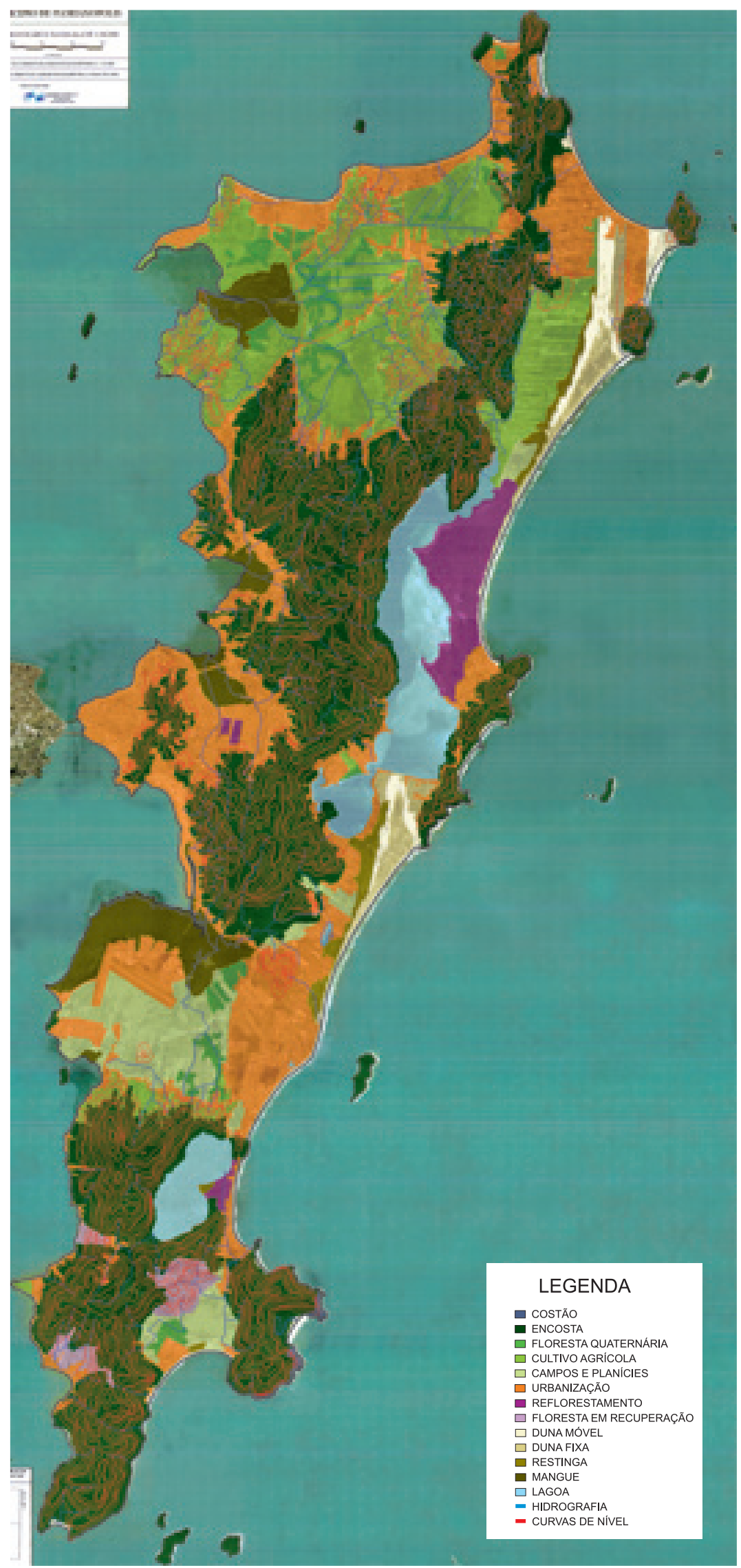

Figura 5.4: Mapa sobre aerofoto de 2002. 


\section{Principais áreas homogêneas com predomínio de elementos naturais}

Dos diferentes sistemas naturais, alguns se destacam pela maior percepção visual na paisagem, e são eles.

Morros e encostas - a mais extensa, contínua e visualizada porção do território, formada por maciços graníticos ou de basalto, com altitudes entre 150 e 519 metros (maior altitude) e declividades variadas. Elemento da paisagem mais presente e característico da ilha, e que se encontra em processo de recuperação de sua cobertura vegetal de origem. Abriga diversas espécies biológicas de flora e fauna (algumas em extinção). Serviram e ainda servem (com bem menos intensidade) de fonte de matéria prima para o modo de vida tradicional. A parte baixa dos morros, mais próxima das planícies, geralmente com declividade menor, com vegetação secundária em regeneração, formada de capoeira, capoeirão e mata atlântica, constituem as encostas. O conjunto de morros e encostas recobertos de vegetação forma a base mais extensa de área homogênea da ilha e são transição entre estas e as áreas urbanizadas ou periurbanizadas. Ecologicamente, têm importância por conter as vertentes - vales por onde correm as águas, com variado perfil que apresentam grande significado ecológico e que irão formar os principais rios e lagos. Além do valor ecológico das vertentes, em algumas áreas apresentam cascatas de grande valor para recreação e a paisagem. Embora a maior parte das vertentes se encontre protegida por legislação e pela localização interiorizada nas matas dos morros e encostas, a ameaça se faz presente em muitas delas pelas ocupações humanas adjacentes, devastando a mata ciliar de proteção, além da utilização de suas águas para uso doméstico e/ou recepção de dejetos. Em termos cênicos, a importância dos morros e encostas reside em sua plástica configuração, com declividades diversas, transição entre sistemas vegetais distintos, e a sua fragilidade ecológica se expõe com a ameaça da ocupação humana inadequada, através de retirada da cobertura vegetal, da conseqüente erosão e do assoreamento de vertentes. A massificação e continuidade de edificações nas encostas, interrompendo fluxos biológicos entre morros e planícies, causa impacto visual negativo pela sensação de urbanidade intensa.

Planícies quaternárias com vegetação de restinga (florestas e vegetação arbustiva e rasteira) - cordões sedimentários mais fixos que as dunas, formando ora planícies costeiras de marismas, ora cordões de relativa altitude, separando planícies interiores do mar. Essas grandes extensões de terra plana, originários dos terrenos eleva- 
dos de depósitos de transição e sedimentares aluviais, apresentam vegetação rasteira e arbustiva de regeneração (capoerinha ou capoeira) ou não, intercalada por florestas de transição entre a mata atlântica e restingas, que formam pequenas faixas contínuas ou pequenos agrupamentos dispersos, restos de florestas de planícies quaternárias. São viveiros e hábitat de diversas espécies biológicas naturais da llha, e destacam-se na paisagem por permitir uma visão ampla e horizontalizada. Historicamente, serviam, e ainda restam exemplos, para a agricultura e pecuária, e, atualmente, para os assentamentos periurbanos. Por sua configuração, são os solos mais demandados para a expansão da cidade. Ecologicamente, os sistemas presentes nas planícies têm a função de conectar encostas e morros, por meio de corredores naturais ainda existentes. Boa parte dessas planícies apresenta baixas declividades $(<2 \%)$ e funcionam como importantes peças no regime hidrológico da llha ao absorver das águas escorridas dos morros. A principal ameaça é a ocupação humana, que tende a incorporá-los como áreas urbanizáveis, com previsíveis, se urbanizadas sem plano de drenagem, problemas hidrológicos nas áreas úmidas ${ }^{2}$. É a área homogênea mais artificializada desde o período colonial quando foram intensamente utilizadas para agricultura e pastoreio e tem perdido grande continuidade que apresentava, originalmente, ao longo da costa leste, especialmente no Campeche e no Rio VermeIho, que, vêm sofrendo agressões irreversíveis por assentamentos humanos, num ritmo forte, desde os anos 1980. As planícies do norte da llha já estão bem comprometidas com a urbanização desde os anos 1970, nas franjas mais próximas da orla. Algumas importantes áreas ainda mantêm alguma integridade: a planície do Pântano do Sul, no sul da Ilha, na planície do Campeche, no centro da Ilha, e junto da Estação Ecológica de Carijós e da bacia do Rio Ratones, no norte da llha. Mesmo com o Parque Florestal do Rio Vermelho reflorestado por espécimes exóticos, tem potencial paisagístico de interesse turístico. Inclui-se, por razões de percepção, nesta área homogênea, a praia, área de transição entre a terra e o mar, com grande interesse paisagístico e de uso para recreação, que é formada pela linha imediatamente junto à orla do mar, geralmente uma estreita faixa de areia e cordões de restingas, com vegetação específica, sob influência direta das oscilações do nível do mar.

2 Os campos comunais eram áreas de uso comum para pastoreio e extrativismo, e atualmente se encontram apropriados em mãos de investidores e mercantilizados (ver Nazareno Campos, 1988), ocupando muitas planícies úmidas. 
Reflorestamento espécies exóticas - áreas com reflorestamento feito, geralmente, à base de espécies de pinus exóticos e eucaliptos, formando grandes porções homogêneas e contrastantes com o entorno originário. Geralmente em planícies, áreas úmidas, restingas e encostas. Ainda que a presença vegetal não seja de todo desagradável, formando paisagens muitas vezes atraentes (como no caso da rodovia que atravessa o distrito do Rio Vermelho, na direção norte-sul na U.T. Leste) não se trata de elemento ecológico local. Em função das espécies utilizadas, a diversidade faunística e de flora complementar é pobre. Hoje em dia, a utilização da madeira extraída já não apresenta valor econômico considerável. Dispersos por todos os recantos da llha, mas com a maior concentração no Parque Florestal do Rio Vermelho, leste da llha, por sobre a restinga. Atualmente, no caso do parque, existem intenções de sua substituição por vegetação nativa.

Dunas - ambiente territorial dinâmico com predomínio de cordões de areia, expostos ou recobertos por vegetação rasteira dispersa, geralmente com forma alongada, junto a praias, ordenadas a partir da configuração do relevo e da ação de dos ventos. Tem interesse ecológico especial, pela diversidade de espécies de flora e fauna, e paisagístico, pela raridade de sua ocorrência e por sua configuração contrastante com as demais áreas homogêneas. Tem mantido a maior parte de sua área, que se apresenta fragmentada em duas grandes porções, ambas na costa leste da llha: dunas da praia dos Ingleses e Santinho e dunas da Joaquina. São protegidas por lei, mas ainda sofrem agressões nas bordas, especialmente nas que mantém contato com assentamentos humanos em expansão e nas que exploram atividades decorrentes do turismo, como esportes e caminhadas de grupos grandes de pessoas.

Mangues - espaços de transição entre um sistema fluvial e um ambiente marinho raso, com bancos salientes ou submersos, formando um sistema distinto com formações de areias porosas, com vegetação arbustiva e arbórea específicas. Em alguns casos, servem de área de extração de moluscos para subsistência de populações tradicionais. Perderam partes significativas nos últimos anos, mas tendem à estabilização pela maior fiscalização e tomada de consciência ambiental. Mantêmse como as manchas mais íntegras, embora dispersas, do mosaico paisagístico, embora não existam áreas de amortecimento entre elas e a urbanização.

Lagoas/Lagunas - corpos hídricos de água doce ou salobra conectados, de modo permanente ou sazonal, ou simplesmente não conectados ao mar, considerando-se tam- 
bém seu entorno imediato, geralmente formado por charcos ou encostas de morros com vegetação fluvial-marinha. Além da diversidade biológica que abrigam, têm grande reconhecimento por sua singularidade e configurações morfológicas, sendo valorizadas também para subsistência do modo de vida tradicional. São áreas que recebem forte valorização afetiva da população pelo grande impacto paisagístico, refletido em duas grandes lagoas: a do Peri, no sul da ilha, protegida por parque municipal, mas ainda com atividades humanas rurais e residenciais; e a Lagoa da Conceição, no centro-leste da llha, com boa parte de sua porção sul cercada de assentamentos humanos que promovem agressões à qualidade das águas, além de privatização de bordas. Além dessas, e duas pequenas lagoas na planície do campeche, a da Chica e a Pequena, também se encontram ameaçadas pela ocupação humana próxima. Também não apresenta, áreas de amortecimento entre elas e a urbanização, o que tem trazido problemas de contaminação de águas e permitido a apropriação privada das bordas.

Costões - encostas de rochas de certa altitude, que chegam ao mar com grande declividade, sem vegetação. Formam um valor paisagístico importante, principalmente quando se olha do mar para a terra, em passeios marítimos, pela verticalidade com que se projetam no oceano. Apresentam fauna marítima de subsistência para os moradores locais. Podem ser incluídas neste tipo de área homogênea, as costas com rochas escalonadas - transições entre o terreno montanhoso de morros e do mar, formado por mesclas de rochas escalonadas e depósitos aluviais, formando vertentes arredondadas e pontas avançando de modo suave no mar. Em alguns casos apresentam beleza singular, pela presença de rochas soltas no mar. Em geral limitam baias das praias.

Ilhas vizinhas - pequenas ilhotas a pouca distância da llha principal, geralmente com vegetação de bosque ou de escarpas desnudas de vegetação, e poucos espaços de praias. Elementos singulares no mar, em geral formados por encostas escarpadas, e em raras ocasiões, por praias, voltadas para a ilha principal, tem presença cênica importante para a valorização paisagística.

\section{Principais áreas homogêneas artificializadas}

Os assentamentos humanos, conforme sua tipologia, têm diferentes repercussões na estrutura territorial e paisagística da llha de Santa Catarina, o que justifica uma 
taxonomia das ocorrências, ainda que estejam mapeadas na escala da llha e tratadas de modo único como urbanizações. A diferenciação entre os tipos se é feita na análise das unidades de paisagem.

Urbanização central - complexo agrupamento de peças de distinta morfologia na cidade permanente, onde se concentram as atividades urbanas que dependem, direta e intensamente, da aglomeração. Apresentam diferentes tipos morfológicos, todos com completa transformação do território. Tem limites no mar e as encostas mais inclinadas do maciço central.

Malha ortogonal regular - desenho derivado da geometria regular, desde a quadrícula xadrez a combinações mais labirínticas, estas em geral com delimitações bem marcadas. Presente na aglomeração central colonial e suas expansões, em bairros novos cerca dela e nos assentamentos dispersos da costa. Apresenta-se em variados tamanhos, porém com dimensionamento das vias urbanas, de acordo com padrões funcionalistas. Quanto às altitudes, se observam variações entre um (1) e dois (2) pavimentos, na maioria das vezes, e até quatro (4) a oito (8) pavimentos que, em algumas vezes, se localizam junto à praia.

Cidade Jardim - enclaves urbanizados com desenho derivado do princípio da cidade jardim. Morfologicamente, sua malha viária apresenta derivações de estruturas orgânicas, ainda que com dimensões funcionais. Geralmente com baixa densidade construtiva e demográfica, em edifícios de dois pavimentos, ainda que algumas mais recentes já apresentem mais alturas (até 4 pavimentos).

Malha ortogonal irregular - morfologia resultante de crescimentos dispersos no tempo e espaço, formando tramas não contínuas e nem sempre retilíneas. Caracterizada pelas altitudes de dois pavimentos e a alta e extensiva ocupação do solo, em especial nos novos assentamentos. Nos assentamentos tradicionais costeiros, as irregularidades lembram tecidos urbanos medievais.

Espinha de peixe - Morfologia vertebrada por um grande eixo principal do qual partem, de um e outro lado, eixos (vias) menores, numa seqüência repetitiva, algumas vezes contínua e em outras, um pouco mais espaçada e de menor freqüência. Predomínio de até dois pavimentos de altitude.

Pente - forma urbana vertebrada a partir de um grande eixo com vias menores, como a espinha de peixe, porém, predominantemente, para um só lado do eixo. 
Assentamento rural - conjuntos ou casarios isolados, nas encostas ou morros de instalações rurais (engenhos e depósitos) ou de residência de trabalhadores rurais. Atualmente, escassos e dispersos na paisagem já recortada e mais complexa, porém, estruturou a paisagem colonial, pela regularidade de distâncias e implantação privilegiada.

Com estes estudos, é possível constatar a rapidez da transformação da paisagem insular no sentido da artificialização, especialmente da segunda metade do século XX em diante, dimensionando o crescimento ou redução dos principais elementos constituintes da paisagem, ecossistêmicos e urbanos, em cada momento.

Nessa escala de abordagem, fica clara a força transformadora de dois principais momentos no processo de formação da cidade e de seu território insular, que se sobrepuseram sobre a paisagem matriz, representados por duas paisagens: a paisagem colonial e a paisagem da urbanização turística. As duas se fazem presentes hoje, por sobre a paisagem original, constituídas por uma diversidade de áreas naturais, semi-

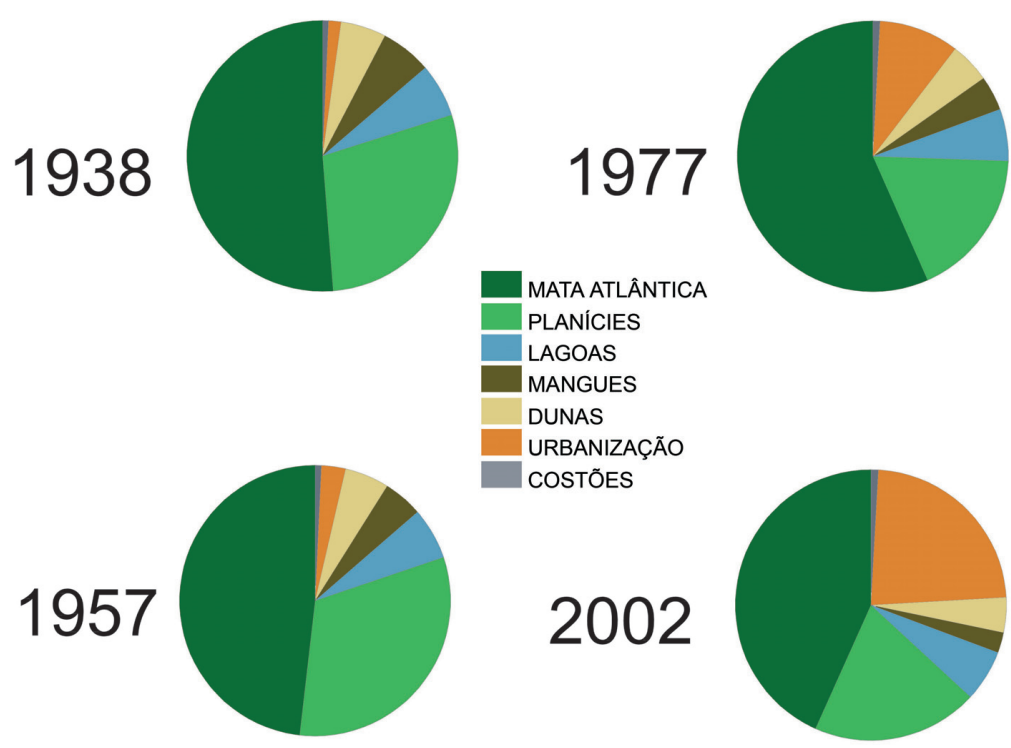

Figura 5.5: Evolução das áreas homogêneas. naturais ou aculturadas, resultando num, ainda, formidável patrimônio paisagístico.

\section{A paisagem matriz}

Para efeitos de comparação, parte-se da paisagem imaginada antes da ocupação humana definitiva descrita por Caruso (1990) como original, em que o ambiente da llha se apresentava com diversidade e equilíbrio entre as diferentes áreas homogêneas, com predomínio das matas em morros e encostas seguidas das planícies sedimentares, de restingas ou com vegetação rasteira, mangues, dunas e corpos hídricos. Conforme aquele estudo as proporções entre os principais elementos 
Os estudos de Caruso sugerem que as florestas de mata atlântica e de planície quaternária cobriam $74 \%$ da área da llha, a vegetação litorânea composta cobria $16 \%$ da área da llha, sendo $9 \%$ de mangues e $7 \%$ de vegetação de praia, dunas semi-fixas e fixas pela vegetação e restingas; as dunas desnudas ocupavam $4 \%$ e as lagoas. $6 \%$ da área da llha.

As intervenções pré-européias, mesmo com desmatamentos para agricultura estável e fixação de contingentes populacionais, não chegaram a alterar de maneira perceptível o ambiental original.

\section{A paisagem colonial}

As transformações mais impactantes na paisagem aconteceram durante os séculos XVIII, XIX e início do século XX, decorrentes da intervenção colonial. A ortofotocarta de 1938, mesmo não representando o momento mais intenso desta transformação, ainda guarda a imagem do que se pode chamar de paisagem colonial, pois foi no início daquele século que a atividade rural começou a entrar em decadência. Os núcleos e assentamentos humanos só haviam assumido dimensões impactantes, considerando a escala da Ilha inteira, na região do centro histórico, e as vias de circulação ainda mantinham as mesmas características e traçados do tempo da formação do espaço rural-litorâneo. Deste modo, é possível fazer a leitura da paisagem colonial a partir desta carta.

Na paisagem de 1938, após mais de dois séculos de ocupação, ainda era percebido o grau de afetação promovido pela atividade agro-pecuária, que até então exportava os excedentes em nível regional e, por aquele momento, servia somente para subsistência das famílias. Esta atividade marcava com mais presença o território insular interiorano e da orla, já que a urbanização densa se concentrava na região central, ocupando área relativamente pequena. Apesar das inadequações do uso do solo pela agricultura colonial, grandes porções do território foram mantidas sem ocupação de alto impacto, e se não permaneceram intactas, ao menos restou a capacidade de regeneração da cobertura vegetal que se revelou após a decadência da atividade.

No nível da estruturação urbana, estabeleceu características únicas que dão especificidade para a Ilha de Santa Catarina. A estruturação polinucleada de assentamentos urbanos pontuando a orla e interior, isolados por grandes áreas abertas de agricultura, recortadas por caminhos no sopé dos morros, nas encostas de baixa declividade 
ou por sobre charcos, emolduradas por morros dominados pelas plantações. Esta característica se torna específica na medida em que é singular dentre as paisagens de outras imigrações colonizadoras do país, tornando-se traço cultural de um modo de apropriação espacial, contribuindo para a formação de um patrimônio paisagístico com potencial de atração de visitantes interessados na cultura espelhada no território.

\section{A paisagem urbano-turística}

Com os primeiros passos da urbanização e da atividade turística, o final dos anos 1950 mostra que, com gradativo abandono das atividades agro-pastoris, a cobertura vegetal dos morros e encostas e de algumas planícies veio se recuperando, boa parte com sua expressão original. Mas já se percebe a ocupação urbana mais intensa fora dos limites da zona central, ocupações e modificações de leitos de rios e riachos em ecossistemas que haviam sido preservados pela agro-pecuária: antigas terras comunais, especialmente, as planícies de inundação com áreas úmidas de pântanos e charcos.

Estas transformações se concentraram na Unidade de Território Norte, na bacia do Rio Papaquara, que desemboca no mangue que hoje conforma a Estação Ecológica de Carijós, e na Unidade de Território Central, na bacia do Rio Tavares, que desemboca no mangue da atual Reserva Extrativista Pirajubaé.

Já a partir de 1977, a tendência de ocupação urbana da franja litorânea, já impulsionada pelo turismo, se faz notar com mais intensidade, se espalhando ao norte e ao sul da llha. Geralmente, essa expansão surge a partir de núcleos urbanos coloniais, ainda relativamente pequenos, mas já são percebidos indícios de expansões isoladas, ainda que próximas daqueles núcleos.

Neste período é possível perceber, também, ocupações não tão turísticas, como a que se implantou na Planície do Campeche, próximo à praia, com característica predominante de residências permanentes, em um tecido urbano com padrão menos atrativo a turistas e fora dos padrões de legalização normatizados pela administração pública. É evidente o predomínio da ocupação turística legalizada na região norte da llha, principalmente pelas facilidades de acessibilidade, mas também pela qualidade das praias e pela temperatura da água. A diminuição das áreas e a fragmentação das principais peças de em planícies do mosaico, como as restingas e as planícies, úmidas ou com vegetação rasteira, já é cartograficamente notável. 
Esse processo de redução e fragmentação dessas áreas é fortemente evidenciado no mosaico de 2002, atingindo setores na costa nordeste da llha, especialmente nos distritos do Rio Vermelho e Ingleses. Nesse período, o capital turístico se encontra em fase de especialização, ao mesmo tempo em que a consciência ambiental também vem se profissionalizando, as áreas de mais fácil ocupação para a atividade turística estão escasseando e se distanciando da primeira franja costeira, fugindo do padrão sol e mar com intensa ocupação frontal à linha da costa.

A paisagem atual permite constatar que o modelo turístico expansivo e consumidor de terras, espacializado em loteamentos de segunda residência e associado à expansão de ocupações e loteamentos irregulares, tende a esgotar as possibilidades desses tipos de crescimento físico num futuro não muito distante, num âmbito estritamente espacial, pela falta de terras, sem considerar aqui as reações da sociedade, que já se fazem notar, em grupos de defesa do ambiente e associações de moradores, ainda que sempre de uma perspectiva localizada e sem evidente percepção da totalidade territorial, nem questões de economia de mercado, que sofrem influências internas e externas.

Nesta escala de apreensão da paisagem é perceptível o avanço da urbanização intenso por sobre as planícies. Mesmo que seu uso rural tenha alterado boa parte de suas funções e substituído a cobertura vegetal, foram mantidas a permeabilidade $\mathrm{e}$ porções amplas com cobertura vegetal, caracterizando um território ainda pouco artificializado. O impacto da urbanização tem efeitos ecológicos mais prejudiciais pela substituição da cobertura vegetal, pela impermeabilização e pela contaminação do solo, além de alterar percepções cênicas de paisagens culturais históricas de valor, com alto potencial de aproveitamento turístico.

O processo de intensa artificialização do território tem como resultado externalidades negativas, tanto para a cidade como para a atividade turística, seja na perda dos atrativos naturais absolutos - diminuição e desaparecimento de elementos e recursos naturais ou pouco artificializados, como pela perda de aproveitamento do potencial de atração do turismo que o patrimônio paisagístico criado pela artificialização. Aqui falamos do natural associado ao cultural, incluindo as terras agro-pastoris e mesmo as ocupadas pelo turismo que formam a estrutura polinucleada de assentamentos que vem sendo ameaçada pela extensividade da expansão urbana. 
Fica evidente, neste nível de investigação, que ao se subtrair o território e as características que qualificaram os elementos da paisagem original e da paisagem colonial, que dão suporte para que a paisagem da llha se concretize como destino turístico, aumenta o risco de inviabilizar, se mantido o modelo adotado, o desenvolvimento da atividade.

Numa outra escala de abordagem, foram sendo identificadas unidades territoriais progressivamente menores até a definição das unidades de paisagem. Esta aproximação permitiu o entendimento de características morfológicas e cênicas, bem como da dinâmica das unidades de paisagem, abrindo caminho para a valoração de trechos específicos do território.

\subsection{As Unidades de Paisagem da Ilha de Santa Catarina}

A próxima escala de trabalho, na qual se utilizou instrumental cartográfico e visual/ perceptivo, possibilitou a delimitação e a análise de Unidades de Território e das Unidades de Paisagem, onde é aprofundado o estudo das formas físicas que constituem o território da llha de Santa Catarina. Nesta abordagem, além de maior aproximação à cada unidade, por meio do estudo das características geomorfológicas e das ações de humanização do território, foram feitas análises da condição de conservação e ameaça dos elementos constituintes de cada área homogênea, bem como a valoração social e ecológica com vistas ao seu potencial de aproveitamento pela atividade turística.

A primeira aproximação ao território da llha de Santa Catarina, apesar de basear-se nos aspectos geomorfológicos gerais sugeridos pelo trabalho de Cruz (2000), considera também aspectos humanos e perceptivos, e se aproxima mais do zoneamento do Plano de Desenvolvimento Turístico de Florianópolis (IPUF-1999), ainda que apresente diferenças de escala de abordagem.

A partir dessa aproximação geomorfológica, associada à identificação dos setores paisagísticos gerais componentes do mosaico territorial da llha de Santa Catarina, foram definidas seis grandes Unidades de Território: U.T. Centro-Oeste, envolvendo o cento urbano da cidade e bairros conurbados contíguos; U.T. Centro-Norte, que é formada pelas áreas insulares voltadas para a baía, imediatamente ao norte da região central; U.T. Norte, compreendendo as áreas do norte da llha a partir da inflexão da dorsal de morros em direção a nordeste; U.T. Leste, definida pelas planícies marinhas, morrotes, promontórios 
e praias a leste da dorsal; U.T. Planície Central, conformada pela extensa planície que corta a continuidade longitudinal de norte a sul da dorsal granítica central; e U.T. Sul, definida pela dorsal central em sua porção sul e pelas planícies marinhas, a leste e sul dela, praias e promontórios que se estabelecem a leste, oeste e sul dos morros.

\section{Unidades Territoriais}

\section{Unidade de Território Norte}

Região com equilíbrio entre morros recobertos com bosques de vegetação primária (floresta subtropical ombrófila) e secundária (capoeira e capoeirão) e planícies com matos dispersos e pastagens por onde se expande uma grande bacia fluvial, formada nas vertentes ao Sul e Leste, que desemboca no mar formando um grande mangue, delimitada por um grande anfiteatro orientado ao Norte formado pelos maciços e morros. Os morros, de altitude máxima perto de 300 metros apresentam junto às planícies declividades suaves, o que permitiu sua intensa exploração agrícola na época colonial. Pequenos morros dividem as praias, orientadas ao Norte e

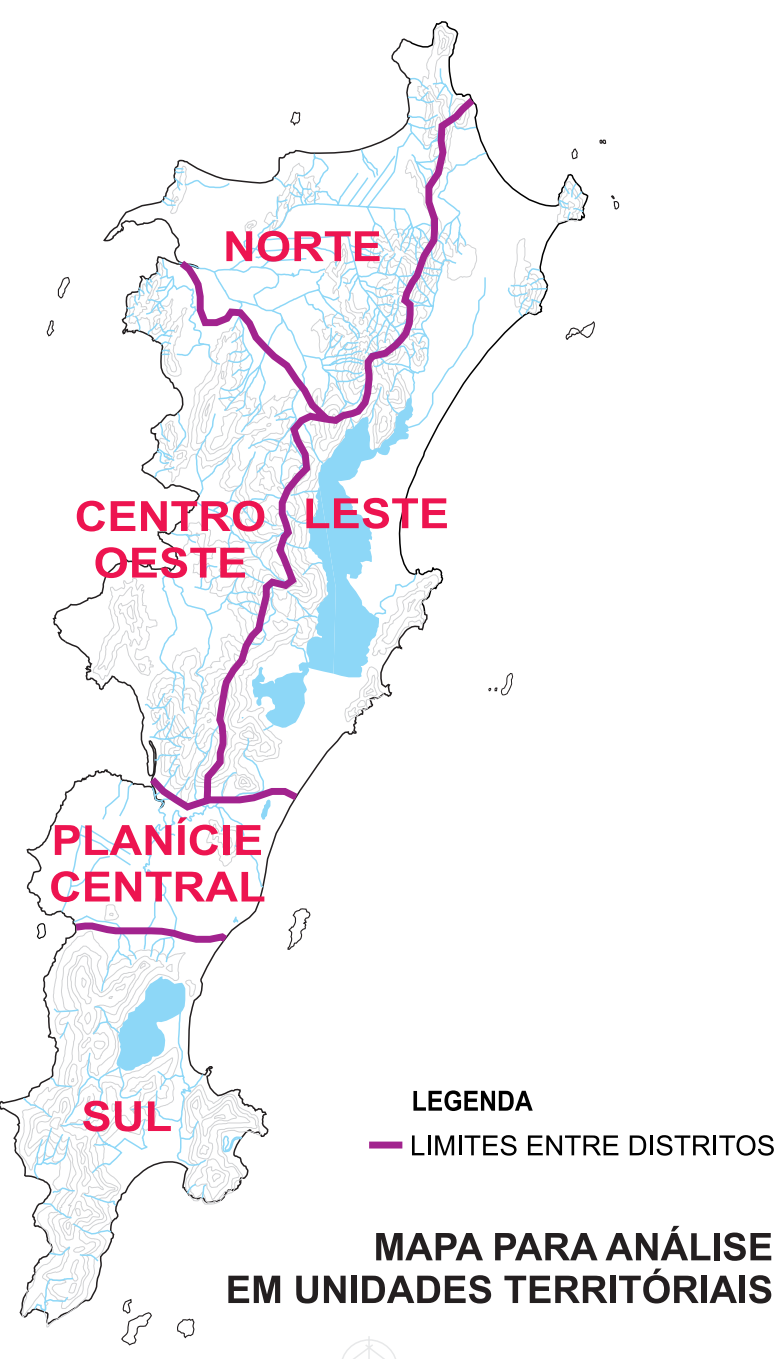

ESCALA GRÁFICA 0

Figura 5.6: Unidades Territoriais. Leste, e as maiores assumem formas de arcos elípticos alongados.

Com acessibilidade facilitada por estrada, sua ocupação atual é devido ao aproveitamento dos benefícios da orla marítima. São encontradas distintas construções urbanísticas de tipo malha ortogonal regular (maioria de segunda residência), bem como o recente uso de áreas rurais desativadas, em rincões mais interiorizados, para residência de grupos sociais de menor renda, distribuídas ao longo das vias de interiorização em periurbanizações, em forma de espinha de peixe. As tipologias arquitetônicas apresentam, em geral, altitude 
de dois pisos, porém, nas edificações urbanas, junto à costa, apresentam alturas de até oito pisos, contudo, não chegam a formar uma barreira contínua.

Faz parte dessa Unidade de Território uma grande área protegida por legislação federal, a Estação Ecológica de Carijós, ainda que sua configuração, descontínua, já se encontre bastante alterada pela implantação de canais de drenagem, com muito impacto sobre os ecossistemas ali presentes.

\section{Unidade de Território Leste}

Conformada por um maciço contínuo, orientado de sudoeste a nordeste, que separa a bacia hidrográfica da Lagoa da Conceição, grande lâmina de água salobra domina a região. Este lado apresenta vertentes escarpadas, recobertas de vegetação primária (nos topos) e secundárias (nas encostas mais baixas), inclinadas até à lagoa e às grandes planícies sedimentares, separando a dorsal do oceano. Existem morros e promontórios isolados, junto à orla, separando as baías das praias, que por sua vez apresentam formas suavemente arqueadas.

A planície do Rio Vermelho, a mais extensa, ao norte da Unidade, é formada por terrenos arenosos e dunas, apresentando grandes alterações devido à ocupação agrícola colonial (apesar da baixa qualidade do solo), hoje em processo de esgotamento, e mais recentemente, pela periurbanização em forma de pente, de baixa altitude e densidade, a partir do atual sistema viário de vertebração, que corre de norte a sul, com os dentes do pente se prolongando até Leste, chegando ao limite das dunas e por sobre a vegetação de restinga em regeneração e já ultrapassando a via do Travessão, via estrutural da época colonial. O Parque Estadual do Rio Vermelho se encontra nessa porção, e constitui, apesar do nome, numa intensa transformação da vegetação original, pois se trata de um imenso reflorestamento com espécies de pinheiros exóticos.

As encostas dos maciços da dorsal norte apresentam grande declividade na borda da laguna, porém, não impede uma ocupação histórica nas partes menos inclinadas por assentamentos de forma linear descontinua, de baixa densidade e altitude, herança da ocupação agrícola colonial que muito impactou a vegetação de encostas, agora em processo regenerativo. 
Junto à parte em que ela se estreita e permite a conexão viária, se encontram dois âmbitos naturais: os terrenos arenosos e as dunas de Leste, e a planície sedimentar que se expande do pé do morro até a laguna, com poucas áreas de vegetação secundária e matas em regeneração, devido à intensa ocupação urbana ali situada. Essa ocupação apresenta distintas formas: malhas ortogonais irregulares ${ }^{3}$ de expansão espontânea de média e baixa renda, edificações de alta renda em malhas regulares e orgânicas, bem como espinha de peixe e pente.

A complexidade da paisagem reflete a importância dessa parte no entendimento da Unidade. Na costa Sul da lagoa e ao Sul dela, a ocupação se conforma, ora em uma sinuosa espinha de peixe, que acompanha a borda lacustre, ora em enclaves de maIhas regulares e um enclave urbano isolado tipo cluster. Na porção mais ao Sul da Unidade, as encostas apresentam declividades variadas, espremendo a planície sedimentar contra o oceano, resultando em faixas longilíneas de dunas e restingas, boa parte protegida por legislação.

\section{Unidade de Território Planície Central}

Extensa planície sedimentar com terraços mais altos a Leste, inclinando ao vale fluvial a Oeste. Os destaques paisagísticos na área são um pequeno lago isolado, junto à borda Leste e um morro a Oeste com baixa altitude ( $<100$ metros). A vegetação se diferencia desde o lado continental ao lado do mar aberto, apresentando desde mangues a Oeste, até restingas a Leste, passando por campos de pastagem e mato de vegetação secundária em regeneração. O extenso mangue é uma Estação Federal de Extração de Recursos de Marinha (Estação Ecológica Extrativista), devido à tradicional exploração de seus recursos pela população dos arredores.

A ocupação urbana e periurbana, intensificada nos últimos dois decênios, se caracteriza por derivações da morfologia da espinha de peixe, sem continuidade, com alguns enclaves de malha ortogonal regular. As tipologias construtivas apresentam baixa altura e média densidade em todos os tipos formais. Nessa U.T. se localiza a Noroeste, o aeroporto da cidade. O que exigiu grandes operações de drenagem em seu entorno, alterando a configuração natural dos canais que correm pelas ranhuras do terreno.

\footnotetext{
${ }^{3}$ A descrição dos tipos de urbanizações, como as aqui citadas, será feita no Estudo das Áreas Homogêneas, adiante.
} 


\section{Unidade de Território Sul}

Dominada pelo maciço dorsal que divide as planícies estreitas, a Oeste, daquelas mais extensas a Leste e Sul. As extensas encostas, de ambos os lados do maciço, apresentam vegetação secundária em regeneração, nas zonas mais baixas, e bosques originais, nos cumes mais altos, dotando a região de grande atrativo paisagístico. A bacia hidrográfica da Lagoa do Peri está protegida por legislação (Parque Municipal), e conserva grande parte de características próximas da original, visto que foi pouco transformada por usos agrícolas e urbanos.

Entretanto, colado à Lagoa, em área de parque se localiza uma estação de tratamento de água, com grande impacto paisagístico negativo, tanto por sua dimensão, como por sua linguagem arquitetônica. O Parque Municipal da Lagoinha do Leste enriquece a paisagem da Unidade pelas características naturais bem conservadas. Os assentamentos do lado Leste apresentam formas distintas: desde sinuosas espinhas de peixe, até expansões de malha regular, passando por enclaves urbanos em restinga com malha regular. $\mathrm{Na}$ costa Leste, a pequena extensão e a descontinuidade das planícies exprimem a ocupação em encostas de diferentes declividades, porém sempre junto à via de acesso. A baixa densidade é a característica dessa região.

\section{Unidade Territorial Centro-Oeste}

Aglomeração urbana central, densa e de múltiplas formas, contando com a presença de um conjunto de morros centrais com a maioria das vertentes em escarpas mamelonadas. Apresenta intensa ocupação, em todos seus lados, de distintas morfologias. Esta porção terá tratamento menos aprofundado que as demais unidades territoriais, em função de suas características, que a destacam pela distância às demais e pelo relativo isolamento devido à acidentes geográficos, que a confinam numa unidade porção de território voltada para o continente, ainda que, administrativamente, além de simbólica e funcionalmente, ser importante parte da llha, articuladora de toda a estrutura urbana. 


\section{Unidades de Paisagem}

A descrição e interpretação das Unidades de Paisagem (U.P.) utiliza as seguintes categorias de análise: as estruturas geomorfológicas, os principais elementos constitutivos da paisagem (naturais e humanos), o caráter da paisagem, os elementos visuais de interesse paisagístico e dos seus processos e dinâmicas intra e extra unidade.

Os limites não obedecem nenhuma demarcação rígida de fronteiras e as U.P. foram definidas a partir de diferentes pontos de observação nestes compartimentos e de diferentes graus de acessibilidade: de mirantes, vias e locais de alta freqüência de visitantes, onde bacias visuais definiram os setores menores do território.

$\mathrm{Na}$ Ilha de Santa Catarina, a partir dos locais de maior acessibilidade e visibilidade, estas bacias visuais são delimitadas de forma ampla, na maioria das vezes e no plano de fundo, ora pelo horizonte marítimo, a leste, e ora pelos distintos planos a oeste, com o mar das baías dando continuidade visual com a urbanização do continente, e num segundo plano, ao fundo, a silhueta das serras do leste catarinense. Também dificulta uma rigidez na delimitação das Unidades de Paisagem, o fato de que é comum, a partir de determinados pontos de observação, a visualização de mais de um ambiente paisagístico, o que induz a utilização de outras formas de setorização que não só as visuais.

Internamente à llha, paisagens, ora amplas e horizontalizadas, ora mais contidas, com fechamentos diversos. O fechamento dos canais de visualização se dá pelas construções ao longo de rodovias, pela vegetação lateral (nativa e exótica) próxima ou distante das vias, pelas florestas quaternárias dispersas nas planícies, pelos promontórios próximos ao mar e encostas dos morros da dorsal principal, com florestas ombrófilas densas, cujos cumes arrematam a silhueta característica do território, desempenhando papel de elemento de transição visual e ecológico entre todas as unidades e sistemas naturais.

As duas grandes massas cristalinas que constituem os morros se estendem longitudinalmente à llha, formando a dorsal principal, que por sua vez é separada pela grande planície no centro-sul da llha, separando a costa leste da costa oeste da llha bem como as bacias hidrográficas. 
Contém grande diversidade de sistemas biológicos, entre eles, espécimes da mata atlântica, que dominam a paisagem na escala de abrangência insular, e têm enorme importância na caracterização de sua imagem, sendo percebidas de variadas distâncias. Na aproximação aos compartimentos, a percepção dessas dorsais se dá, principalmente, pelo fechamento que proporcionam às visuais, a partir dos pontos mais próximos ao nível do mar, mantendo, ainda, forte presença paisagística.

A configuração da costa leste, com planícies mais largas que aquelas a oeste, é dominada por dois extensos arcos de praia arenosos com trechos de urbanização sobre vegetação de restinga, arrematados e interrompidos por galhetas e promontórios e morrotes ainda não ocupados de todo. Estes elementos, isolados da dorsal principal, com cobertura vegetal predominantemente rasteira, avançam sobre o mar e apresentam pequenas praias, gargantas e costões da pedra.

$\mathrm{Na}$ costa oeste, as planícies são mais estreitas e a linha da costa é freqüentemente interrompida por avanços dos morros da dorsal principal até o mar, apresentando recortes menores e com arcos praiais mais fechados. A urbanização se espalha em diversas baías por sobre vegetação de restinga, de florestas quaternárias e da matas das encostas. A planície divisora da dorsal, com amplas áreas de vegetação quaternária, mangue e de restinga, já apresenta urbanização de baixa densidade, compondo o mosaico.

Cada Unidade de Paisagem (U.P.) se encontra dentro de uma determinada Unidade Territorial, com a seguinte distribuição e resultou no seguinte quadro:

Quadro 5.1: Quadro de Unidades de Território e Unidades de Paisagem

\begin{tabular}{c|l}
\hline $\begin{array}{c}\text { Unidades de Território } \\
\text { Centro -Oeste }\end{array}$ & \multicolumn{1}{c}{$\begin{array}{c}\text { Unidades de Paisagem } \\
\text { Centro-Trindade, Saco dos Limões-Costeira, Saco Grande-Monte } \\
\text { Verde e Santo Antônio -Sambaqui. }\end{array}$} \\
\hline Norte & $\begin{array}{l}\text { Jurerê-Daniela, Canasvieiras-Ponta das Ca nas, Lagoinha-Praia } \\
\text { Brava, Ingleses-Santinho e Ratones-Vargem Grande }\end{array}$ \\
\hline Leste & Lagoa da Conceição-Barra da Lagoa e Rio Vermelho. \\
\hline Planície Central & Planície do Campeche \\
\hline Sul & Armação-Peri-, Pântano do Sul e Ribeirão da Ilha.
\end{tabular}


As Unidades de Paisagem situadas na Unidade de Território Centro-Oeste, voltadas para a baía interior, se caracterizam pelas encostas e promontórios à beira mar com dinâmica ocupacional de médio impacto (ocupação de áreas vazias e substituição de residências por condomínios). Merece controle localizado de intervenções de edificações e orientação de usos nas encostas e promontórios, além de zonas de amortecimento junto ao mangue. Com localização paralela ao sistema viário principal que dá acesso às praias do norte, tem aproveitamento turístico ocasional dos as-

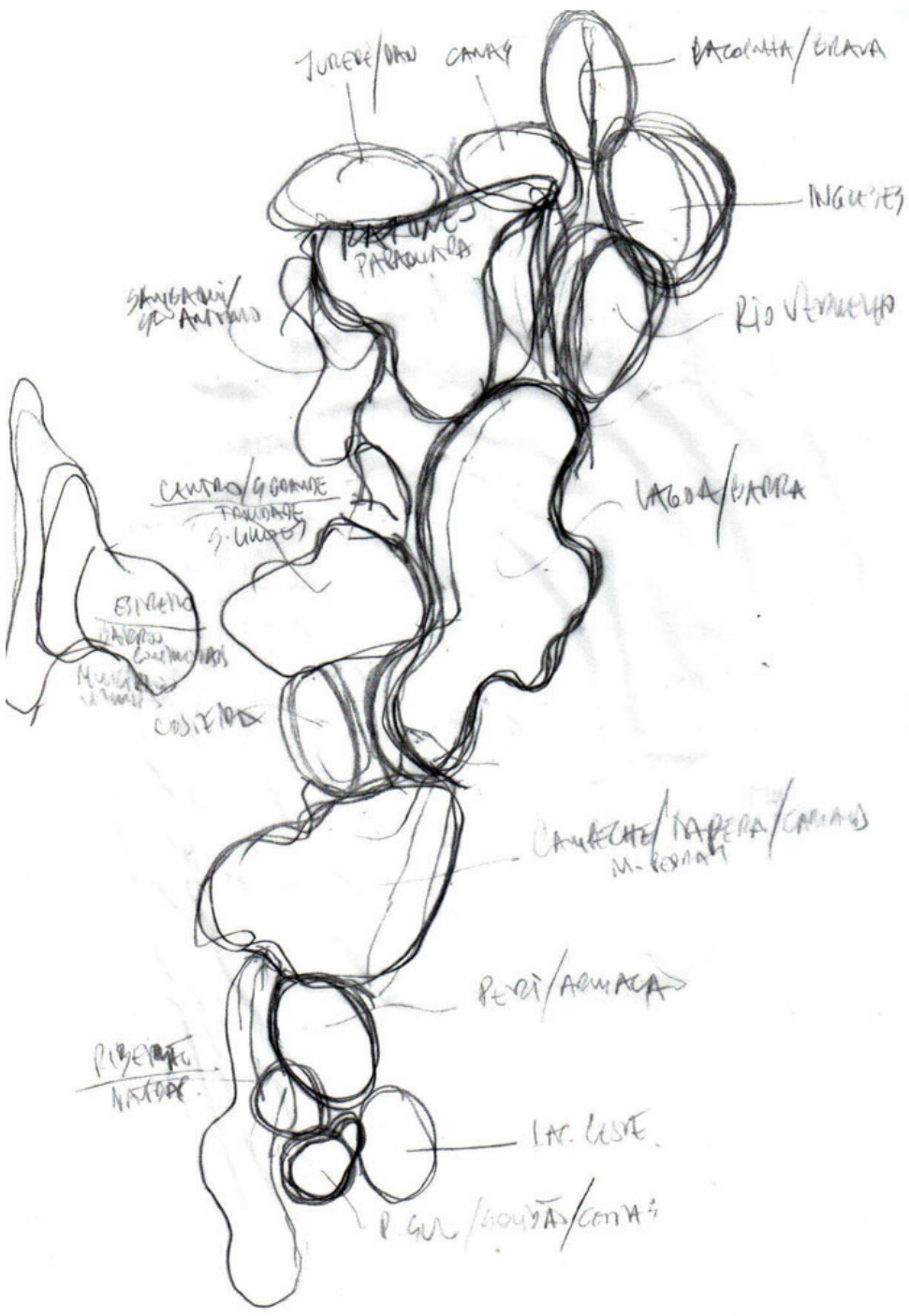

Figura 5.7: Esboço da divisão em Unidades de Paisagem.

pectos da paisagem natural e de forte valor cultural, recentemente incrementado pela opção gastronômica, especialmente nos assentamentos de origem colonial. 


\section{U.P. Centro-Trindade}

Situada no centro oeste da llha de Santa Catarina, núcleo de urbanização pioneiro da cidade. Conformado pela península que se aproxima do continente e pelas regiões adjacentes ao Morro da Cruz, e limitado pelo mar das baías sul e norte a leste pelos maciços cristalinos do espigão central da llha. Envolve os bairros do Centro, Agronômica, João Mendes, Carvoeira, Pantanal, Trindade, Santa Mônica, Córrego Grande e Itacorubi.
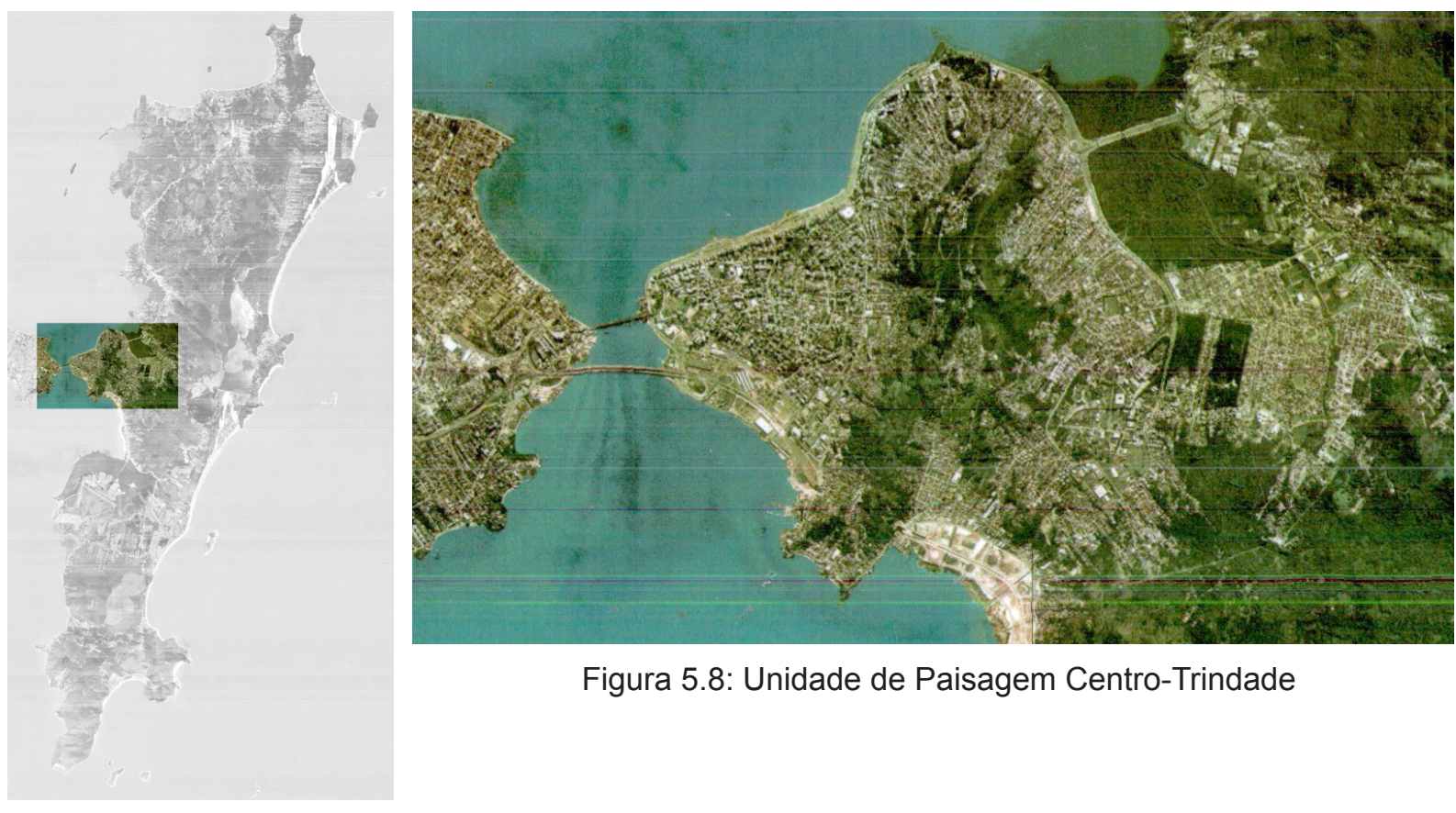

Figura 5.8: Unidade de Paisagem Centro-Trindade

\section{Elementos (naturais e humanos) constitutivos da Paisagem}

Geomorfologia e Hidrografia - matriz de morros circundados por terraços sedimentares e mangues, com altitudes entre 25 e 30 metros formando relevo ondulado, escorados no pequeno espigão cristalino da península que forma o estreito entre a ilha e o continente, com erosões que formaram vertentes suaves com patamares largos. No maciço granítico do Morro da Cruz (antigo do Antão), que domina a Unidade de Paisagem, com altura de aproximadamente 300 metros, estendido no sentido norte-sul, e que delimita aquela península, a erosão dos sedimentos formaram vales de vertentes mais íngremes. Destaca-se na unidade, o Mangue do Itacorubi, formado no nordeste da U.P., na desembocadura dos rios Itacorubi e Sertão, que descem dos morros do maciço central. Hidrologia quase completamen- 
te artificializada nas regiões ocupadas e mantendo alguma naturalidade nas vertentes mais altas. Nas encostas do morro da Cruz, a leste e oeste, a drenagem se organiza em função de vertentes com grande declividade e se reajusta em função de desvios e assoreamento provocados pela ocupação humana, o que provoca acidentes nas enxurradas.

Cobertura vegetal - excetuando pequenas porções nas partes altas do Morro da Cruz, com resquícios de mata atlântica (pouquíssimos trechos com vegetação original e secundária), a cobertura vegetal apresenta vegetação gramínea nas áreas desmatadas e trechos artificializados e dispersos na trama urbana. Vias públicas com baixa intensidade de ocorrência de vegetação, existente em poucas avenidas fora do núcleo colonial. O Aterro da Baía Sul apresenta uma pequena concentração de palmáceas e outras espécies decorativas exóticas com tratamento ornamental de interesse paisagístico (projeto de Burle Marx).

Usos do solo - caracterizado pela urbanização intensa e diversidade de morfologias urbanas. No centro histórico, um padrão de urbanização moderno sobre estrutura urbana colonial, resultando em massa edificada compacta com poucas áreas livres. Nas encostas e cumes de morros, ocupação com padrão morfológico irregular adaptado a declividade, com residências de alta e baixa renda. Diversificação das funções urbanas (residencial, serviços e comércios e pequenas indústrias) que se mesclam e se prolongam no outro lado da ponte, no lado continental da aglomeração urbana de Florianópolis. Destaques para a função residencial na Avenida Beira-Mar Norte e proximidades, formando paredão de edifícios altos, e grandes equipamentos de infraestrutura de transporte coletivo (urbano, suburbano e interurbano) no aterro da baía sul. Edificações de diferentes tipologias e épocas, com destaque para casario colonial preservado junto à borda sul do casco antigo fronteiro ao aterro. A ocupação por habitações de pouca qualidade é constante nas diversas comunidades de baixa renda que cercam e sobem morro acima, formando o maior conjunto de população carente do estado de Santa Catarina, apresentando uma série de problemas, desde a dificuldade em assegurar a titularidade da posse dos terrenos ocupados, a falta infraestrutura e a falta de segurança serviços e públicos, Os bairros, adjacentes ao centro urbano, situados no outro lado do Morro da Cruz, apresentam aspecto urbano mais disperso, com muitas áreas abertas, decorrentes 
da implantação de empresas e instituições de ensino, privado e estatal em grandes lotes. Mistura casas e edifícios residenciais, comerciais e de escritórios, em altura (máximo de 18 pavimentos). Destaca-se, nos bairros adjacentes ao centro, a presença de atividades não residenciais, como instituições educacionais: a Universidade Federal de Santa Catarina - UFSC, no bairro Trindade, e a Universidade Estadual de Santa Catarina - UDESC, no bairro Itacorubi; empresas e autarquias estatais, como a ELETROSUL, no bairro Pantanal, e Brasil Telecom, CIDASC e EPAGRI, entre outras, criando pólos de comércio, serviço e habitação descentralizados, distribuindo a paisagem de edificações em altura por toda a Unidade de Paisagem.

Sistema viário - ponto de conexão veicular entre a llha e o continente por meio de duas pontes em sistema binário (ponte Pedro Ivo Campos e ponte Colombo Sales) e a histórica e simbólica, mas desativada, ponte Hercílio Luz. Conforma o nó central da rede de ruas e vias, municipais e estaduais, que cruzam a ilha. Mistura traçado urbano colonial, com ruas estreitas no centro da península, com largas vias expressas nas bordas e contorno do morro da Cruz. Nas encostas e cumes dos morros, misturam-se vias irregulares de acesso às infraestruturas de comunicações, alguns loteamentos residenciais, e vias estreitas, nas favelas.

\section{O caráter e a organização da paisagem}

A estrutura morfológica da paisagem se configura em uma mancha urbanizada, definida pelas orlas e morros de entorno, com forma de losango, tendo como enclave de aspecto seminatural destacado, o Morro da Cruz. Interpenetrações nas fronteiras entre áreas homogêneas limitadas pela declividade. Presença predominante da artificialização comum aos aglomerados urbanos, com construções e edifícios de distintas alturas e funções. A silhueta e os contornos foram rapidamente alterados a partir da segunda metade do século XX. Se até então as construções acompanhavam o contorno das elevações, com destaque apenas para as torres da catedral da cidade, com a elevação do gabarito das edificações e o aterramento das bordas da península, a paisagem assumiu o caráter atual, de centro metropolitano de tamanho médio, à imagem das cidades americanas modernas. O tecido residencial marca presença na Unidade de Paisagem em diferentes morfologias urbanas e tipologias edificatórias, variando densidades, alturas e faixas de renda dos moradores. 
O maciço do Morro da Cruz domina a unidade em sua parte central, dividindo-a em duas, relegando os bairros de trás o morro, a uma urbanização similar, mas com menos intensidade. O Mangue do Itacorubi, a nordeste da unidade, assume destaque pela função ecológica e paisagística no contexto da das espécies marinhas de flora e fauna, e pelo contraste com as zonas artificializadas.

\section{A visão da paisagem. \\ Belvederes, destaques, corredores e bacias visuais}

A concentração urbana pode ser notada de diferentes pontos e de diferentes distâncias, quando da aproximação pelas rodovias de acesso, onde se destaca a ponte Hercílio Luz, primeiro elemento de conexão entre ilha e continente, com forte valor simbólico e estético na paisagem. Pode-se visualizar belas panorâmicas da llha, e com destaque para trechos do centro urbano, a partir de diversos pontos na orla do mar, de mirantes urbanos e das rodovias de acesso no lado continental. A presença do Morro da Cruz tem destaque, pela forma e dimensão, em contraste com as áreas que o envolvem, ainda que seja notável a ocupação agressiva de suas encostas, por residências de diversos padrões, e de sua crista, por equipamentos de transmissão de sinais eletrônicos e de heliporto policial. A partir do Morro da Cruz, são possíveis vistas para todos os quadrantes, permitindo perceber a totalidade da paisagem da Unidade e de porções do território continental. $\mathrm{O}$ grande contraste entre elementos naturais e artificiais, menos opressor em comparação com as demais capitais e cidades de base industrial do sul do país, é fortemente marcado pela presença dominante do mar em direção às duas baías internas, do mangue e dos morros que configuram a unidade e o entorno.

Dentre os elementos e lugares com valor paisagístico da U.P, destaca-se a Ponta do Coral, pequena península na baía norte, local de antigo atracadouro ainda hoje é local utilizado por pescadores, e o Mangue do Itacorubi, envolto pela urbanização. O centro histórico, além de conjuntos urbanos e exemplares dispersos do patrimônio edificado civil e militar, apresenta paisagem urbana colonial de interesse. A pequena porção de floresta densa na encosta do Morro da Cruz, envolvendo o conjunto arquitetônico tombado do Hospital de Caridade é a principal presença natural junto ao centro histórico e se encontra preservada por lei. 


\section{Dinâmica da paisagem}

A oeste do Morro da Cruz, tendência à estabilidade pela grande ocupação e densidade, com possíveis transformações pontuais em trechos da orla que poderão afetar a silhueta nas panorâmicas à pequena distância. No lado leste da unidade, a tendência é de complementação da urbanização existente, com avanço ocupacional sobre as encostas, verticalização das edificações residenciais e de escritórios, inclusive na Universidade Federal, implantação de novos equipamentos comerciais de grande porte e ocupação das bordas do mangue. O patrimônio arquitetônico e urbano definido por lei tende a se preservar e receber mais cuidados. Com a confirmação destas tendências, a paisagem geral não terá grande alteração em relação ao aspecto adquirido nas últimas décadas do século XX. As ameaças ficam por conta da possibilidade de perda de alguns importantes referenciais paisagísticos como: a Ponta do Coral, alguns exemplares do patrimônio cultural edificado e maior ocupação do Morro da Cruz, e a diminuição da área e poluição do Mangue do Itacorubi.

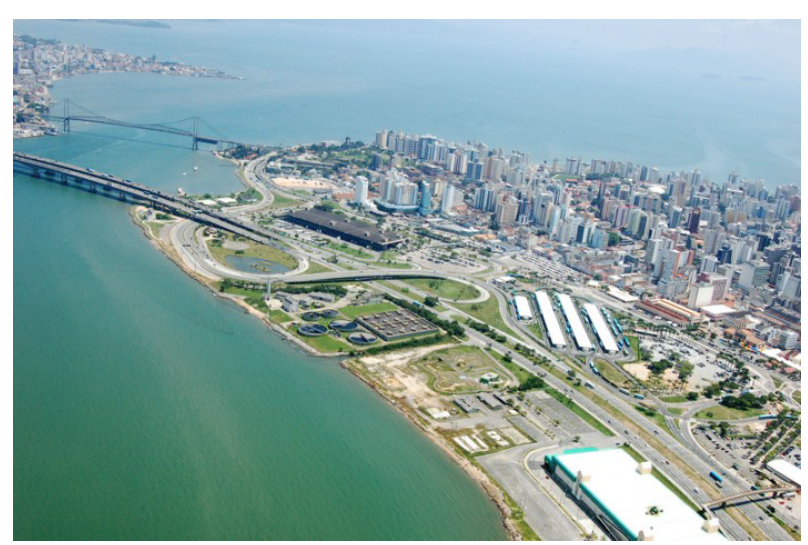

Figura 5.9: Vista do centro insular e pontes.

$\mathrm{O}$ aterro afastou o centro do mar e facilitou a circulação de veículos.

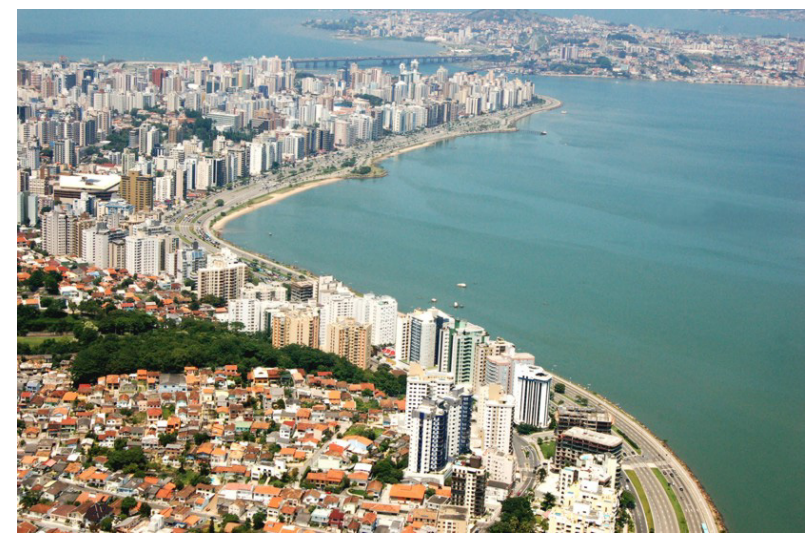

Figura 5.10: Vista da Av. Beira Mar Norte, com edificações verticalizadas.

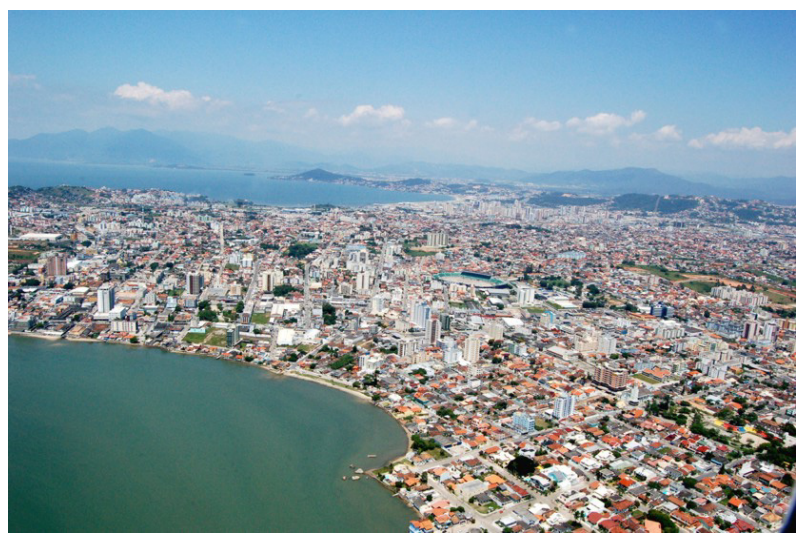

Figura 5.11: Vista do centro e bairros continentais, com a conurbação com os municípios vizinhos.

Tem interesse paisagístico e para a atividade do turismo e pelo sentido histórico de sua paisagem urbana associada ao sítio. Fortes elementos de infraestrutura modernizadora dos fluxos viários, como a ponte Hercílio Luz, o aterro da Baía Sul e a Beira Mar Norte marcam a paisagem urbana. 


\section{U.P. Saco dos Limões-Costeira}

Voltada a oeste para a Baía Sul e áreas continentais, situa-se ao sul da U.P. CentroTrindade. É limitada a leste pelo espigão central e pelo Mangue da Costeira do Pirajubaé ao sul. Engloba as localidades do Saco dos Limões e Costeira.

Figura 5.12: Unidade de Paisagem Sacos dos Limões-Costeira.

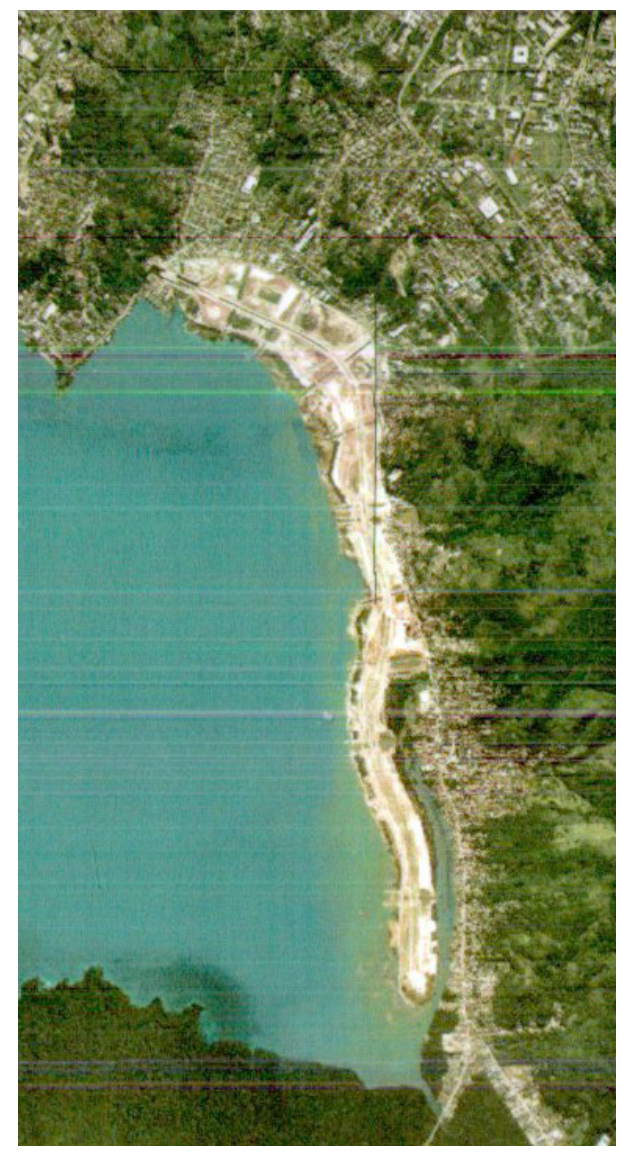

\section{Elementos (naturais e humanos) constitutivos da paisagem}

Geomorfologia e hidrografia: enseada definida pelo espigão central, com alturas superiores a 300 metros, e pelo Morro da Cruz, na U.P. ao norte. Configuram-se encostas sedimentares de depósitos aluviais, debruçadas sobre o mar, com declividades acentuadas. Desenho da parte plana no sopé do morro, que formava a costa, alterado pelo recente aterro artificial. Drenagem definida pela rede de pequenas bacias compostas de poucos córregos perenes, complementados por diversas valas naturais. Alterada em diversas partes pela ocupação urbana e pelo aterro. Conjunto litorâneo de formato linear ao longo da orla, com interpenetrações de manchas artificializadas, que não apresenta continuidade nas encostas cobertas por vegetação de mata atlântica secundária, que se apresentam contínuas somente nos cumes dos morros. 
Cobertura vegetal: parte ocupada pela urbanização das encostas com vegetação arbórea exótica, de uso doméstico e paisagístico, misturada a resquícios de mata atlântica secundária. Trechos extensos, nos cumes e encostas, com espécies gramíneas e de capoeira. Aterro em consolidação com gramíneas recentes, e pouco tratamento paisagístico.

Usos do solo: ocupação urbana por extratos sociais predominantemente de média e baixa renda, sobre antigas áreas agrícolas, das quais quase nada resta. A parte mais próxima ao centro da cidade (Saco dos Limões) apresenta trecho de estrutura urbana em grelha regular (quadrada), que se desfaz ao se adaptar às declividades. Predomina aspecto característico de encostas urbanas brasileiras, próximo ao aspecto de favelas. Morfologia urbana de espinha de peixe, ou seja, a partir da via, no sopé do morro, saem diversas ramificações em direção à parte alta da encosta, com pouca conexão entre elas. Aterro com infraestruturas viárias de grande porte e trechos destinados a usos sociais e econômicos (barracos de pescadores na orla) e recreativos, estes ainda não implantados.

Sistema viário: vias-expressas no aterro, conectando (via túneis sob o Morro da Cruz) o centro da cidade às regiões do sul da llha, e vias locais de distintas dimensões, com destaque para a quantidade de estreitas servidões de acesso às partes altas da encosta. A via local principal ainda mantém função terciária.

\section{O caráter e a organização da paisagem}

Contraste entre a parte plana, praticamente desocupada e a encosta, com a maioria dos trechos com grande declividade, com a dinâmica urbanização avançando sobre a vegetação secundária e vales de córregos. Aspecto suburbano de pouca qualidade paisagística. Destaque para o impacto negativo na cobertura vegetal, decorrentes da implantação de linhas de transmissão de energia que atravessa cumes e encostas.

\section{A visão da paisagem. \\ Belvederes, destaques, corredores e bacias visuais}

Os percursos pelas vias-expressas permitem visuais amplas tanto das encostas como dos morros do entorno continental, por sobre a Baía Sul. As panorâmicas a partir da encosta são pouco aproveitadas, exceto os usuários cotidianos, pela pouca acessi- 
bilidade aos locais mais privilegiados. O aterro da via-expressa sul, apesar da transformação da linha de orla da enseada, já alterada anteriormente, pode representar importante elemento de valorização da paisagem. A Ponta do José Mendes é local de valor paisagístico em processo de incorporação ao conjunto de áreas preservadas.

\section{Dinâmica da paisagem}

Bastante alterada, demonstrando desequilíbrio entre as ocupações nos trechos de alta declividade. Tende a estabilidade nas encostas pela dificuldade de maiores avanços decorrentes da declividade. É possível antever algumas transformações na silhueta do aterro, que ainda não foi todo consolidado e em estado de adensamento do terreno, a partir da implantação de equipamentos de recreação e lazer.

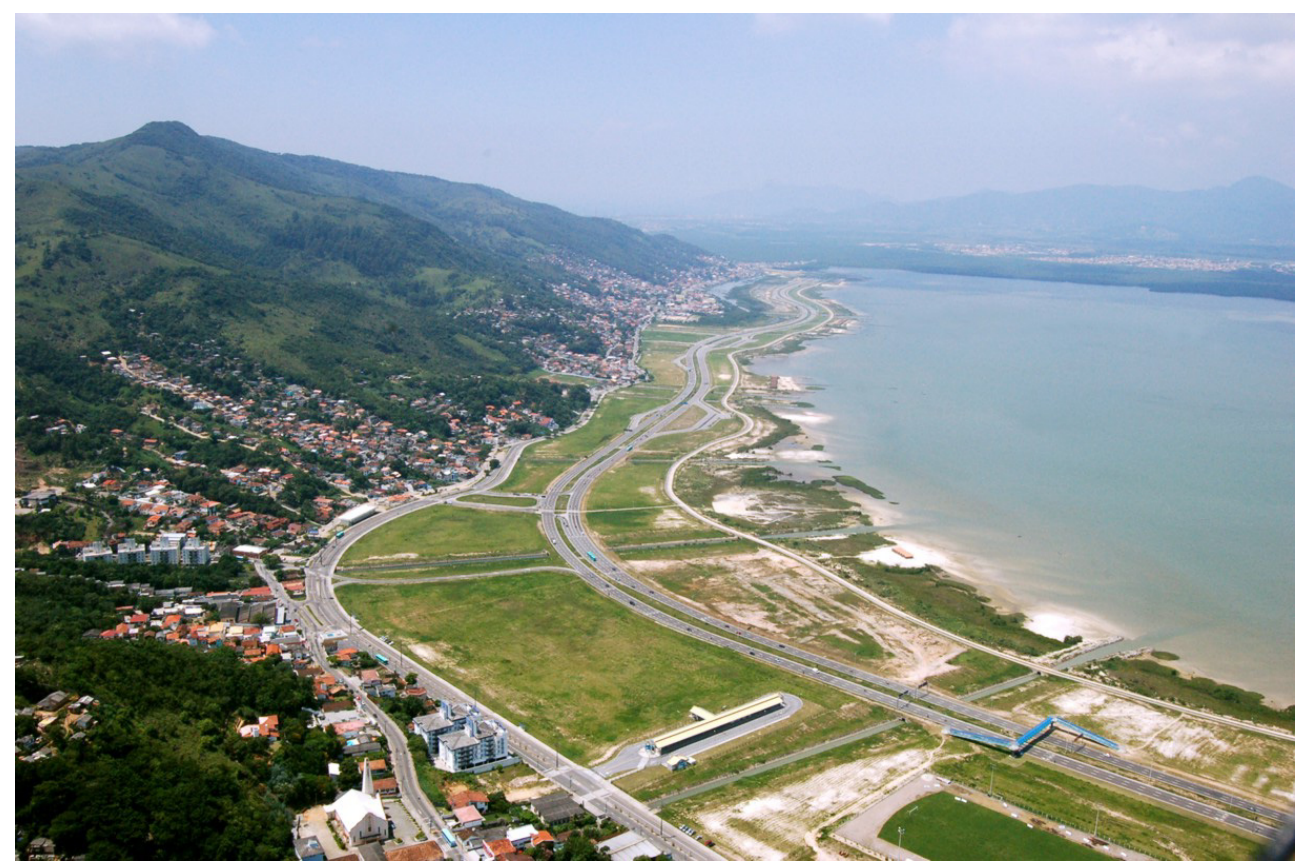

Figura 5.13: Vista da Costeira do Pirajubaé, mostrando aterro novo e encostas ocupadas.

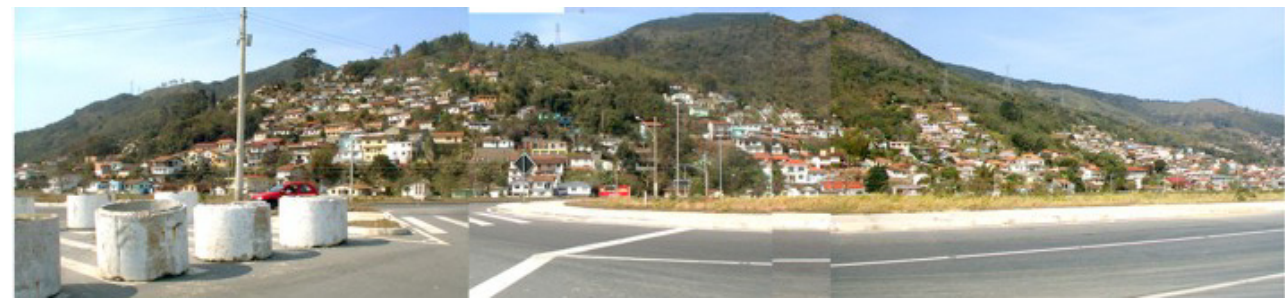

Figura 5.14: Vista da ocupação do morro da Costeira. 


\section{U.P. Saco Grande-Monte Verde}

Situada a norte do centro da cidade, entre o espigão central e a Baía Norte, voltada para oeste. Envolve os bairros Saco Grande, João Paulo e Monte Verde e Caucupé.
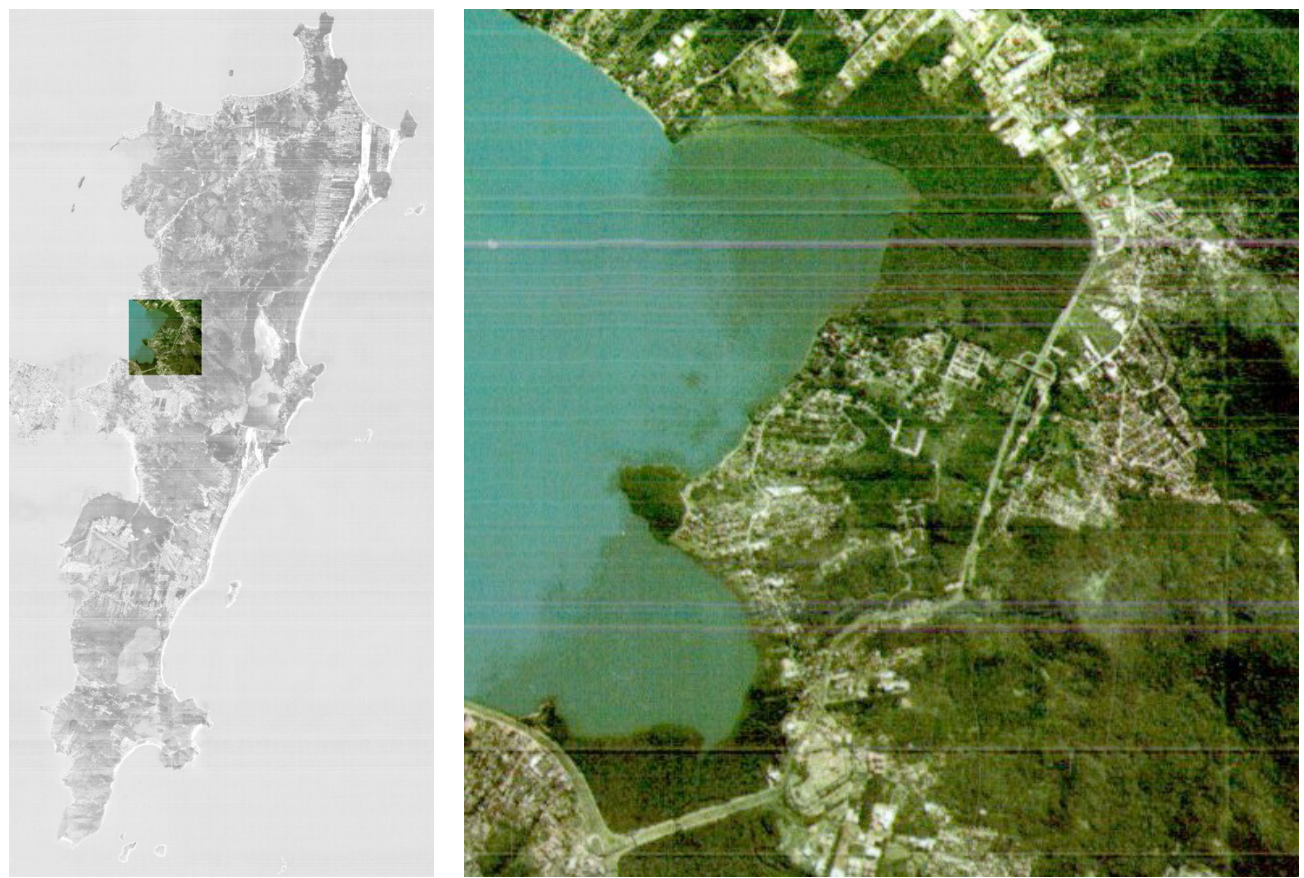

Figura 5.15: Unidade de Paisagem Saco Grande-Monte Verde.

\section{Elementos (naturais e humanos) constitutivos da paisagem}

Geomorfologia e hidrografia - relevo formado pelo encontro das encostas do espigão central com o mar, formando um anfiteatro de morros. Morrotes e promontórios com alturas abaixo de cem metros e formas suavemente arredondadas, que avançam sobre o mar, intermediados por trechos de planícies sedimentares e pelo Mangue do Saco Grande, formando praias de águas calmas, ainda pouco artificializadas. Drenagem em vales amplos e direcionados para noroeste. Os principais cursos d'água, o Rio Pau do Barco e Rio do Mel, desembocam em manguezal com importantes funções ecológicas. Unidade com forma sinuosa, com interpenetrações de urbanização e espaços naturais, espremida entre a orla e as encostas dos morros. 
Cobertura vegetal - resquícios da mata atlântica original somente nos recônditos dos cumes dos morros do espigão central. Vegetação de capoeira em regeneração mesclada com mata secundária e alguns já perceptíveis reflorestamentos arbóreos exóticos (pinus e eucaliptus). Nas áreas urbanizadas, mescla vegetação exótica e nativa nas áreas em torno das edificações e, com menos intensidade, nas vias públicas.

Usos do solo - urbanização sobre áreas agrícolas recentemente abandonadas. Alguns trechos nas encostas, ainda não urbanizados, apresentam processo de recuperação da cobertura vegetal de mata atlântica, misturados com espécies gramíneas. Assentamento urbano residencial derivado da adequação de grelha reticular sobre encosta, e de ocupação linear ao longo das principais vias, com casas e edifícios residenciais em altura na região ao sul mais próxima do centro da cidade. Assentamento linear com zona residencial de característica rururbana de sítios e chácaras de baixa densidade na encosta do promontório de Cacupé. Presença de parque tecnológico em implantação na porção sul da U.P, o ALPHATEC.

Sistema viário - rodovia principal (SC-401), cruzando de norte a sul, localizada entre os morros e a curta planície sedimentar, por sobre trechos de áreas úmidas e mangue. Derivam dela, diversas vias menores, que articulam os tecidos urbanos laterais e os mais interiorizados nas encostas. Urbanização de baixa densidade linear e em malha regular.

\section{O caráter e a organização da paisagem}

Paisagem caracterizada pelos assentamentos suburbanos espalhados extensivamente pelas planícies e de trechos das encostas, e pela ocupação linear de serviços e comércios, de porte médio e grande, ao longo do eixo rodoviário principal, característica de tecido urbano em disperso pela via.

\section{A visão da paisagem.}

\section{Belvederes, destaques, corredores e bacias visuais}

Visuais variadas em foco, alcance e amplitude, a partir do eixo rodoviário principal e de locais na orla, direcionadas para o continente e trechos urbanizados do continente, e para morros ocupados e em processo de ocupação urbana, vales, e enseadas de mar calmo, com destaque para o promontório do Saco Grande. A pouca acessibilidade a pontos de observação nas partes mais altas da U.P. dificultam a fruição das bacias de largo alcance visual. 


\section{Dinâmica da paisagem}

Paisagem em plena transformação de trechos de orla e próximos a ela, com alteração do gabarito de altura e de acabamento das construções, com a implantação de prédios de classe média em substituição às casas isoladas nos lotes, de renda média e baixa. Tendência à ocupação de trechos cada vez mais distantes dos eixos viários, por sobre a cobertura vegetal existente, pela ocupação urbana de condomínios longitudinais, derivados do fracionamento dos lotes coloniais, originalmente já longilíneos. Trama parcelaria visível nas encostas, ainda que em alguns trechos esteja oculta por vegetação doméstica misturada com a nativa. O impacto das ocupações nas encostas é negativo pela qualidade das construções, e junto ao eixo rodoviário a tendência é de perda das visuais laterais amplas, pelo fechamento com construções de comércio e serviços ao longo da via. O mangue do Saco Grande tem sofrido agressões pela proximidade da urbanização, atualmente, em pleno processo de expansão. No promontório do Cacupé, a tendência é de substituição de moradias unifamiliares de baixa densidade para condomínios fechados com maior ocupação de área dos lotes.

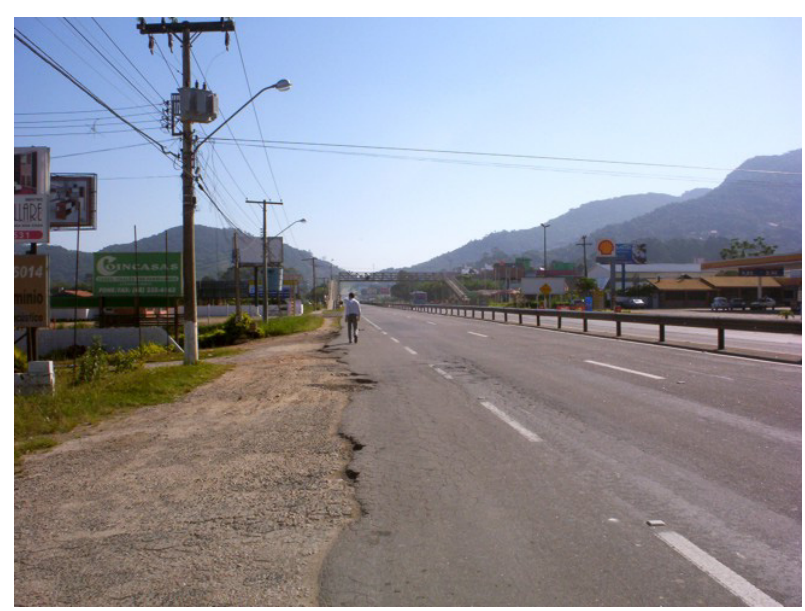

Figura 5.16: Vista da rodovia SC-401 que liga o centro às praias do norte da llha.

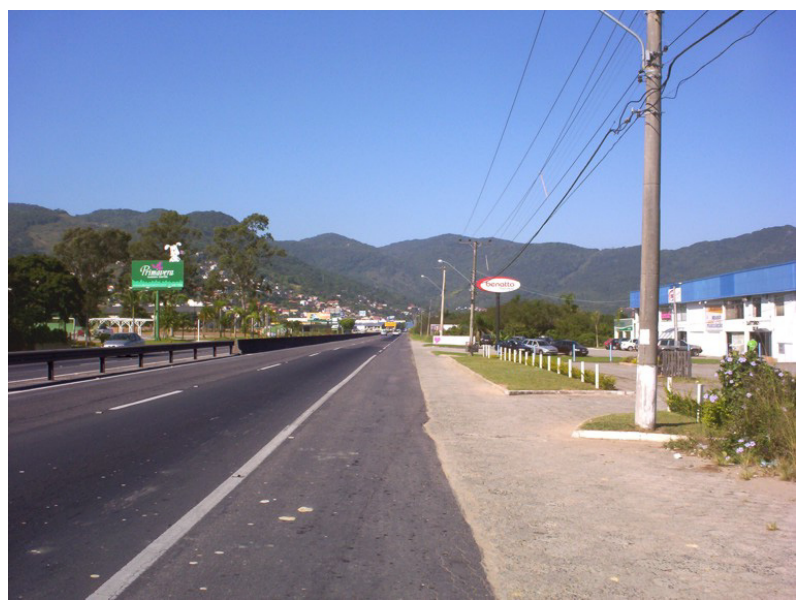

Figura 5.17: Vista da rodovia SC-401 com comércio e serviços de médio porte nas laterais.

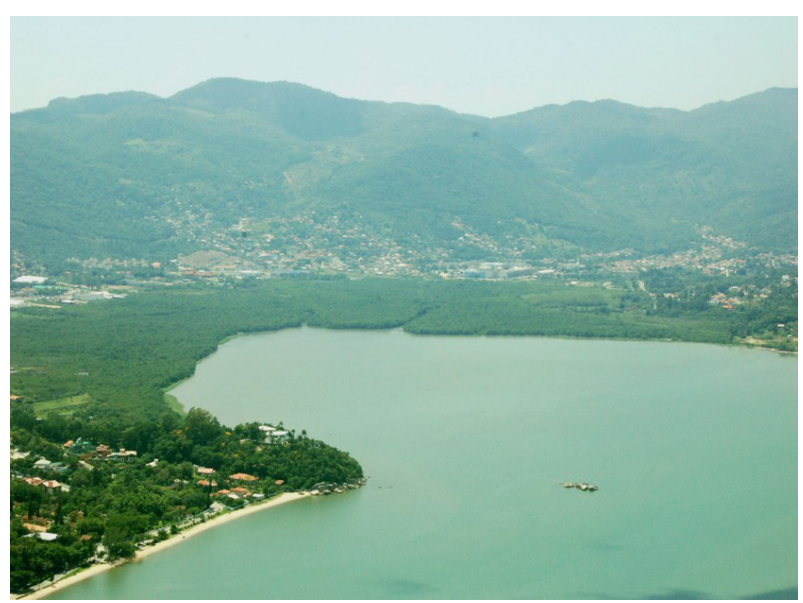

Figura 5.18: Vista do Mangue do Saco Grande, com urbanização próxima e sem amortecimento. 


\section{U.P. Santo Antônio-Sambaqui}

Situada a meio caminho entre o norte da ilha e o centro, espreme-se entre o mar e a baía norte contornada pelos morros do espigão central voltados para oeste. Engloba as localidades de Santo Antônio, Sambaqui e Barra do Sambaqui.

Figura 5.19: Unidade de Paisagem Santo Antônio-Sambaqui.

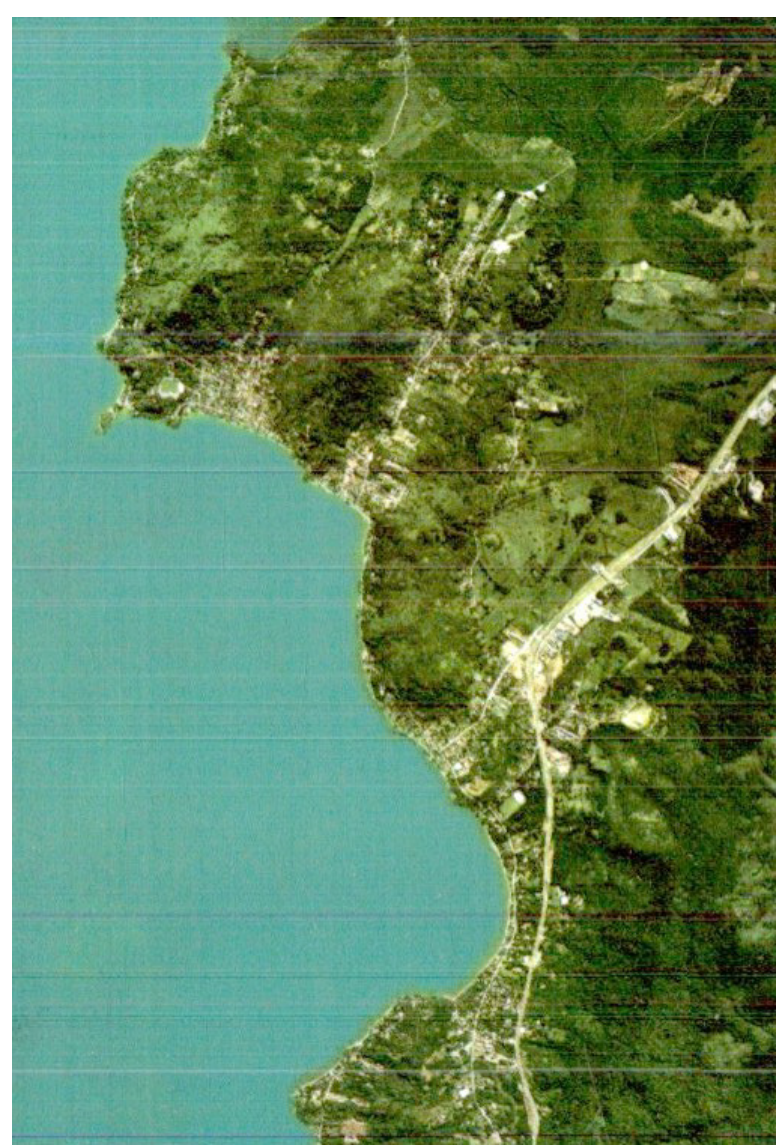

\section{Elementos (naturais e humanos) constitutivos da paisagem}

Geomorfologia e hidrografia - morros, morrotes e encostas com pendentes medianas, em torno de $30^{\circ}$, e promontórios de baixa altura debruçados sobre o mar da baía norte, conformando pequenas praias em baías e enseadas de mar calmo. Drenagem, por entre os morros e promontórios, formando vales, ora suaves, ora com pequenas quedas d'água.

Cobertura vegetal - espécimes da mata atlântica em regeneração e gramíneas em trechos recentemente abandonados pela agricultura, nas partes altas dos morros e em alguns poucos locais nas partes baixas. Vegetação doméstica e exótica nas partes urbanizadas, especialmente nas áreas residenciais. Pequenos trechos de restinga próximos à orla. 
Usos do solo - usos urbanos, com predomínio de residências, com exceção do eixo rodoviário principal. Casas de alto padrão em lotes amplos ao longo do antigo caminho colonial interno, o Caminho dos Açores. Residências, chácaras e condomínios espalhados ao longo da orla. Núcleos coloniais juntos ao mar (Santo Antônio e Sambaqui) em regular estado de conservação. Expansões em direção aos morros. Poucas áreas com uso ainda agrícola e pastoril.

Sistema viário - dominado pela rodovia estadual (SC-401, com 4 pistas de rodagem) que cruza de norte a sul, sinuosamente e por sobre suaves ondulações do terreno, a U.P.. Dela, partem as secundárias em direção à orla ou em direção aos morros, destacando-se o Caminho dos Açores, ligação principal da época colonial que permanece ainda hoje, articulando residências novas e condomínios fechados.

\section{O caráter e a organização da paisagem}

Paisagem de caráter colonial e rururbano organizada pelos dois núcleos coloniais (Santo Antônio e Sambaqui) e pelas residências de lazer ao longo das vias secundárias. As expansões residenciais junto aos núcleos coloniais partem em forma de espinha de peixe em direção à encosta, com o desmembramento em lotes menores, e transversalmente aos longitudinais lotes coloniais, saturando a ocupação especialmente no caminho entre os núcleos.

\section{A visão da paisagem.}

\section{Belvederes, destaques, corredores e bacias visuais}

A paisagem pode ser percebida de diversos pontos a partir da rodovia, de onde se vê as encostas, com a ocupação por casas isoladas no lote, e trechos da orla, já quase toda ocupada por residências muradas. A vista para a baía norte é privilegiada, onde, além do panorama das áreas urbanizadas do continente, fechadas ao longe pelas montanhas das serras catarinenses, se destacam as llhas dos Ratones, a av. Beira Mar Norte, na orla norte da península central da llha, com seu paredão de prédios de razoável altura, e a ponte Hercílio Luz (a noite o destaque é ainda maior). Destaque também para a as vistas em primeiro plano a partir das vias de acesso, do casario colonial, da Igreja de Santo Antônio, e o casarão da antiga alfândega de Sambaqui. A visão a partir dos morros permite 
vistas interessantes das baías e enseadas, em primeiro plano, e também do fechamento visual, ao longe, das montanhas das serras. O núcleo colonial ao longo da enseada de Santo Antônio forma importante conjunto paisagístico. A Ponta do Sambaqui, avançando sobre as águas calmas e ainda com boa cobertura vegetal, forma uma bela paisagem marinha arrematada pelas duas ilhas, Ratones grande, onde se encontra uma fortificação militar tombada, e Ratones pequeno.

\section{Dinâmica da paisagem}

Alguma intensificação na ocupação, residencial e hoteleira, de trechos de encostas suaves entre os caminhos secundários. Junto à rodovia, incremento de construções de comércio e serviços. Contém uma reserva municipal, vinculada a Universidade Federal de Santa Catarina, localizada no espigão central.

Tem interesse paisagístico e turístico pelo ambiente cultural com fortes resquícios do passado e configuração morfológica.

As Unidades de Paisagem localizadas na Unidade Territorial Norte se caracterizam pelas planícies e encostas de promontórios da orla marítima com assentamentos urbano turísticos em processo de densificação, com a aplicação dos índices urbanísticos do PDB-85

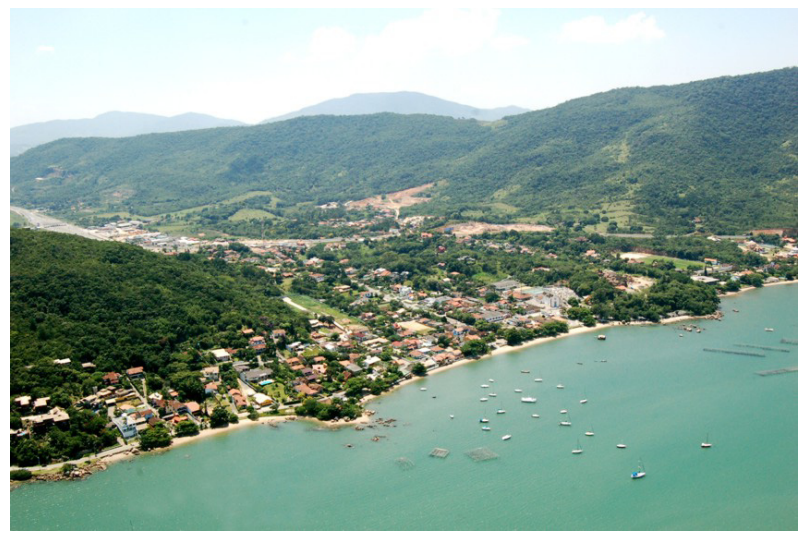

Figura 5.20: Vista do núcleo urbano de Santo Antônio envolvido pela expansão urbana recente.

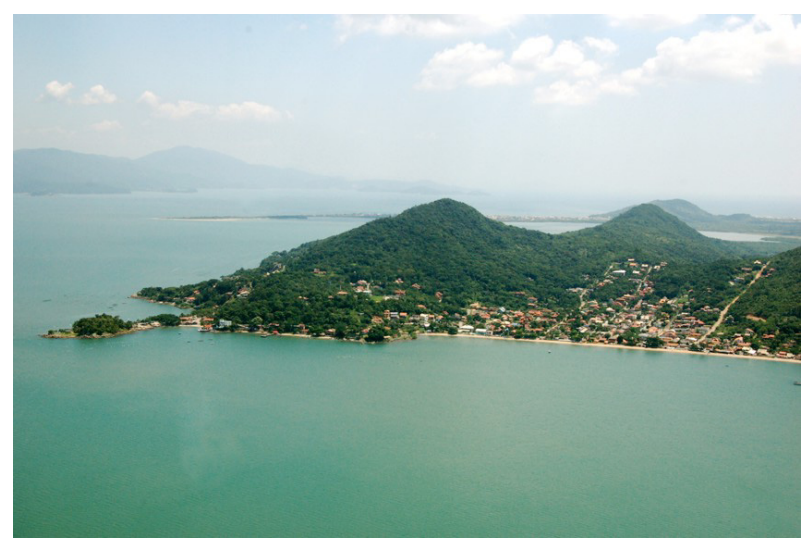

Figura 5.21: Vista da ponta do Sambaqui.

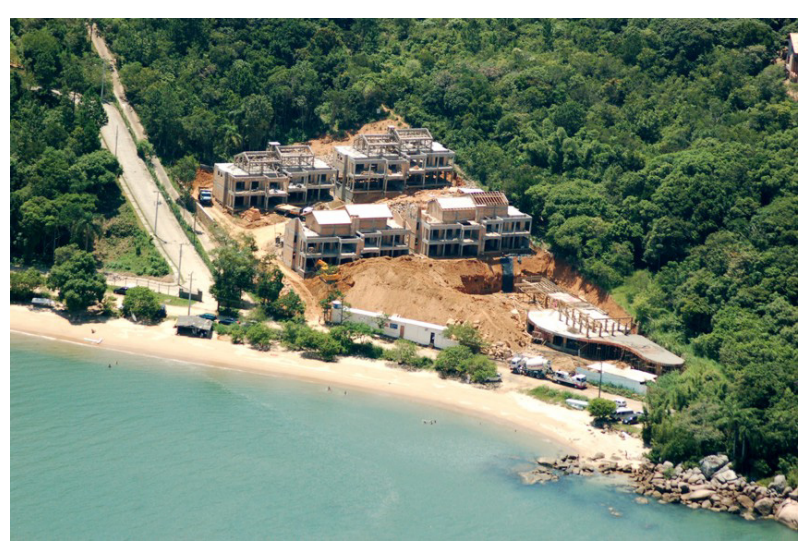

Figura 5.22: Vista de condomínio fechado na orla. (Jurerê e Canasvieiras) e Planos de Urbanização Específicos (Santinho e Brava) e decor- 
rente construção e substituição de edifícios. A situação de intenso consumo de áreas para o padrão urbano-turístico vigente e os congestionamentos nas temporadas de veraneio permitem antever a saturação da região em prazo reduzido, podendo perder atratividade para o turismo e comprometer a bacia do Rio Ratones, especialmente se ocupadas suas áreas livres que amortecem o impacto da intensa ocupação.

\section{U.P. Ratones-Vargem Grande}

Situada no norte da llha, configurada pela bacia hidrográfica do Rio Ratones, e limitada pelos morros do espigão central e pelo mar. Fazem parte desta unidade as localidades de Ratones, Vargem Grande e Vargem Pequena.

\section{Elementos}

(naturais e humanos)

constitutivos da paisagem

\section{Geomorfologia e hidrografia -}

planície úmida, sobre sedimentos aluviais dos morros laterais e de depósitos marinhos, limitada pelas encostas dos morros do espigão central ao sul $\mathrm{e}$ leste, e pelo mar a oeste, e por

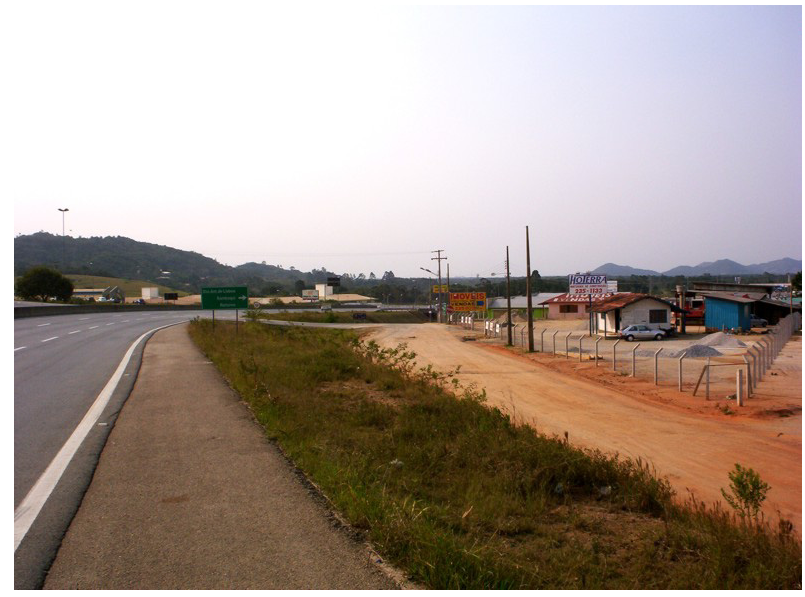

Figura 5.23: Vista da rodovia SC-401 na U.P.

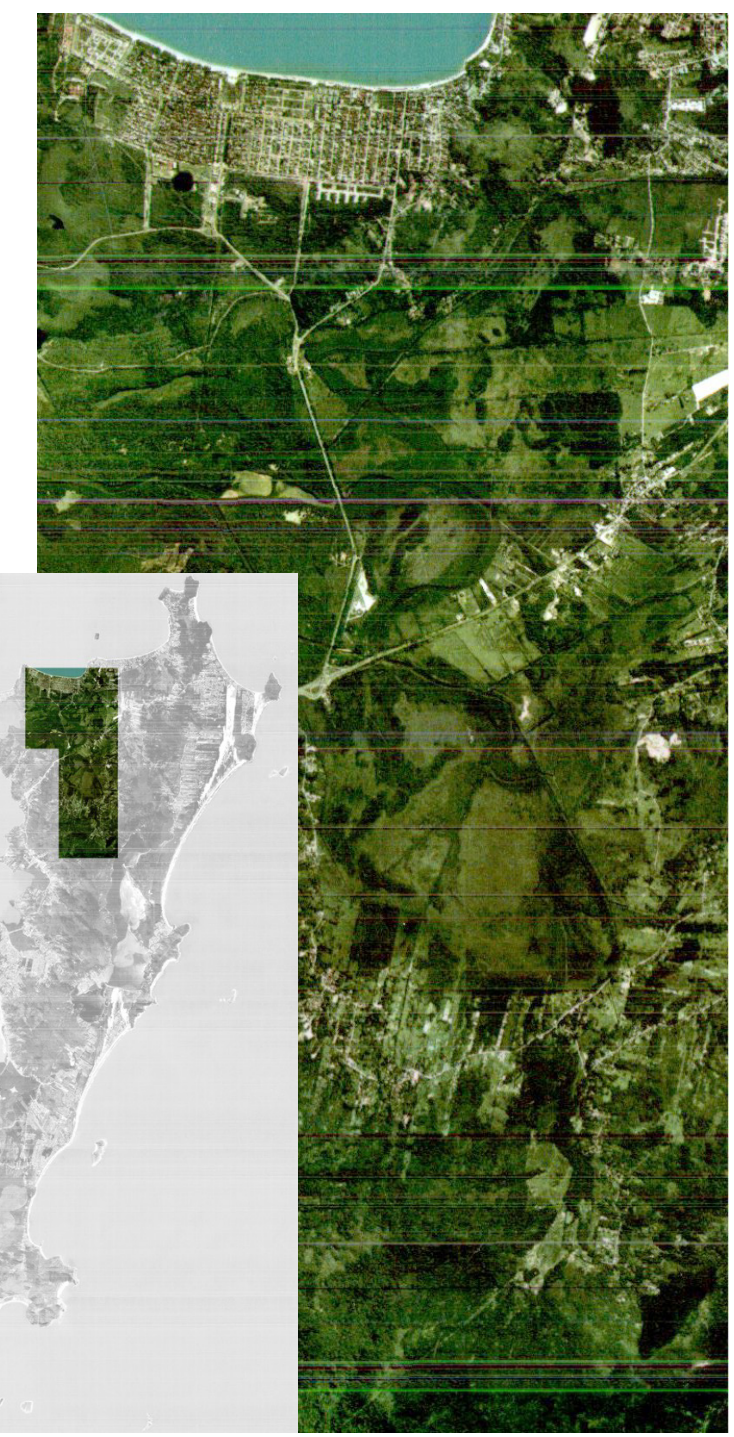

Figura 5.24: UP Ratones-Vargem Grande. 
promontórios e restingas à beira mar pelo norte. A U. P. é constituída pela maior bacia fluvial da llha, com diversos contribuintes que nascem nos morros, caem pelas encostas em vales sinuosos escorrem suavemente pela planície, formando o Rio Ratones. Alguns cursos contribuintes foram modificados, nos trechos mais planos, para fins agrícolas, formando canais retilíneos que alteraram seu regime hidrológico.

Cobertura vegetal - cobertura vegetal variada na planície da U.P. com predomínio de vegetação de mangue, charcos e espécimes de restinga. Pastagens abandonadas em recuperação, com diversos estágios de capoeira, e manchas com reflorestamentos exóticos (pinus e eucaliptus), cobrem antigos campos comunais. Nas encostas não totalmente ocupadas, com exceção das partes mais baixas, vegetação de mata atlântica em diversos estágios de regeneração. Nos cumes dos morros, a vegetação de mata atlântica em recuperação domina a paisagem.

Usos do solo - em função da existência de reserva ecológica com proteção legal (reserva Ecológica de Carijós) para o mangue, na desembocadura do rio, e trechos mais interiorizada de restinga nos meandros dos afluentes, boa parte da U.P. tem ocupação, ainda que ameaçada pela urbanização e pelas vias que limitam e cruzam a reserva. Nas regiões à leste da rodovia SC-401, alguma ocupação com edificações rurais (colônia agro-pastoril com casas isoladas) ainda na planície, e ocupação rururbana pouco densa nas encostas e junto à via, antigo caminho colonial, que passa no sopé dos morros de entorno.

Sistema viário - rodovia estadual e caminhos coloniais distribuem a acessibilidade na planície e bordas dos morros. Existe superposição, em boa parte da U.P., do caminho colonial com a rodovia SC-401 com a via antiga, que se bifurca, formando um laço pelo sopé das encostas dos morros, que dá acessibilidade a sítios e recentes expansões residenciais ao longo da estrada, formando ocupação linear em espinha de peixe.

\section{O caráter e a organização da paisagem}

Paisagem natural parcialmente preservada junto ao mangue; paisagem agro-pastoril nas áreas drenada na planície, e interiorizada pelas encostas. A matriz de planície de restinga e mangue predomina sobre os demais elementos constitutivos da paisagem. 


\section{A visão da paisagem.}

\section{Belvederes, destaques, corredores e bacias visuais}

Paisagem aberta e com pouca ocupação humana. A partir da rodovia principal e variante, que cruzam a U.P., bacias visuais amplas e horizontalizadas, fechadas lateralmente no primeiro plano por vegetação arbustiva de baixo porte, de restinga e mangue.

\section{Dinâmica da paisagem}

Tendência ao equilíbrio nas áreas conservadas (com aproximadamente $40 \%$ do total da U.P.) e algum dinamismo na ocupação das encostas pelo fracionamento dos lotes coloniais para residências isoladas, condomínios e chácaras de lazer.

Tem interesse paisagístico pela ampla área que abrange e pela função

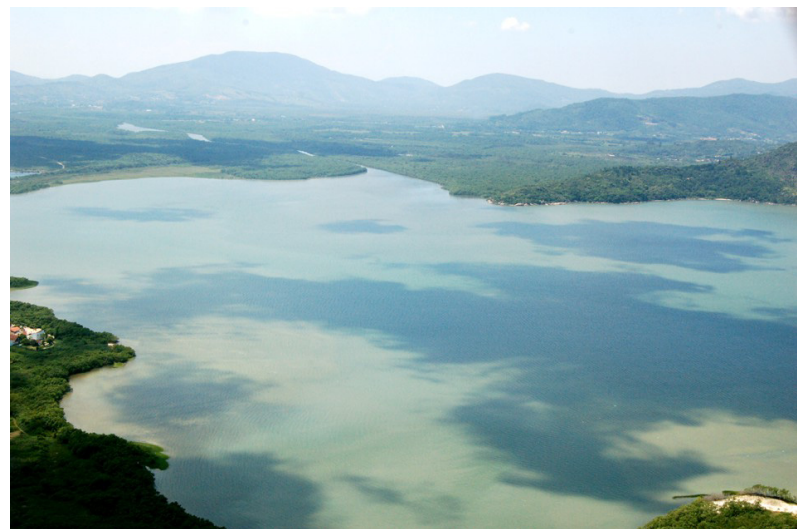

Figura 5.25: Vista da foz do Rio Ratones. de drenagem hidrológica que assume.

As Unidades de Paisagem da Unidade Territorial Leste, dada a grande extensão, apresentam situações diferenciadas. Ao norte, Ingleses-Santinho com características mais urbano-turísticas de uso intenso já sinalizam com certo grau de saturação das planícies e restingas, com forte ameaça às áreas de dunas. A saturação ocupacional por loteamentos lega-

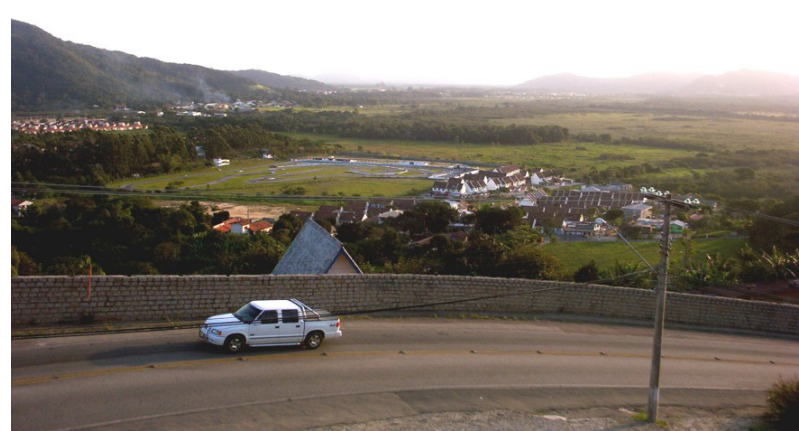

Figura 5.26: Vista da planície com as bacias dos rios Papaquara e Ratones.

lizados e irregulares de baixa densidade confere aspecto caótico e pouco qualificado, merecendo controle da expansão e qualificação das áreas já ocupadas. A planície de restinga que constitui a matriz da Unidade de Paisagem do Rio Vermelho apresenta dinâmica ocupacional intensa, mas de baixa densidade, o que também pode levar a insustentabilidade pelo uso residencial extensivo e de pouco aproveitamento turístico, apesar do potencial da 
planície da orla e encostas dos morros. A Unidade de Paisagem Lagoa da Conceição-Barra da Lagoa, extremamente complexa e com diversos atributos tem alto aproveitamento turístico. A ocupação urbana ainda não obliterou a paisagem natural, embora os ecossistemas se encontrem ameaçados pela carência de infraestrutura de saneamento, já insuficiente para a densidade atual. Merece atenção, mas dado o atual situação de comprometimento do uso do solo com a urbanização em determinadas zonas, como o "centrinho" e a Barra da Lagoa, é possível imaginar, se superadas as deficiências sanitárias e feitos estudos morfológicos, e de impacto de vizinhança específicos, maior aproveitamento construtivo em troca do controle da expansão territorial. O aproveitamento de encostas merece estudo no sentido de incentivar o estabelecimento turístico com impacto similar, mas substituindo ocupação residencial atual. A região da Costa da Lagoa carece de acompanhamento da ocupação por segunda residência que já ameaça a paisagem de encostas e orla do espelho d'água, mas pode ter aproveitamento controlado pra estabelecimentos turísticos de baixo impacto. $\mathrm{O}$

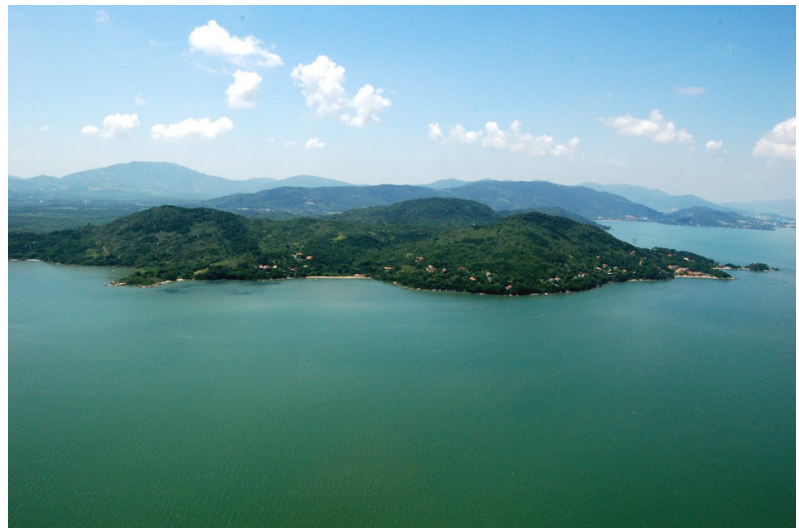

Figura 5.27: Vista de promontório na U.P. com significativa cobertura vegetal.

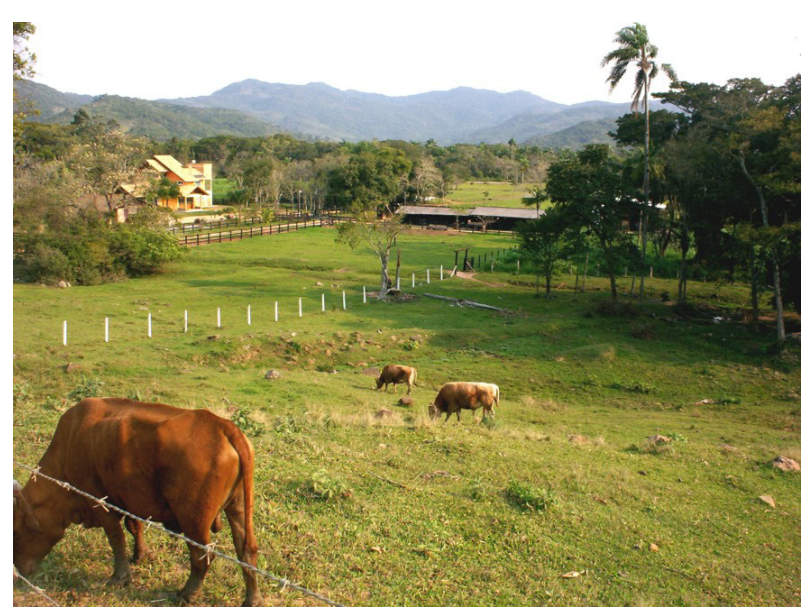

Figura 5.28: Vista de área rural na planície da Vargem Grande.

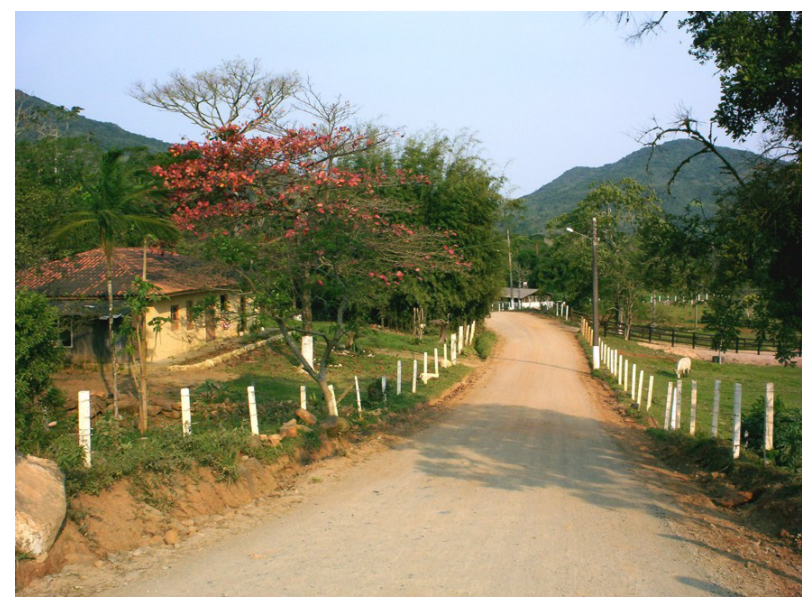

Figura 5.29: Vista de via local na Vargem Grande. maior aproveitamento da Lagoa da Conceição ainda não encontra respaldo da sociedade, embora a instalação de marinas poderia impulsionar o uso turístico. 


\section{U.P. Jurerê-Daniela}

Situada no norte da llha, limitada pelo oceano, ao norte, e pela planície úmida da U.P. Ratones-Vargem Grande, ao sul, e fechada visualmente pelas encostas do espigão central. Engloba as localidades da Daniela, do Forte e Jurerê.

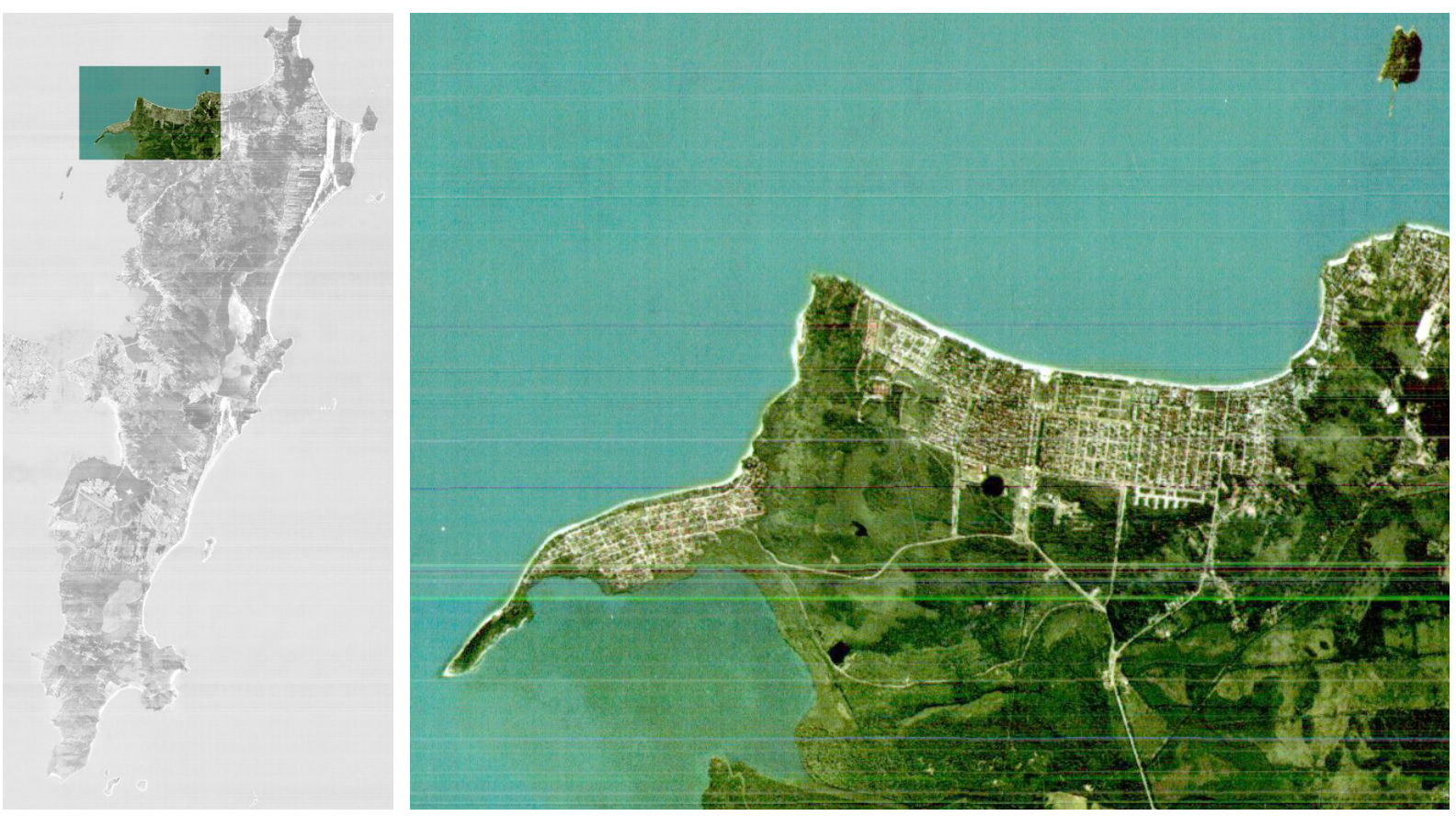

Figura 5.30: Unidade de Paisagem Jurerê-Daniela.

\section{Elementos (naturais e humanos) constitutivos da paisagem}

Geomorfologia e hidrografia - matriz: morrotes e planícies de sedimentos marinhos, que formam cordões arenosos recobertos pela vegetação restinga, e, em pequenos trechos, de terras de aluvião erodidas dos morros de entorno. Promontórios de baixa altura, a noroeste e nordeste da U.P.. A distribuição dos pequenos promontórios configura uma enseada em arco longilínio, orientada para o norte, e uma península de restinga avançando para oeste, fechando a baía norte, com praias rasas, de águas calmas e tépidas (no verão). A drenagem para o sul do promontório central é feita por córregos, muitos canalizados, que descem da elevação ao norte e contribuem para a bacia do Rio Ratones. Outros pequenos córregos que descem dos promontórios em direção ao norte, com baixa declividade, deságuam na enseada em ccanais bastante alterados. 
Cobertura vegetal - resquícios de vegetação de restinga na parte plana, e trechos de mata litorânea nas partes elevadas e nos vales do promontório. Vegetação urbana exótica (gramíneas, arbustos e árvores) com presença destacada nos loteamentos, tanto no espaço público como no privado.

Usos do solo - urbanização linear de origem colonial no sopé dos morrotes, e de veraneio e empreendimentos turísticos nas encostas. Urbanização com loteamentos de traço moderno (grelha regular, cidade jardim e unidades de vizinhança) para classes de renda médias e superiores por sobre áreas de campos comunais, (restingas de capoeirinha e capoeira), restinga, mangue e áreas agrícolas abandonadas. Costões dos promontórios ocupados por empreendimentos turísticos para grupos sociais de alto padrão. Pequena área, pontual e isolada, da Reserva Ecológica Carijós, na praia de Jurerê.

Sistema viário - conectado por rodovia, assentada sobre o mangue e a restinga, ao sistema principal da llha, e por via local, à praia de Canasvieiras, a leste. Nas urbanizações da planície, traçados regulares em forma de grelha; no sopé das elevações, traçados em espinha de peixe, com vias estreitas e desconectadas entre si. Conexões com áreas ao sul e sudoeste interrompidas pela Reserva Ecológica de Carijós.

\section{O caráter e a organização da paisagem}

Paisagem marcada pelo harmônico encontro entre a terra e o mar, e pela ocupação suburbana balneária turística, com loteamentos de segunda residência e de equipamentos de hospedagem permanente e sazonal, de renda média e alta, organizada sobre restingas e áreas úmidas. Menos legível, é a urbanização derivada do loteamento colonial nas encostas dos morros, com casas de moradores nativos e seus descendentes, que paulatinamente vão sendo substituídas por moradias de recém-chegados.

\section{A visão da paisagem. Belvederes, destaques, corredores e bacias visuais}

Panorama com pequenas alterações na silhueta da planície e dos morros, se estendendo sobre a enseada, que pode ser percebido dos percursos possíveis nos promontórios. A partir das praias, é possível vislumbrar parte das terras continentais, os contrafor- 
tes da serra do mar e as Ilhas dos Ratones e Anhatomirim. Destaque para o Forte de São José, patrimônio histórico e arquitetônico do século XVIII, que se alça sobre o promontório que separa a praia da Daniela da praia de Jurerê.

\section{Dinâmica da paisagem}

Paisagem em processo de desenvolvimento urbano com tendência à estabilidade da silhueta, pelo controle urbanístico, em altura e densidades médias. No Jurerê tradicional se nota gradual substituição da tipologia construtiva, implantada a mais de cinqüenta anos, de baixa altura por quatro alturas, decorrentes de possibilidades criadas pelo PDB, adensando a região, mas sem impacto visual forte, ainda que com risco de congestionamento da capacidade do solo em absorver os resíduos sanitários tratados individualmente. As maiores ameaça são a expansão, já planejada, do empreendimento Jurerê Internacional, da empresa Habitasul, em direção ao sul, sobre a planície sedimentar integrante da Estação Ecológica Carijós,

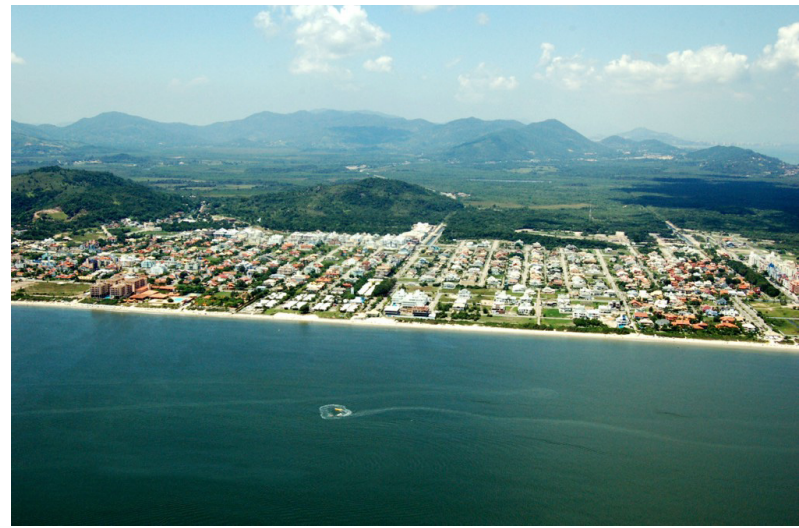

Figura 5.31: Vista de Jurerê com loteamentos em primeiro plano.

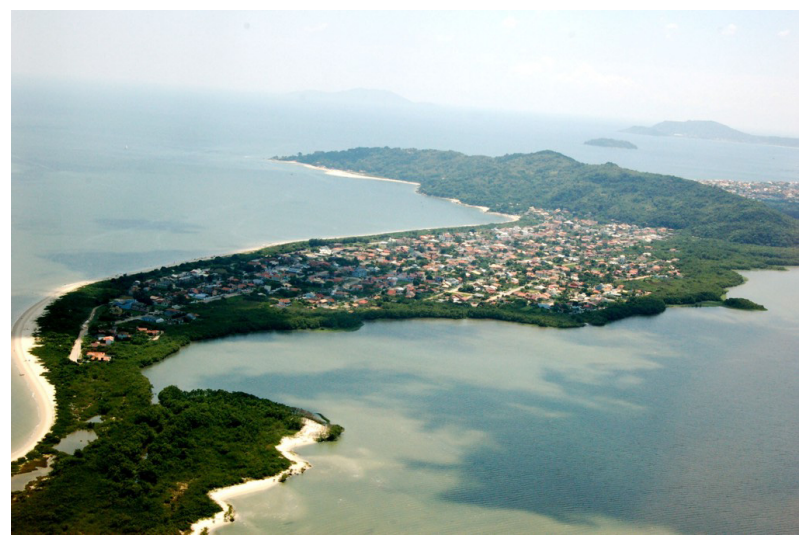

Figura 5.32: Vista da ponta da Daniela, ocupada por loteamento sobre restinga.

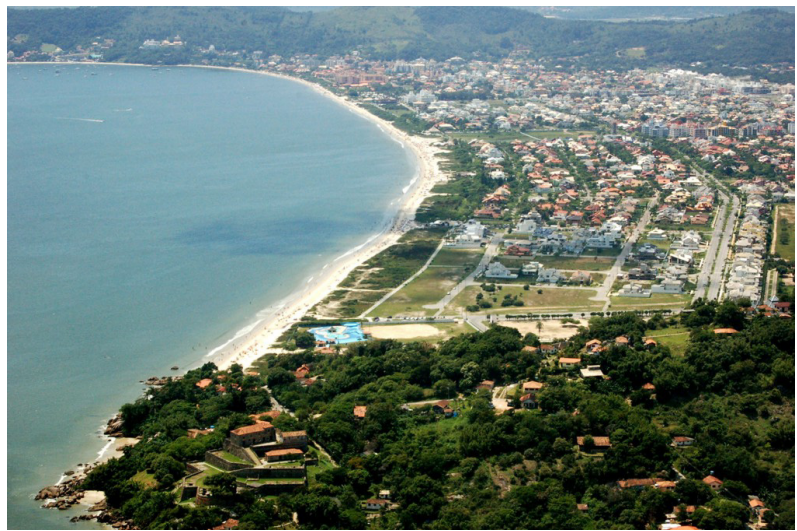

Figura 5.33: Vista de Jurerê e promontório que separa da praia da praia do Forte. e a possibilidade de contaminação do lençol freático pela excessiva ocupação (ainda que boa parte seja atendida por estação de tratamento de esgoto) com conseqüências na desembocadura do Rio Ratones na baía norte. 
Tem interesse paisagístico pela configuração geomorfológica, pelas praias e o Forte, como atrativo histórico-cultural .

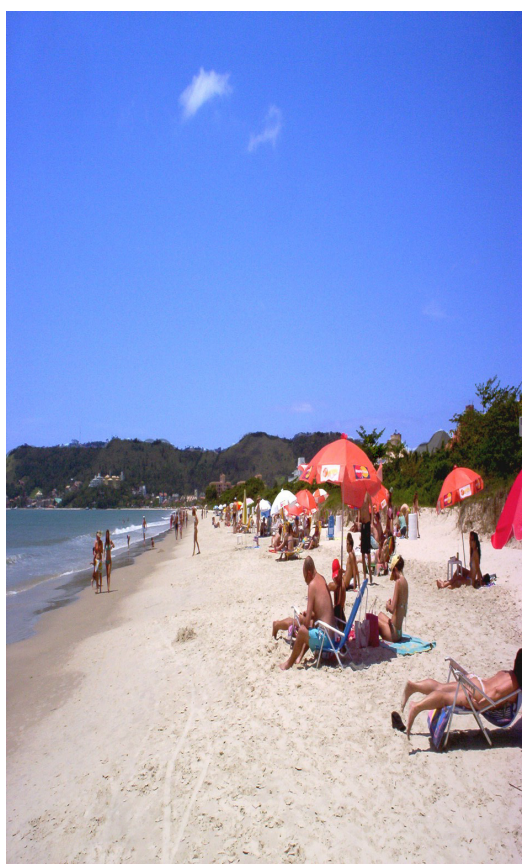

Figura 5.34: Vista da orla praiana em Jurerê.

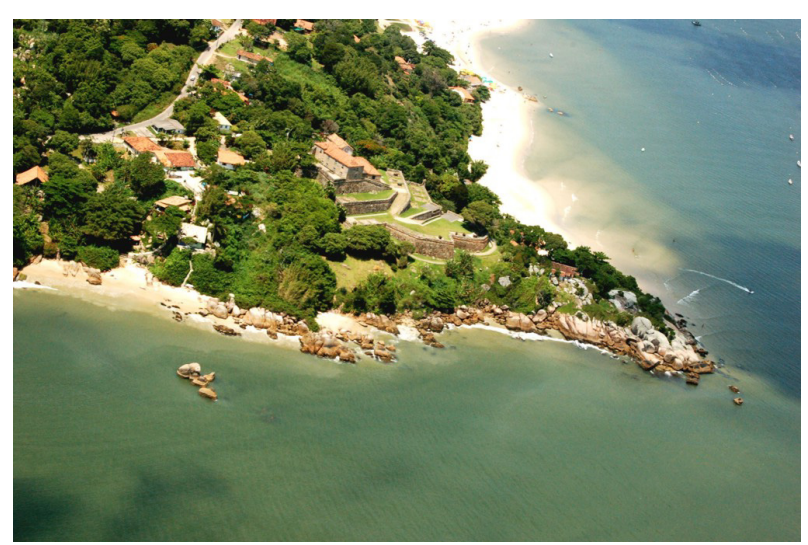

Figura 5.35: Vista do Forte de São José da Ponta Grossa.

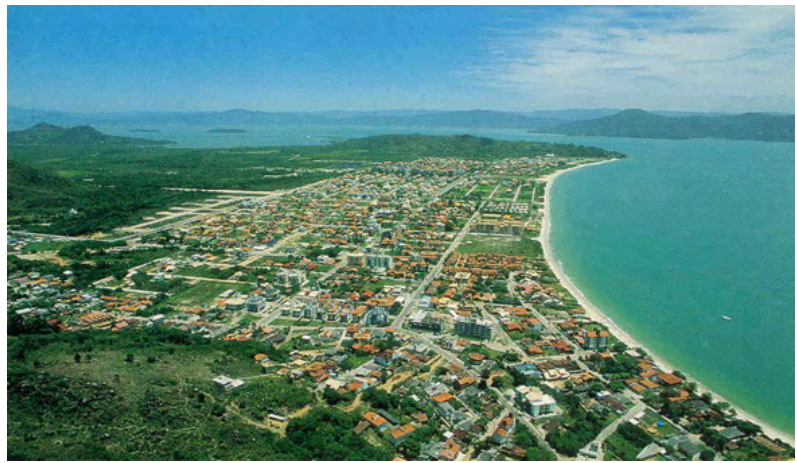

Figura 5.36: Vista geral de Jurerê.

\section{U.P. Canasvieiras-Ponta das Canas}

Situada no norte da llha, limitada ao sul e a leste pela dorsal granítica, e a oeste pelas planícies da bacia do Rio Ratones. Envolve localidades de Canasvieiras, Ponta das Canas e Cachoeira do Bom Jesus.

\section{Elementos (naturais e humanos) constitutivos da paisagem}

Geomorfologia e hidrografia - planície com cordões de sedimentos arenosos, formando baía de arco longo, voltada para o norte, com praia rasa, definida por promontórios relativamente baixos (alturas abaixo de cem metros) a leste e oeste. Na porção interior, áreas úmidas planas da bacia do Rio Ratones, tendo o Rio Papaquara como o principal afluente nesta parte do território, com diversos canais artificiais de drenagem. 

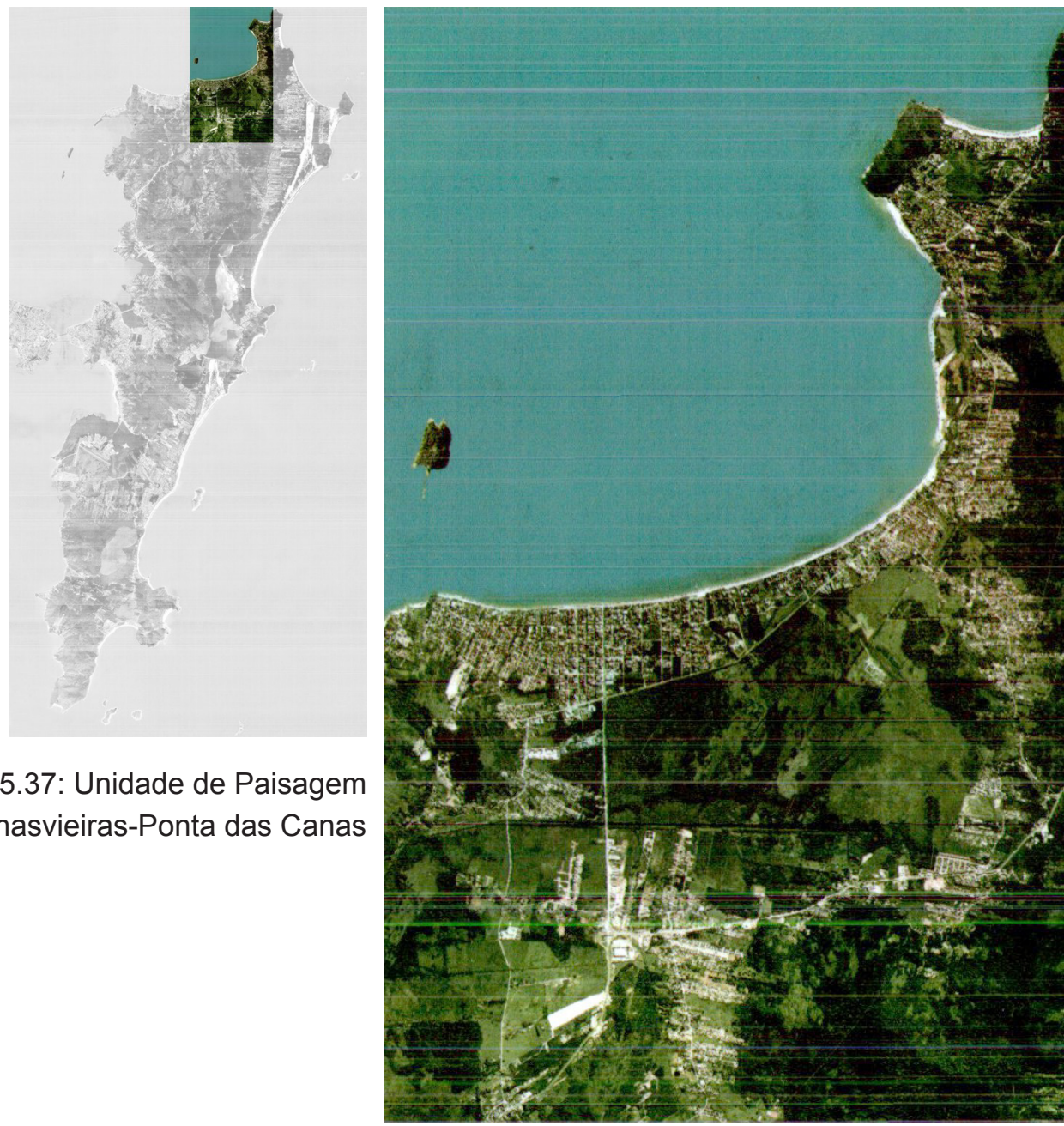

Figura 5.37: Unidade de Paisagem Canasvieiras-Ponta das Canas

Cobertura vegetal - vegetação de restinga, de áreas úmidas e de campos agro-pastoris abandonados (alguns de terras comunais) nas áreas ainda não urbanizadas. A restinga ali encontrada, apesar de bastante alterada, apresenta espécimes vegetais diferenciados das demais planícies. Na urbanização, a vegetação é de caráter decorativo e de sombreamento, típica de loteamentos balneários.

Usos do solo - urbanização turística com loteamentos de baixa densidade, a maioria em malha reticular regular, delimitadas pelo mar, promontórios laterais e rodovia estadual de acesso às praias do norte da Ilha. Uso agrícola de subsistência em pequenos trechos nas áreas planas e encostas dos promontórios.

Sistema viário - acessibilidade limitada às duas rodovias estaduais (SC-401 e SC403) Internamente à U.P., trama urbana de desenho regular na planície, e adaptação da grelha regular a declividade das encostas dos promontórios. 


\section{O caráter e a organização da paisagem}

Praia extensa e longilínea orientadas para o norte, com praia rasa e com águas calmas e tépidas (no verão), com urbanização turística e permanente na primeira franja costeira e encostas, e campos agro-pastoris em processo de abandono, na segunda. A urbanização caracterizada por intenso uso sazonal, agrega alta urbanidade ao local. Com tipologias de segunda residência e edifícios residenciais (pilotis, dois andares mais ático), e equipamentos hoteleiros (com até seis pavimentos mais ático, geralmente junto à orla marítima, configurando paisagem urbana de beira-mar).

\section{A visão da paisagem. \\ Belvederes, destaques, corredores e bacias visuais}

Panorama de ocupação urbana balneária numa matriz costeira de proporções equilibradas. Praias tranqüilas e com boa faixa de areia. Alterações da matriz pela grande ocupação por edifícios em altura, que se destacam na paisagem. Boas visuais a partir dos promontórios laterais em direção à baía, com visão do continente num plano mais distante. Da via interiorizada de conexão interpraias, percebe-se o contraste entre a urbanização, ao norte, e os campos abertos do sul da U.P..

\section{Dinâmica da paisagem}

Vitalidade e estabilidade na urbanização turística, com forte pressão ocupacional sobre os campos abertos. Congestão da paisagem urbana pelo intenso uso das vias e praias, com freqüentes congestionamentos no verão. A maior ameaça é a forte possibilidade de ocupação, já tentada diversas vezes, da grande planície matriz da Unidade. O último projeto, impulsionado pelo governo estadual, dono da maior parte da área, prevê a instalação da um par-

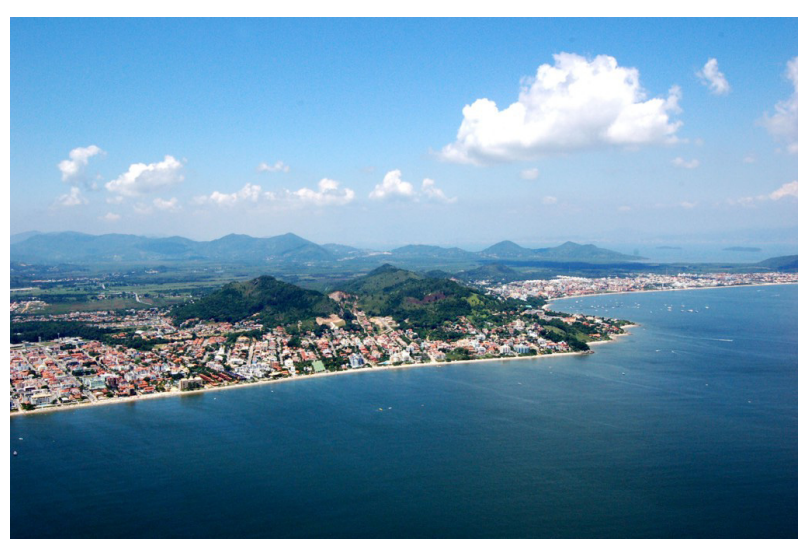

Figura 5.38: Vista de Canasvieiras e promontório que separa de Jurerê. 
que tecnológico, o Sapiens Parque, com a atração e instalação de empresas de porte internacional.

Tem interesse paisagístico pelas praias, morros e ampla planície matriz.

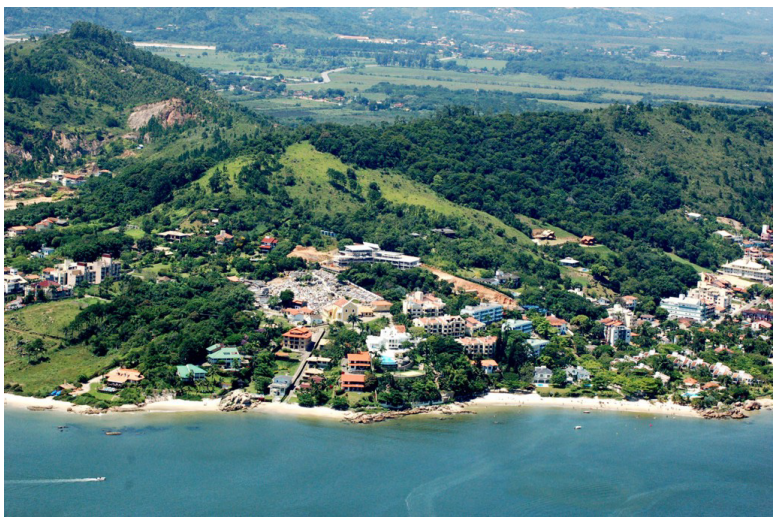

Figura 5.39: Vista do promontório entre Canasvieiras e Jurerê.

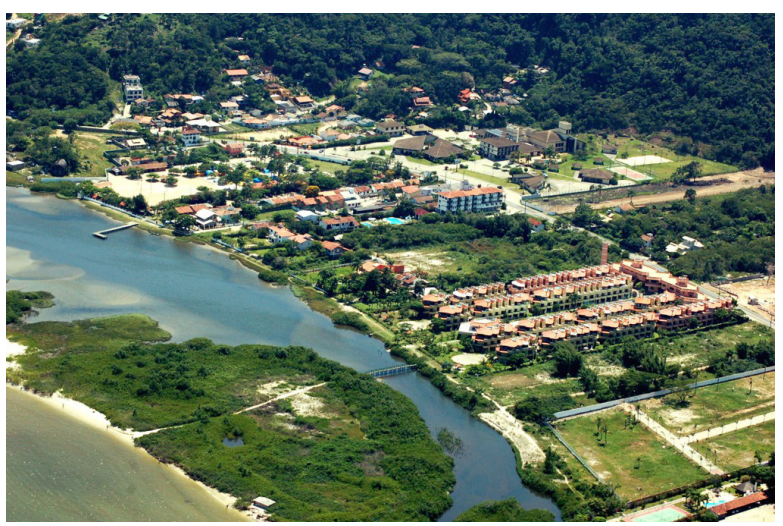

Figura 5.41: Vista da Ponta das Canas e ocupação turística sem zona de amortecimento em relação à restinga recente.

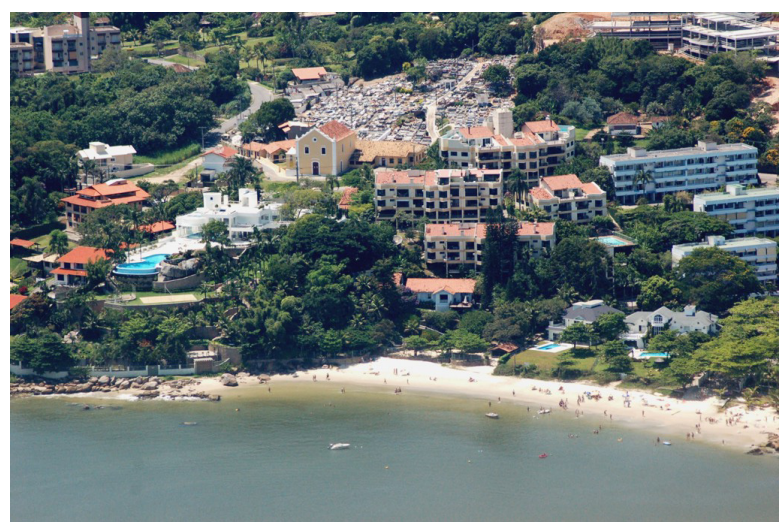

Figura 5.40: Vista da ocupação turística no promontório.

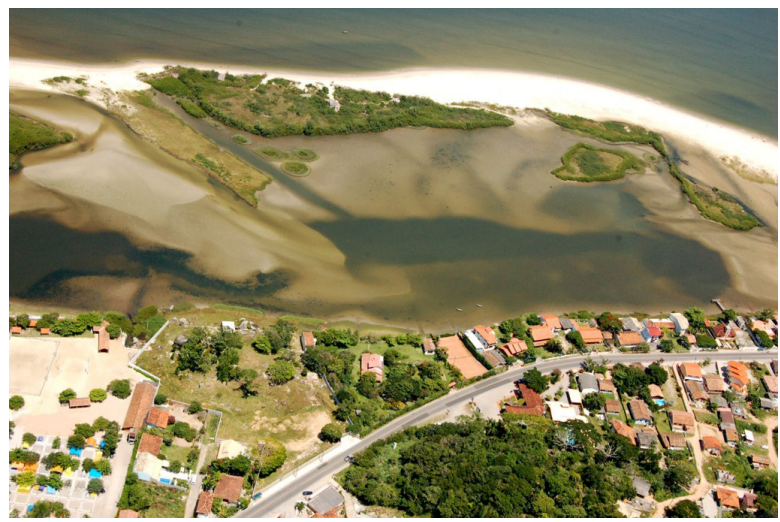

Figura 5.42: Vista da restinga. 


\section{U.P. Lagoinha-Praia Brava}

Situada no extremo norte da llha, encarcerada por promontórios, separa a costa leste da costa norte. Envolve as localidades da praia Brava e Lagoinha.
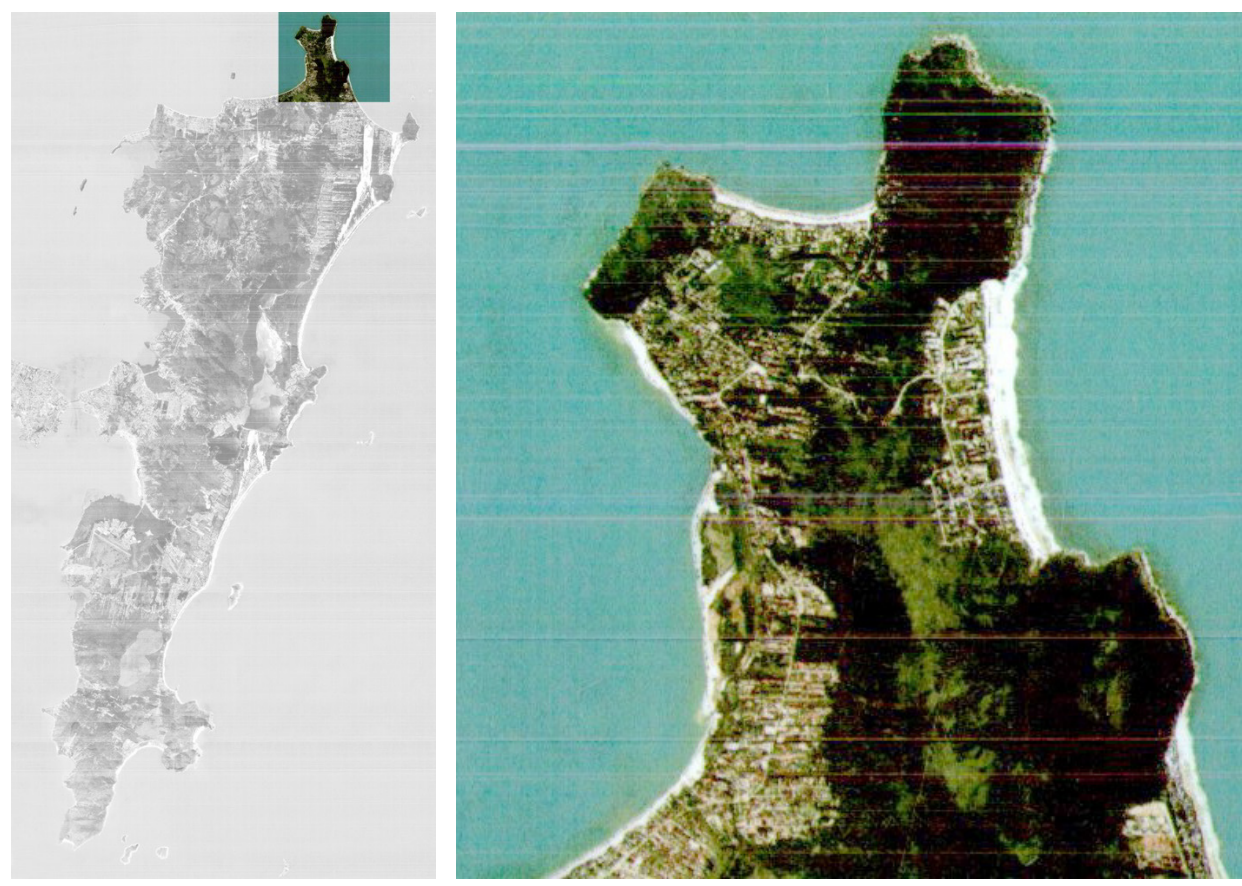

Figura 5.43: Unidade de Paisagem Lagoinha-Praia Brava.

\section{Elementos (naturais e humanos) constitutivos da paisagem}

Geomorfologia e hidrografia - morrotes avançando sobre o mar conformando pequenos arcos praiais. A leste, a praia Brava é conformada pela encosta do morro e se apresenta ao mar aberto e agitado. Ao norte, a praia da Lagoinha se esparrama numa pequena planície de restinga, quase que totalmente urbanizada por loteamentos de segunda residência, e apresenta-se ao mar aberto com águas calmas e tépidas (no verão). A pequena lagoa que deu nome ao lugar se encontra bem processo de aterramento. Anfiteatros conformam as pequenas enseadas com faixa de restinga. Pequenas vertentes e valas de drenagem formando pequenas áreas úmidas, nas partes planas da restinga, e riachos que desembocam em pequenas barras.

Cobertura vegetal - bastante alterada, a cobertura vegetal só se mantém com alguma característica natural nas partes altas dos morros. Nas áreas urbanizadas, substituição da vegetação de restinga por gramíneas, espécimes florais e de sombra. 
Usos do solo - urbanização balneária e sistema viário predominam na U. P., com poucas áreas nas encostas com resquícios de uso agrícola.

Sistema viário - vias secundárias de acesso, conectadas ao sistema principal de rodovias estaduais da Ilha, e circulação interna. Na praia Brava, o sistema de vias se conforma a partir de uma via principal e ramificações com cul-de-sac na borda da praia.

\section{O caráter e a organização da paisagem}

Paisagem balneária de alto padrão de edificações e de urbanização, especialmente na praia Brava. A intensidade da ocupação urbana compromete a qualidade da paisagem. Na Lagoinha, situação menos intensa, mas com cenário futuro semelhante.

\section{A visão da paisagem. \\ Belvederes, destaques, corredores e bacias visuais}

Belas paisagens de praia, com evidente interferência das edificações na Brava. Destaque para o mirante no alto do morro de acesso desta praia, que permite e visão da baía toda.

\section{Dinâmica da paisagem}

Na praia Brava, paisagem praticamente estável pela quase total urbanização, e na Lagoinha, ainda permanece pressão urbana pela existência de áreas vazias que se implantam sobre banhado que deu nome à praia.

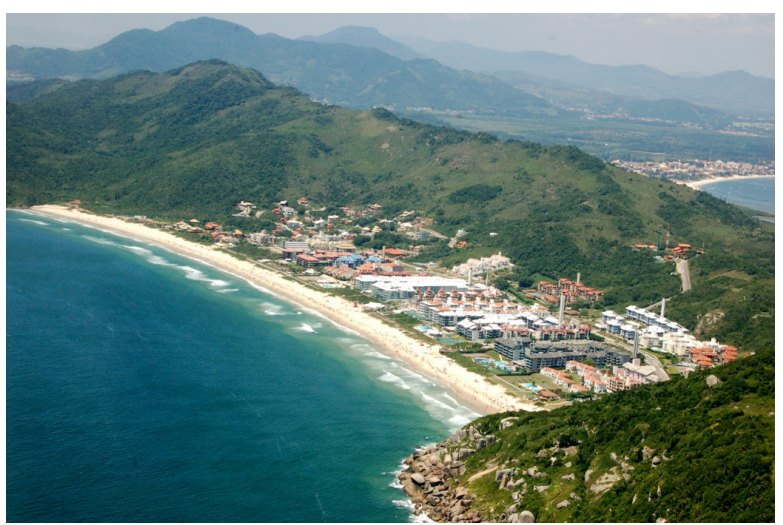

Figura 5.44: Vista da Praia Brava.

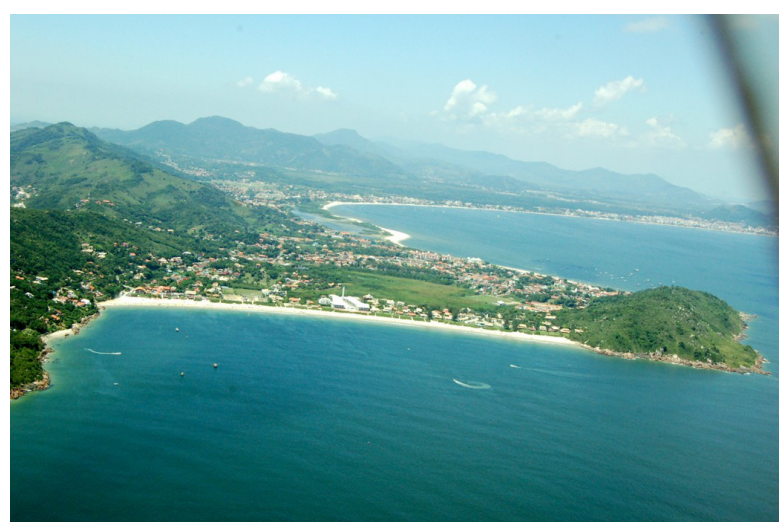

Figura 5.45: Vista da Praia Lagoinha. 


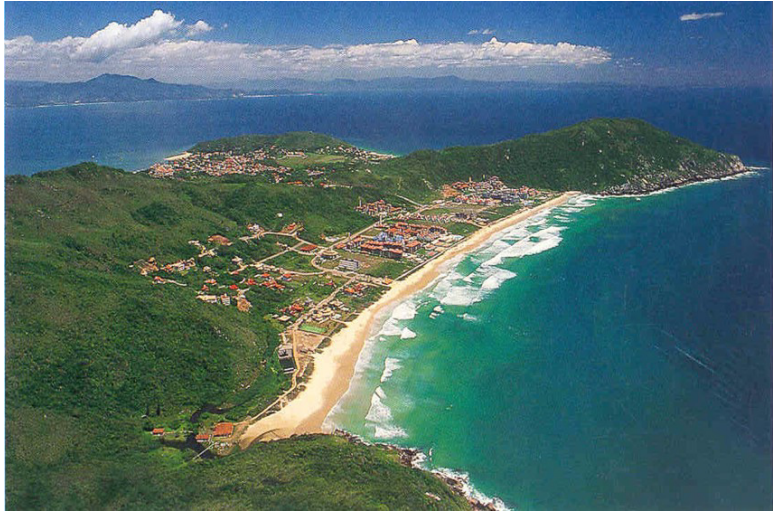

Figura 5.46: Vista da Praia Brava nos anos 1980.

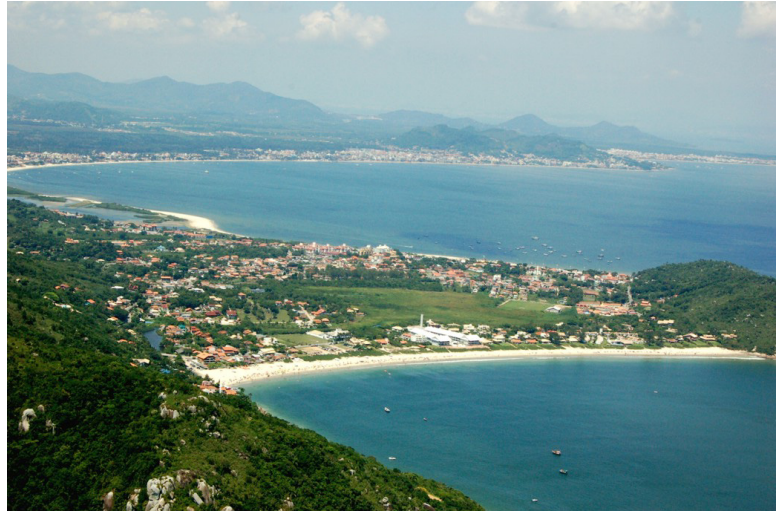

Figura 5.47: Vista praia da Lagoinha com urbanização sobre restinga.

\section{U.P. Ingleses-Santinho}

Situado no nordeste da llha e limitada pela dorsal principal de morros a oeste e pela restinga da U.P. do Rio Vermelho. Engloba os bairros de Capivari de Baixo, e as praias dos Ingleses e do Santinho.

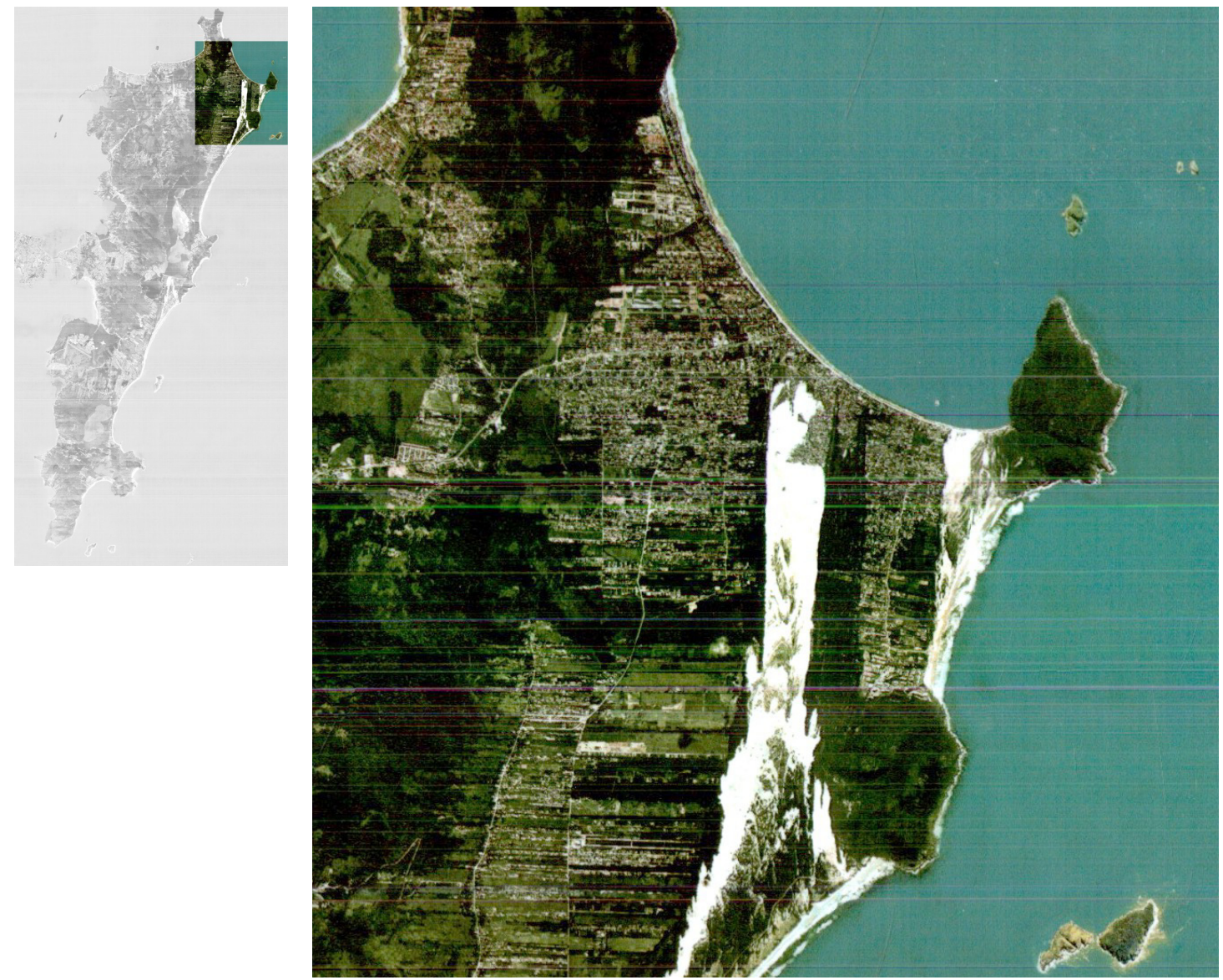

Figura 5.48: Unidade de Paisagem Ingleses-Santinho. 


\section{Elementos (naturais e humanos) constitutivos da paisagem}

Geomorfologia e hidrografia - matriz: planície sedimentar com restingas e dunas fixas e semifixas, ponteada por morrotes que definem os limites dos arcos praiais longilíneos, fechadas à distância pelas encostas dos morros do espigão central. Promontórios exuberantes nas extremas das praias. A variante da dorsal principal dos morros da Ilha de Santa Catarina define a planície a leste entrecortada pelos dois promontórios, formando arcos praiais orientados a nordeste, com patamar de sedimentação com pouca declividade no encontro com o mar, e a leste, com patamar apresentando maior declividade.

Cobertura vegetal - vegetação nativa de restinga e de campos dunares nas planícies, de mata e gramínea, pelo desmatamento humano ou pela ação eólica, nos morros. Nas urbanizações, exótica de sombra, arbustiva e gramínea.

Usos do solo - urbanização balneária e habitacional permanente, esta na segunda franja costeira. Alguns equipamentos de turismo e lazer rural. Urbanização ocupando quase que totalmente à U.P., sobre dunas (semifixas) e restingas, apresentando variedade morfológica com desenhos modernos, reflexo da adoção de tipologia tendendo a segregação espacial dos condomínios fechados, e desenho longitudinal derivado do espaço colonial. O primeiro para grupos sociais de renda média e superior, e o segundo, com composição social mais diversificada. Destaque para o resort Costão do Santinho e sua expansão, o Costão Golfe, formando enclaves suburbanos, de morfologia autocontida, justapostas às ocupações residenciais. Problemas de inserção na paisagem, com relativo impacto visual negativo, pela proximidade aos recursos patrimoniais (sítio arqueológico e paisagem natural).

Sistema viário - vias de acesso secundário conectadas ao sistema principal. Dificuldade de acessibilidade ao resort (veicular e de pedestres) pelas dimensões reduzidas em relação ao fluxo atraído. No trecho sul da praia dos Ingleses e na praia do Santinho a trama de vias, derivada do parcelamento e do fracionamento de lotes coloniais, cria dificuldades de absorção de fluxos alternativos e conexões necessárias. Na porção norte da praia dos Ingleses, a implantação de diversos condomínios fechados sobre estrutura de lotes coloniais tem prejudicado conexões alternativas ao sistema paralelo à praia. 


\section{O caráter e a organização da paisagem}

Paisagem balneária extremamente densa e confusa pela morfologia urbana e sua disposição na matriz natural. As áreas urbanas fragmentam a rerstinga $\mathrm{e}$ se aproximam perigosamente das dunas.

\section{A visão da paisagem. Belvederes, destaques, corredores e bacias visuais}

Da via de acesso tem-se uma perspectiva ampla da praia dos Ingleses, donde se percebe o grau de urbanização caótico que se estabeleceu na U.P., entremeando lugares de diferentes padrões de qualidade urbana.

\section{Dinâmica da paisagem}

Paisagem ainda com intenso dinamismo pela transformação e expansão das áreas urbanizadas. Os campos dunares, mesmo cercados pela urbanização, ainda apresentam considerável dinamismo. Apesar da resistência comunitária, a U.P. sofre ameaças de transformações no sistema viário, projetado por sobre áreas dunares móveis e pela criação de campo de golfe sobre aqüífero que abastece a região.

Tem interesse paisagístico pela função ecológica das planícies e pela qualidade das praias e configuração das praias.

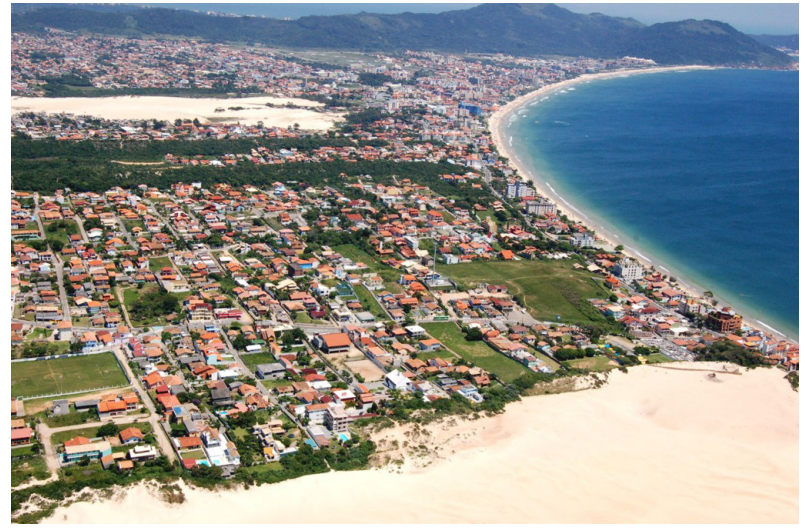

Figura 5.49: Vista da praia dos Ingleses e região. A presença das dunas restringiu em parte a maior expansão dos assentamentos.

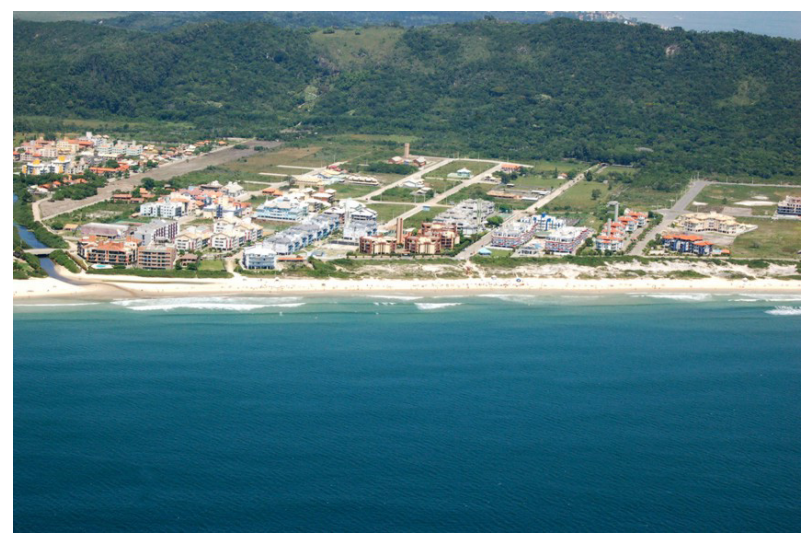

Figura 5.50: Vista da região norte de Ingleses com condomínios em média altura.

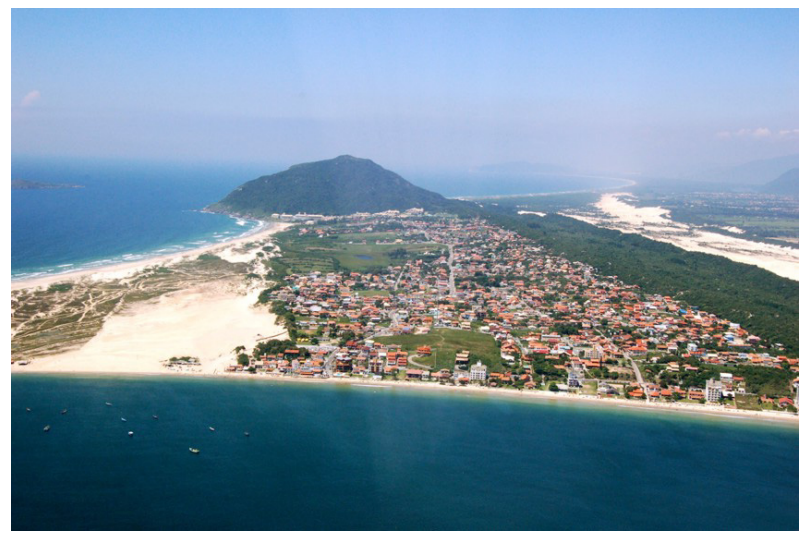

Figura 5.51: Vista do mosaico de restinga, assentamentos e dunas na praia do Santinho. 


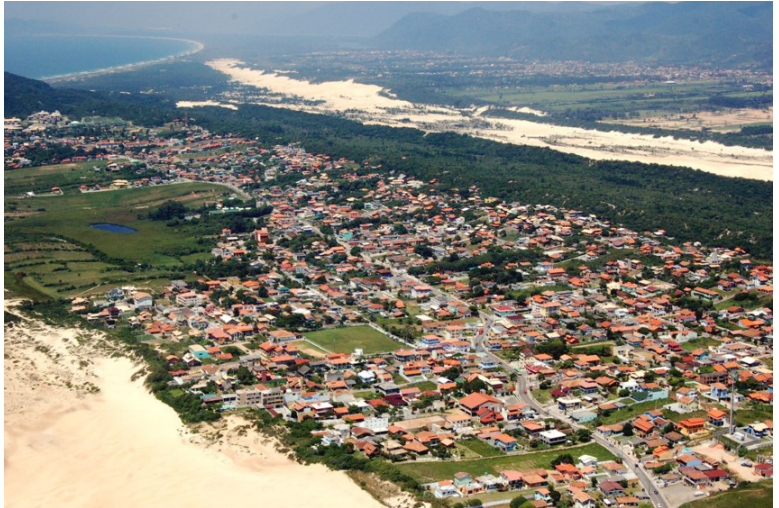

Figura 5.52: Vista Geral da praia do Santinho.

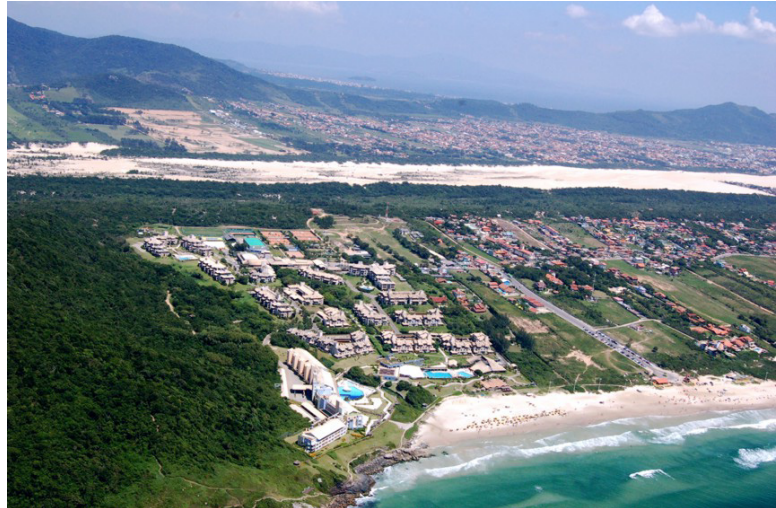

Figura 5.53: Vista da região sul da praia do Santinho com resort em primeiro plano.

\section{U.P. Rio Vermelho}

Situado na costa leste da Ilha, delimitada, a oeste pelos morros e a sudoeste pela Lagoa da Conceição e pela urbanização da Barra da Lagoa. Envolve o bairro do Rio vermelho e a praia do Moçambique.
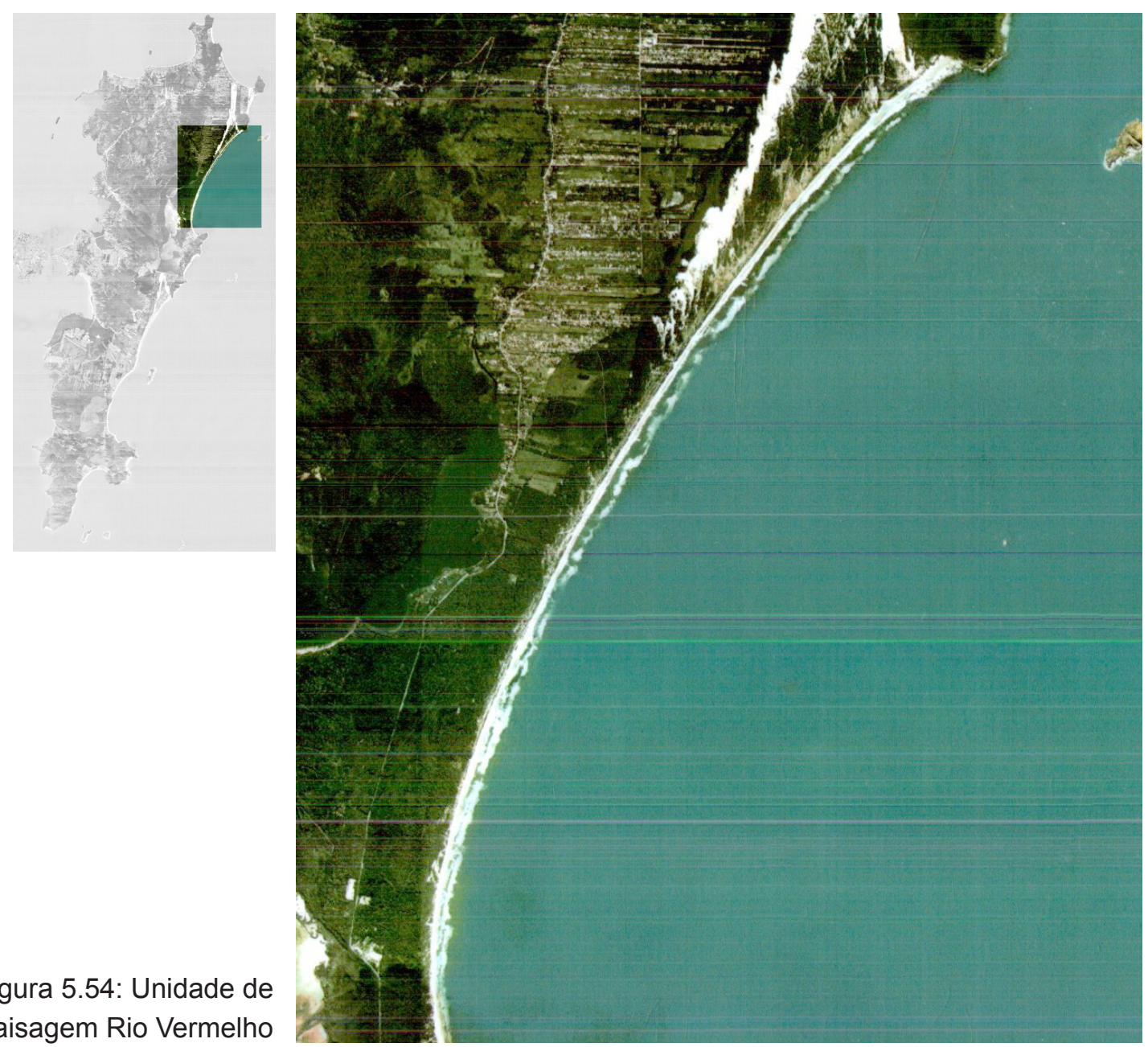

Figura 5.54: Unidade de Paisagem Rio Vermelho 


\section{Elementos (naturais e humanos) constitutivos da paisagem}

Geomorfologia e hidrografia - matriz: planície sedimentar com restingas, dunas fixas e semifixas, conformadas pelos morros do maciço central cobertos pela mata atlântica. Arco praial de mar aberto, orientado para o leste, extenso e longilínio. Grande planície sedimentar definida pela ação marítima e eólica e pela atividade erosiva nos morros. Hidrografia formada por rios e riachos que descem dos morros por vertentes íngremes até a planície. O Rio Vermelho, principal da região, corre na planície do norte para o sul, desembocando na Lagoa da Conceição.

Cobertura vegetal - grande massa vegetal de reflorestamento com diversas espécies exóticas (pinus, eucaliptos e outras), e gramíneas sobre antigas áreas agrícolas e comunais. Nas encostas, predomínio da mata atlântica em diversos estágios de regeneração, após uso agrícola, mas com a maior parte com cobertura arbórea.

Usos do solo - urbanização, em processo de adensamento, com morfologia em pente e espinha de peixe, derivadas da estrutura fundiária colonial, em loteamentos residenciais para grupos sociais de renda predominantemente média baixa, cujo impacto acontece pela extensão ocupacional dos loteamentos e alguns estabelecimentos de hospedagem, pela infraestrutura deficiente, e pela pouca conservação da cobertura do solo em função da baixa fertilidade dos compostos sedimentares arenosos. Morfologia urbana com traçado derivado da estrutura fundiária colonial, formando desenho de pente (vias secundárias saindo de outra via, principal, numa direção preferencial e sem conexão entre elas). Presença do Parque Florestal do Rio Vermelho, com inserções de assentamentos humanos, pontuais e pouco impactantes, para lazer, recreação e hospedagem efêmera (camping).

Sistema viário - dominado pela rodovia estadual SC 406 e, em segundo plano, pelo antigo travessão colonial, dos quais partem vias secundárias, formando estrutura morfológica em espinha de peixe e pente. Problemas de acessibilidade e circulação de veículos pela pouca dimensão das caixas de rua das vias secundárias (algumas com menos de 3 metros) e pela extensão (algumas com mais de 5 quilômetros) e a pouca conectividade entre elas, o que sobrecarrega as vias principais. 


\section{O caráter e a organização da paisagem}

Paisagem de urbanização suburbana, para extratos sociais de renda média e baixa, em expansão sobre antigas áreas rurais abandonadas ou em abandono. Urbanização sobre estrutura fundiária colonial compromete padrões de urbanidade pelo subdimensionamento de vias e lotes, e traçado com poucas conexões entre as vias que partem do eixo principal, a rodovia SC-406.

\section{A visão da paisagem.}

\section{Belvederes, destaques, corredores e bacias visuais}

Visuais de interesse paisagístico a partir da via principal especialmente junto ao núcleo colonial e por entre o parque reflorestado, que apesar do exotismo vegetal, forma, ora um corredor, ora um túnel verde agradável. A partir das encostas dos morros, a vista alcança diversos pontos de interesse, embora o acesso não seja fácil. A partir da extensa e arenosa praia do Moçambique, é possível perceber amplas visuais do horizonte marítimo e dos promontórios que encarceram o arco praial.

\section{Dinâmica da paisagem}

Paisagem com intensa dinâmica, com rápida substituição de campos agrícolas em abandono por urbanização de baixa densidade, sem infraestrutura de saneamento adequada a planície sedimentar, que se aproxima perigosamente da restinga fronteira ao mar. Reflorestamento em lento processo de substituição das espécies vegetais exóticas por nativas da restinga lacustre e marítima. Ameaça de adensamento extremado da planície e de faixas de praia, com impacto visual desagradável e pelas possíveis conseqüências sanitárias.

Tem interesse paisagístico pela conformação da praia e pela, ainda, baixa densidade de ocupação.

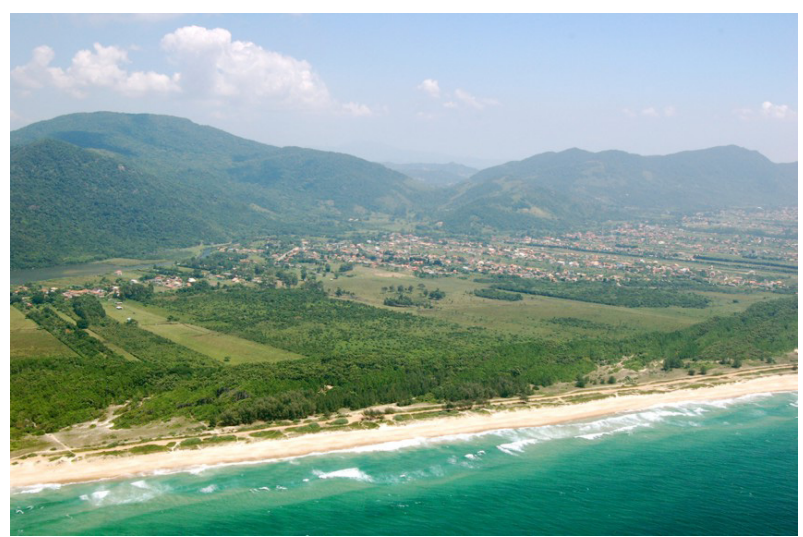

Figura 5.55: Vista da planície do Rio Vermelho. 


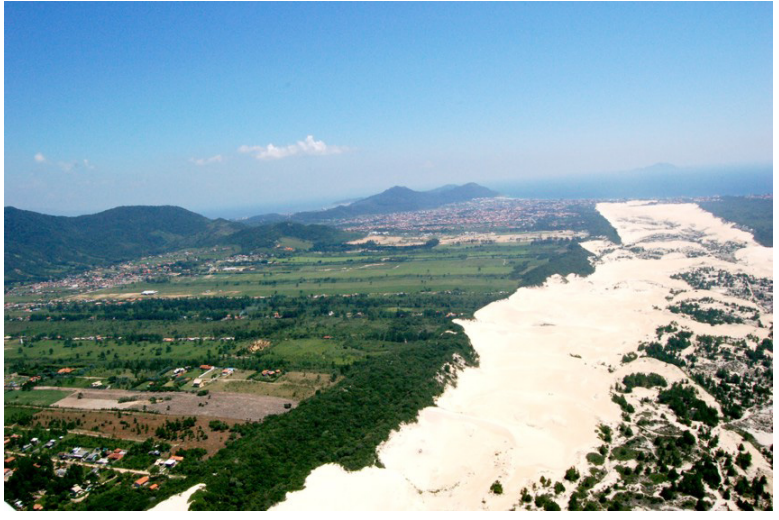

Figura 5.56: Vista da região norte do Rio Vermelho limítrofe às dunas.

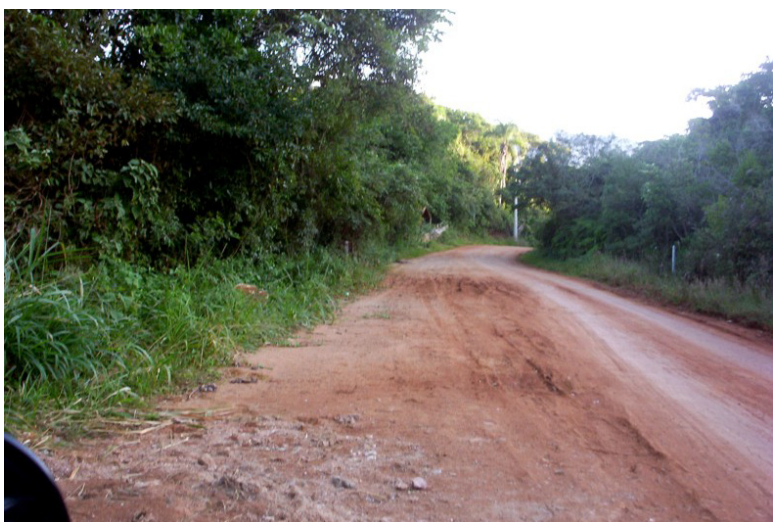

Figura 5.58: Vista de via secundária na U.P.

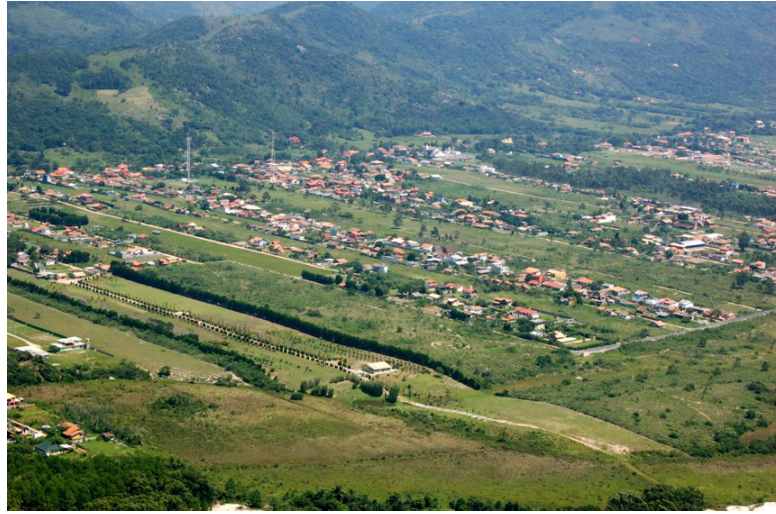

Figura 5.57: Vista das marcas da estrutura fundiária colonial orientando o subparcelamento.

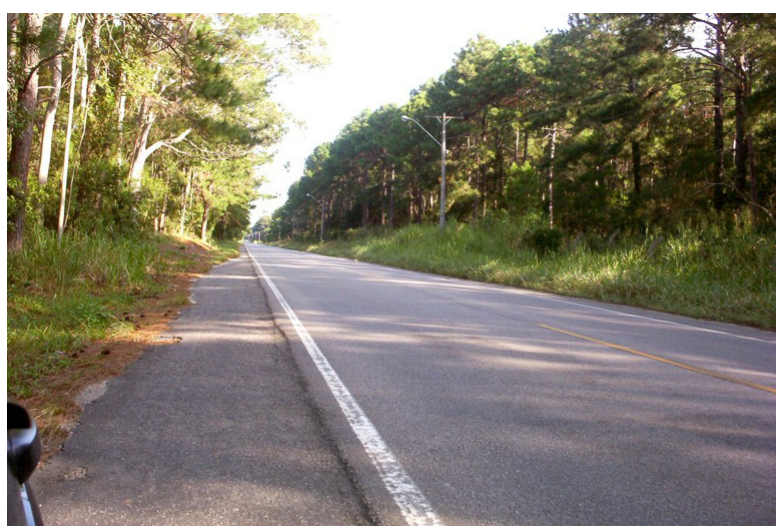

Figura 5.59: Vista da SC-406 em meio ao Parque florestal do Rio Vermelho, com vegetação exótica fechando a perspectiva.

A Unidade de Paisagem da Planície do Campeche que constitui integralmente a Unidade Territorial Planície Central com matriz de planície sedimentar, em parte inundável, bastante afetada pela ocupação clandestina, vem sofrendo ocupação legalizada, que embora com padrão de urbanização mais qualificado, apresenta impacto similar nos ecos-sistemas naturais, principalmente pela carência de infraestrutura de saneamento, além de extensividade da urbanização, comprometendo a diversidade do mosaico paisagístico. As versões da comunidade e do órgão público de plano de ocupação da planície, com diferentes posturas se opõem pelo extremismo entre uma ocupação intensa e outra em que aposta na baixa densidade como principal quesito de qualidade, o que pode tornar insustentável os serviços urbanos, quase inexistente e já bastante comprometido. Merece ordenação que considere as diferentes peças do mosaico das áreas homogêneas da planície, respeitando as manchas de cobertura vegetal, mas também a possibilidade de adensamento, com melhores condições infraestruturais e estudos específicos, em determinadas regiões, com rearranjo fundiário e substituições de situações de baixa qualidade. 


\section{U.P. Lagoa da Conceição-Barra da Lagoa}

Situada no centro da costa leste, definida pelas encostas orientais do espigão central e pelo oceano, tem como limite ao norte os sistemas costeiros e o reflorestamento do Parque Florestal do Rio Vermelho, e ao sul, os sistemas costeiros, de restinga e dunares, da planície do Campeche. Engloba os bairros da Costa da Lagoa, Lagoa da Conceição, Canto da Lagoa, Porto da Lagoa, Rio Tavares, Retiro da Lagoa e Fortaleza da Barra, e das praias da Joaquina, Mole, Barra da Lagoa e Galheta.

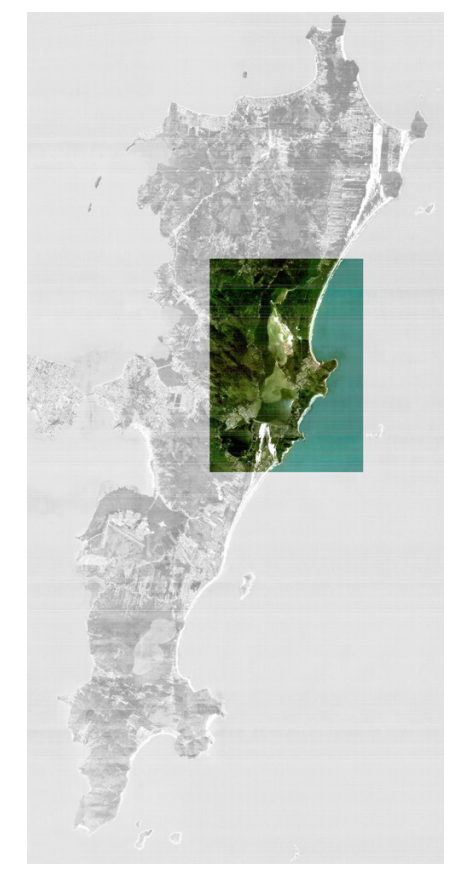

Figura 5.60: Unidade de

Paisagem Lagoa da Conceição-Barra da Lagoa,

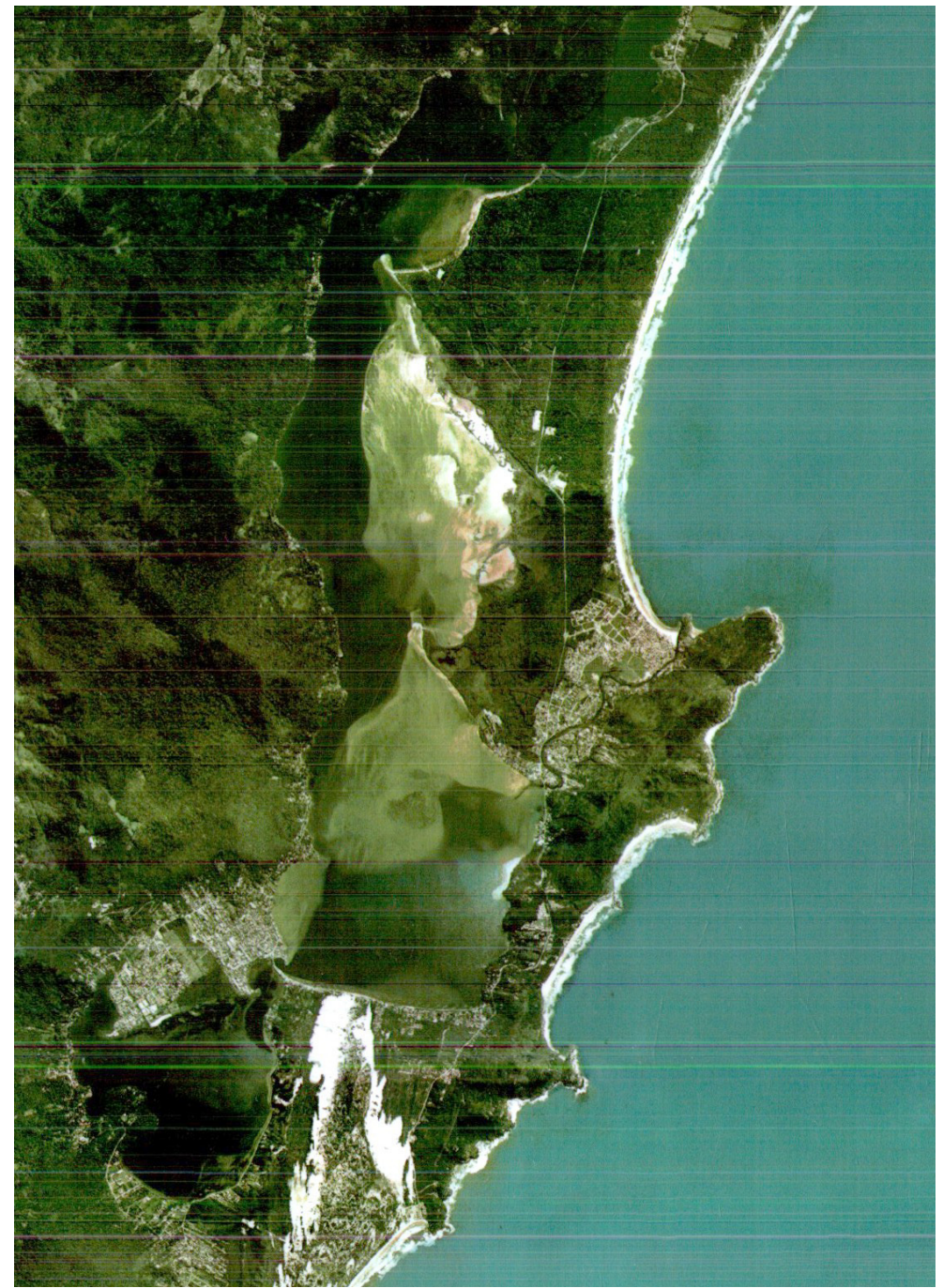

\section{Elementos (naturais e humanos) constitutivos da paisagem}

Geomorfologia e hidrografia - o mosaico desta unidade é bem heterogêneo, com diversos sistemas competindo no espaço. Maciços isolados junto à orla do mar e morros separan- 
do a U.P. da região central da cidade configuram os elementos graníticos que são circundados por planícies sedimentares de restingas e dunas, e espelho d'água de grande valor paisagístico e ecológico. A hidrografia é dominada pela Lagoa da Conceição, espeIho d'água, com 20,65 km² e profundidade de 2 a 6 metros, conectado ao mar pelo canal da Barra da Lagoa, por onde sofre influência das marés. Adrenagem se faz principalmente em direção à lagoa, por meio de vales com pequenos riachos que cortam as encostas, de variadas pendentes (em alguns locais formam-se quedas d'água e noutros, poços entre as pedras, de grande aproveitamento para lazer pela população local).

Cobertura vegetal - diversidade de espécimes vegetais torna a unidade uma das mais agradáveis paisagens. Nas planícies, ainda é possível encontrar grandes manchas ecossistêmicas de flora lacustre, dunar (fixos e móveis), de restingas e de vegetação de floresta quaternária, e nos morros floresta ombrófila da mata atlântica em regeneração e algumas manchas ainda originais. A vegetação nativa nas áreas urbanizadas vem sendo substituída por espécimes exóticos.

Usos do solo - uso urbano com características de bairro, com zonas residenciais e zonas mistas com comércio e serviços. Diversidade de padrões morfológicos urbanos em função da diversidade de extratos renda. Zonas residenciais, do tipo cidade-jardim com construções e urbanização de alto padrão, em loteamentos, condomínios fechados, se localizam em áreas próximas à orla da Lagoa e nas encostas dos morros. Nas planícies dos bairros da Barra da Lagoa e da Lagoa da Conceição, o arruamento derivado do parcelamento dos lotes coloniais do núcleo original forma um imbricado irregular de pequenas e estreitas vias, e recebem residências de diferentes padrões, numa mescla interessante de moradores tradicionais e novos. Alguns poucos equipamentos para atividades náuticas, pequenas pousadas dispersas e muitas residências ocupam a boa parte da orla da Lagoa, que apresenta poucos locais com tratamento adequado para uso público.

Sistema viário - o sistema principal é dominado pelas rodovias estaduais, que é complementado pelas as vias de pé de morro, as antigas estradas gerais. Destas, partem, nas encostas, vias terciárias em formato de espinha de peixe, e nas planícies, em formato irregular decorrente do intenso processo parcelamento dos lotes coloniais e das antigas terras comunais apropriadas em glebas com diversos formatos. Dada a localização central e as poucas alternativas viárias da cidade, a região recebe 
intenso fluxo de acesso às praias do leste da llha, com congestionamentos de veículos em fins-de-semana e diariamente durante a temporada de veraneio.

\section{O caráter e a organização da paisagem}

Mosaico variado com grandes manchas das diversas áreas homogêneas que compõem a U. P., e transmitem um aspecto suburbano de difícil leitura aos bairros. A diversidade fundiária se reflete nas morfologias urbanas.

\section{A visão da paisagem. \\ Belvederes, destaques, corredores e bacias visuais}

A visão da bacia da Lagoa da Conceição a partir do mirante do morro da Lagoa e da rodovia que desce até o bairro é a mais importante do ponto de vista do turismo, sendo reconhecido como um dos mais belos cartões postais de Florianópolis. O domínio visual de todas as áreas homogêneas que compõem o mosaico da região, com áreas verdes, manchas urbanizadas, mar lagoa, dunas, promontórios e morros, faz da U. P. uma das mais demandadas para moradia e visitação. As visuais internas aos bairros também possuem extremado valor paisagístico. Na Lagoa da Conceição, a presença da Igreja da Nossa Senhora da Conceição, localizada em elevação próxima ao núcleo central do bairro, se destaca em quase todas. Na Barra da Lagoa, a presença do sinuoso canal de ligação da lagoa com o mar e dos trapiches e dos barcos de pesca fazem do local uma das paisagens mais pitorescas da cidade, misturando natureza e cultura. As praias da Barra da Lagoa, da Joaquina, Mole e Galheta, esta de reconhecimento internacional, possibilitam belas visuais a partir delas e dos elementos que as delimitam, como os morros e dunas.

\section{Dinâmica da paisagem}

Extremamente dinâmica, a unidade apresenta diversos pontos de tensão entre urbanização e áreas naturais, pela grande demanda de novas expansões e de adensamento das áreas já ocupadas, com a substituição de casas tradicionais por novos edifícios e residências. Os ecossistemas de flora e fauna presentes nas dunas têm dinâmica natural pela mobilidade do substrato arenoso, e os ecossistemas presentes nas planícies e encostas são pressionados pela urbanização que avança rapidamente. 


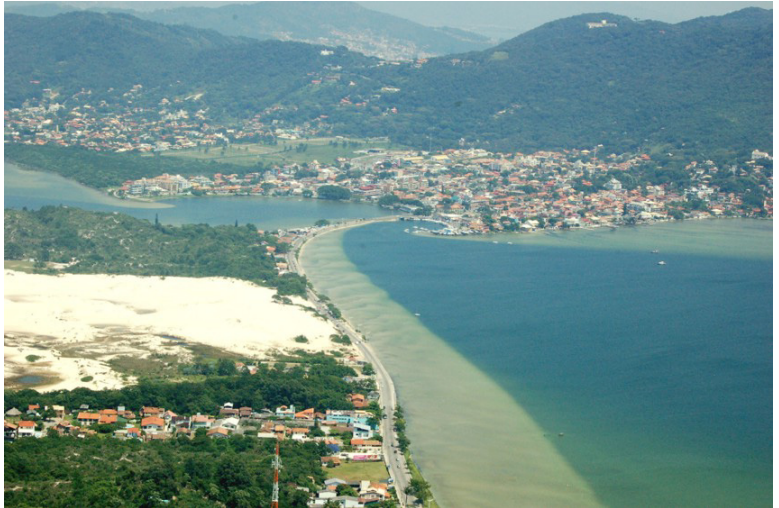

Figura 5.61: Vista do núcleo urbano da Lagoa da Conceição.

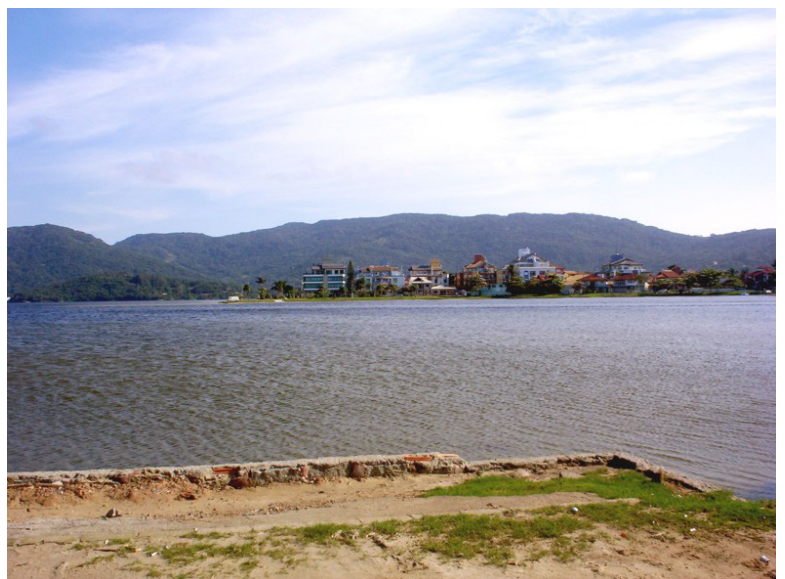

Figura 5.63: Silhueta de trecho urbanizado na Lagoa da Conceição.

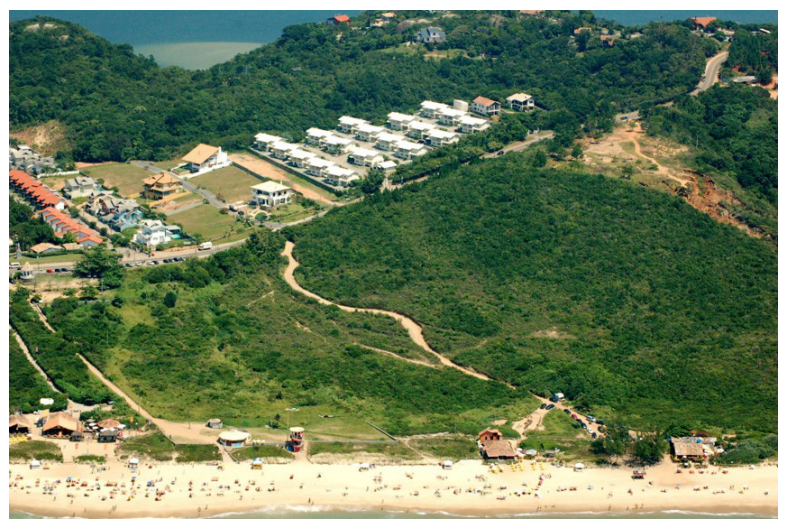

Figura 5.65: Vista de condomínio fechado horizontal na praia Mole.

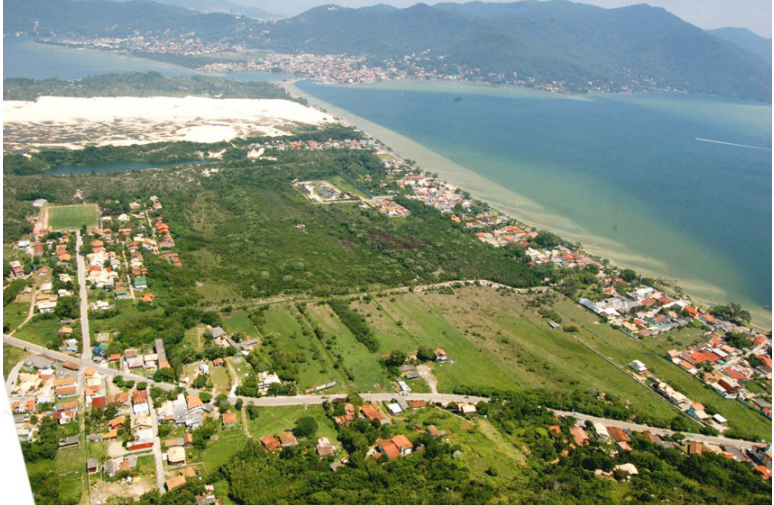

Figura 5.62: Vista da Lagoa da Conceição evidenciando o mosaico da paisagem.

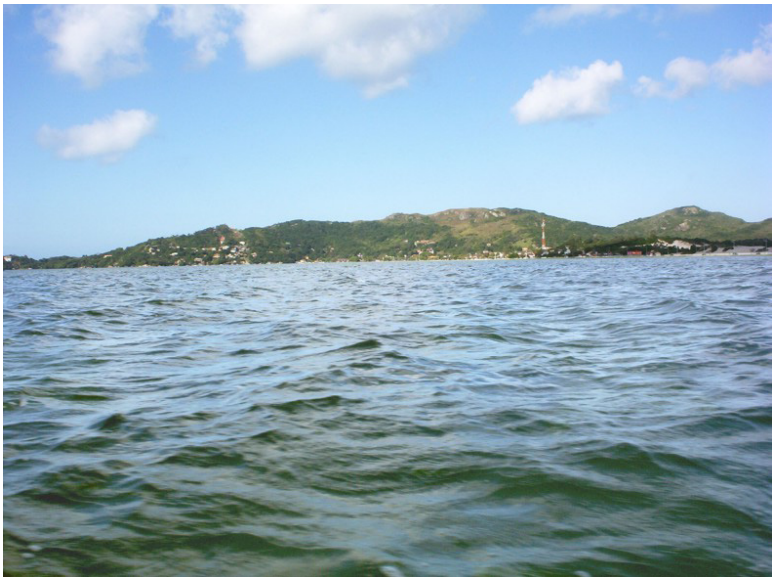

Figura 5.64: Vista dos morros da Praia Mole e Barra da Lagoa.

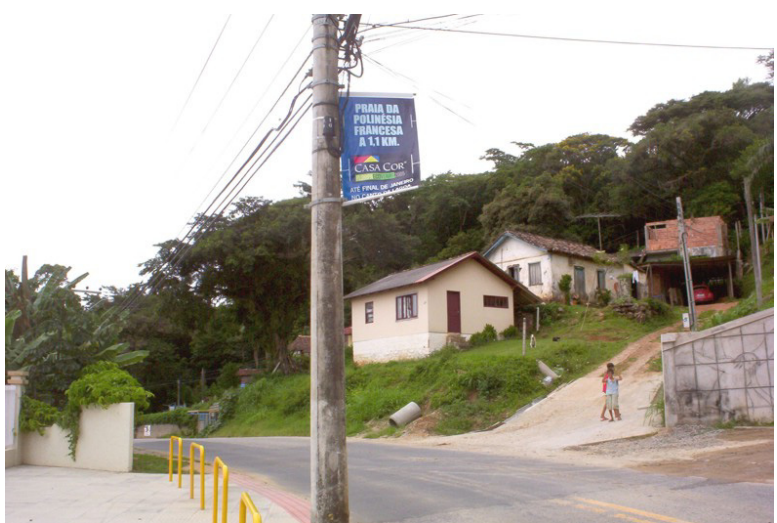

Figura 5.66: Vista de casa colonial tradicional. A placa no poste convida a visitar evento de decoração apelando para praia da Polinésia Francesa. 


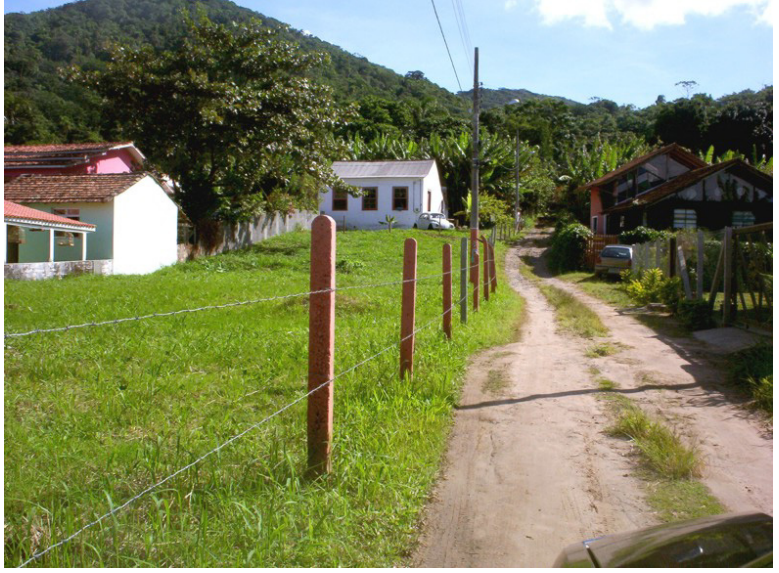

Figura 5.67: Vista de casa tradicional em lote subparcelado em direção à encosta.

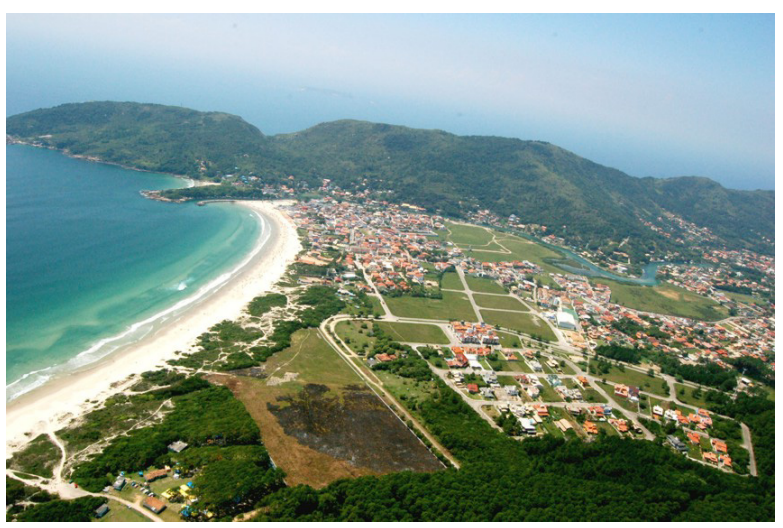

Figura 5.69: Vista da Barra da Lagoa com expansão por loteamento residencial.

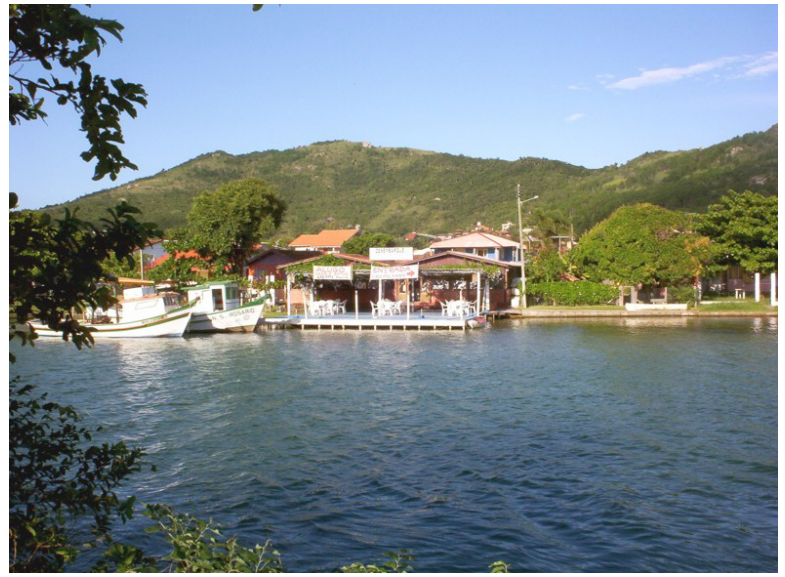

Figura 5.68: Vista do canal da Barra da Lagoa já bastante ocupado na orla.

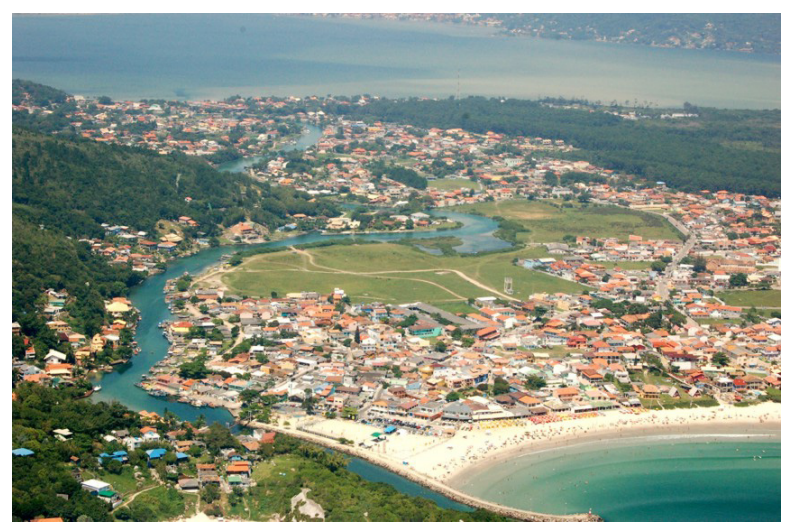

Figura 5.70: Vista do núcleo urbano da Barra da Lagoa.

\section{U.P. Planície do Campeche}

Situada na planície que divide a dorsal granítica central, na porção centro-sul da Ilha de Santa Catarina. A Unidade de Paisagem integrada pelas localidades do Campeche, Areias, São Sebastião e pelos balneários do Campeche e Morro das Pedras, na porção leste, Carianos e Aeroporto, na porção oeste, e Tapera e Alto Ribeirão na porção sul e sudoeste.

\section{Elementos (naturais e humanos) constitutivos da paisagem}

Geomorfologia e hidrografia - Planície sedimentar de baixa declividade orientada para oeste, com aproximadamente $50 \mathrm{~km}^{2}$. Na porção leste, os cordões dunares, em sua maioria já fixados pela vegetação, formam pequenas lagoas e banhados intradunas, 
receptáculos de águas de chuva e de águas de superfície. Hidrografia dominada pelo rio Tavares que, formado na encosta leste dos morros da dorsal central, é alimentado por diversos córregos e riachos em seu trajeto pela planície, desembocando na baía interior, em sua porção sul, formando manguezal de significativa função ecológica junto à foz. $A$ bacia de inundação do rio Tavares recebe águas da chuva dos morros ao norte e ao sul, alimentando lençol freático quase na superfície. Pequenos córregos fluem em direção ao mar. As lagoas da Chica, quase totalmente aterrada, e Pequena, de dimensões reduzidas, mas mais profunda, são as principais lagoas de retenção de águas pluviais.

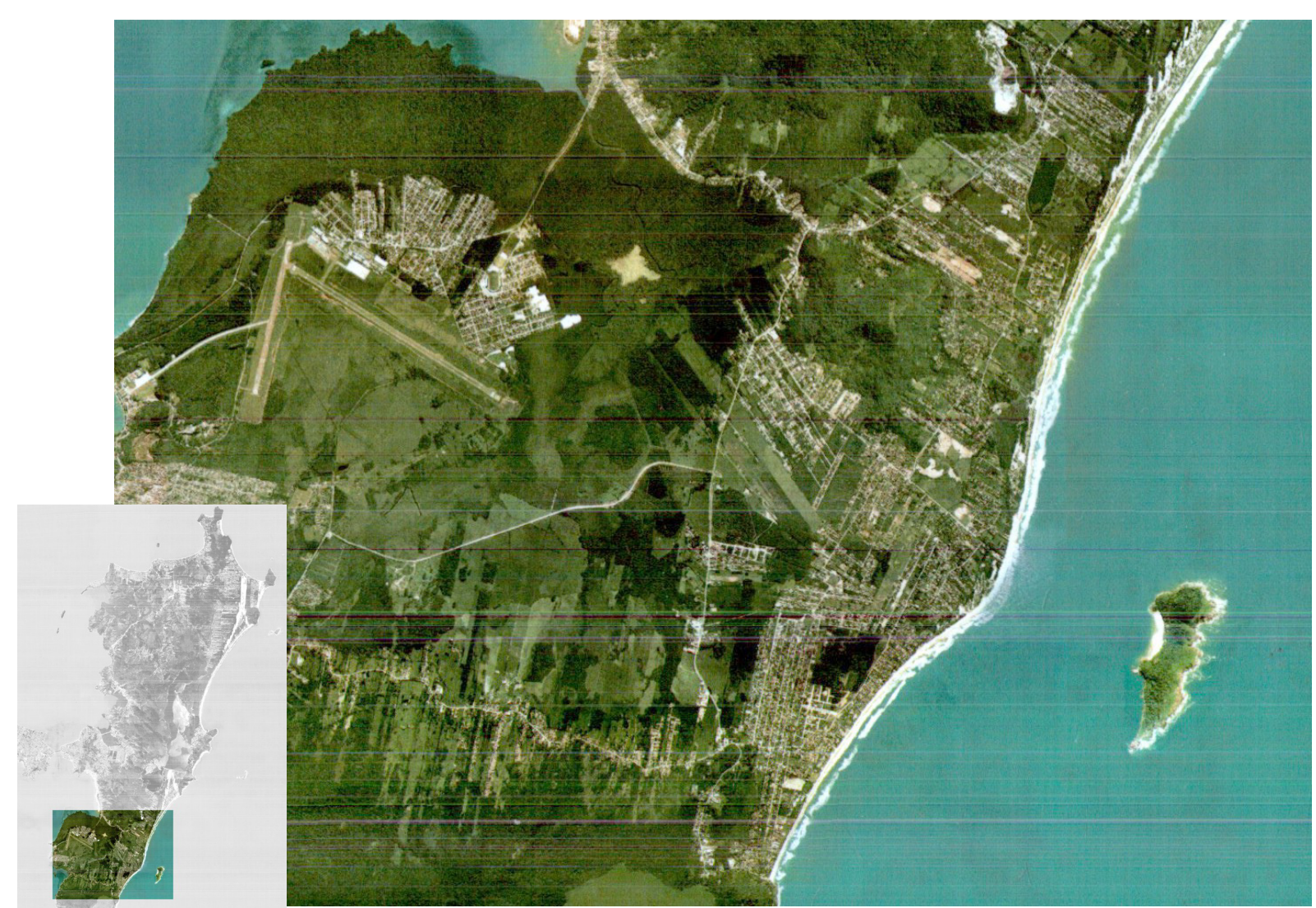

Figura 5.71: Unidade de Paisagem Planície do Campeche.

Cobertura vegetal - a planície é recoberta por vegetação de mangue, restinga e floresta de planície quaternária, distribuídas em manchas isoladas por vegetação de gramíneas de regeneração decorrente de desmatamento para fins rurais. Junto aos extensos cordões dunares que se estendem ao longo da praia, a vegetação de transição entre as dunas e a restinga é característica local. 
Usos do solo - áreas rurais em abandono ou abandonadas predominando na porção oeste e urbanização extensiva de densidade media, com padrões urbanísticos decorrentes de sub-parcelamentos irregulares, baseados na mínima dimensão da parcela e do sistema viário, com poucas e dispersas áreas de uso público, predominando na porção leste. Inserção, regularizada junto ao poder público, de loteamentos e condomínios fechados, com padrão urbano moderno. No final da via principal de acesso à orla marítima do Campeche, se concentram equipamentos de uso coletivo voltados para a atividade balneária. Diversas pousadas vêm se instalando na U. P., especializando a região neste uso, além de contar com loteamentos de segunda residência.

Sistema viário - articulação ao sistema viário da cidade pelas vias SC- 406 e SC 405, além de vias secundárias que acessam o litoral leste e a localidade do Campeche. As vias de acesso às zonas habitacionais de renda média, na maioria subdimensionadas, apresentam irregularidade de traçado, decorrente do parcelamento irregular de lotes coloniais, criando espaços isolados e segregados, enquanto que os lote3amentos e condomínios regularizados junto ao poder público, apresentam traçado regular e longilíneo, também em função da estrutura fundiária colonial.

\section{O caráter e a organização da paisagem}

A paisagem de matriz rural vem sofrendo rápida transformação em diversas partes da planície, com destaque para a urbanização extensiva, legal e clandestina na porção leste, com maior concentração e densidade junto à orla marítima, e na porção sudoeste, nas localidades do Aeroporto, Carianos, onde loteamentos de extratos sociais médios se estabelecem, e da Tapera, onde a urbanização se assemelha a da porção leste, com forte irregularidade de traçado e baixa qualidade urbanística. A mancha de áreas agrícolas em abandono ou abandonadas ainda mantém certa integridade e se insere na paisagem ainda como um espaço natural, mesmo que venha sendo rapidamente dilapidada junto às bordas das vias. Tem interesse paisagístico, cultural, ecológico e cênico.

\section{A visão da paisagem. \\ Belvederes, destaques, corredores e bacias visuais}

A paisagem se apresenta com um amplo espaço natural cercado por urbanizações, evocando paisagens rurais de baixo impacto em contraste com o forte impacto das 
ocupações urbanas extensivas que se espalham pela planície. Das vias e de determinados pontos do interior da Unidade de Paisagem, é possível descortinar belas perspectivas horizontais, fechadas pelos morros ao norte e ao sul, embora venham rareando pelo fechamento lateral das vias por edificações comerciais, de serviços e residenciais. Como aeroporto internacional Hercílio Luz se localiza no limite sul do manguezal, o mosaico inteiro da planície pode ser avistado das aeronaves que dele se utilizam. A ilha do Campeche, localizada a menos de 500 metros da costa em frente ao balneário é forte elemento paisagístico na amplidão da praia, fechando perspectiva da via de acesso. Os cordões dunares e as transições de restinga formam conjunto paisagístico interessante. O conjunto arquitetônico da Igreja de São Sebastião e sua implantação no limite da restinga, é destaque na paisagem construída.

\section{Dinâmica da paisagem}

Rápida transformação de paisagem rural para urbana com fortes vetores de pressão sobre as áreas naturais. Uma grande área não ocupada e pertencente à União vem sendo alvo de pressões ocupacionais por loteamentos oficiosos. A urbanização, irregular ou oficial, de

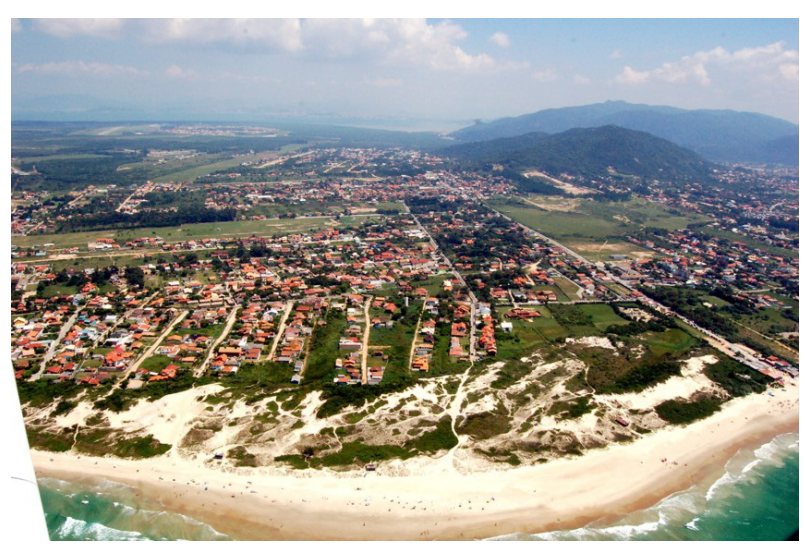

Figura 5.72: Vista geral do pontal do Campeche. modo indiferente, ocupou a planície, gerando a necessidade de planejamento. Há quase uma década, discussões sobre o plano do órgão de planejamento oficial - Plano de Desenvolvimento da Planície de Entremares, conhecido com Plano do Campeche, vem se arrastando num embate entre associações comunitárias, grupos ambientalistas e técnicos de diversas instituições de ensino supe-

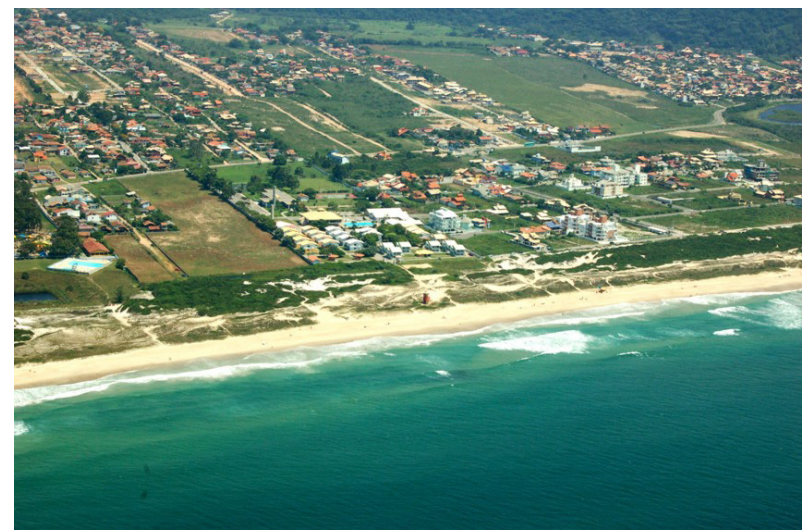

Figura 5.73: Vista do parcelamento na região da região leste do Campeche. rior e áreas do conhecimento, que chegaram a elaborar plano alternativo, contra as diretrizes de ocupação propostas pelo Instituto de Planejamento Urbano de Florianópolis. 
Dentre as ameaças implicadas pela adoção do plano oficial, a adoção de modelo urbano de média densidade, o zoneamento de unidades de vizinhança, e a distribuição de centros funcionais adensados, com alturas inadequadas para a planície, em meio a elas, além da extensividade ocupacional como padrão, são as que mais afetam negativamente a paisagem.

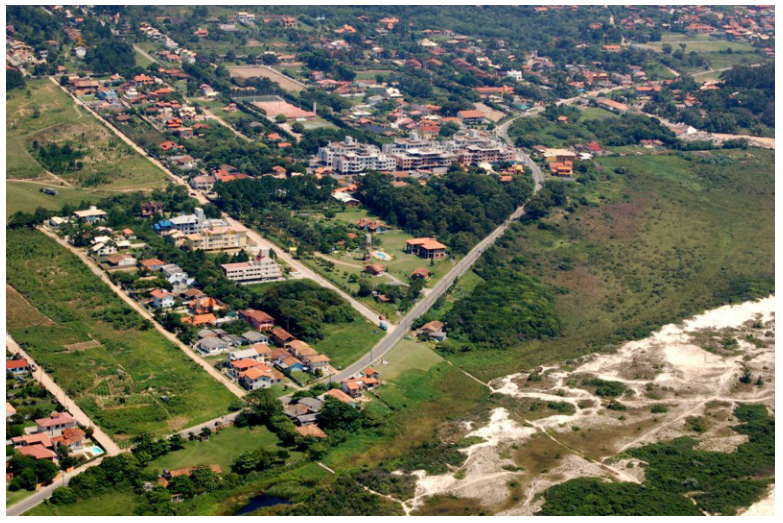

Figura 5.75: Vista do padrão de ocupação suburbana na região do Campeche.

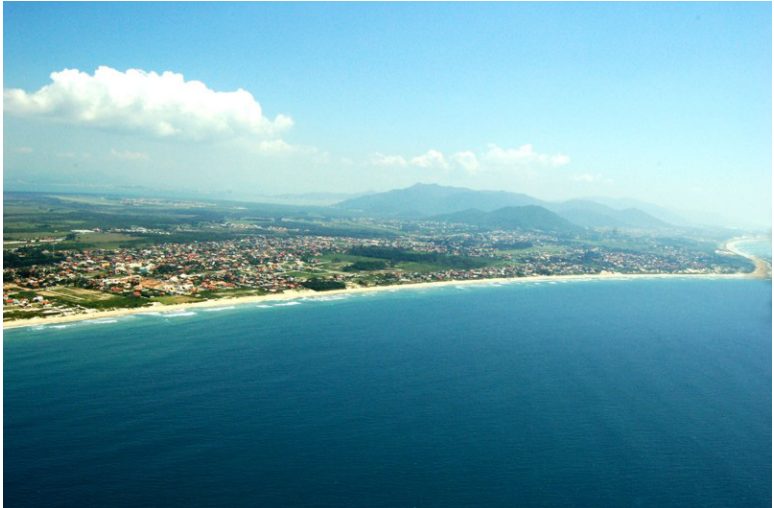

Figura 5.74: Vista geral da praia do Campeche.

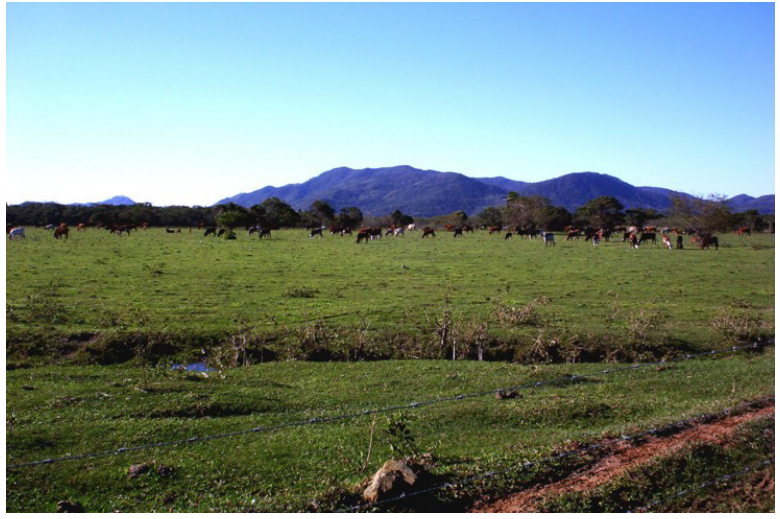

Figura 5.76: Vista de área ainda rural na planície.

As Unidades de Paisagem da Unidade Territorial Sul, apesar de orientadas para quadrantes diferentes e constituídas por matrizes diversas: planície e lagoa à leste, planície de inundação e encostas ao sul e encostas a oeste, apresentam predomínio da paisagem natural, pouco aproveitamento turístico, mas se encontram ameaçadas pela ocupação urbano-turística. A presença dominante da natureza e da cobertura vegetal nos morros e encostas o que the confere potencial paisagístico, sugere atividade turística de pouca intensidade, acompanhada de controle forte nos ecossistemas lacustres e nas planícies de restinga. As encostas, já em processo de ocupação residencial podem ser aproveitadas pêra estabelecimentos turísticos de baixo impacto. 


\section{U.P. Armação - Peri.}

Situado na costa sudeste da llha de Santa Catarina. Envolve as localidades da Armação, Peri e os balneários da Armação e Matadeiro.

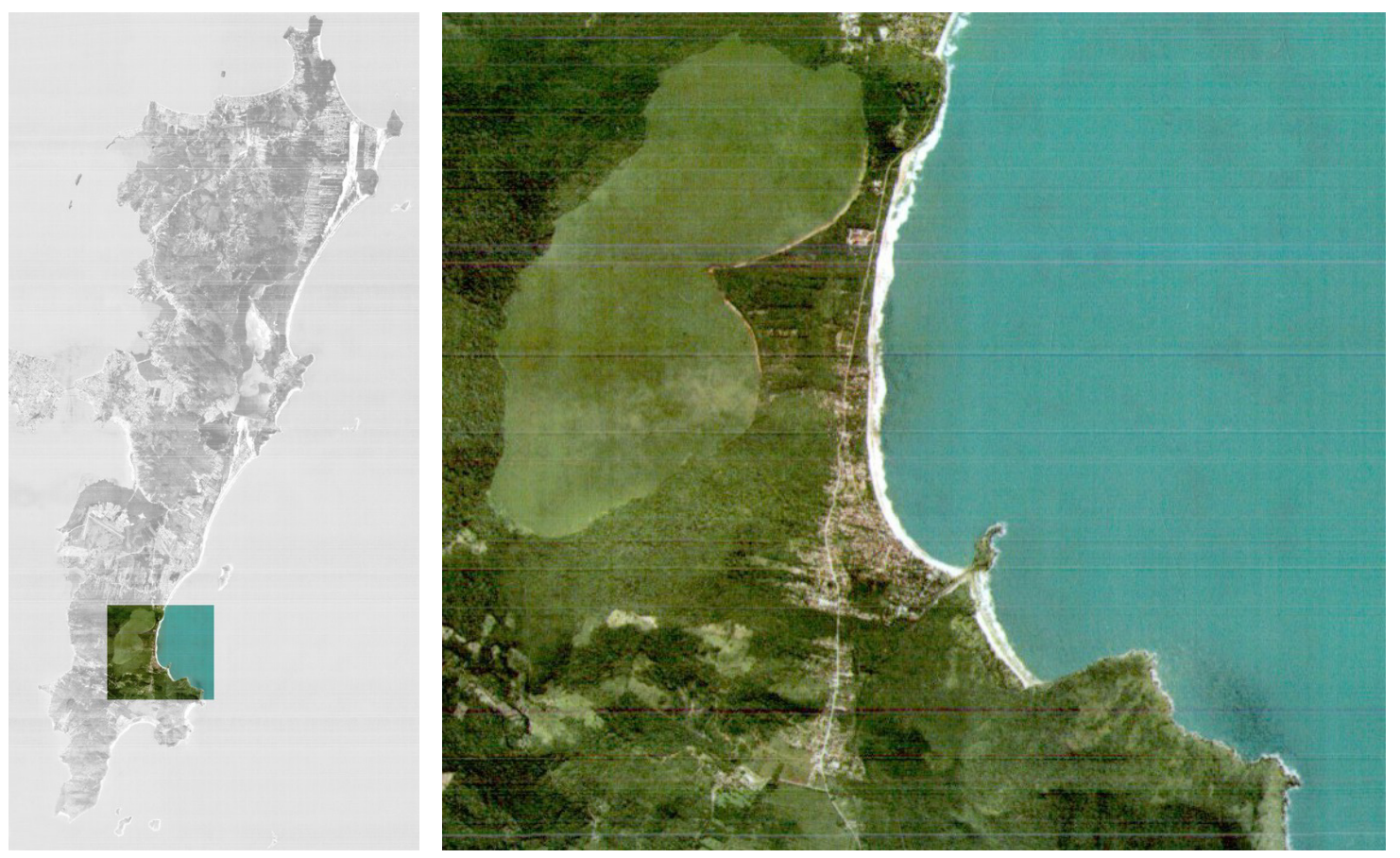

Figura 5.78: Unidade de Paisagem Armação-Peri.

\section{Elementos (naturais e humanos) constitutivos da paisagem}

Geomorfologia e hidrologia - estreita planície sedimentar e lagoa (do Peri) espremidas entre os morros da dorsal sul e o mar, com promontório, derivado do espigão da Lagoinha do Leste, avançando sobre o oceano formando ilhote costeiro colado. As encostas apresentam declividade acentuada especialmente junto à lagoa, formando cenário de anfiteatro pa a mesma. A restinga recente que fecha a lagoa apresenta forma alongada e estreita, com predomínio de solos arenosos. A Lagoa dentro do Parque do Peri, com desenho cordiforme , $5,5 \mathrm{~km}^{2}$ de espelho d 'água e profundidade variando de 2 a $4 \mathrm{e}$ máximo de 11 metros, é depositária de águas de encostas, de chuva, com pequenas vertentes íngremes. Um pequeno rio, o Sangradouro, conecta a lagoa, que se encontra 2 metros acima, com o mar, correndo de norte para sul em meio à restinga. Este rio recebe afluente vindo da planície do Pântano do Sul, que corre de sul para norte no trecho que conecta as duas planícies em meio ao desfiladeiro formado pelos morros. 
Cobertura vegetal - Encostas de morros tomadas por vegetação ombrófila úmida regenerada e em boa parte com bastante vigor, especialmente junto à Lagoa do Peri. Na restinga de fechamento da lagoa, misturam-se remanescentes de vegetação dunar rasteira e espécimes arbustivos de transição para a restinga. Reflorestamento exótico recobre parte da planície junto à localidade do Peri, descontinuando manchas de vegetação de restinga nativa. Nas encostas mais baixas a vegetação exótica de jardim nas áreas ocupadas por residências.

Uso do solo - A urbanização é o uso do solo mais percebido na paisagem e se sobressai enquanto ocupação do território da Unidade de Paisagem. Esta urbanização se apresenta na forma de loteamento de segunda e primeira residência no balneário da Armação, junto à praia e foz do rio Sangradouro, e de zona residencial nas expansões ao longo das vias de acesso e nas encostas de morros. A morfologia da planície é a malha regular dos loteamentos e trechos em do tipo espinha de peixe nas expansões. Os usos terciários se concentram nas vias de acesso ao balneário, polarizando a funcionalidade da Unidade de Paisagem. A existência do Parque Municipal da Lagoa do Peri, com uso recreativo e educacional, mas pouca ocupação por edificações em seu interior, condiciona a ocupação nas faixas não preservadas.

Sistema viário - conexão com o sistema principal da llha por meio da SC-406, principal artéria da qual partem as demais, abastecendo as zonas urbanizadas. $\mathrm{Na}$ encosta, por meio de minúsculas servidões perpendiculares a rodovia, com grandes declividades $\left(100 \%\right.$ ou $45^{\circ}$ ), e na planície, vias com padrão moderno em malha regular.

\section{O caráter e a organização da paisagem}

Paisagem característica da expansão de subúrbio balneário a partir de nucleação colonial, entremeada de remanescentes naturais de importante valor cênico. Apesar de trechos regulares e de boa qualidade urbanística, boa parte ainda se faz sobre estrutura fundiária colonial, implicando morfologias irregulares sub-dimensionadas e inadequadas para terrenos inclinados. A região da Lagoa do Peri apresenta panorama natural de grande impacto no equilíbrio da paisagem. 


\section{A visão da paisagem.}

\section{Belvederes, destaques, corredores e bacias visuais}

O parque da lagoa, por apresentar-se ainda em estado natural na maior parte do território, conserva aspecto de matriz original. $\mathrm{O}$ anfiteatro de morros cobertos de vegetação semelhante à original, encarcera a lagoa, formando belo e bucólico cenário. A praia, com larga faixa de areia e águas agitadas, mas que se acalmam junto à foz do Rio Sangradouro, na parte sul, onde um molhe tirou o isolamento do ilhote das Campanhas, formando uma península, revela paisagens balneárias de forte interesse. Um mosteiro marista, construção de médio porte, mas discreta, de meados do século XX, se implanta no promontório do norte da Unidade de Paisagem, na divisa com a localidade do Morro das Pedras, se destaca na paisagem sem agredi-la. A vista a partir do mosteiro também se revela de forte interesse paisagístico, pela possibilidade de visualizar um mosaico variado formado por montanhas, restingas, lagoas, mar e parte da urbanização. A praia do Matadeiro, ao sul da foz do rio, apresenta cenário agreste, cercada pela montanha que nesta parte tem grande declividade, fechando a perspectiva bem próxima à faixa de areia que se volta para o mar aberto de águas agitadas.

\section{Dinâmica da paisagem}

A dinâmica da paisagem vem se tornando mais intensa pela pressão ocupacional suburbana no entorno do parque e nas encostas dos morros. Esta ocupação, ainda lenta e gradual, tem forte impacto paisagístico, pela acentuada visualização possibilitada pela declividade do morro, e pelo impacto no relevo, pela criação de cor-

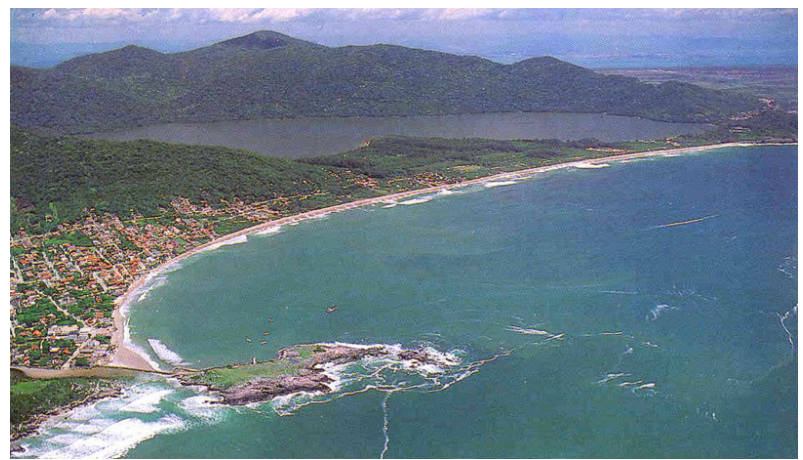

Figura 5.79: Vista da praia da Armação com a Lagoa do Peri e morros do Parque ao fundo. tes e caminhos no terreno de encosta. A Lagoa do Peri, com águas doces que são aproveitadas para abastecimento do sul e leste da llha, por meio de uma estação de tratamento implantada na restinga, entre a lagoa e o mar (e, diga-se de passagem, 
numa edificação com linguagem arquitetônica historicista vulgarizada, inadequada para as funções a que se destina e se houver intenção de criar uma paisagem construída sensível ao local).

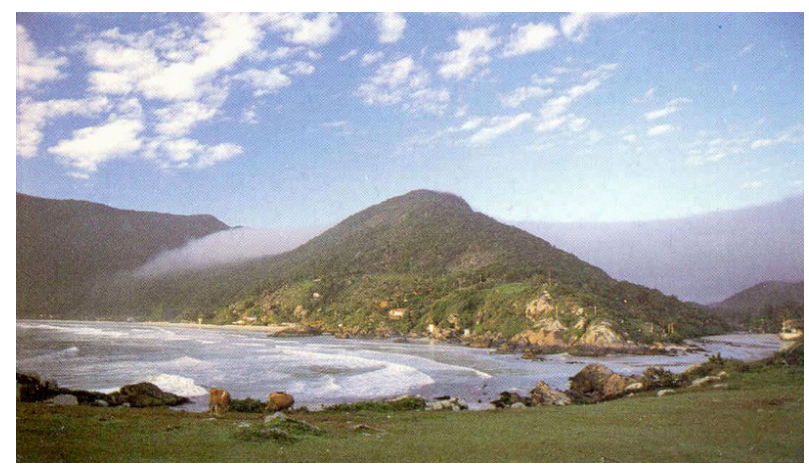

Figura 5.80: Vista da praia do Matadeiro.

\section{U.P. Pântano do Sul}

Situada no extremo sul e sudeste da llha de Santa Catarina. Envolve as localidades do Pântano do Sul, Açores, Costa de Dentro e Costa de Cima, Solidão e Saquinho.

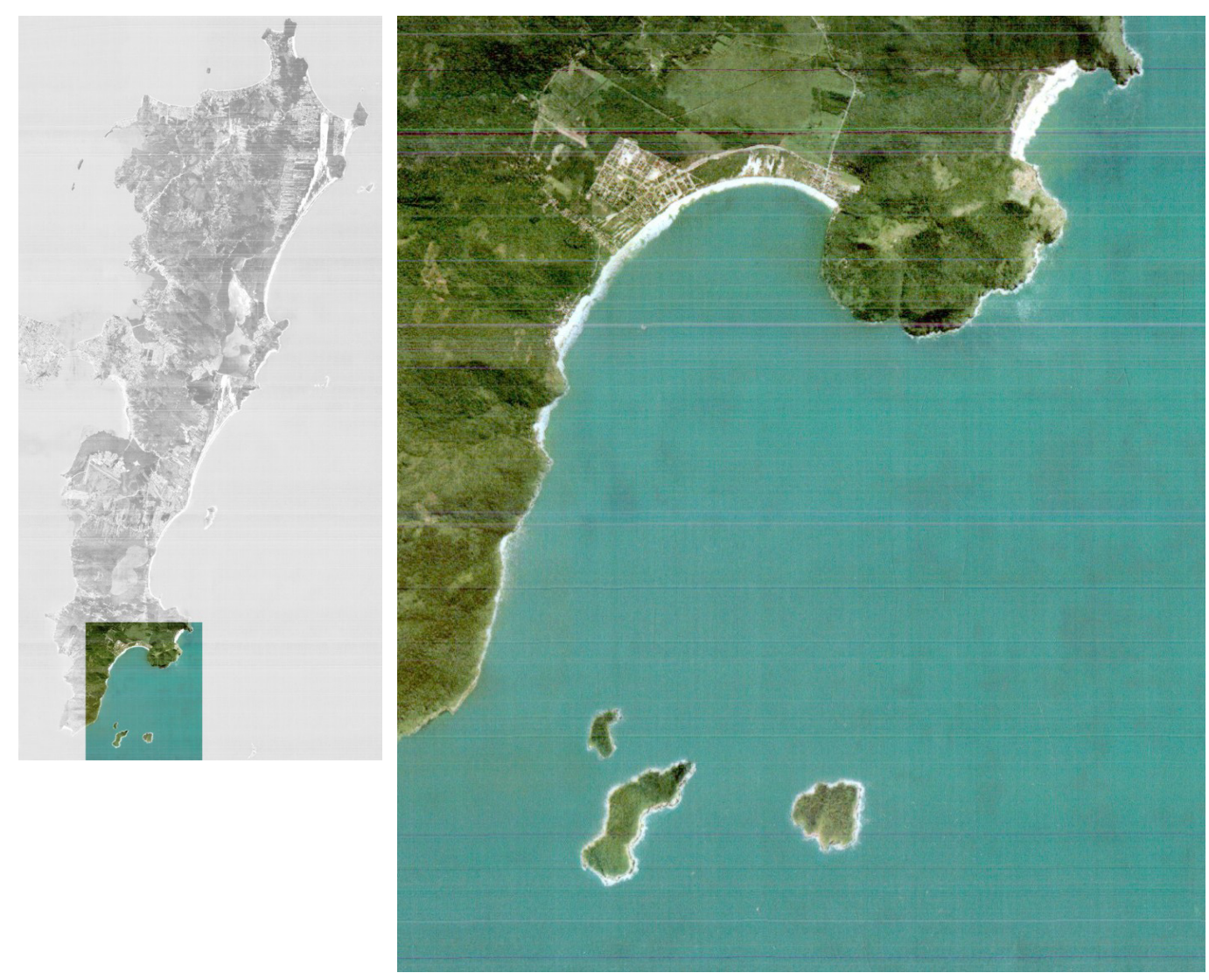

Figura 5.81: Unidade de Paisagem Pântano do Sul. 


\section{Elementos (naturais e humanos) constitutivos da paisagem}

Geomorfologia e hidrologia - Planície sedimentar quaternária separada do mar por estreita faixa dunar, emoldurada por anfiteatro de morros, da dorsal principal em sua porção sul e das montanhas da Lagoinha do Leste, voltadas para o quadrante sul. A planície funciona como retentor das águas que escorrem das encostas dos morros, em vertentes de declividades acentuadas, cortada pelo canal corrigido do Rio da Armação, que vai formar o Rio Quincas Antônio, desaguando na foz do Rio Sangradouro na costa leste. As áreas encharcadas formadas pelo funcionamento da bacia de retenção deram origem ao nome da localidade. Outro pequeno rio (Rio das Pacas) desce das encostas direto na pequena praia de enseada, Solidão, não sem antes formar pequenas cascatas no meio da mata de encosta.

Cobertura vegetal - As encostas dos morros envolventes da Unidade de Paisagem apresentam regeneração parcial da mata ombrófila úmida original, com grandes trechos ainda desmatados e utilizados para agricultura, pecuária ou reflorestamento exótico (eucaliptus e pinus). A planície sedimentar apresenta cobertura de floresta arbórea de planície quaternária em estágio de regeneração avançado, vegetação arbustiva e de restinga em regeneração médio, com boa parte com vegetação rasteira de banhados.

Uso do solo - No núcleo urbano pesqueiro tradicional (o segundo mais ativo do município), no canto leste da planície, junto ao mar, a urbanização se deu sobre apropriações sem preocupação de traçado de vias regulares nem de dimensões de lotes, produzindo um tecido de aspecto medieval, irregular e de vias estreitas, com algumas somente para pedestres. A estrutura fundiária colonial permaneceu nas novas ocupações nas encostas, onde os traçados do tipo espinha de peixe ou pente predominam. Na planície, a ocupação urbana, ainda rarefeita, vem se dando ao longo da via principal de acesso e da via secundária de contorno da planície. Em alguns locais ainda sofre a influência da estrutura fundiária colonial, mas em outros trechos, o remembramento dos lotes, estes já não derivados da colônia, mas das apropriações sobre terras comunais, permite loteamentos com padrões de urbanidade mais contemporâneos, embora ameacem a hidrologia da área. O loteamento dos Açores, aprovado pelos órgãos públicos responsáveis e localizado em frente à 
baía do Pântano do Sul, avança sobre a floresta quaternária da planície, e se destaca na paisagem da unidade. Apresenta traçado de cidade jardim ortogonal, e se conecta com o entorno pela sua principal via, um bulevar de quatro pistas, que articula as edificações de até quatro pisos, na via e na orla marítima, a maioria ainda de segunda residência e em casa de dois pavimentos.

Sistema viário - Uma via de acesso principal de uma pista pavimentada, a SC-406, conecta com as localidades ao norte da Unidade de Paisagem, da qual parte via uma secundária, sem, pavimento e de pouca largura, contorna a planície pelo sopé dos morros, conectando com as encostas dos morros da dorsal principal sul. No núcleo urbano tradicional as ruas e vielas se mesclam de modo irregular, geralmente sub-dimensionadas. No loteamento Açores, a malha viária apresenta desenho e dimensionamento moderno.

\section{O caráter e a organização da paisagem}

Paisagem caracterizada pela ampla planície sedimentar que dá nome à localidade e organizada pelas vias de circulação, que estruturam a ocupação suburbana. Os morros de entorno também caracterizam o fechamento visual da Unidade de Paisagem ao norte e nas laterais. As ocupações em determinados locais nas encostas já apresentam características rururbanas, implantando-se em grandes declividades e em cotas de nível altas. No núcleo tradicional, a paisagem cultural se expressa na tipologia de arruamentos e edificações, nos equipamentos de pesca e nas atividades sociais, ainda bem marcadas pela cultura açoriana.

\section{A visão da paisagem.}

\section{Belvederes, destaques, corredores e bacias visuais}

As visuais proporcionadas pela Unidade de Paisagem são diversas, mas todas com bastante interesse paisagístico. Internamente ao núcleo tradicional, a percepção do ambiente tradicional do pequeno núcleo atrai o olhar visitante. Mesmo as ocupações por edificações no costão de fechamento da baía a leste ainda mantém limites adequados em relação ao conjunto urbano e natural do local. As visões de pontos mais altos dos morros laterais e posteriores permitem abarcar a totalidade da 
Unidade de Paisagem, com o mosaico de áreas homogêneas, algumas já bem fragmentadas, distribuído na planície e nas encostas. Os corredores visuais a partir das vias de circulação permitem percepções de ambientes rurais e bucólicos, na estrada secundária de contorno da planície, e amplas visuais horizontalizadas a partir da estrada principal.

\section{Dinâmica da paisagem}

A paisagem da Unidade encontrase num processo de transformação bem dinâmico pela implantação de loteamentos de baixa densidade, mas extensivos e ocupando a planície inundável. A drenagem de banhados e o levantamento do nível dos terrenos sem plano de manejo da dinâmica hidrológica podem trazer conseqüências já conhecidas do poder público e das populações atingidas por enchentes em outros locais da cidade. A pressão sobre a área tem sido intensa assim como a reação da comunidade e ambientalistas. O Plano Específico de Urbanização se encontra em discussão pública. Tem interesse como paisagem cultural, ecológica e cênica.

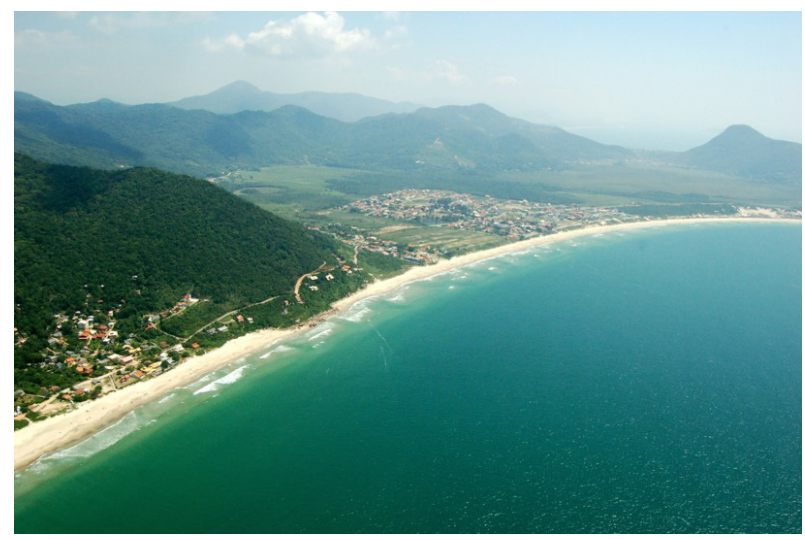

Figura 5.83: Vista da planície do Pântano do Sul.

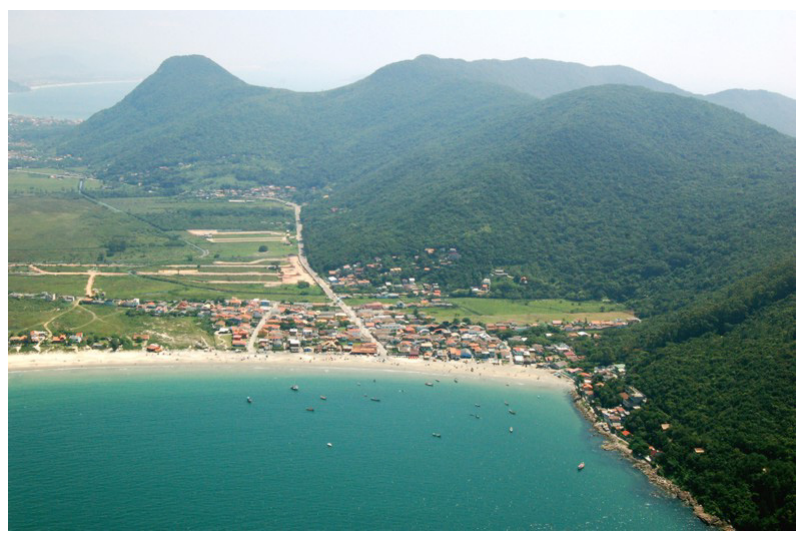

Figura 5.84: Vista do núcleo urbano do Pântano do Sul.

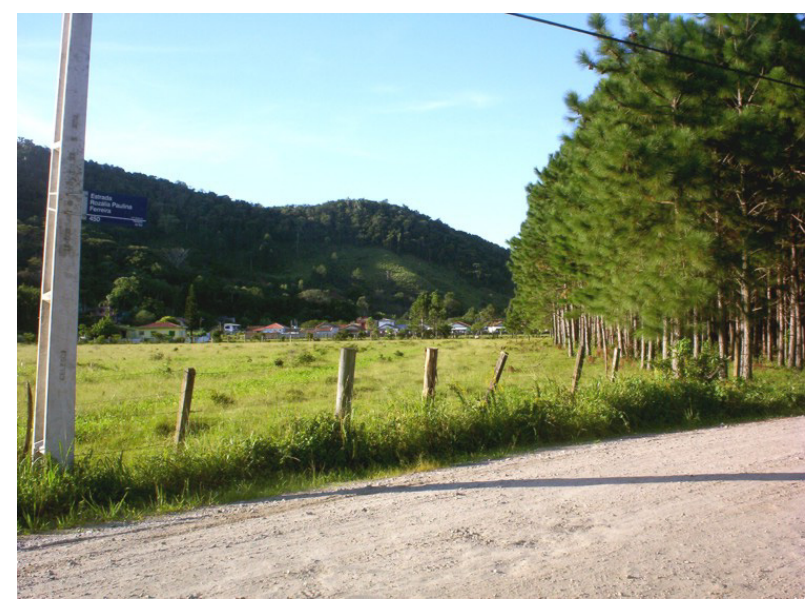

Figura 5.85: Vista de área rural na planície, com ocupação ainda dispersa na encosta. 


\section{U.P. Ribeirão da Ilha}

Situada no sudoeste da llha, voltada para o continente. Envolve as localidades do Ribeirão da Ilha, Caieira da Barra do Sul e a praia de Naufragados, integrante do Parque Estadual do Rio Vermelho.

\section{Elementos}

(naturais e humanos)

\section{constitutivos da paisagem}

\section{Geomorfologia e hidrologia - En-}

contro das encostas em declives acentuados dos morros da dorsal principal em sua porção sul, com o mar interno à baía, com pequenas áreas de sedimentação na junção dos dois domínios, formando pequenas enseadas e baías fechadas por pequenos promontórios. Dos

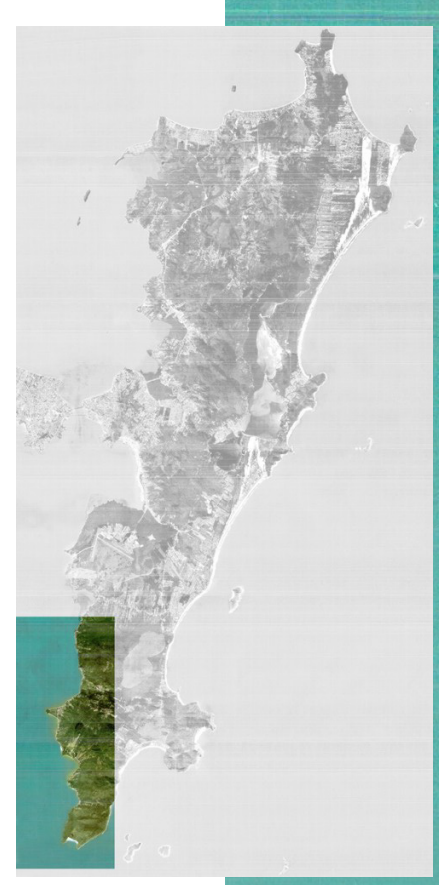

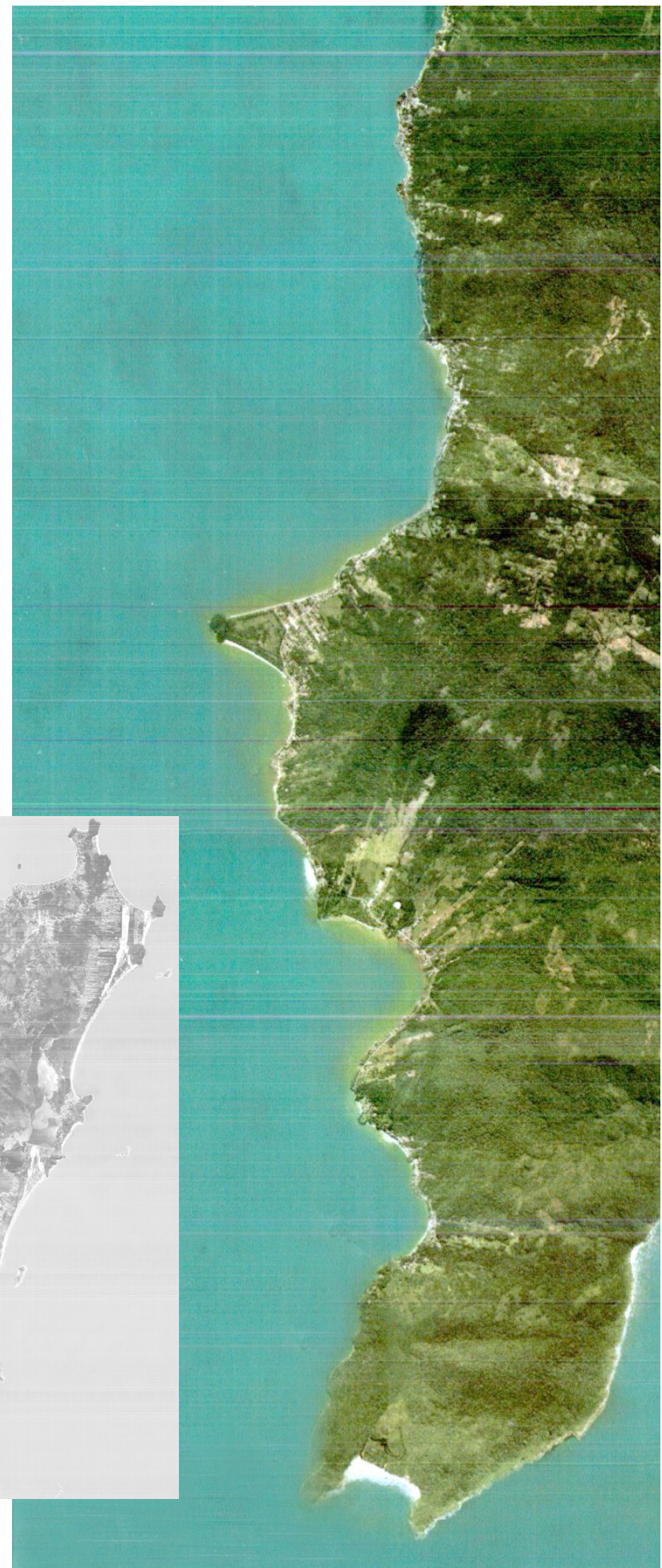

Figura 5.86: Unidade de Paisagem Ribeirão da llha. 300 metros, descem córregos e riachos em vertentes íngremes, desaguando no mar.

Cobertura vegetal - A cobertura dos morros é mata atlântica em diversos estágios regeneração após o uso agrícola e pastoril, que ainda resiste. Nas partes menos íngremes e planas junto ao mar a cobertura de restinga e floresta quaternária 
se encontra bastante reduzida em função da ocupação suburbana linear ao longo do caminho de acesso.

Uso do solo - Uso suburbano mesclado com rural. As ocupações edificadas são de residências permanentes de moradores tradicionais, e de segunda residência, ambas em baixa densidade, configurando uma morfologia de espinha de peixe ou pente, a partir da via principal, ora subindo em direção às encostas, ora em direção ao mar, quando do afastamento da via. O padrão ocupacional é de grupos de renda média, com o incremento de casos de alta renda, que vem se instalando com a migração especializada dos últimos anos, substituindo moradores e casas tradicionais. O uso rural ainda resiste em alguns lotes coloniais, o que mantém boa parte da Unidade de Paisagem com áreas não ocupadas. A maricultura, recentemente implantada como modo de substituir a pesca artesanal em decadência, aproveita as águas calmas das baías internas para a instalação de fazendas marinhas.

Sistema viário - sistema conectado ao principal da llha pela sinuosa via de circulação no sopé dos morros. Pequenos trechos mais adensados no núcleo tradicional da localidade formam desenho de malha regular incompleta.

\section{O caráter e a organização da paisagem}

Paisagens suburbana e rural mesclada se dominadas pela exuberância dos morros de entorno e pela amplidão da Baía Sul, com paisagem cultural ecológica e cênica.

\section{A visão da paisagem. \\ Belvederes, destaques, corredores e bacias visuais}

A distribuição pouco densa de edificações ao longo da costa proporciona visão agradável da ocupação suburbana e rural. Belas visuais para a baía, com o fechamento pelos contrafortes das serras do leste catarinense e das cidades do litoral continental. A vista a partir da estrada varia conforme a sinuosidade, apresentando-se ora fechada pelos morros, ora com amplas perspectivas marinhas. 


\section{Dinâmica da paisagem}

Pela distância ao centro da cidade e pela acessibilidade única, a paisagem apresenta-se em lenta transformação, embora o abandono de atividades rurais e sua substituição por novas residências sejam percebidos.

O interesse nesta paisagem se dá pelas características ambientais culturais e pelos aspectos da ocupação colonial ainda presentes.

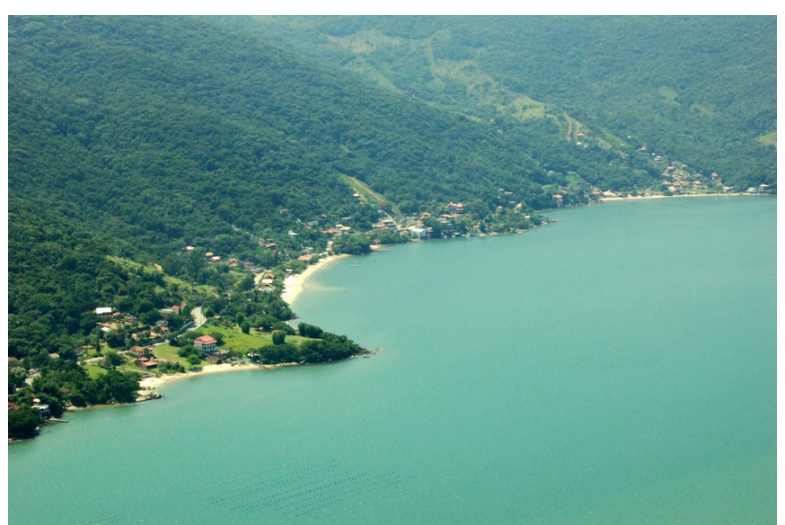

Figura 5.88: Vista das encostas da U.P.

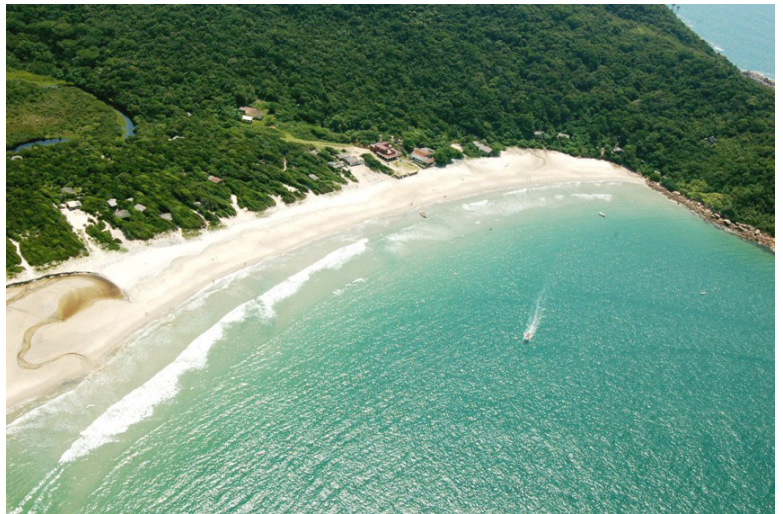

Figura 5.90: Vista da praia dos Naufragados que faz parte do Parque Estadual da Serra do Tabuleiro.

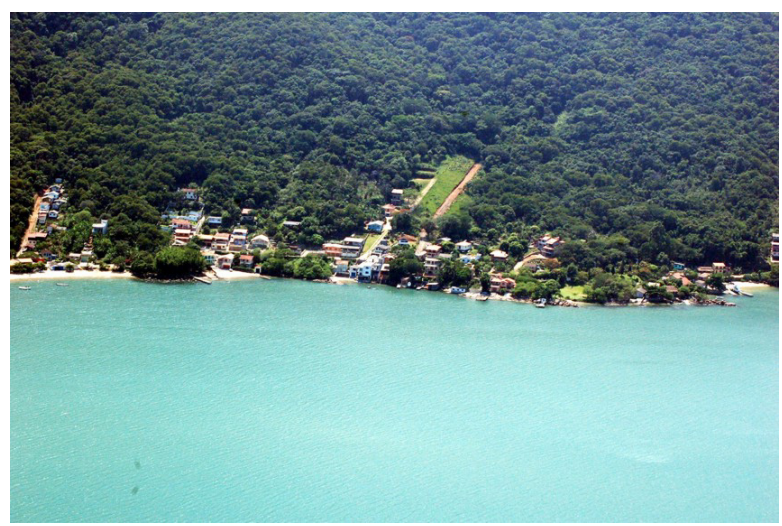

Figura 5.87: Vista da orla da U.P. na baía sul.

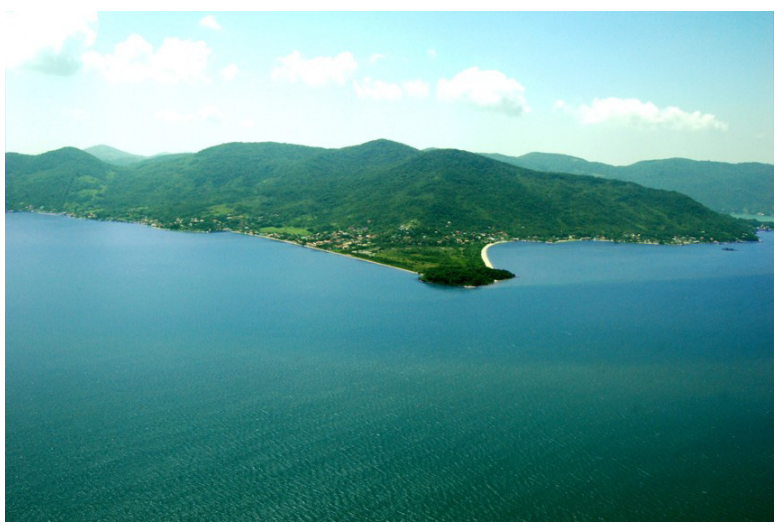

Figura 5.89: Vista da ponta do Caiacangaçú.

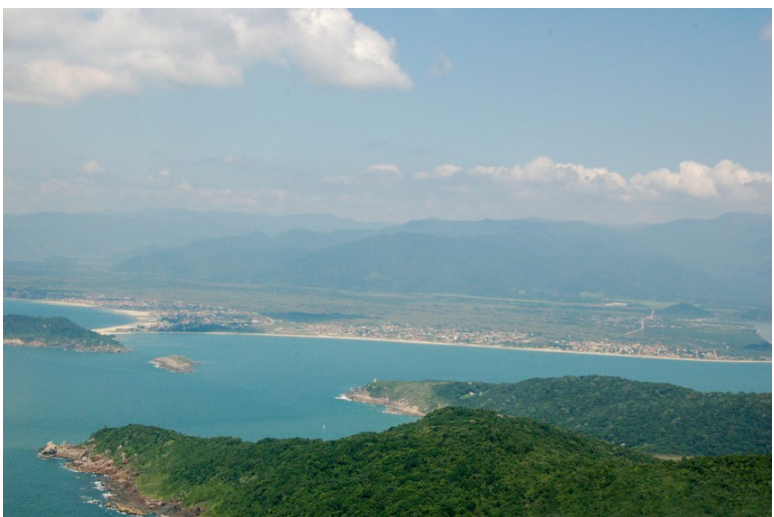

Figura 5.91: Vista da região insular e continental do Parque da Serra do tabuleiro. 


\subsection{Os padrões urbanos e arquitetônicos associados ao turismo na paisagem da Ilha de Santa Catarina}

Os destinos turísticos apresentam diferentes arranjos espaciais urbanos e arquitetônicos que buscam atender a demanda primordial dos visitantes - local para hospedagem. A cada maneira com que a atividade se realiza, seja em função do objetivo da atividade - turismo de sol e praia, turismo cultural, de negócios, turismo ecológico, turismo rural, etc, seja do tipo do agrupamento social do usuário, ou da intensidade com que a atividade se estabelece no tempo e no espaço - de massa, seletivo, etc ou da localização - cidade, praia ou campo, correspondem tipos de turismo que requerem determinadas classificações de zoneamento e localizações especiais, bem como tipos arquitetônicos e determinados serviços.

Mesmo ao apresentarem diferenças significativas de tipos e formas, os estabelecimentos turísticos não alteram as funções básicas - acolher visitantes temporários com determinado grau de conforto e oferta variável de atividades complementares, que varia, em função da demanda. Os estabelecimentos turísticos coletivos, mesmo que em edificações (permanentes ou efêmeras) compartimentadas, têm ofertas de amenidades, locais e equipamentos de lazer e recreação compartilhados, formando conjuntos turísticos conhecidos como hotéis, resorts ou campings.

Ao incorporarem mais serviços ao de hospedagem (leitos), começam a apresentar exigências dimensionais e locacionais que exigem a variação dos padrões arquitetônicos e urbanos, com a função de hospedagem temporária podendo ser feita de modo coletivo em estabelecimentos específicos para a atividade ou individualizadas em edificações sem especificidade de uso.

É reconhecida, porém, a tendência da atividade turística, especialmente no turismo de massa, de homogeneizar os espaços onde se estabelece, na medida em que a lógica fordista implica ampliação progressiva da escala e a padronização de morfologias, desenhos urbanos e até tipos edilícios, atendendo à necessidade de racionalizar procedimentos e otimizar investimentos. Esta tendência de fundo economicista só não se realiza por completo por causa dos fatores diferenciais existentes entre as maneiras de adequação física aos diferentes locais e, apesar da globalização cultural, pela adoção de recursos semióticos das culturas envolvidas. Ainda que seja claramente perceptível a alguma diferenciação de paisagem entre diversos destinos turísticos, é possível reconhecer padrões e tipos semelhantes adotados em diferentes regiões do planeta. 
Em Florianópolis, o processo de desenvolvimento territorial da atividade turística tem estado intrinsecamente ligado ao processo de desenvolvimento da atividade imobiliária e da construção civil, numa inversão de objetivos, prioridades e modos de aproveitamento da base natural que resultam num modelo turístico-urbano massivo e expansivo. O modelo atual, fortemente condicionado pela sazonalidade, é pouco adequado ao contexto ambiental da região e apresenta a tendência ao esgotamento dos recursos que são, e poderiam continuar sendo por prazo mais amplo que o horizonte previsível, motivo dos mais importantes na viabilização da sustentabilidade dos empreendimentos turísticos e imobiliários.

Além desse modelo geral que orienta as ações de planejamento dos espaços turísticos na Ilha de Santa Catarina, os padrões urbanos e arquitetônicos dos estabelecimentos que dão suporte à atividade, em termos de relação com a paisagem - localização, dimensões e desenho dos equipamentos, apresentam determinadas relações com a base natural, interferindo na paisagem e em determinados processo ecológicos e perceptivos de residentes e visitantes, requerendo análise mais detalhada.

No caso da análise realizada em relação aos estabelecimentos turísticos da llha de Santa Catarina, foram consideradas as peças básicas mais representativas resultantes do modelo de desenvolvimento urbano-turístico, de sol e praia, massificado e expansivo, condicionado pela sazonalidade. Embora boa parte dos exemplos de estabelecimentos turísticos esteja presente em regiões centrais da llha, é nos balneários que sua função se cumpre de modo mais pleno, sendo nestas áreas que a análise se concentra.

A quantidade de estabelecimentos de hospedagem torna a cidade no segundo maior parque hoteleiro do estado, logo atrás de Balneário Camboriú, mas as porcentagens dos diferentes estabelecimentos vinculados à organização de representação coletiva - o Sindicato dos Hotéis, Bares, Restaurantes e Similares da Grande Florianópolis SHRBS: somente $35,6 \%$ dos hotéis, $6,2 \%$ das pousadas, $33,3 \%$ dos campings e $66,6 \%$ dos motéis (SHBRS, 2005), refletem um segmento disperso e pouco associativo.

A flexibilização de novas relações de trabalho em setores abastados da sociedade brasileira, geralmente profissionais liberais e especializados, os que podem viajar com mais regularidade, permitem períodos de ócio e lazer fragmentados ao longo do ano, o que, junto com a sazonalidade do veraneio afeta muito o segmento de hospedagem. 
Isto explica, em parte porque, a taxa de ocupação média é em torno de $60 \%$ sendo que taxas de ocupação próximas de $100 \%$ só são alcançadas em períodos excepcionais, como os de passagem de ano e carnaval e com menor intensidade, apesar do esforço institucional para alavancar o crescimento do turismo de eventos, em feriados nacionais fora da alta estação, que se concentra entre dezembro e março (SHBRS, 2005).

A atual legislação, o PDB de 1985, localiza as Áreas Turísticas Residenciais e Áreas Turísticas Exclusivas, que admitem usos relativos à atividade do turismo e implicam incentivos de índices construtivos, nas franjas mais próximas da orla litorânea. $\mathrm{Na}$ segunda franja, o uso residencial (exclusivo ou predominante) em de baixa densidade (em média de 75 hab/ha.) ocupa a maior parte da Zona de Expansão Urbana, e as áreas mistas permitem edificações e funções mais concentradas (com densidade de 150 hab/há.). Nas Áreas Turísticas Especiais, a densidade pode chegar a 350 hab/ha., com alturas de oito pavimentos nios balneários e 18 no centro da cidade.

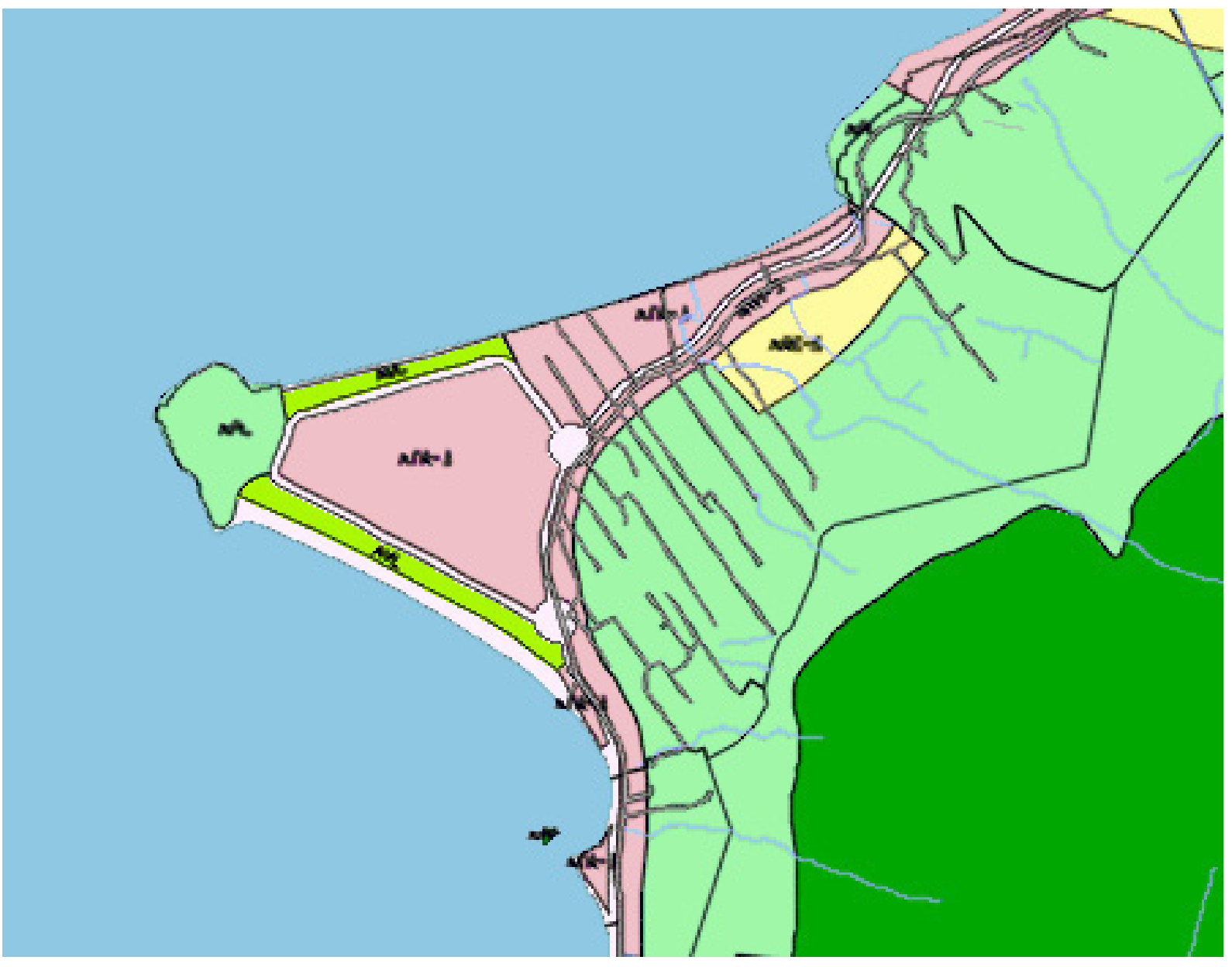

Figura 5.92: Recorte do Plano Diretor com zonas turísticas ATR e ATH e ATE. 
Os principais estabelecimentos urbano-turísticos que configuram a paisagem da zona balneária, loteamentos e condomínios, apresentam diferenças decorrentes da estrutura fundiária em que se assentam, da geomorfologia e da cobertura vegetal do território, do sistema viário e dos usos do solo do entorno. A associação que determinados empreendimentos, em função das dimensões da gleba de loteamentos e condomínios e do tipo morfológico, mais especificamente o traçado do arruamento de loteamentos, mantém com o caráter do capital empregado, também chama a atenção e merece consideração ${ }^{4}$.

As glebas decorrentes de lotes coloniais que configuram boa parte do território insular, nos atuais balneários e regiões mais interiorizadas, têm sido ocupadas por parcelamentos urbanos como loteamentos pequenos, de segunda residência ou permanente, e condomínios horizontais fechados (Oliveira, 1999 e Martins, 2004). As antigas terras comunais nas planícies de restinga frontais às praias, devido ao não condicionamento às reduzidas dimensões dos lotes coloniais e do posterior subparcelamento, têm oferecido glebas amplas, o que permite a implantação de loteamentos e condomínios com maiores dimensões, e com maior número de lotes ou de unidades privadas, respectivamente.

Para a análise dos estabelecimentos urbano-turísticos em relação com a paisagem foram estabelecidas variáveis relacionadas com o território que, permitem valorações qualitativas de implantação de alguns exemplares encontrados na llha de Santa Catarina. A seleção feita e a quantidade de cada tipo é resultado da disponibilidade de dados e reflete situações representativas, não se tratando, portanto, de uma seleção aleatória de viés estatístico que poderia afastar dos objetivos da análise.

$\mathrm{Na}$ análise são consideradas a implantação e sua inserção na paisagem construída ou natural, ou seja, se forma enclave na natureza ou se é expansão de assentamento existente. Seus impactos na paisagem foram estudados a partir categorias de análise utilizadas na descrição das unidades de paisagem, quais sejam os elementos constitutivos da paisagem, mais especificamente, geomorfologia (relevo e hidrologia), cobertura vegetal, uso do solo e sistema viário, e na caracterização, na percepção e na dinâmica da paisagem em questão.

\footnotetext{
${ }^{4}$ É Oliveira (1999) quem, a partir de rigoroso estudo de viés morfológico sobre os loteamentos de Florianópolis, estabelece esta correlação entre loteamentos pequenos em tamanho e número de unidades privadas de terreno com glebas derivadas de sobreparcelamento, por divisão hereditária ou comercial, que os lotes coloniais vêm sofrendo desde o início de sua implantação.
} 
A análise dos estabelecimentos de hospedagem clássica busca identificar sua relação com o território quanto à estrutura fundiária, a inserção sócio-econômica no entorno e sua inserção da silhueta da paisagem a fim de demonstrar os atributos de cada tipo em função da situação. Por se tratarem de elementos espaciais menores que condomínios e loteamentos, têm menor interferência na paisagem, mas a freqüência de alguns deles ${ }^{5}$, como hotéis e pousadas, os tornam presenças importantes. Os resorts, mesmo em número pequeno de estabelecimentos, abrangem áreas de maiores dimensões que os estabelecimentos tradicionais, requerendo atenção especial. Em vista da quantidade de hotéis, pousadas, albergues e campings as análises foram ilustradas por exemplos variados, sem detalhamento, procurando ilustrar os principais impactos que o conjunto exerce na paisagem na escala da llha.

\section{Os loteamentos}

Os loteamentos residenciais se espalharam, ao longo do tempo, por todas as regiões da Ilha, ocupando áreas com diferentes relevos e glebas com diferentes dimensões, número e tamanho dos lotes 6 . A partir dos anos 1950 com o despertar para a atividade turística, a orla litorânea passou a determinar a localização de boa parte dos loteamentos aprovados $^{7}$ e também boa parte dos clandestinos, expandindo a cidade para as localidades tradicionais, transformando-as em pano de fundo dos balneários (Oliveira, 1999).

Se, inicialmente, as praias calmas e cálidas da região norte ${ }^{8}$, atraíram os investimentos desse tipo de parcelamento do solo, a mercantilização, associada à escassez de terras em uma llha, elevando preços de glebas ainda disponíveis naquela zona, fez com que outras partes da llha recebessem investimentos. Os novos

\footnotetext{
${ }^{5}$ Florianópolis, segundo o censo realizado em 2005 na região de abrangência, pela primeira vez sem recorrer a amostragens, e divulgado na Pesquisa Sobre o Número de Estabelecimentos da Categoria do Sindicato dos Hotéis, Restaurantes, Bares e Similares da Grande Florianópolis, conta com 464 estabelecimentos de hospedagem: 174 hotéis (incluindo resorts), 225 pousadas, 13 campings, 46 albergues-dormitórios e 6 motéis, perfazendo um total de 28, 5 mil leitos em 10.400 unidades habitacionais.

6 Oliveira (1999), na sua tese de doutorado, traça interessante painel da evolução da quantidade, localização, tamanho e número de lotes de loteamentos aprovados entre 1940 e o final da década de 1990, identificando a correlação entre implantação de atividades especializadas e loteamentos não balneários nas décadas de 1960 e 1970 nas regiões do distrito sede, e de melhorias na acessibilidade e loteamentos balneários nas décadas posteriores.

7 Segundo Oliveira (1999) até o final daquela década, os loteamentos balneários aprovados representavam em torno de $23 \%$ do total de 158 loteamentos do município, mas ocupando $10 \%$ da área total e mais de $48 \%$ do número total de lotes. A situação atual apresenta tendência a manutenção ou incremento dessas taxas
} 
empreendimentos nos demais quadrantes da IIha, ao buscar rentabilidade para seus investimentos, têm a tendência a atender demandas de grupos sociais de renda média alta, ou seja, aqueles que possuem condições de aquisição de imóveis numa cidade turística e insular, em que a mercadoria solo já atingiu preços inalcançáveis pela maioria da população.

A expansão da mancha suburbana vem alterando a antiga paisagem da colônia que se manteve até recentemente, apresentando tendência de conectar assentamentos antes isolados, num movimento que tem exigido investimentos públicos diversos. A melhoria da acessibilidade, com novos traçados ou pavimentação das principais rodovias, vem permitindo a integração das diversas partes da cidade, fragmentada e polarizada pelo distrito sede, característica decorrente da colonização com núcleos praianos em meio a espaços abertos (naturais ou agrícolas). O sistema viário, fortemente baseado nas rodovias estaduais, passa a ser elemento importante para esse vetor de expansão, na medida em que permite conexões rápidas e aproxima lugares distantes, aproveitando ou isolando antigas estradas gerais coloniais, mas sempre atendendo, de início em pista simples e depois duplicada, as demandas apresentadas pelos empreendimentos.

No recente processo de passagem da residência secundária de veraneio que caracterizou e ainda caracteriza alguns deles, ao status de moradia permanente que a tem caracterizado os últimos anos, essa peça fundamental de expansão da cidade tem atraído atividades complementares à residencial, formando novas centralidades, como especialmente se nota na Lagoa da Conceição, no Campeche, em Jurerê e Canasvieiras, alterando a antiga estrutura da cidade polinucleada com um único centro polarizador de atividades terciárias para, ainda que mantido o predomínio do distrito sede, uma estrutura policêntrica física e funcionalmente.

\footnotetext{
8 O primeiro loteamento balneário aprovado na cidade foi em Canasvieiras, iniciativa da Prefeitura Municipal da época, num processo de privatização de terreno público, ainda que de pequenas dimensões. O primeiro loteamento de grande porte foi o loteamento Jurerê. Resultado de uma parceria estabelecida entre um ex-governador do estado (Aderbal Ramos) e empresários gaúchos, a idéia de uma cidade balneária na praia do Forte, antigo nome da atual Jurerê, tomou tanto impulso que Oscar Niemeyer, já internacionalmente prestigiado, foi convidado para elaborar o projeto urbanístico, que contaria com hotel internacional, restaurante, clube e residências de veraneio. O loteamento, elaborado e implementado entre os anos de 1957 e 58, único setor ainda existente, que tem influência de Niemeyer nas vias de pedestres, não foi totalmente concretizado. O restaurante e o clube foram construídos na mesma época, mas foram demolidos nos anos setenta. Sobre este fato, existe importante descrição na tese de doutorado de Paulo Edi Rivero Martins, defendida na ETSAB/UPC, Barcelona (2004).
} 
Embora a estrutura formal básica da cidade ainda não tenha se alterado por completo, já que a polinucleação ainda é perceptível em diversos níveis de análise, as novas especializações funcionais do espaço fazem com que o processo de urbanização apresente uma dinâmica diferenciada, com vetores de ocupação que permitem antever externalidades negativas advindas da extensividade e da intensidade da urbanização de boa parte das áreas não protegidas da llha.

Os loteamentos balneários estudados resultam de ações anteriores e posteriores à promulgação do PDB-85. Os primeiros loteamentos pela tipologia de subúrbio de casas soltas nos lotes e baixa densidade (em média 75 hab/ha.) acabaram por indicar o padrão ocupacional estimulado pelo Plano e vêm se adaptando a este com a classificação de áreas conforme as diretrizes atuais. Embora localizados em zonas de interesse turístico, os balneários, envolvem áreas próprias para turismo (Áreas Turísticas Residenciais e Áreas Turísticas Exclusivas), áreas residenciais (Áreas Residenciais Exclusivas e Áreas Residenciais Predominantes) e mistas (Áreas Mistas Comerciais e de Serviços).

Os loteamentos de pequeno porte, em função do sobreparcelamento que os lotes originais sofreram ao longo do processo de crescimento demográfico das populações nativas, têm características de traçado simples. Geralmente com poucas vias de acesso e com os lotes de tamanho mínimo ${ }^{9}$ alinhados ortogonalmente a elas, formando desenhos de espinha de peixe ou pente, sendo bastante comum ruas de entra e sai que, pelas poucas conexões com os demais loteamentos, sobrecarrega o sistema viário de veículos de acesso, além de dificultar a continuidade de espaços coletivos de pedestres, o que interfere no potencial de interação social na esfera pública da cidade (Bueno, 1996).

Estas glebas de maiores dimensões, derivadas de remembramento de lotes coloniais ou permitem ações de planejamento único, mas também adequar investimentos e rentabilidades pela implantação em do empreendimento em fases. Os traçados adotados têm evoluído das grelhas simples e regulares em glebas de dimensões relativamente pequenas, conectadas com tecidos existentes ou com possibilidade de conexão com os novos, características dos loteamentos balneários a partir dos anos 1940, para malhas mais imbricadas, tendendo ao auto-isolamento (Bueno, 1996), sobre glebas maiores, características dos loteamentos implantados a partir do início dos anos 1980.

\footnotetext{
${ }^{9}$ Nos balneários a legislação do PDB fixa em o lote mínimo em 450m_, mas dependendo da área de uso, pode aumentar.
} 


\section{Loteamento Jurerê Internacional}

Situado no norte da llha, é emblemático pelo pioneirismo do padrão adotado na urbanização e exigido das edificações e pela grande dimensão da gleba. Localizado no norte da Ilha, o empreendimento teve impulso em 1978 com a venda de Aderbal Ramos, importante político catarinense e dono da Imobiliária Jurerê, proprietária da área (antiga terra comunal), dos primeiros 495 hectares para o Grupo Habitasul, de capital sul riograndense. A implantação da primeira fase do projeto, de autoria do escritório gaúcho Sclovski e Saltz S.A., no começo dos anos 1980, ocupou, priorizando a orla, 145, 67 hectares com 1355 lotes $^{10}$. Em 1995, estavam adquiridos mais 705 hectares, totalizando 1.200 hectares, o que permitiu a expansão do loteamento, adotando maiores de densidades e alturas nas zonas de conexão com loteamentos vizinhos.

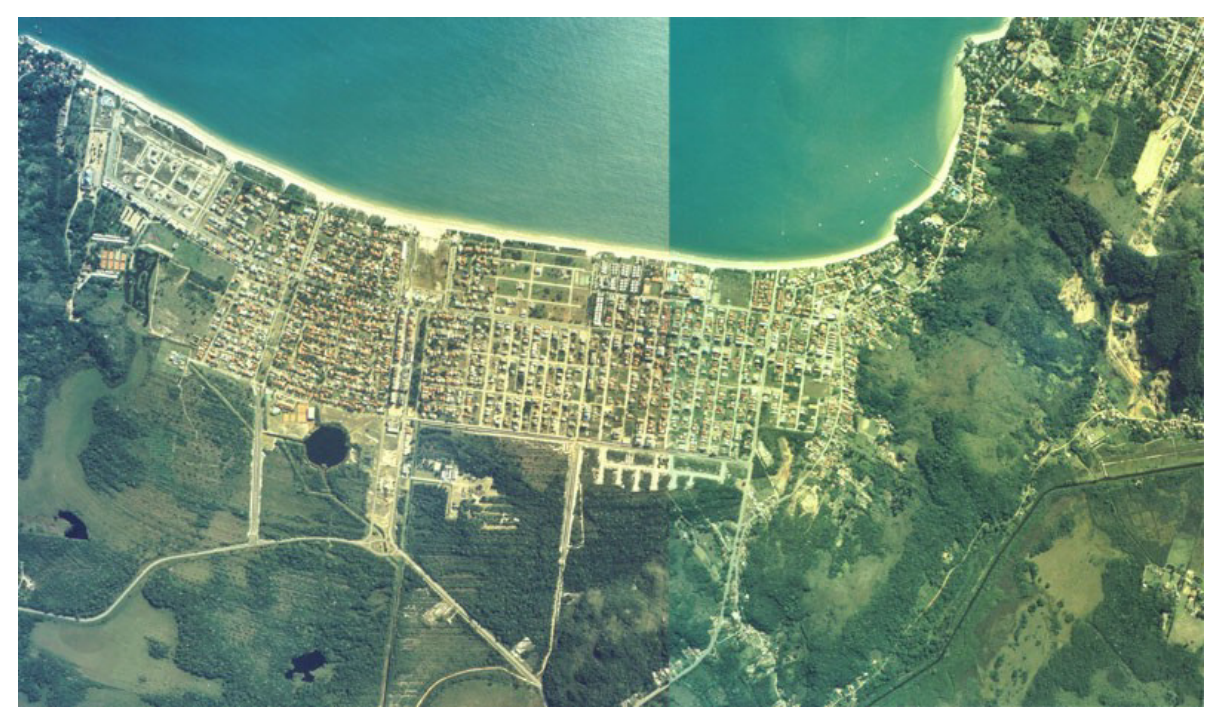

Figura 5.93: Situação do Loteamento Juererê Internacional à esquerda da foto.

Ocupação extensiva sobre planície de restinga de baixa declividade com limites sem transição com vizinha área de proteção ambiental - a Reserva Ecológica de Carijós. Soterramento e alteração de leitos de pequenos rios. Substituição da vegetação, arbustiva e arbórea, de restinga que se encontrava em estágio de regeneração, por vegetação exótica de sombra e jardim. Sistemas de abastecimento de água e saneamento básico próprios. Fonte de energia de rede pública.

\footnotetext{
${ }^{10} \mathrm{Hoje}$, com diversas etapas concluídas e comercializadas, vivem permanentemente quase 500 famílias e cerca de 2000 pessoas, mas boa parte das casas construídas é ainda mantida como segunda residência de famílias não locais, principalmente gaúchas.
} 
Expansão de urbanização balneária anterior (Jurerê Tradicional, do final dos anos 1950), com traçado tipo grelha ortogonal irregular e com pouca conectividade de vias, sugerindo auto-isolamento. Assentamento tipo cidade jardim de alto padrão, com baixa densidade (os menores lotes são de $750 \mathrm{~m}^{2}$ ). Unidades de vizinhança de residências polarizadas por eixo misto de residências, comércio e serviços em edifícios em altura (8 pavimentos) perpendicular à linha da praia. As residências e estabelecimentos comerciais e de hotelaria na primeira franja litorânea são delimitadas por via beira-mar de pedestres. Característica de subúrbio litorâneo de alto padrão com tendência a estabilização, pela expansão controlada, ao final da implantação das fases do projeto, muitas já consolidadas. Sua implantação exerceu pressão imobiliária no loteamento vizinho - Jurerê, valorizando os terrenos e demandando adequações dos índices urbanísticos.

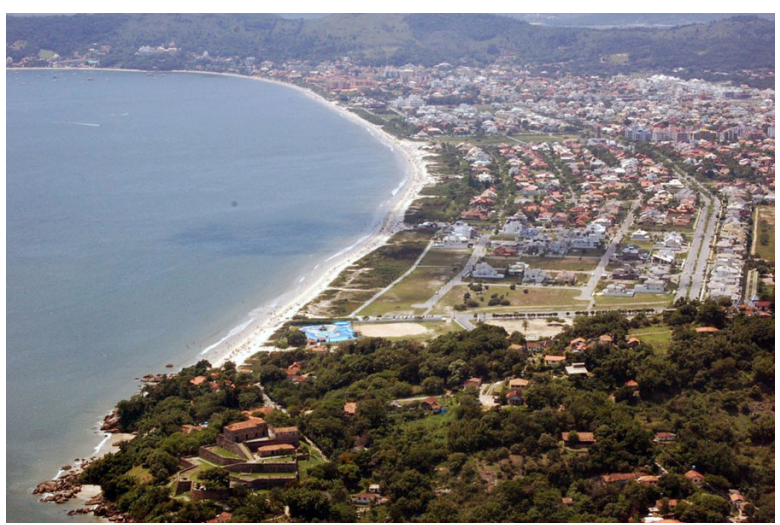

Figura 5.94: Vista geral a partir do oeste do loteamento Jurerê Internacional.

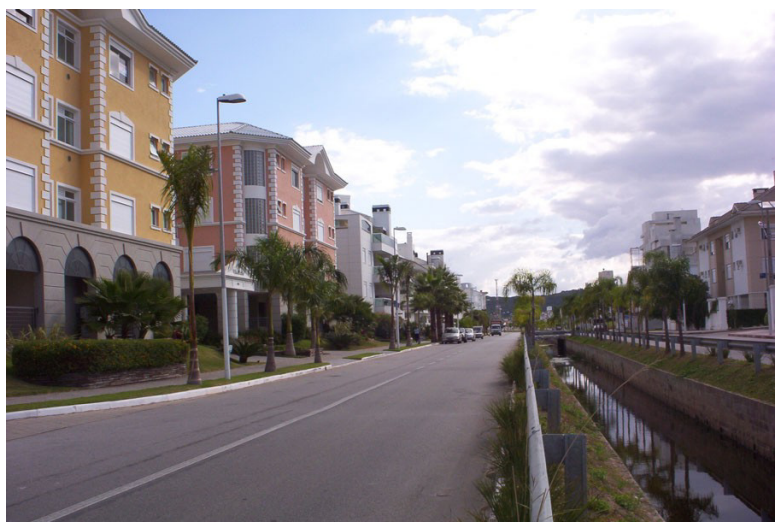

Figura 5.96: Vista de zona residencial adensada recentemente implantada no loteamento.

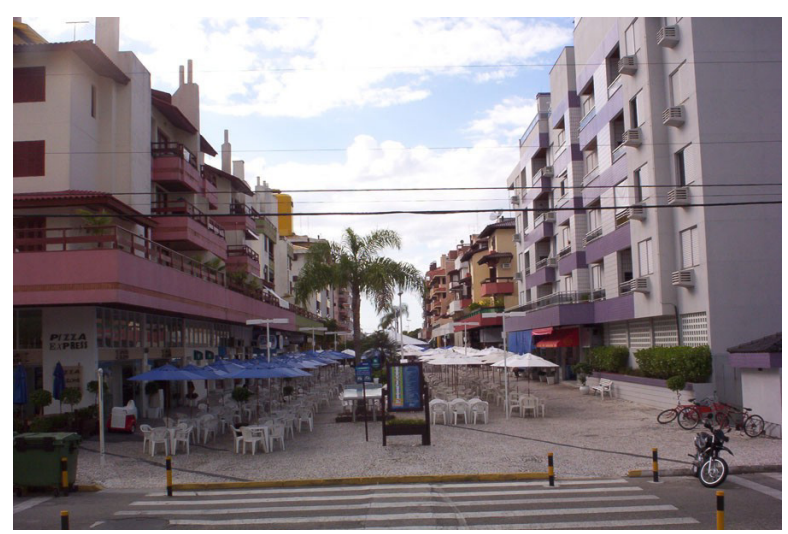

Figura 5.98: Vista do eixo comercial e de serviços - Open Shopping - do loteamento. 


\section{Loteamento Cidade da Barra}

Situado no leste da Ilha, no distrito da Barra da Lagoa, junto à orla, em planície de restinga, antiga terra comunal privatizada em meados do século XX.

Ainda em fase de consolidação com cerca de $30 \%$ dos 184 lotes ocupados, abrange 20,1 hectares, sendo 10,6 ha. de uso privado, 4,9 ha. de arruamentos e 4,9 ha. de áreas verdes. Inaugurado em meados dos anos 1990, apresenta lotes de tamanho entre 450 e $1000 \mathrm{~m}^{2}$, para residências unifamiliares de dois pavimentos e lotes para uso misto de comercio e residência multifamiliar em edificações em altura (térreo, dois pavimentos mais ático).

Ocupando restinga interior, mantém contato direto com a restinga mais próxima da orla, da qual é separada por rua local, e com o Parque Estadual Florestal do Rio Vermelho, sem nenhuma transição. Substituição total da cobertura vegetal anterior. Sistema de abastecimento de água e saneamento dependente das concessionárias públicas. Fonte de energia de rede pública.

Morfologicamente é uma expansão com pouca conexão com o assentamento pesqueiro tradicional organizando arruamento tipo cidade jardim, com arruamento de traçado regular com

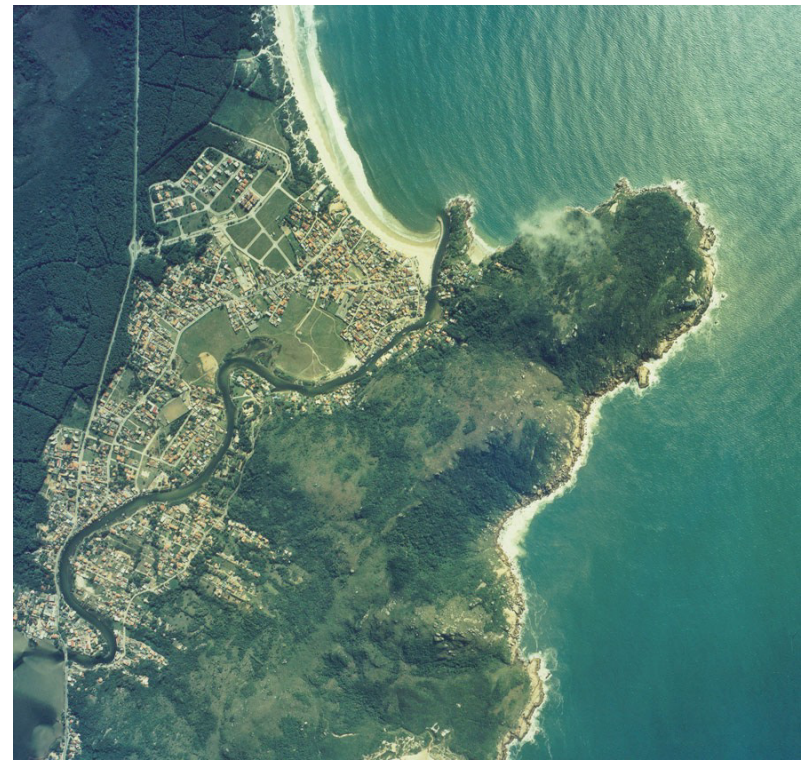

Figura 5.99: Situação do loteamento Cidade da Barra à esquerda da foto.

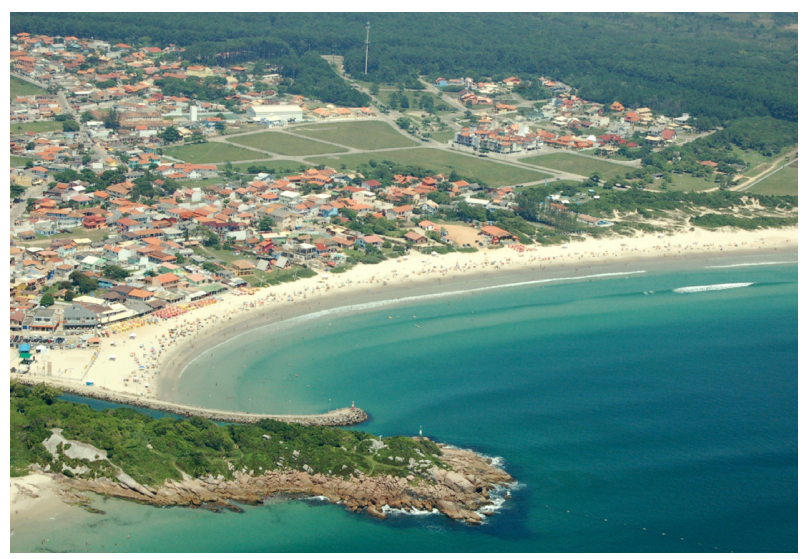

Figura 5.100: Vista do loteamento a partir do sudeste.

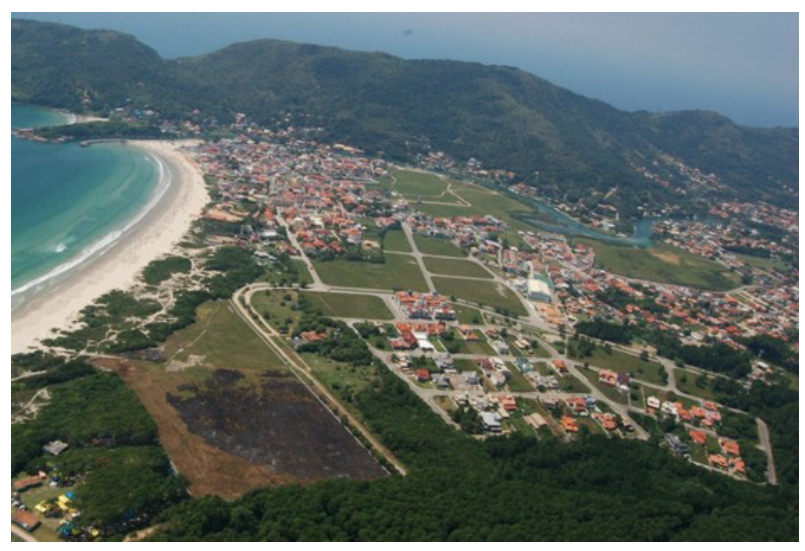

Figura 5.101: Vista do Loteamento a partir do norte. 
pouca conectividade entre as ruas. A via principal é eixo de edificações em altura, mas não tem correspondência funcional por não prever comércio e serviços, tendendo a monotonia de assentamentos monofuncionais. Caráter de bairro suburbano de padrão de renda médio alto com dinâmica de transformação da paisagem lenta, após o forte impacto da terraplanagem inicial.

\section{Loteamento Açores}

Situado no sul da Ilha, no distrito do Pântano do Sul, junto à orla, com 82,37 hectares e mais de 250 lotes, sobre área de restinga plana separada da orla marítima pelo primeiro cordão dunar (de contenção). Projeto global aprovado em 1978, teve implantação iniciada em seguida, mas devido a preferências mercadológicas, até hoje ainda não está totalmente consolidado, com apenas $60 \%$ dos lotes ocupados, muitos com utilização temporária, assumindo características de loteamento suburbano misto de permanente e de segunda residência. Utiliza abastecimento de água e energia elétrica de concessionárias, mas o sistema de tratamento de águas servidas é individualizado, com fossas sépticas e sumidouros em solo sedimentar.

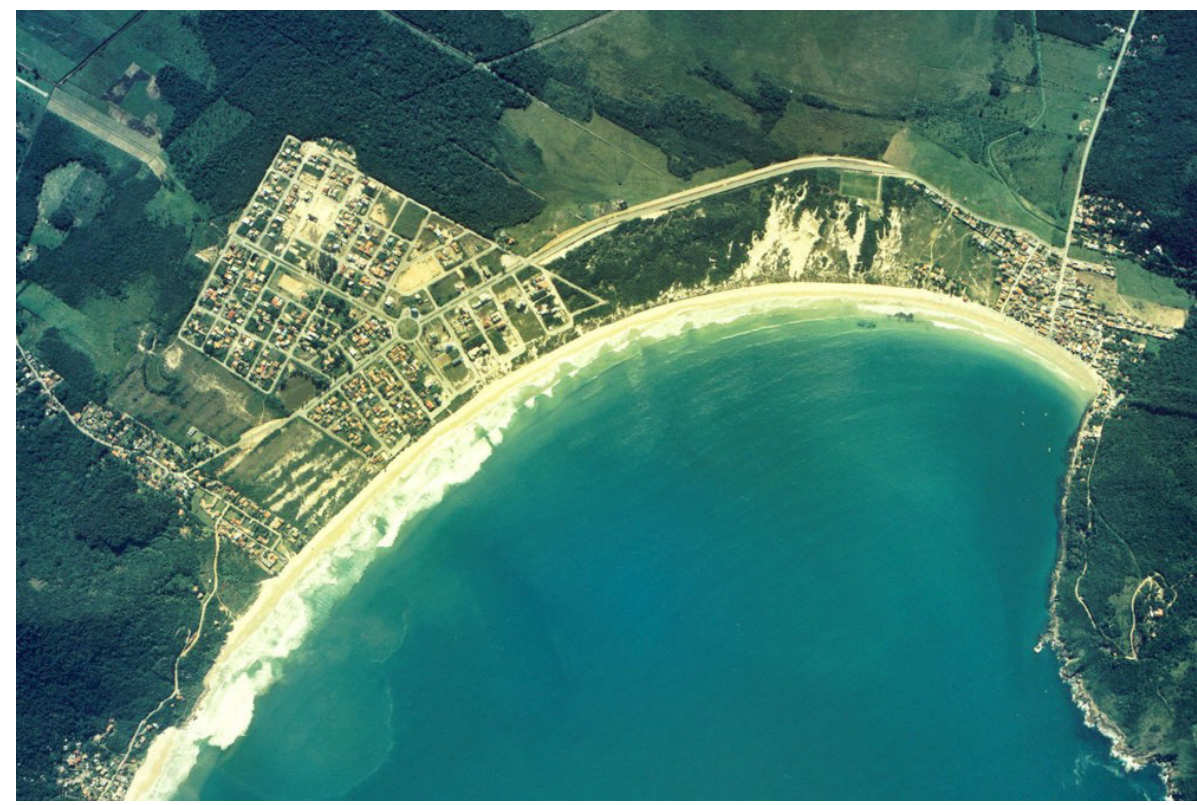

Figura 5.102: Situação do loteamento Açores. 
A restinga em que se implanta apresenta ondulações e rebaixamentos (zonas entre os cordões dunares semi-fixos ou fixos) onde são armazenadas águas de superfície, formando pequenas lagoas e zonas inundáveis, que são tratadas como áreas públicas. Ocupa zona de vegetação arbustiva de restinga e parte significante de floresta de planície quaternária de expressiva presença na paisagem local.

Morfologia de grelha de base ortogonal regular, com diferentes tipos de conectividade entre as vias, definindo zonas residenciais de baixa densidade e altura, articuladas com o sistema viário da cidade por via de duas mãos e canteiro central, onde se implantam atividades mistas (comércio, serviços e residências) em edificações em altura de variando entre dois e quatro pavimentos.

Pela extensão da associação e mesmo de alguns empreendimentos tomados isoladamente, os loteamentos balneários de característica urbano-turística estudados, como a maioria dos legalizados na llha de Santa Catarina, configuram ambiente homogêneo e comum a muitos destinos litorâneos da costa brasileira, assumindo condição de pouco interesse na qualificação da paisagem para um turismo diversificado.

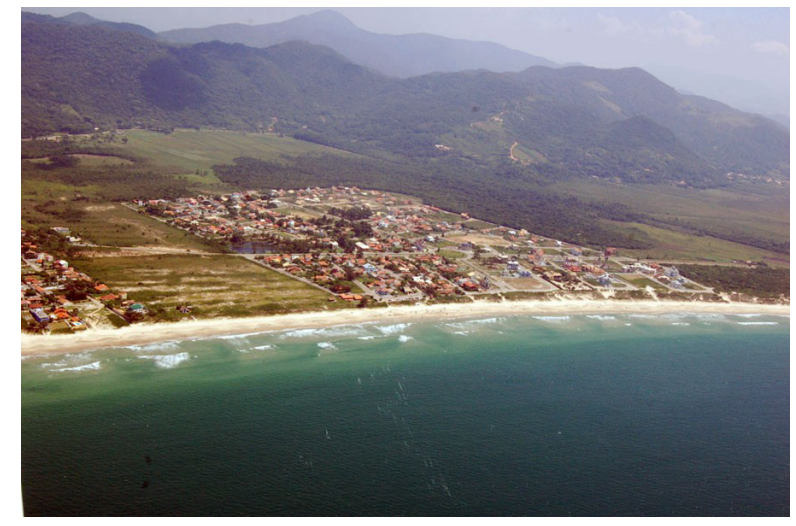

Figura 5.103: Vista geral do loteamento, com floresta quaternária em segundo plano e morros em terceiro plano.

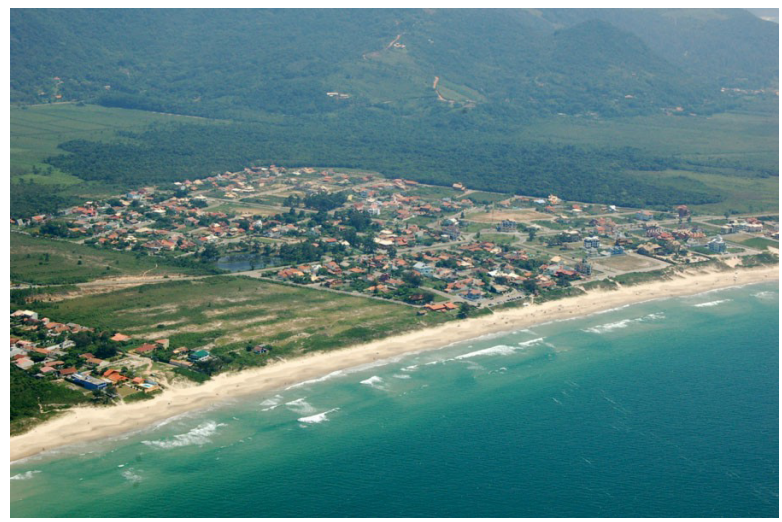

Figura 5.104: Vista geral do loteamento evidenciando o adensamento na orla.

Dada à diferenciação de padrão de urbanização, em termos de dimensionamento e qualidade, dos loteamentos legalizados em relação aos loteamentos clandestinos, sua adoção como padrão de crescimento urbano tem aceitação entre determinados setores da sociedade e agentes do turismo, mesmo que a expansão territorial que a associação entre turismo e urbanização implique homogeneização da paisagem, dilapidação de ecossistemas e deseconomias na implantação de determinados sistemas de infraestruturas. 
Ainda que a correlação direta entre tantas variáveis, como tamanho de gleba, morfologia adotada, tipo de organização empresarial e origem do capital, não possa ser tomada como positiva e constante, é possível a associação dos empreendimentos implantados em glebas de grandes dimensões, geralmente sobre antigas terras comunais ou áreas com remembramento de lotes coloniais, com morfologia tendendo à auto-segregação (Bueno, 1996).

Desta maneira, é pertinente a associação desse padrão de parcelamento com figuras jurídicas e organizações empresariais, geralmente de capital aberto, empresas de grande capital. As organizações empresariais de capital de fora do município, algumas até com capital internacional, são extensões de grupos voltados quase que exclusivamente à incorporação imobiliária.

Por outro lado, não é impossível associar, também sem determinismo estatístico, empreendimentos de capital local, que se utilizam dos excedentes de atividades comerciais e de serviços, a loteamentos e condomínios de pequenas dimensões, onde o traçado, na busca da eficiência econômica, tem sua simplicidade funcional determinada pela forma longilínea e pela pequena dimensão do lote.

Como a incorporação imobiliária trabalha com a lógica do menor investimento para maiores ganhos, e lotear planícies é mais lucrativo do que encostas, as áreas planas restantes pelo interior e pela orla da llha têm sido o alvo preferencial dos novos investimentos e, para tanto, as pressões para transformação da legislação, com adaptação aos interesses dos empresários imobiliários, e controle eficiente dos casos de ocupações clandestinas têm se feito notar.

\section{Os condomínios}

Os condomínios, figura jurídico-urbana recente na organização espacial do município de Florianópolis se caracterizam pela construção de um conjunto de residências em um único lote, pertencente a todos os proprietários que, além de fração ideal de terreno com uma área privativa, dividem áreas comuns. Têm sido alternativa de ocupação do solo das mais expressivas em termos de quantidade e interessante em termos de localização, sendo que de 1978, ano de sua instituição na cidade, a 1999 foram aprovados cerca de cem empreendimentos dessa natureza, 
ocupando mais de 300 hectares e ofertando mais de 1700 unidades de uso exclusivo (Oliveira, 1999) ${ }^{11}$.

Nas áreas mais urbanizadas e densas do distrito sede e bairros adjacentes, o condomínio vertical concretizado em edifícios de apartamentos é a presença mais marcante, mas nas regiões balneárias, o condomínio horizontal e ou vertical de baixa altura (pilotis, dois pavimentos mais ático) é predominante, apresentando relacionamento com o lote que o diferencia de edifícios em altura. Embora a proximidade da beira-mar seja atraente para os grupos sociais a que se destinam os condomínios, a preferência locacional dos condomínios vem sendo desde sua regulamentação em 1978, consolidada pelo PDB em 1985, em glebas de pequenas dimensões decorrentes do sobreparcelamento e desmembramentos dos lotes coloniais.

Essas glebas de menor dimensão e/ou em situação topográfica menos atraentes para a implantação de loteamentos economicamente rentável para o segmento imobiliário tradicional, passam a ser mais atraentes para investimentos de capitais de menor monta, e o condomínio é o arranjo espacial mais adequado. A legislação de 1978, corroborada pela de 1985, previu limites à quantidade de unidades de uso exclusivo (15 para a zona urbana e 25 nas demais), levando os empreendedores a adotarem estratégias de reestruturação fundiária, como desmembramento de glebas, para atender exigência legais quanto ao número máximo de unidades privadas.

Lotes de pequenas dimensões em planícies, encostas e promontórios onde é comum a vizinhança à áreas protegidas por legislação, tem sido aproveitadas para a implantação de condomínios. As situações nas encostas, em meio à floresta, tem sido promovidas como modo de vida mais próximo da natureza, representada pela mata atlântica, e como possibilidades de desfrute de visuais de grande alcance sobre planícies e baías, além de que permitem a caracterização das áreas de preservação permanente como aquelas exigidas por legislação, para preservação ou para uso comum, fazendo parte da fração ideal dos condôminos. Assim, uma situação que inicialmente se apresenta como

\footnotetext{
${ }^{11}$ Inicialmente, a legislação de 1978 (Lei Municipal $n^{\circ}$ 1566) estabeleceu como fração ideal mínima, conforme a setorização então vigente do território insular, a área de 700 m_ para a zona urbana e para 1000 m_no restante da llha (zona de expansão urbana), exigindo um mínimo de $35 \%$ e 45\% respectivamente para áreas de uso comum. No Plano Diretor dos Balneários de 1985, estas definições se alteraram, em função do estabelecimento do zoneamento de uso com vistas a criação de diferenças morfológicas e demográficas, para 720 m_, 1500 m_ e 3000 m_, o que, em determinadas situações de combinação de índices urbanísticos, traz mais retorno econômico à implantação de condomínios do que de loteamentos (Oliveira, 1999).
} 
de menos valia passa a ser encarada pelo promotor como "... fonte de valorização, à qual é passada ao preço da venda" (Oliveira, 1999, p. 107), sugerindo que o condomínio vem se transformando em solução palpável na superação de problemas decorrentes de parcelamentos nas encostas.

Nos promontórios à beira mar, os terrenos são aproveitados para construções em baixa e média altura (dependendo da zona e dos índices urbanísticos incidentes), em arranjos facetados ou escalonados, com a preocupação de orientar o prédio para obtenção das meIhores vistas das baías e planícies.

Quanto à natureza do empreendedor, segundo a pesquisadora Oliveira (1999), até o final doas anos 1990, a tendência pendia para uma maioria de pessoas físicas, fato atribuído a maior facilidade de implantação de condomínios (em relação às exigências de áreas de uso público e implantação de infraestruturas em loteamentos).

Também conhecido como condomínio fechado, esse arranjo espacial, quando em glebas mais extensas ou quando em seqüência com outros tem sido criticado por diversos especialistas que vêm alertando para as conseqüências na desestruturação do espaço público da

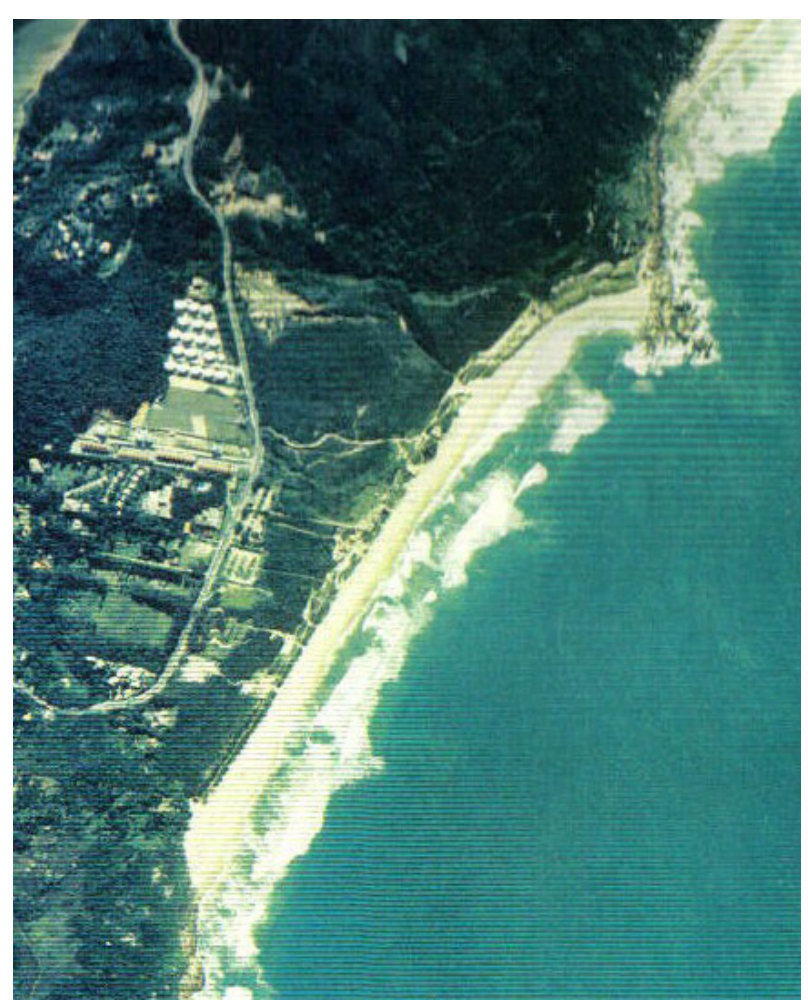

Figura 5.105: Situação de condomínio na praia Mole.

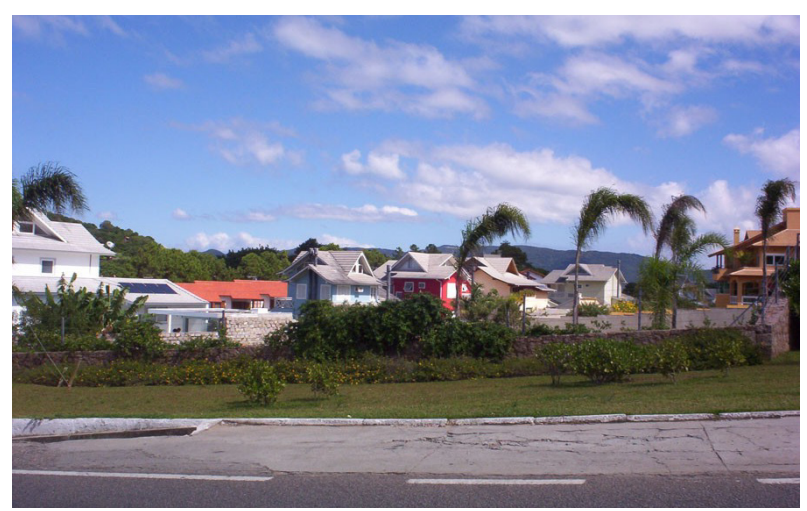

Figura 5.106: Vista da entrada de condomínio fechado na praia Mole.

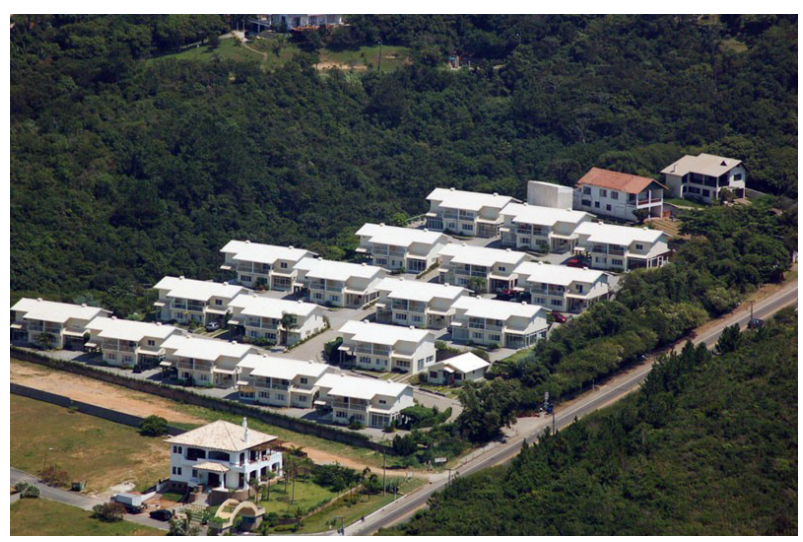

Figura 5.107: Vista do Condomínio evidenciando o excessivo adensamento e a distribuição espacial inadequada. 
cidade decorrentes da segregação e impermeabilidade urbanas promovidas pelos condomínios. O pouco relacionamento com o espaço público e a existência de áreas comuns, que se caracterizam pela introversão, ratificam a idéia contida na expressão. A negação do espaço público é a característica marcante e perversa desse arranjo espacial, visto que as fachadas visíveis dos condomínios se resumem aos pórticos de entrada, cuja linguagem arquitetônica expressa o gosto das classes medias e altas, e às cancelas que pretendem isolar a esfera privada das mazelas e tensões do contexto de desigualdade sócio-econômica nacional exposta na dimensão pública. Ao criar ilhas muradas no tecido da cidade, não contribuem com a continuidade espacial nem para a acessibilidade urbana, esvaziando o espaço comum das ruas e tornando, cada vez mais, árida a interação social em

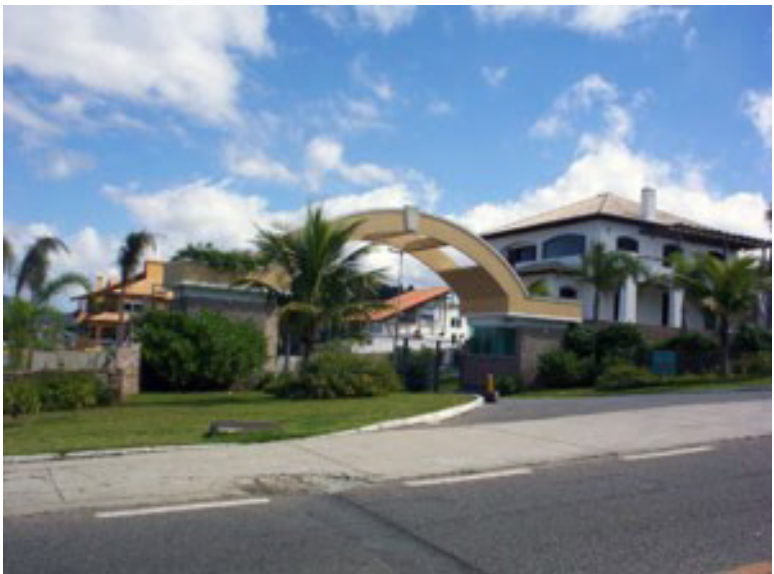

Figura 5.108: Vista de entrada de condomínio fechado.

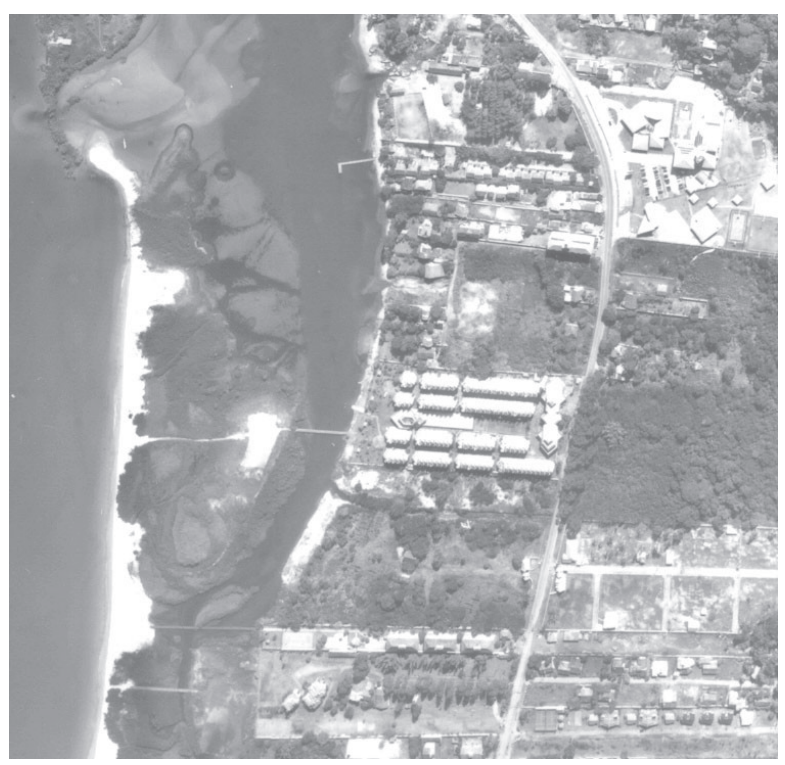

Figura 5.109: Situação de condomínios na Ponta das Canas. áreas públicas, desfavorecendo grupos sociais mais dependentes do convívio na polis.

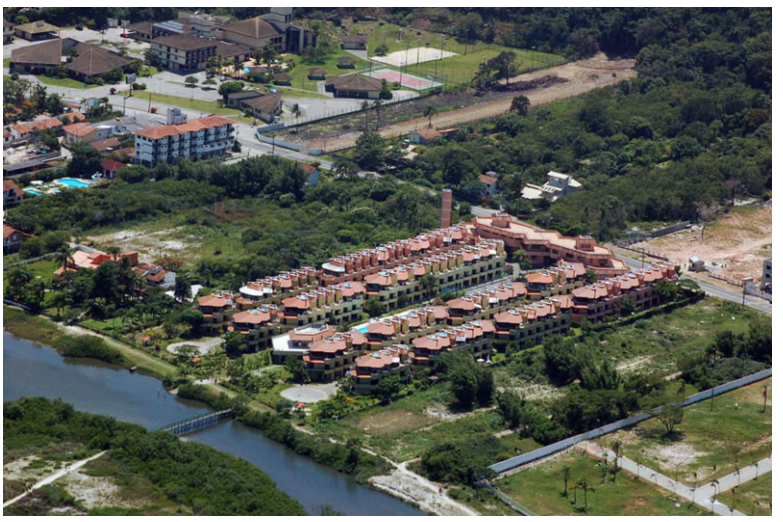

Figura 5.110: Vista de condomínio na Ponta das Canas.

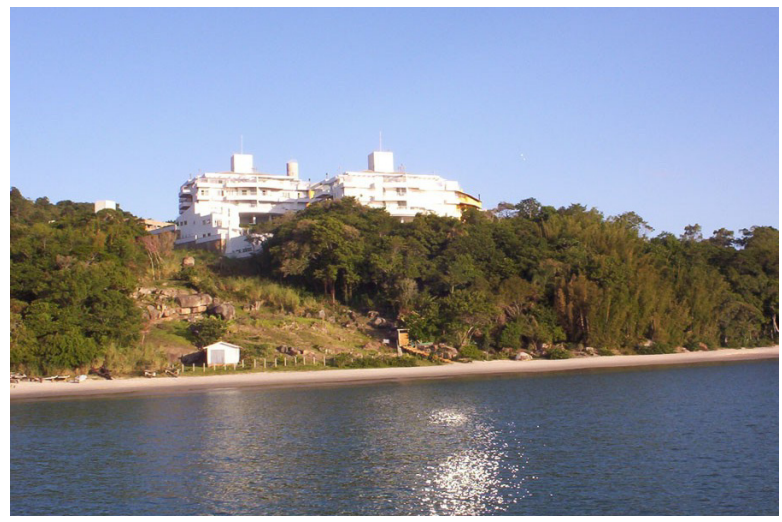

Figura 5.111: Condomínio vertical com muita evidência em promontório em Jurerê. 


\section{Os resorts}

Os resorts são formados pelo conjunto de instalações de hotelaria tradicional associado a quantidade e diversidade maiores de instalações comerciais, de serviços de apoio à estadia do visitante e, especialmente, de recreação e lazer. Formam complexos relativamente auto-suficientes, visando o atendimento das demandas dos visitantes sem a necessidade de saída do complexo, com ambientações que criam, ou recriam, ao se apropriarem de atributos locais, um espírito de lugar diferenciado de outros empreendimentos. Existem em diversos âmbitos territoriais, mas é comum à proximidade a recursos naturais: praias, montanhas ou regiões interioranas rurais, serranas ou com atrativos naturais de grande interesse, como cascatas e florestas tropicais.

A concentração de diversas atrações (naturais ou criadas) atraindo grandes grupos de turistas para obtendo maior eficiência e rentabilidade do investimento (pela expansão quantitativa e temporal do consumo) com menores custos (pela concentração locacional e demanda do produto) é resultante da aplicação extremada da lógica empresarial na área turística.

Uma série de atrativos e equipamentos é comum a todos os tipos e as diferenças são definidas por fatores locacionais de acessibilidade e proximidade aos recursos paisagísticos, por equipamentos diferenciados e pela inserção da arquitetura em relação ao contexto. Os resorts litorâneos podem oferecer, além dos tradicionais atrativos de hotéis de alto padrão, inúmeras atividades relacionadas com o mar, quadras de tênis e mais recentemente, seguindo tendência mundial, campos de golfe e instalações para eventos, buscando superar a sazonalidade.

A tendência mundial de ofertar instalações de esportes ou outras atividades que são comumente associadas às grupos sociais de renda alta, como o golfe, sugere que a oferta destes atrativos em resorts nacionais procura atrair consumidores de padrão elevado, haja vista que essa demanda esportiva não se constitui corriqueira para os padrões do turismo doméstico nacional. Se nos países centrais atendem demandas de classes médias, num movimento de massificação, no Brasil, pelo alto investimento inicial necessário para o empreendimento, com reflexo nos custos, os resorts estão associados a padrões de vida mais elevados, não sendo de fácil acesso para o turismo de massa. 
$\mathrm{Na}$ llha de Santa Catarina, em Florianópolis, a dimensão das glebas de implantação de resorts também é variada e dentre os estudados em Florianópolis, somente uma gleba ultrapassa 5 hectares, e os demais se implantam em lotes menores, mas mesmo assim, maiores que os lotes da hotelaria tradicional. Somente um dos existentes prevê implantação de campos de golfe e marina, e os demais não dispõem de área suficiente para tal empresa. Um outro resort, ainda em luta para licenciamento do projeto, prevê a construção de marina junto ao canal da Barra da Lagoa, no leste da Ilha, mas aponta para um recurso ainda pouco explorado pelo segmento turístico.

A inserção na paisagem de entorno habitado, exemplarmente quando existir o campo de golfe, poderá implicar bastante contraste com os assentamentos próximos. A aparência equilibrada e agradável transmitida pelos gramados pontuados por agrupamentos arbóreos e recortados por pequenas lâminas de água de desenho orgânico surge em contraponto às paisagens pouco legíveis e com aspecto depreciado e caótico das edificações erigidas por grupos sociais de renda limitada que sobrevivem na periferia do local do projeto.

Optou-se por estudar de modo detalhado alguns exemplos paradigmáticos que representam a quase totalidade dos empreendimentos desse segmento.

\section{Costão do Santinho Resort}

Situados no norte da llha, no distrito de Ingleses, inaugurado no início dos anos $1990^{12}$, foi implantado em área de mais de 1 milhão de metros quadrados, dos quais $75 \%$ não são ocupados, incluídas aí as áreas do promontório e de dunas classificadas como de preservação permanente e integrantes da gleba. A área utilizada pelo complexo é de $737,554 \mathrm{~m}^{2}$ sendo mais de $12 \mathrm{mil} \mathrm{m}^{2}$ construídos (entre hotel e apartamentos nas vilas habitacionais). Implanta-se em diversas edificações sobre a restinga inclinada de sedimentos arenosos (as vilas) e no promontório granítico ao sul da baía da praia do Santinho (o hotel). É constituído por conjuntos de unidades habitacionais ( 200 ao todo, sendo $90 \%$ apartamentos e $10 \%$ suítes), distribuídas em 14 vilas totalizando $2300 \mathrm{~m}^{2}$ ). Tem clientela internacional e de alto padrão, sendo recentemente reconhecido por revistas especializadas como o melhor de praia do Brasil.

\footnotetext{
${ }^{12}$ Projetado entre 1985 e 1986 pelo escritório Desenho Alternativo, teve iniciada suas obras em 1989 e concluiu as diversas etapas em 2004.
} 
O extenso programa de necessidades se divide em um setor de animação e serviços, com centro de ócio, próximo à praia, com restaurantes, bares, piscinas, centro de comércio e esportes, próximo do acesso principal do complexo, buscando relacionamento com o sistema urbano da localidade, e um centro ecológico, com capela, lago, espaços para trilhas e fruição da paisagem, e o setor de hospedagem, distribuído nas 14 vilas e em um hotel internacional. O sistema viário diferencia pedestres, este em caminhos pitorescos com passarelas sobre túneis de passagens de pedestres, de veículos, com diversos pequenos espaços de estocagem de veículos buscando minimizar seu impacto. O tratamento paisagístico dos espaços abertos trabalha com sensibilidade formando seqüências visuais expressivas utilizando as particularidades do terreno e espécimes vegetais adaptadas.

A morfologia adotada organiza as vilas residenciais, com agrupamentos de unidades em fitas de três pavimentos e garagem no subsolo, de diferentes formatos derivados do pátio em $U$, com arranjo espacial semelhante a quadras urbanas, implantadas em patamares referenciados nos escalonamentos das fortificações militares existentes na llha fazendo a transição entre os domínios público e privado. O hotel internacional é solucionado por tipologia arquitetônica de barras separadas em quatro volumes de quatro pavimentos articulados por elementos arquitetônicos mais leves junto à encosta do morro. A linguagem arquitetônica adotada pelos arquitetos, com forte referência às edificações do período colonial da ilha, dá movimento aos volumes edificados de três pavimentos.

A presença na paisagem do conjunto de edificações das vilas residenciais com aspecto urbano se espalhando em patamares pela restinga levemente inclinada com declividade média em torno de $10 \%$, destoa do entorno construído pela altura e densidade construída. Já o hotel internacional, que se implanta sobre a encosta do promontório, com altura de quatro pisos e em barras extensas disputa a atração dos olhares com os elementos naturais. Os demais edifícios do complaxo buscam adequação à paisagem, embora nem sempre atingindo o objetivo. Dada à densidade de edificações construídas, e o contraste sócio-econômico com o entorno próximo e o incremento dos fluxos na área faz com que a percepção de impacto na paisagem seja negativa e a aceitação do empreendimento por parte da população não seja consensual. 


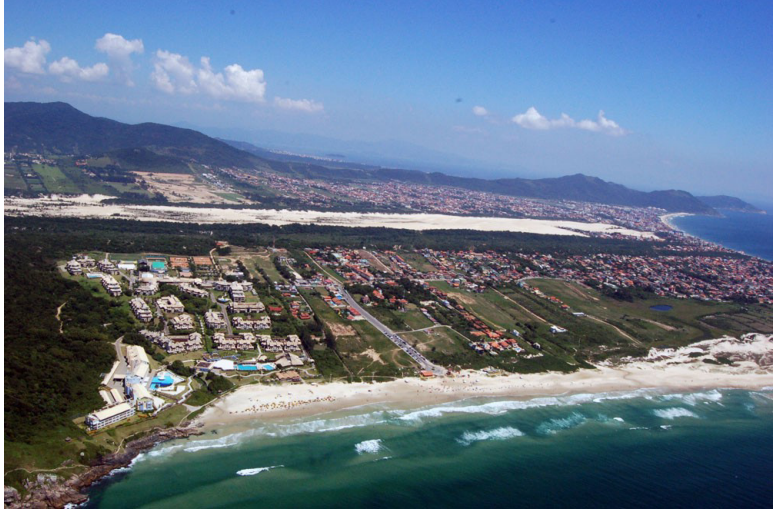

Figura 5.112: Vista do Resort Costão do Santinho e entorno.

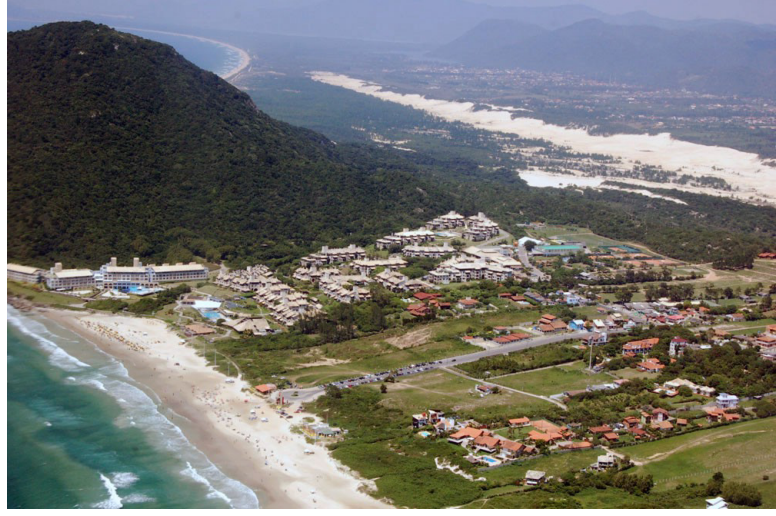

Figura 5.113: Vista do Resort Costão do Santinho evidenciando a superposição ao morro das Aranhas.

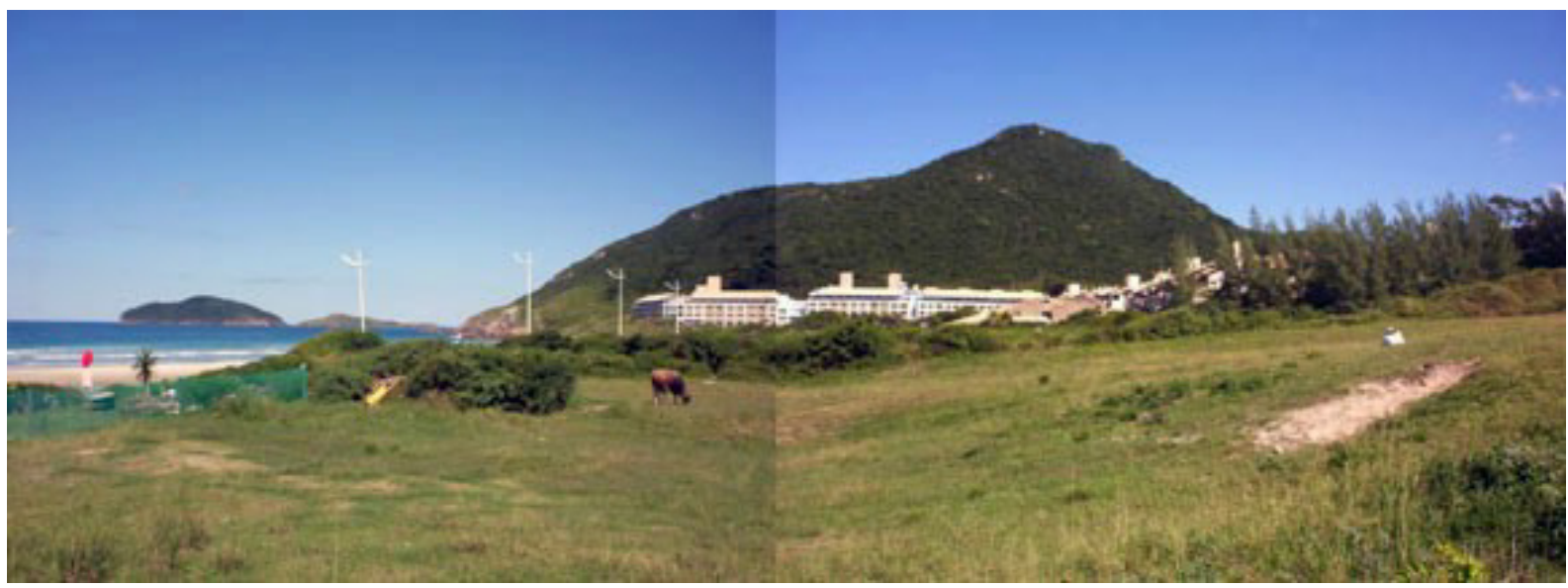

Figura 5.114: Vista lateral do resort.

\section{Mabu Engenho Ecoresort}

Situado no Leste da llha, no distrito do Rio Vermelho, este estabelecimento ocupa gleba de aproximadamente 4 hectares, com 145 unidades habitacionais. Implanta-se sobre a calha do rio João Gualberto, principal contribuinte das águas da Lagoa da Conceição, em área de sedimentos arenosos com leve declividade, distante do mar, entre o morro e a rodovia, em entorno residencial de renda média. A concepção espacial não tem projeto único, com adaptações e reformas ao longo de sua existência, resultando em uma imagem pouco expressiva em termos de linguagem arquitetônica, resultado de investimentos ocasionais de capital.

Sem contato direto com a orla, busca associar a imagem do empreendimento com a qualidade de vida num ambiente ecologicamente correto, refletido, além do nome, nas atividades ofertadas aos hóspedes e na disposição espaçada das edificações. $O$ 
programa, apesar de ser similar aos hotéis tradicionais, aposta nas atividades ao ar livre, com equipamentos para pesca, passeios de caiaque e trilhas para passeios ecológicos nas encostas do morro próximo. Tem tratamento semi-coletivo de águas servidas e abastecimento de água pela concessionária pública, e a fonte de energia é tradicional. O padrão sócio-econômico dos hóspedes é médio e médio-alto.

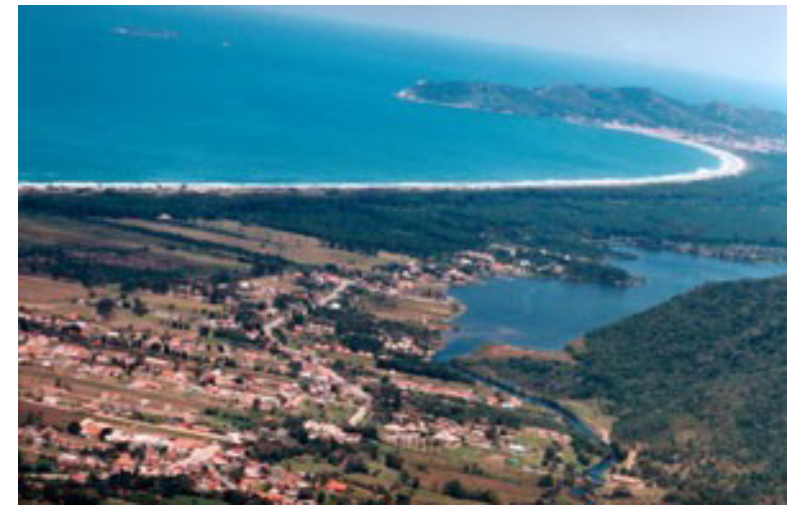

Figura 5.115: Vista da região de implantação do Ecoresort Mabu.

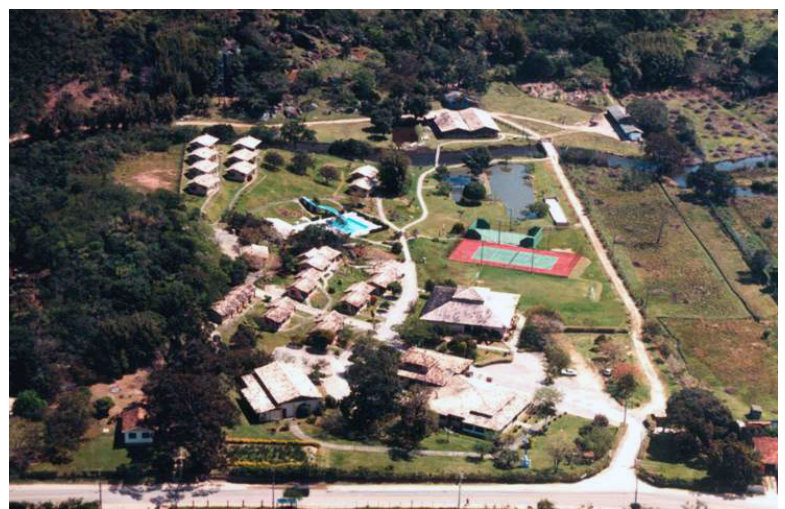

Figura 5.116: Implantação do Ecoresort Mabu.

A organização espacial se baseia na distribuição das cabanas, executadas com materiais quentes (tijolo à vista e esquadrias de madeira de aspecto natural), de modo a adaptá-las à topografia, criando um setor habitacional que envolve os espaços abertos de uso recreativo, como as piscinas e churrasqueiras. O setor de habitações, mais ao fundo, é polarizado por blocos de atividades comuns de animação e alimentação e de serviços, distribuídos irregularmente junto à área de acesso ao complexo.

Pela baixa taxa de ocupação e altura das edificações, imagem reforçada pelo paisagismo que ameniza a visualização dos edifícios, sua inserção na paisagem é percebida como de pouco impacto, embora a proximidade ao rio mereça atenção.

\section{Resort Porto da Lagoa}

Situado às margens da Lagoa da Conceição, no distrito do mesmo nome, na localidade do Porto da Lagoa, este estabelecimento de autoria do escritório Desenho Alternativo, ainda em fase de implantação, foi iniciado em meados dos anos 1990 buscando atrair clientela relacionada com atividades voltadas para a recreação na água. Como não foi implantado completamente, com diversos equipamentos e atividades ainda por 
acontecerem, seus apartamentos têm funcionado como moradia permanente e segunda residência em temporadas de veraneio, desvirtuando a proposta inicial de resort. Tem sistema de saneamento cloacal coletivo interno e abastecimento de água pela concessionária pública, com fonte de energia elétrica de rede pública.

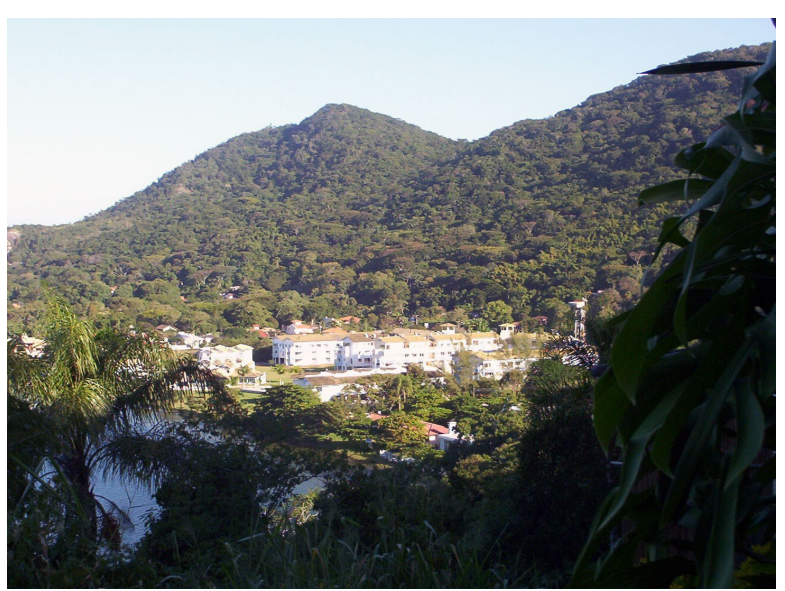

Figura 5.117: Vista Geral do empreendimento que se destaca do entorno pela altura dos prédios.

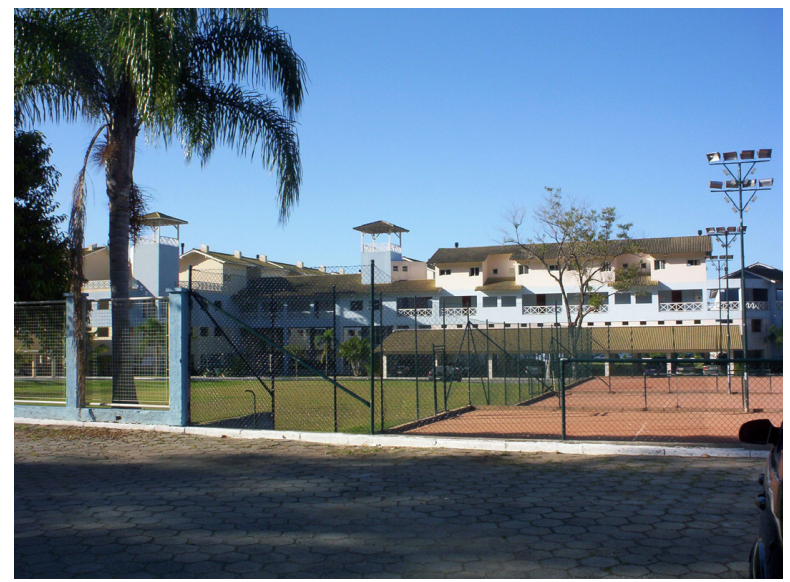

Figura 5.118: Vista da frente do resort.

É composto de edifícios em fita, com pilotis, dois pavimentos mais ático, que formam grandes pátios em $\mathrm{U}$, voltados para a Lagoa, e onde se desenvolverão atividades de recreação e lazer dos visitantes e moradores, além de oferecer marina náutica e hangares para pequenas embarcações, em edificações na orla lacustre.

A percepção de seu impacto na paisagem é forte, pela altura dos edifícios e por se implantar em grande área plana e sem vegetação que mitigue efetivamente o contraste com o entorno sua presença. A baixa taxa de ocupação do terreno não ameniza a percepção negativa que a forma e a altura dos edifícios proporciona, tanto para quem visualiza pela orla da lagoa, como pela via de acesso ao resort.

\section{Hotéis de balneários na paisagem da llha}

Os hotéis, estabelecimentos de hospedagem que se caracterizam pela especialização na oferta de cama para visitantes, normalmente se apresentam em edificações onde a célula habitacional é repetida inúmeras vezes, complementado por edificações de apoio, com ambientes sociais e de serviço. Independente se em cidades, espaços rurais ou praias, eles tendem a se localizar em locais com atributos atrativos aos visi- 
tantes onde, além do conforto do próprio estabelecimento, tem especial atratividade a acessibilidade aos ambientes externos, sejam locais, paisagens (naturais e culturais) ou eventos, de interesse.

No caso da llha de Santa Catarina, o parque hoteleiro do município de Florianópolis apresenta diversidade locacional, com grande concentração de estabelecimentos no centro da cidade e na região continental, mas o expressivo número de hotéis espalhados pelos quatro cantos da llha confirma que a proximidade às praias é um o atributo mais atrativos do turismo de sol e praia, tornando-as lugares preferenciais para implantação de hotéis.

Depois que a cidade passou a ter o planejamento territorial da llha orientado para o turismo com o PDB-85 enquadrando estes estabelecimentos em zonas específicas, as Áreas de Incentivo à Hotelaria-AlH, que se localizam preferencialmente na primeira franja litorânea dos balneários, mas sendo admitida localização em outras áreas como as Áreas Mistas Comerciais - AMC e as Áreas Turísticas Residenciais - ATR, e incentivando com índices urbanísticos mais favoráveis ao empreendimento, diversas regiões próximas à orla passaram a receber estabelecimentos hoteleiros, com destaque para a região norte da Ilha, com inúmeros hotéis em Ingleses, Canasvieiras e Ponta das Canas ${ }^{13}$.

O conjunto de hotéis do município, que em 2005 totalizavam 174 estabelecimentos, apresenta classificação hoteleira variada e, dependendo do padrão, podem oferecer mais ou menos conforto e equipamentos complementares à hospedagem. Dentre esses equipamentos, são bastante comuns piscina, restaurante e estacionamento, ainda que predominem hotéis de padrão médio que oferecem poucos atrativos além de cama e café da manhã. Apesar de muitos exemplos com boa elaboração e técnica construtiva, sejam afinados com a tradição ou afeitos à contemporaneidade arquitetônica, são bastante comuns os exemplos de má arquitetura, com implantações inadequadas e edificações improvisadas, que afetam a qualidade do parque hoteleiro local.

A expansão acentuada de investimentos privados na área de hospedagem se reflete na dimensão do parque hoteleiro da Florianópolis, o segundo do estado. Existem, porém, desvios de condutas na aprovação dos projetos e burlas da legislação. Exis-

\footnotetext{
${ }^{13} \mathrm{~A}$ região norte da Ilha de SC experimentou grande transformação de localidades agrícola-pesqueiras em balneários com a "implantação de empreendimentos hoteleiros e extra-hoteleiros, principalmente, além da edificação de segundas residências" (Moretto, 2005, p.158).
} 
tem inúmeros equipamentos que, apesar de serem aprovados pelo órgão público responsável como hotéis para obterem os incentivos nos índices urbanísticos, não se caracterizam como hotéis, ou seja, são construídos para serem comercializados como chalés e edifícios de uso residencial unifamiliar, descaracterizando o rótulo de hotel, servindo de segunda residência ou de leitos extra-hoteleiros na alta temporada para turistas e de residência de estudantes ou pessoas de pouca renda durante o resto do ano. Exemplo disso é a situação da Praia dos Ingleses, estudada por Moretto (1993), mas a prática é comum em toda a llha, onde edifícios são construídos sob o rótulo de hotel, e, portanto com a possibilidade de alcançar quatro pavimentos mais ático, quando se transformam posteriormente em residenciais, em que a possibilidade de construção seria de apenas três pavimentos mais ático.

Essa flexibilidade proporcionada pela segunda residência para o enfrentamento da sazonalidade turística, garante retornos dos investimentos privados, a maioria de pequenos empresários, para poucos, e custos sociais distribuídos para todos os cidadãos, na medida que tributos são sonegados, retiram hóspedes de hotéis e, principalmente, consomem grandes porções do território insular, além de exigir sobredimensionamento de infraestruturas urbanas em regiões pouco habitadas durante a maior parte do ano, desviando recursos de áreas mais necessitadas da cidade.

O desenvolvimentismo econômico baseado mais na urbanização do que no turismo vem exacerbando essa máxima de privatização dos lucros e externalização dos custos. O empresariado ligado ao segmento hoteleiro e de serviços de hospedagem não se apercebeu que a expansão do número de unidades habitacionais espalhadas em inúmeros loteamentos (regulares ou não), além de competir na absorção de visitantes pela oferta de leitos extra-hoteleiros, deteriora a paisagem atraente aos fluxos turísticos.

Em função da diversidade de classificações de hotéis em função do âmbito programático (recreação, saúde, etc.), categórico (popular, exclusivo, etc.) do local de implantação (praia, montanha, cidade, etc.) ou de sua relação com o sítio (de encosta, planície, água, etc.), foi descartada a classificação proposta pela EMBRATUR, por muito funcional e pouco considerar a dimensão arquitetônica, iniciando-se por uma taxonomia de tipos morfológicos, que transcendem as demais por se referenciar a padrões aceitos mundialmente, para em seguida contextualizá-los com o território e paisagem da cidade. 
Morfologicamente, os tipos mais elaborados de arquitetura hoteleira encontrados na região reproduzem, dentro do contexto sócio-econômico e cultural nacional, padrões de referência internacionalmente reconhecidos, utilizando técnicas arquitetônicas onde as modulações racionais do projeto e execução e a fuga da monotonia decorrente da repetição das associações de células similares são confrontadas na busca do arranjo criativo.

Os padrões arquitetônicos mais reconhecidos pela disciplina e presentes no município são: os hotéis tipo torre, cuja característica marcante é a verticalidade do edifício, admitindo formato variado e diferentes alturas (em função da legislação), normalmente utilizados em lotes urbanos; os hotéis tipo barra - edifícios únicos com forma derivada do paralelepípedo espichado, independente do número de pavimentos; os hotéis com acoplagem linear de edifícios (lateralmente e, em situações de declividade, em patamares escalonados), e hotéis do tipo edificações dispersas horizontalmente no terreno (apartamentos, cabanas ou chalés), articuladas por caminhos

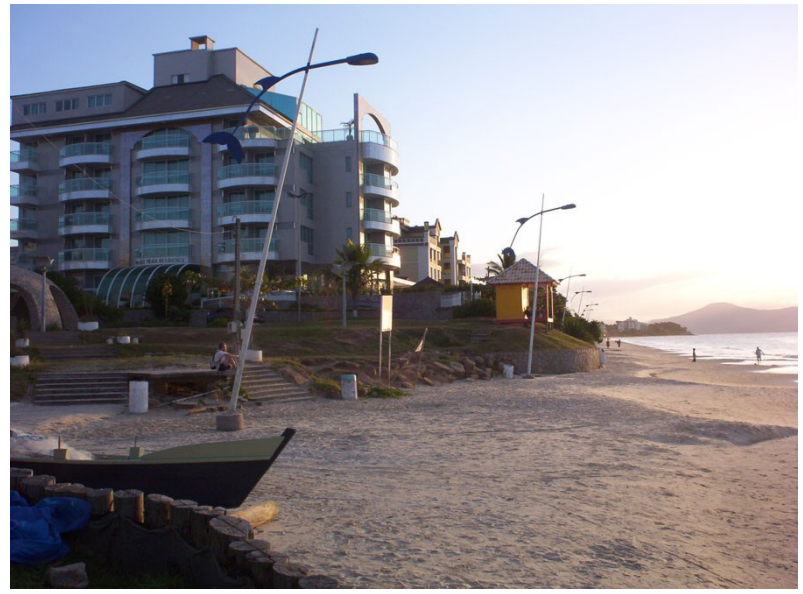

Figura 5.119: Vista de hotel com altura média na orla da Canasvieiras.

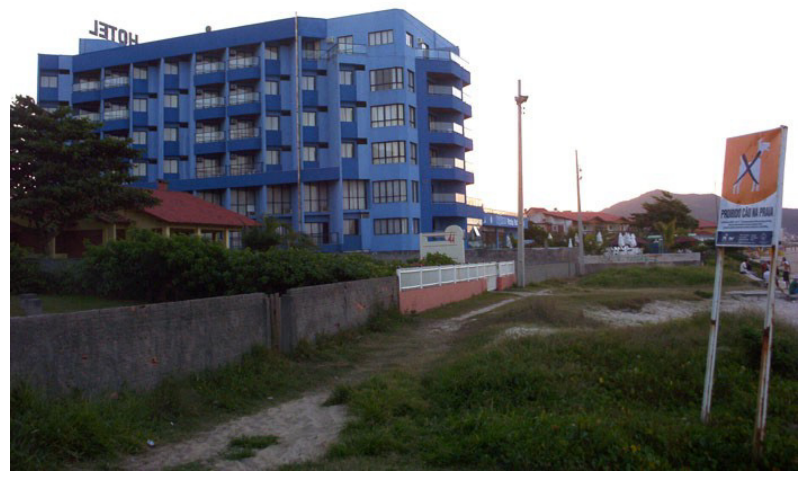

Figura 5.120: Vista de hotel em altura na orla da praia dos Ingleses.

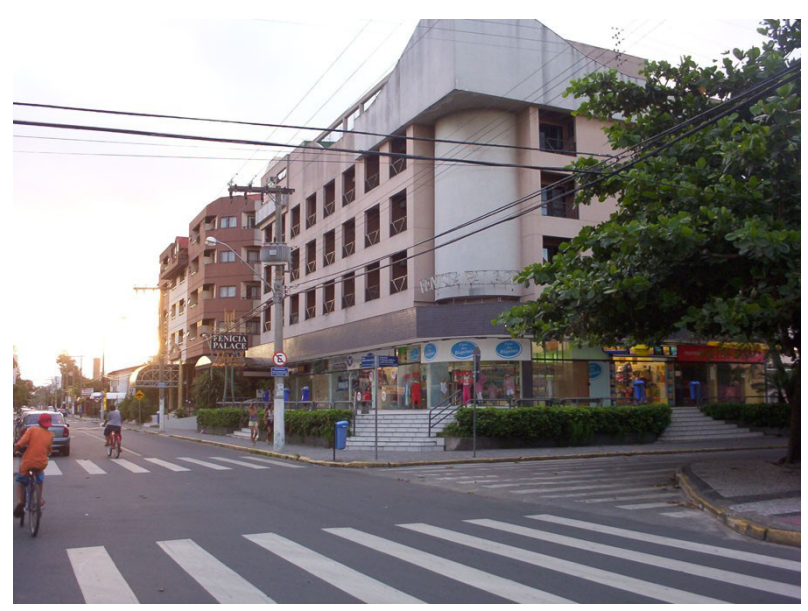

Figura 5.121: Vista de hotel com altura média em rua interna de Canasvieiras.

e polarizadas por edifícios de convívio, sendo os três últimos tipos mais adequados para situações de lotes amplos sem caráter urbano. 
Ainda que a quantidade e a diversidade (locacional e de tipos) dos estabelecimentos hoteleiros possam em um patamar de cidade turística, mesmo dentro do contexto nacional, Florianópolis ainda se ressente de um direcionamento da oferta, buscando a qualificação, pela adequação ao contexto territorial, e pela especialização, com atendendo demandas específicas. Esse direcionamento exige diferenciação espacial que, se acompanhados da profissionalização dos serviços prestados, poderá estabelecer um diferencial entre os destinos turísticos da região. A seguir, são apresentados alguns exemplos de hotéis e sua relação com a paisagem da llha de Santa Catarina.

\section{As pousadas}

As pousadas, estabelecimentos de hospedagem similar à hotelaria tradicional, apresentam-se de distintas formas na paisagem, com destaque para a imagem menos empresarial e mais doméstica que busca transmitir. Essa imagem decorre de diferentes aspectos, entre eles, um de natureza comportamental é possibilidade de adaptação do ambiente aos modos dos proprietários e em forte conformidade com suas expectativas culturais. Outro aspecto é o porte físico do estabelecimento, geralmente com menos impacto que as estruturas hoteleiras tradicionais. Um outro aspecto ainda, é a recorrente adaptação de espaços para a nova função, ou a criação de novos, mas buscando passar sensações de ambientes menos frios e empresariais comuns em hotéis.

Dependendo do profissionalismo do promotor, apresentam forte vínculo com as regiões onde se inserem, por meio de oferecimento de comidas típicas e envolvimento com a paisagem. O visitante consumidor deste tipo de estabelecimento, em geral, evita a massificação de serviços, como em hotéis e resorts, e busca ambiente com referências ambientais e/ou culturais.

Espacialmente, é valorizada a inserção integrada no contexto, seja urbano, utilizando edifícios de valor histórico - casas antigas, conventos, engenhos abandonados, etc., seja natural, buscando mimetizações com a paisagem ou mitigação do impacto no território. Nas regiões onde há disponibilidade área, uma alternativa recorrente é a distribuição de células habitacionais espalhadas horizontalmente no lote, entremeadas pela vegetação. 
Em Florianópolis, como não há legislação específica para este tipo de estabelecimento, boa parte do capital investido é de baixa monta e os pequenos empreendedores locais apresentam baixo grau de profissionalismo, existem diversos exemplos de pousadas que não contribuem para a qualificação desse segmento da hospedagem. Encontra-se desde antigas casas de segunda residência das famílias locais ampliadas por pequenas células habitacionais, justapostas ou isoladas, sem espaços abertos de uso comum, até a utilização de casas pré-fabricadas de madeira, algumas já obsoletas, passando pela repetição monótona de células enfileiradas ad infinitum com espaço reduzido.

Podem ser encontradas em diferentes contextos territoriais da llha de Santa Catarina, como em meio aos assentamentos urbanos tradicionais, em construções novas ou reutilizadas, em áreas mais abertas, em lotes mais amplos que permitem arranjos espaciais menos densos, ou encostas. Algumas pousadas do setor sul da llha, menos desenvolvido turisticamente, tendem a se localizar em regiões de interesse ecológico, próximas a áreas protegidas, com arquitetura adaptada ao contexto.

Este tipo de empreendimento apresenta alto potencial de sustentabilidade econômica pela pequena quantidade de mão de obra necessária, pela flexibilidade de vínculos empregatícios com a absorção de trabalhadores temporários, pela possibilidade de investimento espaçado no tempo e pela possibilidade de administração direta do proprietário. Entretanto e em que pese o grande número de estabelecimentos no contexto da região de Flo-rianópolis, as pousadas não têm representatividade expressiva nas decisões do trade turístico, que é mais influenciado pelos agentes vinculados ao turismo-imobiliário, onde se associam o sub-segmento da construção civil a empreendimentos que impliquem grandes obras.

A alta taxa de mortalidade das pousadas e o funcionamento sazonal de muitas pousadas revelam problemas de gestão empresarial e profissionalismo nessas iniciativas. Muitas pousadas, geralmente de pequeno porte e capital local de pessoas físicas, com pouca experiência no ramo, e implantadas em estruturas físicas adaptadas, que permitem a adequação à flexibilidade exigida pela sazonalidade, funcional e de serviços, têm sido levadas à situação de irregularidade junto aos órgãos de autorização e controle da atividade e também ao órgão de representação. 
Grande número de micro ou pequenas empresas, a falta de informações sobre o segmento, a pouca diversificação da demanda turística, a baixa qualidade de muitos empreendimentos e a baixo grau de profissionalismo e associatividade ${ }^{14}$, podem explicar e a pouca influência desse segmento e a pouca prioridade que lhe é reservada nas propostas de planejamento do turismo.

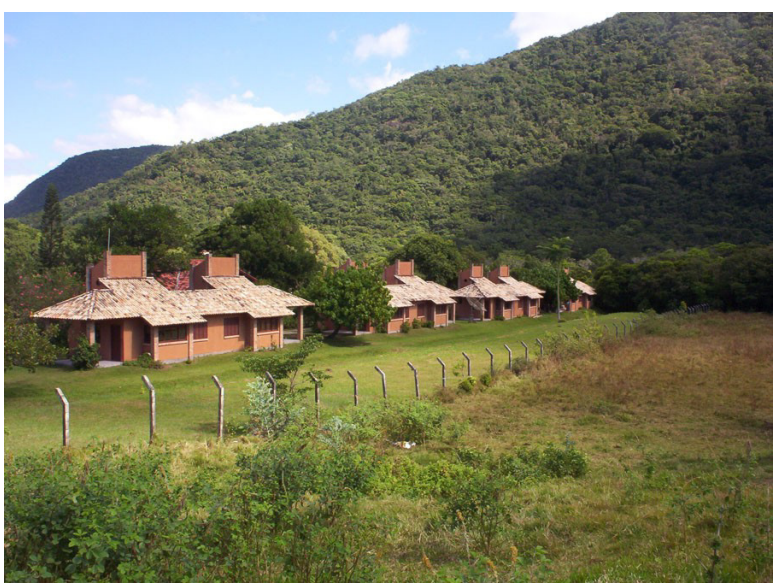

Figura 5.123: Vista de pousada com edificações semi-isoladas e médio impacto na paisagem.

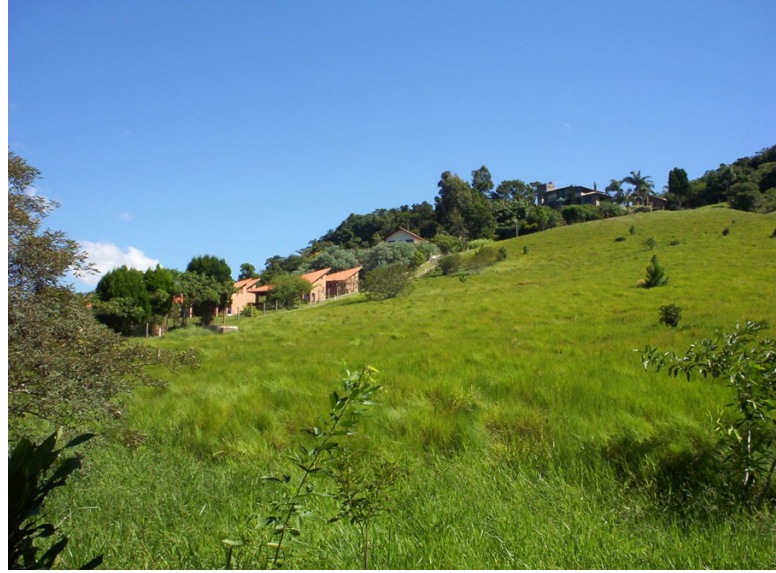

Figura 5.122: Vista de pousada com edificações isoladas em encosta, com baixo impacto na paisagem.

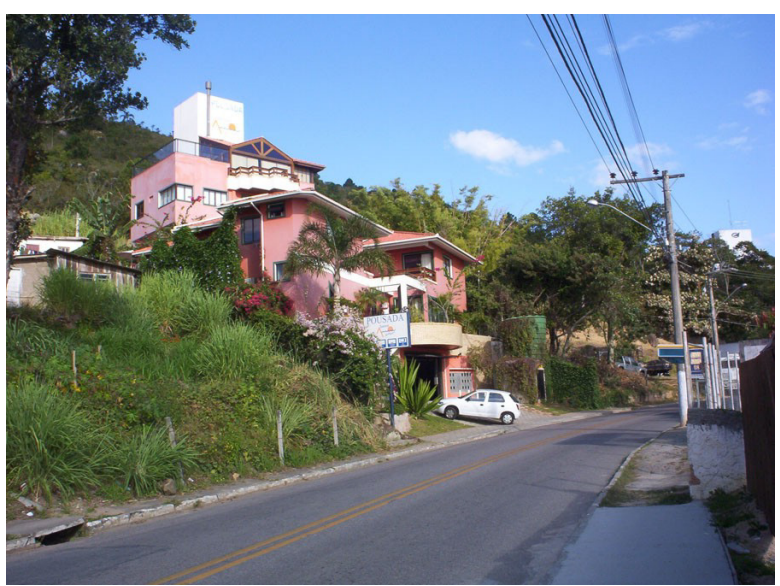

Figura 5.124: Vista de pousada em encosta com impacto similar ao entorno.

\section{Os campings}

Os campings, áreas exclusivas para instalação de equipamentos de hospedagem efêmeros e móveis, como barracas e motor-home. Geralmente se instalam em áreas com grandes espaços livres e oferecem, além de pontos de energia elétrica, equipamentos de banho, espaços para refeições e churrasqueiras, outras atividades de recreação e lazer, como piscinas e salão de jogos. As regiões para implantação mais utilizadas estão próximas e/ou fácil acessibilidade a áreas naturais de interesse paisagístico, embora possam ser encontrados em zonas com mais ocupação humana. Como os equipamentos de hospedagem são móveis e efêmeros, comumente se insta-

\footnotetext{
${ }^{14} \mathrm{O}$ cruzamento de dados da pesquisa recente do SHBRS da Grande Florianópolis (2005) com os relativos aos associados dessa mesma entidade permite essa conclusão.
} 
lando em meio a zonas arborizadas, seu impacto na paisagem tende a ser pequeno e bem aceito pela população local.

\section{Camping da CIDASC (Companhia de Integração e Desenvolvimento da Agricultura do Estado de Santa Catarina)}

Situado no Parque Estadual do Rio Vermelho, no distrito do mesmo nome, em meio à extensa área de reflorestamento de árvores exóticas - pinos e eucaliptos, entremeado pela vegetação de restinga resistente. Junto à rodovia de acesso, tem acessibilidade à praia do Moçambique por caminho de pouca extensão em meio à vegetação, que apesar do exotismo, cria ambiente agradável. Suas instalações apresentam aspecto rústico e oferecem poucos atrativos além da hospedagem,

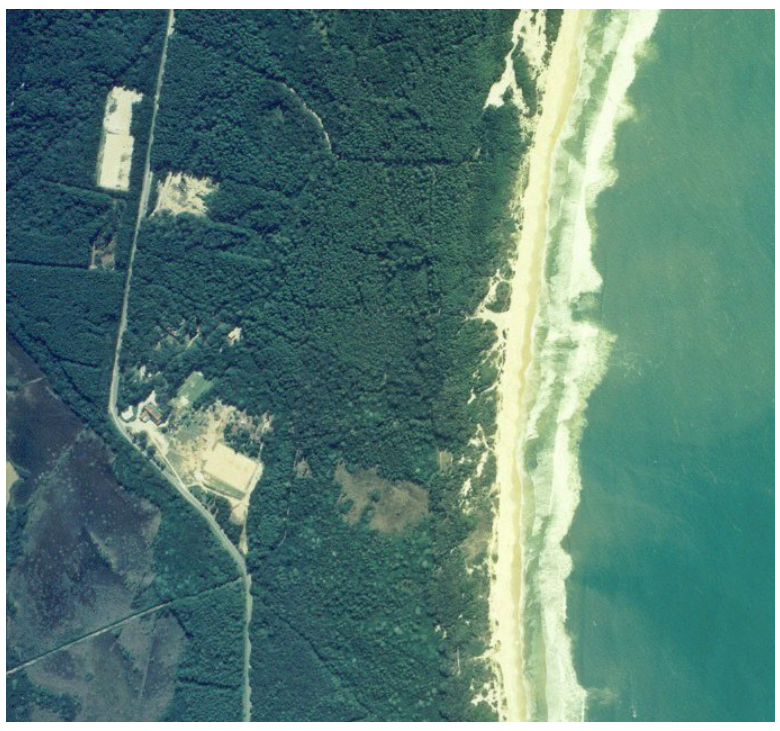

Figura 5.125: Situação do Camping da CIDASC em meio ao Parque Florestal do Rio Vermelho. mas bastante procurado por demanda predominantemente de renda média e baixa. Causa pouco impacto na paisagem natural pela baixa taxa de ocupação de edificações e somente com a alta ocupação nas temporadas sua existência é perceptível. A paisagem se encontra bastante associada com o reflorestamento exótico já aceito pela população. $O$ impacto do fluxo de veículos é bem recebido pela rodovia de acesso ao empreendimento.

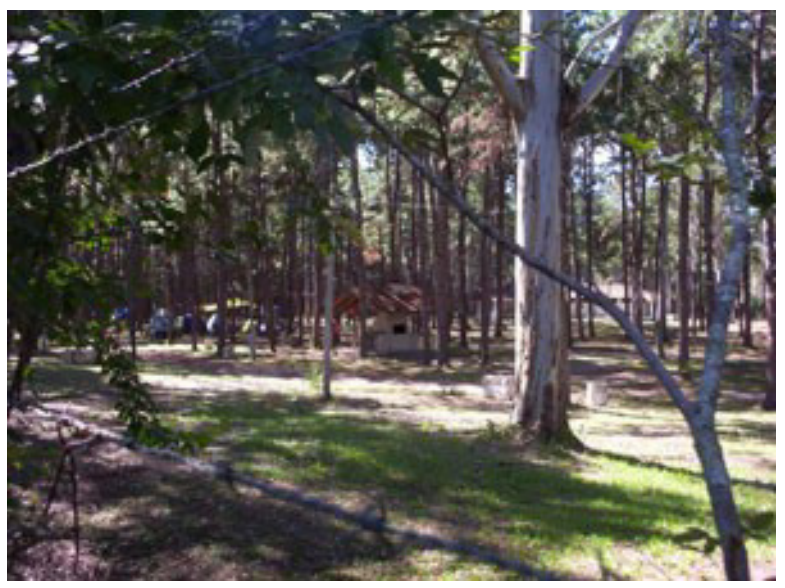

Figura 5.126: Vista do interior do Camping da CIDASC.

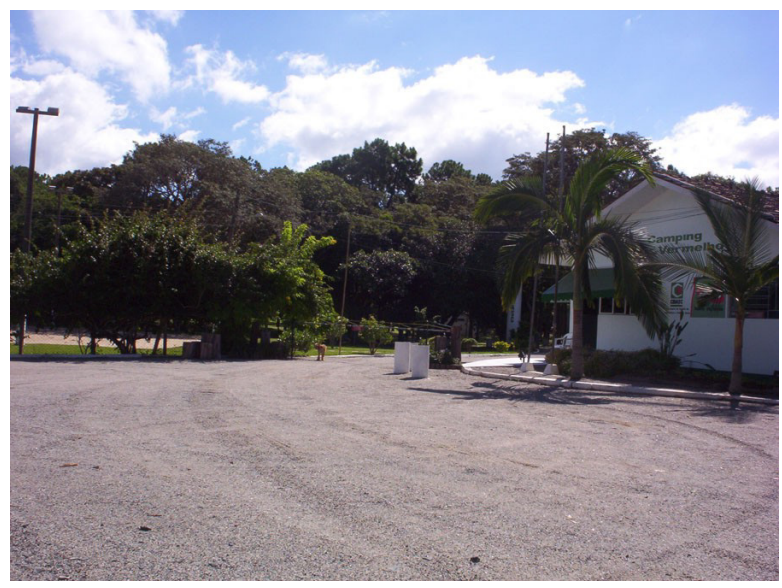

Figura 5.127: Vista do acesso ao Camping da CIDASC. 


\section{Camping dos Escoteiros}

Situado também na restinga do Parque Florestal do Rio Vermelho e implantado em zona reflorestamento, tem identificação difícil na paisagem, pelo encobrimento pela vegetação. É abastecido de água de ponteira e saneado por sistema semi-coletivo.

\subsection{Considerações evidentes sobre a paisagem}

O estudo da paisagem na escala da llha de Santa Catarina permite perceber de modo evidente que determinadas áreas homogêneas naturais vem sendo fragmentadas e ocupadas pela urbanização - as planícies quaternárias de restinga e sedimentação aluvial. São percebidas outras áreas que estavam em processo de regeneração da cobertura vegetal, as encostas baixas dos morros (classificadas como APL no PDB), voltaram a perder parte de sua integridade, pela ocupação residencial, E ainda outras áreas localizadas nas partes mais altas dos morros (as APP) voltaram a ter cobertura com floresta densa.

A urbanização teve um incremento alarmante exatamente por sobre as planícies, e ainda que tenha avançado pelas encostas, nestas, o impacto é incomparavelmente menor, tanto ecológica como cenicamente, não apresentando a extensividade equivalente a da ocupação no plano, e é localizada em certos bairros mais valorizados (Lagoa da Conceição, Jurerê, Cacupé, por exemplo).

As áreas abertas planas remanescentes, cenicamente atrativas e tes-

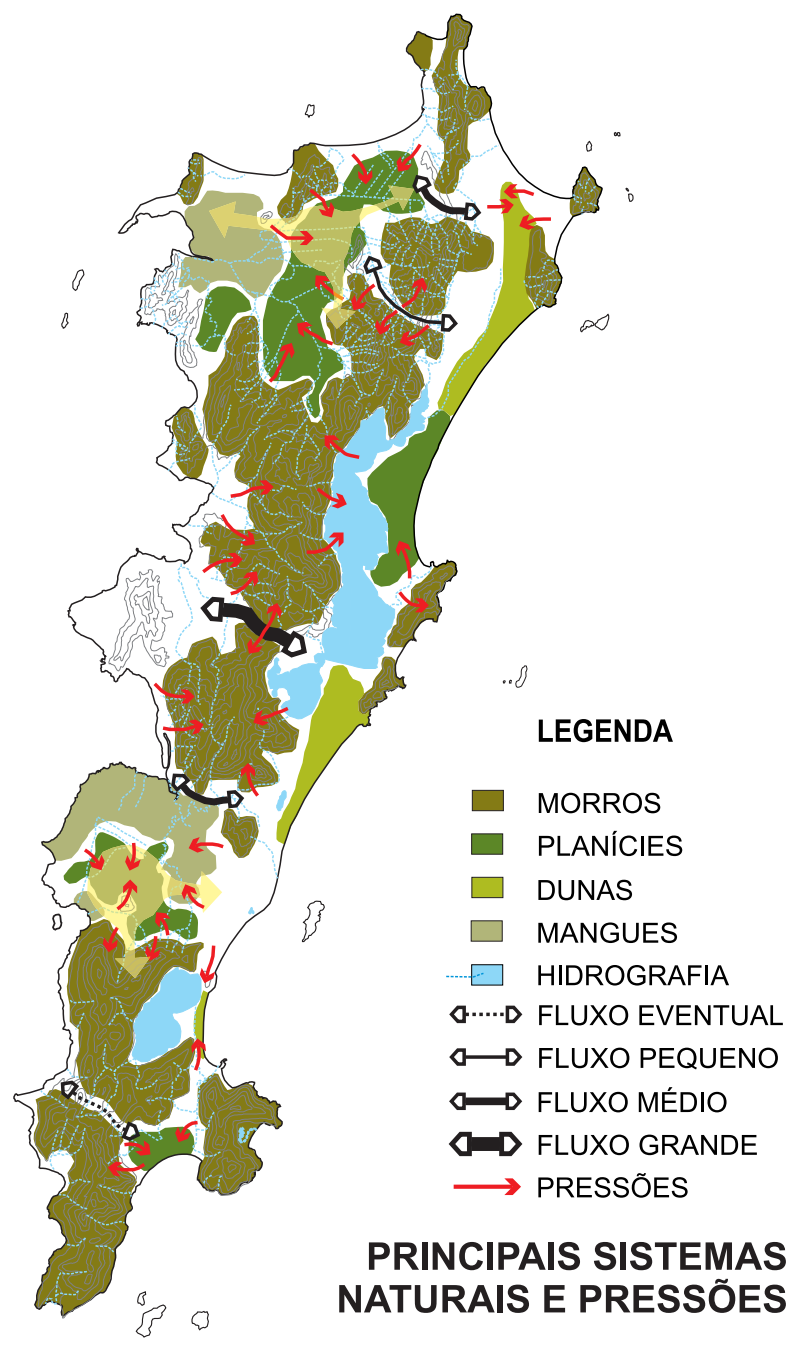

Figura 5.128: Principais sistemas naturais e pressões urbanasa. 
temunhas de práticas culturais tradicionais de valor histórico, além de ecologicamente necessárias para o equilíbrio do regime hidrológico da ambiente insular, assumem enorme interesse do ponto de vista paisagístico. Entretanto, essas planícies sedimentares, em que ocorrem as florestas de planície quaternária e áreas de inundação, não têm garantido, por parte do poder público, nenhuma atenção no sentido de valorizar suas qualidades paisagísticas, preservando-as da ocupação, sendo desconsiderado seu papel cênico e ecológico na formação do mosaico paisagístico da Ilha.

A ocupação dos interstícios de áreas planas entre os assentamentos virá prejudicar os sistemas naturais, com a instabilidade do regime, a fragmentação ainda maior da manchas de homogêneas, a quebra da conectividade entre sistemas que dependem da integridade das planícies para trocas de energia e matéria.

Mas não só na dimensão ecológica haverá perdas. A estrutura polinucleada feita de assentamentos dispersos entremeando as áreas abertas e morros, que caracterizou e, em grau menor, ainda caracteriza a relação entre natureza e assentamentos humanos na llha de Santa Catarina, herança cultural da ocupação açoriana tende a desaparecer.

Esta estrutura urbana, atributo do território que assume valor cultural pela paisagem diferenciada dos demais centros turísticos do litoral brasileiro ainda não é percebida, e neste caso nem pelo poder público nem pela sociedade em geral, como herança cultural, rebatida na paisagem, a ser valorizada e resgatada.

Os morros e encostas que tem recebido ocupação estão ameaçados pela possibilidade de ocupação extensiva na meia encosta se não houver controle e fiscalização da legislação que só permite $10 \%$ de ocupação e aproveitamento nas áreas de proteção limitada. A necessidade de espaçar as edificações na encosta se reveste de significado ecológico pela conectividade entre os sistemas biológicos e hidrográficos das planícies e os dos morros. Esteticamente, o espaçamento é necessário pela percepção de degradação que a substituição da cobertura vegetal, por edificações e paisagismos insensíveis, de maneira contínua proporciona. Nas encostas ainda existem algumas trilhas coloniais e servidões públicas, inventariadas e catalogadas, e que sofrem pressão diante das condições de valorização da terra, 
mas que são consideradas como patrimônio cultural.

Diante das possibilidades de ocupação do solo em encostas e planícies, ainda que com controle e restrições de impacto, com funções diversas, inclusive a turística, e das alternativas de tipologias edificatórias mais sensíveis a paisagem, a homogeneização que vem se implantando, em função do PDB de 1985 e dos Planos Específicos, parece andar na contramão da valorização do mosaico paisagístico da llha.

O estudo da dinâmica da paisagem permitiu aprofundar o estudo das diferentes características e paisagens localizadas, com graus de artificialização e naturalização distintos e que refletem fragilidades, ameaças e potencialidades diferenciadas. Elas sugerem que a alternativa mais adequada à paisagem da llha de Santa Catarina deve incorporar várias possibilidades de aproveitamento da paisagem na atividade turística, pensada também com diferentes graus de impacto em função do tipo de turismo. 


\title{
CAPÍTULO VI
}

\section{EM BUSCA DE UM MODELO TERRITORIAL PARA O DESENVOLVIMENTO TURÍSTICO NA ILHA DE SANTA CATARINA}

\begin{abstract}
"Desarrollo Sostenible es aquel que ofrece servicios ambientales, sociales, y económicos básicos a todos miembros de una comunidad sin poner en peligro la viabilidad de los sistemas naturales, construidos y sociales de los que depende la oferta de estos servicios" (Avance del Plan Territorial Insular de Menorca, Ezquiaga, 1997).
\end{abstract}

Em que pese as intenções dos planos de desenvolvimento da atividade turística e de ordenação do território proclamarem suas intenções de valorização do patrimônio paisagístico, embasados em corretas leituras do ambiente insular, o modelo territorial do turismo, atrelado à expansão da urbanização vem causando efeitos não muito coerentes com as posturas iniciais. Mesmo que as diretrizes de ordenação do território busquem a regulamentação de determinados usos e a proteção de determinadas áreas e sistemas naturais, a situação acima demonstrada não é muito alentadora para a cidade.

Com a extensiva urbanização, afetando a integridade das áreas homogêneas e desqualificando a paisagem, com reflexos na sustentabilidade da atividade escolhida para ser vetor de desenvolvimento sócio-econômico, a cidade se encontra em um processo que pode levar a obsolescência do território enquanto atributo de promoção de melhores condições de vida para a sua população.

Os problemas deste modelo se revelam nas deseconomias do modelo suburbano de baixa densidade, da casa isolada no lote, com caráter individualista e segregador de áreas residenciais, e no incentivo à densificação urbano-turística nas bordas das praias e em áreas ainda sem infraestruturas adequada e na homogeneização com tendência a adensamento construtivo em estabelecimentos turísticos, com evidentes prejuízos na paisagem e no ambiente.

Com base em previsões demográficas genéricas, o plano de ordenação do solo utiliza uma classificação homogênea de zonas adequada a estabelecimentos urbanos e suburbanos, tendendo, desse modo, à homogeneização da paisagem construída em quase todos os quadrantes da llha. Essa utilização de instrumentos urbanísticos similares em grande parte do território, apesar das classificações diferentes do zoneamento 
e de densidade, desconsidera a paisagem e pode ser percebida em diferentes pontos da llha onde o turístico e o residencial se assemelham.

A forte pressão imobiliária se faz tão presente que acarreta a transformação do suburbano de baixa densidade em urbano, por cima de áreas, ora despreparadas, ora não adequadas para tanto. Atualmente, em meio à monótona e dominante dispersão residencial pelas planícies de restingas e campos, a paisagem já é pontuada por edificações de características urbanas. Num processo que se aproveita de incentivos turísticos ou de zoneamentos inadequados, substitui casas de um e dois pisos por prédios com altura equivalente a quatro alturas sobre regiões sem infraestruturas suficientes, de saneamento básico e sistema viário, ou de interesse paisagístico (vide a Lagoa da Conceição, a Barra da Lagoa, e Campeche, as praias do norte da llha e o loteamento do Açores, entre outros exemplos).

Ainda que o padrão urbanístico seja diferente, o parcelamento simples ou o parcelamento ordenado, como sugerido por Reis $(2002)^{1}$, legalizados ou clandestinos, todos apresentam resultados pouco qualificadores da paisagem. As urbanizações legalizadas, efetivando a associação entre urbanização e turismo, e a expansão desordenada das urbanizações clandestinas, sem o reconhecimento por parte do poder público como parte do processo, o que exigiria tratamento específico, se esparramam incontrolavelmente sobre o território. O comprometimento da paisagem não decorre, portanto, somente da ocupação clandestina e desordenada, como muitos proclamam, tentando desviar a atenção do papel da urbanização oficializada e ordenada na ocupação extensiva do território.

Os loteamentos e condomínios legalizados, de primeira ou segunda residência, para uso próprio ou aluguel turístico, com casas de pouca altura, isoladas no lote, com o padrão internacional da cidade jardim, em versões adaptadas e empobrecidas no terceiro mundo, têm sido um dos mais importantes consumidores de paisagem. Derivado do modo de vida suburbano norte-americano, este tipo de assentamento

\footnotetext{
1 Essa classificação proposta por Reis (2002) aponta para dois tipos básicos de urbanização: o simples, que é condicionado diretamente pela estrutura fundiária do parcelamento colonial (lotes estreitos e compridos) e derivações, geralmente resultando em assentamentos tipo espinha de peixe ou pente, muitos em situação irregular junto ao poder público; e o ordenado, que se estabelece, com padrões urbanísticos modernos e tramas regulares, sobre glebas amplas e sem aqueles condicionantes fundiários ou remembradas. Porém, muitas destas glebas também decorrem de herança colonial, pois se implantam em antigas terras comunais, de titulação recente para proprietários interessados na adequação fundiária que, com o respaldo da legislação, facilita este tipo de empreendimento.
} 
com ocupação extensiva de baixa densidade, vem sendo adotado, na crença na disponibilidade infinita do território, o que em Florianópolis e na llha de Santa Catarina não é realidade.

Por outro lado, os condomínios verticalizados da orla dos balneários vêm se misturando na paisagem em conjunto com os estabelecimentos turísticos, ambos com densidades e alturas maiores, formando uma barreira construída junto às áreas de transição entre terra e mar. A valorização imobiliária da primeira franja litorânea só se sustenta na ótica do "quem pode, escolhe" a localização, em um zoneamento influenciado por quem vende e constrói, pois a maior parcela da população é afastada desta área pelo custo, pelo padrão urbanístico e pela distância, entre outros artifícios de segregação. O resultado dessa lógica de apropriação de patrimônio coletivo, representado pelo constrangimento de acesso à orla e pela obstaculização da fruição da paisagem, é bastante conhecido por todos.

Paralelo a isto, as características modernizantes da legislação (PDB-85) que regulamente os parcelamentos, com parâmetros formais e de dimensionamento exigidos para lotes e vias e índices standard, dificultam sua adoção por grupos sociais de baixa renda, além de tornar irreversível a ilegalidade de diversos assentamentos existentes para sua legalização. Mais recentemente, mega-empreendimentos, de capitais associados (locais e exógenos) e com padrão internacional (com spas, marinas e campos de golfe), começam a fazer parte do cotidiano ilhéu, elitizando ainda mais a paisagem.

A desconsideração da ocupação já existente e de suas características, decorrentes da forma territorial colonial que, mesmo resultando, na maioria das vezes, em expansões urbanas carentes de qualidade, expressam uma parte importante do processo urbano existente, inserido na lógica mercantil de produção de espaço, cujas conseqüências na composição e distribuição sócio-espacial são incrementadas pela fraca fiscalização quanto à observação da legislação ambiental, o que permite o avanço sobre áreas e ecossistemas já protegidos.

A percepção da necessidade de manutenção de atividades rurais, em determinadas áreas, não se fez acompanhar de nenhum incentivo (fiscal ou territorial, como a possibilidade de uso de índices de aproveitamento do solo como valor de troca, por exemplo), o que não interrompeu o progressivo e quase definitivo abandono dessas atividades, pouco contribuindo para a manutenção paisagens tradicionais. 
Ou seja, o planejamento não tem sido capaz de interferir na ordenação do território com vistas a proteger e enfatizar espaços importantes de sua paisagem. Principalmente por não incorporar padrões de desenvolvimento adequados ao território e por assumir o desenvolvimento turístico, via assentamentos urbano-turísticos de baixa densidade, consumidores de espaço, como um modelo generalizável. Essa mercantilização imobiliária do território e da paisagem é característica, ainda que não exclusiva, do desenvolvimento turístico de Florianópolis e especialmente da llha de Santa Catarina, o que torna clara a preponderância da perspectiva econômica, especialmente desse segmento empresarial, sobre as demais.

A demonstração de que o modelo de desenvolvimento urbano-turístico que orienta a ocupação e uso do solo em Florianópolis e llha de Santa Catarina não privilegia o mosaico paisagístico do território, quer alertar para o esgotamento da base ambiental, para o aproveitamento indiferenciado de espaços, para a homogeneização dos padrões de ocupação e de edificação dos estabelecimentos turísticos e das taxas de ocupação e densidade inadequadas que vem sendo permitidas.

Esse modelo de desenvolvimento do turismo adotado em Florianópolis, já experimentado em diferentes regiões turísticas do planeta, lugares em que a atividade vem se desenvolvendo há mais tempo, tornando obsoletas diversas estruturas turísticas, urbanas e arquitetônicas, tem sido considerado insustentável. Contra esta perspectiva, urge a conciliação entre respeito ao ambiente e o desenvolvimento da atividade turística (Santiago, 1995), mesmo considerando a dificuldade colocada pela diferença de interesses entre agentes do desenvolvimento turístico e segmentos sociais, de viés ambientalista.

Ao se utilizar a paisagem como um instrumento de compreensão dos processos de apropriação e transformação urbanos, é possível entender seu papel no contexto da ilha de santa Catarina e da cidade de Florianópolis. Para que se possa avançar em direção a uma alternativa ao modelo urbano-turístico atual, entendendo a paisagem como vetor de inclusão, nos mais diversos níveis, e como fator de contribuição para a estruturação do espaço (Santos, 2002) algumas aspectos devem ser considerados.

O primeiro é que, para uma atividade que se constitui de diversos agentes e formas de espacialização, é difícil a generalização de afirmações e decisões, e por isso cabe a particularização das sugestões aqui apresentadas, considerando-as como 
contextualizadas à cidade de Florianópolis, cidade com território predominantemente insular e com poucas alternativas reais de desenvolvimento sócio-econômico se retirada a possibilidade do turismo.

É forçoso dizer que a atividade turística é alternativa real e possível para o desenvolvimento sócio-econômico da cidade, na medida em que existe, em determinados setores da sociedade, a saudade de um tempo em que todos dependiam direta ou indiretamente da tímida atividade terciária ou da administração pública, e em outros a inadvertida idéia de que a cidade poderá manter alguma qualidade ambiental simplesmente evitando a alta densidade e prédios em altura, características urbanas de certo tipo de turismo. As políticas e ações no sentido do controle da ordenação da urbanização legalizada e a coibição da ocupação clandestina, oferecendo alternativa inclusiva aos que dela dependem, dependem do equilíbrio financeiro do município, e o descarte do potencial turístico não parece sensato.

Uma segunda questão a considerar é a premência de colocar a paisagem como centro das preocupações de ordenação do território e fazer dela o elemento principal da ordenação do território. Em um território rico e frágil como o da cidade de Florianópolis, e mais especificamente da llha de Santa Catarina, a premissa da paisagem como elemento fundamental na ordenação das atividades humanas requer a inversão da prioridade. Em vez de pensar, primeiramente, em onde e como se ocupa o território e com quais atividades, é necessário priorizar a definição de quais espaços podem ser utilizados e como devem ser conservados. Esta posição decorre da compreensão de que o patrimônio paisagístico é um recurso, que além de necessário para a qualidade de vida dos residentes, pode ser aproveitada como recurso na atratividade turística, ampliando o pequeno rol de alternativas econômicas da cidade.

Em Florianópolis e na Ilha de Santa Catarina, onde a atividade turística tem alto potencial de desenvolvimento, isto implica ordenar o turismo e o crescimento urbano respeitando a base das áreas naturais que configuram o mosaico natural em sua visão integral, ou seja, destacando os sistemas naturais de maior importância cênica e valor ecológico, e elementos sócio-espaciais da herança colonial que se mantiveram como áreas pouco artificializadas nas planícies e morros, estruturando a distribuição dos assentamentos e dos sistemas de circulação. Dentro desse marco e levando-se em conta as particularidades de cada porção do território, será possível 
apontar as características das diferentes zonas que poderão receber turismo e crescimento urbano, de modo a não dilapidar o patrimônio paisagístico.

Uma terceira questão a ser considerada é a necessidade de dissociação o desenvolvimento turístico do desenvolvimento urbano, pois no contexto da Ilha de Santa Catarina, se valorizado o mosaico da paisagem, essas expressões representam noções opostas, senão excludentes. O capital turístico deve evitar a influência do capital imobiliário (CCRS Arquitects, 1993) e, se a atração do turismo é, de fato, a paisagem e o crescimento da atividade não pode prescindir dela, ele deve acontecer de modo a não obliterar a paisagem.

A atividade turística não se desenvolve somente pelo de consumo extensivo de território e nem atua somente como agressor do ambiente, podendo ser entendida como vetor de formação do território que considera e depende da paisagem. Já a urbanização, que tem um de seus fundamentos na acumulação de capital pelo consumo do solo das cidades, apresenta uma série de inconveniências ao se estabelecer em paisagens valorizadas por moradores e visitantes.

O espaço turístico, resultante dessa dissociação, passa a ser pensado diferentemente das pautas que, atualmente, orientam o espaço urbano. Assim como as restrições e índices urbanísticos teriam condições de refrear a especulação imobiliária, a massificação, o excesso de massa construída e as altas densidades, que podem ser evitados ou aceitavelmente mitigados por legislação com maior rigidez dos parâmetros, as classificações de solo distintas em função das diversas expressões da paisagem permitem dissociar a recorrente e ambígua relação entre turismo e desenho urbano caracterizado pela mancha expandida e difusa, com variadas densidades, ao longo da costa atlântica brasileira.

Uma quarta questão que deve ser considerada é a necessidade de compreender o turismo não só como um segmento a mais da economia, mas como um processo de comunicação, com dimensão cultural e que, diferentemente das demais indústrias, tem um produto e um modo de consumo específico: no caso de Florianópolis, sua paisagem. A paisagem enquanto recurso material a ser aproveitado economicamente na exploração da atividade turística apresenta a especificidade de autonomia em relação aos consumidores e produtores da atividade, estes entendidos como os agentes locais envolvidos com o turismo. 
Considerada enquanto resultante de um processo de produção comunicativa, a paisagem é um produto da natureza e da sociedade, e quando, ao longo do tempo, se degrada, perde as qualidades semióticas, refletidas na imagem da localidade, requeridas por moradores e visitantes. Além disso, a exploração da paisagem por parte da atividade turística, quando produz externalidades negativas, decorrentes do esgotamento do ambiente, passa a cobrar altos custos sociais e econômicos, afetando outros segmentos da economia, diminuindo a possibilidade de inserção com competitividade no mercado mundial.

Por essa razão, é necessária a consideração da retribuição do produto paisagem, por parte dos empresários do ramo turístico e segmentos associados, e medidas para sua recuperação e manutenção, por parte do estado. Sendo um produto específico, mas inserida numa lógica de oferta e procura, a paisagem como bem econômico coletivo e escasso, seu uso racional leva a duas alternativas: a restrição do uso ou a elevação de preço.

A restrição de uso, embora de difícil aplicação, merece ser considerada na medida em que uma das características da paisagem "é ser um bem livre e público, que manifesta externalidades negativas (deseconomias externas), que em longo prazo provoca um custo social. Estas deseconomias externas (degradação da paisagem) afetam a própria indústria turística e reduz sua competitividade" (CCRS Arquitects, 1993, p. 79). A retribuição da paisagem que se sugere aponta para a apropriação e consumo de espaços significativos que a constituem e se revestem de interesse ecológico, cênico ou histórico-cultural, e não para a fruição visual, cuja apropriação não desgasta a paisagem observada.

Quanto à elevação do custo de acesso à paisagem, cabe lembrar que ela é um bem público, cuja gestão envolve múltiplos interesses fundamentais e contrapostos, e não tendo demanda mercadológica clara, torna-se difícil estabelecer parâmetros econômicos de retribuição. E mais difícil ainda costuma ser a distribuição desta retribuição em localidades onde determinados grupos econômicos organizados dos segmentos turísticos e imobiliários, que em Florianópolis se confundem, influenciam o aparato estatal de planejamento. Desse modo, a retribuição pelo uso do território pela atividade turística deve se rebater na própria paisagem, fazendo com que a possibilidade de sua apropriação e fruição coletiva seja real e maior do que a perspectiva que se apresenta atualmente. 
O desenvolvimento turístico contemporâneo tem valorizado identidades turísticas singulares e paisagens que resultem da adequação do modelo ao território, mas também adequando o território ao novo modelo de turismo, levantando a possibilidade de o turismo ser uma oportunidade de manter a paisagem. Nessa perspectiva, a paisagem tem condições de ser um recurso comunicativo cujo resultado é um produto imagem (CCRS Arquitects, 1993).

Em Florianópolis, a riqueza dos atributos paisagísticos, consideradas a diversidade de sistemas geo-ecológicos e a significância da herança colonial na estrutura territorial, se apresenta com forte possibilidade de dar sustentação à imagem da llha, abrindo portas para as habituais, mas, também, novas demandas turísticas.

As idéias gerais abaixo apresentadas vêm sendo irradiadas por diversos estudiosos $^{2}$ preocupados com a necessidade de controlar o impacto do turismo com os recursos e se tornam adequadas ao contexto de Florianópolis na busca de um modelo de desenvolvimento da atividade turística diferente do até hoje adotado.

Compreendendo que "a indicação de diretrizes mesmo que gerais são também específicas desde que ao serem determinadas no todo incidem nas partes e viceversa, uma retroalimentando a outra" (Santos, 2002, p. 27), o encadeamento das idéias aqui apresentado segue as questões trabalhadas no percurso da investigação, não abrangendo todas as dimensões do planejamento, mas buscando coerência e articulação propositiva em relação à valorização da paisagem, em suas dimensões ecológica, cultural e cênica e visando uma possível conciliação entre turismo e ambiente, com proposto por Santiago (1995).

O uso de políticas radicais, características de sistemas e decisões rígidas e de acessibilidade muito restrita deve ser reconsiderado. A flexibilização de leis restritivas tem tido maior aceitação nos meios acadêmicos e na sociedade. O estímulo à utilização racional dos instrumentos legislativos e de sua regulamentação deve ser prioritário, considerando experiências em que o desequilíbrio entre medidas de incentivo e medidas de dissuasão e a intensidade da aplicação de normas e regulamentos têm levado ao seu descumprimento.

\footnotetext{
1 Progresso e desenvolvimento econômico, conceitos instituído já na primeira revolução científica - o renascimento, significava crescimento numa direção, de modo linear e em busca de um estado de equilíbrio estático. A moderna ideologia do progresso tem seu fundamento na consolidação do imaginário da conquista da natureza pelo homem.
} 
São preferíveis políticas preventivas e programas de conscientização dos empreendedores através de exemplos bem sucedidos, evitando posturas tecnocratas e hierárquicas, de viés ecológico ou qualquer outro. A indução a novos comportamentos em relação ao ambiente e ao desenvolvimento turístico por meio, principalmente da conscientização, poderá levar a restrição voluntária do ímpeto desenvolvimentista de agentes envolvidos no processo.

A legitimação das políticas e ações em relação à gestão do território e do turismo deve decorrer de processo de estímulo e ampliação da participação dos moradores locais nas decisões propostas para o desenvolvimento turístico, tendo em vista a necessidade de equilibrar poderes e presenças nas decisões relativas à ordenação do território e do desenvolvimento do turismo, o que garante pactos sociais mais duradouros.

Será necessária a avaliação dos custos e benefícios econômico, sociais, culturais e ecológicos do desenvolvimento turístico. A qualidade do meio ambiente é diretamente relacionada à qualidade do turismo, mas apresenta custos que a sociedade deve discutir e decidir o compromisso de assumi-los. A consideração do custo da qualidade deve partir da concepção do produto e estruturar-se nas características da região turística.

No sentido de garantir a continuidade da atividade turística e de sua relação respeitosa com a paisagem, é necessário intensificar a pesquisa e estimular a unificação metodológica de obtenção e tratamento dos dados quantitativos e qualitativos para fins de comparação, análise e projeções relativas à atividade.

Quanto aos aspectos físico-espaciais requeridos por um modelo de ordenação territorial alternativo para dar suporte à atividade turística apontando para a sustentabilidade, é promordial a ampliação da escala do planejamento territorial do turismo, permitindo a inserção do território estudado em uma região com características de atratividade semelhantes ou complementares.

É importantíssimo considerar os aspectos ambientais do território municipal como fundamentais na capacidade de desenvolvimento de destinações turísticas, respeitando e protegendo os recursos naturais e culturais, os interesses da população local, suas tradições e cultura, e do monitoramento dos impactos resultantes do planejamento, da implantação de arquiteturas e da operação dos equipamentos turísticos; 
A utilização racional do solo das localidades turísticas, evitando a ocupação desordenada, com critérios para a alocação atividades e empreendimentos, deve favorecer a liberação de áreas livres e o controle de edificações em zonas protegidas e preservando os recursos naturais que necessitam cuidados especiais por sua beleza e fragilidade, como morros, planícies, florestas, águas superficiais e subterrâneas, assim com manter e recuperar algumas das atividades originais das localidades, tais como agricultura e pesca, que tenham motivações econômicas e sociais, preservando a cultura e inserindo a comunidade nas trocas com os visitantes.

A implantação e melhoria dos serviços urbanos e de infraestrutura de saneamento básico devem anteceder qualquer ação no sentido de incrementar a ocupação física do território, considerando-se que este é um dos maiores problemas reconhecidos por usuários permanentes ou ocasionais do território de Florianópolis. Além disso, mudanças no sentido de favorecimento ao transporte coletivo e público, também para as localidades turísticas, evitando congestionamentos, e maiores opções e permeabilidade no sistema viário, passam a ser medidas importantes para criar alternativas de circulação no espaço insular onde as rotas são, pelo condicionamento territorial, escassas.

A aplicação de taxas de ocupação e uso de recursos turísticos tanto para investidores como para visitantes, mesmo que isto possa implicar certo grau de seleção na utilização dos espaços turísticos, o que pode ser evitado com medidas adequadas, deve ser incluída no rol de instrumentos aplicáveis, a fim de transformar custos sociais em custos individuais (públicos em privados).

Adoção de padrões e tipologias urbanas e arquitetônicas não tecnicistas, com a busca de integração arquitetônica dos equipamentos turísticos às paisagens (naturais e culturais). No caso da integração à paisagem a adaptação mimética tende a ser mais aceitável do que a produção de novos elementos paisagísticos.

Dentre as medidas de correção de rumo do desenvolvimento da atividade turística, o uso adequado da paisagem requer mudanças de perspectivas em relação ao modelo estabelecido na cidade de Florianópolis. Algumas questões pertinentes a um modelo alternativo de desenvolvimento territorial do turismo comprometido com o desenvolvimento sustentável, são apontadas, tendo em vista que o maior controle e a restrição do uso propostos afetarão áreas incorporadas no processo de urbanização-turística, 
que por sua vez, absorve o crescimento populacional da cidade, mas também possibilita o lucro a custa da degradação paisagística.

Uma questão fundamental se apresenta quando se pensa num modelo de ordenação territorial, respeitando as qualidades paisagísticas locais, especialmente num território municipal de uma capital bastante atraente aos fluxos migratórios e com poucas alternativas de financiamento e capacidade de absorção de mão de obra.

A crescente urbanização não será abruptamente interrompida e o turismo, como alternativa econômica real, também não pode ser desconsiderado. Mas se a urbanização turística atual, que resultou da associação das duas atividades, tem levado à deterioração da paisagem, qual deve ser o lugar de um e de outro no território da cidade de Florianópolis e, especialmente, da Ilha de Santa Catarina? A resposta, certamente, deve ser dada pelo conjunto da sociedade, mas os estudos e a concepção apresentados pela investigação apontam para uma separação imediata de lócus dos dois vetores de ocupação do território, cujos impactos são bem diferenciados, é bom que se repita.

Mesmo que a região central da cidade e os bairros adjacentes apresentem atributos atraentes ao turismo, estes não são diretamente dependentes dos elementos territoriais, as pesquisas de demanda, encomendadas por agências estatais e privadas, e as investigações aqui levadas a cabo remetem ao reconhecimento das áreas balneárias como as mais procuradas pela atividade turística e como local das áreas mais valorizadas do ponto de vista da paisagem, como as planícies das bacias inundáveis do território insular, além daquelas já protegidas por lei.

Estas paisagens, atrativas ao turismo ainda apresentam porções pouco artificializadas e outras pouco afetadas pela urbanização, mantendo atributos naturais e culturais, muitos herdados da colonização, são as mais propícias, se mantidas assim, para a consolidação de uma imagem da cidade vinculada a atributos raros em cidades turísticas e muito menos em capitais: aqueles relacionados com o patrimônio paisagístico de forte conotação natural com resquícios de uma cultura tradicional diferenciada.

Tendo em vista o sacrifício da paisagem imposto pela urbanização, de alta ou baixa intensidade, em contraponto com a possibilidade de absorção de um turismo controlado e de baixo impacto, com estabelecimentos com padrão arquitetônico sensível ao 
ambiente, a aposta na contenção da urbanização junto ao centro da cidade e em algumas regiões balneárias e interior da Ilha, a distribuição equilibrada de zonas turísticas nas regiões balneárias ganha coerência e sustentação.

Por outro lado, isto não significa a entrega descontrolada da totalidade daquelas áreas de alta valoração paisagística, mas também econômica, para a atividade turística, e menos ainda ao modelo empresarial com visão de curto prazo e pouco comprometido com o desenvolvimento sustentável.

Para as zonas de interesse paisagístico e turístico deverão ser estabelecidas diretrizes gerais, de limitações e possibilidades de uso da cidade, com critérios diferenciados, no que tange aos padrões arquitetônicos dos estabelecimentos, em função das especificidades das Unidades de Paisagem. Entende-se que as paisagens destas áreas, desobrigadas de receber a pressão urbana, deverão permanecer descomprimidas e com baixo impacto ocupacional, em função de um grau de artificialização socialmente pactuado, mantendo-se paisagisticamente atraentes a residentes e visitantes.

Reconhecendo o dinamismo da paisagem, conseqüência do dinamismo dos elementos da natureza, mas também, e no caso de Florianópolis, principalmente, da sociedade, percebe-se que as diretrizes de consentimento ou de restrição das atuações sobre o território são privilegiadas quando do trato de áreas de áreas de interesse ecológico e paisagístico. Esta postura, cujo traço é característico da conservação passiva dos espaços, comum à gestão do território na maioria das cidades brasileira, tem limitações quanto a sua capacidade de aliviar tensões e estimular o conhecimento como modo de incrementar o reconhecimento e valorização dessas mesmas áreas.

Neste sentido, a alternativa aqui apresentada aponta para a gestão ativa do território e de áreas de interesse ecológico e paisagístico, onde a conservação é entendida como maneira de superar a cristalização e mitificação dos ambientes, inclusive com a possibilidade de aproveitamento de seu potencial em atividades não que não a consumam de modo definitivo, com transformações de baixo impacto, controladas e acompanhadas ${ }^{3}$.

\footnotetext{
2 Como Villamil, 1983; Vera, 1996 e1997, Franco, 2001 e Ruschman, 2002, entre outros.

3 Com esta visão, algumas as áreas em Florianópolis, como o Parque do Rio Vermelho, por exemplo, hoje restrito a dois campings, um viveiro de plantas e ao aproveitamento da orla por alguns poucos grupos, poderiam ter outro tratamento. Pelas dimensões territoriais do Parque, atualmente comprometido pela vegetação exótica, ele poderia ser pensado como uma área diferenciada, aceitando a instalação de um par de estabelecimentos com edificações de baixo impacto, distanciados entre si e das faixas mais significativas de restinga, a serem recuperadas, para um turismo de característica social, não massificado, mais voltado para a natureza, demanda pouco explorada no litoral catarinense.
} 
A visão da gestão territorial com caráter ativo reconhece os espaços naturais e abertos como elementos incentivadores da economia local, cujo aproveitamento é "capaz de gerar recursos econômicos em função de suas características e a partir de uma intervenção adequada" (CCRS Arquitects, 1993, p. 51), superando a visão mais passiva e que o planejamento tradicional tem da conservação das áreas de interesse natural, que aposta somente no controle e restrição do uso do solo.

Por outro lado, na medida em que o crescimento da população não é interrompido, a expansão da mancha urbana sobre áreas de interesse paisagístico irá seguir, de modo legal ou ilegal, a não ser que sejam dados limites aos empreendimentos legalizados e oferecidas alternativas locacionais aos excluídos da legalidade. E parece óbvio, ao meu juízo, que estas áreas de incremento urbano não deverão as mais valorizadas paisagisticamente e que as áreas mais habilitadas para isso e as que menos sofreriam impacto paisagístico são aquelas já comprometidas com a urbanização.

O aumento da população da cidade, decorrente do crescimento vegetativo da população residente e da migração, terá de ser solucionado considerando novos limites e utilizando estratégias de compactação da urbanização em determinadas zonas e regiões que não comprometam as áreas e atributos morfológicos que se revestem de importância identificadas pela investigação. A compactação da urbanização, mesmo não sendo comum nas cidades do novo mundo, pela crença na disponibilidade infinita de áreas, em Florianópolis assume sentido paisagístico, ecológico e cultural premente, pois permitirá manter a estruturação urbana polinucleada que tanto diferencia a capital catarinense das demais da região e do país e da região continental, reforçando valores de identidade sócio-cultural e atributos territoriais competitivos no mercado do turismo.

A compactação urbana, ao assumir o adensamento e certa verticalização em determinadas zonas, com o uso de tipologias urbanas e edificatórias que evitam a dispersão, permite proteção de paisagens socialmente valorizadas e apresenta-se à sociedade como uma opção efetiva à dispersão. Em troca, as áreas definidas como de interesse paisagístico, mormente as áreas planas do interior e orla da ilha, poderão se manter com menor ou sem ocupação. E isso poderá acontecer sem afetar profunda- 
mente direitos adquiridos, supostos ou de fato ${ }^{4}$, por meio de negociações e instrumentos que regularizem o incentivo à transferência de índices, para aquelas regiões que foram determinadas como prioritárias para a urbanização.

Assim, a escolha dessas áreas para adensamento deve acontecer em função da disponibilidade de infraestruturas de saneamento, de serviços urbanos e de sistema viário capaz de suportar os fluxos veiculares o ano inteiro, inclusive nas temporadas de turismo. O grau de adensamento e os limites de verticalização das edificações deverão ser definidos em função da paisagem e das condições da região em termos de geomorfologia, cobertura vegetal, hidrografia, demografia, usos e serviços urbanos, sistema de circulação veicular e silhueta da região, mas, principalmente, de negociação com as populações locais atingidas, num marco mais abrangente que o localismo das reivindicações comunitárias.

Esta negociação entre interesses das comunidades afetadas e interesses da cidade, a fim de valorizar o mosaico paisagístico, portanto, deverá ter em conta que a possibilidade de grande parte dos residentes da cidade, atuais e vindouros, vir a morar em casas isoladas mantendo a paisagem ainda atrativa é nula, e que somente com o entendimento do território de maneira integrada será possível atingir alguma qualidade de vida, seja com a opção do turismo ou não.

Ou seja, é necessária a compreensão, por parte de todos os envolvido, especialmente dos segmentos sociais resistentes ao turismo e favoráveis aos padrões urbanos de baixa densidade, de que só será possível manter as qualidades essenciais da paisagem da ilha se houver mudança de atitude com relação às prioridades entre interesses locais e globais da cidade, independente do fato de que a paisagem possa vir a ser compartilhada entre residentes e turistas.

Isto requer, portanto, considerar aspectos relativos à capacidade de suporte do território de Florianópolis. De maneira geral, a questão da capacidade de suporte tem sido apontada como um limitador importante das possibilidades de uso e apropriação dos ambientes, podendo ser definida por uma série de indicadores e buscando proteção e conservação de áreas por meios técnicos, o que solucionaria ou facilitaria pela ausência de discussão do significado da questão.

\footnotetext{
${ }^{4}$ Os direitos de uso privado da terra e das possibilidades de nela construir são considerados supostos, na medida em que o direito de construir é outorgado pelo município, dentro do marco constitucional da função social da terra. Os direitos são reconhecidos de fato pelo preceito do direito, também constitucional, à moradia.
} 
Por outro lado, embora a capacidade de suporte dos ambientes possa ser definida a partir de parâmetros técnicos em diferentes campos do conhecimento (geológico, biológico, etc.), as questões sócio-políticas permeiam esta discussão, podendo assumir mais importância do que os aspectos e indicadores técnicos, que geralmente têm sido escolhidos a fim de suportar o discurso que se pretende hegemônico. Portanto, é intrínseco a essa discussão, o fato de que cada grupo social tem uma noção da questão, pois mesmo alguns parâmetros e variáveis são escolhidos e estabelecidos em função das idiossincrasias dos cientistas, fazendo com que o balizamento pela capacidade de carga seja também de ordem moral e ética. A condição de sociedade inserida numa economia de mercado também passa a interferir na identificação da capacidade de suporte, na medida em que prioridades de subsistência, sustentabilidade e instalação da população são metas a serem atingidas, e, portanto, o desenvolvimento sócioeconômico não pode ser retirado da pauta.

Em Florianópolis, a superação da capacidade de suporte tem sido alegada em diversas situações e por diversas entidades e pessoas. A demonstração quantitativa não tem sido o argumento mais forte dessa evidência, mas o "achismo", com base numa avaliação, supostamente, qualitativa tem sido forte recurso argumentativo em discussões ambientais, reforçando o discurso alarmista e apocalíptico de determinados grupos ambientalistas. Esta consideração não tem o objetivo de desacreditar as necessárias intenções de conservação e proteção ambiental, mas o de reforçar a certeza de que a clivagem entre as diferentes percepções da capacidade de carga, embora sendo parte do jogo democrático, não contribui para o debate e tem de ser superada pela análise conjunta de componentes qualitativos quantitativos, técnicos e sócio-políticos.

No caso da llha de Santa Catarina, em que poucos estudos quantitativos sobre a capacidade de suporte têm sido levados a cabo, tem sido recorrente a utilização do argumento da sua superação em determinadas regiões e mesmo da llha para receber mais ocupação e urbanização. Sem dúvida, a percepção da excessiva urbanização e dos problemas dela decorrentes é fato notório.

Os congestionamentos de gente e veículos, as deficiências de infraestruturas, a degradação da paisagem e ambientes necessários para a manutenção do equilíbrio e diversidade ecológicos, refletidas na ocupação de extensas áreas, fragmentação de outras tantas, inun- 
dações em planícies, erosões em encostas, entre outros problemas, já permite afirmar que em determinados aspectos a capacidade de suporte já foi superada, ao menos nas temporadas turísticas, de modo irreversível, especialmente nas regiões balneárias. Em outros aspectos e locais, o limite da capacidade de suporte ainda não foi atingido ou pode ser ampliado. Seja pela existência de recursos em termos de quantidade, pela possibilidade de recuperação ou de resiliência de determinados ambientes, ou ainda, pela possibilidade de inovações tecnológicas e uso de artifícios, como a dessalinização de águas do mar.

Neste sentido a aceitação de usos de determinadas porções do território além da expectativa da visão ambientalista extremada (eco-tecnocracia), entendida pela ciência humana de viés crítico como a mercantilização desnecessária e interesseira da paisagem, merece reconsideração. Nos casos em que a alternativa turística se torna importante para o desenvolvimento da cidade, a busca de um aproveitamento ótimo do território adequando-o ao modelo e o modelo ao território, considerando as suas especificidades, com controle das forças de mercado, pode ser uma alternativa atraente e sustentável.

Em vez de um parâmetro global externo, definido somente por critérios técnicos e quantitativos, sem referência com o território, a capacidade de suporte passa a ser um atributo do modelo de desenvolvimento sócio-ambiental discutido e eleito pelo conjunto da população e demais envolvidos, com a informação democratizada. E, como em todo plano de ordenação do território, o limite tem de ser considerado um indicador de tendência, dinâmico e com prazo de validade, dependendo da escala de valores socialmente pactuada.

Uma outra questão remete à baixa densidade demográfica, que é geralmente associada à qualidade da paisagem, mas que não pode ser entendida de maneira simplista. Em Florianópolis a densidade demográfica não chega a apresentar taxa absoluta muito alta, em torno de $818 \mathrm{hab} / \mathrm{km}^{2}$, mas se consideradas as áreas protegidas ( $42 \%$ da área do município), eleva-se para aproximadamente $1300 \mathrm{hab} / \mathrm{km}^{2}$. Se considerarmos a fragilidade ecológica dos sistemas naturais e a finitude do território, elementos que determinam a qualidade paisagística da cidade, fatos reforçados pela mitificação do simbolismo de viver em uma ilha, a percepção é de que a densidade é maior do que a real, especialmente nas temporadas de turismo.

Porém, a baixa densidade demográfica das expansões de caráter suburbano de média e alta renda nas ocupações legalizadas e de média e baixa renda nas clandestinas, não deve se entendida como sinônimo de qualidade paisagística e, muito 
menos, como padrão urbanístico economicamente viável. Os custos sociais, econômicos e ambientais do urbanismo difuso, que têm sido evidenciados por estudos e desafiado as administrações públicas, fazem perceber que a densidade demográfica e construtiva baixa é necessária, mas não suficiente para se alcançar qualidade e sustentabilidade sócio-ambiental.

Em boa parte dos casos, o baixo impacto dos assentamentos depende mais da forma, localização e de uma distribuição inteligente e criativa das edificações do que da extensividade e do modelo da casa solta no lote. Além do mais, ela tem de se referenciar à totalidade do território ${ }^{5}$, considerando as condições individuais das unidades de paisagem, passando a ser uma variável dependente das regras de composição morfológica do território: sua fisiografia, sua estrutura de parcelamento e de propriedade, usos estabelecidos e desejados, demografia, atual e prognosticada, e fluxos sazonais.

"Uma boa gestão do territorial envolve o reconhecimento e o estabelecimento dos limites que não podem ser ultrapassados em nome do desenvolvimento. A nova tendência do turismo nos espaços naturais associa-se, principalmente, 'a rarefação dos espaços pouco poluídos e dos preservados (....). O valor ecológico está associado ao valor da paisagem e, consequentemente, à sua atratividade turística" (Ruschmann, 2002, pp.79-80).

Evidentemente, que as sugestões aqui apresentadas, privilegiando a paisagem nos termos do que ela representa para a sustentabilidade sócio-ambiental da cidade, deverá ser confrontada, em algum momento, com estudos demográficos, econômicos e sociais, mas servem de referência primordial para um modelo territorial que inclua a paisagem como importante elemento de projetação do desenvolvimento sustentável da atividade turística.

Se houver o real interesse em valorizar a paisagem em sua dimensão ecológica, com o equilíbrio e vitalidade dos ecossistemas; em sua dimensão cênica, presente na possibilidade de fruição de visuais abertas e esteticamente agradáveis, característica valorizada por residentes e turistas; e em sua dimensão histórico-cultural única, de estrutura urbana diferenciada pelos assentamentos coloniais atomizados, ainda que

\footnotetext{
${ }^{5}$ Exemplo paradigmático de destino turístico sazonal, a região de Langudoc Rousillon, no litoral mediterrâneo da França, recebe cerca de cinco milhões de visitantes/ano, utilizando-se de modelo de distribuição espacial concentrando as pessoas em núcleos urbanizados dispersos ao longo de grandes extensões de restingas e lagunas protegidas. A densidade média de 22,5 camas/ha, o que perfaz aproximadamente $500 \mathrm{~m}^{2} /$ casal, e já considerada alta para os padrões da região. Alguns estudos sugerem para regiões litorâneas entre 70 e $80 \mathrm{~m}^{2} /$ casal em hotéis e $300 \mathrm{~m}^{2} /$ casal
} 
atualmente em expansão, mas ainda mantendo estrutura polinucleada, articulados pelo sistema de vias em meio a encostas e planícies, deverão ser consideradas alternativas de distribuição espacial dos usos e funções da cidade muito diferentes da atual.

Dentre estas alternativas, a compactação urbana concentrada em determinados núcleos, preferencialmente aqueles já comprometidos com o modelo urbano e mais servidos, ou que possam vir a ser, de infraestruturas públicas, merece ser conhecida pelo conjunto da sociedade, soberana para definir a questão. 


\section{PARTE IV}

Conclusão e Bibliografia 


\section{CONCLUSÃO}

"Nem valor de troca, economia de escala nem princípios desenvolvimentistas têm valor num espaço onde crescimento já não é sinônimo de desenvolvimento" (Sabaté, 2000, p. 98).

A existência de indicativos de que o âmbito sócio-territorial vem recebendo consideração equivalente àquela que a sócio-economia sempre recebeu sugere outras posturas que podem contribuir na busca de uma possível conciliação entre turismo, urbanização e ambiente. As novas relações da sociedade com a natureza e a cultura abrem oportunidades para a consideração de novo paradigma e para a incorporação de práticas e ações no sentido da sustentabilidade sócio-espacial. A possibilidade de utilização da temática ambiental como elemento catalisador de outras transformações tem sido uma proposição teórica consistente.

É fato reconhecido que o consumo de recursos do meio ambiente é característica essencial da construção dos espaços de uso humano e, como sustenta Sunkel:“... é necessário reconhecer que as transformações ambientais são inevitáveis e inerentes ao desenvolvimento" (1983, p. 204) e a "... atividade social é, entre outras coisas, uma atividade de transformação da natureza” (idem). Nesse marco, a atividade turística, que "consome" paisagens, é sempre uma dialética entre o que, quanto, onde, quando e como melhor aproveitar os recursos ambientais.

No caso do desenvolvimento da atividade turística em Florianópolis e em sua porção insular, esta questão se apresenta como desafio fundamental na construção do presente e do futuro. Sem um exame de potencial de outros modelos de ordenação territorial do turismo, que busquem adequação ao ambiente local, os impactos da associação entre turismo e urbanização, que se refletem em perdas de espaços importantes e inúmeras deseconomias, o prognóstico é o breve esgotamento do principal atributo de atração: a base natural e o ambiente dos assentamentos tradicionais.

Sem um plano de ordenação e um marco regulador que tomem em consideração as especificidades do território insular a as injustiças implicadas em seu processo de formação, principalmente os decorrentes da expansão urbana de natureza turísticoimobiliária, os impactos ambientais associados que ameaçam a qualidade de vida e da paisagem na cidade de Florianópolis e na Ilha de Santa Catarina, comprometendo a sustentabilidade, permanecerão. 
Nesse sentido, é importante identificar "... as ações que o Estado pode empreender para controlar a atividade turística e o processo de apropriação e modificação do meio ambiente, e o papel que cabe à oferta turística nativa e aos agentes privados..." (Veiga, 1983, p. 161), tendo em mente que para que se estabeleça “... um desenvolvimento sustentável, ou um desenvolvimento 'harmônico' do turismo, se faz necessário constituir uma política integral de desenvolvimento" (Januário, 1997, p. 51).

Mesmo que a idealização do desenvolvimento sustentado exija, além da revisão de paradigmas, uma outra ordem mundial de relações de produção, sempre é possível partir da experiência local. Se o conceito se reveste da noção de responsabilidades coletivas e de perspectivas de qualidade de vida futura, exigindo que o desenvolvimento econômico se restrinja aos limites dos recursos naturais que não são renováveis, e a construção de sociedades mais justas, com amplas oportunidades de trabalho e acesso a cidadania social, a postura aqui sugerida pode ser uma alternativa.

E ainda que se tenha em conta que posturas protecionistas extremas carecem de maior representatividade nas sociedades de economia de mercado e, "portanto, uma posição conservacionista ou ecologista extrema é sensivelmente inaceitável." (Sunkel, 1983, p. 204), é de fundamental importância buscar a conciliação entre a manutenção das condições ambientais que geraram a própria atratividade turística. E, também, a inclusão das comunidades residentes no processo, tendo em mente os desafios que a proteção extremada implica.

Este debate tende a ser mais acirrado ainda em países periféricos, levando alguns estudiosos à posição extremadas de aceitação ou não da hegemonia do projeto de modernidade capitalista, sendo comuns posturas niilistas, quando não cínicas e pouco pragmáticas, com resultados tão nefastos quanto aquelas posturas desenvolvimentistas.

A própria valorização do patrimônio paisagístico é ameaçada pela necessidade de inclusão social, na medida em que, nas sociedades de economia de mercado, e mais ainda em destinos turísticos de países periféricos, a qualificação do ambiente valoriza a terra, favorecendo processos de gentrificação e atraindo moradores de renda mais alta, o que leva à formação de espaços segregados e segregadores.

"No espaço turístico, por exemplo, em que sejam observados os limites no uso do adensamento do solo e na fixação de residentes permanentes e eventuais, a partir da lógica de mercado vigente, esse processo redunda na supervalorização do espaço, no conseqüente incremento de renda por parte 
do incorporador e na formação de núcleos segregados, os quais chocam-se com os pressupostos que fundamentam o desenvolvimento sustentável" (Moretto, 1993, p. 9).

Se, via de regra, os modelo que buscam a eficiência espacial, pela compactação ou expansão controlada, apresentam tendência a segregação sócio-espacial, normalmente com riscos para as populações excluídas do processo, esta situação poderá ser superada se entendermos a cidade como espaço de reconstituição da legitimidade das políticas urbanas construídas sobre pactos sociais capazes de reproduzir no tempo as condições que os legitimaram, ou seja, a base tecno-material construída pelas vontades políticas.

Dada à complexidade e amplitude de proposições que os planos de ordenação territorial e desenvolvimento sócio-econômico implicam, a preeminência da paisagem na elaboração de planos de ordenação territorial pode sugerir uma postura que não só não resolverá todos os conflitos e problemas da cidade como, também, uma atitude diletante diante dos urgentes e graves problemas que Florianópolis e região encerram.

A construção social do território é sempre permeada de contradições e conflitos, especialmente, como no caso de Florianópolis e da Ilha de Santa Catarina, onde a questão ambiental assume fundamental importância, e interesses globalizados se incorporam aos locais no desenvolvimento da atividade turística, sendo comum que o ambiente e os socialmente menos favorecidos sejam os mais prejudicados.

Mas a paisagem pode ser entendida como um elemento de construção de identidade e mesmo como um modo de promoção de cidadania, “... já que a afirmação dos mais diferentes grupos, num contexto de participação no planejamento, passaria por sua inclusão no sistema, como meio de eliminar a miséria da paisagem" (Yázigi, 1997, p. 74).

Ao se pensar o planejamento do desenvolvimento das cidades como relações horizontais de interdependência entre as dimensões que buscam explicar a sociedade, com a contribuição específica da ordenação do território, cujo campo de reflexão tem autonomia, não se desconsidera parâmetros ou diretrizes sócio-econômicas. Ao contrário, se pretende a integração a eles, enriquecendo o processo de construção sócio-ambiental a partir de dentro do arcabouço reflexivo do projeto da paisagem e do urbano.

Sabendo-se que a discussão do futuro da cidade não será fácil nem breve, devido às diferentes percepções, vontades e interesses dos atores envolvidos, especialmente no contexto de assimetria de poderes no espectro econômico-cultural da sociedade florianopolitana, isto não deve ser motivo para a acomodação, e como sugere Yazigi 
(1997), a questão paisagística no Brasil parece ser mais uma questão de vontade política do que determinada pela economia, porquanto que nem mesmo a voracidade do capital justifica aberrações no espaço público e privado.

Fica evidente que, ao discurso da sustentabilidade baseado na afirmação do discurso de eficiência da urbanização sobre o território, com a escala adequada para a utilização da natureza, a autonomia local como postura antiglobalizadora e a permanente discussão dos modos de apropriação do mundo material (Acselrad, 1999), se deve associar o processo de construção social, a partir da incorporação da diversidade de atores.

Atualmente, uma modalidade de turismo vem atraindo interesse em diversos pólos emissores e oferecendo alternativas aos receptores de turistas e tem base no binômio - natureza e cultura. Ao se vislumbrar a possibilidade de associar uma identidade turística calcada em seu singular patrimônio paisagístico se deve alçar a paisagem à condição de centro das preocupações da ordenação territorial. Esse tipo de turismo sugere que a lógica para a preservação e mesmo a criação de identidades em regiões turísticas aconteça mais por meio da gestão ativa da paisagem do que por ambientes cristalizados, pelas intervenções arquitetônicas (tendo em vista a dificuldade de imposição de padrões de criatividade e excelência arquitetônica e urbanística dos empreendimentos turísticos) ou outros elementos de menor perceptividade.

Se a paisagem for assumida como principal elemento de construção e re-significação da identidade regional, será possível ampliar o controle na preservação de áreas protegidas com respeito às premissas ecológicas, e na arquitetura e no urbanismo, que apresentarão a tendência de serem gerados segundo esta diretriz.

Sendo a paisagem elemento de manutenção de identidade cultural ao mesmo tempo em que se oferece ao turismo, ela supera a simples oferta de atributos, na medida em que sua conservação transcende a demanda e passa a servir aos residentes, atingindo o conceito de habitabilidade, ou seja, a possibilidade de a população local se beneficiar dele. "Falar de personalidade de um lugar implica reconhecer múltiplas identidades que vão desde os aspectos físicos à captação do amplo movimento contemporâneo, gerado por migrações, populações de aposentados e minorias..." (idem, p.97).

No contexto da cidade de Florianópolis e da llha de Santa Catarina, a causa ambiental pode ser catalisadora de uma possível transformação sócio-ambiental, e a aposta em seu poder emancipatório passa pelo reconhecimento de que o desenvolvimento da 
atividade turística será passível de sustentabilidade ampla, sempre que o crescimento econômico não seja alheio às dimensões ecológica, cultural e política, e aponte para propostas mais progressivas no que tange a busca de maior qualidade de vida com justiça social, ambientes mais saudáveis e compromissados com o futuro.

No caso da llha de Santa Catarina e do município de Florianópolis, onde a paisagem é reconhecidamente um elemento de atratividade forte, é bem provável, talvez mais fácil do que em outros lugares, que ela possa ser vista como um patrimônio fundamental na construção da identidade cultural. De certo modo, esse passo já está sendo dado boa parte da sociedade, e assumir a paisagem como elemento estruturante do território e agente de desenvolvimento social parece não ser impossível, ainda que o consenso para ações além do reconhecimento das qualidades da paisagem requeira processo de intensa discussão.

As organizações produtivas diretamente relacionadas com o turismo, que buscam a rentabilidade de investimentos alocados e um empreendimento duradouro, assim com as agencias fomentadoras da atividade, têm sido desafiadas a participarem de modo ativo nesta transformação sócio-econômica. Se o turismo "supõe uma apropriação do ambiente" e a transformação da paisagem em mercadoria, é possível imaginálo se adequando a novas posturas, incorporando valores e demandas sociais menos mercantilistas "e para isso devem existir planos de controle e regulação..." (Villamil, 1983, p. 7) que reflitam no suporte físico, o território, as políticas públicas necessárias para a busca da qualidade de vida.

Com a incorporação de novos paradigmas, novas demandas orientando o planejamento e a atividade turística e novos marcos legais, que garantam a função social da cidade e a participação da sociedade, a produção e a ordenação do espaço da cidade têm a oportunidade se vir a se transformar em um processo mais democrático e compreensivo, além de cultural e ambientalmente mais correto, superando a tradição tecnoburocrático-centralizadora e regulando as forças mercadológicas, se entendermos o planejamento "... enquanto instrumento de gestão e espaço de negociação dos diversos interesses existentes na sociedade e que disputam as políticas públicas" (Moura, 1993, p. 182, apud Januário, 1997).

E se toda essa reflexão, em uma sociedade que é dominada pelas forças de mercado e da expansão econômica em detrimento do convívio mais harmônico entre natu- 
reza e cultura, parece se revestir de certo grau de idealização, cabe lembrar, entretanto, que algumas experiências existentes no Brasil e exterior, permitem imaginar outro modelo de desenvolvimento da atividade turística, não com otimismo ingênuo com caráter positivista, mas permeado de um determinado grau de utopia necessário para vislumbrar o devir, na medida em que "... o que move tanto a ciência como as transformação social é a perseverança da utopia" (Costa, 2000). 


\section{BIBLIOGRAFIA}

Ab’Sáber, Aziz Nacib. Litoral do Brasil. Metalivros, São Paulo, 2005.

Acarenza, Miguel Angel. Administración del Turismo: planificación y dirección. Trillas, México, 1985.

Acselrad, Henry. Discursos da Sustentabilidade Urbana. Revista Brasileira de estudos Urbanos e Regionais, n.2, Recife, maio de 1999.

Adams, Betina. Preservação Urbana. Gestão e resgate de uma história. Patrimônio de Florianópolis. Editora da UFSC. Florianópolis, 2002.

Arrilaga, José. Introdução ao Estudo do Turismo. Editora Rio. Rio de Janeiro, 1976.

Agenda 21. Conferência das Nações Unidas sobre o Meio Ambiente e Desenvolvimento. Senado Federal - Subsecretaria de Edições Técnicas, Brasília, 2000.

Barba, Rosa e Pié, Ricard (eds). Arquitectura y Turismo. Planes y Proyectos. Edição do Departamento de Urbanismo y Ordenación del Territorio de la Universiidad Politécnica da Cataluña. Barcelona, 1996.

Barretto, Margarita e Tamanini, Elisabete (orgs.). Redescobrindo a Ecologia no Turismo. EDUCS, Caxias do Sul, 2002.

Bartley, Howards. Principios de la Percepción. Trillas, México, 1978.

Bastos, Érica Ferreira de, Lapolli, Edis Mafra e Bueno, Liane da Silva. Unidades Geoambientais Subsidiando o Mapeamento das Classes de Uso e Ocupação do Solo da llha de Santa Catarina. Anais do XI SBSR, p. 1725 - 1732, INPE, Belo Horizonte, 2003.

BDT - Banco de Dados Tropical. Diagnóstico da Situação e Ações Prioritárias para a Conservação da Zona Costeira da Região Sul - Rio Grande do Sul e Santa Catarina. Divulgação BDT, 2003.

Beck, Anamaria. Comunidades Pesqueiras e Expansão Capitalista. In: O Mar e seus Recursos. Editora da UFSC, Florianópolis, 1980.

Berry, Bryan J. L. Mudanças Deliberadas nos Sistemas Espaciais: metas estratégicas e sua avaliação. Geografia e Planejamento, Instituto de Geografia/USP, São Paulo, 1975. 
Berque, Augustin. Cinque Propositions pour une Theorie du Paisaje. Champ Vallon, Paris, 1994. Vivre l'espace au Japon, 1982. apud Géosystèmes et Paisajes. Bilan et méthodes Gabriel Rougerre \& Nicolas Berouchachvili. Armand Colin, Paris, 1991.

Berque, Augustin, Conan, M.\& Donadieu, P. Mouvance Cinquante Mots pour le Paysage. La Villete, Paris, 1999.

Bertrand, Georges. Les Structures Naturelles de L'Espace Géographique. L'example des montagnes cantabriques centrals (nord-ouest de L'Espagne). In: Revue Géographique des Pyrenees et du Sud-ouest, tomo 43, n. 2, abril, 1972. . Ecologie d'un Espace Géographique: les géosystemes du valle del Prioro. In: L'Espace Géographique, n.2. Paris, 1972.

. Paisaje y Geografía Física Global. In: El Pensamiento Geográfico. J.G. Mendoza \& N.O. Jiménez. Alianza, Madrid, 1982.

Boullon, Roberto C. Planificación del Espacio Turístico. Trillas, México, 1985. . Los Municipios Turísticos. Trillas, México, 1995.

Bourdin, Alain. A Questão Local. DP\&A, Rio de Janeiro, 2001.

Bueno, Ayrton Portilho. Breves Notas Comparativas Sobre Dos Íconos del Turismo de Sol y Playa: Benidorm, en la costa Valenciana, Espanha y Balneário Camboriú, en la costa Catarinense, Brasil. Trabalho programado do Estágio de Doutorado/PDDE/ CAPES/USP junto à Universidade Politécnica da Catalunha, Barcelona, 2003 - Novos Loteamentos, Velhos Paradigmas: o caso de Florianópolis. In Urbanização Brasileira, pp. 175-184, Leonardo Barci Castriota (org.). C/Arte, Belo Horizonte, 2003. . Estudos Sintáticos em Assentamentos Costeiros na llha de Santa Catarina. Integração e segregação em balneários turísticos. Dissertação de Mestrado. Departamento de Urbanismo, FAU, UnB, Brasília, 1996.

Busquets, Joan; Domingo, Miquel; Eizaguirre, Xavier e Moro, Antonio. Les Formes Urbanes del Litoral Cátala. Diputació Barcelona, Barcelona, 2003. 
Cabral, Osvaldo Rodrigues. Nossa Senhora do Desterro 1 - Notícia. Lunardelli, Florianópolis, 1979a. . Nossa Senhora do Desterro 2 - Memória. Lunardelli, Florianópolis, 1979 b.

Cals i Guell, Joan. Els Canvis Turistics. Incidencia en els municipis costaners de Barcelona. Diputació de Barcelona, Barcelona, 1991. . Entorno, Competitividad de la Oferta y Rentabilidad Social de los Proyectos Turísticos. In: Arquitectura y Turismo. Planes y Proyectos, pp. 49-58, Rosa Barba e Ricard Pie, UPC, Barcelona, 1996.

Campos, Edson Telê. A Expansão Imobiliária e seus Impactos Ambientais em Florianópolis. Insular, Florianópolis, 2004.

Campos, Nazareno José de. Terras Comunais na Ilha de Santa Catarina. Editora da UFSC, Florianópolis, 1991.

Caruso, Mariléa Martins Leal. O Desmatamento da llha de Santa Catarina de 1500 aos Dias Atuais. Editora da UFSC, Florianópolis, 1990.

Casseti, Valter. Ambiente e Apropriação do Relevo. Contexto, Goiânia, 1991.

Castello, Lineu. Towards a Theoretical Background to Planning for Tourism. Dissertação de Mestrado, University of Edimburg. Edimburg, 1974.

CCRS Arquitectes. PIOT - Plan Insular de Ordenación de Tenerife. Santa Cruz de Tenerife, 1993 (primeira versão).

. PIOT - Plan Insular de Ordenación de Tenerife. Santa Cruz de Tenerife, 1994 (segunda versão).

CEAG/SC - Centro de Assistência Gerencial - Santa Catarina. Evolução Histórica e Econômica de santa Catarina: estudo de alterações estruturais. Século XVII-1960. Secretaria de Administração Gerencial/SC, Florianópolis, 1981.

COAC - Col-lei Oficial d'Arquitectes de Catalunya. Debat Costa Brava. Congrés: Um Futur Sostenible. Palestras e Apostilas do Congresso. Diversos autores. Colégio Oficial de Arquitetos da Catalunha. Diversas localidades da Costa Brava, Comunidade da Cataluña. Março-abril de 2004. 
Comissão de Desenvolvimento e Meio Ambiente da América Latina e do Caribe. Nossa Própria Agenda. Banco Interamericano de Desenvolvimento e Programa das Nações Unidas para o Desenvolvimento. Brasília, 1992.

Comissão Mundial Sobre Meio Ambiente e Desenvolvimento. Nosso Futuro Comum. Fundação Getúlio Vargas. São Paulo, 1988.

Constanza, R. Economia Ecológica. Uma agenda de pesquisa. In: Valorando a natureza, P. H. May \& R. S. da Motta, Campus, Rio de janeiro, 1994.

Costa, Heloísa Soares da Moura. Desenvolvimento Urbano Sustentável: uma contradição de termos. Revista Brasileira de Estudos Urbanos e Regionais, Recife, n.2, março de 2000.

Crowe, Sylvia. Shapping Tomorrow's Landscape: preservation of existing values in landscapes and the creation of new landscapes. Djambatan, Amsterdam, 1964.

Cruz, Olga. A Ilha de Santa Catarina e o Continente Próximo. Um estudo de geomorfologia costeira. Editora da UFSC, Florianópolis, 1998.

CTTGC - Consejería de Turismo y Transporte Del Gobierno de Canarias. Libro Blanco del Turismo Canario. Santa Cruz de Tenerife, 1997.

Cullen, Gordon, Townscape. Architectural Press, Londres, 1961.

DEATUR - Departamento Autônomo de Turismo de Santa Catarina. Plano Regional de Turismo. DEATUR, Florianópolis, 1973.

D’Eça, Luiz Felipe Gama Lobo. São José. Um pedaço do Universo. Incepi/Fundação Vidal ramos. Florianópolis, 2000.

Delpoux, M. Ecosystéme et Paysage. Revue Géographique des Pyrenees et du Sudouest, tomo 43, n. 2, abril, 1972.

. Métodos em Questão: ecosistema e paisagem. Instituto de Geografia da USP, São Paulo, 23p. , 1974

De Roo, Gertt e Miller, Donald (editors).Compact Cities and Sustainable Urban Development. Ashgate, Aldershot, 2000. 
Diegues, Antonio Carlos Sant'Ana. Povos e Mares: leituras em sócio-antropologia marítima. NUPAUB, São Paulo, 1995.

Donadieu, Pierre. La Société Paysagiste. Acles Sud, Paris, 2002.

Donaire, Josep Antoni. El Turismo a los Ojos Del Postmodernismo. Una lectura desde dialéctica socioespacial. Tese de Doutorado, Universidad Autónoma de Barcelona, Barcelona,1996.

Drucker, Peter F. Administrando para Obter Resultados. Pioneira, São Paulo, 1998.

Echenique, Marcial. Modelos Matemáticos de la Estructura Urbana. SIAP, Buenos Aires, 1976

Elias, Norbert e Scottson, John L. Os Estabelecidos e os Outsiders. Jorge Zahar, Rio de Janeiro, 2000.

Español, Joaquim (cura). Arquitectes en el Paisatge. COAC, Girona, 2000.

Ezquiaga - Arquitectura, Sociedad y Territorio S.L. - consultores de las administraciones públicas, UTE. Avance del Plan Territorial Insular de Menorca. Consell Insular de Menorca, 1997.

Falcão, José Augusto Guedes. O Turismo Internacional e os Mecanismos de Transferência de Renda. In: Turismo, Paisagem e Cultura. Eduardo Yázigi, Ana Fani Alessandri Carlos e Rita de Cássio Ariza de Cruz (orgs), Hucitec, São Paulo, 1996.

Fantin, Márcia. Cidade Dividida, Dilemas e disputas simbólicas em Florianópolis. Cidade Futura, Florianópolis, 2000.

Felippe, Ana Paula. Análise da Paisagem como Premissa para Elaboração de Plano Diretor. Paisagem Ambiente $n^{\circ} 16$, Faculdade de Arquitetura e Urbanismo, Universidade de São Paulo, São Paulo, 2002.

Ferreira, Francisco Antônio Carneiro. Natureza e Projeto Urbano em Florianópolis. In: Florianópolis do Outro Lado do Espelho, pp. 103-122, Margareth de C. A. Pimenta (org.). Editora da UFSC, Florianópolis, 2005.

Figueirola, Manuel Palomo. Teoría Económica Del Turismo. Alianza Editorial, Madrid, 1985. 
Folch, Ramon. El Territorio como Sistema. Conceptos y Herramientas de Ordenación. Diputació de Barcelona, Barcelona, 2003 a. . Los Conceptos Socioecológicos de Partida Principios Ecológicos versus Criterios Territoriales. In: El Territorio como Sistema. Conceptos y Herramientas de Ordenación. Ramon Folch (coord.), pp. 19-42. Diputació de Barcelona, Barcelona, 2003 b. . Tres Aproximaciones metropolitanas al Proyecto Territorial Sostenibilista. In: El Territorio como Sistema. Conceptos y Herramientas de Ordenación, pp. 191220, Ramon Folch (coord.), Diputació de Barcelona, Barcelona, 2003 c.

Font, Antonio (coord.). Planeamiento Urbanístico. De la Controversia a la Renovación. CUIMPB y Diputació Barcelona, 2003.

Forman, Richard T. T. Land Mosaics: the ecology of landscapes and regions. Cambridge University Press, Canbridge, 1995. . Mosaico Territorial de la Región Metropolitana de Barcelona. Gustavo Gili, Barcelona, 2004.

Franco, Maria Assunção Ribeiro. Planejamento Ambiental para a Cidade Sustentável. Annablume e EDIFURB, São Paulo, 2001. . Desenho Ambiental. Uma Introdução à Arquitetura da Paisagem com o Paradigma Ecológico. Annablume, São Paulo, 1997.

Fraguell, Rosa M. Turismo Residencial $i$ Territori. La Segona Resiència a la Régio de Girona. L’Eix, Girona, 1994.

Freestone, Robert (edit.). Urban Planning in a Changing World. The twentieth century experience. E\&FN Spoon, Londres, 1999.

Galindo, Juan. Un Model Estructural per al Delta Del Llobregat. In: Patrimoni y Projecte Territorial, Diputació de Barcelona, Barcelona 2004.

Gomes, Alessandra Gutierrez. Turismo Rural em Santa Catarina: uma indústria sem chaminé. Hotéis-Fazenda em Florianópolis e o compromisso com a cultura açoriana. In: Anais do Congresso de História e Geografia de Santa Catarina, pp. 674-683. Instituto Histórico e Geográfico de Santa Catarina - IHGSC, Florianópolis, 1996. 
Gottdiener, Mark. A Produção Social do Espaço Urbano. Editora da Universidade de São Paulo, 1997.

Hackett, Brian. Landscape Planning: an introduction to theory and practice. Oriel, Newcastle upon Tyne, 1971.

Harvey, David. Justice, Nature and the Geography of Difference. Blackwell Publishers, Nova York, 1996.

Hernandez, Raul Augusto e Mochofsky, Raquel Graciela. Propuesta de Organización del Entorno de los Andes Sur. El Habitat - Paisaje como Organización Extensiva no Deteriorante. SUMMA, n. 93, Buenos Aires, 1975.

Holanda, Frederico de; Kohlsdorf, Maria Elaine; Farret, Ricardo Libanez e Cordeiro; Sonia Helena Camargo. Forma Urbana: que maneiras de compreensão e representação? In: Revista Brasileira de Estudos Urbanos e Regionais, $n^{\circ} 3$, novembro de 2000, pp. 9-18. ANPUR e Editora Norma Lacerda, Recife, 2000.

Holanda, Frederico R. B. Excepcional Space. Tese de doutorado. Bartlett School, London University, Londres, 1997.

Holder, Jean S. Pattern and Impact of Tourism on the Environment of the Caribeean, in: S, Medlik, Meanning Tourism, londres, Butterworth-Heinemann, 1991, p.279, apud Doris Ruschmann, Turismo e Planejamento Sustentável - a proteção do meio ambiente. Papirus, Campinas, 2002.

Hübener, Laura Machado O Comércio da Cidade do Desterro no Século XIX. Editora da UFSC, 1981.

IBGE - Instituto Brasileiro de Geografia e Estatística. Atlas Escolar de Santa Catarina. 1999.

IBGE - Instituto Brasileiro de Geografia e Estatística. Censo Demográfico 2000. Disponível em www.ibge.gov.br, 2003.

IPUF -. Instituto de Planejamento Urbano de Florianópolis. Atlas de Florianópolis. IPUFPMF, Florianópolis, 2004. - Instituto de Planejamento Urbano de Florianópolis. Parecer Técnico n. 214/98. IPUF, Florianópolis, 1998. 
IPUF - Instituto de Planejamento Urbano de Florianópolis. Plano Diretor do Distrito Sede. IPUF, Florianópolis, 1997a.

- Instituto de Planejamento Urbano de Florianópolis. Plano de Urbanização Específica de Ingleses Sul e Santinho. IPUF, Florianópolis, 1997b.

- Instituto de Planejamento Urbano de Florianópolis. Plano de Desenvolvimento

Entremares para o Campeche. Diagnóstico-rezoneamento. IPUF, Florianópolis, 1997c. - Instituto de Planejamento Urbano de Florianópolis. Florianópolis: Problemas e Ações. Documento interno do corpo Técnico do IPUF, Florianópolis, 1996.

- Instituto de Planejamento Urbano de Santa Catarina. Plano de Desenvolvimen-

to Turístico - Atualização. Florianópolis, 1996.

- Instituto de Planejamento Urbano de Florianópolis. Plano de Desenvolvimento do Campeche. IPUF, Florianópolis, 1992a.

- Instituto de Planejamento Urbano de Florianópolis. Plano de Reestruturação Urbana da Praia Mole. IPUF, Florianópolis, 1992b.

- Instituto de Planejamento Urbano de Florianópolis. Plano de Reestruturação Urbana da Barra da Lagoa. IPUF, Florianópolis, 1991.

- Instituto de Planejamento Urbano de Florianópolis. Plano Diretor dos Balneários e Interior da Ilha. Diagnóstico IPUF/PMF, Florianópolis, 1985. - Instituto de Planejamento Urbano de Florianópolis. Plano de Desenvolvimento Turístico do Aglomerado Urbano de Florianópolis. IPUF/PMF, Florianópolis, 1981. - Instituto de Planejamento Urbano de Florianópolis. Plano Diretor de Uso do Solo dos Balneários da Costa Norte da llha de Santa Catarina. IPUF, Florianópolis, 1978. - Instituto de Planejamento Urbano de Florianópolis. Plano de Estruturação do Aglomerado Urbano de Florianópolis - Estudos setoriais. IPUF/PMF - Florianópolis, 1977. - Instituto de Planejamento Urbano de Florianópolis. Plano Diretor de Florianópolis e Código Municipal de Florianópolis. PMF, Florianópolis, 1955.

Jacobs, Jane. Morte e Vida nas grandes cidades. Martins Fontes. São Paulo, 2000. . A Natureza das Economias. Beca, São Paulo, 2001. 
Januário, Sérgio Saturnino. Organização, Ação e Representação do Empresariado do Setor Turístico em Florianópolis. Dissertação de Mestrado em Sociologia Política, CFH, UFSC, Florianópolis, 1997.

Kohlsdorf, Maria Elaine. A Apreensão da Forma da Cidade. Editora da Universidade de Brasília, 1996.

Kotler, Philip; Haider, Donald H. e Rein, Irving. Marketing Público: como atrair investimentos, empresas e turismo para cidades, regiões, estados e países. Makron Books, São Paulo, 1994.

Krippendorf, Jost. Sociologia do Turismo. Para uma Nova Compreensão do Lazer e das Viagens. Civilização Brasileira, Rio de janeiro, 1989.

Lage, Beatriz H. Gelas e Milone, Paulo César. Economia do Turismo. Papirus, 1998.

Lago, Mara Coelho de Souza. Memória de uma Comunidade que se transforma: de localidade agrícola-pesqueira a balneário. Dissertação de Mestrado. Departamento de Antropologia, UFSC, Florianópolis, 1983.

. Modos de Vida e Identidade. Sujeitos no processo de Urbanização da Ilha de Santa Catarina. Editora da UFSC, Florianópolis, 1996.

Lago, Paulo Fernando. A Terra e o Homem. In: Santa Catarina no Século XX, Sílvio Coelho dos Santos (org.), Editora da UFSC, UNIVALI e Fundação Catarinense de Cultura, Florianópolis, 1999.

. Florianópolis e a Polêmica Urbana. Palavra Comunicação,

Florianópolis, 1996 a.

. Florianópolis: o legado natural transformado. In: Revista do Instituto de História e Geografia de Santa Catarina, pp. 69-83. Instituto de História e Geografia de Santa Catarina - IHGSC, Florianópolis, 1996 b.

Laurie, Michael. An Introduction to Landscape Architecture. Pitman Publishing Ltd. Londres, 1978.

Leão, Silvia Carneiro. A Sintaxe Espacial Aplicada a Espaços Turísticos: estudo de dois resorts em Santa Catarina. Trabalho do curso de Mestrado, PROPAR, UFRGS, Porto Alegre, 1993. 
Ledo, B.S. e Soriano-Serra, E. J. Atributos e Processo Condicionantes da Hidrodinâmica na Lagoa da Conceição, Ilha de Santa Catarina, Brasil. In: Anais do III Simpósio de Ecossistemas da Costa Brasileira - subsídios a um gerenciamento ambiental. FURG, Rio Grande, 1994.

Leite, Maria Ângela Faggin Pereira. A Região Socialmente Construída: Natureza e Cultura como Processo de Organização Regional, in: Sinopses, n. 16, FAUUSP, São Paulo,1992.

Novos valores, destruição ou reconstrução. Tese de Doutorado, FAUUSP, São Paulo, 1992.

Uma Fundamentação Geográfica ao Paisagismo

Regional. In: Revista Paisagem e Ambiente, Grupo Paisagem e Ambiente/FAU/USP, No. 5. São Paulo, 1986.

Leung, Hok Lin. Routes \& Perceptions, Tourism for Gananoque. Landscape Architecture, vol. 75, n. 3, Washington, 1987.

Lins, Hoyêdo Nunes. Herança Açoriana e Turismo na Ilha de Santa Catarina. In: revista de Ciências Humanas, vol. 10, n 14. Centro de Filosofia e Ciências Humanas UFSC, Florianópolis, 1999.

. Santa Catarina e o Mercosul: uma abordagem sobre as estruturas regionais catarinenses no âmbito da integração. In: Anais do Congresso de História e Geografia de Santa Catarina, pp. 416-429. Instituto Histórico e Geográfico de Santa Catarina - IHGSC, Florianópolis, 1996.

A Sócio-economia do Turismo. Investigações sobre o crescimento turístico recente em Florianópolis e algumas de suas implicações. Dissertação de mestrado, Departamento de Ciências Econômicas/CCE, UFSC, Florianópolis, 1991.

Llop, Carles. De la Reserva Urbana al Proyecto de Territorio Municipal. In: Planeamiento Urbanístico. De la Controversia a la Renovación, pp. 151-168, Antonio Font (coord.), CUIMPB y Diputació Barcelona, Barcelona, 2003.

Lonardoni, Fernanda Maria. Transformações no Espaço Costeiro: Reconhecimento dos Processos de Crescimento Urbano-turístico no Litoral Catarinense. Relatório 
de Pesquisa. PET - Programa Especial de Treinamento, ARQ-UFSC, Departamento de Arquitetura e Urbanismo. Florianópolis, 2003.

Lyle, John Tilman. Design for Human Ecosystem: landscape, land, use and natural resources. Van Nostrand Reinhold, New York, 1985.

Macedo, Silvio Soares. Paisagem, Urbanização e Litoral. Do éden a cidade. Tese de Livre-docência. FAUUSP, São Paulo, 1993.

Mac Harg, lan. Proyectar con la Naturaleza. Gustavo Gili, Barcelona, 2000 (original: Design with nature. John Wiley \& Sons, New York, 1969).

Magnoli, Miranda M. E. M. Paisagem: pesquisa sobre o desenho do espaço. In: Paisagem e Ambiente - Ensaios. FAUUSP, São Paulo, 1986.

Martin, Javier Leonardo, Echevarri, Julio Pozueta. Transformación del Litoral y Intervención Pública: el caso de Cantábria. Ciudad y Territorio, Madrid, outubro de 1984.

Martins, Paulo Edi Rivero. Patrones Arquitectónicos y Urbanísticos del Turismo en Florianópolis. Tese de Doutorado. ETSAB, UPC, Barcelona, 2004.

Mathieson, Alister e Wall, Geoffrey. Tourism. Economic, Phisical and Social Impacts. Longman, Londres, 1982.

Mazzer, Augusto M. Análise de Ecologia da Paisagem em Ilhas do Litoral de Santa Catarina. Monografia de Conclusão de Curso de Oceanografia. CTTMar, UNIVALI, Itajaí, 1998.

Metzger, Jean Paul. O que é Ecologia da Paisagem? Boletim eletrônico: Biota Neotropica, vol. 1, n. 1 e 2, (http://www. biotaneotropica.org.br), Campinas, 2001.

Monteiro, Carlos Augusto de Figueiredo. Florianópolis: o direito e o avesso. In: Florianópolis do Outro Lado do Espelho, pp. 7-34, Margareth de C. A. Pimenta (org.). Editora da UFSC, Florianópolis, 2005.

Moraes, Antônio Carlos Robert. Beira-mar, lugar comum? A valorização e a valoração dos espaços litorâneos, in: Contribuições para a Gestão da Zona Costeira do Brasil Elementos para uma Geografia do Litoral Brasileiro, Edusp/Hucitec, Sâo Paulo, 1999. 
Moreira, Antonio Cláudio M. L. Megaprojetos e ambiente urbano: uma metodologia para elaboração do relatório de impacto de vizinhança. Tese de doutoramento na FAU-USP, agosto de 1997.

Moreira, Antônio Cláudio M. L. Conceitos de Ambiente Urbano e de Impacto Ambiental Aplicáveis ao Meio Urbano. Material Didático da Disciplina AUP5861 - Políticas Públicas Ambientais Urbanas do Curso de Pós-graduação da FAUUSP, São Paulo, 2000.

Moretto Neto, Luis. A Competitividade de Destinos Turísticos Aplicada aos Espaços Insulares de Gran-Canária/Espanha e Florianópolis/Brasil: Estudo de multicasos. Tese de Doutorado, Departamento de Engenharia de Produção, UFSC, Florianópolis, 2005. . A Atividade Turística e o Desenvolvimento Sustentado: Estudo de caso: O Balneário de Ingleses e o Projeto Costa Norte - Ilha de Santa Catarina, no período de 1960-1990. Dissertação de Mestrado, Departamento de geociências, Curso de Geografia, CFH, UFSC, Florianópolis, 1993.

Moroni, Antonio. Ecologia. Piccin, Parma, 1974.

MPB Saneamento. Sistema de Esgoto Sanitário do Balneário dos Ingleses - Município de Florianópolis/SC: estudo da concepção do sistema de esgoto sanitário. Relatório técnico, Florianópolis, 1992.

Mullins, P. Tourism Urbanization. In: International Journal of Urban and Regional Research, 15 (3), pp. 326-42. 1991.

Muñoz, J. M. B. Ordenación, Planificación y Gestión del Espacio Litoral. Oikos-Tau, Barcelona, 1994.

MVRDV. Costa Ibérica. Hacia la ciudad del ocio. Actar, Barcelona, 2000.

Naisbitt, J. Paradoxo Global: quanto maior a economia mundial, mais poderosos serão os seus protagonistas e menores serão as nações, empresas e indivíduos. Campus, Rio de Janeiro, 1994.

Nogué Font, Joan e Rufí, Vicente. Geopólitica, identidad y globalización. Ariel Geografía, Barcelona, 2001. 
Odum, Eugene P. Ecologia. Guanabara, Rio de Janeiro,1988.

Oliveira, Lisete Assen de. Formas de Vir-a-ser cidade. Loteamentos e condomínios na Ilha de Santa Catarina. Tese de Doutorado, FAUUSP, São Paulo, 1999.

. O Rio Vermelho no seu Vir-a-ser cidade: estudo da dinâmica da organização espacial. Dissertação de Mestrado. FAUUSP, São Paulo, 1993.

Ouriques, Helton Ricardo. Turismo em Florianópolis. Uma crítica à indústria pós-moderna. Editora da UFSC, Florianópolis, 1998.

Pacheco, Regina Silvia; Loureiro, Maria Rita; Fingermann, Henrique; Amaral e Silva, Helena Kerr do e Mac Dowell, Silvia. Atores e Conflitos em Questões Ambientais Urbanas. Centro de Estudos de Administração Pública e Governo. Fundação Getúlio Vargas. São Paulo, 1993.

Paiva, Edvaldo; Ribeiro, Demétrio e Graeff, Edgar. Plano Diretor de Florianópolis. Estudos Preliminares. Prefeitura Municipal de Florianópolis, Florianópolis, 1952. . Estudos de Geografia Urbana em Santa Catarina. Editora da UFSC, Florianópolis, 1991.

Palet, Amélia de Farias. Proposta de Apoio Turístico com Desenvolvimento Sustentável. Dissertação de Mestrado. FAUUSP, São Paulo, 1988.

Pauli, Evaldo. A Fundação de Florianópolis. Lunardelli, Florianópolis, 1987.

Peet, R e Watts, M. Liberation Ecologies. Environment, development, social movements. Routledge, Londres, 1996.

Pellegrini Filho, Américo. Ecologia, Cultura e Turismo. Papirus, Campinas, 2001.

Pellegrino, Paulo R.P. Paisagem e Ambiente. Tese de Doutorado, FAUUSP, São Paulo, 1987.

Peluso Jr., Vitor A. O Crescimento Populacional de Florianópolis e suas repercussões no Plano e na Estrutura da Cidade. In: Revista do Instituto de História e Geografia de Santa Catarina - IHGSC, pp. 7-54. Instituto de História e Geografia de Santa Catarina - IHGSC, Florianópolis, 1981. 
Pereira, Nereu do Vale. Desenvolvimento e Modernização (um estudo da modernização em Florianópolis). Lunardelli, Florianópolis, 1974.

Pesci, Ruben. El Urbanismo y la Cultura Ambiental. In: El Territorio como Sistema. Conceptos y Herramientas de Ordenación. Ramon Folch (coord.), pp. 101-120, Diputació de Barcelona - Xarxa de Municipis, Barcelona, 2003.

. La Ciudad de la Urbanidad. Kliczkowski Publisher e Fundación CEPA, Buenos Ayres, 1999.

Pessoto, Carla e Martins, Celso. IPUF Discute Ocupação de Santo Antônio. Reportagem disponível no site www.pmf.sc em 2003.

Piazza, Walter. Historiografia Catarinense. In: Revista do Instituto de História e Geografia de Santa Catarina - IHGSC, pp. 57-75. Instituto de História e Geografia de Santa Catarina - IHGSC, Florianópolis, 1981.

Picot, Blandine. Mass Education, Ou le Petit Projet Touristique d'une Grande ONG Indienne. Les limites d'une forme idéale de tourisme. Disponível em http:// rives.revues.org, 2005.

Pié, Ricard e Barba, Rosa. Segunda Residência y Turismo Versus Residência Permanente. In: Arquitectura y Turismo, pp. 43-48, Rosa Barba e Ricard Pie, UPC, BarceIona, 1996.

Pimenta, Margareth Castro Afeche (org.). Florianópolis do Outro Lado do Espelho. Editora da UFSC, Florianópolis, 2005.

Pittaluga, Alessandro. /l Paesaggio nel Território. Hoepli, Milão, 1986.

PMF. Prefeitura Municipal de Florianópolis. Perfil de Florianópolis Características Ambientais Biológicas, disponível em www.pmf.sc, em dezembro de 2003.

Poon, Auliana. Competitive Strategies for a "New Tourism". In: Cooper, C. (org), Progress in tourism, recreation and hospitality management, pp. 91-102. Belheaven Perss. Londres, 1989.

Presidência da República. Estatuto da Cidade. Lei No.10.257/2001. Brasília, 2001. 
Reis, Almir Francisco. Permanências e Transformações no Espaço Costeiro: Formas e Processos de Crescimento Urbano Turístico na Ilha de Santa Catarina. Tese de Doutorado. FAUUSP, São Paulo, 2002.

Reitz, José Raulino. Vegetação na Zona Marítima de Santa Catarina. Selowia, Florianópolis, 1962.

Rial, Carmem. Mar de Dentro: a transformação do espaço social na Lagoa da Conceição. Dissertação de Mestrado, Departamento de Antropologia, UFRGS, Porto Alegre, 1988.

Rizzo, Paulo Marcos. Do Urbanismo ao Planejamento Urbano. Utopia e Ideologia. O caso de Florianópolis. Dissertação de Mestrado. Departamento de Geografia/CFH, UFSC. Florianópolis, 1993.

. A Natimorta Tecnópolis do Campeche - delírio de tecnocratas, pesadelo dos moradores. In: Florianópolis do Outro Lado do Espelho, pp. 61-84, Margareth de C. A. Pimenta. Editora da UFSC, Florianópolis, 2005.

Rocha, Rosana Moreira da. A Restinga como Exemplo de Ecossistema e a sua urbanização - subsídios para possíveis intervenções. Paisagem Ambiente- Ensaios, $\mathrm{n}$. 6 p. 57, pp. 57-73, FAUUSP, São Paulo, 1994

Rock, Martin. La Ecología desde el Punto de Vista Antropológico y Ético; in: El Medio Ambiente en la Economía de Mercado, Fundacón Konrad Adenauer/CIEDLA, Buenos Aires, 1990.

Rodà, Ferran. La Matriz Ecológica, la Conectividad y la Transformación Territorial. Las funciones ecológicas de la Matriz. In: El Territorio como Sistema. Conceptos y Herramientas de Ordenación, pp. 19-42, Ramon Folch (coord.), Diputació de Barcelona, Barcelona, 2003.

Rodrigues, Adyr Balastreri. Turismo e Espaço. Rumo a um conhecimento transdisciplinar. Hucitec, São Paulo, 1997 a.

Rodrigues, Adyr Balastreri (org.). Turismo e Desenvolvimento Local. Hucitec, São Paulo, 1997 b.

Paulo, 1997 c. 
Rougerre, Gabriel e Berouchachvili, Nicolas. Géosystèmes et Paisajes. Bilan et méthodes. Armand Colin, Paris, 1991.

Ruschmann, Doris. Turismo e Planejamento Sustentável - a proteção do meio ambiente. Papirus, Campinas, 2002.

Sabaté Bel, Joaquim (coord.). Patrimoni i Projecte Territorial. Colònies, Sèquia de Manresa i Delta Del Llobregat. Diputació Barcelona, Barcelona, 2004 a. . Patrimoni i Desenvolupament Territorial: algunes reflexiones. In: Patrimoni i Projecte Territorial. Colònies, Sèquia de Manresa i Delta Del Llobregat, pp.75-100, Joaquim Sabaté Bel (coord.). Diputació Barcelona, Barcelona, 2004 b. . Elements per a la Construció d'un Projecte Territorial. In: Patrimoni i Projecte Territorial. Colònies, Sèquia de Manresa i Delta Del Llobregat, pp.115-126, Joaquim Sabaté Bel (coord.). Diputació Barcelona, Barcelona, 2004 c. . Balance y Perspectivas del Planteamiento Urbanístico Municipal. In: Planeamiento Urbanístico. De la Controversia a la Renovación, pp. 181206, Antonio Font (coord.), CUIMPB y Diputació Barcelona, 2003. . Plan Insular de Tenerife - Ordenación Territorial del Turismo. In: Arquitectura Y Turismo: Planes y Proyectos, pp. 142-149, Rosa Barba e Ricard Pié (eds), UPC, Barcelona, 1996.

Sabaté Bel, Joaquim e Schuster, Mark J. Projectant l'Eix de Llobregat. UPC e MIT, Barcelona, 2001.

Saboya, Renato. Análises Espaciais em Planejamento Urbano. In: Revista Brasileira de Estudos Urbanos e Regionais, $n^{\circ} 3$, novembro de 2000, pp. 61-80. ANPUR e Editora Norma Lacerda, Recife, 2000.

Saint-Martin, Yann. La Répartition des Espaces Verts à Palma de Majorque. Analyse des contextes politique, historique et géographique. Disponível em http:// rives.revues.org, 2005.

Salles, Colombo Machado. A Região Costeira Meridional de Santa Catarina. Editora Unisul, Tubarão, 2005. 
Sánchez, Joan Eugeni. Por Una Geografía del Turismo de Litoral. Una aproximación metodológica. In: Estudios Territoriales, n. 17, pp. 103-122, Madrid, 1985

Santos, Cristina Pereira. Planejamento Turístico e seus Reflexos no Processo de Urbanização nas Praias de Canasvieiras e Jurerê. Dissertação de Mestrado, Departamento de Geociências, UFSC, Florianópolis, 1993.

Santos, Emanuel Antonio dos. As Paisagens do Plano e os Planos da Paisagem. Da paisagem no planejamento ao planejamento com a paisagem. Tese de doutorado. FAUUSP. São Paulo, 2002.

Santos, Milton. A Natureza do Espaço. Técnica e tempo. Razão e Emoção. Hucitec, São Paulo, 1996. . Meio técnico-científico e Urbanização: tendências e perspectivas. In: Resgate, Revista de Cultura, n. 3, Campinas, 1991. . Espaço e Método. Nobel, São Paulo, 1985. . De la Société au Paisaje. La signification de l'espace humain. Paris, 1978.

Santos, Rosely Ferreira dos. Planejamento Ambiental. Teoria e Prática. Oficina de textos. São Paulo, 2004.

Santos, Silvio Coelho dos. A Zona Rural da Ilha de Santa Catarina. In: Ensaios sobre Sociologia e Desenvolvimento em Santa Catarina, Edeme, Florianópolis, 1971. (org.). Santa Catarina no Século XX. Editora da UFSC, UNIVALI e Fundação Catarinense de Cultura, Florianópolis, 1999.

SANTUR - Santa Catarina Turismo S/A e Secretaria de Estado da Organização do Lazer de Santa Catarina Programa de Desenvolvimento do Turismo no Sul do Brasil, PRODETUR -SUL. Florianópolis, 2003.

- Santa Catarina Turismo S/A. Pesquisa Mercadológica Estudo da Demanda Turística.Florianópolis, 2003.

Sartori, Lourdes Feline. Turismo. Uma Atividade Municipal. UNIVEST, Caxias do Sul, 1980. 
SBPC - Sociedade Brasileira para o Progresso da Ciência. Anais da $3^{a}$ Reunião Especial da SBPC - Ecossistemas Costeiros. Do conhecimento à gestão. UFSC, Florianópolis, 1996.

Secchi, Bernardo. La Ciudad Contemporánea y su Proyecto. In: Planeamiento Urbanístico. De la Controversia a la Renovación, pp. 91-120, Antonio Font (coord.). CUIMPB y Diputació Barcelona, 2003.

. Nuevos Elementos en el Proyecto Territorial. UPC/ETSAB, Departamento de Urbanismo y Ordenación del Territorio, Barcelona, 1998.

SDE - Secretaria de Estado do Desenvolvimento Econômico e Integração ao Mercosul. Anuário Estatístico do Estado de Santa Catarina 1960-2000. Disponível em www.sde.sc.gov.br, 2004.

- Secretaria de Estado do Desenvolvimento Econômico e Integração ao Mercosul e IBGE - Fundação Instituto Brasileiro de Geografia e Estatística. Gerco - Projeto de Gerenciamento Costeiro - SC. Diagnóstico Ambiental do Litoral de Santa Catarina Caracterização Sócio-ambiental da Zona Costeira de Santa Catarina. SDE/IBGE, Florianópolis, 1997.

SDM - Secretaria de Estado do Desenvolvimento Urbano e Meio Ambiente. Plano Básico de Desenvolvimento Ecológico-Econômico - Associação dos Municípios da Grande Florianópolis, Florianópolis, 1996.

- Secretaria de Estado do Desenvolvimento Urbano e Meio Ambiente. Programa de Gerenciamento Costeiro de Santa Catarina. SDM, Florianópolis, 2003.

Sejenovich, Héctor. Turismo y Ordenamiento Ambiental. In: Medio Ambiente y Turismo, José Villamil et alli. CLACSO, Buenos Aires, 1983.

Serra, Geraldo. O Espaço Natural e a Forma Urbana. Nobel, São Paulo, 1987.

Silva, Célia Maria; Machado, Ewerton Vieira e Campos, Nazareno José de. A (Re)Produção do Espaço Litorâneo Catarinense. In: Anais do Congresso de História e Geografia de Santa Catarina, pp. 468-479. Instituto Histórico e Geográfico de Santa Catarina - IHGSC, Florianópolis, 1996. 
Smith, Valene. Host and Guest. University Pennsylvania Press. Filadélfia, 1977.

Solá-Morales Manuel de. Sobre Metodolgía Urbanística. Laboratório de Urbanismo, ETSAB, UPC, Barcelona,1969.

Soja, Edward. Geografias Pós-modernas: A Reafirmação do Espaço na Teoria Social Crítica. Zahar, Rio de Janeiro, 1993.

Sotchava, V. B. O Estudo dos Geossistemas. In: Métodos em Questão, n. 16 Instituto de Geografia, USP, São Paulo, 1977.

Spirn, Ane Whiston. Landscpe, Planning and the City. In: Landscape and Urban Planning, n. 13. New York, 1986.

Sugai, Maria Inês. As Intervenções Viárias e as Transformações do Espaço Urbano. A Via de Contorno Norte-Ilha. Dissertação de mestrado. FAUUSP, São Paulo, 1994.

Sunkel, Osvaldo. Por Que es Imprescindible y Urgente Incorporar las Preocupaciones Ambientales en la Problemática del Desarrollo. In: Medio Ambiente y Turismo, José Villamil et alli. CLACSO, Buenos Aires, 1983.

Taylor-Flores, Henny Consuelo. O Planejamento Ambiental Como Alternativa de Desenvolvimento Sustentável em Território Insular. Dissertação de Mestrado. FAUUSP, São Paulo, 2000.

Terradas, Jaume. La Concepción Científica y la Ecología del Paisaje. La historia y los conceptos en torno a la Idea de paisaje. In: El Territorio como Sistema. Conceptos y Herramientas de Ordenación, pp. 19-42, Ramon Folch (coord.), Diputació de Barcelona, Barcelona, 2003.

Toledo, Benedito Lima. In: Macedo, Sílvio Soares. Higienópolis e Arredores - Processo de Mutação de Paisagem Urbana. EDUSP, São Paulo, 1987.

Torres, Sergio. Plan Insular de Gran Canaria. In: Arquitectura y Turismo. Planes y Proyectos, pp. 150-159, Rosa Barba e Ricard Pié, UPC, Barcelona, 1996.

Towle, Albert e Otto, James H. Biologia. Interamericana, México, 1988.

Tricart, J. J. L. Paysage et Écologie. Revue de Géomorphologie Dynamique: géodynamique externe. Études Intégrée du Milieu Naturel, vol. XXVIII, n. 3, Paris, 1979. 
Trigo, Luiz Gonzaga Godoi. Turismo e Qualidade: tendências contemporâneas. Papirus, São Paulo, 1998.

Turner, Tom. City as Landscape. A post-postmodern view of design and planning. E\&FN Spon. Londres, 1996.

Vainer, Carlos B. Pátria, Empresa e Mercadoria. Notas sobre o Planejamento Estratégico Urbano. Portal Vitruvios - www.vitruvius.com.br, 2006.

Várzea, Virgílio. Santa Catarina: a llha. Lunardelli, Florianópolis, 1984.

Veiga, Danilo. Medio Ambiente y Turismo en la Costa Balnearia Uruguaya. In: Medio Ambiente y Turismo, José Villamil et alli. CLACSO, Buenos Aires, 1983.

Vera Rebollo, Fernando. La Variable Territorial en los Procesos de Desarrollo Turístico. In: Arquitectura Y Turismo: Planes y Proyectos, pp. 87-98, Rosa Barba e Ricard Pié (eds), UPC, Barcelona, 1996.

Vera Rebollo, J. Fernando; Lopez Palomeque, Francisco; Marchena, Manuel J. e Antón, Salvador. Análisis Territorial del Turismo. Ariel, Barcelona, 1997.

Villamil, José J. Apuntes Sobre el Impacto del Turismo: la experiencia del caribe. In: Medio Ambiente y Turismo, José Villamil et alli. CLACSO, Buenos Aires, 1983.

Viola, Eduardo José. A Degradação Sócio-ambiental e a Emergência dos Movimentos Ecológicos na América Latina. In: Sonia Laranjeira (org.) Classes e Movimentos Sociais na América Latina. Hucitec, São Paulo, 1990.

e Boeira, Sérgio Luís. A Emergência do Ambientalismo Complexo-Multissetorial no Brasil (particularmente na microrregião de Florianópolis). In: Textos Básicos do IV Seminário Nacional sobre Universidade e Meio Ambiente, pp. 41-99, UFSC, Florianópolis, 1990.

Vittori, Jean Emanuel. Les Dynamiques Locales Face au Tourisme aux lles Baleares. Disponível em http://rives.revues.org, 2005.

Volle, Aurélie. Majorque: un modèle touristique entre dynamiques locales et logiques globales. Disponível em http://rives.revues.org, 2005. 
Yázigi, Eduardo. A Fisiografia e sua Paisagem na Busca da Personalidade do Lugar. In: Paisagem Ambiente - Ensaios, n. 11, pp 73-98. Faculdade de Arquitetura e Urbanismo, Universidade de São Paulo, São Paulo, 1997.

Yázigi, Eduardo; Carlos, Ana Fani Alessandri e Cruz, Rita de Cássio Ariza de (orgs). Turismo, Paisagem e Cultura. Hucitec, São Paulo, 1996.

Zeferino, Augusto César. A Questão dos ElAs - O Estado como Parceiro. In: Revista do Instituto de História e Geografia de Santa Catarina - IHGSC, pp. 87- 112. Instituto de História e Geografia de Santa Catarina - IHGSC, Florianópolis, 1996.

Zanchetti, Sílvio Mendes. A Valorização da Paisagem no Meio Ambiente Urbano In: Anais de Seminário Interuniversitário - Questões Ambientais Litorâneas, Universidade de São Paulo, Universidade de Dublin e Universidade Técnica, São Paulo, 1993, pp. 68-75.

Werner, Denis. Political Patronage in Santa Catarina, Brasil. In: Current Anthropology, vol. 26, n. 1, fevereiro, Los Angeles, 1985. 


\section{A PROTEÇÃO DO AMBIENTE NATURAL EM FLORIANÓPOLIS E ILHA DE SANTA CATARINA}

A região da llha da Santa Catarina, território integrante do domínio da mata atlântica, passou a fazer parte da Reserva da Biosfera da Mata Atlântica - RBMA conforme declaração da UNESCO1 ${ }^{1}$, a partir da terceira fase de implantação, em 1993. Embora faça parte desta importante reserva, cuja missão é contribuir de forma eficaz para o estabelecimento de uma relação harmônica entre as sociedades humanas e o ambiente na área da Mata Atlântica, na prática, nenhuma ação de conservação e manejo relativa a este titulação se faz notar trato do território insular e do município de Florianópolis.

A presença predominante de área urbanizada e populosa em seu entorno com cerca de 600 mil habitantes e atividades econômicas importantes para o estado de Santa Catarina, ainda que entremeada de remanescentes naturais, dificulta o alcance pleno dos objetivos de uma reserva. Além de integrar a Reserva da Biosfera da Mata Atlântica, referendada pela UNESCO, a região da llha de Santa Catarina ainda conta com uma série de áreas naturais protegidas por legislação em diferentes níveis da administração.

As ações de conservação do patrimônio natural da cidade foram reforçadas nos anos 1990, quando o desmonte estatal era a regra, com a instituição, em 1995, da Fundação Municipal de Meio Ambiente - FLORAM ${ }^{2}$, órgão executivo do município e a criação do Conselho Municipal do Meio Ambiente ${ }^{3}$, em 1993.

\footnotetext{
${ }^{1}$ A Reserva da Biosfera da Mata Atlântica - RBMA cuja área foi reconhecida pela UNESCO, em cinco fases sucessivas entre 1991 e 2002, foi a primeira unidade da Rede Mundial de Reservas da Biosfera declarada no Brasil. É a maior reserva da biosfera em área florestada do planeta, com cerca de 35 milhões de hectares, abrangendo áreas de 15 dos 17 estados brasileiros onde ocorre a Mata Atlântica, o que permite sua atuação na escala de todo o Bioma. A RBMA estende-se por mais de 5000 dos $8000 \mathrm{Km}$ do litoral nacional, desde o Ceará ao Rio Grande do Sul, avançando mar afora englobando diversas ilhas oceânicas como Fernando de Noronha, Abrolhos e Trindade e adentrando no interior de vários estados costeiros, bem como em Minas Gerais e Mato Grosso do Sul. Tem como funções: a conservação da biodiversidade e dos demais atributos naturais da Mata Atlântica, incluindo a paisagem e os recursos hídricos; a valorização da sócio-diversidade e do patrimônio étnico e cultural a ela vinculados; o fomento ao desenvolvimento econômico que seja social, cultural e ecologicamente sustentável, e o apoio a projetos demonstrativos, à produção e difusão do conhecimento, à educação ambiental e capacitação, à pesquisa científica e o monitoramento nos campos da conservação e do desenvolvimento sustentável. A Reserva da Biosfera da Mata Atlântica inclui todos os tipos de formações florestais e outros ecossistemas terrestres e marinhos que compõem o Domínio da Mata Atlântica, bem como os principais remanescentes florestais e a maioria das unidades de conservação da Mata Atlântica, onde está protegida grande parte da mega-biodiversidade brasileira.

2 Lei municipal 4.645 de 21/06/1995.

${ }^{3}$ O Conselho Municipal de Meio Ambiente, criado por lei em 1993, foi regulamentado pela lei que criou a FLORAM e é integrado por 17 membros: IPUF, UFSC, UDESC, IBAM, FATMA, Câmera Municipal, representante de entidades ambientais, Associação Brasileira de Engenharia sanitária, IPHAN, Associação catarinense de Engenheiros e o superintendente da FLORAM.
} 
Reproduzindo o movimento da área da preservação do patrimônio histórico e cultural, o movimento estatal de preservação do patrimônio natural que até então se dava a partir de um conselho, passa a ter suporte administrativo de execução das políticas em órgãos estatais e um conselho multissetorial (Adams, 2002).

Mesmo com a existência de legislação pertinente em diversos níveis da administração pública, existe muita dificuldade para o Município de Florianópolis, o responsável de fato, em responder às exigências de implantação, gestão e manutenção das Unidades de Conservação. Invasões e depredações da integridade das unidades são constantes e em alguns casos, irreversíveis.

Aproximadamente $42 \%$ da área do município são constituídos por áreas protegidas, a maioria delas sobre terrenos de particulares não desapropriados, o que gera conflitos judiciais e, por conseguinte, demora na materialização da lei. A responsabilidade pela fiscalização dessas áreas, que a partir de meados dos anos 1990 passou à, então, recém criada Fundação Municipal de Meio Ambiente, já havia sido de diversos órgãos ligados à Prefeitura de Florianópolis, como o IPUF e a SUSP, sempre com problemas de gestão. A falta de orçamento e de material humano para fiscalização eficiente e o desnível de conscientização ambiental entre os diversos órgãos envolvidos com a questão, são alguns desses problemas.

As políticas de conservação e proteção ambiental do município de Florianópolis são decorrentes dos Planos diretores do Município propostos pelo IPUF (Leis 1851/82 e $2193 / 85$ ), delimitando $42 \%$ do território municipal em UC de várias categorias, com base em legislação federal, estadual e municipal.

Estações ecológicas: mangues do Ratones e do Saco Grande;

Reservas ecológicas: mangue do Rio Tavares e faixas sanitárias dos rios;

Parques estaduais: Tabuleiro e Rio Vermelho;

Parques Municipais: Lagoa do Peri, Lagoinha do Leste, Galheta e Maciço a Costeira; Áreas tombadas como patrimônio natural e paisagístico do município: dunas da Lagoa, Santinho e Ingleses e Pântano do Sul, lagoas em geral, Ponta do Sambaqui e restinga da Ponta das Canas;

Áreas de Preservação Permanente: encostas que apresentem declividades superiores a $25^{\circ}$ (ou $47 \%$ de inclinação) e alguns banhados, dunas e mangues não incluídos nas reservas e estações ecológicas; 


\section{Áreas de Preservação Limitada}

Além dos problemas de responsabilidade e competências entre os diversos órgãos e agências estatais, a criação de UCs sem desapropriação dos proprietários, as invasões por ocupações clandestinas e a falta de fiscalização (antes SUSP e agora FLORAM) e verbas orçamentárias são sérios impedimentos para a implantação e gestão. Também a condescendência do judiciário para com invasões populares, o que não acontece com o poder público e empreendedores (sic, ?).

Ao demandar política Ambiental clara, simples e objetiva, o IPUF se alinha à expectativa do empresariado do ramo turístico-imobiliário.

A pouca educação ambiental geral e o extremismo de grupos ambientalistas impedem maior aproveitamento destas áreas, o que permitiria a entrada de recursos necessários a sua manutenção.

Outro problema levantado pelos técnicos do IPUF (1996), em relação a esta questão, está relacionado com a assimetria de postura do sistema judiciário e do Ministério Público, em função do grupo social agressor do meio ambiente, o que acabaria por incentivar ocupações ilegais. Segundo os técnicos daquele órgão, esta assimetria se manifesta num aludido descaso (de viés populista, segundo os técnicos do IPUF) com que o judiciário e o Ministério Público tratam de invasões clandestinas de origem popular, somente submetendo às punições legais o poder público e empresas do ramo imobiliário, além de não envolverem outros órgãos responsáveis de esferas ligadas à questão. A falta de recursos, a dificuldade de coordenação e cooperação entre os diferentes órgãos e a convivência de diferentes orientações sócio-políticas dos técnicos seriam, então, os maiores problemas enfrentados na implementação e gerenciamento das Unidades de Conservação na llha de Florianópolis. A listagem a seguir, tem base em informações da Prefeitura Municipal de Florianópolis (www.pmf.sc, 2003).

\section{a) Instituídas por Legislação Federal}

Estação Ecológica dos Carijós - criada pelo Decreto Federal n 94.656/87, é composta pelos manguezais de Ratones (área $=61,87 \mathrm{ha}$ ) e do Saco Grande (área $=9,35 \mathrm{ha}$ ), totalizando 71,22 ha. Apesar da delimitação da área protegida, ainda se 
percebe muitas agressões nas bordas e é ameaçada por loteamento vizinho sem áreas de transição que amorteça poluições do lençol freático e dilapidação dacobertura vegetal

Reserva Biológica Marinha do Arvoredo - criada pelo Decreto Federal n. ${ }^{\circ}$ 99.142/90 com o objetivo de proteger amostra representativa dos ecossistemas da região costeira. Abrange as Ilhas do Arvoredo, das Galés e Deserta, o Calhau de São Pedro e área marinha que os circunda (municípios de Florianópolis e Governador Celso Ramos), totalizando 17.800 ha.

Área de Proteção Ambiental Anhatomirim - instituída pelo Decreto Federal n. ${ }^{\circ}$ 528/ 92, compreende uma área de 3.000 ha localizada na baía Sul e em terras do Município de Governador Celso Ramos. Seu objetivo é assegurar a proteção da população de boto Sotalia fluviatilis, a sua área de alimentação e reprodução, bem como áreas remanescentes da Floresta Atlântica e fontes hídricas de interesse para a sobrevivência das comunidades de pescadores artesanais da região.

Reserva Extrativista Marinha de Pirajubaé - instituída pelo Decreto Federal n. ${ }^{\circ}$ 533/ 92, é constituída pelo manguezal do Rio Tavares (área $=740$ ha) e o baixio a sua frente (área = 704 ha), totalizando 1.444 ha. Tem sido bastante agredida na borda interna pelo impacto da urbanização que se faz presente com rodovia e loteamentos próximos ao aeroporto. Na borda marítima mantém conservação adequada.

\section{b) Instituídas por Legislação Estadual}

Parque Florestal do Rio Vermelho - criado em princípio como Estação Florestal do Rio Vermelho pelo Decreto Estadual n. ${ }^{\circ} 2.006 / 62$, era destinado à experimentação de espécies comercializáveis de pinus e eucaliptus e à comprovação dos melhores índices de desenvolvimento de variedades adaptáveis à região catarinense. $\mathrm{O}$ Decreto Estadual n. ${ }^{\circ}$ 994/74 transformou a Estação em Parque Florestal, o qual abrange uma área de 1.110 ha. Existem zonas no Parque com uso para pesquisa, um camping de entidade filantrópica (escoteiros) e outro de estatal (CODESC). Além desses usos, a região do parque é cruzada por diversos caminhos de ligação entre a rodovia e a praia, bastante freqüentada na alta temporada por amantes de esportes náuticos e praias naturais. 
Parque Estadual da Serra do Tabuleiro - criado pelo Decreto Estadual n. ${ }^{0}$ 1.260/75, abrange áreas de mata atlântica, dunas, restinga, manguezais e capoeirões. Dos 90.000 ha decretados, uma área de 346,5 ha localiza-se na ponta sul da Ilha de Santa Catarina, Florianópolis, na localidade da praia dos Naufragados. Este parque foi instituído sem desapropriação dos antigos moradores e apresenta diversos problemas decorrentes disso. Na Ilha, as maiores agressões decorrem da apropriação de áreas na praia dos Naufragados, tendo mais de 10 construções na praia com função residencial e comercial, algumas se aproveitando de condescendência da fiscalização, pois foram implantadas depois da instituição do Parque.

\section{c) Instituídas por Legislação Municipal}

Dunas da Lagoa da Conceição - tombadas pelo Decreto Municipal n. ${ }^{0}$ 1.261/75. O Decreto Municipal n. ${ }^{\circ}$ 213/79 amplia a área tombada pelo decreto anterior, limítrofes e adjacentes às dunas, com as quais tem estreita interação e dependência, totalizando 563 ha de área. As agressões mais perceptíveis decorrem de ações da própria prefeitura na implantação de estacionamento e, apesar da capacidade de resiliência do sistema dunar, de intensa utilização das dunas para esportes e passeios de grupos grandes turistas.

Parque Municipal da Lagoa do Peri - A Lei n. ${ }^{0} 1.828 / 81$ cria o parque e institui seu Plano Diretor e o Decreto n. ${ }^{\circ}$ 91/82 regulamenta a referida lei. Possui uma área de 2.030 ha. Também apresenta problemas de desapropriações não feitas e construções irregulares. Dentro de sua área se encontram prédio do órgão de meio Ambiente de Florianópolis - FLORAM, com funções de educação ambiental e controle, e balneário junto a orla da lagoa, com equipamentos de churrasqueiras e sanitários, e camping de escoteiros.

Dunas de Ingleses/Santinho, Campeche, Armação e Pântano do Sul - o Decreto n. ${ }^{\circ}$ 112/85 tomba o sistema físico natural das dunas de Ingleses (área = 953,3 ha), Santinho (área $=91,5$ ha), Campeche (área $=121$ ha), Armação do Pântano do Sul (área = 5,9 ha) e Pântano do Sul (área = 24,2 ha), proibindo quaisquer atividades ou edificações nessas áreas, mas nos Ingleses/Santinho existe grave problema sócio-ambiental decorrente de ocupação clandestina por grupos de baixa renda. 
Restinga de Ponta das Canas e Ponta do Sambaqui - o Decreto Municipal n. ${ }^{\circ}$ 216/85 tomba como Patrimônio Natural e Paisagístico do Município de Florianópolis a restinga de Ponta das Canas, com uma área de 21,5 ha, e a ponta do Sambaqui, com 1,3 ha de área, localizada no Distrito de Santo Antônio de Lisboa. Ambas são consideradas área de preservação permanente. A restinga de recente formação, se encontra bastante ameaçada pela proximidade de construções balneárias e estabelecimentos turísticos.

Áreas de Preservação Permanente e de Uso Limitado - a Lei Municipal n. ${ }^{\circ}$ 2.193/ 85, que dispõe sobre o zoneamento, o uso e a ocupação do solo nos Balneários da Ilha de Santa Catarina, declarando-os área especial de interesse turístico, institui as Áreas de Preservação Permanente (APP), considerando o que determina a Lei Federal n. ${ }^{\circ}$ 4.771/65 (Código Florestal) e Áreas de Uso Limitado (APL). Totaliza 10.074,2 ha de área de APP, incluindo o mangue de Itacorubi (área = 150 ha) e o mangue da Tapera (área $=52,5$ ha).

Região da Costa da Lagoa da Conceição - o Decreto Municipal n. ${ }^{\circ}$ 247/86 tomba como Patrimônio Histórico e Natural do Município de Florianópolis a encosta da margem Oeste da Lagoa da Conceição, desde a Ponta dos Araçás até a Ponta do Saquinho, e o caminho da Costa da Lagoa, totalizando 967, 5 ha.

Lagoa da Chica e Lagoinha Pequena - o Decreto n. ${ }^{\circ}$ 135/88 tomba como Patrimônio Natural e Paisagístico a Lagoinha Pequena, no Rio Tavares, antes considerada área verde de lazer pela Lei n. ${ }^{\circ} 2.193 / 85$ (área = 27,5 ha), e a Lagoinha da Chica, no Campeche (área = 3,75 ha).

Parque Municipal da Galheta - criado pela Lei $n .^{\circ} 3.455 / 90$, que considera a área de 149,3 ha como de preservação permanente.

Parque Municipal da Lagoinha do Leste - criado pela Lei n. ${ }^{\circ} 3.701 / 92$, que protege uma área de 453 ha, maior que a Bacia Hidrográfica da Lagoinha que anteriormente foi tombada como Patrimônio Natural e Paisagístico pelo Decreto Municipal n. ${ }^{\circ}$ 153/87.

Dunas da Barra da Lagoa - a Lei Municipal n. ${ }^{\circ} 3.771 / 92$ institui o Plano de Reestruturação Urbano da Barra da Lagoa, alterando a Lei n. ${ }^{\circ} 2.193 / 85$ e protege as dunas da Barra da Lagoa em uma área de 6,6 ha. Tendo em vista o amortecimento proporcionado pelo Parque Florestal do Rio Vermelho, as dunas se encontram em bom estado de conservação. 
Parque Municipal do Maciço da Costeira - Criado pela Lei Municipal 4.605/95 e regulamentado pelo Decreto n. ${ }^{\circ} 154 / 95$ possui uma área de $1.456,3$ ha. O parque se situa a $5 \mathrm{~km}$ do centro de Florianópolis, sendo que o acesso se faz somente por trilhas a partir das servidões que sobem encostas acima. Abrange áreas com relevo montanhoso, e visa a proteção da vegetação da floresta atlântica, fauna e os mananciais hídricos, já bastante agredidos ao longo do tempo.

Pontal da Daniela - Área de Preservação Permanente tombada pela Lei Municipal 5091/97. Com área de 15,64 ha, visa proteção de ecossistemas de manguezal e restinga, já bastante alterados em seus limites. 